\title{
The Old World Paleolithic and the Development of a National Collection
}

\author{
Michael Petraglia and Richard Potts
}

\author{
FOREWORD BY \\ Lawrence Guy Straus
}

ILLUSTRATIONS BY

Marcia Bakry

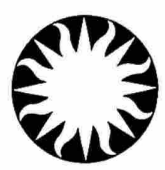

Smithsonian Contributions and Studies Series

AN IMPRINT OF SMITHSONIAN BOOKS

Washington, D.C. 


\section{A B S T R A C T}

Petraglia, Michael, and Richard Potts. The Old World Paleolithic and the Development of a National Collection. Smithsonian Contributions to Anthropology, number 48, 148 pages, 99 figures, 5 tables, 2004.-Beginning with the first accession of Paleolithic collections in 1869, the Smithsonian Institution and its scientific staff have shown great interest in pursuing research, education, and exhibition of early human lifeways. During the more than 130-year history of acquiring objects from the Old World, a total of 22,000 objects has been amassed from some 332 Lower to Upper Paleolithic localities. Certain objects are rare pieces from classic Paleolithic localities, although many others were obtained as representative pieces for comparative purposes and exhibition. Documents and letters of correspondence between Old and New World investigators provide the historical context of collection acquisition and the motivations of those involved in the international transfer and exchange of artifacts. Synthesis of the documentation shows variability in the tempo of collection acquisition and biases in geographic interests that are tied to patterns of scientific inquiry, world wars, and later, adherence to antiquity laws and reorientation of modern paleoanthropological methods and approaches. Because we refer extensively to archived letters and memoranda in the text, Appendix 1 provides a chronological list of these materials and the specific Smithsonian Institution archive where they are located.

OfFicIAL PUBLICATION DATE is handstamped in a limited number of initial copies and is recorded in the Institution's annual report, Annals of the Smithsonian Institution. SERIES COVER DESIGN:

Library of Congress Cataloging-in-Publications Data

Petraglia, M.D. (Michael D.)

The Old World Paleolithic and the development of a national collection / Michael Petraglia and Richard Potts ; with a foreword by Lawrence Guy Straus ; and illustrations by Marcia Bakry.

p. cm. - (Smithsonian contributions to anthropology ; no. 48)

Includes bibliographical references.

1. Paleolithic period-Collectors and collecting. 2. Tools, Prehistoric-Collectors and collecting. 3. MuseumsAcquisitions-Washington (D.C.) 4. Museums-Collection management-Washington (D.C.) 5. Smithsonian Institution. Bureau of American Ethnology. 6. Museum of Natural History (U.S.) Dept. of Anthropology. I. Potts, Richard, 1953- II. Title. III. Series.

(2) The paper used in this publication meets the minimum requirements of the American National Standard for Permanence of Paper for Printed Library Materials Z39.48 - 1984 . 


\section{Contents}

Foreword: The Paleolithic in America, A Preamble to the "Excavation" of a Great

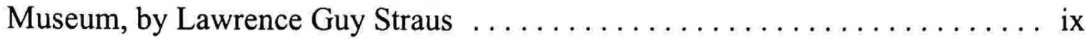

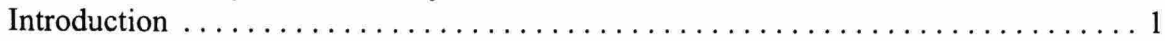

The Paleolithic Collections and the Smithsonian Institution $\ldots \ldots \ldots \ldots \ldots \ldots \ldots$

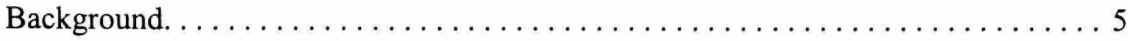

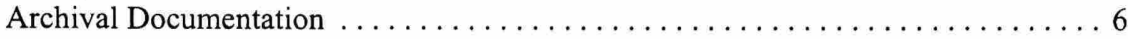

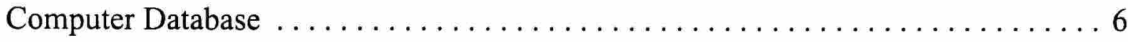

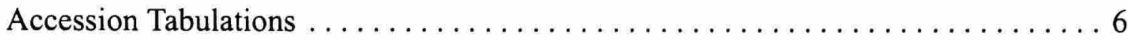

Motivations for the Acquisition of the Collections $\ldots \ldots \ldots \ldots \ldots \ldots \ldots \ldots$

Involvement of the Secretaries and the Administration . . . . . . . . . . . . . 11

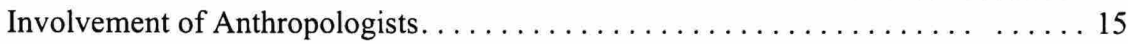

Thomas Wilson, Curator of Prehistoric Anthropology $\ldots \ldots \ldots \ldots \ldots \ldots \ldots$

Career and Appointment. . . . . . . . . . . . . . . . . . . . . . . 15

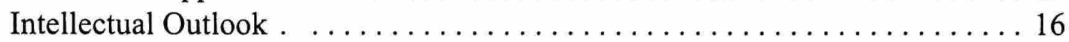

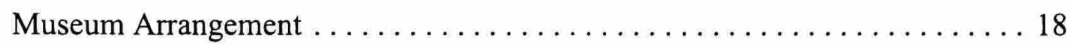

The North American Paleolithic Debate ..................... 21

Collection Controversy: Deposit or Smithsonian Property? ........... 21

Aleš Hrdlička and the American School of Prehistoric Research . . . . . . . . . 23

Career and Intellectual Outlook . . . . . . . . . . . . . . . . . . . 23

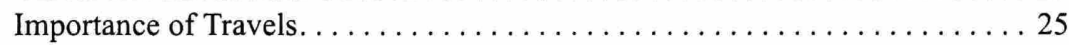

Involvement with the American School of Prehistoric Research. . . . . . . 25

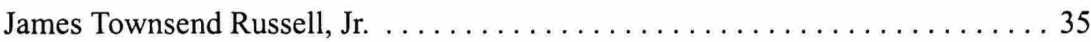

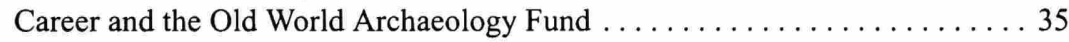

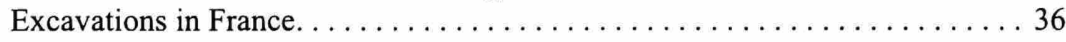

An Abrupt End to a Promising Career .......................... 37

The Modern Era of Paleoanthropology .............................. 37

T. Dale Stewart and the Post-World War II Period.................... 37

The Human Origins Program . . . . . . . . . . . . . . . . . . . . . . . 39

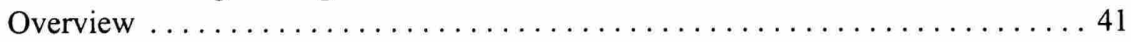

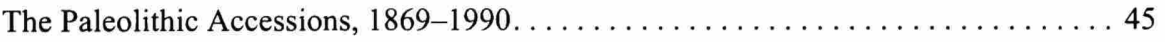

Lartet $($ acc. 1529, 3546) . . . . . . . . . . . . . . . . . . . . . 45

Blackmore (acc. 1846, 2371) . . . . . . . . . . . . . . . . . 64

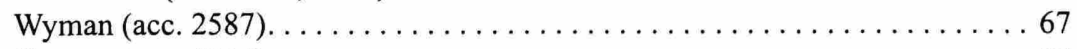

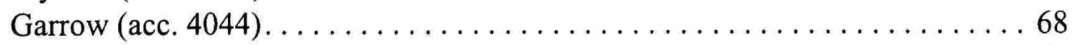

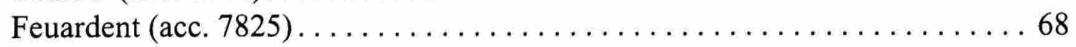

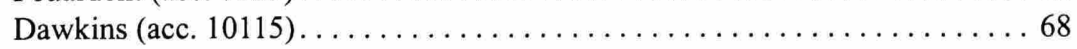

Musée Royal d'Histoire Naturelle de Belgique (acc. 10470). . . . . . . . . . . 69

Museum of Le Havre (acc. 10666) . . . . . . . . . . . . . . . . . . 69

Pengelly (acc. 13075) . . . . . . . . . . . . . . . . . . . . . 69

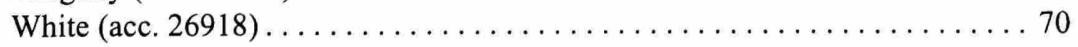

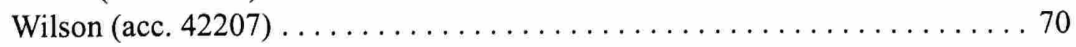

Musée des Antiquités Nationales, St. Germain-en-Laye (acc. 18891) . . . . . 78

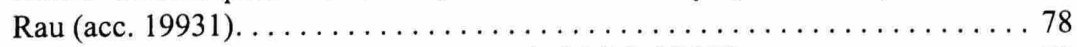

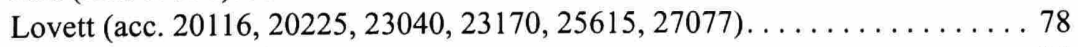

Ransom (acc. 20668) . . . . . . . . . . . . . . . . . . . . . . 81

American Museum of Natural History (acc. 21293) . . . . . . . . . . 81

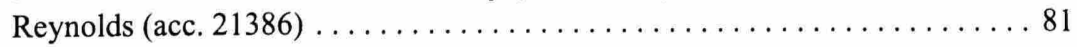




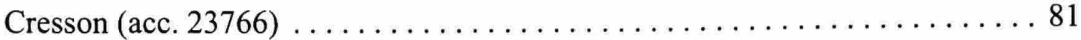

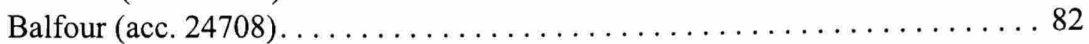

Museo Zoologico dei Vertebrati, Florence (acc. 24918, 25949) ........ . 82

Powell (acc. 27665) . . . . . . . . . . . . . . . . . . . . . . 83

Camp (acc. 28914) . . . . . . . . . . . . . . . . . . . . . . . . 84

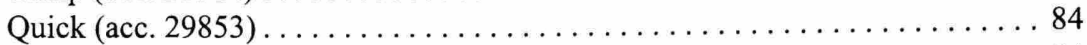

Harrison (acc. 30109) . . . . . . . . . . . . . . . . . . . . . . . 84

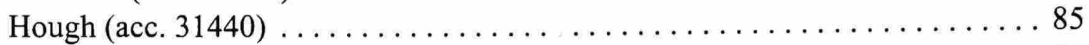

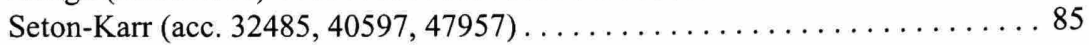

Miguel (acc. $36097,43727,44831,46030) \ldots \ldots \ldots \ldots \ldots \ldots \ldots \ldots \ldots 88$

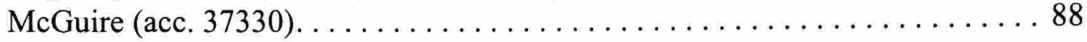

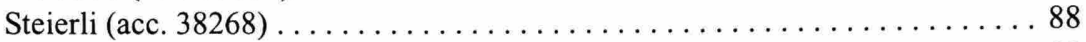

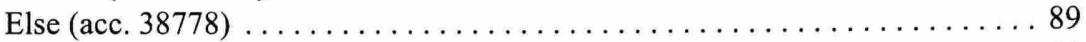

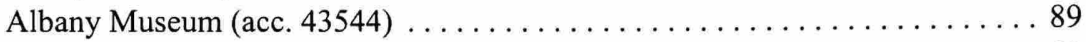

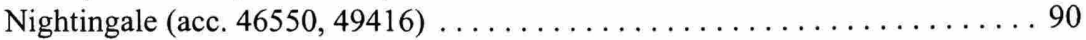

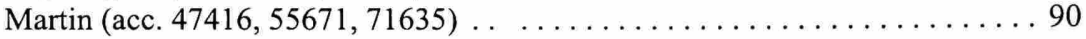

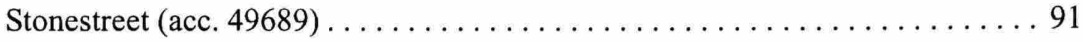

Musée d'Histoire Naturelle, Elbeuf (acc. 49696, 50268) . . . . . . . . . . . 91

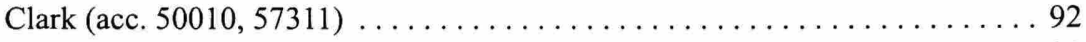

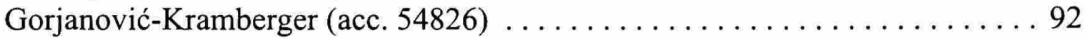

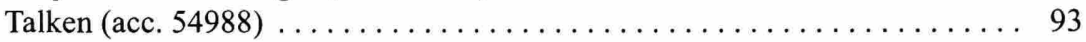

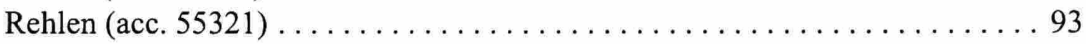

Stadtisches Museum (acc. 55436) . . . . . . . . . . . . . . . . 94

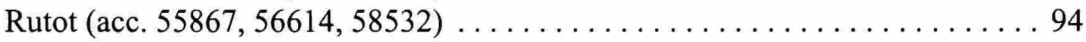

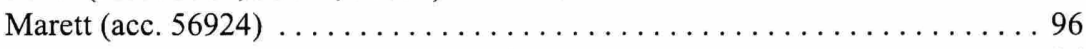

Naturhistoriska Riksmuseum, Stockholm (acc. 57262) . . . . . . . . . 96

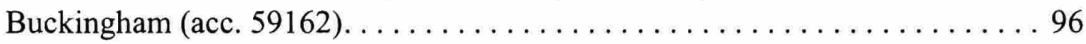

The Royal Ontario Museum of Archaeology (acc. 62402) . . . . . . . . . 96

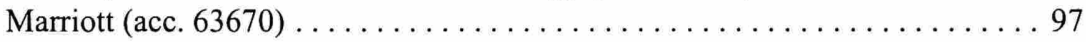

American Presbyterian Congo Mission (acc. 70046) . . . . . . . . . . . . . . . 97

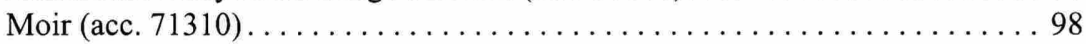

Hrdlička (acc. 71514, 89903) . . . . . . . . . . . . . . . . . 98

Archaeological Society of Washington and American School of Prehistoric

Research (acc. 84988, 90005, 98484, 95150, 95604, 103151, 107359,

$112197,115831,121286,126298,132332,133080) \ldots \ldots \ldots \ldots \ldots \ldots 98$

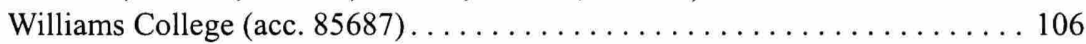

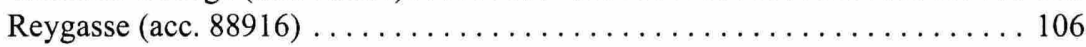

Government Museum, Madras (acc. 88426) . . . . . . . . . . . . . 108

Jones (acc. 89904) . . . . . . . . . . . . . . . . . . . . . . . . . . . . 109

Bodding (acc. 90169) . . . . . . . . . . . . . . . . . . . . 109

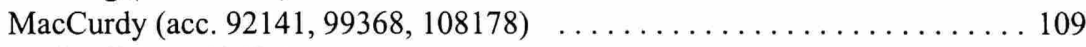

Bushnell (acc. 93521) . . . . . . . . . . . . . . . . . . . . . . . . . 109

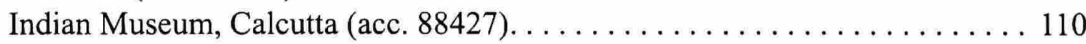

South African Museum (acc. 101485) . . . . . . . . . . . . . . . . . . 110

Provincial Museum, Czechoslovakia (acc. 107637) . . . . . . . . . 110

Russell and Old World Archaeology Fund (acc. 112339, 116916, 117631,

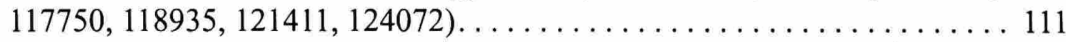

Serrano y Sanz (acc. 114125) . . . . . . . . . . . . . . . . . . . . . . 113

Bégouën (acc. 117494) . . . . . . . . . . . . . . . . . . . . . . . . . . . . 114

Abbott (acc. 124660, 128495, 134685, 140811, 150229) . ............ 114

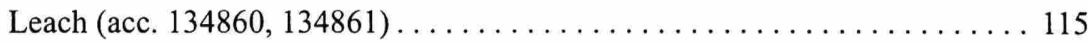

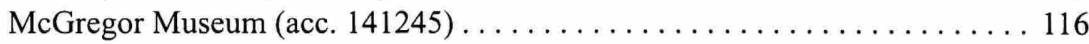

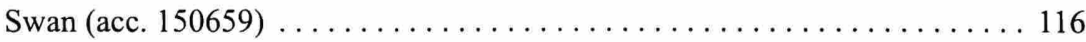

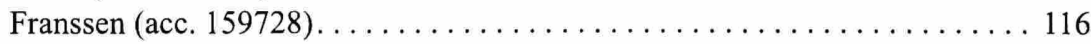


Reeves (acc. 170049) . . . . . . . . . . . . . . . . . . . . . . . . . . 117

Bruce Hughes Fund (acc. 177782) . . . . . . . . . . . . . . . . . . 117

Wymer (acc. 197463) . . . . . . . . . . . . . . . . . . . . . . . . . 117

Vass (acc. 197993) . . . . . . . . . . . . . . . . . . . . . 117

Bordes (acc. 213032) . . . . . . . . . . . . . . . . . . . . 117

Paige (acc. 214613) ............................... 118

Solecki (acc. 217009) ................................... . 119

Iraq Museum (acc. 220078) . . . . . . . . . . . . . . . . . . . 119

Government Museum, Madras (acc. 202973) . . . . . . . . . . . . . 123

Jones $($ acc. 249458) . . . . . . . . . . . . . . . . . . . . . . . 123

Uganda Museum (acc. 259009) . . . . . . . . . . . . . . . . . . 123

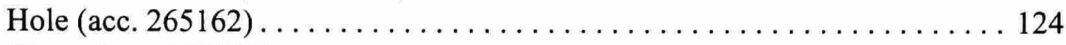

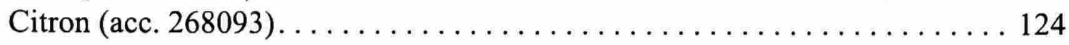

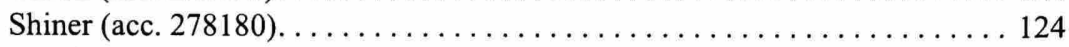

Muséum National d'Histoire Naturelle (acc. 295641) . . . . . . . . . . . . 125

Gibson (acc. 307731) . . . . . . . . . . . . . . . . . . . . . . . 125

Barbour (acc. 305126) .............................. 125

Lightner (acc. 316299) . . . . . . . . . . . . . . . . . . . . . . . 126

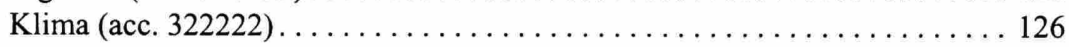

Institute of Vertebrate Paleontology and Paleoanthropology (acc. 323176) . . 126

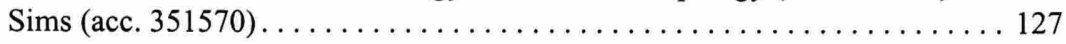

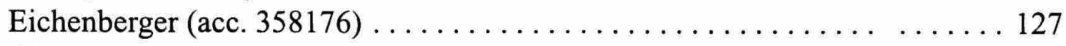

Old (acc. 387104) . . . . . . . . . . . . . . . . . . . . . . . . . . . . 129

Human Origins Program. . . . . . . . . . . . . . . . . . . . . . . . . . . 129

Kenya Collections ...................................... 129

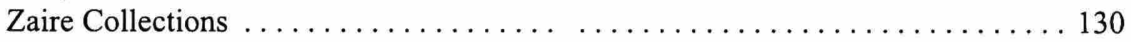

Botswana Collections................................ 130

Ethiopia Collections . . . . . . . . . . . . . . . . . . . . . . . . . 131

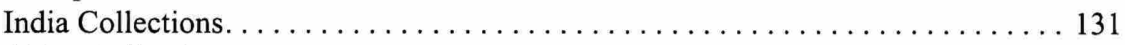

China Collections . . . . . . . . . . . . . . . . . . . . . . . 131

Concluding Remarks and Future Prospects $\ldots \ldots \ldots \ldots \ldots \ldots \ldots \ldots \ldots \ldots \ldots \ldots \ldots \ldots \ldots$

Appendix 1: Location of Correspondence ......................... 135

Literature Cited. . . . . . . . . . . . . . . . . . . . . . . . 143

\section{FIGURES}

Figure 1.-Example of an incoming letter of correspondence, from George Grant MacCurdy to Aleš Hrdlička, 23 September $1932 \ldots \ldots \ldots \ldots \ldots \ldots \ldots 2$

Figure 2.-Typical accession documentation for a collection $\ldots \ldots \ldots \ldots \ldots \ldots$

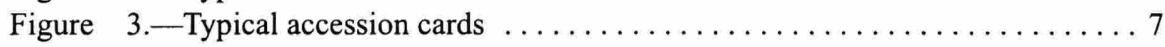

Figure 4.-Map of the Old World, showing the number of Paleolithic localities represented in the NMNH collections. ..................... 8

Figure 5.-Countries with the greatest number of Paleolithic localities represented

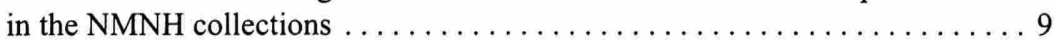

Figure 6.-Countries with the greatest number of Paleolithic artifacts in the NMNH collections . ............................. 9

Figure 7.- Number of Paleolithic artifacts accessioned by decade . . . . . . . 10

Figure 8.-Archaeological sites represented by the greatest number of artifacts in

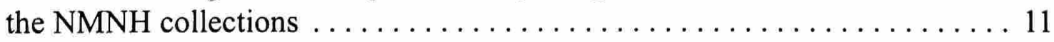

Figure 9.-Photograph of exhibits in the first Smithsonian museum ("the Castle"). . . 14

Figure 10.-Photograph of Thomas Wilson ........................ 16

Figure 11._Paleolithic "Chelléen" implements .................... 17

Figure 12.-Representation of the Neanderthal or Canstadt Race of Men. (The Chellean epoch of the Paleolithic Age.) . . . . . . . . . . . . . . . . 19 
Figure 13.- Representation of the Cro-Magnon Race of Men. (Cavern period of the

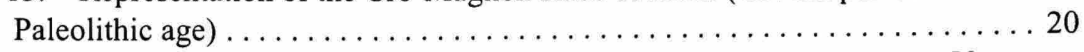

Figure 14.-Chipped quartzite implements of Paleolithic type, found at Mount Ver-

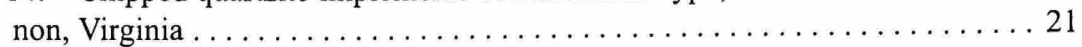

Figure 15 .- Shipping stamp on an incoming box $\ldots \ldots \ldots \ldots \ldots \ldots \ldots \ldots \ldots \ldots \ldots$

Figure 16.-Aleš Hrdlička seated at his desk, ca. 1930s . . . . . . . . . . . 24

Figure 17.-Photograph of M. Lesvignes taken at La Madeleine, France . . . . . . . 26

Figure 18.-Photograph taken at Laugerie Basse, France $\ldots \ldots \ldots \ldots \ldots \ldots \ldots \ldots$

Figure 19.-Photograph taken at Cro-Magnon, France $\ldots \ldots \ldots \ldots \ldots \ldots \ldots \ldots$

Figure 20.-Photograph taken at Laugerie Haute, France ................ 28

Figure 21.-Photograph taken at L'Abri du Chateau Les Eyzies, France . . . . . . . . 29

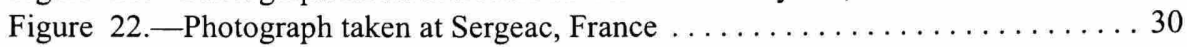

Figure 23.-Photograph taken at Laugerie Haute, France ................ 31

Figure 24.-A postcard of Castel-Merle, France, sent by MacCurdy to Hrdlička . . 33

Figure 25.- James Townsend Russell, Jr., pictured in the Binghamton Press, on 10

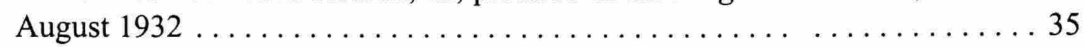

Figure 26.-T. Dale Stewart examining a Shanidar Neanderthal, $1958 \ldots \ldots \ldots 37$

Figure 27.-Exhibit in the National Museum of Natural History, $2001 \ldots \ldots \ldots 38$

Figure 28.- International research team directed by Richard Potts (Human Origins Program, Smithsonian Institution) at the Olorgesailie Prehistoric Site . . . . 39

Figure 29.-Excavation conducted by the Human Origins Program, Smithsonian Institution, of an elephant (Elephas recki) butchery site in Member 1 of the Olorgesailie Formation, southern Kenya ................. 40

Figure 30.-Smithsonian excavation at Kanjera North on the Homa Peninsula, western Kenya, a collaborative project of the National Museums of Kenya and the Human Origins Program, Smithsonian Institution ............. 41

Figure 31.- International team excavation at Katanda 2, in Zaire (now Democratic Republic of the Congo), directed by John Yellen (Human Origins Program, Smithsonian Institution, and National Science Foundation) $\ldots \ldots \ldots \ldots \ldots 4$

Figure 32.--International team excavation at Katanda 16, in Zaire (now Democratic Republic of the Congo), directed by Alison Brooks (Human Origins Program, Smithsonian Institution, and George Washington University) . . . . 43

Figure 33.- Joint excavation at the Lakhmapur locality, in the Malaprabha Valley, India, co-directed by Ravi Korisettar (Karnatak University, India) and Michael Petraglia (Human Origins Program, Smithsonian Institution) . . . . 43

Figure 34.- Joint excavation at the Isampur Site, Hunsgi Valley, India, co-directed by K. Paddayya (Deccan College, India) and Michael Petraglia (Human Origins Program, Smithsonian Institution) $\ldots \ldots \ldots \ldots \ldots \ldots \ldots \ldots \ldots 4$

Figure 35.-Excavation in the Bose Basin, Guangxi Zhuang Autonomous Region, People's Republic of China, co-directed by Huang Weiwen (Institute of Vertebrate Paleontology and Paleoanthropology, Academia Sinica, China) and Richard Potts (Human Origins Program, Smithsonian Institution) . . . . . 44

Figure 36.-Sagaies from La Madeleine, France $\ldots \ldots \ldots \ldots \ldots \ldots \ldots \ldots \ldots \ldots \ldots \ldots \ldots$

Figure 37.-Worked and incised bones, decorated sagaies from La Madeleine,

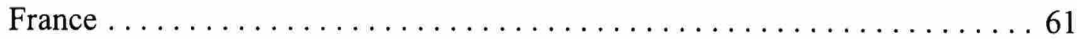

Figure 38.-Harpoons from La Madeleine, France .................. 62

Figure 39.-Drawing of Baton de Commandement from La Madeleine, France . . . . 62

Figure 40.-Worked antler with horse engraving from La Madeleine, France . . . . . 63

Figure 41.-Burins and composite burin-scrapers from La Madeleine, France . . . . . 63

Figure 42.-Antler from Cro-Magnon, France $\ldots \ldots \ldots \ldots \ldots \ldots \ldots \ldots \ldots \ldots . \ldots \ldots$

Figure 43.-Drawing of worked antler from Le Moustier, France . . . . . . . . . 64

Figure 44.-Worked bone from Massat, France $\ldots \ldots \ldots \ldots . \ldots 6$

Figure 45.-Worked stag antler from Massat, Ariège, France . . . . . . . . . . . 65

Figure 46.- "Mortar" from La Madeleine, France $\ldots \ldots \ldots \ldots \ldots \ldots \ldots \ldots \ldots 6 . \ldots \ldots$

Figure 47.-Horse skeletal elements from Solutré, France $\ldots \ldots \ldots \ldots \ldots \ldots 66$ 
Figure 48. - Handaxes from Thetford, England . . . . . . . . . . . . . . . 67

Figure 49.-Handaxes from St. Acheul, France $\ldots \ldots \ldots \ldots \ldots \ldots \ldots \ldots \ldots \ldots \ldots$

Figure 50.-Solutrean points, scrapers, and burins from Laugerie Haute, France . . . 71

Figure 51.-Worked bone, sagaie, and harpoon from Laugerie Basse, France . . . . . 72

Figure 52.-Needle fragments from Laugerie Basse, France .............. 72

Figure 53.-End-scrapers, burinated scrapers, and gravers from Laugerie Basse,

France .................................... 73

Figure 54.-Drawings of worked bone from Rossignol, France . . . . . . . . . . . . 74

Figure $55 .-$ Cave bear coprolites from a cave near Pisa, Italy $\ldots \ldots \ldots \ldots \ldots \ldots 75$

Figure 56.-Drawings of worked bone and photograph of splintered antler from Laugerie Haute/Basse, France. . . . . . . . . . . . . . . . . . . . 78

Figure 57.—Drawings of worked bones from Solutré and La Madeleine, France . . . 79

Figure 58.-Drawings of worked bone awls from unknown location, France . . . . 880

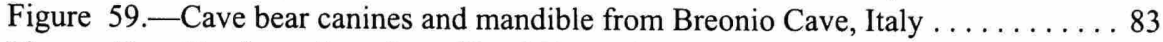

Figure 60. -Handaxes from Somaliland [Somalia] .................. 86

Figure $61 .-$ Handaxes from Penaar River valley, India . . . . . . . . . . . . . . 87

Figure 62.-Hyaena mandible and gnawed bones from Kent's Cavern, England . . . . 89

Figure 63.-Handaxes from Rephaim, Palestine ..................... 92

Figure 64.-Handaxes from Windsorton, South Africa ................ 93

Figure 65.-Handaxes from Templeux Le-Guerard, France . . . . . . . . . . . . 95

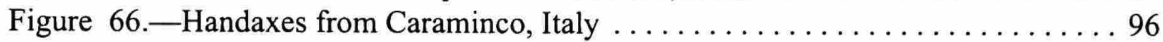

Figure 67.-Handaxes from Maidenhead, England ................. 97

Figure 68.-Photograph of an excavation at Foxhall pit near Ipswich, England . . . . . 99

Figure 69.-Photograph of the Foxhall pit near Ipswich, England $\ldots \ldots \ldots \ldots \ldots$

Figure 70.-Cross section of Abri des Merveilles excavations . . . . . . . . . 101

Figure 71.-Scrapers from Abri des Merveilles, France .............. 102

Figure 72.-Long-bone fragments and split long-bone shaft from Abri des Mer-

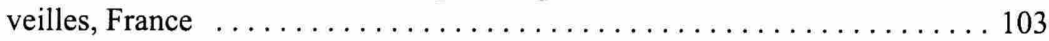

Figure 73.-Cleavers and hammerstone from Abri des Merveilles, France . . . . . 104

Figure 74.-Point, perforators, scrapers, and core from Kebara, Palestine . . . . . 105

Figure 75.-Scrapers from Mugharet es-Skūhl, Palestine . . . . . . . . . . . . 106

Figure 76.-Photograph of the Mugharet et-Tabūn excavations . . . . . . . . 107

Figure 77.-Chopper, discoid, side scraper, handaxe, points, and graver from

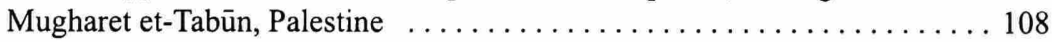

Figure 78.-Cores, handaxe (cleaver), and handaxe from Montagu Cave, South Af-

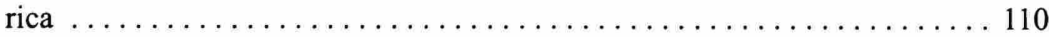

Figure 79.-Handaxe from Meyral, France $\ldots \ldots \ldots \ldots \ldots \ldots \ldots \ldots \ldots \ldots \ldots \ldots \ldots \ldots$

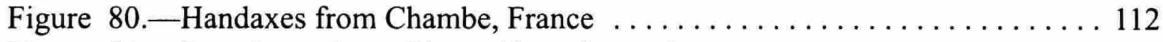

Figure 81.-Drawings of two flint artifacts from Chambe, France . . . . . . . . 112

Figure $82 .-$ Cross section of the Marsoulas excavations $\ldots \ldots \ldots \ldots \ldots \ldots \ldots \ldots 113$

Figure 83.—“Artist's Palette" from Tarté, France .................. 113

Figure 84.-Handaxes from Swanscombe, England ................ 115

Figure 85.-Handaxes and discoid from Klippies Pan, South Africa . . . . . . . 116

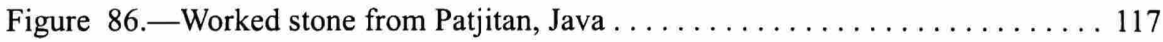

Figure 87.-Photograph of François Bordes replicating stone-tool manufacture . . 118

Figure 88.- Photograph of T. Dale Stewart meeting with Dr. Naji al Asid from

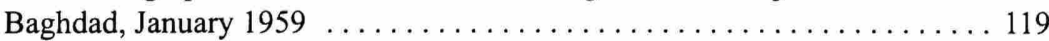

Figure 89.-Cross section of Shanidar excavations .................. 120

Figure 90.-Photograph of Ralph Solecki and a Kurdish woman excavating skeleton of a child found in Mousterian deposits in Shanidar Cave, Zagros Mountains, Valley of the Great Zab River, northern Iraq $\ldots \ldots \ldots \ldots \ldots \ldots 121$

Figure 91.-Drawing of animal bones overlying Neanderthal skeleton no. 1, and showing areas of soil samples for botanical analysis . . . . . . . . . 122

Figure 92.-Carinated burins, Baradostian burin, and cores from Shanidar Cave,

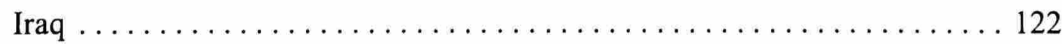


Figure 93.-Bifaces from Nsongezi, Uganda $\ldots \ldots \ldots \ldots \ldots \ldots \ldots \ldots \ldots \ldots \ldots$

Figure 94.-Points, scrapers, and side scrapers from Gar Arjeneh, Iran . . . . . . 125

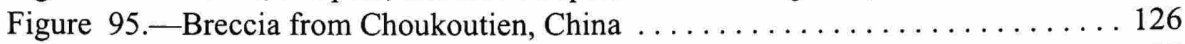

Figure 96.-Handaxes from Sebha, Libya . . . . . . . . . . . . . . . . . 127

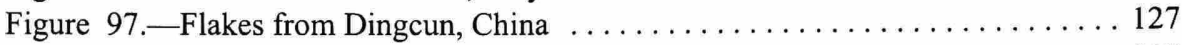

Figure 98.-A discoid and three handaxes from Fjaje, Jordan $\ldots \ldots \ldots \ldots \ldots 128$

Figure 99. - Scrapers from Qasr Kharanah, Jordan .................. 128 


\title{
Foreword
}

\section{The Paleolithic in America, A Preamble to the "Excavation" of a Great Museum}

\begin{abstract}
Although perhaps a platitude, it is nonetheless true to state that much of the world's prehistoric archaeological heritage already resides in museums. Paleolithic research (viz., digging) has been going on for more than 170 years, particularly in western Europe. Whereas artifacts and bones are not infinite resources - any more than fossil fuels or minerals - and whereas potentially recoverable, in situ remains are strictly limited in quantity, extant museum collections must be regarded as representing a not insignificant proportion of the universal cultural patrimony of humankind's past. Although it is easy to bemoan the frequent lack of specific provenience information, the biased collection and curation practices of the past, and other acknowledged flaws attendant upon many museum collections, a more constructive approach is to devise methods for extracting information about the prehistoric condition from these otherwise lifeless, often forgotten archaeological resources.
\end{abstract}

Before major museum holdings can be seriously studied they must be systematically organized. This immense (and generally thankless) task involves not only the formal compilation of inventories, verification of proveniences, afixing of labels, and securing storage locations, but also the gathering, sorting, preservation, and analysis of related archival documentation (field notes, correspondence related to donations, publications, graphic and photographic evidence, etc.). This groundwork literally enables the fullest degree of archaeological analysis of the objects themselves, by providing the essential contextual information (including not only historical background and provenience data, which are not always self-evident, but also indications of potential collection biases). This is the difference between active and passive curation of museum holdings: scholarship versus mere custodianship. Thus, organizing old museum collections of archaeological materials of any substantial quantity requires a major institutional commitment and a significant, longterm effort. Such a commitment was made by Richard Potts when he became Curator of Hominid Evolution Research at the Smithsonian Institution's National Museum of Natural History (NMNH) - laudably supported by the administration of the museum. Such an effort has been made by Michael Petraglia, first as a postdoctoral fellow and later as a research associate at the NMNH, ably assisted by museum research and technical staff members. The first fruits of the "organization" or "active curation" of the NMNH paleolithic collections was a series of articles by Petraglia, Potts, and others on some of the French collections. The major material result of their commitment and effort, however, is this book, a catalog of the Old World paleolithic materials in the NMNH, which will certainly facilitate further studies and analyses of the museum's collections. Furthermore, this study of the collections adds to our store of knowledge: portions of the collections are reported or described for the first time, whereas other portions are redescribed after years of silence since their initial and generally only preliminary publication. Further work is planned by the authors and hopefully others will join in, as there is material for many kinds of analyses.

Once the collections are organized and their significance highlighted, then it becomes clearer how the judicious application of modern analytical methods (e.g., radiocarbon dating - especially by accelerator mass spectrometry-isotopic, trace element, pigment, and residue analyses, paleontological identification, archaeozoological study, lithic microwear analysis) can extract information from seemingly marginal or apparently worthless ob- 
jects. It is true, sadly, that many things (e.g., lithic débitage technological analyses, spatial analyses, economic anatomical element analyses of animal carcasses, diachronic assemblage composition analyses requiring fine chronological control) cannot be done with old museum collections, but many others can and indeed, given the shrinking archaeological resource base in the field for especially the most ancient periods, must be done. Even if a site represented in a museum only provides a dot on a map with which can be associated an approximate age based on a temporally diagnostic artifact or a radiometrically dateable bone, this can be potentially important, as the site may have been lost or destroyed since the time of original recovery. Once properly organized, a museum's archaeological holdings may not only be "mined," they can be "excavated."

Such was our experience with often-cited, but inadequately published sites in the foothill region of the French central Pyrenees, represented by important collections in the NMNH that were made through excavations in 1931 by J. Townsend Russell (an honorary Research Collaborator of the former U.S. National Museum) and Count Henri Bégouën (Professor of Prehistory at the Université de Toulouse). Among these collections are rare and spectacular antler points (sagaies), modified fossil shells, and works of engraved and pigmented antler and bone "portable art" from the rupestral art cave site of Marsoulas. They also include breccia samples from the nearby site of Tarte (described in the excavators' reports (Russell, 1932; Bégouën and Russell, 1933). Surprisingly two of the breccia samples have a radiocarbon date of 20,000 BP. The date confirms the presence of a Solutrean occupation at Tarté. This occupation is, in addition to the better-known Aurignacian one, well represented by classic artifacts in the NMNH collection that add significant data to the rather poor early Upper Paleolithic record from the French Pyrenean region. Although Russell and Bégouën found no Solutrean points in the remnant breccias along the rock face at Tarté, there are old references to such discoveries at that site (see references in Bahn (1984:222)), but none have ever been analyzed or formally published (not even by P.E.L. Smith (1966) in his monumental study of the Solutrean in France) as they apparently had been lost. Thus, the Smithsonian's radiocarbon dates for the bone, charcoal, and artifact-containing lumps of breccia constitute the next-best-thing in terms of pinpointing human settlement along the northern flank of the central Pyrenees during the height of the last glacial maximum. Solutrean sites (especially ones that have been excavated using modern methods) along the edges of the Pyrenees are very scarce and radiocarbon dates are virtually absent, so the Smithsonian evidence is all the more valuable. They also help to shed light on the known Solutrean occupation of the adjacent localities of Roquecourbère-which are represented in the NMNH holdings by materials from a quarry-workshop site (a type of site often ignored in the classic literature). These data, combined with those from other sketchily known find spots, indicate there was a definite "concentration" of Solutrean sites in the area of the Salat-Garonne confluence. This cluster matches other, rather similarly isolated concentrations at the western and eastern ends of the Pyrenees (Straus, 1991). It could be hypothesized that these site clusters represent Solutrean band territories. Thus, after residing for more than 70 years in a drawer in the NMNH, the lumps of Tarté breccia have finally provided valuable information about the pleniglaical distribution of humans in southwestern Europe- - even if many details have forever been lost.

Furthermore, comparative analyses of ochre pigments in the collection from the important archaeological site in Marsoulas (which is almost certain to include a Middle Magdalenian component, based on some lithic tools and antler point styles) and of ochre paintings on the walls of the same cave could be critical to the dating of the rupestral art and to placing it in relationship to human settlement. The artists could potentially be shown to have left behind their materials on site. This would be very much along the lines of the pigment research that has recently managed to relate distinctive "recipes" at the nearby living and art cave sites of La Vache and Niaux in the Ariège uplands and at the adjacent Volp Caves of Enlène (habitation site) and Les Trois Frères (art site) in the lowlands near Marsoulas (Clottes, 1997). Certainly the presence of an "artist's palette" at nearby Tarté (Petraglia et al., 1992) is germane to pigment-related activities at both it and Marsoulas. 
Quite independent of our NMNH work, a study of French and American collections from the Ariège sites is underway (Foucher and San Juan, 2000a, 2000b). Thus, we are likely to soon learn even more about these often-cited but insufficiently described sites in the vicinity of such famous neighbors as the Volp and Lespugue Caves, Mas d'Azil, Montespan, and Le Portel.

\section{A History of Prehistory: Writ in Stone, Bone and Bundles of Letters}

This book contains a microcosm of major chapters in the history of prehistoric investigations in the Old World, as reflected across the Atlantic, especially in the age of steamship travel (one of the great international artifact collectors, Sir Henry W. Seton-Karr, went down with the RMS Empress of Ireland, a major maritime disaster second only to the Titanic!), courtly correspondence, honorary appointments, crates of "paleoliths" and bones (some requiring two men to lift), and artifact exchanges and purchases to "fill gaps"hopefully with "quality material." It is absolutely fascinating to read the correspondence assembled by Petraglia and Potts between Smithsonian administrators and central figures investigating paleolithic prehistory, such as Edouard Lartet, William Pengelly, Denis Peyrony, Henri Martin, D. Karl Gorjanovic-Kramberger, J. Reid Moir, A.L. Rutot, Karl Absolon, and Jesús Carballo. The importance of the "type" concept comes to life, for example, in many of the letters. "Typical" pieces were most sought-after, whereas duplicates were given away as exchanges, and bone and tooth fragments and even "minimally used stone hammers" were simply "culled" (discarded) from the collections. There also is some degree of shock in reading how some great prehistorians needed to sell artifacts to make ends meet, and antiquarians dangled the prospect of donations (which sometimes actually became sales) to obtain official appointments or at least honorific titles at the Smithsonian. The line between good prehistorians and professional looters (such as Otto Hauser) seems to have been a fine one at times.

The use of the famous Piney Branch quarry in Washington, D.C., as a kind of mine for items to be exchanged for real "paleoliths" is a fascinating story (Holmes, 1890, 1897). It resembles the common European practice in the nineteenth and early twentieth century by which prehistorians disposed of surplus or duplicate materials from the principal sites at which they dug or collected, in order to obtain "representative" samples from other sites being "exploited" by their confrères. For example, the collections of Guy Magnant contain many artifacts from the sites of Le Placard and Le Petit Puymoyen in Charente at which he personally "dug" in the early 1910s and 1920s; in addition, his collections contain single or small numbers of "typical" artifacts from many classic sites, especially those of Peyrony's "fief" around Les Eyzies, Dordogne (Straus, 1985). Thus, even as late as the 1930s the field of archaeology had yet to adopt the concept of artifact assemblages. For that development we owe a great debt to the late François Bordes and others of the post-World War II generation of prehistorians.

In recent years, like other fields, paleoanthropology has entered a self-reflective phase, paying serious attention to its roots and development. This is perhaps best manifested by American publications by such authors as D. Grayson (1983, 1990), J. Sackett (1981, 1991), A.B. Van Riper (1993), M. Landau (1991), F. Spencer (1990), L. Straus (1994, 1996), and E. Trinkaus and P. Shipman (1992). The NMNH collections brought to these shores the artifacts of many of the great epochs and events in the history of Old World (especially European and Near Eastern) prehistory: the establishment of human antiquity, the development of competing chronological periodization schemes (G. de Mortillet's typesite, type-artifact scheme versus the paleontological fossiles directeurs schemes of $\mathrm{E}$. Lartet and E. Piette), the "eolithic" controversy, the Moulin-Quignon fraud, the debate concerning the place of the Neanderthals in the evolutionary trajectory of humankind, the construction of universal cultural evolutionary stages based on sweeping inter-continental artifact comparisons, etc. Prehistoric discovery and polemic were made tangible, despite great physical distance, by means of collections. These were being acquired by American 
institutions almost from the inception of such research in western Europe, especially France.

The primacy of France in the American view of Old World paleolithic prehistory, both in terms of acquisitions and in terms of where Americans (such as George Grant MacCurdy) went to excavate, was established early and has been enduring. This Francocentric perspective came at the expense of not only other (nonetheless archaeologically well-endowed) European countries (such as Spain, whose only artifact collection in the NMNH is a small, poorly documented group of "Precapsian" pieces from a Madrid area sandpit), but also Africa and East Asia. The social, cultural, and economic reasons for American collecting in and archaeological relations with France deserve further scholarly treatment. It is clear, however, that as a result of this tradition, the American view of the Paleolithic was, until recent years, conditioned by a very narrow spectrum of direct experience- especially in the Aquitaine region of "la belle France." Clearly, a major secondary collection focus in the twentieth century had been on the Holy Land and, by extension, the Near East, which was perceived as a critical cultural crossroads. The ability to expand the museum's holdings in this region was facilitated by complacent colonial and early post-colonial governments.

Through purchases, gifts, and exchanges, the Smithsonian Institution came to possess either original artifacts ("duplicates," which were traded about like modern-day baseball cards) or casts, which allowed it and, by extension, the United States, to share in such seminal discoveries as Lartet's and Peyrony's in the Vézère valley, Pengelly's at Kent's Cavern, Henri Martin's at La Quina, or Edouard Dupont's in the Meuse valley of southern Belgium. They don't get any more classic than these!

\section{An American Enterprise}

Although on a scale far less grand than that of the British Museum (the great institution of another country which lacked at least the great wealth of Upper Paleolithic France, but which sought to remedy that condition by fabulous early acquisitions from "perfidious Gallia"), the museums of the United States and Canada actively engaged in paleolithic collection acquisition throughout the late nineteenth and early twentieth centuries. In this effort, the Smithsonian,s National Museum of Natural History was by no means alone; the Field Museum of Natural History in Chicago, the Peabody Museum of Harvard University, the American Museum of Natural History in New York, the Logan Museum of Beloit College, the Royal Ontario Museum in Toronto, among others, all acquired significant Old World-especially French-collections. A few significant individuals (Henry Field, Henri Ami, and even Henri Breuil) were instrumental in bringing major collections to America in the period before national and international antiquities laws ended such massive commerce. Many American (and British and other) museums, universities, and colleges financially participated in this process, and 40 (!) such shared in the spoils (directly or indirectly through re-sales or exchanges) of Dorothy Garrod's monumental excavations in the caves of Mount Carmel (then Palestine). This arrangement (which seems strange, if not outrageous, from today's viewpoint, as it resulted in the far-flung dispersion of the collections, making their comprehensive restudy virtually impossible) is fully (and gratefully) described by Garrod in the preface to volume 1 of The Stone Age of Mount Carmel (Garrod and Bate, 1937), the foreword of which was written by George Grant MacCurdy.

The United States, as "officially" represented by the Smithsonian Institution (through the former U.S. National Museum), was becoming institutionally committed to paleolithic research throughout the last third of the nineteenth and the first third of the twentieth centuries. Its first agents often were members of the consular corps, as documented in this book, not only in the curious figure of Thomas Wilson, but also many other consuls in the years after the large Wilson donation/loan/deposit/sale. This phenomenon also followed a time-honored European custom, namely that of consuls (mainly British and French) acquiring Greek, Egyptian, and Mesopotamian antiquities for such venerable institutions 
back home as the British Museum and the Louvre.

The Smithsonian-sometimes in alliance with other American institutions, such as Yale University or the Archaeological Society of Washington, and their creations, the American School of Prehistoric Research or the Franco-American Union for Prehistoric Research- eventually went further by actually conducting or participating in excavations, notably through the efforts of J. Townsend Russell (see above) and Professor MacCurdy of Yale. The latter can be considered the first American professional paleolithic archaeologist. MacCurdy's most significant material contribution to the NMNH holdings is the substantial collections from his 1925-1930 excavations at Castel Merle, under the auspices of the American School (MacCurdy, 1931).

This book also documents the diligent (often difficult) work of Aleš Hrdlička-the "Father of American Physical Anthropology"- to keep both himself and the Smithsonian upto-date with developments in Old World prehistory and human paleontology. Keeping the institution's "finger in" significant paleolithic research meant that MacCurdy and Hrdlička conspired to assure that the American School's representative in Garrod's Mount Carmel expedition, Berkeley Professor Theodore McCown, would have co-authorship of the study of the hominid discoveries. (This new Smithsonian interest in Near Eastern hominid evolution would continue in the 1950s-1970s, with T. Dale Stewart's study of the Shanidar Neanderthals.) By the 1930s, the United States and the Smithsonian were no longer content to be passive observers, purchasers, and donees of materials discovered by Europeans. The NMNH was a center of human evolutionary research in the United States. This research was of course interrupted by World War II but resumed after 1945, just as the acquisition of Old World paleolithic objects by U.S. institutions came to a virtual halt, as a consequence of the end of colonialism in the Third World and the enforcement of strict antiquities laws throughout much of the world. Significant exceptions include collections made in Jordan by the famous Biblical archaeologist Nelson Glueck of Hebrew Union College, and at Shanidar and Zawi Chemi Shanidar (Iraq) by Ralph Solecki of Columbia University. In general, however, new data and ideas - not artifacts per se-would flow back to the U.S., as American researchers took or shared the lead in prehistoric investigations throughout much of the Old World and as a major shift in human evolutionary studies toward Africa occurred (as witnessed by the NMNH focus of the Human Origins Program under Potts).

\section{Concluding Remarks}

This book, with its dual focus on archival and artifactual materials, represents a first major step in highlighting and, hence, making accessible the vast and important paleolithic holdings of the Smithsonian's National Museum of Natural History. It is itself, like the collections, a mine of information. Petraglia and Potts have done a thorough job, but it is just the beginning. Now these once forgotten collections must be classified, studied in context, analyzed to the hilt in light of contemporary research questions, and then published in detail. One can hope that similar books will be forthcoming, not only from other American museums, but also from European institutions. Such work has already begun at the British Museum, for example, with A. Sieveking's (1987) catalog of portable art objects, J. Cook and H. Martingell's (1994) book on Stone Age artifacts from India, and Peter Mitchell's (2002) study of its Southern African holdings. Just as archaeologists worldwide are making inventory of the (dwindling) list of surviving sites, so must we also take stock of the prehistoric cultural resources that lie neglected in our great museums.

Lawrence Guy Straus

Department of Anthropology

University of New Mexico

Albuquerque, New Mexico 87131 


\title{
The Old World Paleolithic and the Development of a National Collection
}

\author{
Michael Petraglia and Richard Potts
}

\section{Introduction}

During the summer of 1987 , the authors began a collaborative study of Paleolithic site formation as part of Petraglia's Smithsonian postdoctoral fellowship. During our research, we wondered whether the National Museum of Natural History's (NMNH) collection of stone tools had any pertinent research value for examining our topic. Because little was known about the nature of the museum's Paleolithic collections, storage units holding the collections were inspected during one afternoon in 1988. To our delight, review of the storage units and drawers indicated that sizeable Lower, Middle, and Upper Paleolithic assemblages were indeed present. Further review indicated that the collections were from many sites in various regions of the Old World. It was quickly realized, however, that the assemblages were biased towards objects from classic localities in western Europe, mainly France and England, and the Mount Carmel sites in Palestine (now Israel). Many typical items, such as chipped-stone artifacts, were abundantly represented, among them Lower Paleolithic bifaces, Middle Paleolithic flake tools and bifaces, and Upper Paleolithic blade tools. More rare French Upper Paleolithic objects also were identified, including stone mortars from the classic type site of La Madeleine, an artist's palette from the cave of Tarté in the Pyrenees, and a variety of worked bones from both the Périgord and Ariège regions, such as needles, sagaies, and harpoons, and a variety of faunal remains. We soon realized that some collections were devoid of certain tool classes, and others only contained single items from certain sites. Yet others were far more substantial, with some storage units and drawers containing numerous objects from single sites, especially from France

Michael Petraglia, Leverhulme Centre for Human Evolutionary Studies, Downing Street, University of Cambridge, Cambridge CB2 3DZ, England. Richard Potts, Department of Anthropology, National Museum of Natural History, Smithsonian Institution, Washington, D.C. 20560-0112. and Palestine. Therefore, it was surmised that some collections represented sufficient samples of "excavated" sites, not just small collections or single artifacts. Although we did not include the NMNH collections in our study of site formation, we realized that the Paleolithic assemblages were substantial and had potential research value. We also surmised that other researchers may wish to know about the NMNH collections.

Although the "rediscovery" of these collections was fortunate, equally important was the related correspondence in the Smithsonian Archives (Figure 1). These letters were a crucial aspect of the research, as they shed light on the motivations and methods of nineteenth- and early twentieth-century museum professionals, Paleolithic prehistorians, and avocational workers from around the world. We therefore considered this to be an opportunity to detail the involvement of numerous persons and institutions in the development of Old World Paleolithic archaeology. The preservation of the artifact collections and the related archival correspondence provided the vehicle to examine these historic developments. Moreover, the collections provided the potential to conduct scientific re-examination, although it was realized that topics would need to be specifically tailored to the condition of the assemblage in question.

As background to our museum research, researchers have increasingly recognized the need to study the history of archaeology and paleoanthropology. Books and articles have been devoted to the development of archaeology as a scientific discipline (i.e., the methods, techniques, and types of interpretation) (Daniel, 1975; Willey and Sabloff, 1993) and the cultural and social milieu in which the subject was born and evolved (e.g., Trigger, 1989; Patterson, 1995). Related to our topic, researchers have specifically examined the rise and development of Old World archaeology and the growth of anthropological museums (e.g., Sackett, 1981; Grayson, 1983; Trigger, 1989). Historical accounts of Old World archaeology clearly demonstrate that many important Paleolithic localities were excavated by professional and avocational investigators 


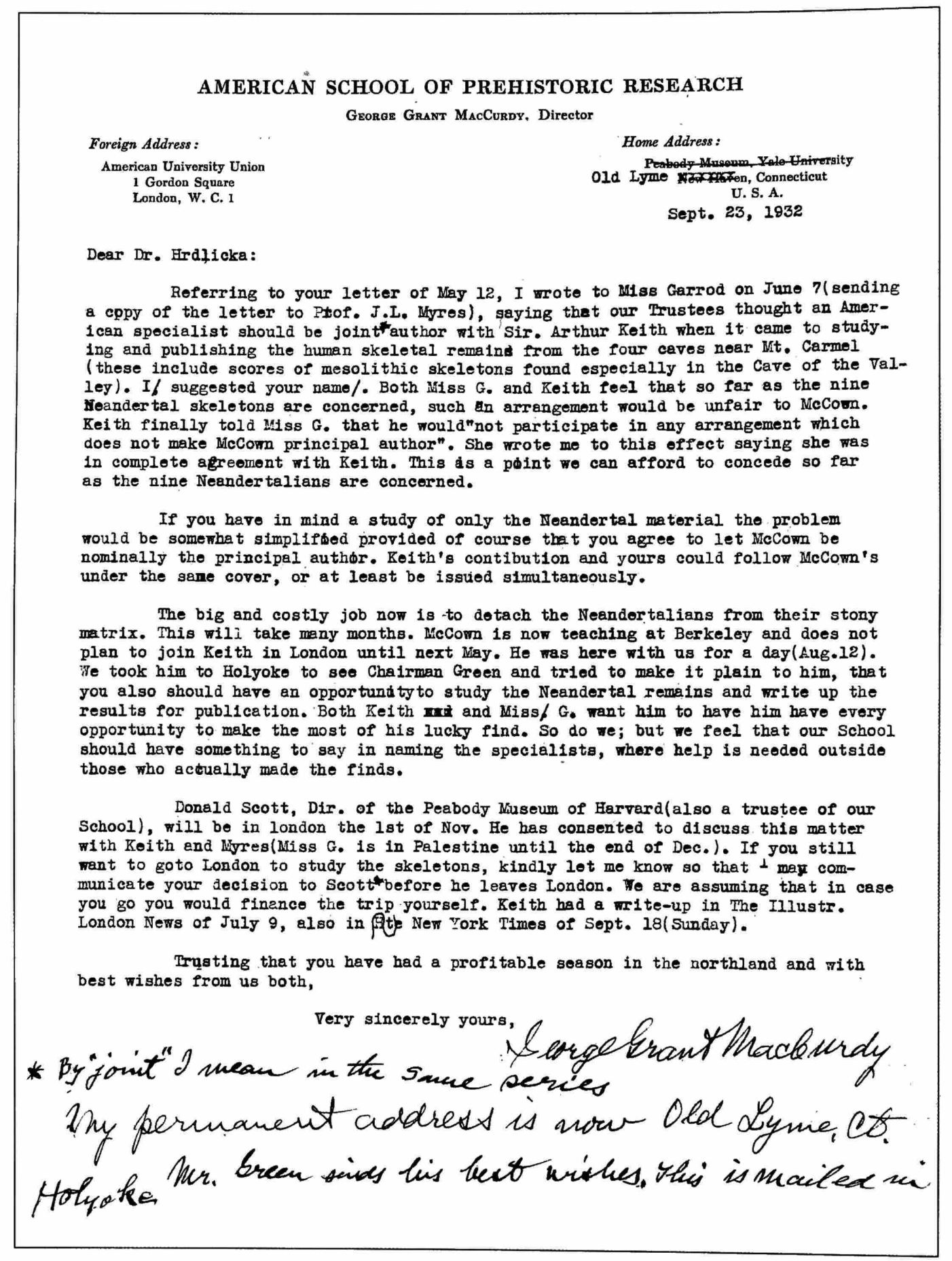

FIGURE 1.-Example of an incoming letter of correspondence, from George Grant MacCurdy to Aleš Hrdlička, 23 September 1932. [In this case, the letter is an original type-written example, whereas others often are handwritten or a carbon-copy.]

during the nineteenth and early twentieth centuries. Significant artifacts often became part of private collections; others went to museums and universities throughout North America. Given that many important sites were excavated and assemblages widely distributed to many institutions, there has been a need to document the existence and location of these significant and often extraordinary Old World collections (e.g., Bahn and Cole, 1986; Simek, 1986; White, 1986a, 1986b, 1988; White 


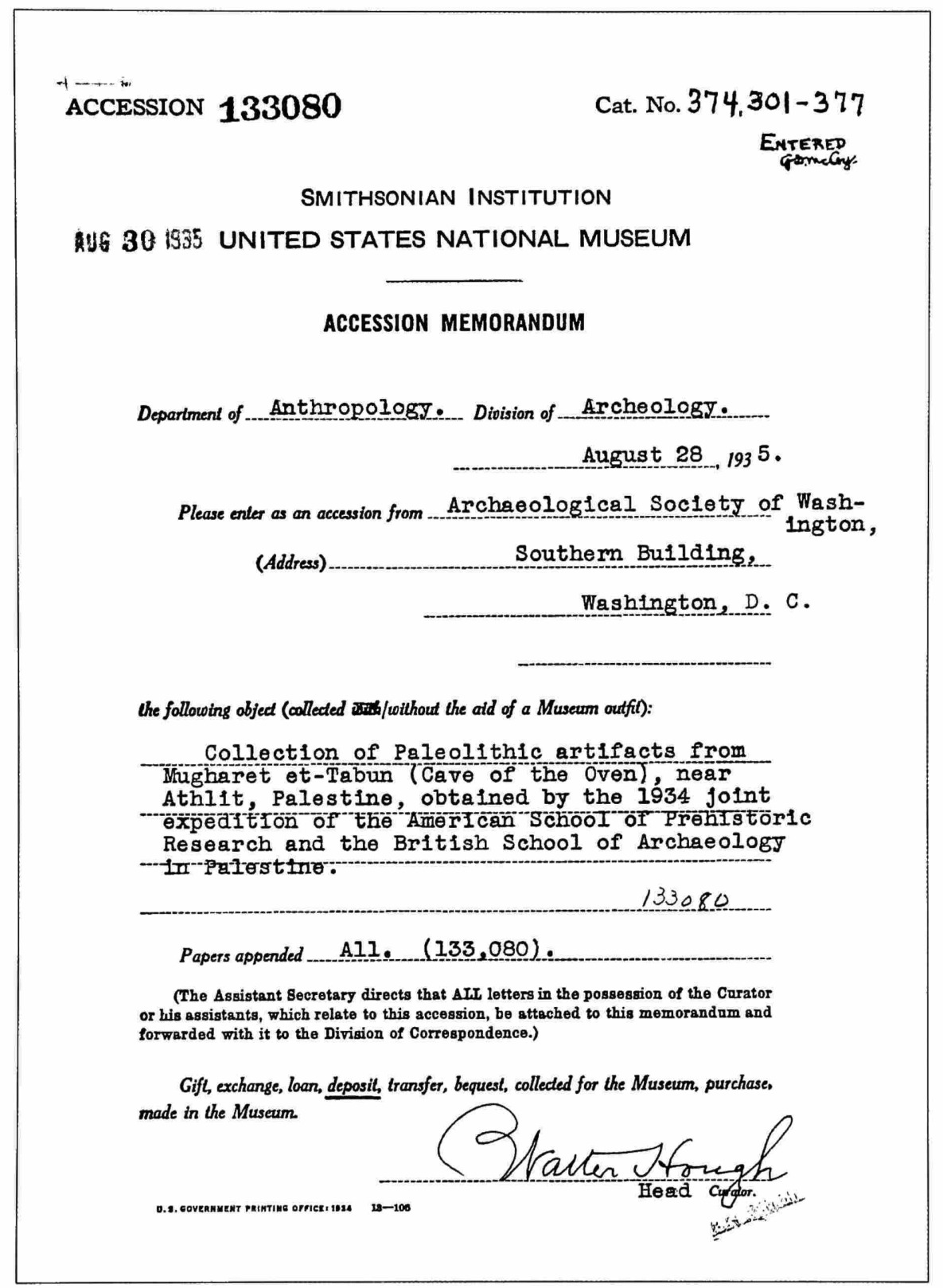

FIGURE 2.-Typical accession documentation for a collection [accession 133080].

and Breitborde, 1992; Straus, 1996).

Our work represents a historical overview of the development of the Old World Paleolithic collections curated in the Smithsonian Institution (Table 1). In compiling this book, two goals of the project were formulated: (1) to document the existence of the collections and to create an inventory of accessions by provenience and artifact types; and (2) to more closely relate archival and accession information in order to indicate why and how the collections were acquired. With respect to the first aim, artifact accession counts have been organized by geo- graphic location and site provenience (Figure 2). Thus, for the first time, this book centrally codifies the provenience, nature, and size of the Paleolithic collections. For the second goal, the original collection-related correspondence and artifact inventories in various Smithsonian archives were reviewed to provide a history of the activities of institutions and persons involved in the transactions. The archival material ranged from the first recorded transaction in 1869 to the most recent accession as of 1990 , a period of 121 years. Because we refer extensively in the text to archival letters and memoranda, Appendix 1 pro- 
TABLE 1.-Important events in the development of the Old World collections at the Smithsonian Institution.

\begin{tabular}{|c|c|}
\hline Year & Event \\
\hline 1846 & Smithsonian Institution established by the United States Congress; Joseph Henry appointed first Secretary. \\
\hline 1869 & First Paleolithic accession, from French prehistorian Edouard Lartet. \\
\hline 1883 & $\begin{array}{l}\text { The Department of Ethnology (led by Otis Mason) and the Department of Antiquities (led by Charles Rau) were estab- } \\
\text { lished. }\end{array}$ \\
\hline 1887 & Thomas Wilson appointed administrator and then curator of the Department of Prehistoric Anthropology. \\
\hline 1896 & Wilson published a major work, "Prehistoric Art...," in the Annual Report, U.S. National Museum. \\
\hline 1902 & Wilson died, and in 1904 his collections were purchased by the Smithsonian for $\$ 2,650$ [about $\$ 61,426$ in 2003 dollars]. \\
\hline 1897 & William H. Holmes appointed as head curator of the Department of Anthropology. \\
\hline 1903 & Holmes hired Aleš Hrdlička and the new Division of Physical Anthropology was established. \\
\hline 1918 & Hrdlička founded the American Journal of Physical Anthropology. \\
\hline 1922 & $\begin{array}{l}\text { Hrdlička became a member of the board of directors of the "American School in France of Prehistoric Studies" at the invi- } \\
\text { tation of Charles Peabody and George Grant MacCurdy of Yale University. }\end{array}$ \\
\hline 1923 & Hrdlička became Director of the American School for the 1923 season; traveled extensively with students in Europe. \\
\hline 1924 & $\begin{array}{l}\text { Hrdlička received permission from Denis Peyrony to conduct excavations at Sergeac, France, and secured funding from a } \\
\text { trustee of the Archaeological Society of Washington to conduct excavations at Abri des Merveilles, France. } \\
\text { T. Dale Stewart hired as temporary aide to Hrdlička. }\end{array}$ \\
\hline 1925 & $\begin{array}{l}\text { Substantial collections from Abri des Merveilles, France, were first accessioned and deposited by the Archaeological So- } \\
\text { ciety of Washington and the American School. } \\
\text { J. Townsend Russell enrolled as a student of the American School, became a trustee of the school in } 1926 .\end{array}$ \\
\hline 1926 & "American School of Prehistoric Research" was incorporated in Washington, D.C.; Hrdlička named as a trustee. \\
\hline 1927 & Hrdlička published the influential article, "The Neanderthal Phase of Man." \\
\hline 1928 & $\begin{array}{l}\text { Joint excavations conducted in Iraq with the British School of Archaeology in Jerusalem. } \\
\text { Russell named temporary assistant in archaeology at the Smithsonian. }\end{array}$ \\
\hline 1928 & Hrdlička won approval for formation of the American Association of Physical Anthropologists. \\
\hline 1929 & $\begin{array}{l}\text { Joint excavations began at Mount Carmel, Palestine, by the American and British Schools. } \\
\text { Russell became a collaborator in Old World Archaeology and establishes the Old World Archaeology Fund. }\end{array}$ \\
\hline 1930 & The first collections from the Middle East obtained by the American and British Schools. \\
\hline 1931 & $\begin{array}{l}\text { First human fossils discovered at Mugharet es-Skūhl, Palestine, by Theodore McCown (representative of the American } \\
\text { School). Mount Carmel assemblages were accessioned at the Smithsonian. } \\
\text { Russell conducted joint excavations with Count Henri Bégouën in France, and published his article, "Report on Archaeo- } \\
\text { logical Research in the Foothills of the Pyrenees" (1932). }\end{array}$ \\
\hline 1934 & Final season of joint American-British excavations at Mount Carmel, Palestine. \\
\hline 1937 & Volume 1 of The Stone Age of Mount Carmel published (Garrod and Bate). \\
\hline 1939 & Volume 2 of The Stone Age of Mount Carmel published (McCown and Keith). \\
\hline 1943 & Hrdlička died. \\
\hline 1957 & Stewart began analysis of Shanidar Neanderthals. \\
\hline 1977 & Stewart published his major and final work on the Shanidar Neanderthals. \\
\hline 1985 & Potts hired as assistant curator in Physical Anthropology. \\
\hline 1990 & Human Origins Program established. \\
\hline 1997 & Stewart died. \\
\hline
\end{tabular}


vides a chronological list of these materials and the specific Smithsonian archive where they are located. This project challenged us to examine our own modern research programs in light of past work. The current Human Origins Program (1990 to the present) is presented in the context of this historic framework. In sum, this book documents nineteenth and twentieth century Paleolithic research and collection activities at the Smithsonian, complementing other works devoted to the establishment of the former United States National Museum (which became the National Museum of Natural History) and the development of anthropology research in the institution (e.g., Riedman, 1961; Hinsley, 1981; Kohlstedt, 1991; Rivinus and Youssef, 1992).

It is hoped that this project will encourage the historic and scientific study of the collections. The accessions and related correspondence offer much information about the development of paleoanthropology in particular countries and regions. We find that there is value in examining artifacts from particular countries and site materials and placing them in a historic context. For example, we have already examined how La Madeleine "mortars" from Lartet and Christy's excavations came to the Smithsonian in 1869 (Petraglia and Potts, 1992); how the Ariège cave and rockshelter material came to the National Museum in the 1930s (Petraglia et al., 1992; Petraglia et al., 2002); and how the Lower Paleolithic stone tool collections from India were acquired (Petraglia and Noll, 2001). Although most of the collections are clearly old and often partial in composition, thereby limiting scientific research possibilities, it also may be reasoned that certain goals can be achieved if there is a careful match between particular questions and specific assemblages. In fact, we have been engaged in such research, attempting to examine Upper Paleolithic pigment processing techniques by conducting technical analyses on specific objects collected in 1869 and 1931 (Petraglia et al., 1992; Vandiver et al., 1994), and conducting stone tool attribute analysis as part of larger analytical studies (Petraglia and Noll, 2001). As part of this re-evaluation, we also have radiocarbon dated breccia from one cave in southern France, placing assemblages in absolute temporal context, thus filling a gap in our knowledge of human settlement along the northern flank of the Pyrenees during the last glacial maximum (Petraglia et al., 2002). Thus, the application of modern technical analyses to old collections may prove fruitful, allowing for comparison with other modern studies. Our main hope is that this book will further stimulate others to engage in similar research projects.

The Paleolithic collections project began in 1988 and continued on a part-time basis for 13 years. This project would not have been concluded successfully without institutional support and the encouragement of numerous individuals during this period. Funding for this work was obtained from several Collections Improvement Grants and an Exhibits Grant from the National Museum of Natural History. Previous chairpersons of the Department of Anthropology, Donald Ortner, Dennis Stanford, and Carolyn Rose, endorsed the implementation of this project from its inception; and current chairperson Dan Rogers has helped guide the manuscript to publication. Many colleagues from the Smithsonian Institution Archives, the NMNH Office of the Registrar, the Department of Anthropology, the National Anthropological Archives, the Anthropology Library, the Processing Laboratory, and Collections Management were of great assistance during the course of this project. We wish to especially acknowledge the assistance of Jennifer Clark, Norma Kellogg Crumbley, Maggie Dittemore, Catherine Creek, Candace Greene, Greta Hansen, Deborah Hull-Walski, Johanna Humphrey, Andy Klafter, James Krakker, Mayda Riopedre, and Virtues Thomas. Mindy Zeder is thanked for providing her preliminary faunal inventory. Marcia Bakry enhanced the usefulness and quality of this book tremendously, providing all line-art, photographs, and digital images. We also appreciate the assistance of interns Cindy Cordero and Steve Walker, who helped to update the artifact counts. Alison Brooks kindly provided information on her research in Africa and China. Many of our colleagues have helped us to improve this volume by providing background information and comments, including Paul Bahn, Jean Clottes, Naama Goren-Inbar, Donald Grayson, David Meltzer, Dennis Stanford, Lawrence Straus, and Randall White.

\section{The Paleolithic Collections and the Smithsonian Institution}

\section{Background}

The year 1869 marked the first accession of Old World Paleolithic material at the Smithsonian Institution. For many decades afterwards, there was a sustained effort to obtain objects for exhibits concerning human inventions and lifeways and for cross-continental comparisons of material culture. From the outset, the secretaries and other top administrators of the institution were involved in these international exchanges. As the Smithsonian grew in size and scope, curators and departmental staff became more centrally involved in collection acquisition and organization. Although Paleolithic collections were contin- uously sought, first by Secretaries Henry and Baird, and then by curators, such as Thomas Wilson and Aleš Hrdlička, their central administrative and research commitments were elsewhere. The result of their efforts to obtain Old World material for exhibit and comparative purposes is the vast, essentially unpublished, Paleolithic collection.

Prior to describing the history of collection acquisition and the involvement of museum professionals in its compilation, the methods and results of our research are briefly described. As indicated below, correspondence and documentation material were gathered at several Smithsonian archives, whereas initial 
artifact provenience information was obtained from the Smithsonian's central computer database. The positive and negative aspects behind these information sources are briefly described. Based upon this information, the nature of the Paleolithic holdings and an overview of collections development is provided.

\section{Archival Documentation}

One of the first tasks in compiling this study was to place the Paleolithic collections in their appropriate historical and chronological frameworks. This was possible because of the preservation of primary documents in three main Smithsonian archives: the Smithsonian Institution Archives; the Office of the Registrar, National Museum of Natural History; and the National Anthropological Archives. The Smithsonian Institution Archives retained the records and correspondence of Smithsonian secretaries and other administrators; the National Museum of Natural History Office of the Registrar contained artifact inventories and related transportation records; and the National Anthropological Archives preserved correspondence of various anthropologists. Fortunately, the Smithsonian Institution has preserved written records, thereby providing information about the motivations of scholars and about the collections. No single archival source was comprehensive, however, and in order to conduct historical research and compile information on context, the separate archives needed to be cross-checked. In some cases, the collections were accompanied by artifact inventories with good provenience information; in other cases, the archival documents had little information about the Paleolithic assemblages other than simply noting country, region, or site designations. Sometimes original correspondence written in foreign languages were translated by Smithsonian staff, and the original letters were not retained in the archival material. This sometimes resulted in imprecise English translations that have been reproduced here. Some of the correspondence that we quote had minor spelling mistakes and missing symbols. These minor errors have been corrected. Unfortunately, missing entirely from the Smithsonian archives are any field notes or primary field records (if they ever existed), despite the fact that some of the excavations and material gathering were conducted by Smithsonian researchers.

\section{Computer Database}

Aiding in the compilation of the Paleolithic assemblages was the fact that all anthropology objects in the NMNH were entered into an IBM mainframe computer database in the 1970s. Each object in the database had a field for museum storage location and catalog information. The catalog information was complied from hand-written and typed catalog cards and accession inventories, the earlier method by which controls and organization were established (Figure 3). The computer inventory is continually updated with new information as collections are acquired or provenience information is improved. Storage and catalog information is accessed using a database manage- ment program called INQUIRE. In 2002, the computer inventory was changed to a new software, Electronic Museum (Emu), as part of a multimedia catalog system.

Although computer codification is of great utility for the management of, and search for, specific objects, the database's field for cultural affiliation had not been completely coded at the inception of this project. Therefore, the first step was to find Paleolithic artifacts among the world-wide anthropological collections. This was achieved by searching the database, using variables such as site provenience and object name, and locating key words that would potentially denote age affiliation. From the resulting computer list, objects were then examined to see if they were Paleolithic. The end result of this routine was the coding of the variable "Paleolithic" into the database in order to obtain a comprehensive listing apart from other museum holdings. Although this effort was successful, it should be noted that an even more systematic review of the collections may yield additional items for placement on the Paleolithic inventory. Problems persist in the database because the inventory was derived from old and sometimes incomplete catalog records and, additionally, artifact types were sometimes recorded by non-specialists. Exacerbating problems, quantities above a count of five were coded as ranges. In particular, counts of more than 20 artifacts were listed only as greater than 20. Numerous items from certain proveniences were assigned a single catalog number, and in the computer inventory they were counted as " 1 lot." The problem was that a catalog record listed as greater than 20 or as one lot could consist of several hundred items. To help rectify this, initial hand counts were conducted for artifacts numbering more than 20 , thereby resulting in more accurate estimates. It also should be noted that the classifications as noted in the assemblage figures of this book are not based upon detailed study. Detailed examination of the collections by future researchers will certainly lead to revised counts and functional types.

\section{Accession Tabulations}

The Old World Paleolithic collection represents 332 locations in 30 countries, ranging through Africa, Europe, and Asia (Figure 4). There are approximately 22,000 objects in the collection, indicating that most assemblages are, on average, small samples of localities. The assemblages consist of the entire sequence of the Paleolithic, abundantly represented by Lower $\mathrm{Pa}$ leolithic handaxe industries, Middle Paleolithic cores and flakes, and Upper Paleolithic blade and bone technologies. The collections were acquired between 1869 and 1990, mainly through donations and exchanges, in addition to some purchases, deposits, and loans. A total of 138 accessions accumulated, represented by 91 individuals and institutions.

Reflecting a bias in collection, the majority of the materials were obtained from western Europe, particularly France and England (Figure 5). Of the 332 locations represented in the collections, $162(49 \%)$ are in France and $49(15 \%)$ are in England, together accounting for $64 \%$ of all the locations. The total 


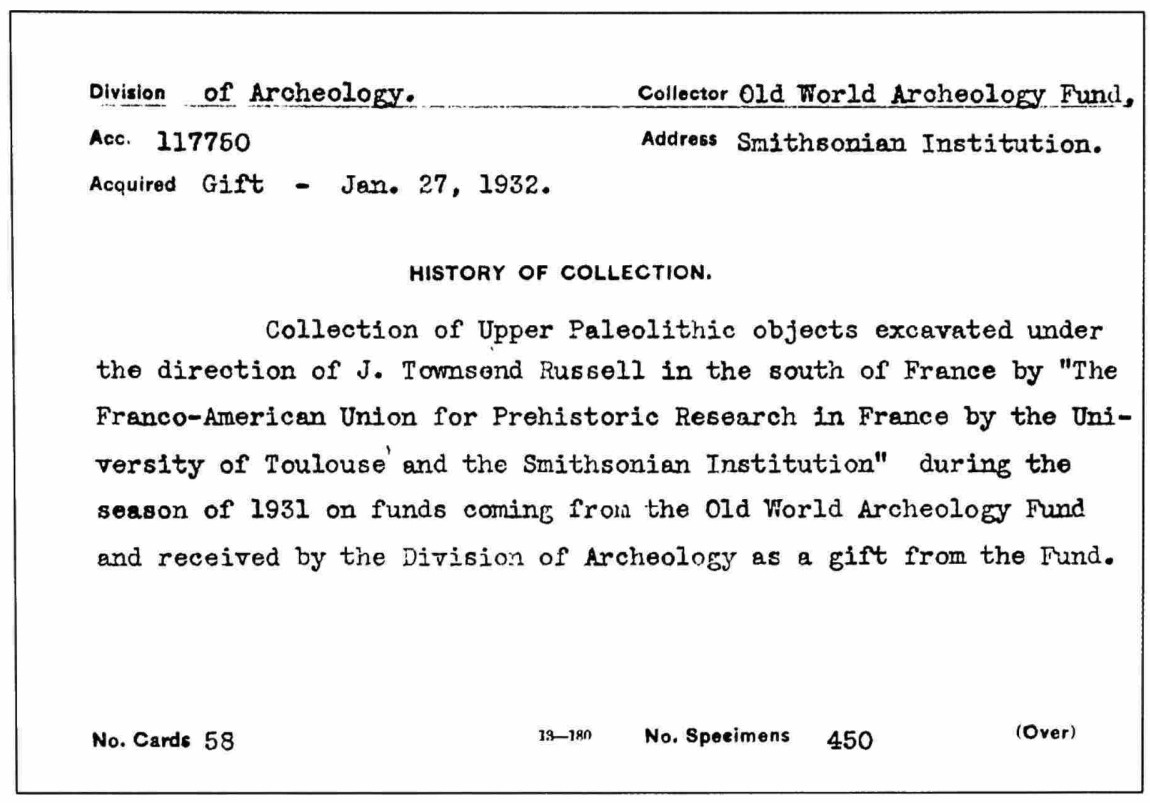

a

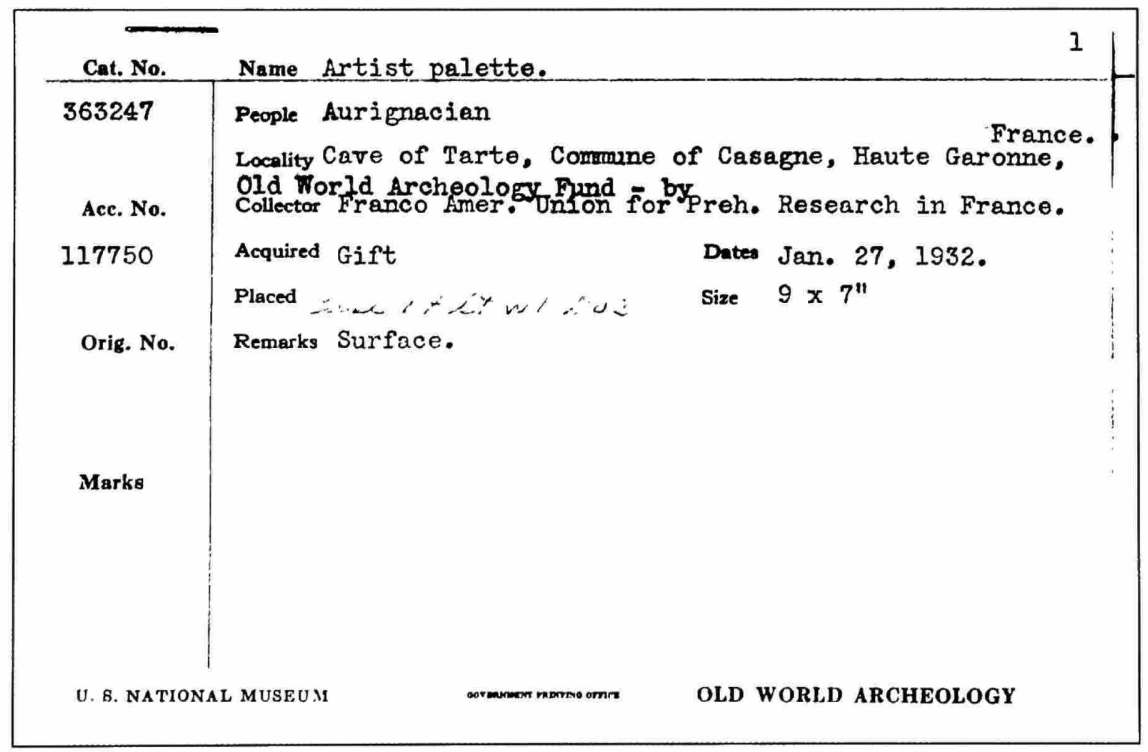

FIGURE 3.-Typical accession cards. [(a) History of collection card; and (b) artifact catalog card. Current computer database was constructed from this information.]

number of objects in the collections by country or geographic area again shows the preponderance of the assemblages from France and England, accounting for 12,020 artifacts, or $54.6 \%$ of the total (Figure 6). Artifacts from Palestine (now Israel) are abundant, totaling 4033 objects. The high artifact counts and the small number of locations from Palestine are the result of intensive excavations by the American School of Prehistoric Research. The large number of artifacts from Uganda $(n=1948)$ and Iraq $(n=1462)$ are primarily the result of targeted excavations of particular areas.
Tabulation of artifact totals by decade indicates variation in the pace of collections acquisition (Figure 7). The greatest numbers of artifacts were obtained in the periods 1929-1938 $(n=6125)$ and 1919-1928 $(n=4084)$. The large collections correspond with large deposits of excavated material by the American School for Prehistoric Research through curator Aleš Hrdlička and the donations of research collaborator James T. Russell and his Old World Archaeology Fund. The surge in the period 1899 to 1908 is mainly the result of the purchase of the estate collections of curator Thomas Wilson in 1904. The small 


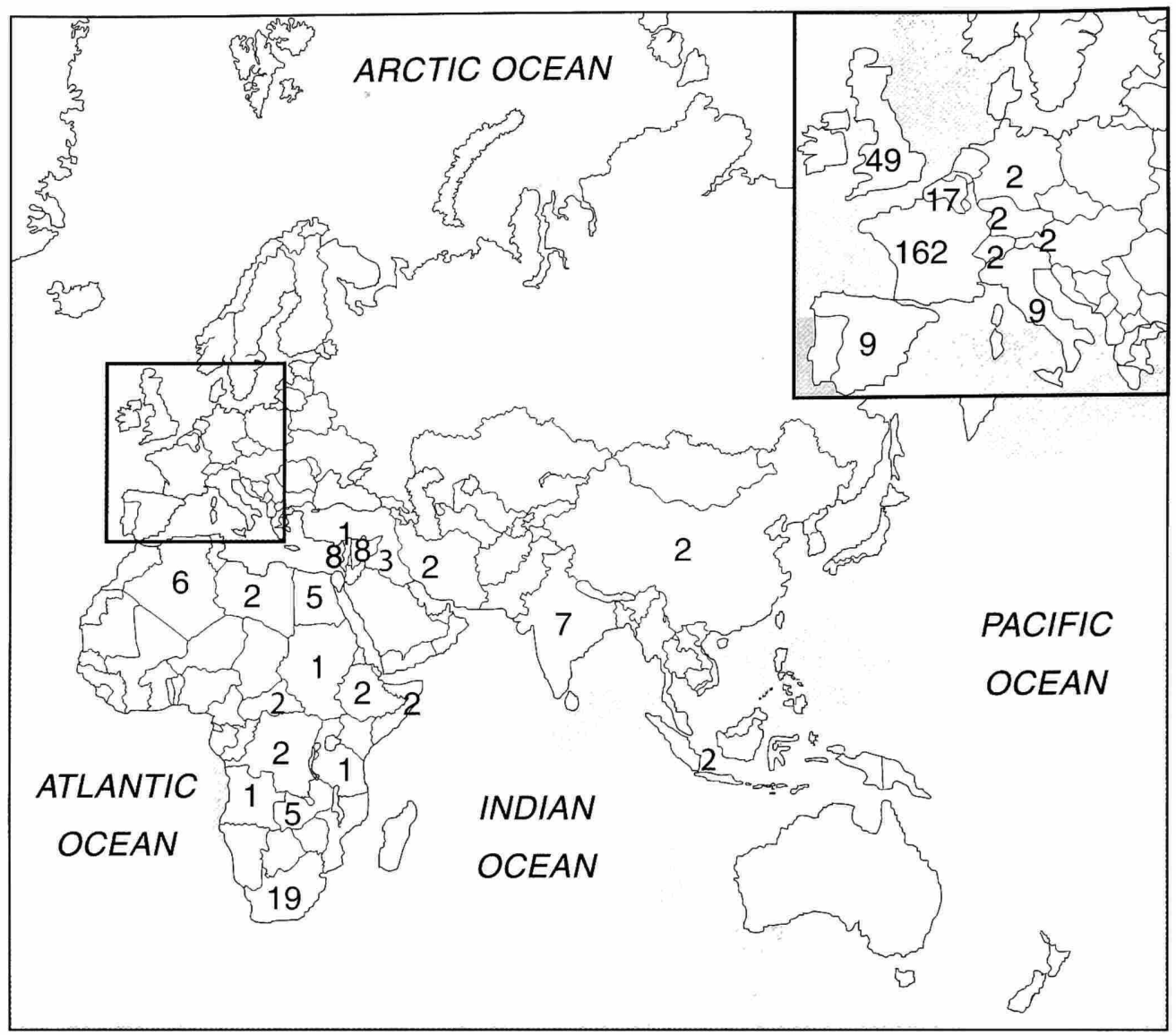

FIGURE 4.- Map of the Old World, showing the number of Paleolithic localities represented in the NMNH collections.

number of artifacts from 1909 to $1918(\mathrm{n}=765)$ and the accession of 16 artifacts from 1939 to 1948 reflect disruptions caused by World War I and World War II, respectively. The deposit of the Shanidar Cave material in 1958 resulted in higher artifact counts from 1949 to 1958, and the deposit of material from Magosi and Nsongezi in 1965 resulted in the higher totals from 1959 to 1968 . Of note is that few artifacts have been accessioned during the last three decades, even at the height of systematic field investigations by members of the $\mathrm{Hu}$ man Origins Program. The lack of accessions after 1969 is the result of legal controls of home-country artifacts established by antiquities legislation.

Certain archaeological locations are numerically well represented as the result of excavations or repeated collections from certain areas (Figure 8). The largest collections are from Abri des Merveilles, France ( $\mathrm{n}=4357)$, and Mugharet et-Tabūn, Palestine $(n=2793)$, from excavations by the American School for Prehistoric Research. The Magosi assemblages were obtained by the Uganda Museum and the excavator Glen Cole. The
Shanidar material was provided by the excavations of Ralph Solecki and Curator T.D. Stewart. The Kent's Cavern material resulted from acquisition of the excavated material obtained by William Pengelly.

\section{Motivations for the Acquisition of the Collections}

A review of official records and letters of correspondence shows that the Smithsonian's Old World Paleolithic collections (together with many other collections of different periods and geographic regions) were obtained to acquire representative material for comparative research and for exhibit. By 1860, the consensus in western Europe was that ancient humans co-existed with extinct animals and that they had been on earth prior to its present form (Grayson, 1983). The desire to gather Old World Paleolithic collections began in the early years of the Smithsonian, and geologists and archaeologists presumed that human antiquity of Europe and North America would be similar (Meltzer, 1983). Secretary Henry was an ardent supporter of 

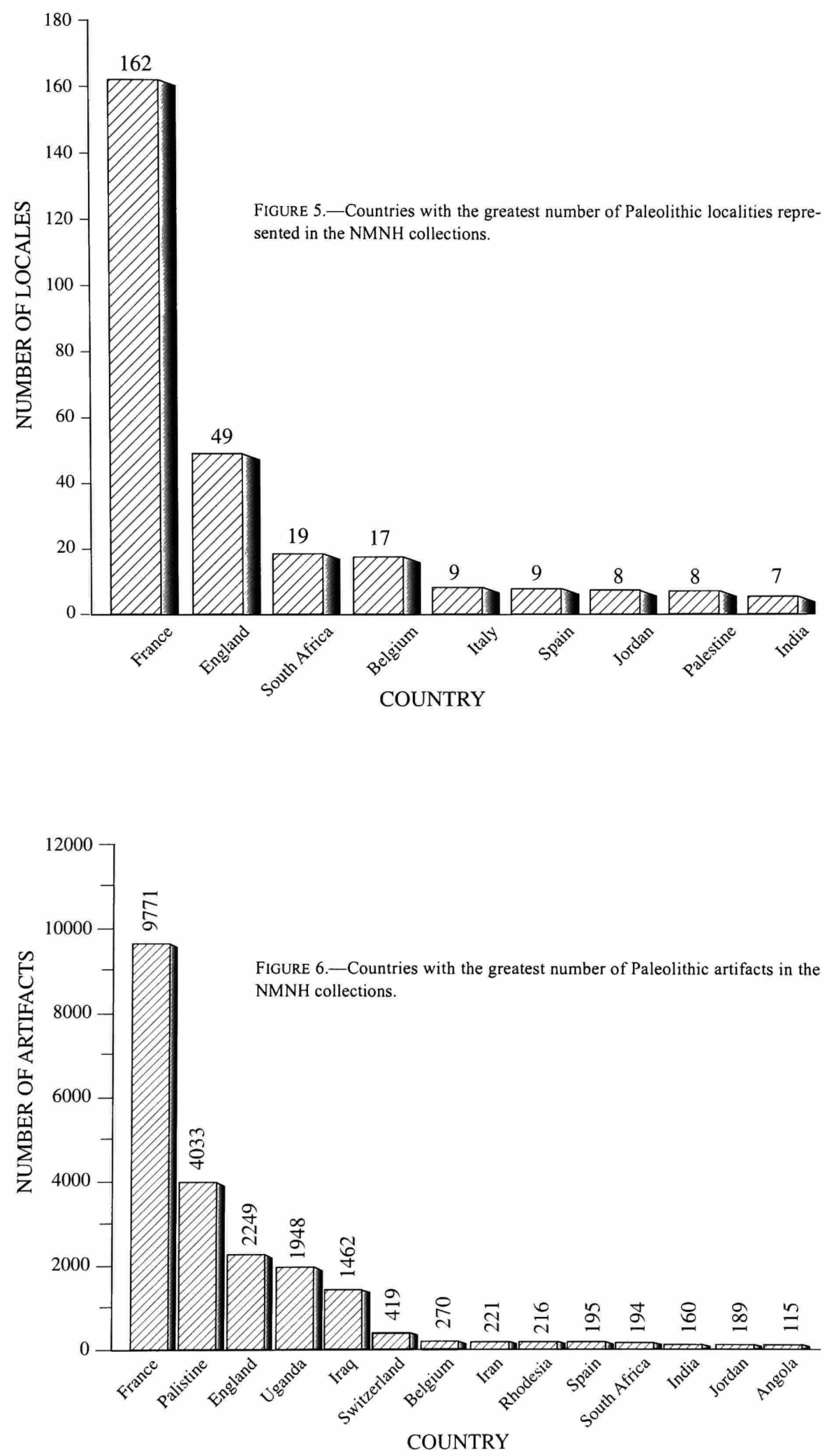


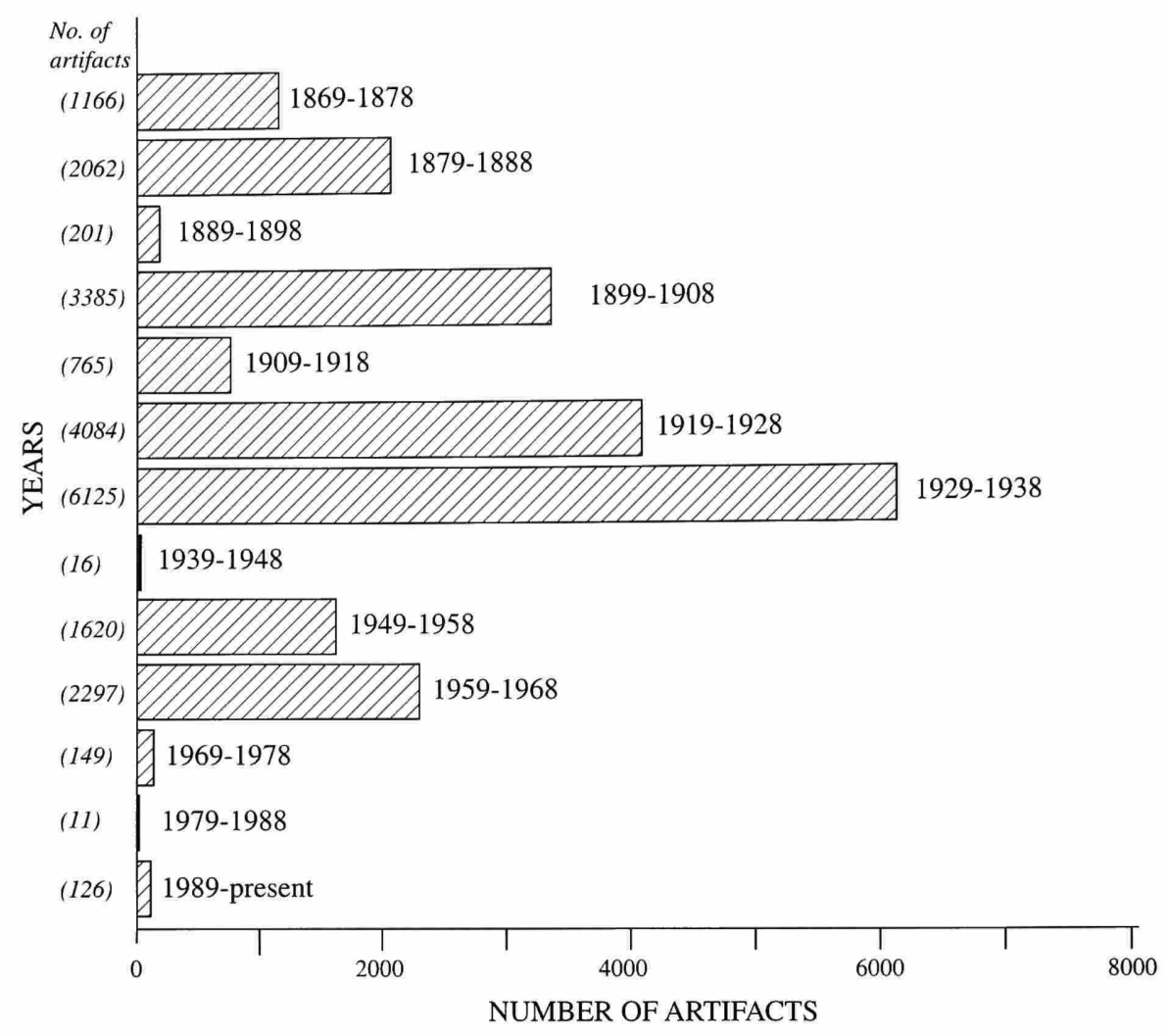

FIGURE 7.-Number of Paleolithic artifacts accessioned by decade.

archaeological work, and he was well aware of the significance of the European discoveries (Meltzer, 1983, 1998).

Interest in acquiring specimens demonstrating the history of ancient humans is shown in a letter from the first secretary of the Smithsonian, Joseph Henry, to the prominent French prehistorian Gabriel de Mortillet (first curator of the Paleolithic of the Musée des Antiquités Nationales at St. Germain-en-Laye and founder of the first prehistoric archaeology journal in 1864), on 11 December 1868:

We are entirely destitute of specimens illustrating the early history of the human race in France, such as have excited so much interest of late years and as well expressed in the collections formerly belonging to you now in possession of the Peabody Museum in Cambridge and still now so in the magnificent establishment now under your charge. If you have any duplicate specimens to spare illustrating the reindeer or other prehistoric periods of France, we shall be much indebted to you for them and will send in exchange such articles from America as we have for a similar purpose.

The compilation of Old World assemblages through exchange became a common practice in the development of the national collection. As a research institution that emphasized the anthropology of North America, exchange was the desired method because the Smithsonian had a surplus of Native American materials. During the Hrdlička era, the exchange of materials became a viable way to secure Paleolithic material.
Cases of "duplicate" materials from Holmes' famous excavations in the Piney Branch quarry in Washington, D.C., became a medium of exchange. Although the Smithsonian had a ready supply of common quarry material, the most valuable objects, such as platform pipes from Hopewell mounds, were never considered as a basis for exchange. Indeed, purchase of rare and expensive Paleolithic objects was never considered because government funds were limited and emphasis was placed on research. As a result, the Smithsonian collections received in exchange often were considered "representative" and "ordinary," clearly contrasting with other Old World Paleolithic collections in the United States, consisting of rare pieces and spectacular art objects, such as those obtained by purchase in the collections of the Field Museum of Natural History in Chicago or Beloit College in Wisconsin (see Bahn and Cole, 1986; White and Breitborde, 1992). Exceptions to this general rule were the controversial purchase of the Wilson collections, the financial support provided through the American School of Prehistoric Research for the temporary leasing of archaeological sites for excavation, and the purchase of materials by the Old World Archaeology Fund established through the estate of J. Townsend Russell, as described below. 


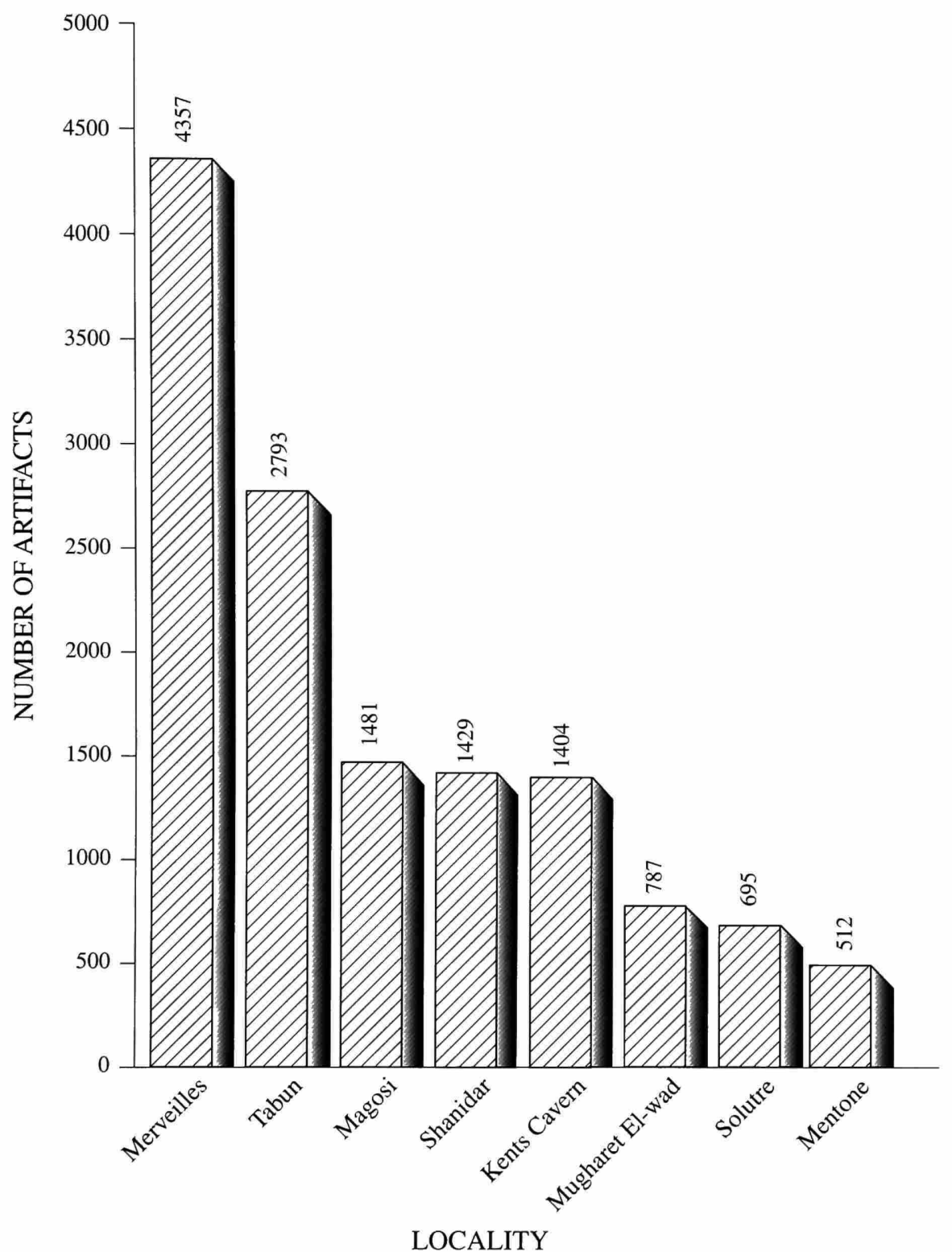

FIGURE 8.-Archaeological sites represented by the greatest number of artifacts in the NMNH collections.

\section{Involvement of the Secretaries and the Administration}

Secretaries of the Smithsonian have always been responsible for shaping the institution's policies and directing its operations (Table 2). Since the creation of the Smithsonian Institution in 1846 by an act of Congress, the study of humans and their place in the natural world has always been encouraged. This focus on the human condition began with the first secretary of the Smithsonian, Joseph Henry, who, as one historian of Smithsonian anthropology put it, "committed the prestige and resources of the young Institution to studies in linguistics, ar- chaeology, and ethnology as part of his program to diffuse among Americans not only scientific knowledge but the pious experience of doing science" (Hinsley, 1981:9). Henry played a pivotal role in developing anthropology at the Smithsonian Institution, including the initiation of the development of the Old World Paleolithic collections, as he was in personal contact with institutions and scientists abroad.

In formulating a vision for the Smithsonian, Henry supported basic research projects and the dissemination of the results of research through scholarly publication, in contrast to simply building a national collection. The goal to conduct ba- 
TABLE 2.-Smithsonian administrators involved in collection acquisition and mentioned in the text (see Smithsonian Institution, 1996).

\begin{tabular}{|c|c|c|}
\hline Administrator & Title & Years \\
\hline Joseph Henry & 1st Secretary & $1846-1878$ \\
\hline \multirow[t]{2}{*}{ Spencer F. Baird } & Assistant Secretary & $1850-1878$ \\
\hline & 2nd Secretary & $1878-1887$ \\
\hline Samuel P. Langley & 3rd Secretary & $1887-1906$ \\
\hline \multirow[t]{4}{*}{ Charles D. Walcott } & United States Geological Survey & $1879-1907$ \\
\hline & Honorary Assistant Curator and Curator & $1882-1907$ \\
\hline & Acting Assistant Secretary & $1897-1898$ \\
\hline & 4th Secretary & $1907-1927$ \\
\hline \multirow[t]{3}{*}{ George Brown Goode } & Assistant Curator and Curator, USNM & $1873-1881$ \\
\hline & Assistant Director, USNM & $1881-1887$ \\
\hline & Assistant Secretary & $1888-1896$ \\
\hline \multirow[t]{2}{*}{ Richard Rathbun } & Honorary Curator & $1881-1914$ \\
\hline & Assistant Secretary & $1897-1918$ \\
\hline \multirow[t]{5}{*}{ Frederick True } & Administrative Officer, Smithsonian Library & $1881-1887$ \\
\hline & Curator, Mammals & $1883-1909$ \\
\hline & Executive Curator, USNM & $1894-1902$ \\
\hline & Head Curator, Biology & $1897-1911$ \\
\hline & Assistant Secretary in Charge of Library and Exchanges & $1911-1914$ \\
\hline \multirow[t]{4}{*}{ Charles G. Abbott } & Assistant, Astrophysical Lab & $1895-1906$ \\
\hline & Director, Astrophysical Lab & $1907-1944$ \\
\hline & Assistant Secretary & $1918-1928$ \\
\hline & 5th Secretary & $1928-1944$ \\
\hline W. de C. Ravenel & Administrative Assistant to the Secretary & $1918-1925$ \\
\hline \multirow[t]{3}{*}{ Alexander Wetmore } & Superintendent, National Zoo & 1924 (informal prior to 1924 ) \\
\hline & Assistant Secretary & $1925-1944$ \\
\hline & 6th Secretary & $1945-1952$ \\
\hline \multirow[t]{2}{*}{ John E. Graf } & Associate Director, USNM & $1931-1945$ \\
\hline & Assistant Secretary & $1946-1957$ \\
\hline Leonard Carmichael & 7th Secretary & $1953-1964$ \\
\hline \multirow[t]{3}{*}{ T. Dale Stewart } & Assistant Curator, Associate Curator, Curator & $1924-1963$ \\
\hline & Director NMNH & $1963-1966$ \\
\hline & Assistant Secretary & 1966 \\
\hline \multirow[t]{3}{*}{ A. Remington Kellogg } & Curator, Mammals & $1928-1948$ \\
\hline & Director, USNM & $1948-1962$ \\
\hline & Assistant Secretary & $1958-1962$ \\
\hline Frank Taylor & Director, USNM & $1962-1967$ \\
\hline S. Dillon Ripley & 8th Secretary & $1964-1984$ \\
\hline Robert Mc. Adams & 9th Secretary & 1984-1994 \\
\hline
\end{tabular}

sic research also aided the development of the discipline of anthropology at the institution. The exchange of anthropological material was not to build collections per se, but to obtain information important for scientific research. Henry conveyed his philosophy, in the Report of the Secretary for 1867 :
Our object is to collect well-characterized specimens illustrative of the remains of ancient industry; ... for the formation of a collection as perfect as possible. It may be observed that, in making exchanges of specimens, the object is not alone to enrich our museum, but to furnish the means throughout the world of a more comprehensive comparison, and consequently to facilitate the study of the various states of the development of human invention. ( $A n$ - 
nual Report, Smithsonian Institution, 1872:34-35)

The scientific development of the Smithsonian corresponded with the maturation of anthropology itself during the second half of the nineteenth century, gradually evolving from an avocation to a professional discipline (Spencer, 1981). Between 1875 and 1900 , most of those who were engaged in archaeological research in the United States were connected to the government and a few museums, including the Smithsonian's National Museum and the Bureau of [American] Ethnology (Patterson, 1995). During this period, professional activity increased in museums and in academia, but archaeological research still had no distinct identity and was thought of as part of other fields, such as natural history, geology, or art. Although university-based anthropology developed at this time, it was not until World War I that university programs began to exert more influence than museums, as anthropology was formally incorporated within other academic programs (e.g., Sociology, Philosophy, Economics) (Spencer, 1981).

During the nineteenth century, the Smithsonian was interested in collecting Old World archaeological material representative of different epochs. "It has lately been proposed to divide the Stone Age into two - the palaeolithic, or first Stone Age, and the neolithic, or the second Stone Age; and from the discoveries which have been made of late, and which have been so cumulative, we can scarcely question the conclusions to which they all seem to point, namely that though the remains of man are found in a very recent geological period, yet, in a historical point of view, the antiquity of the remains is much greater than was formerly supposed" (Annual Report, Smithsonian Institution, 1871:35-36). The 1860 s and the early 1870 s marked the maturation of Old World archaeology in the West, clearly establishing the antiquity of early man in Europe and emphasizing the importance of scientific investigations on human evolution (Daniel, 1975; Hinsley, 1981).

Henry used his extensive contacts to initiate dialog with European scholars. Henry's correspondence with Charles Rau, prior to his employment with the Smithsonian, indicates how such interactions were stimulated. Rau suggested to Henry, on 7 October 1869, that contact with leading prehistorians may lead to exchanges:

I have been for some time in communication with Messrs. [Messieurs] Trutat \& Cartailhac, the leading officers of the Museum of Nat. Hist. [Muséum d'Histoire Naturelle] in Toulouse, and editors of the "Materiaux de l'Histoire Primitive \& Naturelle de l'Homme [Matériaux pour l'Histoire Primitive de l'Homme]," formerly edited by Mr. Gabriel Mortillet. These gentlemen wish to exchange antiquities from the reindeer caves, dolmens, etc., of south France for Indian relics. You must have a great many duplicates of Indian articles (especially of stone), and as I know that you wish to obtain suits of European relics, I draw your attention to the fact. Here you have the chance to obtain good and well authenticated specimens from the French caves, dolmens, etc., without actual expense, excepting, perhaps, that of transportation. Of rare and unique specimens you can get excellent casts. The two gentlemen are men of honor, and of scientific and literary reputation.

On 25 October 1869, Henry responded to Rau's suggestion, and indicated that exchange would be a means of acquiring ma- terial, foreshadowing the method commonly used for the next several decades:

We are indebted to you for your suggestion that this Institution enter into correspondence with the Natural History Museum in Toulouse in regard to exchanges of specimens of American Archaeology for European and shall at once address a communication on that subject. We have recently received several valuable articles from $\mathrm{Mr}$. Lartet of the kind you mention, and can probably readily supply to the gentlemen you name, enough specimens of American antiquity to compensate him [them] for any that he [they] may be inclined to send us.

As indicated in Henry's letter, Smithsonian interest in European antiquities eventually culminated in the first accession, a substantial donation of Paleolithic material by Edouard Lartet in 1869 (acc. 1529). The European collections were arranged in display cases that permitted a comparison of the Paleolithic objects with North American examples. The exhibit cases were below hanging portraits of Native American tribal leaders. "The table cases are...filled with ethnological specimens, among which are many exhibiting the rarer specimens of Indian workmanship, and also those of prehistoric times, from the explored caverns of France, presented by Professor Lartet" (Annual Report, Smithsonian Institution, 1869:26) (Figure 9). Interest in European discoveries and museum arrangements is indicated by the translation and publication of articles, such as "Man as the Contemporary of the Mammoth and the Reindeer in Middle Europe" (trans. by C.A. Alexander, 1872), "Ethnological Department of the French Exposition, 1867" (de Mortillet, 1872), and, "The Troglodytes, or Cave-Dwellers, of the Valley of the Vézère" (Broca, 1873).

Although Henry placed emphasis on research, the number of natural history collections grew steadily nevertheless, mainly because of Assistant Secretary Spencer F. Baird's passion for collection (Hinsley, 1981). Early in the National Museum's history, the Smithsonian inherited miscellaneous collections from the "National Institute" collections (a mid-19th century institution established for maintaining objects from diverse sources and scientific expeditions), and Congress began to appropriate funds for maintaining the collections in the National Museum. In 1876, Baird was member of an inter-agency committee for the preparation of public exhibits for the Centennial Exposition celebrating the birth of the nation. Many of these sizeable collections subsequently were donated to the National Museum. After Secretary Henry's death in 1878, Spencer F. Baird became the second secretary of the Smithsonian. During Baird's tenure, he gained support for further development of the U.S. National Museum, through official recognition by Congress in 1879. The goal was to classify collections and to add them to existing displays, so that researchers and the public could view collections as scientific and national resources.

To establish a comprehensive inventory of "natural history specimens," including anthropological materials, new collections were acquired by the Smithsonian in five ways: “(a) from the various Government surveys and expeditions, ...(b) by gift from individuals, from other institutions, and from foreign gov- 


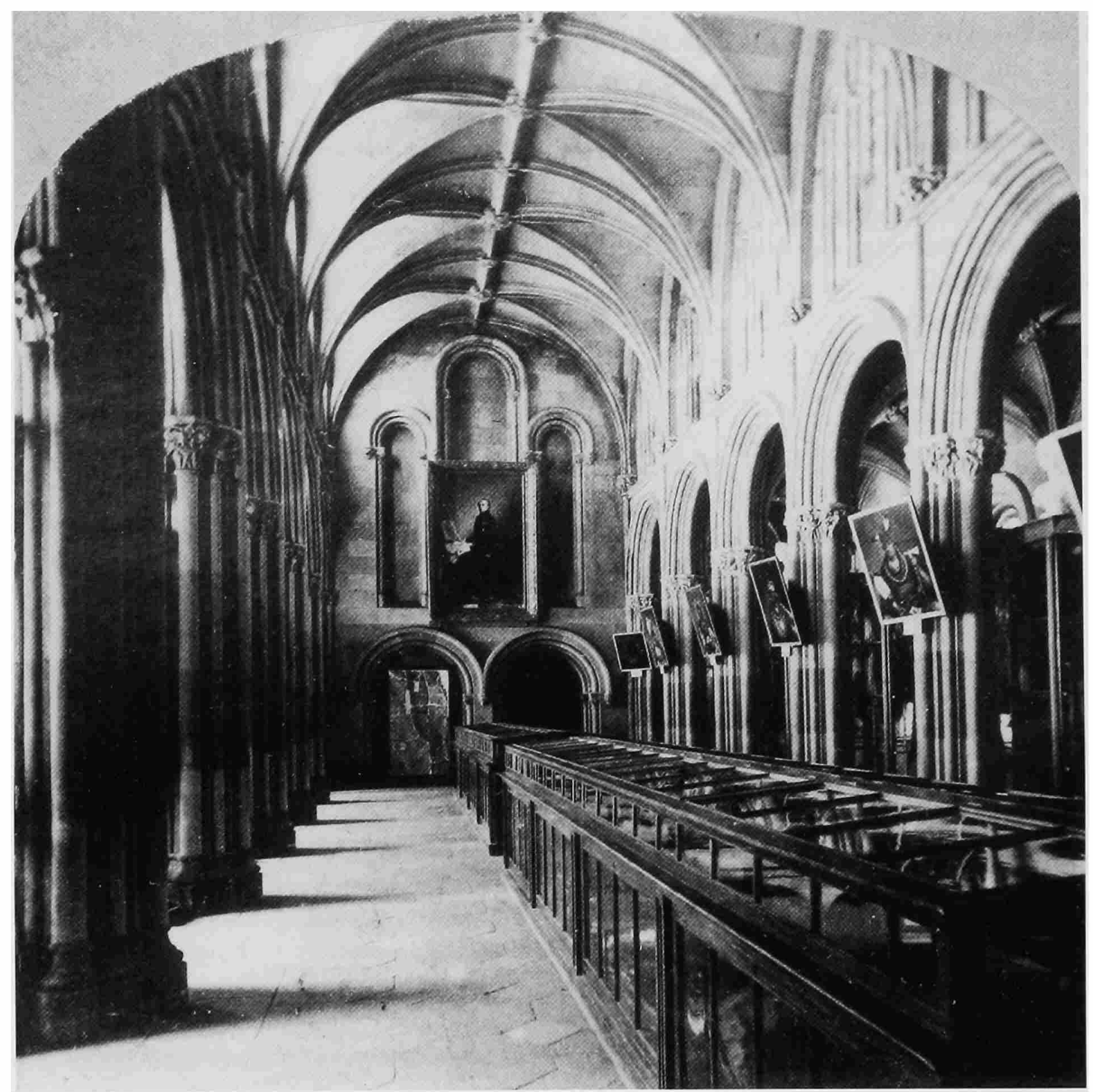

FIGURE 9.-Exhibits in the first Smithsonian museum ("the Castle"). [The photograph is labeled: "The w.[est] range of the Smithsonian Institution Building around 1871. The range displayed ethnological specimens of N.[orth] American Indian workmanship along with artifacts from China, Japan, and prehistoric France for purposes of comparison. Along the arcades hung portraits depicting Indian delegates visiting Washington between 1858 and 1869," Smithsonian Institution Archives (number 95-20765). Photo in Annual Report, Smithsonian Institution, 1869:26.]

ernments; (c) by exchange for its duplicate specimens or publications; (d) by the efforts of officers of the museum, who make collections in connection with their regular duties, or are detailed for special service of this nature; (e) by purchase..." (Annual Report, Smithsonian Institution, 1885:7). The purpose of the collection of natural history specimens was to document past scientific achievements, address current scientific research, and to educate the public:

1. It is a museum of record, in which are preserved the material foundations of a very great number of scientific memoirs-the types of numerous past investigations... 2. It is a museum of research, by reason of the policy which aims to make its contents serve as fully as possible as a stimulus to and a foundation for the students of scientific investigators. Research is a necessary part of the work, in order that the collections may be properly identified and arranged. Its officers are selected for their capacity as investigators, as well as for their ability as custodians, and its treasures are open to the use of any trustworthy student. 3. It is an educational museum of the broadest type, by reason of its policy of illustrating by specimens of every group of natural objects and, so far as it may prove practicable, such other collections as may be found useful for the instruction of the public which are explained by displaying descriptive labels adapted to the popular mind, and by its policy of distributing its publications and its named series of duplicates. (Annual Report, Smithsonian Institution, 1885:7-8)

After the death of Baird in 1887, the central role played by secretaries in the acquisition of Paleolithic material diminished. As the Smithsonian bureaucracy and the technical staff increased, anthropologists became more directly engaged in the accumulation of collections, identified potential acquisitions, and directly dealt with their colleagues for exchange and donation. By the start of the twentieth century, administrators were no longer centrally involved in acquring collections, but the role of the administration never entirely ceased. The administration played a key role in the growth of anthropology by hiring more curators and technicians and by supporting field investigations, collection accumulations, and publications. 


\section{Involvement of Anthropologists}

As the Smithsonian's administration established general goals for the growth of anthropology in the institution during the late 1800s, the accumulation of Old World Paleolithic collections increasingly became the responsibility of anthropologists. In the early $1880 \mathrm{~s}$, the U.S. National Museum (in what is now called the Arts and Industries Building) opened, and anthropology was officially institutionalized in 1883 as the Department of Ethnology (led by Curator Otis Mason) and the Department of Antiquities (led by Curator Charles Rau, and later by Thomas Wilson) (Hinsley, 1981). The Department of Anthropology was formally recognized in 1897 as one of three major departments (also Biology, Geology) in the National Museum. The Division of Physical Anthropology was added to Anthropology in 1904. The new U.S. National Museum building (the current National Museum of Natural History) was opened in 1909.

Three Smithsonian anthropologists, Thomas Wilson, Aleš Hrdlička, and James Townsend Russell, stand out as main correspondents and builders of the Paleolithic collections. These and other anthropologists responsible for acquiring collections or who played some administrative role are listed in Table 3. As Wilson, Hrdlička, and Russell played key roles in the development of the Paleolithic collections, each of their contributions is discussed separately. This is followed by a review of the modern era of paleoanthropology at the institution, including the activity and role of the current Human Origins Program.

\section{Thomas Wilson, CuRAtor of Prehistoric ANThropology}

\section{Career and Appointment}

Thomas Wilson became affiliated with the U.S. National Museum in 1887 as an administrator and soon after as curator of the Department of Prehistoric Anthropology. After the death of Charles Rau, Wilson became the first curator of antiquities (Figure 10). He wrote monographs on anthropology and folklore, including The Swastika, the Earliest Known Symbol, and Its Migrations (1894) and Bluebeard: A Contribution to History and Folklore (1899a). He also published general works on archaeology and industry, including compendia: A Study of Prehistoric Anthropology: Handbook for Beginners (1890a); Prehistoric Art, or the Origin of Art as Manifested in the Works of Prehistoric Man (1896); and Arrowheads, Spearheads, and Knives of Prehistoric Times (1899b).

Prior to his Smithsonian employment, Wilson practiced law, a profession from which he retired (Annual Report, U.S. National Museum, 1904:49). In 1881, he was appointed to the position of United States Consul in Ghent, Belgium, and later he served in France, in Nantes and Nice, spending much time traveling. Like Rau, Wilson gathered Paleolithic material from Europe for comparison with American specimens. Wilson's avocational interest in antiquities was not unusual in the late nineteenth century, as most researchers had training in some
TABLE 3.-Smithsonian anthropologists mentioned in text and involved in collection activities.

\begin{tabular}{|l|l|}
\hline \multicolumn{1}{|c|}{ Anthropologist } & \multicolumn{1}{c|}{ Years } \\
\hline Charles Rau & $1867-1887$ \\
\hline Major John Wesley Powell & 1883 \\
\hline Thomas Wilson & $1883-1902$ \\
\hline Otis T. Mason & $1883-1908$ \\
\hline William Henry Holmes & $1890-1918$ \\
\hline Walter Hough & $1893-1935$ \\
\hline Aleš Hrdlička & $1903-1943$ \\
\hline Edwin P. Upham & $1905-1909$ \\
\hline James Townsend Russell & $1925-1962$ \\
\hline Neil M. Judd & $1928-1952$ \\
\hline Frank M. Setzler & $1947-1957$ \\
\hline Waldo R. Wedel & 1952 \\
\hline Ralph Solecki & $1956-1958$ \\
\hline T. Dale Stewart & $1957-1977$ \\
\hline Gus Van Beek & $1964-1966,1989-1990$ \\
\hline Clifford Evans & 1965,1973 \\
\hline Kent Flannery & 1966 \\
\hline Richard Woodbury & 1966 \\
\hline William Fitzhugh & $1975-1976$ \\
\hline Herman Viola & 1976 \\
\hline Douglas Ubelaker & 1984 \\
\hline $\begin{array}{l}\text { Richard Potts, Alison Brooks, Michael Petraglia, } \\
\text { John Yellen }\end{array}$ & $1985-$ present \\
\hline Melinda Zeder & $1987-1990$ \\
\hline & \\
\hline
\end{tabular}

other discipline, and few individuals claimed to be professional archaeologists at that time because there was no distinct discipline other than a broad field of anthropology or the "study of man" (Hinsley, 1976; Meltzer, 1985). Wilson's hiring reflected the social milieu of the day, namely the appointment of persons of some social stature and prominence, rather than individuals who were academically trained in particular areas of science (Patterson, 1995).

Wilson's first contact with the museum was in 1883 , specifically with Major John Wesley Powell, the first director of the Bureau of [American] Ethnology. Wilson had apparently already met Powell, as he wrote with some degree of personal familiarity. In a letter to Powell on 22 June 1883, Wilson expressed his interest in conducting anthropological work:

I have had my thoughts \& recollections turned towards you for some time twice past owing my interest in ethnographical subjects as excited by reason of my residence in this country so rich in the evidence of prehistoric man. I have [sic] [am] studying it with much pleasure \& gratification. My past life has been so busy in my profession that I could not attend to anything else-now I am in the midst of the evidences \& they excite \& interest me greatly.

During Wilson's service as United States Consul in Europe, he visited and worked at many archaeological sites in western 


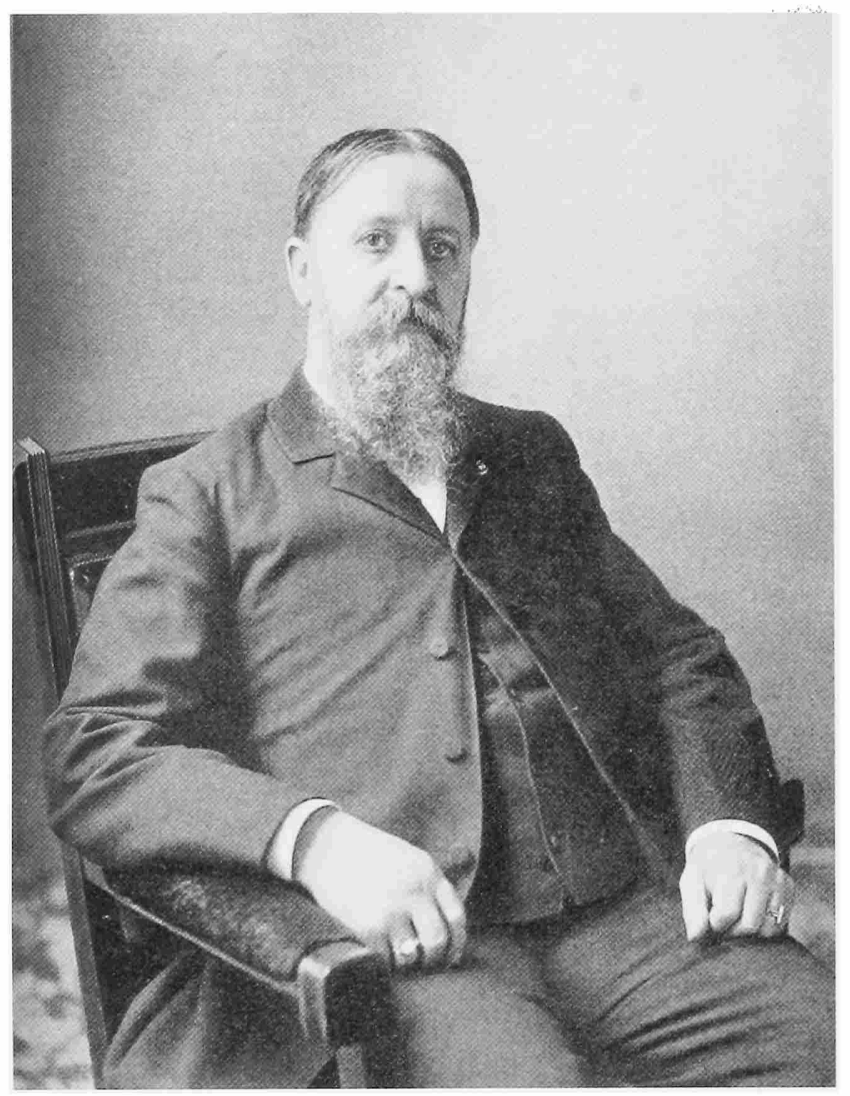

FIGURE 10.-Photograph of Thomas Wilson. [From an obituary written by O.T. Mason, 1902.]

Europe, as later retold by Mason (1902:3-4):

In the first named place [Ghent, Belgium], he was at once in touch with the cave man and the cave bear of the Mousterian epoch. His stay in Nantes brought him into immediate connection with the megalithic monuments at Brittany and the marvelous collection of cave life in the Garonne region at the south. At Nice he was easily in reach of Switzerland, Italy, and southern France. After five years of consular service, Doctor Wilson spent two years traveling over Europe, exploring and studying wherever there was a new prehistoric station to be opened or a new collection to be examined. During the official period he was constantly on the lookout for knowledge beneficial to his countrymen. In the entire seven years of residence abroad archaeology was his lure. With untiring zeal, accompanied by Mrs. Wilson, you saw him exploring caves and cemeteries, measuring the monoliths of Brittany, trampling over Scandinavia and the British Isles, looking down through the glass bottom of his boat upon the remains of Swiss lake cultures, searching for hidden treasures in Etruscan tombs, and all the while taking notes, gathering photographs and publications, and collecting substantial specimens of man's ancient handicraft.

During his stay in Europe, Wilson met many other prehistorians and became a member of professional societies in Belgium, France, Great Britain, and Ireland. During his service in the United States Consular Corps, Wilson amassed an impressive archaeological collection from Europe, mainly Paleolithic assemblages from France. Wilson's activity in Europe and his Paleolithic collection aroused attention at the Smithsonian:
Mr. Thomas Wilson, late consul at Nice, France, has been busy during the greater part of his official term as consul, first at Nantes and then at Nice, in France, in explorations into the remains of prehistoric man, and has presented a very large collection, the unpacking of which only awaits his return to this country. It is believed that this collection, filling a large number of boxes, will prove to be one of the richest and most complete of its kind ever sent to the United States. (Annual Report, Smithsonian Institution, 1886:9-10)

Thus, it was with great anticipation that Wilson deposited this collection in the U.S. National Museum. As the curator of the Department of Archaeology (formerly Antiquities), Charles Rau (1889:84) described the deposit in an 1887 report:

Thomas Wilson, of Washington, recently United States consul at Nice, has deposited a large and valuable collection of prehistoric and, to some extent, historic antiquities, gathered by himself in Italy, Switzerland, France, England, and the Scandinavian countries, which was received and catalogued during the latter part of this year. The contribution embraces drift and cave relics (Paleolithic age), objects belonging to the neolithic age and to the bronze period, and specimens of Etruscan and Roman origin. The whole collection, the value of which can hardly be overestimated, contains 10,297 articles, and the entries nearly all fill a volume of the catalogue.

In 1887, Baird nominated Wilson to the Cosmos Club, a national organization of prominent scientists, founded and led by Smithsonian scholars, including Baird and Powell, in Washington, D.C. (Washburn, 1978). In a nomination letter dated 6 January 1887 , Baird described why he favored Wilson's membership:

I respectfully nominate, for membership of the Cosmos Club, Mr. Thomas Wilson, of No. 1218 Connecticut Avenue, and late U.S. Consul at Nice. Mr. Wilson, during an absence of five years on official duty in Europe, has paid special attention to the subject of prehistoric man, and has not only prosecuted researches very extensively on his own account, but has made many purchases and exchanges, by means of which he has secured one of the largest collections of the remains of pre-historic man in Europe. The collections, filling over 60 boxes, has been presented to the National Museum, and will be carefully and appropriately arranged by him. The close relationships held by Mr. Wilson, during his sojourn in Europe, with the principal archaeologists of France, Italy, and Scandinavia, and his careful study of the European collections of a similar character with his own, have made him thoroughly au fait with everything bearing on the subject.

Wilson (1892a:2) described his understanding of his new field of endeavor thusly: "Prehistoric Anthropology deals with man's early existence. It investigates man's industries through the objects thereof. It invades his workshops and his tombs, and in them finds the remains of the man and his family, and the objects made and used by him during his life, and from this determines the life and history of the prehistoric man." Wilson worked at the National Museum for 13 years until his death on 4 May 1902, at the age of 70 . During his tenure, he deposited a large collection of Paleolithic material, first upon his arrival, and then subsequently during his 16 -year career through acquisitions.

\section{Intellectual Outlook}

During Wilson's years at the Smithsonian, he lectured and published extensively on a wide range of anthropological subjects. At the beginning of his tenure, Wilson (1891a:651) was 

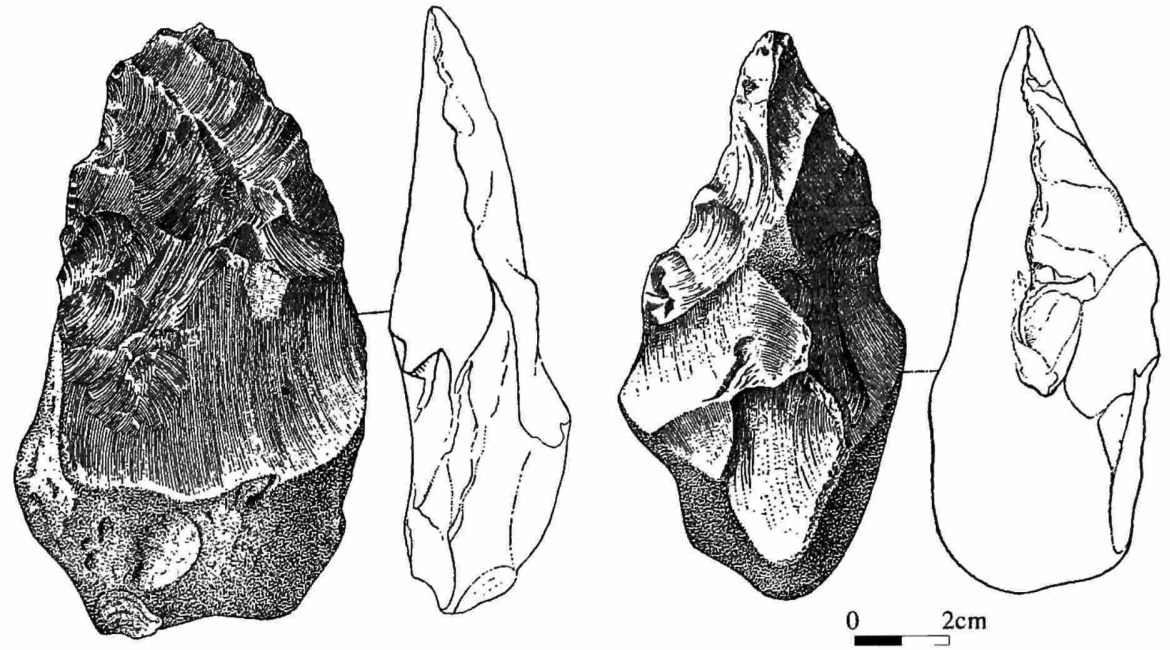

FiguRE 11.-Paleolithic "Chelléen" implements [from "Prehistoric Art" (Wilson, 1896, figs. 2, 3), which compares an implement from Thennes, France (left), with one from Thetford, England (right).]

aware that much was still unknown about the Paleolithic, and in a report on his visit to the Paris Exposition in 1889, he noted, "M. Georges Perrat, member of the Institute of Paris, says that humanity has not even the faintest idea of these two ages [M. Cartailhac's Paleolithic division, age of the alluvium and the caverns]. All our studies have not even pierced the darkness. We are lost in the night of our ignorance, and all our studies have not taken us over the threshold of that night." At the Smithsonian, Wilson dedicated most of his time to exhibit-management and to speculation about the habits of prehistoric man.

In an address on prehistory before members of the Cosmos Club, Manassas, Virginia, in August 1895, Wilson summarized his understanding of the life of ancient man:

The earliest knowledge we have of man shows him to have spread over a large portion of the territory of the earth. Without speculating at all upon his origin and consequent antiquity, we may know that man belonged to the preceding as well as the present geologic period. Only in rare cases, and many of them uncertain, have the remains of man been found in these early deposits, but the tools and implements which he had made have been found, and they are as good evidence of his existence at that time and his presence in that locality as though we had found the man himself. The most noted locality in which the earlier prehistoric man has been found is in Western Europe. This may, however be more from the fact that the deposits have been there better studied than elsewhere. A short sketch may not be interesting. It is to be supposed at that time that man was there an animal among animals. The contemporaneous fauna are largely extinct. The hairy mammoth, the wooly rhinoceros, the cavebear, the Irish elk and similar animals have been found in Europe intimately associated with man and his works in such a way as to establish their contemporaneity in that locality. Man occupied the country while the river-valleys were being scooped out, when the rivers themselves were great floods rushing rapidly to the sea, which, as in the time they lost their force, lowered their quantities and levels, the river-terraces were gradually formed $\&$ deposited, as we know them, while their sands and gravels contained the stone or flint implements of man associated with the bones of the extinct animals. Man is supposed to have been at that time a wild, naked, hairy savage. The climate was warm and moist. It is supposed that he needed neither clothes nor shelter \& there is no evidence that he employed either. He was a hunter and fisher and lived by the chase with what fruits, berries, roots \&c. he could gather. The sup- position is that in a succeeding epoch the glaciers came down from the north and the climate changed from moist and warm to moist and cold. Accordingly, man sought the caves of the country for protection against cold. Here have been found repeated many hundred times the evidences of his occupation, in the shape of tools, implements, art-work, like spears, scrapers, harpoons, bonepoints, needles, \&c., \&c. The necessity for clothes, it may be assumed, produced his first attempt in that direction; accordingly, we find the flint scraper with which he could dress hides, and the bone point and needle, which with the sinew of the killed animal, he would sew the skins together and make them into a covering.

Wilson (1896:357) reiterated this view in his major publication, Prehistoric Art:

The man of this time has passed for a savage, and he doubtless was one. He had no tribal organizations, no sociology, no belief in a future state, no religion; he did not bury his dead, he erected no monuments, he built no houses; he was a hunter and fisher, he had no local habitation, dwelt in no villages except such as could be so called from a number of people living in a cavern for the purpose of shelter.

In Prehistoric Art, Wilson provided the evidence and foundation upon which interpretations about ancient lifestyles were made. In his work, "prehistoric" was meant as the period before written history, whereas the word "art" was defined as the making and the decoration of objects (Wilson, 1896:354). In covering prehistory, Wilson attempted an encyclopedic review of objects by period and location:

On the subject of his art and art work it is believed that the present paper will be found exhaustive. It furnishes the foundation upon which theory and speculation may but built ad libitum, but it is believed that the foundation is laid as broadly and as deeply as it can be in the present condition of the world's knowledge. What future discoveries may bring forth no one may venture to prophesy. (Wilson, 1896:352)

Wilson emphasized the importance of comparing artifacts from various localities (Figure 11). In discussing the subject of art, Wilson (1896:352-353) found prehistoric industry to be in a fairly rudimentary state of artistic effort and expression: 
The objects figured and described show art work done for art's sake, to the end that the maker may obtain sensuous pleasure from form and line. Man did not do this work for the sake of religion for, so far as can be understood, he had no religion, nor did he make these things for the sake of power or wealth. It does not appear that he considered himself in any way better off by having these objects decorated than he would if they had been plain. There are many hundreds of them which are entirely plain, of equal value for service, evidently utilitarian, without ornament or decoration, and apparently serving as weapons of the chase or war equally well with those highly decorated. Therefore these objects, beautifully designed as they may have been, were no addition to his wealth or power, and as for information he was not busying himself about that. He gained information, it is true, by experience and his own effort, as he and every other human being did and will, but this wrought his own education and was not for the purpose of educating those around him.

Similarly, Paleolithic objects were considered objects of individual expression, changes identifiable through comparison of objects through time:

He made these things because they were pleasing to him, and he (each man) decided for himself what was pleasing. These works of art were the material expression of the delight of their maker. The man of the Paleolithic period, savage though he was, had his ideal. The existence of these art works, the representation of the animals which he saw, of the plants and flowers which he must have recognized as beautiful, the existence of these in the caverns which he inhabited, and part of the possessions fabricated by him; their mere existence proves the fact of his ideality, proves that he had a taste and a desire, and are evidence of his gratification thereof. What other ideals he may have had we do not know; he has left no manifestation thereof. (Wilson, 1896:353)

Although the most rudimentary forms of art were found in the earliest times, Paleolithic peoples of later times "occupied, in the Solutréen epoch, the highest rank as a flint chipper, and in the Madelainien epoch the highest place as an engraver on bone and ivory. His materials were the bones, horns, and tusks of the animals he killed. His tools or implements were sharply worked points or gravers of flint" (Wilson, 1896:357). Wilson indicated, however, that major changes are not evident in the Paleolithic apart from the broadest of patterns: "So far as we know man his tastes are continually changing, but whether the man of the Paleolithic period changed his tastes or not is not now determinable except so far as shown by his works, first of flint and then of bone, and finally of engraving and sculpture. It is only by these that we may know what were his tastes and what their changes" (Wilson, 1896:353). Although Wilson stated that these broad patterns can be witnessed, he also stated that the rate of change was considered only occasional: "There seems to have been practically no change in the ideals of the Paleolithic man in the center of France. So the flint chipping and bone polishing, although they might have been steps of evolution in man's progress, at last ended in the art objects presented in the first chapters" (Wilson, 1896:354).

\section{Museum Arrangement}

The earliest and most systematic archaeological classifications in North America were devised by the Smithsonian prehistorians, particularly Rau, and later by Wilson (Dunnell,
1986). As Rau's successor, Wilson was responsible for the routine work, which involved receipt of objects and their subsequent examination, classification, arrangement, entering, numbering, and display (Wilson, 1891b, 1892a, 1892b). Wilson's discussion of artifact classification often turned to pragmatic issues having to do with museum arrangement. Because the National Museum collections were displayed to the public, they had to be arranged in a manner that would interest those viewers:

Museums should be arranged for the interest and edification of the masses; they should please the eye, gratify the taste for beauty, increase the knowledge and elevate the standard of the people, and at the same time be of value to the artist, the student, the historian and the scientist. While the arrangement may be artistic, it may also be utilitarian and add to the knowledge of the most uninterested idler and pleasure seeker. (Wilson, n.d.)

Although public enjoyment of specimens was important for attracting attention, the most important goal was public education. "The gratification of the public may be considered, but a higher right is that of education, cultivation of taste, elevation of art standards; and these must be kept above the mere decoration of the walls by the display of handsome paintings" (Wilson, n.d.).

For Wilson, classification of specimens was functional in design, showing the evolution of forms. This was the common practice of the time, when there was a concern with extending history into prehistory, with attention to sequence and chronology (Meltzer, 1985). Evolution of classes of forms also could be shown as progress through time and space:

To best accomplish the education and to give the most comprehensive understanding of the subject in the shortest time and with the least fatigue, the specimens should be arranged in series; there must be a leading from one part or section to another, possibly from one implement or specimen to another. If it is a museum of arts or industries, the arrangement should be such as to show the history of the object displayed-its beginning, its growth, its evolution, its condition at various epochs, and the differences between different localities or possibly different nations.

In the one case the fine art or the industrial art of Primitive Man should be shown, and thence the growth from the lower to the higher stages according to each epoch of time and geographic division, so that the visitor may be able to see the beginning of the arts and to trace them through their evolution in the various times and countries. (Wilson, n.d.)

Wilson drew inspiration from European prehistory and from his visit to the Paris Exposition with O.T. Mason (Anthropology at the Paris Exposition in 1889; Wilson, 1889). The display and arrangement of Paleolithic objects from the collections of leading French authorities were carefully noted. Regarding the significance of his France trip, Wilson (1891a:651) noted:

I trust enough has been said to demonstrate the extent and importance of the anthropologic display at this exposition, and to show the importance with which the science is regarded by the savants of France and its adjoining countries. Professor Mason was quite right when he said, as he did in his paper read before the Anthropological Society of Washington, and published in the "Anthropologist," that the opportunities to study the natural history of man in Paris during the exposition were unparalleled, and that at any time the French capital affords rare advantages to the anthropologist. 


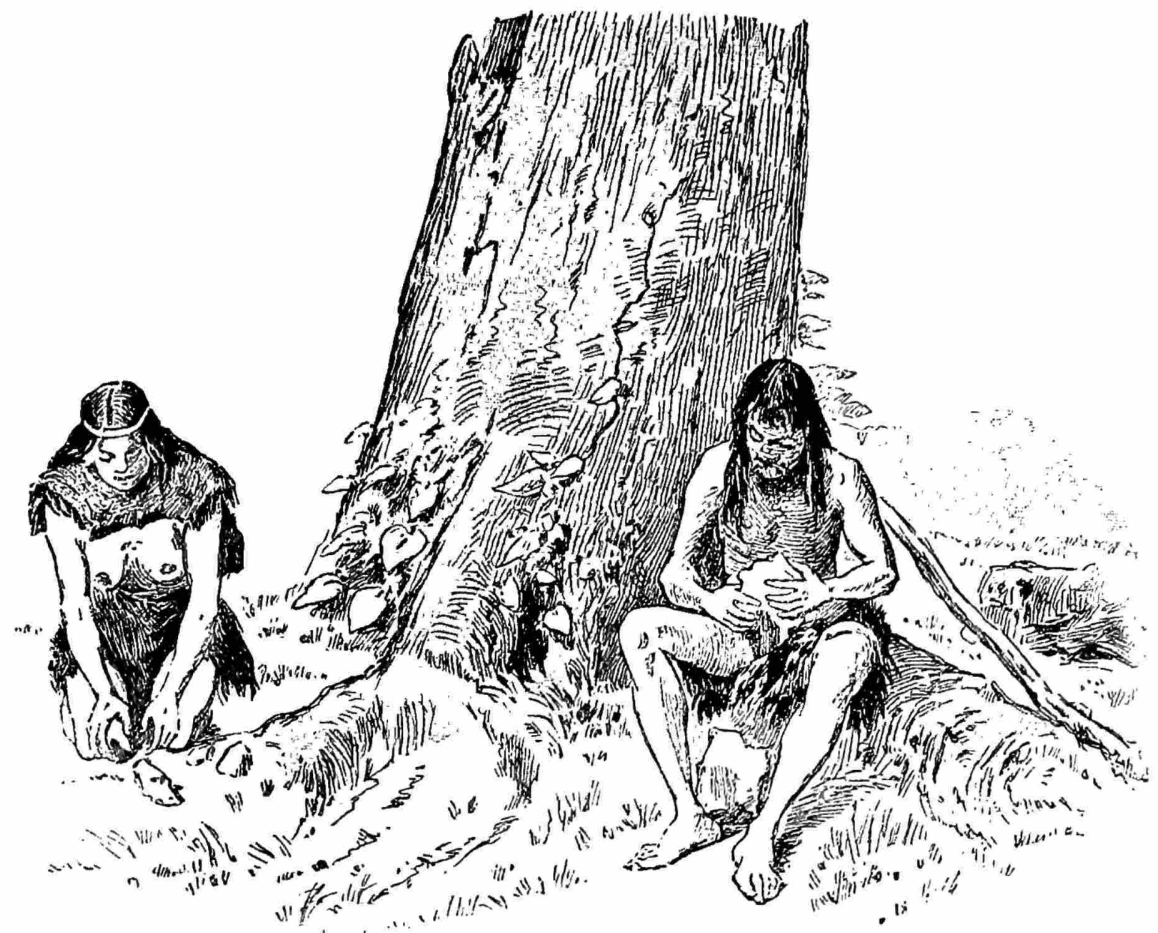

FIGURE 12.-The original caption stated, "Representation of the Neanderthal or Canstadt Race of Men. (The Chellean epoch of the Paleolithic Age.)" [The man and woman are engaged in making the "rude flint implements of the epoch" (Wilson, 1891a).]

Regarding the Paris Exposition, Wilson noted (1891a:651) that the reconstructions of lifeways were

probably the most interesting and instructive collection displayed under the head of prehistoric anthropology and archaeology, certainly that which attracted the most attention, was the reconstruction of the families of men of the different prehistoric races. The figures were life-size and reproduced after the most accurate study. The greatest care was used in the details of the anatomy, the industry, the costume, and surroundings. They were the combined work of scientists and artists the most capable, and all that the anthropologist, ethnologist, anatomist, and artist sculptor could do was done to make them true and correct representations. One group represented the chellèen epoch or the age of the mammoth, or alluvium, and this was called the first industry [Figure 12]. The second represented the cavern period, or the age of the reindeer, and was called the first artist [Figure 13].

These illustrations were influential in Wilson's works and they were described and reproduced as the most accurate renditions available (Wilson, 1891b, 1896).

The general method of artifact arrangement-according to geographic area, chronology, and locality and sequence-was exemplified in Wilson's major archaeological works, Prehistoric Art (1896) and Arrowheads, Spearheads, and Knives of Prehistoric Times (1899b). Wilson wished to show the evolution and progress of industry by displaying objects according to sequence and distinct geographic entities:
Some criticism has been passed upon this method, and there has been a contention in favour of grouping each class of objects together and separate from other objects or classes. I defend my classification, by saying, that if the desire of the student be to study the object, to write its history, to discover its evolution, then the method of classification by objects may be best. But the student of prehistoric anthropology does not study independently the object or implement. His study is of the man who made and used them, and the state of culture of that man, whether industrial, social, or political. This being my desire, I prefer to group all the objects and implements made or used by the prehistoric man in a given locality, so that we may see at one glance everything bearing upon his capacity, condition, industry, and his social and political life. (Wilson, 1890b:513-514)

The critique mentioned in this quote may have come from other Smithsonian colleagues, such as Otis T. Mason of the National Museum and John Wesley Powell of the Bureau of American Ethnology, who arranged objects according to universal inventions (e.g., fire-making, transportation, crafts), so that specimens from diverse cultures were placed together according to evolution of types (Hinsley, 1981; Jacknis, 1985). Wilson also may have been reacting to Franz Boas' published 1887 criticisms of the National Museum's practice, which Boas viewed as an unfortunate scattering of objects without regard to tribal provenance (Jacknis, 1985). Mason, Powell, and Boas became embroiled in bitter debates for more than a decade concerning proper museum exhibition, concepts of culture, and 


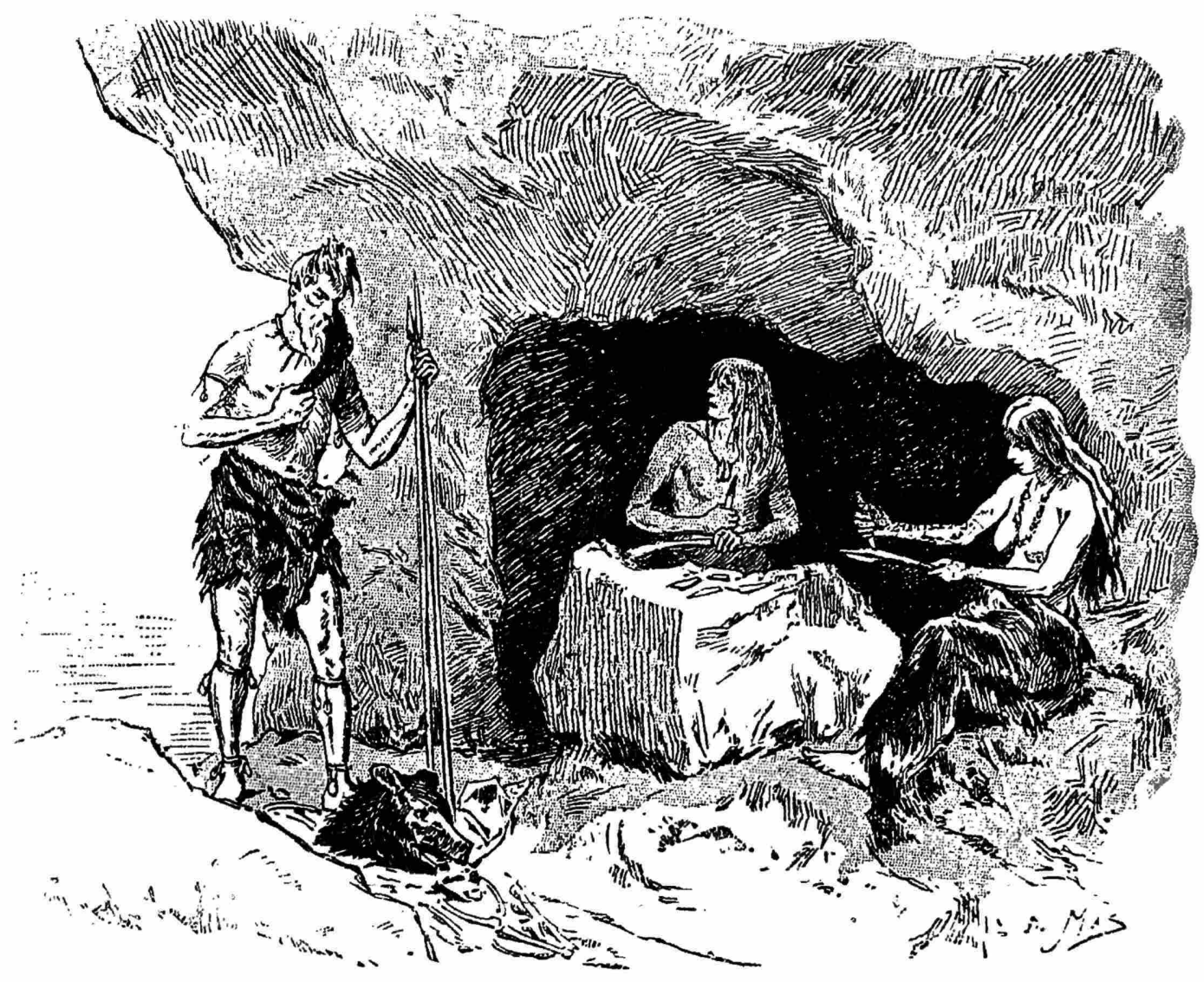

FIGURE 13.-The original caption stated, "Representation of the Cro-Magnon Race of Men. (Cavern period of the Paleolithic age.)" [The scene "represents a woman and a young man engaged in engraving the reindeer horn" and the "father of the family has just returned from the chase and carries the hind quarters of a mountain goat, which he has killed" (Wilson, 1891a:654, plate CLVIII).]

evolutionary schemes. This tension concerning the "proper" display of objects was reflected in Wilson's (1892a) proposed classification for anthropology and prehistoric archaeology at the Chicago Universal Exposition. Old World objects of human industry were arranged according to phases of fabrication and function and ordered according to stages of the Paleolithic as then conceived (i.e., Chellean, Acheulean, Alluvium, Mammoth, Mousterian, etc.). North American materials were treated differently, based upon the classifications of Rau and Mason, which arranged objects according to major functions (e.g., aliment, habitations, furniture, vessels and utensil for household use, etc.). Although Wilson established this practice for North American material, indicating it was probably the most practical way to exhibit Native American artifacts because there were so many tribal groups, he also strongly urged the display of all objects from representative tribes so that "daily life" could be shown.

Although he argued for some level of geographic and chronological organization, Wilson adopted the view that objects demonstrated the lifeways and progress of man:
In the author's own division of Prehistoric Archaeology the dominating idea is the history of prehistoric man; the objects displayed deal with his entire life, his physical form, his anatomy, his race or various races and their geographic distribution, his monuments, implements, objects of every nature, his tombs, monuments, mounds, dress; and through these to study his government, religion, habits of life, means of subsistence, his language if any be found, and his needs. We have to depend almost entirely on these for information to enable us to write his history-now these specimens must not only be exceedingly numerous (so numerous, indeed that it is almost impossible to put a limit on them) but they must also be kept under such condition as to admit of ready and close examination. (Wilson, n.d.)

In order to fully illustrate the evolving habits of man, Wilson emphasized the necessity of gathering comprehensive collections:

In the author's Division, where everything is needed to study the history of prehistoric man, ... he wants every specimen of every kind, with all its associations from all localities and in as great number as possible; but this [is] for study and instruction, and not exclusively for display. He [Wilson] has established in a convenient line of cases..., a synopsis or epitome of his entire Division. It is incomplete, is not sufficiently extended, many objects had to be left out, many countries are unrepresented, many phases of prehistoric man of those countries he finds impossible to present, but finally it presents an epitome of the imple- 
ments and objects of the prehistoric man used in most parts of the world. (Wilson, n.d.)

\section{The North American Paleolithic Debate}

Like his predecessor, Charles Rau, Wilson promoted the existence of a Paleolithic in North America (Hinsley, 1985). Although the North American record did not have the sequences of antiquity that were evident in Europe, American prehistorians argued that the similarity of the forms of stone tools was apparent (Meltzer, 1983). Wilson extensively published on the subject of the American Paleolithic, including such titles as, Man in North America during the Palaeolithic Period (1888), The Paleolithic Period in the District of Columbia (1889, $1890 \mathrm{e})$, Results of an Inquiry as to the Existence of Man in North America During the Paleolithic Period of the Stone Age (1890c), and Primitive Industry (1893). The belief that crude American artifact forms represented old objects was a natural conclusion for Wilson, who adopted European taxonomies and historical sequences. Wilson (1896:366) noted that "implements in large numbers have been discovered in nearly every State of the United States, bearing great resemblance in form, appearance, and mode of manufacture to the Paleolithic (Chelléen and St. Acheuléen) implements from western Europe. If accepted as such, their presence would prove the occupation of America by a prehistoric race of the same culture status" (Figure 14).

Wilson's methods and beliefs on the subject were in opposition to those of other Smithsonian anthropologists, for example, William H. Holmes of the Bureau of American Ethnology, who used observations and analogies drawn from the anthropology of American Indians. Based upon this different approach in examining archaeological materials, Holmes concluded that there was no evidence for early man in North America. After Holmes was appointed to supervise the archaeological work of the Bureau of American Ethnology in 1889, excavations were conducted at the Piney Branch Quarry in Washington, D.C., to examine the issue of the Paleolithic in North America (Holmes, 1890, 1897). The choice of Piney Branch was deliberate, as Wilson had concluded earlier that it was an American Paleolithic site, based upon the similarity of artifacts with European forms (Wilson, 1889). Holmes concluded that the stone tools from the excavations were not Paleolithic, but instead were rejects from the manufacturing process used by native inhabitants (Holmes, 1890). From 1890 to 1903 , Holmes visited almost every North American Paleolithic site, and discredited any evidence that suggested their early age (Meltzer and Dunnell, 1992).

Wilson continued to believe in an American Paleolithic (Wilson, 1896), despite the fact that by the turn of the century no new discoveries of ancient artifacts had been made (Meltzer and Dunnell, 1992). Holmes was appointed head curator of the Department of Anthropology in 1897, and one of his major achievements was the establishment of the new Division of Physical Anthropology in 1903 under the direction of Aleš

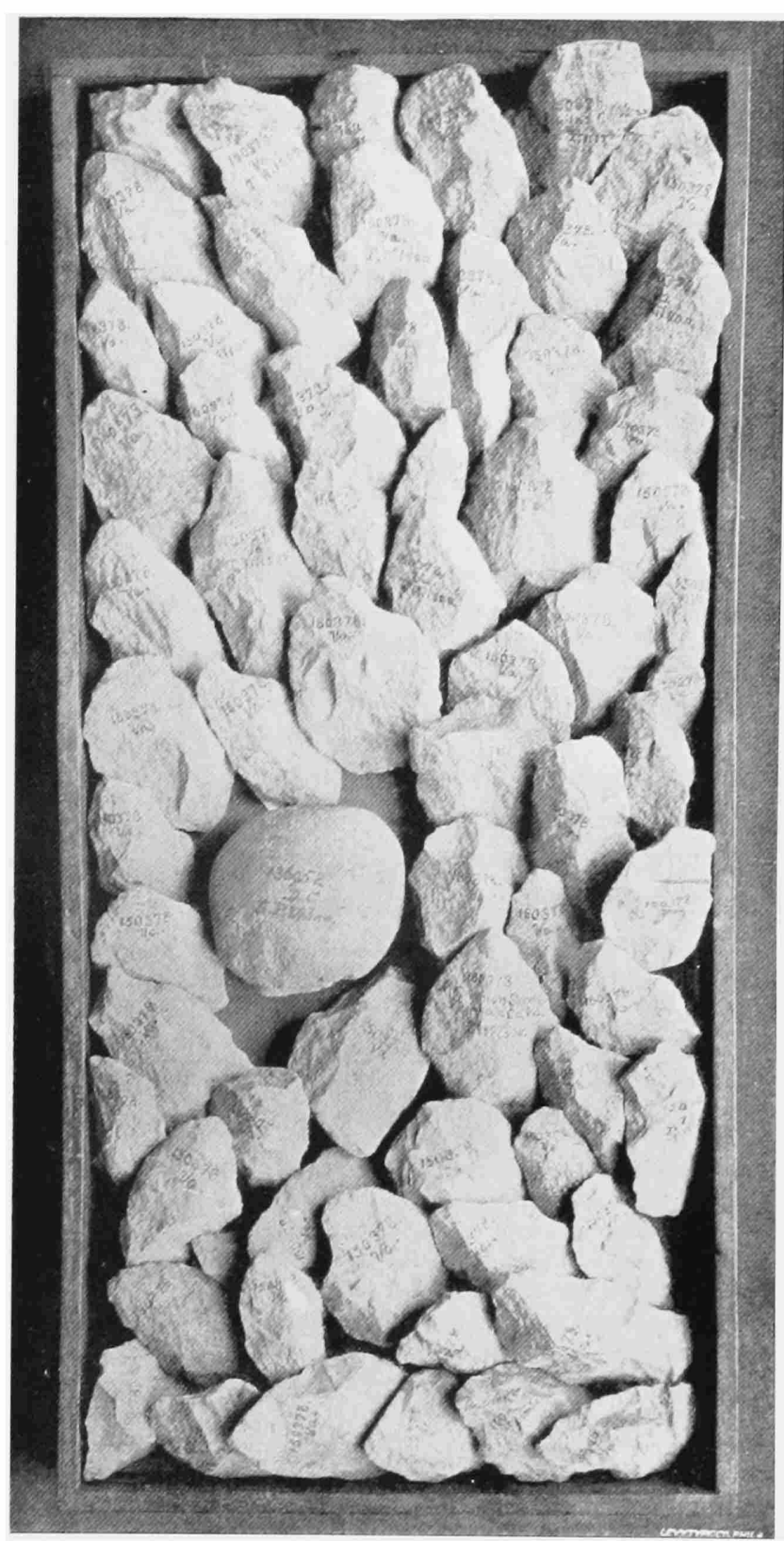

FIGURE 14.- Artifacts described by Wilson (1896, plate 4) as "rudely chipped quartzite implements of Paleolithic type," found at Mount Vernon, Virginia.

Hrdlička, his loyal friend and an ardent defender of the concept of a late peopling of the Americas. Ironically, Hrdlička's new position was partially supported by funds derived from the death of Wilson in 1902 (Meltzer and Dunnell, 1992).

\section{Collection Controversy: Deposit or Smithsonian Property?}

During his tenure at the National Museum, Wilson deposited 
12 collections of Paleolithic material. The method by which he contributed the objects to the Smithsonian set off a controversy after his death in 1902. Seven years before, on 18 January 1895, Wilson had written to Assistant Secretary George Brown Goode:

I find, on examination of the accession papers of the collections deposited in the Museum by me, that certain of them read or appear as 'gifts' when they should appear as 'deposits' or 'loans.' I have always said that all my collections were on deposit and not to be entered otherwise. I have no present intention to remove any of my collections from the Museum, nor to change their present condition in any way whatever, but I desire that the records should show the true position. If I wish to dispose of any portion of my collections to the Museum by my will, on certain conditions, such, for example, as the establishment of a course of lectures to be known by my name, I do not wish that my gift at that time should be met with the response that the collections are not mine to give. Some of these accessions marked as gifts, may have passed through my own hands and have received my own initials, but if so, these were by inadvertence and there has been no direction from me that they should be so entered. I am informed that in former times these distinctions were not strictly kept. I have prepared a letter which, if you will kindly sign and have placed on the records, it will satisfy me, and I have no doubt will make the record correct so as to be indisputable when we shall both have passed away.

Goode responded to Wilson on 19 January 1895: "I have to say that I have no doubt of the correctness of your statements concerning your intention to place your various collections in the National Museum on deposits and not as gifts. This letter being on file will serve to correct the record, and all your collections will stand on the Museum books as Deposits and not as Gifts." This was not the end of this subject, as Wilson corresponded, with some irritation, with museum officials two and a half years later. In a letter to Assistant Secretary Charles D. Walcott, on 20 July 1897, Wilson wrote:

I know there is a rule, or there should be, prohibiting Curators or, indeed, any employee, from the purchase or procuration of specimens. With a view to making a collection in opposition to, or in competition with, the Museum. I have always recognized the justice of this rule and have adhered to and acted on it. In all the collections I have made, some of which have been deposited in the $\mathrm{Mu}$ seum, I have never entered into competition with the Museum in their procuration. All the specimens I have ever procured have either been such as the Museum did not collect, or such as, offered to the Museum, it did not desire to obtain. I have recommended the purchase of a great many objects which the authorities of the Museum, usually Dr. Goode, declined. After such declination, I have felt myself at liberty to make any purchase I might be able to negotiate.

Apparently, there must have been some dissension at the museum on this subject. Expanding on the same subject on $11 \mathrm{Au}-$ gust, Wilson wrote to the National Museum's Executive Curator, Frederick True:

The collections which I have in the National Museum were always understood by me to be on deposit, and not registered as gifts-that was the understanding between myself, Professor Baird and Dr. Goode. It seems there was some misunderstanding with regard to the matter, and that some of the accessions are entered, not as deposits, but as gifts. Dr. Goode and myself had an overhauling of the entire matter, which was reduced to writing before he died, and ended in his giving directions to Mr. S.C. Brown to have any of these accessions of mine which were marked as gifts changed to deposits. These papers were put into the hands of Mr. Brown for the purpose of executing this order. I have asked upon sundry occasions about the progress made, and requested that it should be at- tended to with as much celerity as was convenient. You may imagine my astonishment the other day when informed by Mr. Brown that we had been instructed not to make any changes in the records when they were entered as gifts, and with the intention so far as Mr. Brown's records are concerned, of letting these accessions stand in that way. This was in direct opposition to the agreement between Dr. Goode and myself. I do not understand how, or for what reason, such a direction should have been given to Mr. Brown, not I can only suppose, upon its being called to your attention, that it will be carried out as agreed between Dr. Goode and myself. Whatever may be said or done, I state the fact to you in as positive terms as possible - that I never parted with, nor intended to part with, the title or my right of property in these objects, and my present desire is that the record should be made to correspond with that intention. However, I do not propose to harass you with an argument upon that subject, for it was all gone over between Dr. Goode and myself and settled between us on that basis. I will be much pleased to know that the changes are to be made. I do not understand that it will be much labor, for these were comparatively few entries made as gifts.

The accession debate resumed five years after Wilson's death. In a letter on 26 January 1903, the law offices of Hemphill \& Peter, of Washington, D.C., informed Secretary Samuel P. Langley that "under the will of the late Thomas Wilson his son James F. Wilson is bequeathed a certain archaeological collection on exhibition at the Smithsonian Institute, for which purpose it had been lent by the said Thomas Wilson. Mr. James F. Wilson desires to dispose of the same to some $\mathrm{Mu}$ seum in this Country with as little delay as possible, and with that in view we, as his attorneys, hereby request that you make us an offer for said collection." This letter shocked Smithsonian officials, and in a memorandum dated 9 April 1903, from R.I. Geare, chief of the Office of Correspondence and Documents, the circumstances of the deposit and the letters of correspondence were provided to Assistant Secretary Richard Rathbun:

I return herewith the letters from Messrs. Hemphill and Peter relating to the archaeological material obtained (chiefly in Europe) by the late Mr. Thomas Wilson, together with copies of certain letters which, I think, show very plainly how Professor Baird regarded the matter of ownership. While it seems quite probable that the Government could establish a satisfactory claim to these collections, this can be done only by setting aside Mr. Goode's decision of January 19,1895 (made in compliance with Mr. Wilson's request and prepared in typewriting by Mr. Wilson for Mr. Goode to sign), a copy of which is among the papers appended. Among the reasons which might be set forth in favor of Government ownership are the following: (1) Mr. Wilson made the collections while in the employ of the Government, and largely as the result of correspondence with Professor Baird, in which he continually assured the latter that he was prompted solely by a desire to serve the Smithsonian Institution and advance the cause of science. (2) Large numbers of specimens were sent from the National Museum from time to time, at his urgent and oft-repeated request, for use in procuring specimens by exchange, and the specimens thus obtained can be shown (according to the Registrar) to be included in the collections in question. (3) Mr. Wilson does not appear to have contradicted the general belief that the collections were given to the Museum, till several years after the death of Prof. Baird, in whose presence he had been heard by the Registrar to state that they were so given. (4) The Registrar declares that he has seen a letter signed by Mr. Wilson, giving these collections to the Museum. This letter cannot be found, although it was at one time in the Registrar's files. (5) The Smithsonian Institution asked for the free entry of the collections and paid large freight bills in connection with their transportation to Washington. (6) The labels which were fastened to the boxes containing these collections, bore the words 'Anthropological Specimens for the Museum,' as seen on the sample attached 


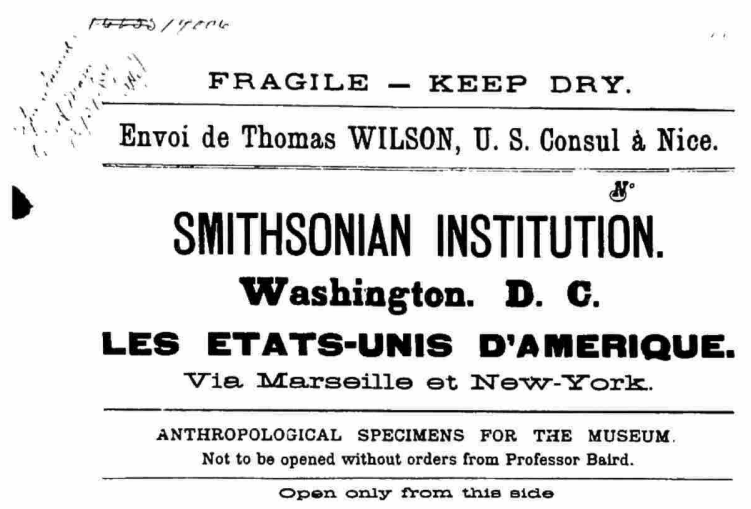

FIGURE 15.-Shipping stamp on an incoming box, Wilson accession.

[Figure 15]. While there would thus appear to be abundant evidence that for many years these collections were regarded as given to the Government, there cannot be now be produced, so far as I can learn, any positive documentary proof to substantiate such a claim.

Rathbun outlined the situation to Secretary Langley in a memorandum dated 7 December 1903, discussing the importance of the collection and the potential price:

I have already acquainted you with the fact that in his will the late Doctor Thomas Wilson bequethed his entire collection in prehistoric archeology to his son, James Franklin Wilson, and that the said collection is now offered for sale to the National Museum. It has been understood that Doctor Wilson valued the collection at $\$ 5,000$ [about $\$ 128,769$ in 2003 dollars], but the Museum has been requested to state the figure which it is willing to pay for it. Mr. James Wilson is not directly known in the transaction, all the correspondence so far having been between his legal adviser, Mr. Arthur Peter, and the Museum, beginning as long ago as January 26,1903 . It seems quite unnecessary for me to enter into the history of the Thomas Wilson Collection, which contains material from Europe, Egypt and America, the really valuable parts being practically all European. The first and main part of the collection was received here from Europe in 1886 and, as it was then understood that the collection was to be a gift, the Museum paid all charges connected with its transportation. The question of ownership of this part of the collection, as of all others which had been in doubt, was, however, finally settled in January, 1895, as vested in Doctor Wilson, as will be seen from the following copies of letters.

Rathbun also provided Secretary Langley with excerpts of letters from Wilson to Goode (18 January 1895), and from Goode to Wilson (19 January 1895). Rathburn then instructed William Henry Holmes, Chief of the Bureau of American Ethnology, to prepare an invoice and valuation of the collection. In reference to Holmes' valuation, Rathbun stated to Langley, on 5 December 1903:

Mr. Holmes, who has examined this collection with a view to deciding upon its value to the Museum, reports that for the European specimens he would name $\$ 2500$ [about $\$ 57,949$ in 2003 dollars] as a maximum valuation and for the American specimens $\$ 150$ [about $\$ 3,476$ ].

To lose the European material however, would make a large gap in our archeological series, though with time and the expenditure of no greater sum than $\$ 2,500$ it might be possible to obtain as full a set of this class of objects from
Europe as the National Museum would need to possess. The figures named by Mr. Holmes are based on the needs of the National Museum rather than on current prices for such material and, unless we can offer more than $\$ 2,500$, it seems reasonably certain that we shall lose the collection. I am constrained, however, to stand by Mr. Holmes' valuation, and so recommend that this sum be offered.

In the final correspondence on this ownership dispute, dated 16 January 1904, the attorney for Hemphill \& Peter replied to Secretary Langley that "On behalf of Mr. James F. Wilson, we do hereby accept the offer of the National Museum, therein contained, for the Archaeological collection now belonging to Mr. James F. Wilson and on exhibit at your Museum." In 1904, the museum collection was purchased for the extraordinary price of $\$ 2,650.00$ [about $\$ 61,426$ in 2003 dollars] from the Wilson estate. This transaction represented the largest single purchase of Paleolithic material in the Smithsonian's history.

\section{ALEŠ HRDLIČKA AND THE AMERICAN SCHOOL OF PREHISTORIC RESEARCH}

\section{Career and Intellectual Outlook}

Aleš Hrdlička had a long and illustrious career in anthropology, achieving fame for his research in physical anthropology (Stewart, 1940, 1981; Montagu, 1944; Schultz, 1945; Spencer, 1979; Loring and Prokopec, 1994) (Figure 16). Although the focus of Hrdlička's career was physical anthropology, he also made significant contributions to American archaeology, especially as it pertained to the peopling of North America (Spencer and Smith, 1981; Harper and Laughlin, 1982; Willey and Sabloff, 1993). Hrdlička strongly argued for a late age of human occupation of North America and the Old World, both of which eventually were proven wrong. Although shown to be incorrect, Hrdlička's stubborn belief in a late peopling of America forced other investigators to validate their chronological claims.

Hrdlička's career at the museum began on 1 May 1903, when he became an assistant curator in charge of the new Division of Physical Anthropology. He served as full curator from 1910 until his retirement in 1941. During his many decades at the National Museum, Hrdlička trained a large number of researchers in anthropology and anthropometric techniques (Spencer, 1982), thereby directly contributing to increasing the ranks of physical anthropologists. From the beginning of his career, he modeled physical anthropology after the biomedical sciences, and his institution plans closely followed M. Paul Broca's famous anthropological organizations in France (Spencer, 1981), with an ultimate desire to form an "institute" in Washington, D.C. (Stewart and Spencer, 1978).

Hrdlička founded the American Journal of Physical Anthropology in 1918. The founding of the journal was a landmark in the development of the field, as it established the discipline's identity, codified standards for the discipline, and provided an outlet to support the growth of physical anthropology (Spencer, 


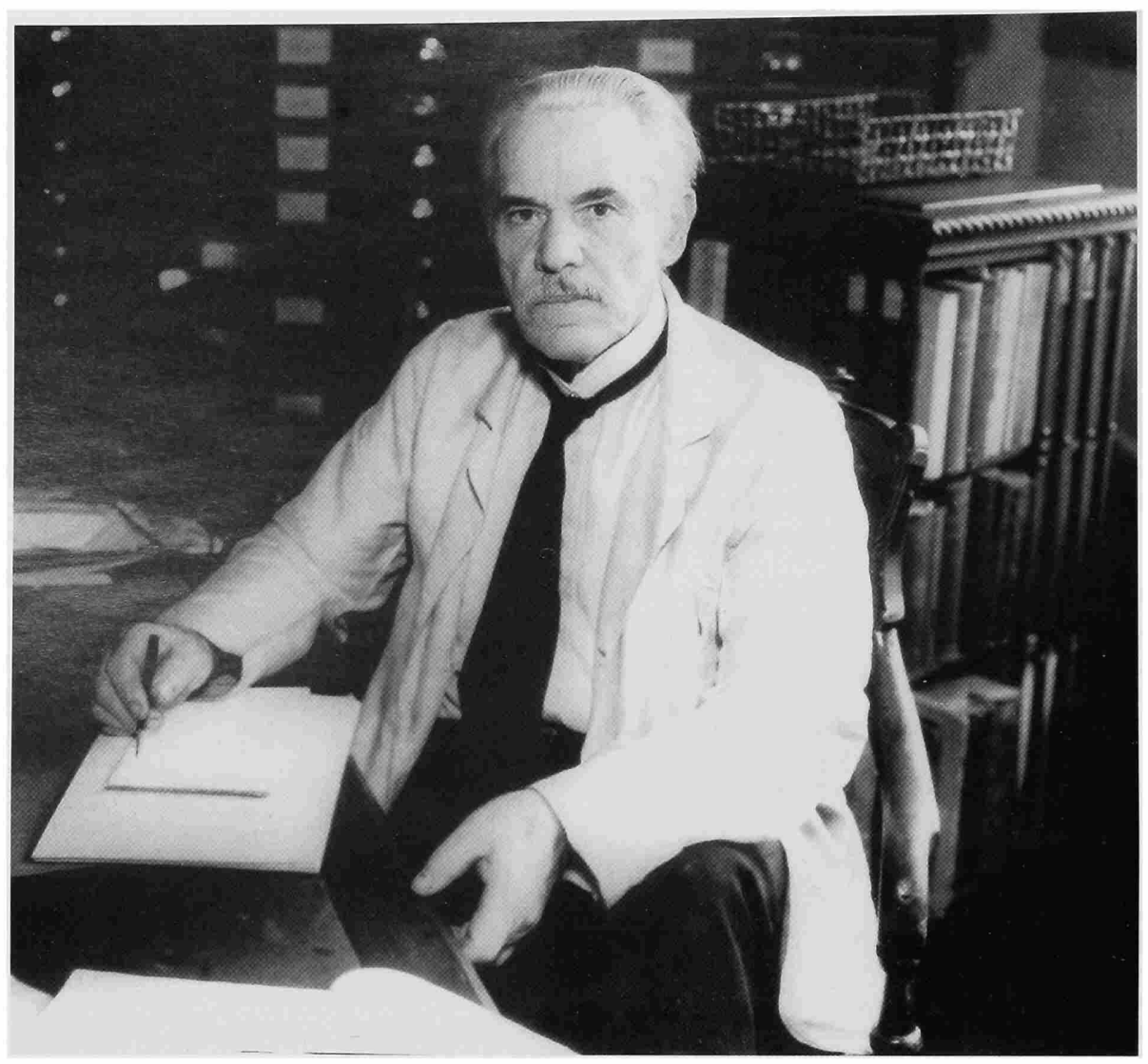

FIGURE 16.-Portrait of Aleš Hrdlička seated at his desk, ca. 1930s. [National Anthropological Archives, NMNH.]

1981). Hrdlička proposed the formation of American Association of Physical Anthropologists at the American Association for the Advancement of Science meetings in 1928. The proposal won approval at that meeting, after previous attempts during the 1920 s failed. The inaugural meeting of the organization was held in Charlottesville, Virginia, in 1930. Hrdlička also was involved in the establishment and growth of the American School of Prehistoric Research in the 1920s and 1930s (detailed below). During his career, Hrdlička published extensively on many subjects in physical anthropology, but during the 1930s he concentrated on his Arctic expeditions and on documenting morphological variation in Homo sapiens (e.g., Hrdlička, 1930b, 1944, 1945).

Concerning evolutionary skeletal studies in particular, Hrdlička published important technical works, including The Most Ancient Skeletal Remains of Man (1913) and the more extensive compendium, The Skeletal Remains of Early Man (1930a). Hrdlička also was engaged in popular writing on evolution, co-authoring the work Man from the Farthest Past (1930) with Associate Curator Carl Whiting Bishop (Freer Gallery of Art) and Secretary Charles G. Abbott.
With respect to early man of the Old World, Hrdlička contended that modern Homo sapiens evolved from Neanderthal populations (Spencer, 1997). In this model, he reasoned that hominids had slowly spread eastward into Asia and ultimately into the New World at the end of the Pleistocene (Hrdlička, 1921). Hrdlička's 1927 publication, based upon his Huxley Memorial Lecture to the Royal Anthropological Institute, The Neanderthal Phase of Man, was a very influential work in anthropology (Spencer and Smith, 1981). On the basis of anatomical observations, such as the shovel-shaped incisor trait, Hrdlička argued that Neanderthals were the direct ancestors of modern humans (Hrdlička, 1920, 1927; see also Spencer, 1979; Trinkaus, 1982). In the Huxley lecture, Hrdlička also marshaled archaeological data, seeing a cultural continuity from the Mousterian to the Aurignacian. As an argument against abrupt change, Hrdlička observed that many European Aurignacian occupations were located in the same places as Mousterian sites. Moreover, Aurignacian artifact assemblages resembled those of the preceding period, suggesting some degree of continuity. Although few scientists at the time supported Hrdlička's thesis that Neanderthals were direct ancestors, he made significant 
points about archaeological sites and hominid anatomical features that could represent adaptations to cold climatic conditions and variations among fossil populations (Trinkaus and Shipman, 1992). Although Hrdlička was concerned with evolutionary issues, he never concentrated his research on the material culture of the Old World, except for traveling extensively and leading the American School for Prehistoric Research, first as a direct participant and later as a facilitator. Hrdlička did, however, amass a large Paleolithic archaeological collection at the National Museum as a result of his extensive physical anthropological and evolutionary studies.

\section{Importance of Travels}

As a curator in the Department of Anthropology, Hrdlička traveled extensively to foreign countries to establish contacts with colleagues and to acquire collections. In 1908, he made his first request for permission to travel abroad. In a letter to the head curator of the department, O.T. Mason, on 1 May 1908, Hrdlička described why he considered such a trip important:

I know well that you share with me the desire to see the Division which I am in charge of abreast of the times. It is already well ahead of anything this Country [sic] in the quantity, character, and availability of its collections, and I should like to make it representative in every particular. With this object in view, it would be of great service if I were enabled to become acquainted, through personal examination, with the advancement in physical anthropology and allied branches much has been realized within the last 12 years, or since my last visit, in various European Institutions. I know through scientific writings as well as from private information that the advance has been substantial, while new collections and laboratories have been established, and there is no other satisfactory means than a personal visit through which most of the valuable details concerning new material, methods, etc., can be learned. I shall state in brief what such journey might safely be expected to result, all of which would be a more or less direct asset to the Museum: 1. Visit the principal European laboratories and collections in physical anthropology would furnish the knowledge of everything contemporaneous in the lines of existence, preparation, conservation and exhibition of material. 2. It would result in the establishment or renewal of personal contact with men in the same field of research, which is a factor of great advantage in many particulars. 3 . It would in all probability lay foundations, or lead directly, to desirable exchanges of material.

Mason agreed with Hrdlička on the importance of foreign travel to obtain collections and wrote to Assistant Secretary Rathbun on 4 May 1908, requesting permission for such a trip:

In begging you to grant Doctor Hrdlicka's [sic] request, 1 recall the great boon that fell on me in 1889, when Professor Langley sent me to the Paris Exposition and on the inspection tour of museums. Doctor Hrdlička, familiar with German, educated at the Ecole d'Anthropologie, at Paris, personally acquainted with the men and the situation, would make his visit most helpful to the future development of the Division. He could learn the best of the best methods, see the various ways of managing study series and exhibits, and acquaint himself with the sources of materials which might be obtained through exchange. I know that it will be with the sacrifice of personal comfort for him to make the journey and I think that the mission would in every way rebound to the upbuilding of the National Museum.

Hrdlička was granted his travel request, visiting Egypt, Greece, Turkey, Hungary, and Bohemia, among others. Hrdlička's desire to travel, to build rapport with foreign scien- tists, and to amass collections in anatomy and archaeology continued after his first extensive trip. In 1920, he traveled to China, Japan, Korea, Manchuria, and Mongolia, and in 1922, he visited Spain, France, Germany, Moravia, and England. In 1923, as Director of the American School for Prehistoric Studies in Europe, he visited England, France, Holland, Belgium, Germany, Bohemia, Austria, Croatia, and Italy, and in 1925, he traveled to Australia, India, Java, South Africa, and Europe. Hrdlička's motivations for such wide-ranging trips were described in his letter to Hough on 24 January 1908, prior to his Asia trip:

To visit India [and] all the Institutions that possess anthropological, archaeological and paleontological collections for the purpose of becoming acquainted with just what there is in these lines in that country in relation to the fossil apes and early man. From India I shall proceed to Java, stopping if possible at the Straits settlements to see the local workers and collections. In Java I shall endeavor to become acquainted with all the collections of interest to anthropology; to visit the sites of the discovery of the first as well as the most recent second Pithecanthropus, and any such excavations or sites of importance as I may learn of after my arrival.

Hrdlička continued his official travels throughout his career, acquainting himself with other paleoanthropologists, visiting archaeological and paleontological sites, working in museums reviewing their specimens, and establishing connections with individuals and institutions for the purpose of obtaining primary artifactual material and human fossil casts for the museum.

\section{Involvement with the American School of Prehistoric Research}

The American School of Prehistoric Research, as it was later called, was established to train students in prehistory and to conduct field investigations of prehistoric sites, especially famous localities in France (Figures 17-21). Establishing the school was considered a significant enterprise to its advocates as there were only five universities with doctoral programs in anthropology in the 1920s (Spencer, 1981; Griffin, 1985), and none had offered specific training in the Paleolithic.

The organization began in 1921, when George Grant MacCurdy and Charles Peabody, of Yale University, officially applied the name, the "American School in France for Prehistoric Studies." Just prior to its founding, Hrdlička encouraged Peabody in a letter to him dated 6 December 1920: "I am glad to hear from you and of your work in France. I regard the resumption [after World War I] of investigations of Early Man as of the utmost importance, and hope once to see established a special Association of patrons and workers in that line." The school was affiliated with the Archaeological Institute of America, an organization that studied ancient civilizations. MacCurdy was the school's first director; he was succeeded by Charles Peabody in 1922. The founding of the school marked the beginning of sustained research in the pre-literate history of Europe by American scholars (Patterson, 1995). In 1923, Hrdlička became director of the school and in 1924, MacCurdy, who had just published major works on human origins (MacCurdy, 1924), assumed the directorship for the duration of 


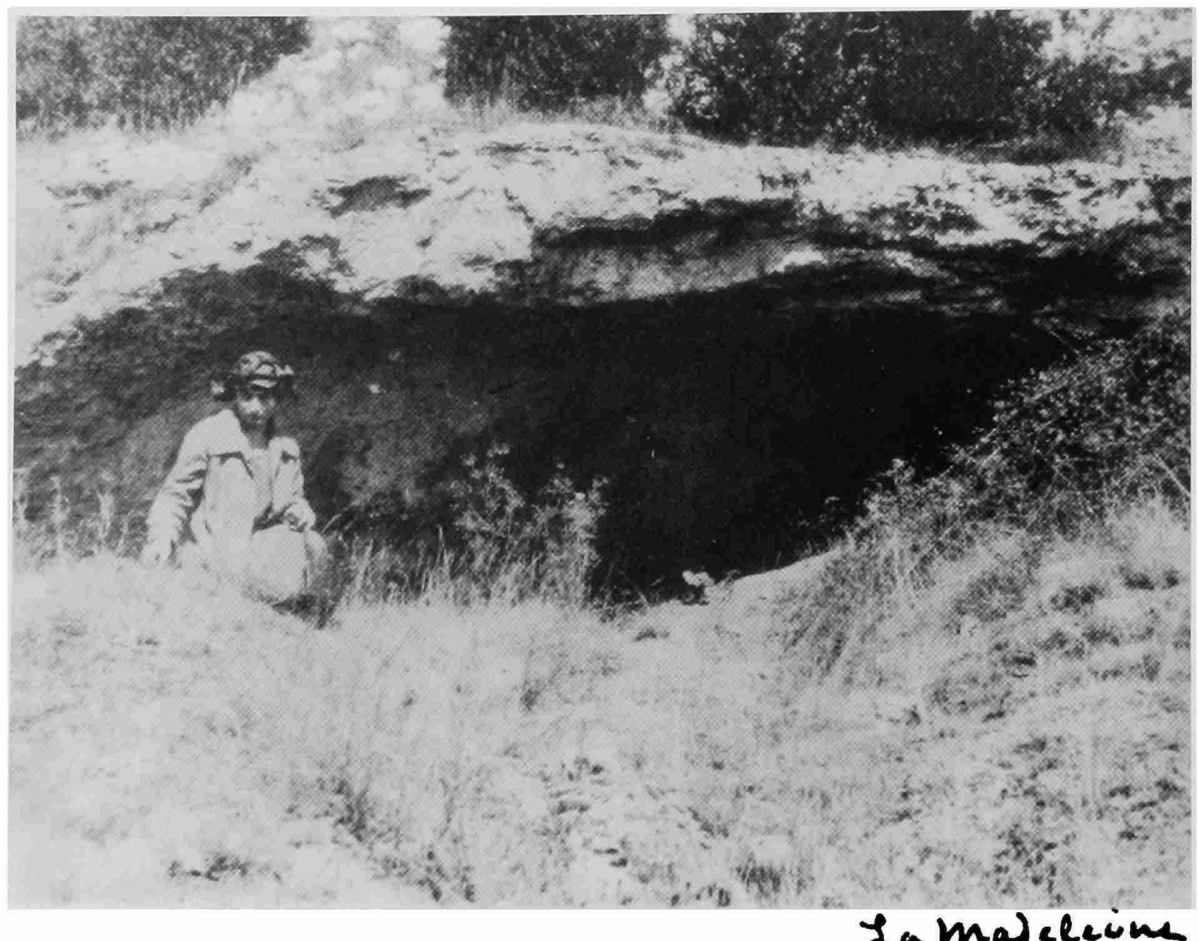

FIGURE 17 (left).-Photograph taken at La Madeleine, France. [M. Lesvignes is seated next to the cave entrance. Photograph by $\mathrm{H}$. Ami, 1923. Hrdlička collection, National Anthropological Archives, NMNH (number 96-10200).]

FIGURE 18 (below).-Photograph taken at Laugerie Basse, France. [Photograph by $\mathrm{H}$. Ami, 1924. Hrdlička collection, National Anthropological Archives, NMNH (number 96-10314).]

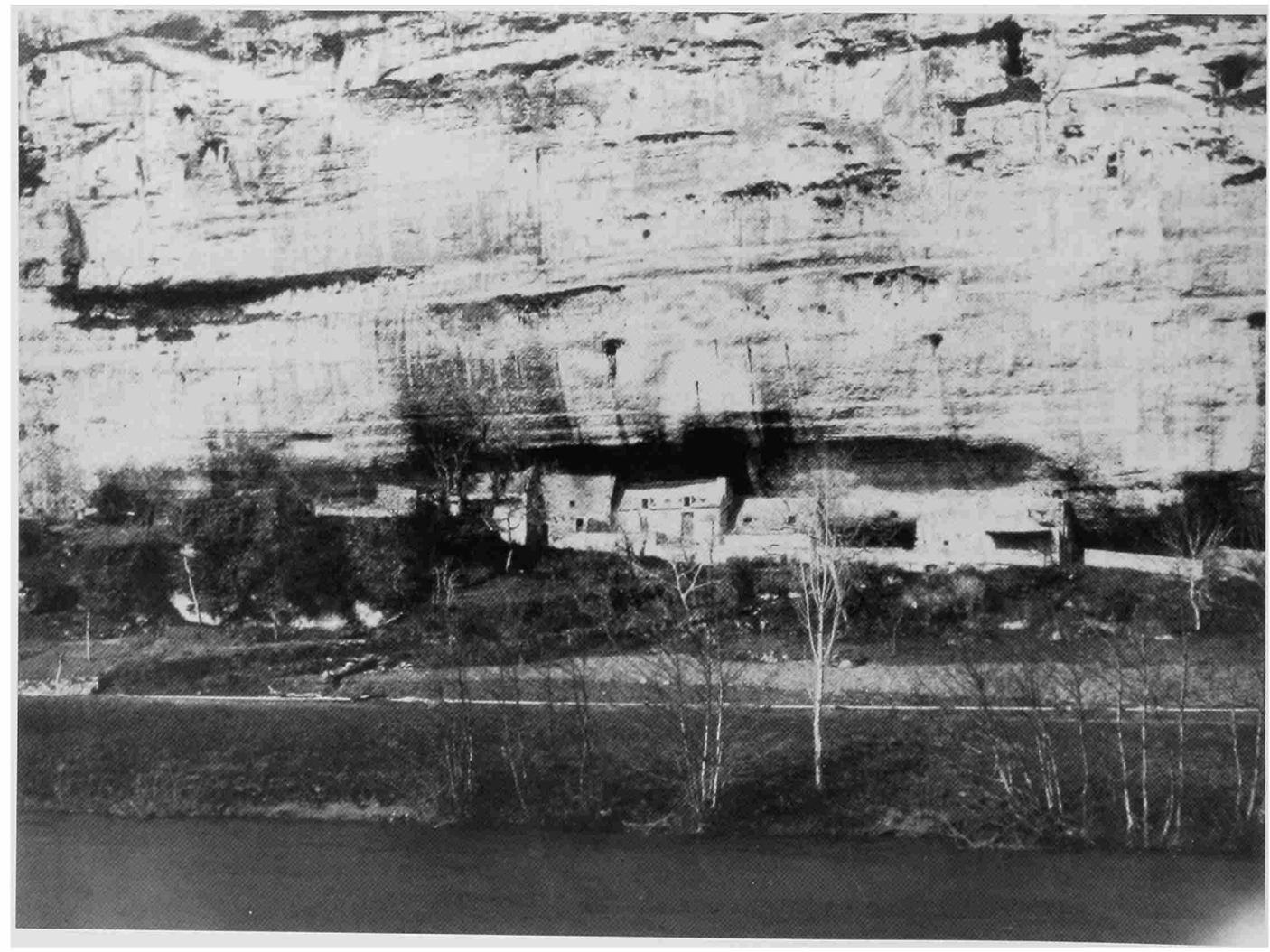




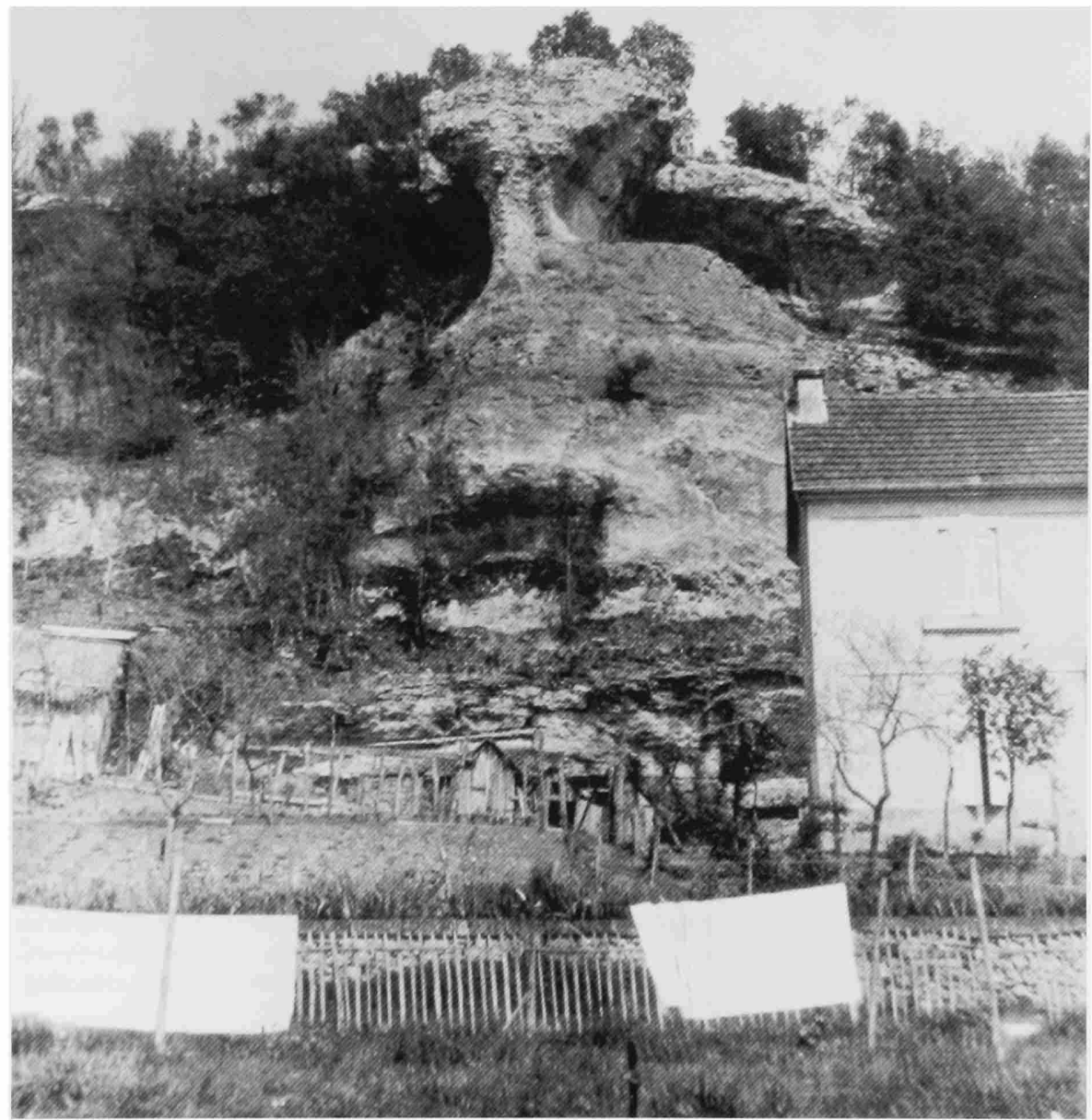

FIGURE 19.-Photograph taken at Cro-Magnon, France. [Labeled, "Room-like rock on hilltop. Five skeletons found below, under shelter." Photograph by H. Ami, 1923. Hrdlička collection, National Anthropological Archives, NMNH (number 96-10329).]

its activities (McCown, 1948). Based upon the accomplishments of the school during the 1920s and 1930s, MacCurdy is considered to have done more than any other American scholar of his generation to promote interest in Paleolithic archaeology (DeSimone, 1997).

The first season's fieldwork of the American School in France for Prehistoric Studies opened on 2 July 1921, at the famous Mousterian site of La Quina, in coordination with the well-known prehistorian Dr. Henri Martin. Martin was a medical doctor who had found Neanderthal fossils at La Quina in 1910. A decade before the first season's work at La Quina, Hrdlička had already established a relationship with Martin, meeting him in 1912. Long-term collaboration with Martin was probably a consequence of the importance attached to his Neanderthal discoveries (e.g., Martin, 1911, 1912a, 1912b). The activities of the school in 1921 were to last for nine weeks. This was followed by brief searches at other sites and excursions to other parts of France (MacCurdy, 1922). In a letter dated 31 July 1921, from France, MacCurdy wrote to Hrdlička about their progress: "The School opened at La Quina on July 4 and our laboratory is gradually filling with specimens. Thus far we have found no skeletal remains of Neandertal Man; but we have found in a cave near La Quina four or five human teeth belonging to the Magdalenian epoch. Dr. Charles Peabody paid us a visit here on July 20 . He seemed well pleased with the progress already made and with the outlook of the future." Hrdlička also was interested in obtaining Neanderthal casts and material, as described in a letter to MacCurdy on 3 December 1921. "As soon as I get the address of Dr. Martin's modeller we shall order a copy of the reproduction of the skull and what- 


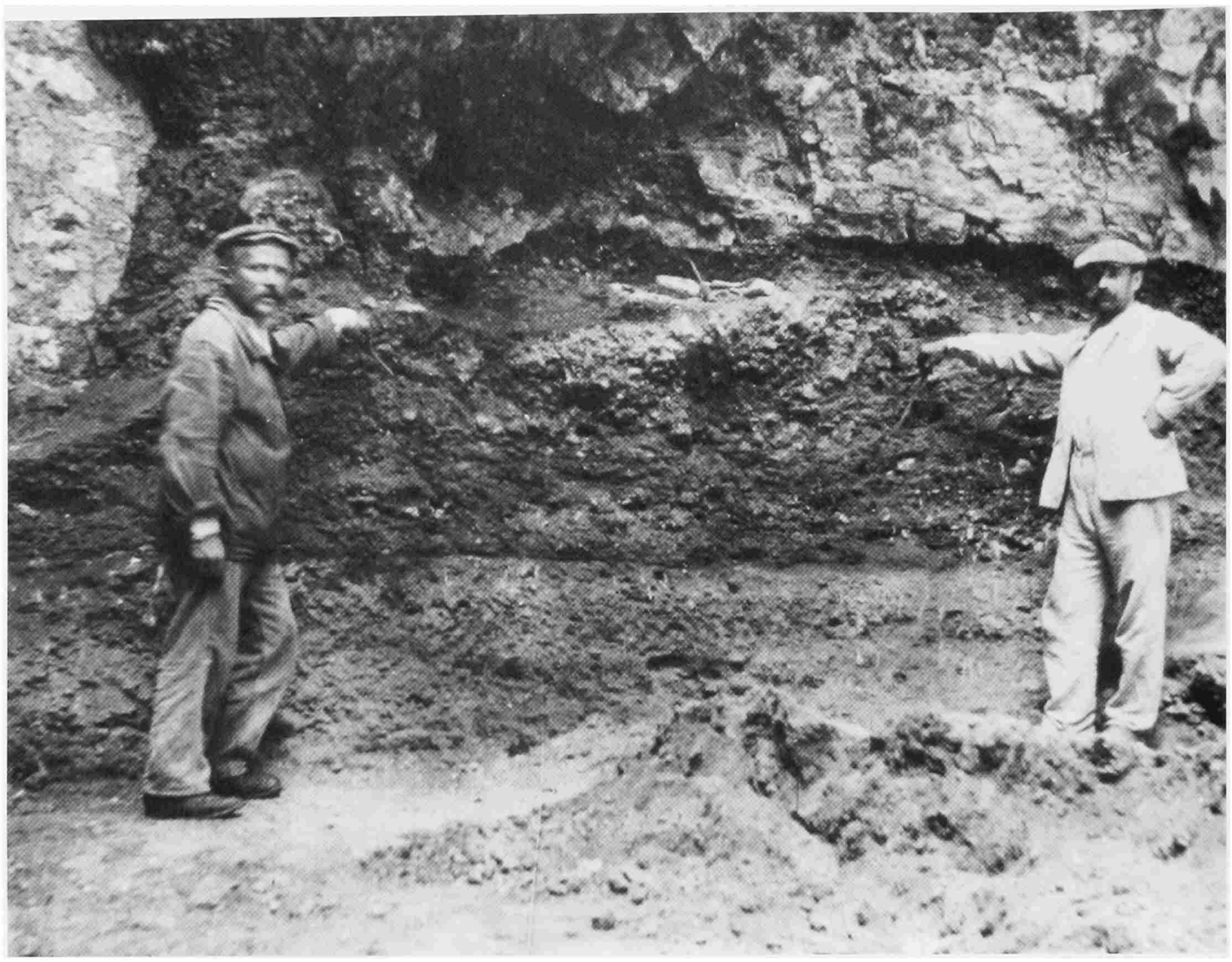

FIGURE 20.- Photograph taken at Laugerie Haute, France. [Labeled, "Magdalenian, Solutrean, and Aurignacian Section." Note the small hand tools resting on top of the section, the fresh backdirt pile, and the fresh profile section with horizontal layers demarcated. Photograph by H. Ami, 1923. Hrdlička collection, National Anthropological Archives, NMNH (number 96-10327). Men in photo are not identified.]

ever other specimens he may have already. But I wonder if Dr. Martin would not wish to give the National Museum copies of these in exchange for some of our archaeological or other material. We would surely endeavor to give him a full equivalent. Due to congressional restrictions in our appropriation it is getting more and more difficult for the Institution to buy anything."

Hrdlička's involvement with the school increased in 1922. In a letter dated 20 January 1922, Peabody requested Hrdlička's involvement and explained the informality of the workings of its board of directors. "Our Board meeting is a very simple affair, and the discussion has been so far informal and cordial, around a table. A consensus of opinion on the excavation work of next year in view of the possibilities is at hand, and of the future scope of the activities of the School." During that year, Peabody became the director of the school, supervising excavations at La Quina, where he dug trenches and recovered abundant artifact and faunal collections (Peabody, 1923). On 23 May 1922, Peabody wrote a cordial letter to Hrdlička: "It is really a great pleasure to know that you are to be in France next fall; count on me for any possible aid that I can give. If we are still at La Quina we shall be much put about if you do not come there and see us. Dr. Martin's laboratory will interest you, though I believe the skull of La Quina is in Paris. Of course as you know, [Abbé Henri] Breuil (address c/o Muséum de Paléontologie Humaine Paris) and [Marcellin] Boule (address c/o Muséum d'Histoire Naturelle, Paris) are the ones you will hob nob with. I believe there is always some one, generally [Denis] Peyrony at Les Eyzies, where they have now a very important Museum."

Just as Hrdlička assumed directorship for the 1923 season, problems arose concerning the relationship between Martin and the school. Martin had long made clear his wish to control all activities at La Quina. He had purchased the site and had prevented local amateurs from digging at the excavation (Trinkaus and Shipman, 1992). The school's problems with Martin concerned excavation privileges and artifact shares and ownership. MacCurdy reviewed what he understood to be the terms of the agreement with Hrdlička on 4 May 1923. "His [Martin's] original agreement in 1921 was that the School could have everything except human bones; apparently he [Martin] reserved the right to make new stipulations from year 


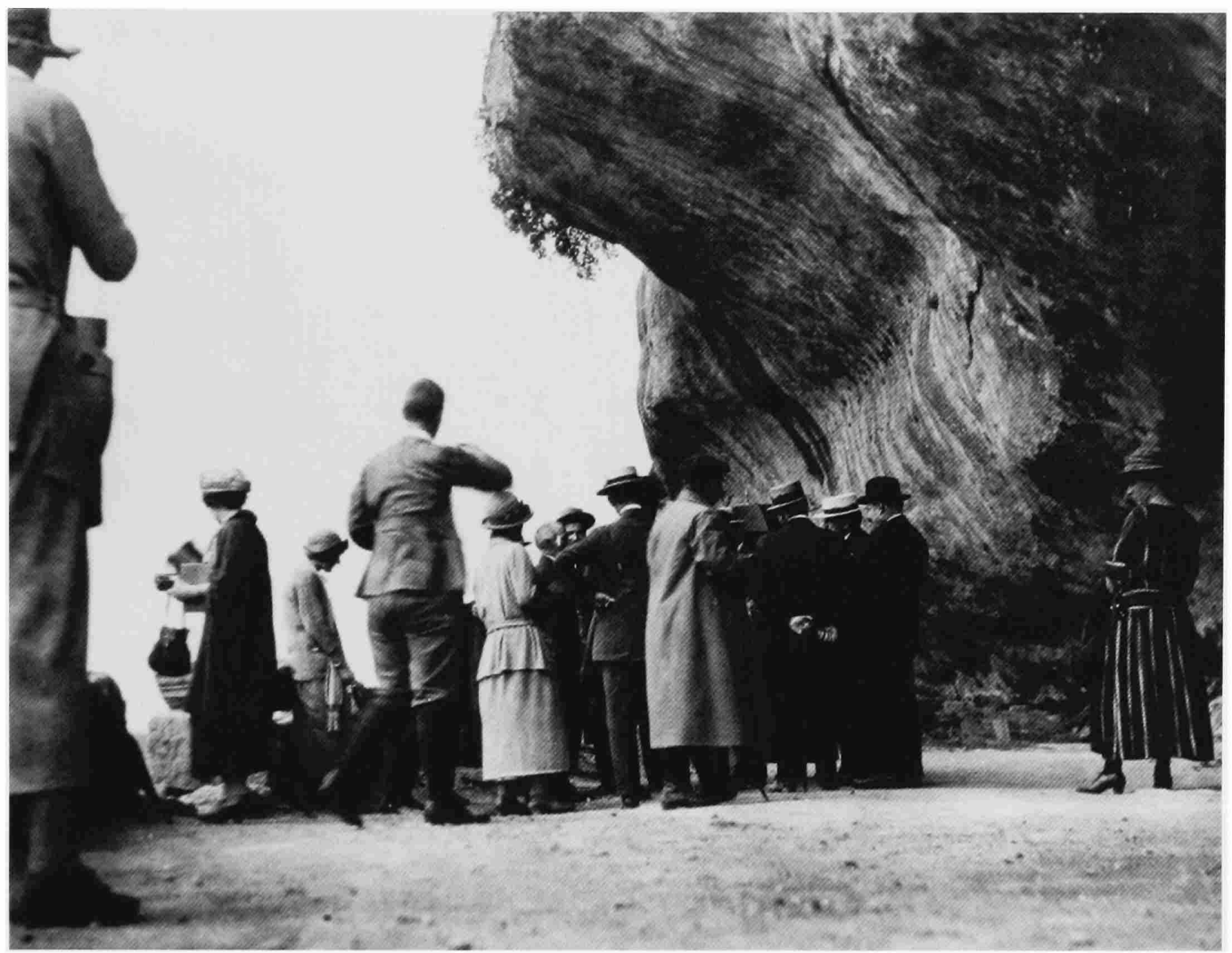

FIGURE 21.-Photograph taken at L'Abri du Chateau Les Eyzies, France. [Labeled, "During the visit of Dr. Hrdlička and the School of Prehistoric [Research]." Photograph by H. Ami, 1923. Hrdlička collection, National Anthropological Archives, NMNH (number 96-10326).]

to year. By the same token we should be left free to accept his stipulations or leave out La Quina altogether as the School may think best." Apparently, Hrdlička could not accept Martin's revision of the terms, diplomatically explaining his position to Peabody in a letter dated 5 May 1923:

Regarding the agreement with Dr. Martin, the Committee was of the unanimous opinion that it should not be signed for this year, but that matters should be in the most friendly spirit explained to Dr. Martin, to whom the School is much indebted, and that an arrangement be made with him for the reception of the School after its preliminary trip and for a short time only. I feel sure that he will see the justice of our procedure.

On the same day, however, Hrdlička wrote a blistering letter on the same subject to MacCurdy: "The contract with Martin is identical with that sent before. It is unworthy of the School and I will not have anything to do with it. The National Museum, even if it has the first choice, will not, I am sure, hog things and no trouble need to be anticipated."

Instead of excavating at La Quina, Hrdlička proposed to take students to Europe to meet with prominent scholars and to review sites and collections. Hrdlička explained his position on the question of the La Quina excavation and the proposal to travel to Europe with students in his same letter to Peabody, on 5 May:

The object is to give the students the best possible returns, and thus help to further raise the standards of the School. The intensive work at La Quina alone does not have sufficient attraction to the best of students, they know but little about the whole subject of Ancient Man and want some solid basis to start with. Under these conditions and in view of the kind of students we shall have this year it was deemed best to precede any local work by visits to and examinations of the most important sites of ancient man and of their yield in various parts of western and central Europe, and only then come to La Quina for excavation. The plan is feasible, for I have personal knowledge of practically all these sites as well as the specimens outside of France, and the firsthand knowledge thus gained of the whole field will be a great boon to the students, several of whom are instructors. I believe you will see the wisdom of this course, which may or need not be repeated in future years, according to conditions.

During the summer and fall of 1923, for three-and-a-half months, Hrdlička and his students visited dozens of sites, institutions, and museums in western and central Europe (Hrdlička, 1923). On 18 July 1923, Hrdlička wrote to Hough at the museum, about his travels in Europe:

Things are going so well, and my days are so crowded that I find but little time for writing. Of all my trips to Europe this promises, in fact has been already, the most fruitful. I find everywhere but friendship and helpful hands, until at 


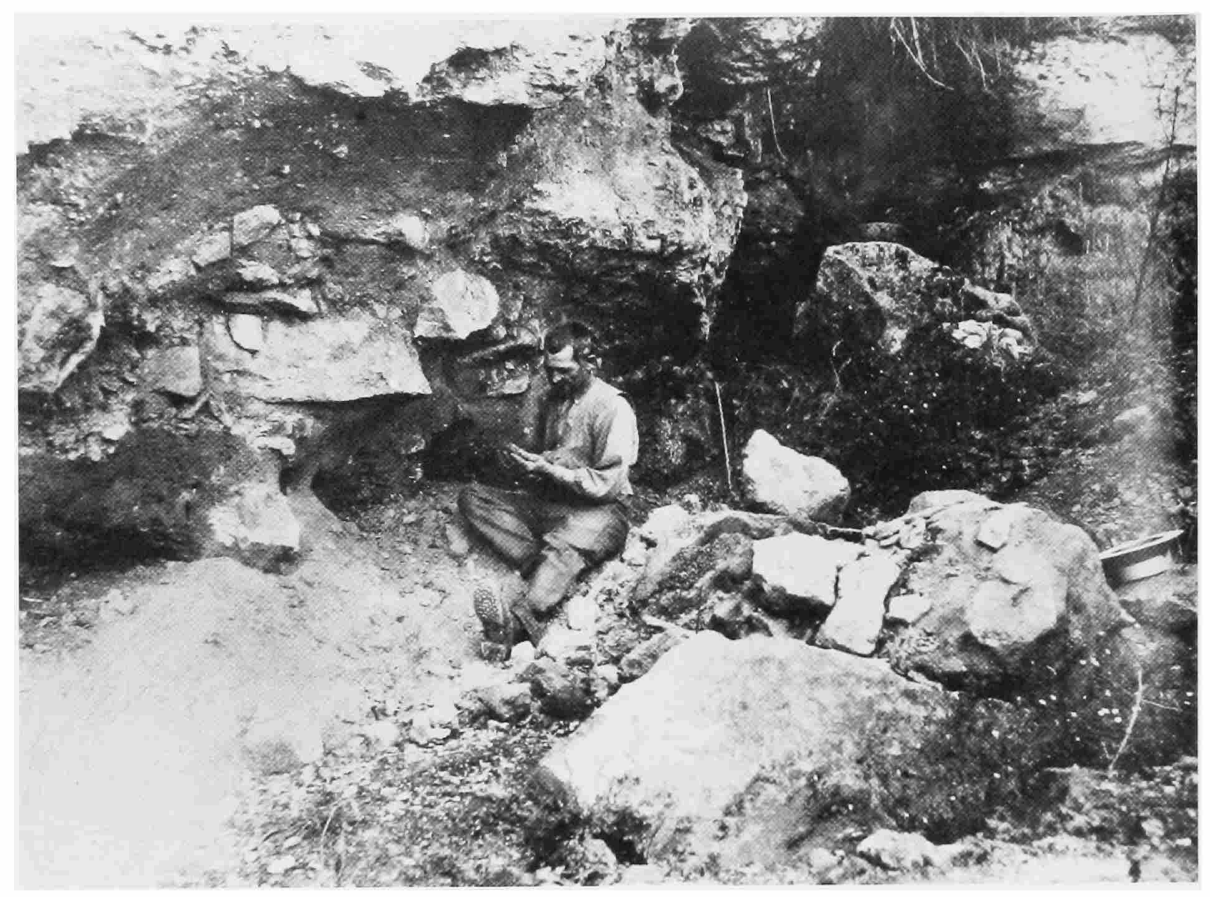

FIGURE 22.-Photograph taken at Sergeac, France. [Labeled, "M. Castanet, Sergeac, September 4, 1923."] Note the deep excavation profile, the fresh section, backdirt, and the removed eboulis blocks and artifacts. [Hrdlička collection, National Anthropological Archives, NMNH (number 96-10876).]

times I am almost ashamed and apprehensive as to whether we shall ever be able to return this kindness. I strongly feel that, in our Institution at least, for all that is tendered to me I am sure belongs foremost to the Institution, we shall never be able to do enough for foreign men of science.

During the summer, Hrdlička received a letter from a perturbed Peabody on 31 July 1923, explaining the French position, which he apparently agreed with:

Before leaving the last time for America Mr. Hubert at St. Germain called me aside and had a very serious talk-Dr. Martin will explain his views at La Quina-I may say that I am absolutely in accordance with them-so is Mr. Hubert \& he thinks that we Americans should know the situation. Dr. Martin owns La Quina - we are his guests at his invitation—such conditions as he makes are his right. The ambitions at other such sites would certainly be the same- - Hubert is as you know, under the government $\&$ would \& could do as he says. All the French have extended these years courtesies without number to the School \& I feel in debt of him. It is entirely through me that the money for his life work has been the discovery of skeletal remains at this site and (with the addition of flints \& bones) the publication of them. In case of further discoveries in the American section, he cannot permit others to take over his own duty \& privilege-\& naturally he can not permit such exportations. Hubert agrees with him \& if it were necessary would have a law passed tomorrow preventing it.

Hrdlička and his students did spend eight days with Martin at La Quina, but consistent with his statement, the school did not work at this site alone (Hrdlička, 1923).

In preparing for the 1924 season, Hrdlička had discussions with European prehistorians about new sites. On 17 October 1923, Denis Peyrony, a French prehistorian and excavator of
Neanderthals at La Ferrassie, contacted Hrdlička concerning joint excavations in France proposed by M. Castanet (Figure 22). On 2 November 1923, Hrdlička replied to Peyrony:

Your good letter of October 17 has just reached me and I am glad to hear that the little contribution which I could make towards your work has been favorably received. I wish I could do more for you. Regarding the Sergeac proposition (M. Castanet), I am urging the lease of the site as much as I am able, and it is not impossible that M. Peabody has been to see it before this reaches you. I have given practically all that remained of this year's expenses to the School and which was to have been my 'salary' to that end. I trust M. Castanet will be reasonable. I returned very happy that I could see all the work about Les Eyzies and particularly your own careful explorations at L'Augerie Haute [Figures 20, 23] together with the site at La Ferrassie. I feel convinced that the region is far from exhausted and that it will yield new and valuable evidence as the work progresses.

At the same time, there was a growing disagreement between Hrdlička and MacCurdy, on the one side, and Peabody, on the other, concerning the research focus of the school. Indicating he would not support the school in its new direction, Peabody wrote a terse letter to MacCurdy on 26 January 1924: "Need I say that I disclaim all responsibility in financing and direction of the School from this time on? The sum of three thousand dollars [about $\$ 31,543$ in 2003 dollars] is too much for me to raise, the change of name substituting 'Europe' for 'France' does not meet my approval, and the enlargement of the comparatively modest School of excavation and study seems to me unnecessary. The Managing Committee seem to have departed 


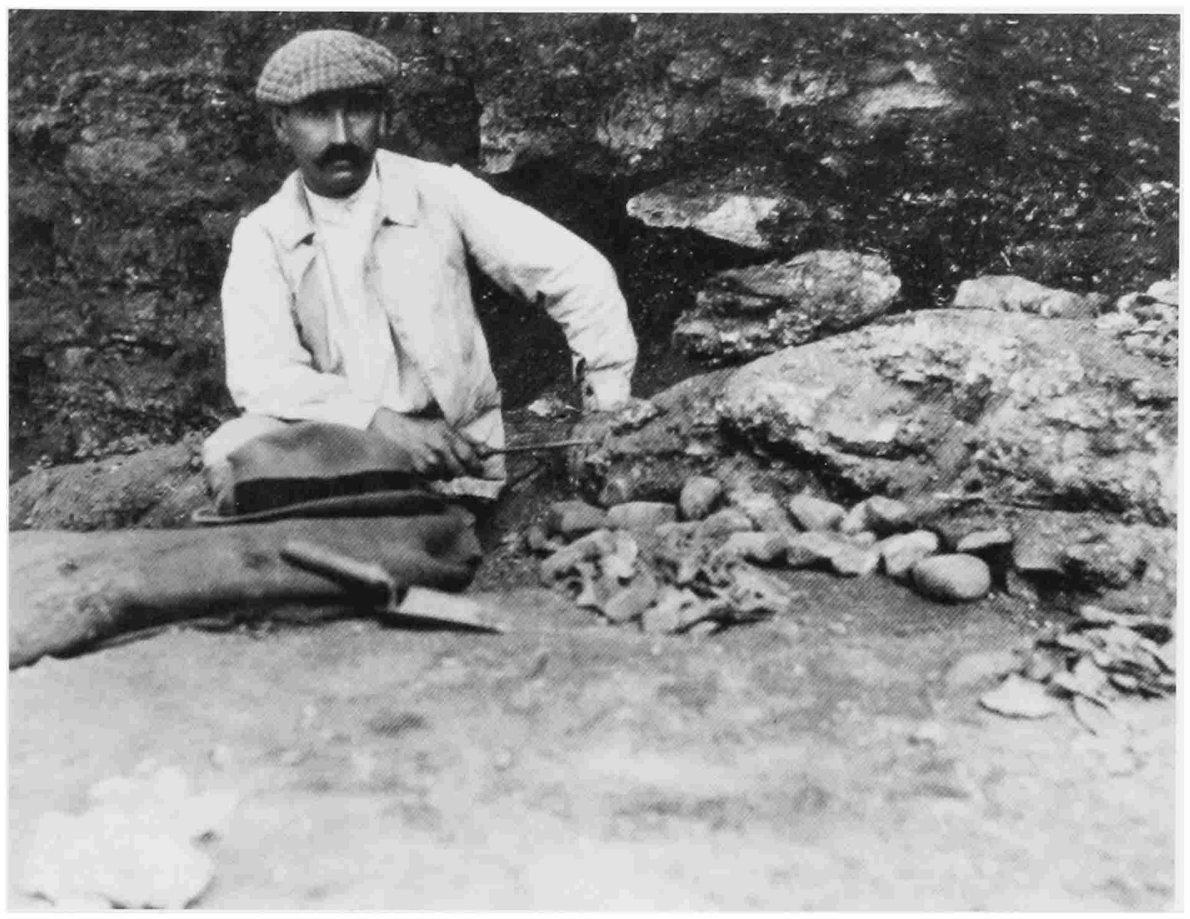

FIGURE 23.-Photograph taken at Laugerie Haute, France. [Labeled, "Solutrean fireplace, hearth pebbles." See Figure 20 for another view of the excavations. Photograph by H. Ami, 1923. Hrdlička collection, National Anthropological Archives, NMNH (no. 96-10328). Man in photo is not identified.]

from the ideas that Dr. Martin and I had in mind in founding the School and not to have kept in mind what the former has contributed to its successes." As a consequence, Hrdlička and MacCurdy turned their efforts to broadening the work of the school. On 16 February 1924, Hrdlička wrote to MacCurdy: "I think Peabody's letter settles matters quite definitively. It is plain that he still holds to the original small object which now has even become ever so much smaller. He feels of course bad about the change without perceiving that there is no alternative. If the School is to be worthy of its name it must be reorganized on broader and sound principles."

Hrdlička and MacCurdy began excavating other potential sites and developing relationships with other researchers. Hrdlička wrote to Peyrony, on 25 June 1924:

With the coming of warm weather, thoughts naturally turn again to field work. I presume you have been busy for many weeks already. This is to let you know that I have been trying hard to realize the plan I spoke to you about last year, namely the lease of the site at Sergeac; and there is some hope that at last the necessary amount for the leasing of the site may be raised. The School this year will be again under the direction of Professor MacCurdy who will have seven or eight excellent scholars with him, and the need of some good site which may be called the School Zone is very urgent. I trust you will help us again as you did last year, for both Dr. MacCurdy and myself have the fullest confidence in you. As a small return I have been trying to raise again a little sum for the help of your own Museum or exploration, and my wish is that we could contribute a little every year towards your meritorious work. But it is hard nowadays to raise money for scientific purposes, due to the heavy taxation that resulted from the war. I also wish to remind you that all here would be most thankful to you if you would notify us briefly as you may wish, of any possible important new finds of skeletal remains of Early Man in your district. Interest in Old World archaeology here is growing and we want to stimulate as much as possible.

On 9 July 1924, Peyrony replied to Hrdlička's letter, approving excavations with MacCurdy near Eyzies and indicating that the site at Sergeac would be acceptable. Hrdlička immediately sought funding for the excavations, approaching the Research Committee of the Archaeological Society of Washington about the great potential of the site (Carroll, 1925). As a result, one of the trustees of the society paid a 10-year lease for exclusive rights to excavate at the rich Mousterian and Aurignacian rockshelter site of Les Merveilles at Castel Merle, in the town of Sergeac (MacCurdy, 1925). The 1924 season also included excavations at Solutré and visits to other institutions and museums in France and Switzerland.

After digging at Sergeac for a week, MacCurdy described the excavations in a letter to Hrdlička, on 10 August 1924: "Six besides Mrs. MacC. and myself are at the diggings. A good deal of manual labor has been and will continue to be necessary. We already have as many specimens as we got at La Quina in 10 
weeks." Hrdlička was proud of this accomplishment, boasting about the excavations to prehistorian Henry Ami of the Geological Survey of Ottawa, in a letter dated 26 August 1924:

You will be interested to hear that the American School, at my instigation, has succeeded in leasing for ten years the very promising site at Sergeac. They have already begun work and Dr. MacCurdy writes me that they have recovered in one week more specimens than in ten weeks two years ago at La Quina. The main thing, however, is that the School will now have its own home in the richest region archaeologically of France.

Ami was delighted to hear of this work, immediately responding favorably in his letter of 30 August 1924:

I am indeed much interested to learn that the 'American School' has succeeded in leasing the very promising site at Sergeac. How thrilling it would be [to be] there now, or at any time. By digging in these old habitations and reading the daily life and manners of these good old folks of the Palaeolithic Period in the fire-places where they cooked their meats, and where they fashioned their flint implements beside the much needed fires of the very frigid territories which they occupied, one can not but live over again that great past on which we depend so much, to which we owe so much, if we can only recognize it, and enjoy with them the sweet odours of their grills $\&$ feasts.

The Sergeac excavations were considered the most successful season the school had had to date, and the digging continued for several years, identifying stratified Upper and Middle Paleolithic horizons (MacCurdy, 1931). Extensive collections of artifacts were shipped to Washington, D.C., and accessioned at the National Museum, resulting in a collection of more than 4000 artifacts. MacCurdy was grateful to Hrdlička, thanking him on 10 June 1926: "The School owes you a debt of gratitude for looking after its affairs so efficiently. We especially appreciate your willingness to help prepare students for the course in case they are able to go to Washington for that purpose before they sail." MacCurdy also delighted in the fact that rival American institutions would no longer engage in excavation of sites or purchases of objects in France, thereby providing more opportunity to the Archaeological Society of Washington for additional work, "Perhaps our best bit of news is from Collie, $\mathrm{Cu}$ rator of the Logan Museum, Beloit College." He says: "It may relieve your mind to know that the Logan Museum has given up its plan and so far as I personally am concerned I doubt whether I should ever come to organize another one. The trouble and expense connected with the endeavor is so great that it would rather deter me from entering on the project again. Let us hope that this is the end of the Beloit movement in so far as it may effect our own School."

On 11 February 1926, the American School of Prehistoric Research was incorporated in Washington, D.C., with both Hrdlička and MacCurdy as trustees, for the purpose of fund raising and for the promotion of their scientific and teaching programs. Regarding the Smithsonian's role in the founding of the corporation, Hrdlička explained this to Assistant Secretary Wetmore on February 19: "When it came to the question of the connections of the School with the Smithsonian, I told them that after a consultation with you I was not able to make definite promises; I assured the School that the Institution will do for it the best that may be possible, but that a definite decision on any point must await special and detailed requests by the School. In other words, I tried to convey the impression that the Institution could not commit itself in general but that it will be glad to give its benevolent consideration to each request of the School when definitely made."

The 1926 season included work in western and central Europe, with a continuation of excavations in France (MacCurdy, 1927). During the same season, the MacCurdys visited Palestine, drawn by news that Neanderthal fossils had been recovered there in 1925. As a result of this trip, the school concentrated its future research activities in Palestine, in joint sponsorship with the British School of Archaeology at Jerusalem. In 1927, the American School of Prehistoric Research continued its work in western Europe at Castel-Merle (Figure 24), but unlike previous years the directorship was assigned temporarily to students and several prospecting parties were sent into the field (MacCurdy, 1928).

In 1928, the school conducted brief excavations in Kurdistan, Iraq, with the British School of Archaeology in Jerusalem (Garrod, 1930). At about the same time, the American School turned its focus to Palestine and the famous caves of Mount Carmel, Mugharet et-Tabūn, Mugharet es-Skūhl, and Mugharet el-Wad, where excavations were conducted from 1929 to 1934 (MacCurdy, 1934, 1938). During this period, MacCurdy and Hrdlička were interested primarily in the recovery of Neanderthal fossils, but although many archaeological artifacts were sent to the United States, little attention was given to these assemblages. While these scholars were training students and leading major archaeological excavations overseas, their other activities (teaching and writing) continued unabated after the start of the Great Depression.

To rally support for the school and to attract students, MacCurdy composed an advertisement dated 1 March 1929 for mailing:

Would you not like to become a subscriber to the funds of the American School of Prehistoric Research and thus have a share in solving the prehistoric problems which bear on the when, where and how of human origins? Our School is the only American institution incorporated for the purpose of solving these problems. The ninth summer session will open in Europe in July. For nine years we have been training students to teach the subject, to do field work and to be curators in museums and during the nine years, we have added materially to the prehistoric collections in a number of museums. In addition to our summer training School, we are carrying on expeditions manned in part by the students we have trained. In order to expand we need not only additional funds for current expenses, but also endowment. Through our present collaboration with the British we have a most valuable permit to excavate in the British mandates of Iraq, Palestine, and Transjordania. Unless we take advantage of the opportunities open to us through this permit, it will eventually go to others. We completed a most successful joint expedition in Sulaimani in December, which means additional collections for our museums. This month we begin jointly with the British School of Archaeology at Jerusalem to excavate caves on Mt. Carmel which have already yielded some remarkable examples of cave art. And this is only a beginning, a foretaste of what may be expected with sufficient support. We need your help and on the other hand we are convinced that whatever amount you may put into this going concern will be money wisely spent on your part. 


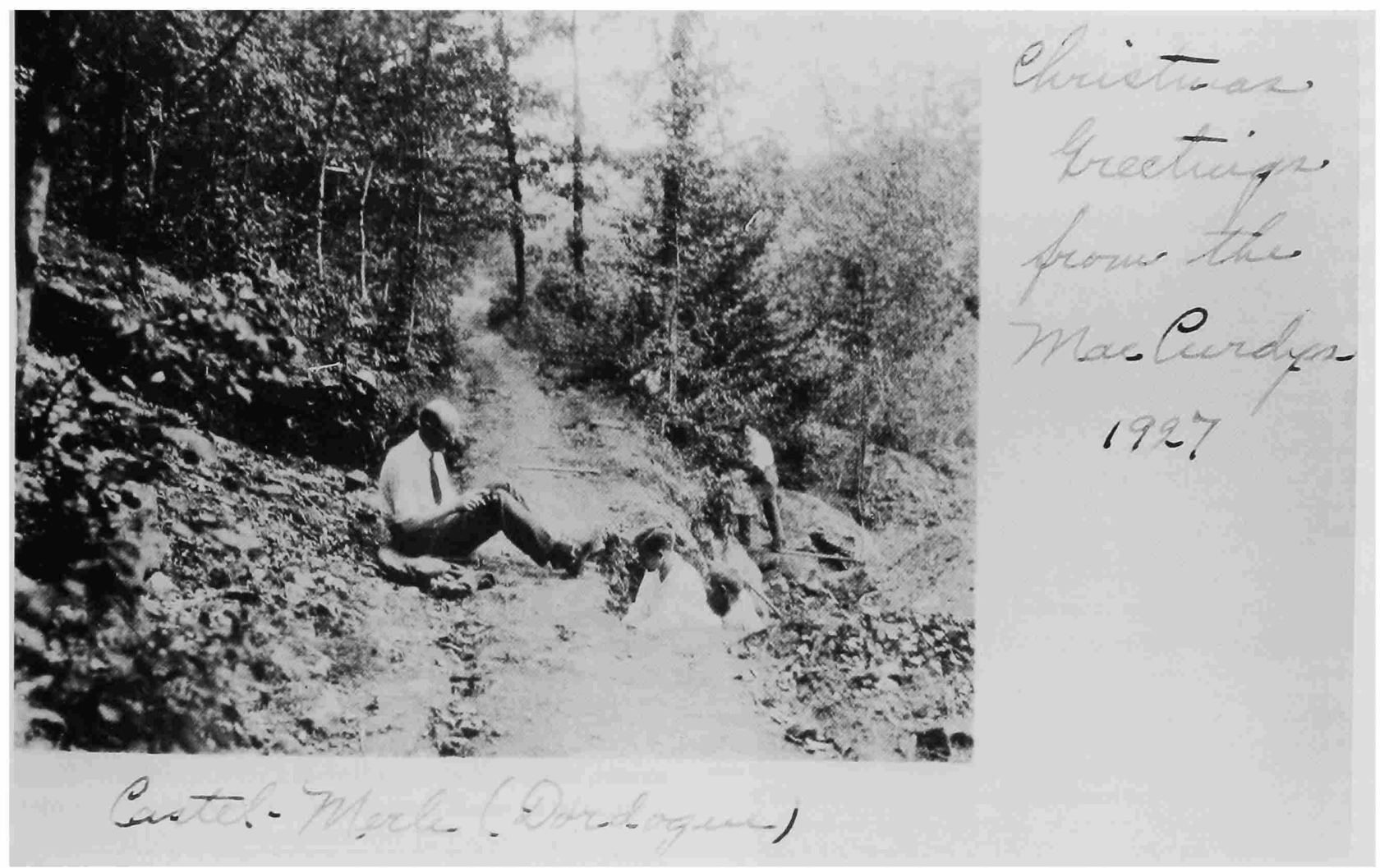

FIGURE 24.-Postcard of Castel-Merle, France. The card was sent to Hrdlička and is labeled, "Christmas Greetings from the MacCurdy's, 1927." MacCurdy and other excavators are shown at the excavation. [Hrdlička collection, National Anthropological Archives, NMNH (no. 96-10871).]

During each season, the American School, acting jointly with the British School of Archaeology in Jerusalem, conducted extensive excavations at the Mount Carmel sites (MacCurdy, 1934). Dorothy Garrod, of the British School, directed the excavations for five seasons $(1929-1931,1933,1934)$ and Theodore McCown, associated with the American School and a faculty member at the University of California, Berkeley, directed the 1932 excavations. In May of 1931, McCown discovered the first of a series of Neanderthal skeletons in the Mugharet es-Skūhl cave, and, in 1932, he was invited to direct the excavations (Kennedy, 1997). These excavations were to be monumental in their findings, uncovering assemblages from the Lower Paleolithic to the Mesolithic (or now Epi-Paleolithic), including human fossils and significant Middle Paleolithic assemblages. The excavations were thorough for that period, with relatively well-controlled provenience and fully labeled artifact assemblages (Penniman, 1974). Approximately 100,000 artifacts were recovered from Wadi El-Mughara. Artifacts were sent to 40 institutions, including 26 museums in the Near East and Europe and 14 museums in the United States, including the U.S. National Museum (approximately 3700 arti- facts, or $3.7 \%$ of the 100,000 assemblages, which was slightly more than the number supplied to the other 39 institutions).

The recovery of more human fossils was extremely important, and Hrdlička, complaining about access, was anxious to review the new specimens, as he wrote to MacCurdy on 5 May 1932: "Happy to read of the discovery in Palestine. I wonder if we could not get the privilege of examining the specimens here in this country. It does not feel good to play seconds to the Europeans all the time and then perhaps be obliged to do the work over." MacCurdy responded somewhat gingerly to Hrdlička on 9 May 1932, indicating that the British School had observed proper procedures, and also that Sir Arthur Keith, an anatomist who was already an authority on the subject (e.g., Keith, 1925, 1931), would review the specimens. "Miss Garrod began by sending the remains to Sir Arthur Keith of London, which seemed the proper thing to do. If I attend the Congress in London August 1-7, where all these remains will be on exhibition, I will discuss this matter with Miss Garrod as well as Sir Arthur Keith.”

Recognizing the extreme importance of the presumed Neanderthal specimens, Hrdlička apparently gave up hope of having the specimens shipped to the United States, and instead, in a 
letter to MacCurdy on 12 May 1932, he volunteered to go to London to study the fossils: "If we would get the privilege of working up the three skeletons after they were brought into suitable condition for examination in London, I might be willing, in view of the importance of the matter, to go to London for the work."

MacCurdy presented Hrdlička's request to the British. At the same time that these letters were exchanged, more human fossils were uncovered at Mount Carmel by Theodore McCown, who represented the American School, as described by MacCurdy on 7 June 1932:

I have written to Miss Garrod and to Prof. J.L. Myres concerning your willingness to go to London in order to work over the human skeletal material found in the four caves by the joint expedition of our School with the British. You will be interested to know that Mr. McCown has found four more skeletons in the same cave, making seven in all during the first two weeks in May, or eight including the child found a year ago.

MacCurdy received a reply from the British School, and on 23 September 1932, he informed Hrdlička that the request to analyze the specimens was rejected because McCown deserved to be the primary author of the fossil descriptions:

1 wrote to Miss Garrod on June 7 ..., saying that our Trustees thought an American specialist should be joint author with Sir. Arthur Keith when it came to studying and publishing the human skeletal remains from the four caves near Mt. Carmel. I suggested your name. Both Miss G.[arrod] and Keith feel that so far as the nine Neandertal skeletons are concerned, such an arrangement would be unfair to McCown. Keith finally told Miss G. that he would 'not participate in any arrangement which does not make McCown principal author.' She wrote me to this effect saying she was in complete agreement with Keith. This is a point we can afford to concede so far as the nine Neandertalians are concerned. If you have in mind a study of only the Neandertal material the problem would be somewhat simplified provided of course that you agree to let McCown be nominally the principal author. Keith's contribution and yours could follow McCown's under the same cover, or at least be issued simultaneously. The big and costly job now is to detach the Neandertalians from their stony matrix. This will take many months. McCown is now teaching at Berkeley and does not plan to join Keith in London until next May. He was here with us a day (Aug. 12). We took him to Holyoke to see Chairman Green and tried to make it plain to him, that you also should have an opportunity to study the $\mathrm{Ne}$ andertal remains and write up the results for publication. Both Keith and Miss G. want him to have every opportunity to make the most of his lucky find. So do we; but we feel that our School should have something to say in naming the specialists, where help is needed outside those who actually made the finds. Donald Scott, Dir.[ector] of the Peabody Museum of Harvard (also a trustee of our School), will be in London the 1st of Nov. He has consented to discuss this matter with Keith and Myres (Miss G. is in Palestine until the end of Dec.). If you still want to go to London to study the skeletons, kindly let me know so that I may communicate your decision to Scott before he leaves London. We are assuming that in case you go you would finance the trip yourself.

Hrdlička responded on 26 September, indicating that this matter was not for personal gain, but was of importance for maintaining the scientific reputation of the American School. In emphasizing such an approach, Hrdlička relinquished his personal involvement in examining the fossils, and instead he suggested that McCown and the American School should provide the fossil descriptions and be part of future publications:

I should be happy indeed to undertake the work in question, under such equitable arrangements as could be made. This [is] not from any personal ambition, but to safeguard the interests of our School and of American science in general.
It is just, it seems to me, that we participate in the study and report on the specimens, and that particularly in view of their highly interesting characters, as indicated by the reports that have so far come to our hands. I should be quite content if some one else, say you or [Ernest] Hooton [professor of physical anthropology, Harvard] would charge himself with this work. But if that were impracticable, then I should stand ready to do whatever might be needed. I have, of course, nothing but the most cordial friendship and admiration for Sir Arthur Keith, and were not other important factors involved, I should be happy to see everything in his hands. With the amount of material it seems to me there may be enough for all. McCown should by all means head the volume with a detailed account of the discovery. And as to the description of the skeletal remains, perhaps we could so divide with Sir Arthur that I would undertake the general description of the remains, while he would devote himself to the most interesting and valuable part of the study which will be that of the brain cavities and casts, for which he would have more time at his disposal. Sir Arthur has always been one of my closest and esteemed European friends, so that I am very confident we could work out everything in the closest harmony and with mutual helpfulness. It seems to me such an arrangement as here suggested would adequately safeguard, both for the present and for the future...the interests of our School, and of the standing of American Anthropology in general. We do not deserve to appear perpetually in a position of inferiority to our colleagues abroad. The work has been carried on with American money, by an American young scientist, under the auspices of the American School. To give nonAmericans the complete right of the report and study on and of the specimens would be a blow and a precedent from which it would be hard to recover, and for which a very serious blame might be incurred.

Reaching a consensus concerning this sensitive research matter, MacCurdy wrote to Hrdlička, on 10 October 1932, indicating that he would contact all parties concerned:

I have your letter of Sept. 26 and am sending copies of it to Chairman Green, Director Scott of Harvard Peabody, ... Sir Arthur Keith, and Mr. McCown. I am sure all of them will appreciate your attitude in the matter. I feel quite sure that both Keith and McCown have in mind that McCown also is to make a study of the nine skeletons in addition to a detailed account of the discovery. This is a matter that can no doubt be arranged in a manner satisfactory to all concerned.

Between 1933 and 1937, most of the fossil material was forwarded to the Royal College of Surgeons, London, where McCown and Sir Arthur Keith conducted their study (Kennedy, 1997). A series of articles about the specimens and the archaeological implications of the discoveries at the caves appeared in the Bulletin of the American School of Prehistoric Research, authored by British and American authors (Garrod, 1931, 1932, 1934, 1936, 1937; McCown, 1932, 1933, 1934, 1936; Keith and McCown, 1937; Beggs, 1938). Hrdlička never published on the fossil specimens, but he did ensure that the American School participated in the research, with McCown as primary or secondary author of several works. Although MacCurdy was a major influence on the joint expedition and was supported vigorously by Hrdlička, neither man apparently participated in the excavations. The Mount Carmel excavations eventually culminated in monumental works by the joint expedition, including The Stone Age of Mount Carmel: Excavations at the Wady El-Mughara (Garrod and Bate, 1937) and The Stone Age of Mount Carmel: The Fossil Human Remains from the Levalloiso-Mousterian (McCown and Keith, 1939). The discovery of the Mount Carmel hominids provided support for Hrdlička's (1927) earlier proposition that the Neanderthal phenotype was marked by an expression of morphological variation (Spencer and Smith, 1981). In accordance with the joint agreements, the 
Smithsonian received its annual allotments of Middle Paleolithic artifact assemblages from these excavations.

\section{JAMES TOWNSEND RUSSELL, JR.}

\section{Career and the Old World Archaeology Fund}

James Townsend Russell, Jr., enrolled as a student in 1925 with the American School of Prehistoric Research, during its formative years (Figure 25). Russell participated in the first stages of excavation at Sergeac, France, during the 1926 season, and he was named a trustee of the school thereafter. Russell remained in France for several years, working either independently or with the Abbé Henri Breuil, a well-known French prehistorian. The Russell family had several residences, including one in France, and upon inheritance of a considerable fortune from his father's estate, Russell became the sponsor of the Smithsonian's Old World Archaeology Fund. Russell had serious academic interests and was considered a promising young scholar, as well as an important financial supporter of the excavations in France. Russell temporarily directed excavations conducted by the school. He also published articles based upon that work (Russell, 1928, 1929) and translated Luquet's (1926) influential book, L'Art et la Religion des Hommes Fossiles (Luquet, 1930; MacCurdy, 1930).

In addition to Russell's contact with Hrdlička from his earliest involvement with the American School, he also contacted the Smithsonian in an effort to secure a position in archaeology. Assistant Secretary Wetmore responded to Russell's request in a letter dated 18 October 1928:

Following our recent conversation I have discussed our collections in Old World archeology with Dr. Hough, and have examined some of the material personally. At your convenience I should appreciate it if you can come down to talk over your proposal for work on these specimens with Mr. Neil M. Judd who I believe told you will have these materials under his charge when we effect the reorganization planned for the near future.

This meeting resulted in Russell's temporary appointment as an assistant in archaeology in 1928.

Although Hrdlička secured excavation rights at Sergeac in France, it was Russell who initially had mentioned the possibility that the Archaeological Society of Washington could lease the site for the American School of Prehistoric Research. In a letter to Wetmore, on 3 April 1929, Russell indicated that the funds may be available:

I take the liberty of writing you entirely unofficially and confidentially in regard to a matter which I think would be of interest to the Smithsonian Institution. The Archaeological Society of Washington has the funds necessary to buy for excavation a prehistoric site on the southern [sic, northern] slope of the Pyrenees from which it wishes the collections of the United States National Museum to benefit. In order to do as much good as possible it is proposed that the Society cooperate with the American School of Prehistoric Research in Europe in the working of the site.

Wetmore, with Hrdlička's approval, was apparently enthusiastic about this proposal, as the lease was quickly granted. Shortly thereafter, Russell was granted a position as collabora-

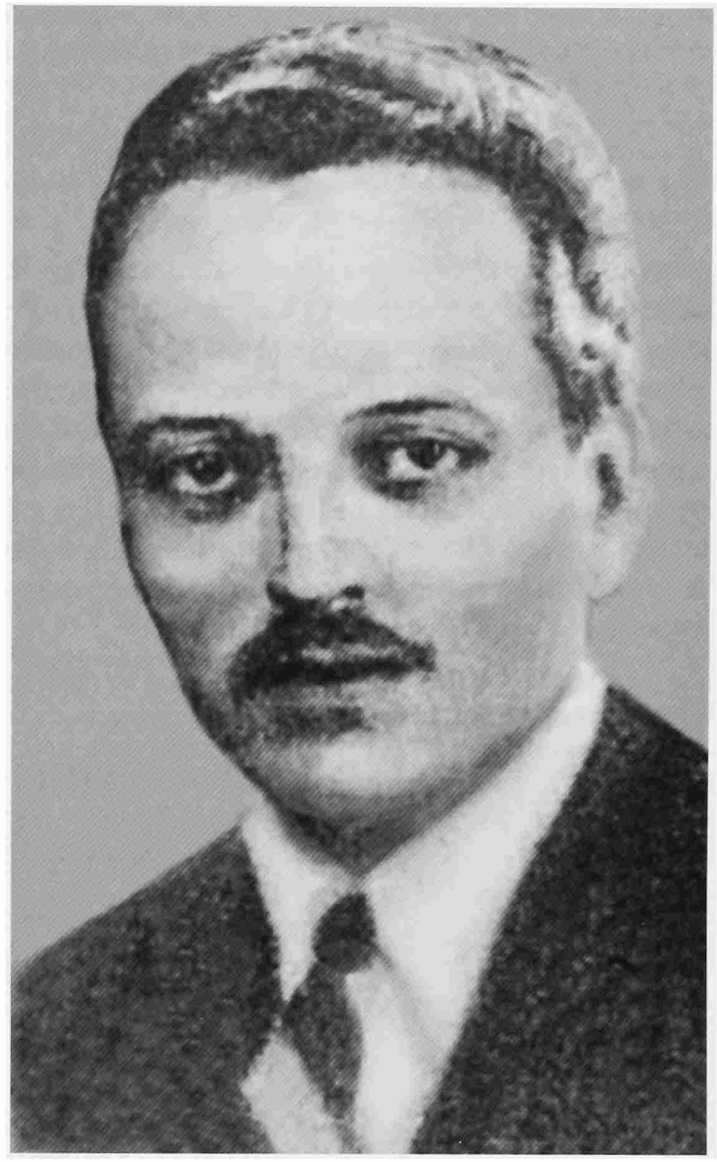

FIGURE 25.-James Townsend Russell, Jr., pictured in the Binghamton Press, on 10 August 1932. [In an article entitled, "Tells Tales of Cavemen." The caption to the photograph reads "J. Townsend Russell, who told the Kiwanians today how their acts were influenced by lives of their cavemen ancestors."]

tor in Old World Archaeology. Russell's appointment was acknowledged by Wetmore on 17 May 1929:

It is my pleasure to send you herewith designation to the honorary position of collaborator in Old World Archeology, under the Smithsonian Institution. We are greatly pleased to have you associated with us in this capacity. Your interest in this work, particularly as regards our collections, is gratifying, and I hope may continue to mutual advantage.

Russell, with his inheritance, established the Old World Archaeology Fund as an endowment. The fund provided support for salaries, exhibit improvements, expenses, and the purchase of collections. Russell also solicited outside funds, as described in Russell's letter to Neil Judd, a Smithsonian anthropologist, on 9 February 1930: "You will be glad to hear that I have secured a pledge of five hundred dollars to buy specimens for the Museum collection. It comes from Evelyn Pierpont a rich old lady and old friend of my family." Purchasing collections was a difficult task, however, because of the high cost of objects, as Russell described to Wetmore on 27 June 1930: 
Since I have been here I have done a great deal of searching for material for sale that would be of use to our collections and I must say that the outlook is not at all good. Certain American museums have sent men over here in late years that have combed the field leaving little and paying prices that has sent the market value beyond all reason. As you say for every authentic piece to be had there is a fake that deceives even experts. At present I feel convinced that our museum should only have material that is collected by original research.

Russell limited his purchases to casts and paintings, as described to Wetmore on 6 August 1930: "The situation for finding collections for our museum has not altered. I secured valuable objects for our collections consisting of casts numbering about 10 in all. For this purpose, I used Miss Pierpont's money. I also ordered copies of the Spanish cave paintings which will be very worth our while."

Wetmore, agreed with Russell, on 20 August 1930, stating that the casts will be useful and the copies of the Spanish cave paintings should be excellent, further noting:

I agree with you that it is not advisable to pay too high prices for archaeological material from western Europe. While it may be advisable to purchase a few exceptional pieces that are valued highly, a general buying of that kind is hardly warranted. It is almost certain that sooner or later there will come some opportunity to acquire some comprehensive collection, perhaps by gift.

\section{Excavations in France}

Considering the expense of purchasing objects, Russell turned to collaborative excavation in order to obtain French Paleolithic collections. During the time Hrdlička concentrated his attention on the American School and supported the work in Palestine, Russell worked with the famous prehistorian, Count Henri Bégouën, a professor at the University of Toulouse, and attempted to secure an agreement to excavate in France. During the summer of 1931, the Smithsonian conducted archaeological research projects in départements Haute Garonne and Ariège, France, in an informal collaboration with the University of Toulouse. As a result of this work, a formal agreement was made between the two institutions to continue similar investigations for ten years (Annual Report, Smithsonian Institution, 1932:23). The joint agreement received some publicity in a brief article published in The New York Times on 3 December 1931, "Smithsonian to Work with French College."

Russell promoted such international collaboration, as he was quoted in the Binghamton Press, in August of 1932:

The Smithsonian Institution has as its greatest aim the dissemination of knowledge, in other words education in whatever lines may be found of value. This work is not carried on for the benefit of a few scholars living in Washington but for the country as a whole, and greater still, for the world in general. In connection with this great work the Smithsonian has been carrying on research in collaboration with one of the governmental institutions of France. While the results and outlay are shared by our two countries this has the happy effect of accumulating knowledge and at the same time it promotes international friendship as an aid to world peace. Peace is and should be the paramount aim of every individual and nation. The results of war are too evident to be discussed and I only need to say that in this regard my feeling is one of great optimism for future generations if not for our own.

Under the terms of the Franco-American agreement, the
Smithsonian was granted access to three Upper Paleolithic sites, Marsoulas, Tarté, and Roquecourbère. The agreement provided for collaboration between the two institutions, with the burden of the work to be mutually shared. The University of Toulouse furnished the excavation concession and the Smithsonian Institution paid the expenses. Under the terms of the agreement, the rarest and most important discoveries were to remain in France as the property of the University of Toulouse, whereas other objects were to be divided equally between the two parties (the French share of the collections remains in the Natural History Museum of Toulouse).

At the conclusion of the excavations at the three sites, however, there was considerable disappointment because only limited deposits were found. Despite this fact, an article on the initial work at the sites was published in English, "Report on Archeological Research in the Foothills of the Pyrenees" (Russell, 1932), and in French, "La Campagne de Fouilles de 1931 á Marsoulas, Tarté et Roquecourbère" (Bégouën and Russell, 1933).

Although the University of Toulouse had no other sites that it could offer to continue this cooperative enterprise, another agreement was sought with the Ministry of the Beaux Arts to excavate some of the most famous Upper Paleolithic cave art sites. Concerning these potential excavations, Russell wrote to Wetmore, on 2 December 1932:

During the month of September which I spent in France, I had several conferences with the Abbé Breuil, Professor of Prehistory at the College of France, and Count Bégouën, Professor of Prehistory at the University of Toulouse, both of whom are members of the Beaux Arts Commission for classified monuments in France. These gentlemen expressed considerable satisfaction at the results of the collaboration in excavation between the Smithsonian Institution and the University of Toulouse, and felt that the scope of the work should be extended. They expressed the opinion that the Beaux Arts Ministry itself might be willing to collaborate with the Smithsonian Institution for further work and that they would favor the cave Mas d'Azil as a site for such cooperative excavation. Mas d'Azil is one of the largest caves in France containing an unusually large prehistoric level of the Upper Paleolithic and Azilian, or transition culture to the Neolithic of which it is the type station. As such, it is the site most worthy of excavation in France, while in the past it has only been superficially worked. I suggest, therefore, that a formal request be made to the French government for this privilege.

This proposal was strongly supported by the Smithsonian Administration, and on 10 February 1933, Secretary Charles Abbott wrote to the United States Secretary of State, seeking his assistance through the American Ambassador in Paris:

It has been suggested that the Ministry of the Beaux Arts might be willing to consider such a form of collaboration at one of the Upper Paleolithic or related sites under its control, possibly in the cave at Mas d'Azil or some equally important area, with a similar understanding, i.e., that the Smithsonian Institution would pay all expenses of the work, that the most important finds would remain in France, and that the remainder would be divided, a part coming to America for the Smithsonian Institution.

Russell's Smithsonian activities were greatly appreciated, and on 13 May 1933, he was made an honorary assistant curator of Old World Archaeology. 


\section{An Abrupt End to a Promising Career}

All of these excavation plans in France ended suddenly when Russell became severely ill in the fall of 1933 and was admitted to a sanitarium. On 5 April 1934, Arthur Moritz, Russell's estate attorney, wrote to Assistant Secretary Wetmore: "It is highly desirable that while at the sanitarium Mr. Russell be engaged in some constructive work of the type he is particularly interested in. I have been thinking that perhaps you could send him an assignment of some kind which would keep him occupied for a considerable period of time."

In response to the request of Russell's attorney, Wetmore wrote to Russell on 19 April 1934:

Mr. Judd and I have spoken frequently of you, and your work in archeology, and I trust that your studies are proceeding favorably and to your satisfaction.
In connection with this it has occurred to me that you might find it profitable and interesting to make literal translation of some of the papers dealing with prehistoric man in western Europe that have appeared in French.

No evidence was found that Russell began the translations, although correspondence between Russell and Smithsonian staff continued throughout 1935. After 1932, Russell never engaged in archaeological work. He did retain his title as assistant curator of Old World Archaeology until 1952, corresponding with Wetmore and Judd and providing financial support until 1954. In his last will and testament, sealed on 13 March 1962, Russell bequeathed the Smithsonian Institution his collection of anthropological material, which was already in the museum's possession, including his books, photographs, and artifact collections.

\section{The Modern Era of Paleoanthropology}

\section{T. Dale Stewart and the Post-World War II Period}

After World War II, the U.S. National Museum continued collecting natural history specimens, leading to large increases in the collections (Yochelson, 1990). The post-war era was a period of growth and prosperity in American archaeology, with increasing numbers of institutions and individuals involved in archaeological research (Patterson, 1995). This growth of archaeology in the United States, however, was not reflected in the growth of Old World Paleolithic collections nor was it reflected in significant paleoanthropological activity at the Smithsonian. The curtailed development of Old World Paleolithic collections was likely the result of a lack of a full-time curator of Old World Paleolithic archaeology or paleoanthropology and the passage of antiquity laws by foreign governments that forbade the export of artifacts from the countries of origin.

After Hrdlička's tenure, the curator in charge of physical anthropology and Old World collections was T. Dale Stewart (Figure 26). Stewart was hired by the U.S. National Museum (the U.S. National Museum (USNM) was established in 1842 and ceased existence as an administrative unit in 1967) in 1924 as a temporary aide to Hrdlička. He became an assistant curator in 1931, the same year he received his medical degree from Johns Hopkins. Hrdlička also had a degree in medicine; very few of their predecessors had degrees in physical anthropology (Spencer, 1982). Stewart was promoted to associate curator in 1939 and then curator in 1942 . He served as the director of the Natural History Museum from 1963 to 1966 (the Museum of Natural History (MNH) was renamed the National Museum of Natural History (NMNH) in 1969), and briefly served as assistant secretary of the institution in 1966. After his retirement in 1971, he continued his affiliation with the museum as curator emeritus until his death in 1997. Stewart had many research interests, including human genetics, study-

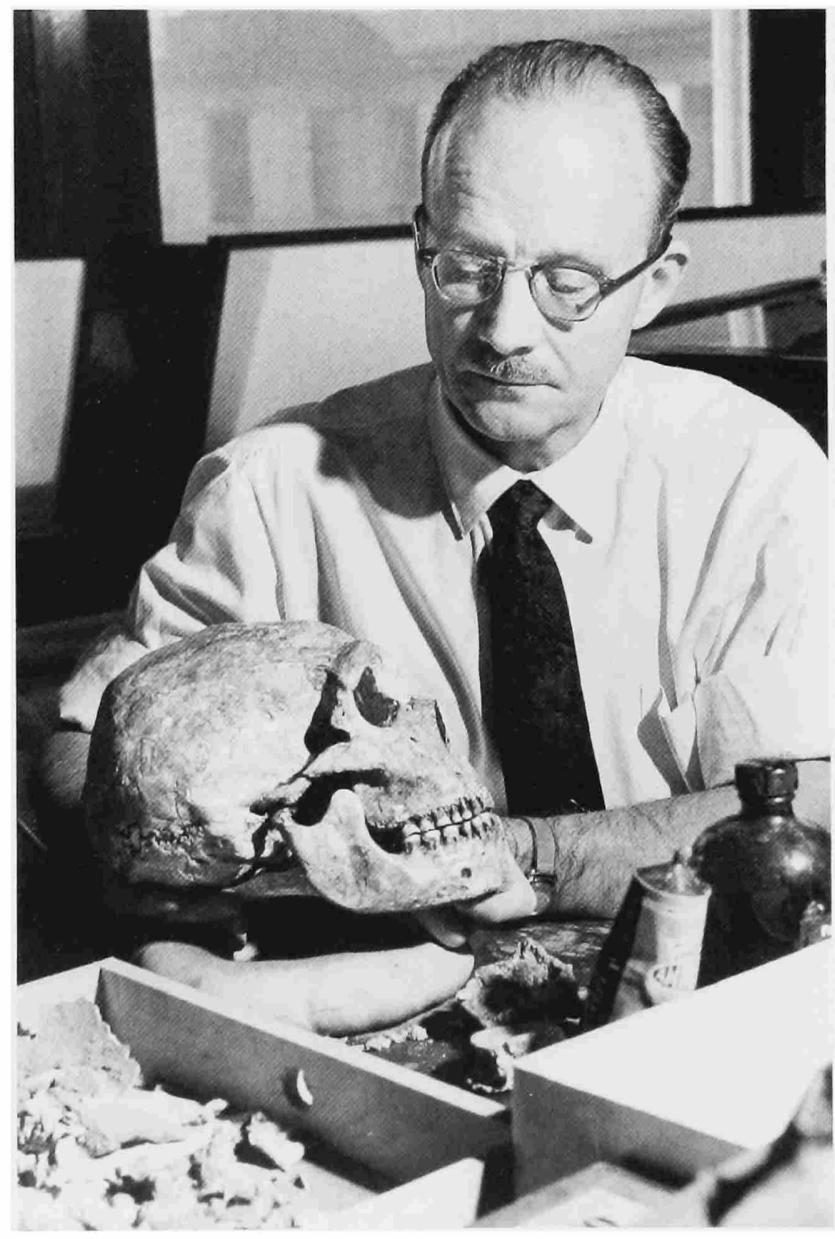

FigURE 26.-Photograph of T. Dale Stewart examining a Shanidar Neanderthal, 1958. [Solecki collection, National Anthropological Archives (MS 7091), NMNH.] 
ing New World skeletal populations, Neanderthals and their evolutionary position, and forensic anthropology (Angel, 1976).

During the 1950s, the major accession to the museum's Old World collections came from Shanidar cave, Iraq, primarily through a large donation from the Iraq Museum. Dr. Ralph Solecki, who discovered the site, was a curator in the Department of Anthropology at the NMNH for a brief period and had supervised the excavations at Shanidar. Beginning in 1954, the archaeological work at Shanidar was supported by the National Science Foundation (Patterson, 1995). In 1958 and 1960, Stewart studied Neanderthal remains in Iraq (Ubelaker, 1997), which eventually led him to publish several articles on Neanderthal anatomy (Stewart, 1958, 1962, 1965, 1977). Another important addition to the collections was a donation from the Uganda Museum in 1965, through Dr. Glen Cole. The Uganda accession included a sizeable sample of excavated artifacts from the sites of Magosi and Nsongezi, Rwanda. Although relatively small, collections from other sites in Iran were obtained from archaeologists Frank Hole and Kent Flannery (who was affiliated with the museum) in 1966.

Although Stewart dedicated some of his research efforts to the study of the Shanidar Neanderthals, little other Old World Paleolithic research was conducted at the Smithsonian from the 1950 s through the 1970s. Human origins studies and archaeological field work were essentially unrepresented in the museum's permanent research staff, except by appointment of Research Associates John Yellen and Alison Brooks in the 1970s.

Few collections were acquired and primary Paleolithic research at the National Museum essentially ceased during this period, although some exhibits and dioramas were created for public education (Figure 27). Beyond the Smithsonian, the connection between physical anthropology and Paleolithic archaeology continued and strengthened. By the 1980s, the field of paleoanthropology had emerged as a purposeful union of physical anthropology, archaeology, evolutionary biology, environmental sciences, and primate and ethnographic research.

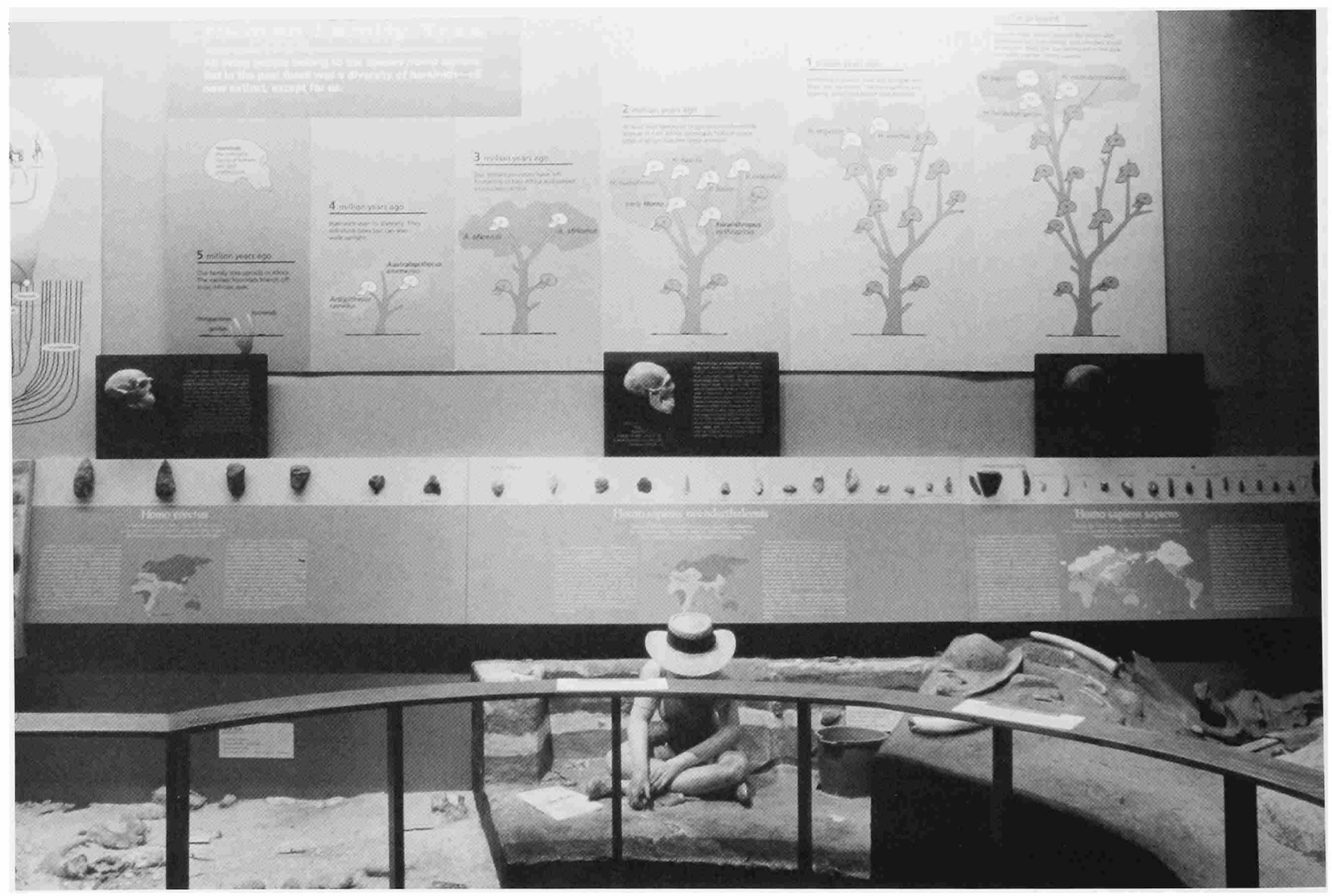

FIGURE 27.-Exhibit in the National Museum of Natural History, photographed in 2001. [The simulated excavation was created in the 1970s and depicts Olduvai and other sites. The stone tools arranged in the background were drawn from the collections and show variation in Paleolithic typology and technology. The Human Family Tree was created in the late 1990s and shows scenarios for hominid evolution from 5 million years ago to the present.] 


\section{The Human Origins Program}

The most recent involvement of the National Museum of Natural History (NMNH) in paleoanthropological research has been marked by the hiring of Richard Potts in 1985 as an assistant curator in physical anthropology. The decision to hire a research curator in hominid evolution coincided with the development of human origins as an important and relatively wellfunded area of inquiry during the last several decades (Patterson, 1995). Since 1985 there has been a large increase in Smithsonian field projects and research activities related to early hominids, with the corresponding collection of large samples of Paleolithic artifacts, fossil animal remains, and contextual information.

Reflecting the integration of multiple disciplines, recent $\mathrm{NMNH}$ research has focused on the behavioral and ecological dimensions of human evolutionary history. Although largely influenced by interests in human biological evolution, paleoecology, and the geological sciences, Smithsonian researchers have applied the excavation methods of Paleolithic archaeology to sites and have sought to answer behavioral questions concerning hominid subsistence, technology, and interactions with the environment. The application of these archaeological methods was influenced by Potts' earlier work at Olduvai Gorge (e.g., Potts, 1982, 1983, 1988) and have continued to develop during more than 15 years of Smithsonian sponsored research in East Africa, particularly at Olorgesailie, Kenya.

By 1990, a formal Human Origins Program had been organized at the NMNH with four major goals: (1) to conduct original field research on the ecological aspects of human evolution (Figures 28-35); (2) to develop a new exhibition hall of human origins; (3) to establish an international paleoanthropological consortium devoted to the worldwide comparison of fossils and archaeological sites; and (4) to develop educational programs and databases concerning human evolution.

Staff of the Human Origins Program are creating the hominid fossil cast collection in the Division of Physical Anthropology and are conducting new research on the Old World Paleolithic collections. The Smithson Light Isotope Laboratory, which performs stable isotopic analysis of ancient and modern soil carbonates, also operates under the auspicies of the Human Origins Program. The principal focus of the program, however,

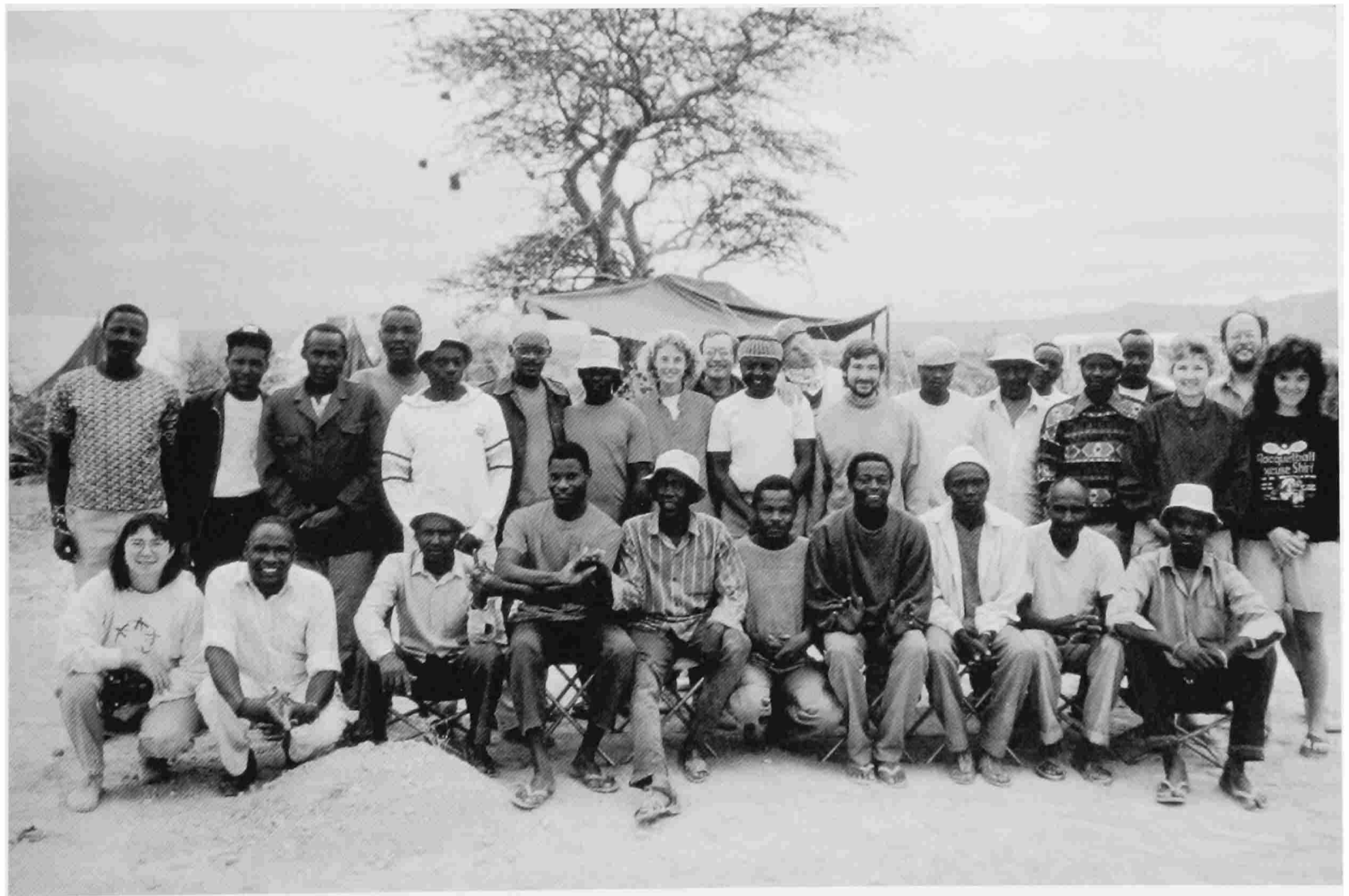

FIGURE 28.--International research team directed by Richard Potts (Human Origins Program, Smithsonian Institution) at the Olorgesailie Prehistoric Site. [A collaborative project of the National Museums of Kenya and the Smithsonian Institution.] 


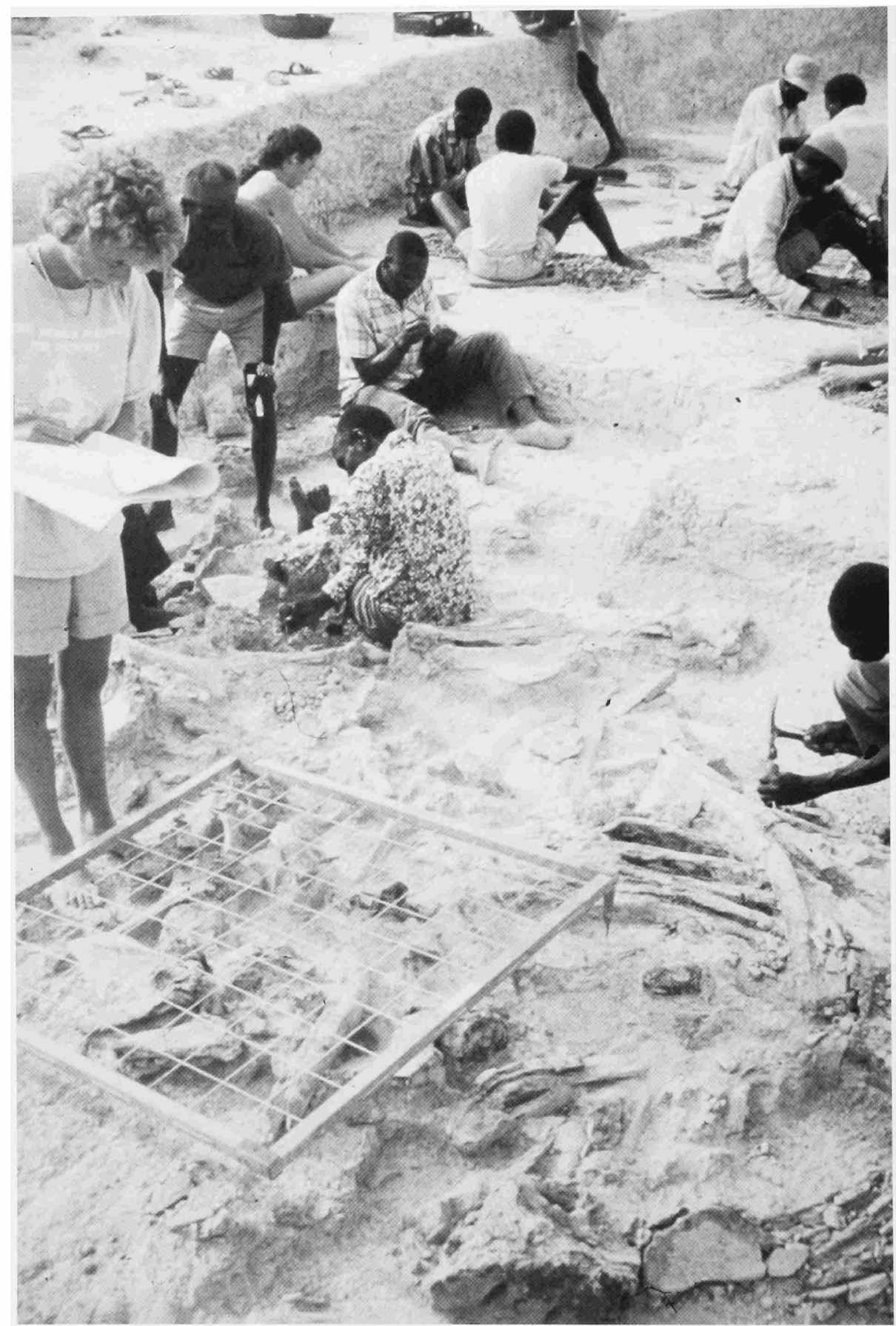

FIgure 29.-Excavation conducted by the Human Origins Program, Smithsonian Institution, of an elephant (Elephas recki) butchery site in Member 1 of the Olorgesailie Formation, southern Kenya.

continues to be long-term field projects in Africa, India, and China in collaboration with foreign institutions and scholars. These projects have been funded since 1992, primarily by Congressional appropriation, under the NMNH budget heading $\mathrm{Hu}-$ man Ecological History, and by the Smithsonian's Scholarly Studies Program.

The professional staff of the program maintains its status in two ways: (1) by the long-term appointment of research associ- 


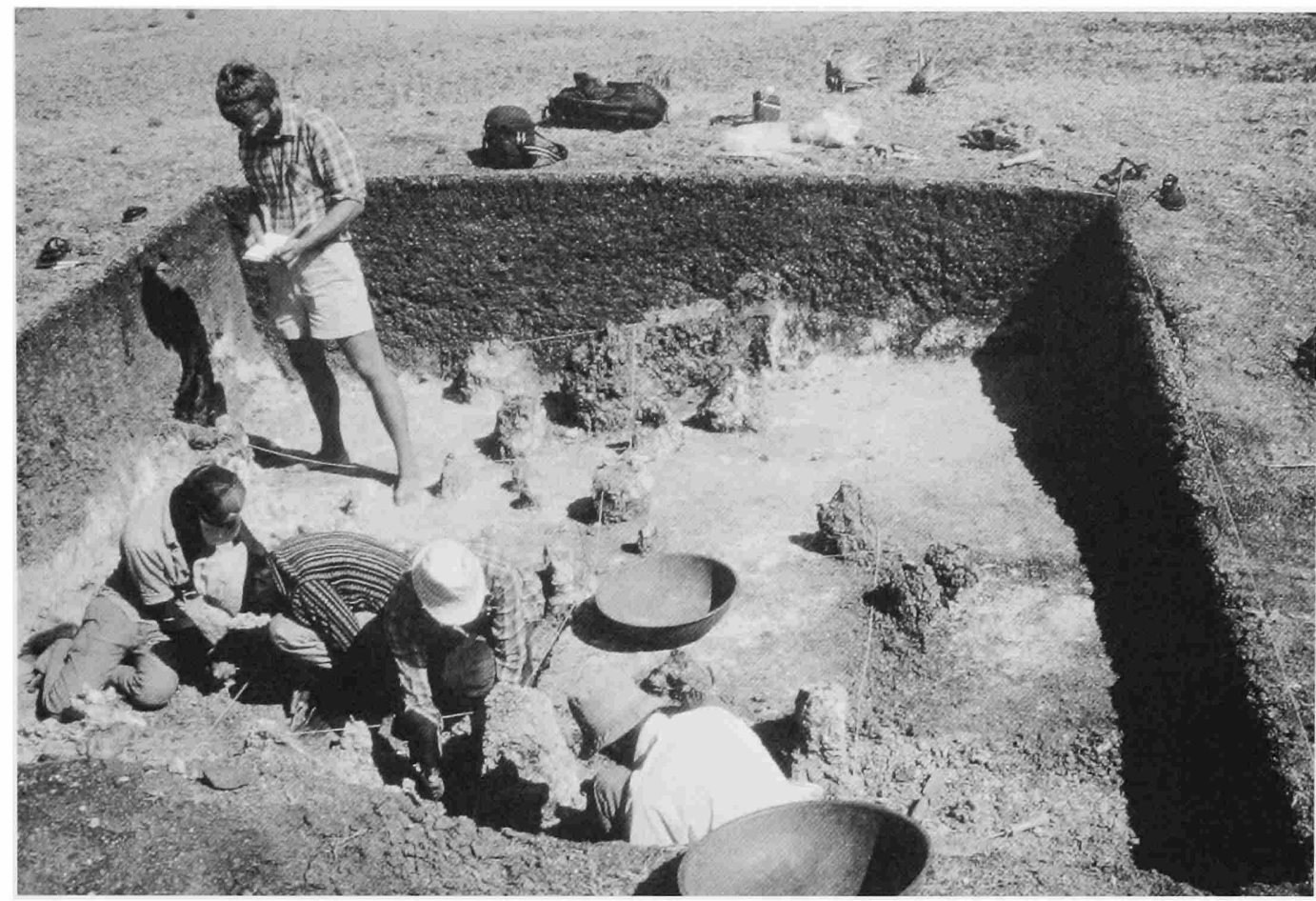

Figure 30.-Smithsonian excavation at Kanjera North on the Homa Peninsula, western Kenya, a collaborative project of the National Museums of Kenya and the Human Origins Program, Smithsonian Institution.

ates (including archaeologists Alison Brooks in 1972, John E. Yellen in 1974, and Michael Petraglia in 1988); and (2) by the development of a new faculty position in hominid paleobiology at George Washington University, beginning with the appointment of Bernard Wood as the Henry Luce Professor of Human Origins and Senior Adjunct Scientist in the Smithsonian's Human Origins Program. The research associates have established programs of Paleolithic archaeological research in Botswana, Zaire (now Democratic Republic of the Congo), Ethiopia (Brooks and Yellen), and India (Petraglia) Since 1985, more Old World Paleolithic investigations have been conducted by Smithsonian researchers than during any other period in the history of the institution. This research activity has not resulted in collections accessions (Figure 7), however, because materials are now curated primarily in the countries of origin.

\section{Overview}

Since the initial collection of materials in 1869 , a number of individuals, including Smithsonan administrators and researchers, were responsible for the development of the Paleolithic collection. Secretaries Henry and Baird were directly involved in the collection of material for research and display, but it was not until the research appointment of Thomas Wilson that more diverse and substantial collections came to the National Mu- seum. The material was obtained primarily for comparative purposes and for exhibition. The American School of Prehistoric Research, under the aegis of Aleš Hrdlička, did most of the collecting in the 1920s and 1930s. In the later years of the school, the collections eventually broadened as a result of excavations in the Middle East. James Russell's excavations, although brief, brought substantial collections to the Smithsonian, supplementing French materials that were already represented in the National Museum. In the post-World War II era, the Smithsonian was no longer engaged in the acquisition of substantial Paleolithic collections. T. Dale Stewart became a curator of physical anthropology and conducted substantial analytical research on Neanderthals from Shanidar, Iraq. Several collections were acquired in the $1950 \mathrm{~s}$ and 1960 s, including those from Shanidar and from localities in Iran and Uganda. Although collections now remain in their home countries, the current Human Origins Program has become widely engaged in the archaeology of many countries, including Kenya, Zaire, Botswana, Ethiopia, India, and China. The following sections of this book will document how and why accessions were obtained during the period 1869-1990, and the final section will place the current Human Origins Program (1990 to present) in the context of the history of the U.S. National Museum. 


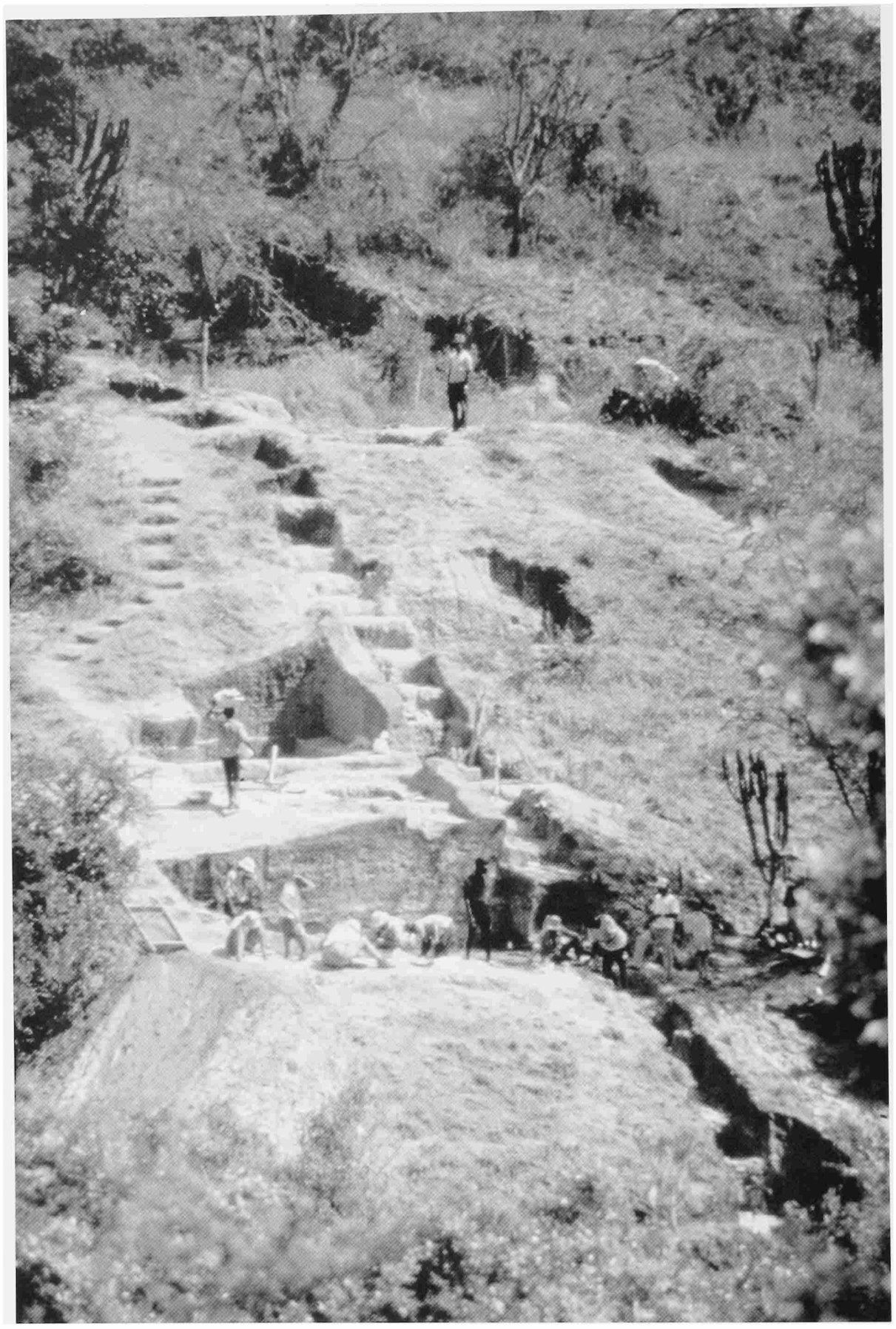

FiguRE 31.-International team excavation at Katanda 2, in Zaire (now Democratic Republic of the Congo), directed by John Yellen (Human Origins Program, Smithsonian Institution, and National Science Foundation). 


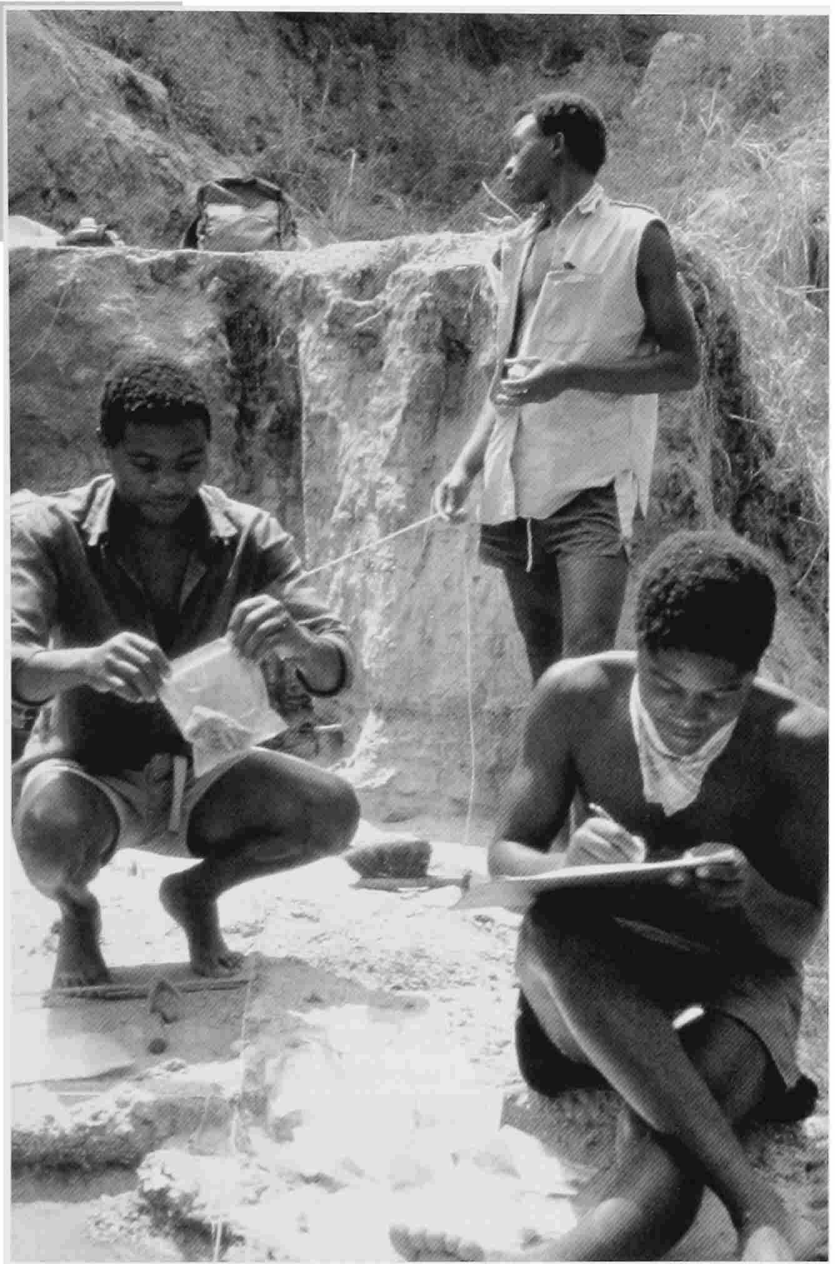

FIGURE 32.- International team excavation at Katanda 16, in Zaire (now Democratic Republic of the Congo), directed by Alison Brooks (Human Origins Program, Smithsonian Institution, and George Washington University).

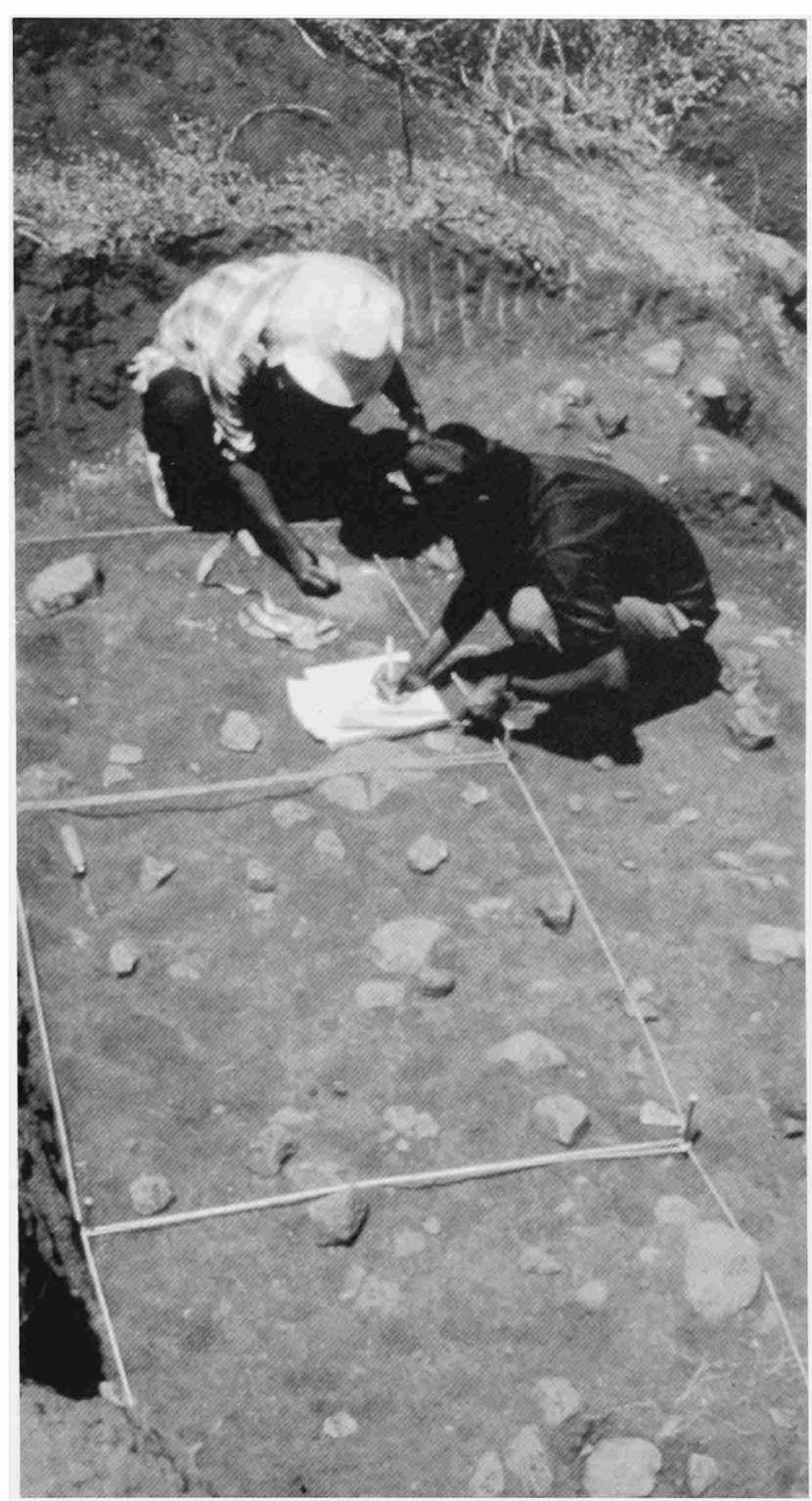

FigURE 33.-Joint excavation at the Lakhmapur locality, in the Malaprabha Valley, India, co-directed by Ravi Korisettar (Karnatak University, India) and Michael Petraglia (Human Origins Program, Smithsonian Institution). 


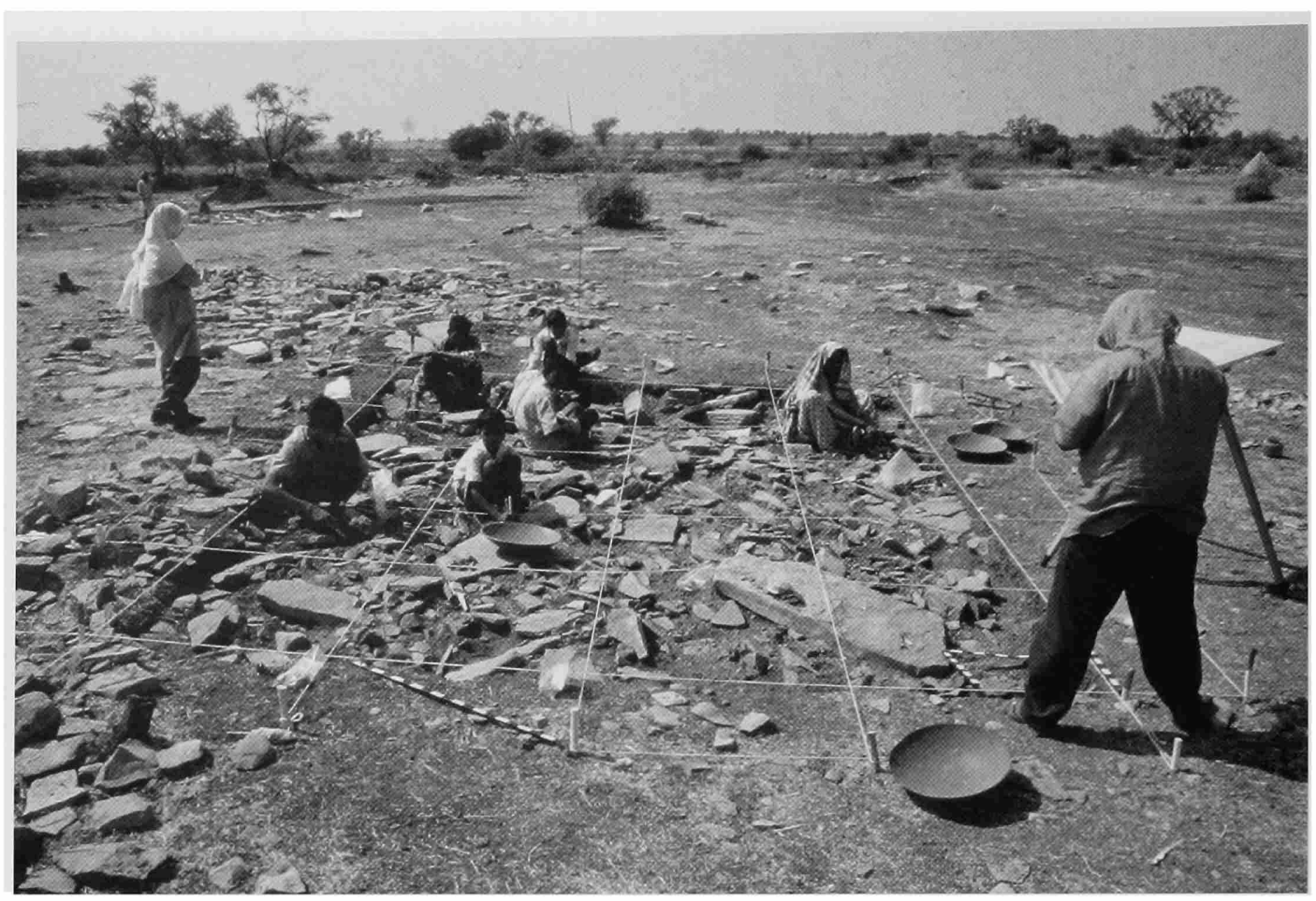

FIGURE 34.-Joint excavation at the Isampur Site, Hunsgi Valley, India, co-directed by K. Paddayya (Deccan College, India) and Michael Petraglia (Human Origins Program, Smithsonian Institution).

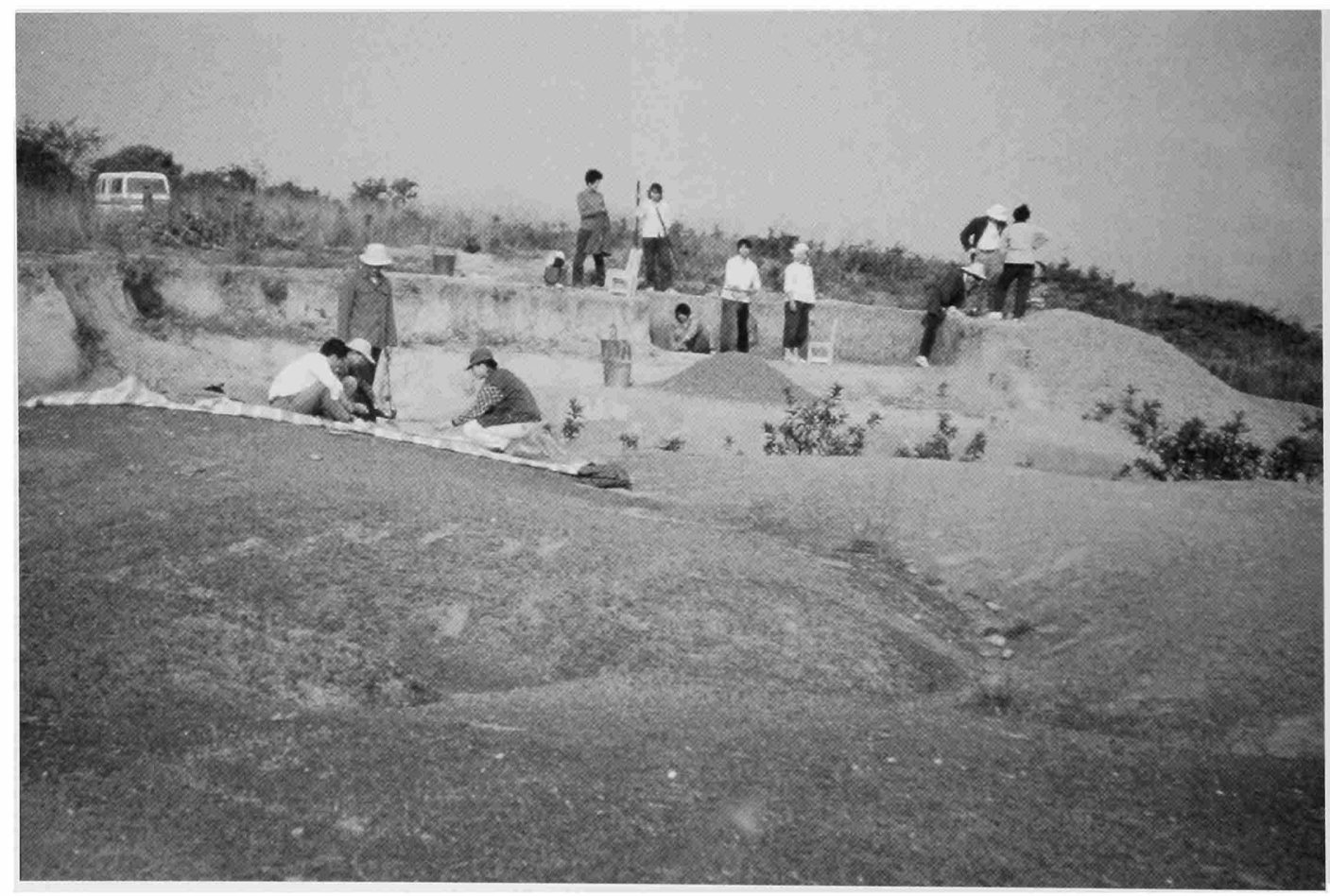

FIGURE 35.-Excavation in the Bose Basin, Guangxi Zhuang Autonomous Region, People's Republic of China, co-directed by Huang Weiwen (Institute of Vertebrate Paleontology and Paleoanthropology, Academia Sinica, China) and Richard Potts (Human Origins Program, Smithsonian Institution). 


\section{The Paleolithic Accessions, 1869-1990}

The following is a general chronology of Paleolithic accessions. Donations and purchases are listed by individuals or institutions. This section presents the relevant correspondence concerning the acquisition of the Paleolithic accessions and a description of the circumstances involved in the collection of the artifact assemblages from 1869 to 1990 . The last section provides a synopsis and remarks about the future of Paleolithic research and of museum-based investigations. Because we could not possibly re-evaluate and re-classify all the artifacts within a modern framework, we use general terms in the construction of the comprehensive listing in Table 4 (e.g., chipped stone, bone), rather than the INQUIRE artifact typology, which uses historic typology terms that have inaccuracies. Because fauna may be of interest to researchers, preliminary identifications made in 1987 by Melinda Zeder are provided (Table 5).

\section{Lartet (acc. 1529, 3546)}

The first recorded contribution of Old World Paleolithic artifacts to the U.S. National Museum (acc. 1529) occurred in 1869. The collection was a gift from Edouard Lartet, a paleontologist and pioneer in French prehistory, whose career began in 1834 (Fischer, 1873; Ferembach, 1997). A second collection of artifacts was accessioned as a gift (acc. 3546) in 1874, after his death in 1871 . These collections were donated at the end of Lartet's long career; thus, they can be viewed as a sample of Lartet's lifetime of work of site surveys. The donations consisted of an assortment of both original artifacts and casts from localities in France, England, and Italy.

Lartet, working with English banker Henry Christy, discovered many important Paleolithic sites in western Europe, and both researchers proposed a now famous sequence of ages, which divided the times during which "Primitive Man" had lived, based upon associations with extinct animals (i.e., Age of the Cave Bear, Age of the Elephant and Rhinoceros, Age of the Reindeer, Age of the Aurochs). Lartet and Christy's association ultimately culminated in the major site compendium of the time, Reliquae Aquitanicae (1865-1875).

Correspondence between Lartet and Secretary Henry concerning Smithsonian Old World acquisitions began in 1868 . This early correspondence showed the interest of Smithsonian officials in obtaining Paleolithic collections. The correspondence is fairly extensive and detailed, describing the materials exchanged and their places of origin. On 17 November 1868, Henry wrote to inquire about the possibility of obtaining Old World Paleolithic material. Lartet replied on 4 March 1869, stating that objects would be sent to the Smithsonian. The letter described particular objects, including chipped stone, bone, and breccia from a number of locations in western Europe.
Here, at Paris, I had prepared a...box which ... contains, besides a certain number of moulds of the principal specimens of art and industry figured in the Reliquae Aquitanicae, some original arrows, needles, \& other fragments of the horn of the Reindeer wrought, some of them bearing marks and one with the outline of an animal carved, etc. There will be found a considerable quantity of silex of different types characterizing chiefly our Paleolithic stations of Perigord and other regions of France.

I have taken care to direct to you only objects which are not to be had in commerce. The box contains also fossil bones; but the short \& flat bones are all that have remained entire, those which had a medullary cavity having been broken or cleft by the indigenous of the epoch. I have thought proper to add to this remittance two small specimens of breccia from Les Eyzies, of which one encloses a jaw of the reindeer with the upper molars, and the other a fragment of an antler.

Each specimen will be found to bear its label, except some fossil bones dispersed through the box, and which, if I have not attached a label, may be considered as coming from the rock-shelter (abris sous rocher) of the Madalaine in Perigord. You will find also five specimens of a type analogous to those of St. Acheul, which come from a new repository (Tilly) of the department of the Allias (France) and which I believe to be of very great antiquity. Finally, M. Rebourg, who has been for a number of years engaged in collecting rare specimens of wrought silex in the diluvium of Paris, has been good enough to add to my package some of those specimens, which I offer you in his name with a note from him and a section of the stratum.

You will find in the box a ticket indicating a certain number of pieces of carved silex proceeding from the burying-place of Cro-Magnon, figured in the VII part of the Reliquae Aquitanicae; the human skulls exhumed from the same place are represented in part VI of the same work.

Among the French materials donated by Lartet in this first accession, those from La Madeleine [also Madelaine] stand out in the number of stone tools and worked bone and antler pieces. A number of sagaies from La Madeleine show basal splitting and flattening and characteristic working of the points (Figure 36). Labels affixed to many of the artifacts include the initials "L/C" (Lartet and Christy), the date "1863," and site provenience information (e.g., "La Madelaine, Dordogne, France"). Among the artifacts are pieces with lateral incising and chevron-shaped incising at their distal ends. Several examples have elaborately engraved midsections (Figure 37). Harpoons from La Madeleine display incising and engraving at their barbs and in their midsections (Figure 38). Among the most spectacular and rarest pieces from La Madeleine is a $\mathrm{Ba}$ ton de Commandement, a rare and enigmatic Upper Paleolithic artifact, surmised to function as a utilitarian shaft-straightener or as a symbol in special ceremonial contexts (Figure 39). As mentioned by Lartet in his letter of 4 March 1869, one of the antler pieces bears "the outline of a carved animal," which almost certainly is a horse, based upon the appearance of its snout, eye, body, front and back legs, and tail (Figure 40). Among the more typical objects from La Madeleine are chipped stone artifacts, including burins and burinated scrapers on blades (Figure 41). Objects from other Paleolithic sites include an antler from Cro-Magnon (Figure 42), a worked antler 
TABLE 4.-Paleolithic Collections in the Smithsonian Institution.

\begin{tabular}{|c|c|c|c|c|c|}
\hline Source & Date & Accession & Country & Locale & Description \\
\hline \multirow[t]{27}{*}{ Lartet } & \multirow[t]{24}{*}{1869} & \multirow[t]{24}{*}{1529} & \multirow[t]{21}{*}{ France } & Ariège & $\begin{array}{l}5 \text { objects: } 1 \text { bone, } 1 \text { worked bone, } 1 \text { antler, } 1 \text { tooth, } 1 \text { en- } \\
\text { graved antler cast }\end{array}$ \\
\hline & & & & Aurignac & 19 objects: 6 chipped stones, 2 bones, 6 jaws, 5 teeth \\
\hline & & & & Bruniquel & 45 objects: 41 chipped stones, 2 handles, 2 figurine casts \\
\hline & & & & Clichy & 6 chipped stones \\
\hline & & & & Cro-Magnon & 32 objects: 21 chipped stones, 2 bones, 1 antler, 8 shells \\
\hline & & & & Dordogne & $\begin{array}{l}32 \text { objects: } 2 \text { chipped stones, } 19 \text { bones, } 11 \text { worked bones (11 } \\
\text { worked bone casts) }\end{array}$ \\
\hline & & & & Gorge d'Enfer & 41 objects: 35 chipped stones, 6 bones \\
\hline & & & & Grottes de Fin Alliez & 2 bones \\
\hline & & & & La Madeleine & $\begin{array}{l}133 \text { objects: } 84 \text { chipped stones, } 3 \text { mortars, } 1 \text { antler, } 17 \text { bones, } \\
2 \text { jaws, } 1 \text { hoof, } 25 \text { worked bones ( } 3 \text { worked bone, } 1 \text { harpoon, } \\
1 \text { mortar casts) }\end{array}$ \\
\hline & & & & Laugerie & 3 objects: 2 bones, 1 jaw \\
\hline & & & & Laugerie Basse & $\begin{array}{l}36 \text { objects: } 34 \text { chipped stones, } 1 \text { breccia piece, } 1 \text { engraved } \\
\text { antler cast }\end{array}$ \\
\hline & & & & Les Batignoles & 4 chipped stones \\
\hline & & & & Le Moustier & 38 objects: 33 chipped stones, 4 teeth, 1 worked antler \\
\hline & & & & Les Eyzies & $\begin{array}{l}6 \text { objects: } 2 \text { chipped stones, } 1 \text { jaw, } 1 \text { tooth, } 1 \text { breccia piece, } 1 \\
\text { engraved bone cast }\end{array}$ \\
\hline & & & & Levallois & 3 chipped stones \\
\hline & & & & Lourdes & 1 tooth \\
\hline & & & & Massat & 2 objects: 1 antler, 1 bone \\
\hline & & & & Montastruc & 1 figurine (cast) \\
\hline & & & & Neuilly & 4 chipped stones \\
\hline & & & & Tilly & 10 objects: 5 chipped stones, 5 hammerstones \\
\hline & & & & Unknown & 16 chipped stones \\
\hline & & & \multirow[t]{2}{*}{ Italy } & Elba Island & 3 chipped stones \\
\hline & & & & Pisa & 1 bone \\
\hline & & & England & Hoxne & 2 chipped stones ( 1 cast) \\
\hline & \multirow[t]{3}{*}{1874} & \multirow[t]{3}{*}{3546} & \multirow[t]{3}{*}{ France } & Loire Valley & 2 quartz \\
\hline & & & & Solutré & $\begin{array}{l}603 \text { objects: } 201 \text { chipped stones, } 389 \text { bones, } 1 \text { hammerstone, } \\
4 \text { hearthstones, } 2 \text { antlers, } 3 \text { teeth, } 2 \text { breccia pieces, } 1 \text { concre- } \\
\text { tion }\end{array}$ \\
\hline & & & & Somme Valley & 2 chipped stones \\
\hline \multirow[t]{6}{*}{ Blackmore } & 1870 & 1846 & England & Thetford & 23 chipped stones ( 3 casts) \\
\hline & \multirow[t]{5}{*}{1872} & \multirow[t]{5}{*}{2371} & \multirow[t]{4}{*}{ England } & Reculvert & 1 chipped stone cast \\
\hline & & & & Shrub Hill & 1 chipped stone cast \\
\hline & & & & Thetford & 41 chipped stones ( 2 casts) \\
\hline & & & & Virandon & 2 chipped stones \\
\hline & & & Italy & Rome & 6 chipped stones \\
\hline \multirow[t]{2}{*}{ Wyman } & \multirow[t]{2}{*}{1872} & \multirow[t]{2}{*}{2587} & \multirow[t]{2}{*}{ France } & Pont Le Roy & 22 objects: 20 chipped stones, 2 hammerstones \\
\hline & & & & St. Acheul & 3 chipped stones \\
\hline Garrow & 1875 & 4044 & France & Solutré & 15 objects: 8 bones, 6 chipped stones, 1 tooth \\
\hline \multirow[t]{4}{*}{ Feuardent } & \multirow[t]{4}{*}{1879} & \multirow[t]{4}{*}{7825} & \multirow[t]{4}{*}{ France } & Abbeville & 14 chipped stones \\
\hline & & & & Loire Basin & 26 chipped stones \\
\hline & & & & Montières & 7 chipped stones \\
\hline & & & & St. Acheul & 21 chipped stones \\
\hline
\end{tabular}


TABLE 4.-Continued.

\begin{tabular}{|c|c|c|c|c|c|}
\hline Source & Date & Accession & Country & Locale & Description \\
\hline \multirow[t]{5}{*}{ Dawkins } & \multirow[t]{5}{*}{1881} & \multirow[t]{5}{*}{10115} & \multirow[t]{5}{*}{ England } & Church Hole & $\begin{array}{l}114 \text { objects: } 18 \text { chipped stones, } 2 \text { pebbles, } 46 \text { bones, } 33 \\
\text { teeth, } 15 \text { antlers (casts of } 3 \text { chipped stones, } 8 \text { teeth) }\end{array}$ \\
\hline & & & & Derbyshire & 1 bone \\
\hline & & & & Mother Grundy's Parlour & 14 objects 1 bone, 1 jaw (cast) 12 teeth (casts) \\
\hline & & & & Robin Hood & $\begin{array}{l}208 \text { objects: } 1 \text { antler, } 163 \text { bones, } 2 \text { jaws, } 30 \text { teeth, } 4 \text { coproli- } \\
\text { tes, } 8 \text { chipped stones }\end{array}$ \\
\hline & & & & Windy Knoll & 94 objects: 88 bones, 5 teeth, 1 antler \\
\hline \multirow{9}{*}{$\begin{array}{l}\text { Musée Royal d'Histoire } \\
\text { Naturelle de Belgique }\end{array}$} & \multirow[t]{9}{*}{1881} & \multirow[t]{9}{*}{10470} & \multirow[t]{9}{*}{ Belgium } & Blaireaux & 1 jaw (maxilla cast) \\
\hline & & & & Chaleux & 21 objects: 10 chipped stones, 11 bones (casts) \\
\hline & & & & Frontal & 3 bones (casts) \\
\hline & & & & Goyet & $\begin{array}{l}18 \text { objects: } 5 \text { chipped stones, } 11 \text { bones, } 2 \text { worked bones (har- } \\
\text { poon) (casts) }\end{array}$ \\
\hline & & & & Hastière & 2 objects: 1 bone, 1 jaw (casts) \\
\hline & & & & Magrite & $\begin{array}{l}11 \text { objects: } 5 \text { chipped stones, } 4 \text { bones, } 1 \text { figurine, } 1 \text { antler } \\
\text { (casts) }\end{array}$ \\
\hline & & & & Trou de Nuton & 26 objects: 24 bones, 1 skull, 1 jaw (casts) \\
\hline & & & & Trou Rosette & 3 bones (casts) \\
\hline & & & & Sureau & 5 objects: 4 chipped stones, 1 bone (casts) \\
\hline Museum of Le Havre & 1881 & 10666 & France & Moulin Quignon & 1 chipped stone \\
\hline Pengelly & 1883 & 13075 & England & Kent's Cavern & 1264 objects: 632 bones, 632 teeth \\
\hline White & 1883 & 26918 & India & Madras & 3 chipped stones \\
\hline \multirow[t]{24}{*}{ Wilson } & \multirow[t]{24}{*}{$1883-1904$} & \multirow[t]{24}{*}{42207} & Belgium & Chaleux & 1 chipped stone \\
\hline & & & \multirow[t]{3}{*}{ England } & Ightham & 3 chipped stones \\
\hline & & & & Kent's Cavern & 1 stalagmite \\
\hline & & & & Thetford & 3 chipped stones \\
\hline & & & \multirow[t]{20}{*}{ France } & Abbeville & 48 chipped stones \\
\hline & & & & Amiens & 2 chipped stones \\
\hline & & & & Badegoule & 152 objects: 128 chipped stones, 8 bones, 16 breccia pieces \\
\hline & & & & Balutie & 3 chipped stones \\
\hline & & & & Belcaire & 9 chipped stones \\
\hline & & & & Bois du Rocher & 15 chipped stones ( 1 cast) \\
\hline & & & & Bruniquel & 19 chipped stones, 2 worked bone casts \\
\hline & & & & Butte du Abaret & 1 chipped stone \\
\hline & & & & Castel Merle & 13 chipped stones \\
\hline & & & & Chelles & 33 objects: 28 chipped stones, 2 teeth, 3 pebbles \\
\hline & & & & Chez Pourret & 119 chipped stones \\
\hline & & & & Chiffand & 2 chipped stones \\
\hline & & & & Combe Grenelle & 1 chipped stone \\
\hline & & & & Combe Negre & 67 chipped stones \\
\hline & & & & Coussay Les Bois & 2 chipped stones \\
\hline & & & & Cro-Magnon & 1 chipped stone \\
\hline & & & & Dinnimont & 1 chipped stone \\
\hline & & & & Dordogne & $\begin{array}{l}97 \text { objects: } 92 \text { chipped stones, } 1 \text { tooth, } 2 \text { figurine casts, } 2 \\
\text { worked bone casts }\end{array}$ \\
\hline & & & & Finel & 1 bone \\
\hline & & & & Fixmount & 1 chipped stone \\
\hline
\end{tabular}


TABLE 4.-Continued.

\begin{tabular}{|c|c|c|c|c|c|}
\hline Source & Date & Accession & Country & Locale & Description \\
\hline \multirow[t]{38}{*}{ Wilson } & \multirow[t]{38}{*}{$1883-1904$} & \multirow[t]{38}{*}{42207} & \multirow[t]{38}{*}{ France } & Fonds Mause & 16 chipped stones \\
\hline & & & & Foulanges & 2 chipped stones \\
\hline & & & & Fontmaure & 4 chipped stones \\
\hline & & & & Gourdan & $\begin{array}{l}113 \text { objects: } 58 \text { chipped stones, } 37 \text { bones, } 5 \text { breccia pieces, } 9 \\
\text { teeth, } 4 \text { hammerstones }\end{array}$ \\
\hline & & & & Grotte de Bize & $\begin{array}{l}160 \text { objects: } 86 \text { chipped stones, } 41 \text { bones, } 3 \text { breccia pieces, } 1 \\
\text { stalactite, } 23 \text { teeth, } 5 \text { worked bones, } 1 \text { granite piece }\end{array}$ \\
\hline & & & & Grotte de L'Herm & 5 objects: 4 bones, 1 skeleton \\
\hline & & & & Hérault & 1 tooth \\
\hline & & & & Joinville / Conneville & 4 chipped stones \\
\hline & & & & La Balutie & 1 chipped stone \\
\hline & & & & La Costette & 2 chipped stones \\
\hline & & & & La Madeleine & $\begin{array}{l}129 \text { objects: } 105 \text { chipped stones, } 6 \text { bones, } 7 \text { antlers, } 11 \\
\text { worked bones ( } 5 \text { antler and } 11 \text { worked bone casts) }\end{array}$ \\
\hline & & & & La Micoque & 25 chipped stones \\
\hline & & & & La Motte Piquet & 1 chipped stone \\
\hline & & & & La Vignolle & 4 chipped stones \\
\hline & & & & Laugerie & 3 objects: 2 bones, 1 tooth \\
\hline & & & & Laugerie Basse & $\begin{array}{l}52 \text { objects: } 24 \text { chipped stones, } 2 \text { bones, } 1 \text { figurine, } 2 \text { antlers, } \\
18 \text { worked bones, } 5 \text { worked bone casts }\end{array}$ \\
\hline & & & & Laugerie Haute & $\begin{array}{l}15 \text { objects: } 13 \text { chipped stones, } 1 \text { breccia piece, } 1 \text { worked } \\
\text { bone }\end{array}$ \\
\hline & & & & Laugerie Haute/Basse & $\begin{array}{l}458 \text { objects: } 359 \text { chipped stones, } 71 \text { bones, } 4 \text { teeth, } 4 \text { antlers, } \\
6 \text { worked antler, } 5 \text { fossil, } 9 \text { worked bone casts }\end{array}$ \\
\hline & & & & Le Moustier & 33 chipped stones \\
\hline & & & & Le Moustier, Plateau & 7 chipped stones \\
\hline & & & & Le Pey & 19 objects: 17 chipped stones, 2 teeth \\
\hline & & & & Leigne Les Bois & 1 chipped stone \\
\hline & & & & Les Eyzies & 36 objects: 33 chipped stones, 1 bone, 2 breccia pieces \\
\hline & & & & Les Roches & 10 objects: 9 chipped stones, 1 ochre \\
\hline & & & & Luisseau & 4 chipped stones \\
\hline & & & & Lunneville Cavern & 9 objects: 4 fossils, 5 teeth \\
\hline & & & & Marinaux & 8 chipped stones \\
\hline & & & & Menton & $\begin{array}{l}496 \text { objects: } 388 \text { chipped stones, } 6 \text { antlers, } 9 \text { breccia pieces, } \\
16 \text { fossils, } 7 \text { ochre, } 20 \text { teeth, } 2 \text { tusks, } 31 \text { bones, } 12 \text { shells, } 1 \\
\text { hammerstone, } 4 \text { polishers }\end{array}$ \\
\hline & & & & Montignac & 3 chipped stones \\
\hline & & & & Navelière & 9 chipped stones \\
\hline & & & & Petit Puy Rousseau & 2 teeth \\
\hline & & & & Plaine de Losse, Thorac & 2 chipped stones \\
\hline & & & & Plateau du Milhol & 1 chipped stone \\
\hline & & & & Poitou & 1 chipped stone \\
\hline & & & & Reilhac & 141 chipped stones \\
\hline & & & & Ribezsol & 3 chipped stones \\
\hline & & & & Rochebestier & 3 chipped stones \\
\hline & & & & Rossignol & $\begin{array}{l}27 \text { objects: } 2 \text { chipped stones, } 2 \text { bones, } 15 \text { worked bones, } 5 \\
\text { fossils, } 2 \text { teeth, } 1 \text { worked antler }\end{array}$ \\
\hline
\end{tabular}


TABLE 4.- Continued.

\begin{tabular}{|c|c|c|c|c|c|}
\hline Source & Date & Accession & Country & Locale & Description \\
\hline \multirow[t]{18}{*}{ Wilson } & \multirow[t]{18}{*}{$1883-1904$} & \multirow[t]{18}{*}{42207} & \multirow[t]{13}{*}{ France } & Saintes & 10 chipped stones \\
\hline & & & & Salmon & 8 chipped stones \\
\hline & & & & Saltpêtrière & 28 objects: 20 chipped stones, 8 worked bones \\
\hline & & & & Seine-et-Marne & 1 "drift" deposit \\
\hline & & & & Seine-et-Oise & 1 hammerstone \\
\hline & & & & Solutré & 25 objects: 1 chipped stone, 24 worked bones \\
\hline & & & & Solutré and La Madeleine & 3 objects: 1 chipped stone, 2 worked bones \\
\hline & & & & Somme Valley & 23 chipped stones \\
\hline & & & & St. Acheul & 14 chipped stones \\
\hline & & & & Tarn-et-Garonne & 1 chipped stone \\
\hline & & & & Thennes & 1 chipped stone \\
\hline & & & & Unknown & $\begin{array}{l}21 \text { objects: } 1 \text { antler, } 14 \text { chipped stones, } 6 \text { worked bones } \\
\text { (awls) }\end{array}$ \\
\hline & & & & Vézère, Caverns de & 20 chipped stones \\
\hline & & & \multirow[t]{4}{*}{ Italy } & Fate Finale & 1 bone \\
\hline & & & & Perugia & 6 chipped stones \\
\hline & & & & Pisa, cave near & 8 coprolites \\
\hline & & & & Vibrata Valley & 1 chipped stone \\
\hline & & & Switzerland & Thayngen & 57 objects: 33 chipped stones, 24 bones \\
\hline \multirow{6}{*}{$\begin{array}{c}\text { Musée des Antiquités } \\
\text { Nationales, St. Germain- } \\
\text { en-Laye }\end{array}$} & \multirow[t]{6}{*}{1887} & \multirow[t]{6}{*}{18891} & \multirow[t]{5}{*}{ France } & Dordogne & $\begin{array}{l}12 \text { objects: } 1 \text { figurine, } 10 \text { engraved bones, } 1 \text { worked bone } \\
\text { (cast) }\end{array}$ \\
\hline & & & & La Madeleine & $\begin{array}{l}13 \text { objects: } 4 \text { antlers, } 5 \text { bones, } 4 \text { worked bones ( } 3 \text { worked } \\
\text { bone casts) }\end{array}$ \\
\hline & & & & Laugerie Basse & 2 worked bones (shaft straightners) (casts) \\
\hline & & & & Laugerie Haute & 1 worked bone (shaft straightener) (cast) \\
\hline & & & & Paris & 4 objects: 1 bone, 3 worked bones (harpoons, point) (casts) \\
\hline & & & Switzerland & Thayngen & 1 antler (cast) \\
\hline \multirow[t]{9}{*}{ Rau } & \multirow[t]{9}{*}{1887} & \multirow[t]{9}{*}{19931} & \multirow[t]{2}{*}{ England } & Icklingham & 1 chipped stone \\
\hline & & & & Thetford & 1 chipped stone \\
\hline & & & \multirow[t]{7}{*}{ France } & Bruniquel & 13 objects: 9 worked bones, 4 antler \\
\hline & & & & La Madeleine & 14 objects: 1 chipped stone, 13 worked bones \\
\hline & & & & Les Eyzies & I breccia piece \\
\hline & & & & Mas d'Azil & 6 worked bones \\
\hline & & & & Poitou & 3 chipped stones \\
\hline & & & & St. Acheul & 6 chipped stones \\
\hline & & & & Unknown & 2 bones \\
\hline \multirow[t]{10}{*}{ Lovett } & \multirow[t]{10}{*}{1888} & \multirow[t]{10}{*}{20116} & \multirow[t]{10}{*}{ England } & Bedford & 1 chipped stone \\
\hline & & & & Broome & 1 chipped stone \\
\hline & & & & Chard & 1 chipped stone \\
\hline & & & & Clacton & 3 chipped stones \\
\hline & & & & Grime's Graves & 4 chipped stones \\
\hline & & & & Hackney & 1 chipped stone \\
\hline & & & & Kempston & 1 chipped stone \\
\hline & & & & Stamford Hill & 3 chipped stones \\
\hline & & & & Suffolk & 1 chipped stone \\
\hline & & & & Warren Hill & 1 chipped stone \\
\hline
\end{tabular}


TABLE 4.-Continued.

\begin{tabular}{|c|c|c|c|c|c|}
\hline Source & Date & Accession & Country & Locale & Description \\
\hline \multirow[t]{19}{*}{ Lovett } & 1888 & 20116 & India & Poondi & 2 chipped stones \\
\hline & 1888 & 20225 & England & Grime's Graves & 5 chipped stones \\
\hline & \multirow[t]{4}{*}{1890} & \multirow[t]{4}{*}{23040} & \multirow[t]{4}{*}{ England } & Bedford & 1 chipped stone \\
\hline & & & & Broome & 1 chipped stone \\
\hline & & & & Ightham & 1 chipped stone \\
\hline & & & & Warren Hill & 3 chipped stones \\
\hline & 1890 & 23170 & England & Northfleet & 7 chipped stones \\
\hline & \multirow[t]{11}{*}{1892} & \multirow[t]{11}{*}{25615} & \multirow[t]{11}{*}{ England } & Bedford & 1 chipped stone \\
\hline & & & & Cheswick & 1 chipped stone \\
\hline & & & & Chevit Farm & 1 chipped stone \\
\hline & & & & Grime's Graves & 2 chipped stones \\
\hline & & & & Hanwell & 1 chipped stone \\
\hline & & & & Igtham & 1 chipped stone \\
\hline & & & & Kingsfield & 1 chipped stone \\
\hline & & & & Stamford Hill & 5 chipped stones \\
\hline & & & & Thames Valley & 1 chipped stone \\
\hline & & & & Unknown & 1 chipped stone \\
\hline & & & & Warren Hill & 1 chipped stone \\
\hline & 1893 & 27077 & England & Kent & 1 chipped stone \\
\hline Ransom & 1888 & 20668 & England & Hitchin & 8 chipped stones \\
\hline $\begin{array}{l}\text { American Museum of } \\
\text { Natural History }\end{array}$ & 1888 & 21293 & France & St. Acheul & 1 chipped stone (cast) \\
\hline \multirow[t]{14}{*}{ Reynolds } & \multirow[t]{14}{*}{1888} & \multirow[t]{14}{*}{21386} & \multirow[t]{14}{*}{ France } & Bois du Rocher & 2 chipped stones \\
\hline & & & & Bray & 3 chipped stones \\
\hline & & & & Bruniquel & 25 chipped stones \\
\hline & & & & Jaulne & 1 chipped stone \\
\hline & & & & La Guizonière & 1 chipped stone \\
\hline & & & & La Madeleine & 7 chipped stones \\
\hline & & & & Laugerie Haute & 3 chipped stones \\
\hline & & & & Le Moustier & 1 chipped stone \\
\hline & & & & Lilly & 1 chipped stone \\
\hline & & & & Montguillain & 33 chipped stones \\
\hline & & & & Paris & 1 chipped stone \\
\hline & & & & Pont Le Roy & 2 chipped stones \\
\hline & & & & Pouline & 1 chipped stone \\
\hline & & & & St. Acheul & 13 chipped stones \\
\hline Cresson & 1890 & 23766 & France & Le Moustier & 5 chipped stones \\
\hline \multirow[t]{2}{*}{ Balfour } & \multirow[t]{2}{*}{1891} & \multirow[t]{2}{*}{24708} & \multirow[t]{2}{*}{ France } & Les Eyzies & 2 chipped stones \\
\hline & & & & Unknown & 1 chipped stone \\
\hline \multirow{3}{*}{$\begin{array}{l}\text { Museo Zoologico dei } \\
\text { Vertebrati, Florence }\end{array}$} & \multirow[t]{2}{*}{1891} & \multirow[t]{2}{*}{24918} & France & Les Eyzies & 1 breccia piece \\
\hline & & & Italy & Levanzo Island Cave & 8 bones \\
\hline & 1892 & 25949 & Italy & Breonio Cave & 8 bones and teeth \\
\hline \multirow[t]{4}{*}{ Powell } & \multirow[t]{4}{*}{1893} & \multirow[t]{4}{*}{27665} & \multirow[t]{2}{*}{ England } & Oxfordshire & 1 chipped stone \\
\hline & & & & Warren Hill & 7 chipped stones \\
\hline & & & \multirow[t]{2}{*}{ France } & Bois du Rocher & 1 chipped stone \\
\hline & & & & Etcheroz & 6 objects: 5 bones, 1 tooth \\
\hline
\end{tabular}


TABLE 4.-Continued.

\begin{tabular}{|c|c|c|c|c|c|}
\hline Source & Date & Accession & Country & Locale & Description \\
\hline \multirow[t]{7}{*}{ Powell } & \multirow[t]{7}{*}{1893} & \multirow[t]{7}{*}{27665} & \multirow[t]{7}{*}{ France } & Grotte de Cabrières & 1 antler \\
\hline & & & & Grotte de L'Herm & 3 bones \\
\hline & & & & Grotte de Minerve & 2 teeth \\
\hline & & & & Grotte de Passaron & 2 teeth \\
\hline & & & & Lananve & 1 chipped stone \\
\hline & & & & Placard & 2 chipped stones \\
\hline & & & & St. Cernois & 1 chipped stone \\
\hline Camp & 1895 & 28914 & Africa & Unknown & 2 chipped stones \\
\hline \multirow[t]{2}{*}{ Quick } & \multirow[t]{2}{*}{1895} & \multirow[t]{2}{*}{29853} & \multirow[t]{2}{*}{ England } & Icklingham & 1 chipped stone \\
\hline & & & & Salisbury & 1 chipped stone \\
\hline \multirow[t]{3}{*}{ Harrison } & \multirow[t]{3}{*}{1895} & \multirow[t]{3}{*}{30109} & \multirow[t]{3}{*}{ England } & Gravesend & 1 chipped stone \\
\hline & & & & Thames Valley & 2 chipped stones \\
\hline & & & & Unknown & 20 chipped stones \\
\hline Hough & 1896 & 31440 & France & Menton & 16 chipped stones \\
\hline \multirow[t]{4}{*}{ Seton-Karr } & \multirow[t]{2}{*}{1897} & \multirow[t]{2}{*}{32485} & \multirow[t]{2}{*}{ Somalia } & Marodijeh & 20 chipped stones \\
\hline & & & & Somaliland & 56 chipped stones \\
\hline & 1903 & 40597 & India & Poondi & 15 chipped stones \\
\hline & 1907 & 47957 & India & Penner River & 83 chipped stones \\
\hline \multirow[t]{24}{*}{ Miguel } & \multirow[t]{2}{*}{1900} & \multirow[t]{2}{*}{36097} & \multirow[t]{2}{*}{ France } & Grotte de Bize & 5 chipped stones \\
\hline & & & & La Madeleine & 2 chipped stones \\
\hline & \multirow[t]{10}{*}{1905} & \multirow[t]{7}{*}{43727} & Algeria & Aumale & 1 chipped stone \\
\hline & & & \multirow[t]{6}{*}{ France } & Bousanow & 1 bone point \\
\hline & & & & Grotte de Bize & 4 objects: 1 chipped stone, 3 teeth \\
\hline & & & & Grotte de Cabrières & 2 objects: 1 bone point, 1 shell \\
\hline & & & & Solutré & 1 chipped stone \\
\hline & & & & Thohyb Verout & 2 chipped stones \\
\hline & & & & Ville sur Jarnioux & 1 chipped stone \\
\hline & & 44831 & Algeria & Aumale & 2 chipped stones \\
\hline & & & France & Cahière & 1 shell \\
\hline & & & & Grotte de Bize & 9 objects: 1 antler, 6 chipped stones, 2 bones \\
\hline & 1906 & 46030 & France & Angoulême & 1 chipped stone \\
\hline & & & & Bergerac & 1 chipped stone \\
\hline & & & & Bolbec & 1 chipped stone \\
\hline & & & & Etcheroz & 6 objects: 5 bones, 1 tooth \\
\hline & & & & Grotte de Bize & 20 objects: 12 bones, 4 chipped stones, 4 points \\
\hline & & & & Grotte de Cabrières & 1 antler \\
\hline & & & & Grotte de L'Herm, & 3 bones \\
\hline & & & & Grotte de Minerve & 2 teeth \\
\hline & & & & Grotte de Passaron & 2 teeth \\
\hline & & & & Lananve & 1 chipped stone \\
\hline & & & & Placard & 2 chipped stones \\
\hline & & & & St Cernois & 1 chipped stone \\
\hline McGuire & 1900 & 37330 & France & Clichy & 2 chipped stones \\
\hline & & & & Côtes-du-Nord & 9 worked bones \\
\hline & & & & Levallois & 1 chipped stone \\
\hline
\end{tabular}


TABLE 4.-Continued.

\begin{tabular}{|c|c|c|c|c|c|}
\hline Source & Date & Accession & Country & Locale & Description \\
\hline \multirow[t]{2}{*}{ Steierli } & \multirow[t]{2}{*}{1901} & \multirow[t]{2}{*}{38268} & Switzerland & Kesslerloch Cavern & $\begin{array}{l}361 \text { objects: } 118 \text { chipped stones, } 222 \text { bones, } 16 \text { teeth, } 5 \text { brec- } \\
\text { cia pieces }\end{array}$ \\
\hline & & & France & Dordogne & 4 worked bones \\
\hline Else & 1901 & 38778 & England & Kent's Cavern & $\begin{array}{l}139 \text { objects: } 53 \text { chipped stones, } 29 \text { bones, } 54 \text { teeth, } 3 \text { stalag- } \\
\text { mite }\end{array}$ \\
\hline \multirow[t]{3}{*}{ Albany Museum } & \multirow[t]{3}{*}{1904} & \multirow[t]{3}{*}{43544} & \multirow[t]{3}{*}{ South Africa } & Bezuidenhout Valley & 5 chipped stones \\
\hline & & & & East London & 7 chipped stones \\
\hline & & & & Griqualand West & 1 chipped stone \\
\hline \multirow[t]{2}{*}{ Nightingale } & 1906 & 46550 & England & Swaffham & 4 chipped stones \\
\hline & 1908 & 49416 & England & Beachamwell & 8 chipped stones \\
\hline \multirow[t]{3}{*}{ Martin } & 1907 & 47416 & France & La Quina & 41 chipped stones \\
\hline & 1913 & 55671 & France & La Quina & $\begin{array}{l}59 \text { objects: } 1 \text { antler, } 2 \text { bones, } 1 \text { breccia piece, } 53 \text { chipped } \\
\text { stones, } 2 \text { teeth }\end{array}$ \\
\hline & 1924 & 71635 & France & La Quina & 8 objects: 5 chipped stones, 3 bones \\
\hline Stonestreet & 1909 & 49689 & South Africa & Christiana & 1 chipped stone \\
\hline \multirow[t]{7}{*}{$\begin{array}{l}\text { Musée d'Histoire Na- } \\
\text { turelle, Elbeuf }\end{array}$} & \multirow[t]{7}{*}{1909} & \multirow[t]{4}{*}{49696} & \multirow[t]{4}{*}{ France } & Petit-Essarts & $\begin{array}{l}111 \text { objects: } 100 \text { chipped stones, } 1 \text { hammerstone, } 2 \text { pebbles, } \\
8 \text { implements }\end{array}$ \\
\hline & & & & Radepont & 24 chipped stones \\
\hline & & & & St. Julien de la Liegne & 3 chipped stones \\
\hline & & & & St. Ouen de Tilleul & 3 chipped stones \\
\hline & & \multirow[t]{3}{*}{50268} & \multirow[t]{3}{*}{ France } & Critot & 7 chipped stones \\
\hline & & & & Petit-Essarts & 26 chipped stones \\
\hline & & & & Radepont & 11 chipped stones \\
\hline \multirow[t]{2}{*}{ Clark } & 1909 & 50010 & Palestine & Rephaim & 37 chipped stones \\
\hline & 1914 & 57311 & Palestine & Samaria & 15 chipped stones \\
\hline Gorjanović-Kramberger & 1912 & 54826 & Austria & Krapina & 9 objects: 8 chipped stones, 1 figurine (casts) \\
\hline Talken & 1913 & 54988 & South Africa & Windsorton & 8 chipped stones \\
\hline Rehlen & 1913 & 55321 & Egypt & Deir Bahau & 4 chipped stones \\
\hline Stadtisches Museum & 1913 & 55436 & Germany & Taubach & $\begin{array}{l}33 \text { objects: } 3 \text { bones, } 6 \text { breccia pieces, } 11 \text { teeth, } 13 \text { chipped } \\
\text { stones ( } 8 \text { chipped stone casts) }\end{array}$ \\
\hline \multirow[t]{7}{*}{ Rutot } & \multirow[t]{2}{*}{1913} & \multirow[t]{2}{*}{55867} & \multirow[t]{2}{*}{ Belgium } & Brussels & 22 chipped stones (casts) \\
\hline & & & & Spiennes & $\begin{array}{l}49 \text { objects: } 47 \text { chipped stones, } 2 \text { hammerstones ( } 4 \text { chipped } \\
\text { stone casts) }\end{array}$ \\
\hline & \multirow[t]{5}{*}{1914} & \multirow[t]{5}{*}{56614} & \multirow[t]{4}{*}{ Belgium } & $\begin{array}{l}\text { Binche and Haine Valley, St. } \\
\text { Pierre }\end{array}$ & 3 chipped stones \\
\hline & & & & Spiennes & 31 chipped stones \\
\hline & & & & St. Ріепе & I chipped stone \\
\hline & & & & St. Symphorien & 31 chipped stones \\
\hline & & & France & St. Acheul & 14 chipped stones \\
\hline $\begin{array}{l}\text { (Panama-California Ex- } \\
\text { position) }\end{array}$ & 1915 & 58532 & France & Templeux Le-Guerard & 10 chipped stones \\
\hline Marett & 1914 & 56924 & England & Jersey Caves & 113 objects: 95 chipped stones, 18 pebbles \\
\hline $\begin{array}{l}\text { Naturhistoriska Riks- } \\
\text { museum, Stockholm }\end{array}$ & 1914 & 57262 & Italy & Caraminco & 33 chipped stones \\
\hline Buckingham & 1915 & 59162 & France & Unknown & 29 chipped stones \\
\hline \multirow{2}{*}{$\begin{array}{l}\text { The Royal Ontario Mu- } \\
\text { seum of Archaeology }\end{array}$} & \multirow[t]{2}{*}{1918} & \multirow[t]{2}{*}{62402} & \multirow[t]{2}{*}{ Egypt } & Unknown & 28 chipped stones \\
\hline & & & & Thebaid & 10 chipped stones \\
\hline
\end{tabular}


TABLE 4.-Continued.

\begin{tabular}{|c|c|c|c|c|c|}
\hline Source & Date & Accession & Country & Locale & Description \\
\hline \multirow{6}{*}{$\begin{array}{l}\text { The Royal Ontario Mu- } \\
\text { seum of Archaeology }\end{array}$} & \multirow[t]{6}{*}{1918} & \multirow[t]{6}{*}{62402} & England & Maidenhead & 32 chipped stones \\
\hline & & & \multirow[t]{5}{*}{ France } & Badegoule & I chipped stone \\
\hline & & & & Le Moustier & 1 chipped stone \\
\hline & & & & Le Moustier, Talus & 1 chipped stone \\
\hline & & & & Les Roches & 1 chipped stone \\
\hline & & & & Placard & 4 objects: 3 chipped stones, 1 worked bone (needle) \\
\hline \multirow[t]{2}{*}{ Marriott } & \multirow[t]{2}{*}{1919} & \multirow[t]{2}{*}{63670} & \multirow[t]{2}{*}{ France } & Dordogne & 14 bones \\
\hline & & & & Izère River Valley & 35 chipped stones \\
\hline $\begin{array}{l}\text { American Presbyterian } \\
\text { Congo Mission }\end{array}$ & 1923 & 70046 & Zaire & Luebo & 4 objects: 3 chipped stones, 1 pebble \\
\hline \multirow[t]{3}{*}{ Moir } & \multirow[t]{3}{*}{1924} & \multirow[t]{3}{*}{71310} & \multirow[t]{3}{*}{ England } & Cromer & 3 chipped stones \\
\hline & & & & Foxhall & 15 chipped stones \\
\hline & & & & Ipswich & 14 chipped stones \\
\hline \multirow[t]{24}{*}{ Hrdlička } & \multirow[t]{20}{*}{1924} & \multirow[t]{20}{*}{71514} & \multirow[t]{5}{*}{ Belgium } & Goyet & 7 objects: 4 chipped stones, 3 worked-bone casts \\
\hline & & & & Magrite & 3 objects: 1 antler, 2 figurine casts \\
\hline & & & & Montaigle & 1 bone \\
\hline & & & & Spiennes & 5 chipped stones \\
\hline & & & & Sureau & 1 chipped stone \\
\hline & & & Egypt & Thebes & 5 chipped stones \\
\hline & & & \multirow[t]{13}{*}{ France } & Amiens & 2 chipped stones \\
\hline & & & & Bay Bonnet & 1 bone \\
\hline & & & & Chaleux & 2 objects: 1 chipped stone, 1 worked-bone cast \\
\hline & & & & Dordogne & 26 chipped stones \\
\hline & & & & La Madeleine & 1 worked bone (harpoon) \\
\hline & & & & La Quina & 12 bones \\
\hline & & & & La Souquette & I chipped stone \\
\hline & & & & Laugerie Basse & 6 chipped stones \\
\hline & & & & Quay Moutière & 2 chipped stones \\
\hline & & & & Rouen & 11 chipped stones \\
\hline & & & & St. Acheul & 4 chipped stones \\
\hline & & & & Unknown & 49 objects: 46 chipped stones, 2 pebbles, 1 hammerstone \\
\hline & & & & Vézère & 13 chipped stones \\
\hline & & & Germany & Mauer Quarry & 3 chipped stones \\
\hline & \multirow[t]{4}{*}{1926} & \multirow[t]{4}{*}{89903} & \multirow[t]{4}{*}{ Rhodesia } & Unknown & 1 worked bone (awl) \\
\hline & & & & Victoria Falls & 157 objects: 153 chipped stones, 4 hammerstones \\
\hline & & & & Victoria Falls, vicinity of & 40 chipped stones \\
\hline & & & & $\begin{array}{l}\text { Victoria Falls, Buxton } \\
\text { Quarry }\end{array}$ & 4 chipped stones, 1 plaque \\
\hline \multirow{4}{*}{$\begin{array}{l}\text { Archaeological Society } \\
\text { of Washington and } \\
\text { American School for } \\
\text { Prehistoric Research }\end{array}$} & \multirow[t]{2}{*}{1925} & \multirow[t]{2}{*}{84988} & \multirow[t]{2}{*}{ France } & Abri des Merveilles & $\begin{array}{l}946 \text { objects: } 88 \text { teeth, } 806 \text { chipped stones, } 34 \text { hammerstones, } \\
18 \text { bones }\end{array}$ \\
\hline & & & & Solutré & $\begin{array}{l}51 \text { objects: } 46 \text { chipped stones, } 2 \text { breccia pieces, } 1 \text { limestone, } \\
2 \text { pieces of ochre }\end{array}$ \\
\hline & 1926 & 90005 & France & Abri des Merveilles & 765 objects: 745 chipped stones, 20 hammerstones \\
\hline & 1927 & 95150 & France & Abri des Merveilles & $\begin{array}{l}970 \text { objects: } 694 \text { chipped stones, } 3 \text { hammerstones, } 104 \\
\text { bones, } 1 \text { antler, } 168 \text { teeth }\end{array}$ \\
\hline
\end{tabular}


TABLE 4.-Continued.

\begin{tabular}{|c|c|c|c|c|c|}
\hline Source & Date & Accession & Country & Locale & Description \\
\hline \multirow[t]{14}{*}{$\begin{array}{l}\text { Archaeological Society } \\
\text { of Washington and } \\
\text { American School for } \\
\text { Prehistoric Research }\end{array}$} & 1928 & 98484 & France & Abri des Merveilles & $\begin{array}{l}697 \text { objects: } 480 \text { chipped stones, } 64 \text { bones, } 1 \text { antler, } 143 \\
\text { teeth, } 9 \text { hammerstones }\end{array}$ \\
\hline & \multirow[t]{2}{*}{1929} & \multirow[t]{2}{*}{103151} & \multirow[t]{2}{*}{ France } & Abri des Merveilles & $\begin{array}{l}285 \text { objects: } 191 \text { chipped stones, } 44 \text { bones, } 36 \text { teeth, } 14 \text { ham- } \\
\text { merstones }\end{array}$ \\
\hline & & & & La Madeleine & 11 objects: 10 chipped stones, 1 antler \\
\hline & 1929 & 107359 & France & Abri des Merveilles & 525 objects: 422 chipped stones, 27 bones, 76 teeth \\
\hline & 1930 & 95604 & France & Abri des Merveilles & 169 objects: 164 chipped stones, 5 hammerstones \\
\hline & \multirow[t]{2}{*}{1930} & & \multirow[t]{2}{*}{ Iraq } & Ashkot-I-Takik & 11 chipped stones \\
\hline & & & & Zarzi & 22 chipped stones \\
\hline & 1932 & 115831 & Palestine & Mugharet-el-Wad & 507 objects: 498 chipped stones, 8 beads, 1 worked bone \\
\hline & \multirow[t]{2}{*}{1932} & \multirow[t]{2}{*}{121286} & \multirow[t]{2}{*}{ Palestine } & Kebara & $\begin{array}{l}206 \text { objects: } 160 \text { chipped stones, } 21 \text { worked bones, } 11 \text { beads, } \\
8 \text { teeth, } 1 \text { hammerstone, } 2 \text { pieces of ochre, } 3 \text { shells }\end{array}$ \\
\hline & & & & Mugharet-el-Wad & 280 chipped stones \\
\hline & \multirow[t]{2}{*}{1934} & \multirow[t]{2}{*}{126298} & \multirow[t]{2}{*}{ Palestine } & Mugharet es-Skūhl & 175 chipped stones \\
\hline & & & & Mugharet et-Tabūn & 363 chipped stones \\
\hline & 1934 & 132332 & Palestine & Mugharet et-Tabūn & 833 chipped stones \\
\hline & 1935 & 133080 & Palestine & Mugharet et-Tabūn & 1597 chipped stones \\
\hline \multirow[t]{2}{*}{ Williams College } & \multirow[t]{2}{*}{1925} & \multirow[t]{2}{*}{85687} & \multirow[t]{2}{*}{ France } & Laugerie Basse & 2 chipped stones \\
\hline & & & & Les Eyzies & 45 chipped stones \\
\hline Reygasse & 1925 & 88916 & Algeria & Tebessa & 34 chipped stones \\
\hline $\begin{array}{c}\text { Government Museum, } \\
\text { Madras }\end{array}$ & 1926 & 88426 & India & Madras & 1 chipped stone \\
\hline Jones & 1926 & 89904 & Rhodesia & Southern Rhodesia & 14 chipped stones \\
\hline Bodding & 1926 & 90169 & India & Mohulpahari & 6 chipped stones \\
\hline \multirow[t]{5}{*}{ MacCurdy } & 1926 & 92141 & Palestine & Sambariyeh & 7 chipped stones \\
\hline & \multirow[t]{3}{*}{1927} & \multirow[t]{3}{*}{99368} & \multirow[t]{3}{*}{ France } & Caguy & 1 chipped stone \\
\hline & & & & Le Moustier & 1 chipped stone \\
\hline & & & & Montières & 7 chipped stones \\
\hline & 1929 & 108178 & France & La Magdalaine & 6 chipped stones \\
\hline \multirow[t]{11}{*}{ Bushnell } & \multirow[t]{11}{*}{1926} & \multirow[t]{11}{*}{93521} & \multirow[t]{3}{*}{ Belgium } & Leval & 2 chipped stones \\
\hline & & & & Spiennes & 2 chipped stones \\
\hline & & & & St. Symphorien & 1 chipped stone \\
\hline & & & \multirow[t]{4}{*}{ England } & Cambridge & 1 chipped stone \\
\hline & & & & Dawley & 1 chipped stone \\
\hline & & & & Swanscombe & 2 chipped stones \\
\hline & & & & Warren Hill & 3 chipped stones \\
\hline & & & \multirow[t]{2}{*}{ France } & Amiens & 6 chipped stones \\
\hline & & & & Montières & 1 chipped stone \\
\hline & & & India & Poondi & 1 chipped stone \\
\hline & & & Italy & Caramanico & 5 chipped stones \\
\hline Indian Museum, Cal- & 1928 & 88427 & India & Chingleput District & 17 chipped stones \\
\hline cutta & & & & Cuddapan District & 10 chipped stones \\
\hline & & & & Marpha & 20 chipped stones \\
\hline South African Museum & 1928 & 101485 & South Africa & Montagu Cave & 7 chipped stones \\
\hline
\end{tabular}


TABLE 4.-Continued.

\begin{tabular}{|c|c|c|c|c|c|}
\hline Source & Date & Accession & Country & Locale & Description \\
\hline \multirow[t]{2}{*}{ Provincial Museum } & \multirow[t]{2}{*}{1929} & \multirow[t]{2}{*}{107637} & \multirow[t]{2}{*}{ Czechoslovakia } & Dolni Věstonice & 1 statuette (cast) \\
\hline & & & & Moravia & 3 objects: 1 carving, 1 skull, 1 chipped stone point (casts) \\
\hline \multirow{39}{*}{$\begin{array}{l}\text { Russell and Old World } \\
\text { Archaeology Fund }\end{array}$} & 1930 & 112339 & Austria & Willendorf & 1 sculpture (cast) \\
\hline & \multirow[t]{7}{*}{1931} & \multirow[t]{7}{*}{117631} & \multirow[t]{7}{*}{ Spain } & Altamira & 15 drawings \\
\hline & & & & Castillo (Puente Viesgo) & 3 drawings \\
\hline & & & & Charco del Agua Amarga & 1 drawing \\
\hline & & & & Cogul & 1 drawing \\
\hline & & & & La Vieja & 1 drawing \\
\hline & & & & Pindal & 2 drawings \\
\hline & & & & Unknown & 13 bones \\
\hline & \multirow[t]{31}{*}{1932} & \multirow[t]{29}{*}{116916} & \multirow[t]{5}{*}{ Algeria } & Clairfontaine & 9 chipped stones \\
\hline & & & & $\begin{array}{l}\text { Tebessa, Bir-Roubat, El- } \\
\text { Monkhaad }\end{array}$ & 6 chipped stones \\
\hline & & & & Tebessa, El-Ma-El-Aboid & 6 chipped stones \\
\hline & & & & Tebessa, Escargotière & 10 chipped stones \\
\hline & & & & Tebessa, Fidh-El-Begue & 1 chipped stone \\
\hline & & & \multirow[t]{2}{*}{ England } & Ipswich & 2 chipped stones \\
\hline & & & & Warren Hill & 5 chipped stones \\
\hline & & & \multirow[t]{20}{*}{ France } & Abbeville & 3 chipped stones \\
\hline & & & & Chaffaud & 9 chipped stones \\
\hline & & & & Chambe & 83 chipped stones \\
\hline & & & & Combe-Chapelle & 1 chipped stone \\
\hline & & & & Fanzan & 4 bones \\
\hline & & & & Fontaine & 1 chipped stone \\
\hline & & & & Grand Pressigny & 1 chipped stone \\
\hline & & & & La Quina & 42 chipped stones \\
\hline & & & & La Souquette & 5 chipped stones \\
\hline & & & & Le Moustier, vicinity of & 23 chipped stones \\
\hline & & & & \begin{tabular}{|l|} 
Laugerie Haute \\
\end{tabular} & $\begin{array}{l}19 \text { objects: } 11 \text { chipped stones, } 8 \text { worked bones ( } 8 \text { worked } \\
\text { bone casts) }\end{array}$ \\
\hline & & & & Limeuil & 4 chipped stones \\
\hline & & & & Malpac, Abri & 1 chipped stone \\
\hline & & & & Merveilles & 2 chipped stones (casts) \\
\hline & & & & Meyral & 1 chipped stone \\
\hline & & & & Nielon & 3 chipped stones \\
\hline & & & & Pech de la Boissière & 26 objects: 25 chipped stones, 1 ochre \\
\hline & & & & Poitons & 1 chipped stone \\
\hline & & & & Puits & 1 worked bone \\
\hline & & & & St. Acheul & 4 chipped stones \\
\hline & & & Palestine & Sambariyeh & 12 chipped stones \\
\hline & & & Spain & Bartolos Quarry & 1 chipped stone \\
\hline & & \multirow[t]{2}{*}{117750} & \multirow[t]{2}{*}{ France } & Marsoulas & $\begin{array}{l}134 \text { objects: } 63 \text { chipped stones, } 49 \text { bones, } 10 \text { worked bones, } \\
2 \text { ochre pieces, } 1 \text { shell, } 7 \text { limestone pieces, } 2 \text { travertine }\end{array}$ \\
\hline & & & & Roquecourbère & 58 chipped stones \\
\hline
\end{tabular}


TABLE 4.-Continued.

\begin{tabular}{|c|c|c|c|c|c|}
\hline Source & Date & Accession & Country & Locale & Description \\
\hline \multirow[t]{8}{*}{$\begin{array}{l}\text { Russell and Old World } \\
\text { Archaeology Fund }\end{array}$} & \multirow[t]{8}{*}{1932} & 117750 & France & Tarté & $\begin{array}{l}200 \text { objects: } 158 \text { chipped stones, } 1 \text { hammerstone, } 11 \text { bones, } 2 \\
\text { worked bones, } 1 \text { ochre, } 1 \text { breccia piece, } 1 \text { palette, } 22 \text { objects, } \\
3 \text { polishers }\end{array}$ \\
\hline & & \multirow[t]{3}{*}{118935} & \multirow[t]{3}{*}{ France } & Marsoulas & 1 photograph \\
\hline & & & & Roquecourbère & 5 chipped stones \\
\hline & & & & Tarté & 9 chipped stones \\
\hline & & \multirow[t]{4}{*}{121411} & \multirow[t]{4}{*}{ France } & Montespan & 1 photograph \\
\hline & & & & Niaux & 2 photographs \\
\hline & & & & Trois Frères & 15 photographs \\
\hline & & & & Tuc d'Audoubert & 9 photographs \\
\hline \multirow{9}{*}{$\begin{array}{c}\text { (Photographic Labora- } \\
\text { tory) }\end{array}$} & \multirow[t]{9}{*}{1933} & \multirow[t]{9}{*}{124072} & Indonesia & Trinil & 1 photograph \\
\hline & & & England & Piltdown & 1 photograph \\
\hline & & & \multirow[t]{5}{*}{ France } & La Chapelle-aux-Saints & 1 photograph \\
\hline & & & & La Madeleine & 1 photograph \\
\hline & & & & La Quina & 1 photograph \\
\hline & & & & Laugerie Haute & 1 photograph \\
\hline & & & & Le Moustier & 1 photograph \\
\hline & & & Germany & Mauer Quarry & 1 photograph \\
\hline & & & Palestine & Mugharet el-Zuttiyeh & 1 photograph \\
\hline Sanz & 1931 & 114125 & Spain & Villaverde Bajo & 158 chipped stones \\
\hline \multirow[t]{3}{*}{ Bégouën } & \multirow[t]{3}{*}{1931} & \multirow[t]{3}{*}{117494} & \multirow[t]{3}{*}{ France } & Bédeilhac & 2 engravings (casts) \\
\hline & & & & Cabrerets & 2 footprints (casts) \\
\hline & & & & Tuc d'Audoubert & 7 objects: 4 footprints, 3 fingerprints (casts) \\
\hline \multirow[t]{7}{*}{ Abbott } & 1933 & 124660 & South Africa & Tanbryn Farm & 4 chipped stones \\
\hline & \multirow[t]{2}{*}{1934} & \multirow[t]{2}{*}{128495} & \multirow[t]{2}{*}{ South Africa } & Alexandersfontein & 19 chipped stones \\
\hline & & & & Capetown & 10 chipped stones \\
\hline & \multirow[t]{2}{*}{1935} & \multirow[t]{2}{*}{134685} & \multirow[t]{2}{*}{ South Africa } & Alexandersfontein & 23 chipped stones \\
\hline & & & & Cape Hanglip & 6 chipped stones \\
\hline & 1936 & 140811 & South Africa & Capetown & 17 chipped stones \\
\hline & 1938 & 150229 & South Africa & Witsands & 38 objects: 37 chipped stones, 1 hammerstone \\
\hline \multirow[t]{3}{*}{ Leach } & \multirow[t]{2}{*}{1935} & \multirow[t]{2}{*}{134860} & \multirow[t]{2}{*}{ England } & North Downs & 2 chipped stones \\
\hline & & & & Swanscombe & 15 chipped stones \\
\hline & 1935 & 134861 & England & Swanscombe & 16 chipped stones \\
\hline \multirow[t]{4}{*}{ McGregor Museum } & 1936 & 141245 & South Africa & Griqualand West & 2 chipped stones \\
\hline & & & & Kimberley & 1 chipped stone \\
\hline & & & & Klippies Pan & 12 chipped stones \\
\hline & & & & Vaal River & 1 chipped stone \\
\hline Swan & 1938 & 150659 & South Africa & Kimberley Sliuts & 6 chipped stones \\
\hline & & & & Modder River & 10 chipped stones \\
\hline & & & & Paardeberg & 6 chipped stones \\
\hline Swan & 1938 & 150659 & South Africa & Smidts Drift Road & 5 chipped stones \\
\hline & & & & Windsorton & 4 chipped stones \\
\hline
\end{tabular}


TABLE 4.-Continued

\begin{tabular}{|c|c|c|c|c|c|}
\hline Source & Date & Accession & Country & Locale & Description \\
\hline Franssen & 1941 & 159728 & Indonesia & Patjitan & 14 chipped stones \\
\hline Reeves & 1945 & 170049 & England & Unknown & 2 chipped stones \\
\hline \multirow[t]{2}{*}{ Bruce Hughes Fund } & \multirow[t]{2}{*}{1952} & \multirow[t]{2}{*}{177782} & \multirow[t]{2}{*}{ Jordan } & Khirbet Kharaneh & 59 objects: 57 chipped stones, 2 hammerstones \\
\hline & & & & Qurun Hattin & 4 chipped stones \\
\hline \multirow[t]{3}{*}{ Wymer } & \multirow[t]{3}{*}{1953} & \multirow[t]{3}{*}{197463} & \multirow[t]{3}{*}{ England } & Boyn Hill & I chipped stone \\
\hline & & & & Gray's Thurrock & 2 chipped stones \\
\hline & & & & Warren Hill & 2 chipped stones \\
\hline Vass & 1953 & 197993 & Zaire & Lulua River & 26 chipped stones \\
\hline \multirow[t]{4}{*}{ Bordes } & \multirow[t]{4}{*}{1956} & \multirow[t]{4}{*}{213032} & \multirow[t]{4}{*}{ France } & Combe Grenelle & 1 chipped stone \\
\hline & & & & Dordogne & $\begin{array}{l}35 \text { objects: } 33 \text { chipped stones, } 1 \text { stick, } 1 \text { hammerstone (ex- } \\
\text { perimental) }\end{array}$ \\
\hline & & & & La Ferrassie & 1 chipped stone \\
\hline & & & & Pech de L'Azé & 6 chipped stones \\
\hline Paige & 1957 & 214613 & Belgium & Tongres & 21 chipped stones \\
\hline Solecki & 1957 & 217009 & Lebanon & Ras Beirut & 33 chipped stones \\
\hline Iraq Museum & 1958 & 220078 & Iraq & Shanidar Cave & $\begin{array}{l}1429 \text { objects: } 8 \text { worked bones, } 1 \text { bead, } 1282 \text { chipped stones, } \\
64 \text { soil samples, } 2 \text { ochre pieces, } 2 \text { pebbles, } 8 \text { rocks, } 62 \text { shells }\end{array}$ \\
\hline $\begin{array}{l}\text { Government Museum, } \\
\text { Madras }\end{array}$ & 1959 & 202973 & India & Chingleput District & 2 chipped stones \\
\hline Jones & 1963 & 249458 & Libya & Temenhent & 4 chipped stones \\
\hline \multirow[t]{2}{*}{ Uganda Museum } & \multirow[t]{2}{*}{1965} & \multirow[t]{2}{*}{259009} & \multirow[t]{2}{*}{ Uganda } & Magosi & 1481 chipped stones \\
\hline & & & & Nsongezi & 467 chipped stones \\
\hline \multirow[t]{2}{*}{ Hole } & \multirow[t]{2}{*}{1966} & \multirow[t]{2}{*}{265162} & \multirow[t]{2}{*}{ Iran } & Gar Arjeneh & 221 chipped stones \\
\hline & & & & Kunji Cave & 23 chipped stones \\
\hline \multirow[t]{2}{*}{ Citron } & \multirow[t]{2}{*}{1966} & \multirow[t]{2}{*}{268093} & \multirow[t]{2}{*}{ Ethiopia } & Melka Kontouré & 4 chipped stones \\
\hline & & & & Sabata & 94 chipped stones \\
\hline Shiner & 1968 & 278180 & Sudan & Khashm El Girba & 1 chipped stone \\
\hline $\begin{array}{c}\text { Muséum National d'His- } \\
\text { toire Naturelle, Paris }\end{array}$ & 1971 & 295641 & France & Lespugue & 1 figurine (cast) \\
\hline Gibson & 1973 & 307731 & Angola & Munhino & 115 chipped stones \\
\hline Barbour & 1973 & 305126 & China & Choukoutien & 1 breccia piece \\
\hline Lightner & 1975 & 316299 & Libya & Sebha & 17 chipped stones \\
\hline Klima & 1976 & 322222 & Czechoslovakia & Dolni Věstonice & 10 objects: 6 figurines, 1 tusk, 3 ornaments (casts) \\
\hline IVPP & 1976 & 323176 & China & Dingcun & 5 chipped stones \\
\hline Sims & 1986 & 351570 & Kenya & Olorgesailie & 2 chipped stones \\
\hline \multirow[t]{7}{*}{ Eichenberger } & 1986 & 358176 & Egypt & Sand Sea Region & 1 chipped stone (cast) \\
\hline & & & France & Brassempouy & 1 figurine (cast) \\
\hline & & & & La Madeleine & 2 chipped stones (cast) \\
\hline & & & & Le Moustier & 1 chipped stone (cast) \\
\hline & & & & Pont Arcy & I chipped stone (cast) \\
\hline & & & & Somme Valley & 2 chipped stones (cast) \\
\hline & & & South Africa & Bott's Farm & 1 chipped stone (cast) \\
\hline Old & 1990 & 387104 & Jordan & Ain el-Assad & 11 chipped stones \\
\hline & & & & Fjaje & 35 chipped stones \\
\hline & & & & Jafr & 14 chipped stones \\
\hline
\end{tabular}


TABLE 4.-Continued.

\begin{tabular}{|c|c|c|c|c|c|}
\hline Source & Date & Accession & Country & Locale & Description \\
\hline \multirow[t]{3}{*}{ Old } & \multirow[t]{3}{*}{1990} & \multirow[t]{3}{*}{387104} & \multirow[t]{3}{*}{ Jordan } & Jebel Uweinid & 4 chipped stones \\
\hline & & & & Qasr Kharaneh & 38 chipped stones \\
\hline & & & & Wadi Qilat & 24 chipped stones \\
\hline \multirow{16}{*}{ Human Origins Program } & \multirow{16}{*}{$\begin{array}{l}\text { 1980s- } \\
\text { present }\end{array}$} & & \multirow[t]{2}{*}{ Kenya } & Olorgesailie & 30 chipped stones; sediment and rock samples \\
\hline & & & & Kanjera & none \\
\hline & & & \multirow[t]{7}{*}{ Zaire } & Kasaka & 100 chipped stones \\
\hline & & & & Katanda 2 (ESA) & 1400 objects: 1,000 chipped stones, 400 bones \\
\hline & & & & $\begin{array}{l}\text { Katanda } 2 \text { (Sangoan, Late } \\
\text { Acheulian) }\end{array}$ & 100 chipped stones \\
\hline & & & & Katanda 2 (MSA) & 3775 objects: 3700 chipped stones, 75 bones \\
\hline & & & & Katanda 9 (MSA) & $\begin{array}{l}>15,379 \text { objects: }>8000 \text { chipped stones, } 7369 \text { bones, } 10 \text { bone } \\
\text { tools }\end{array}$ \\
\hline & & & & Katanda 16 (MSA) & $\begin{array}{l}11,851 \text { objects: } 1500 \text { chipped stones, } 10,350 \text { bones, } 1 \text { bone } \\
\text { tool }\end{array}$ \\
\hline & & & & Ishango 11,14 (LSA) & $\begin{array}{l}15,250 \text { objects: } 10,000 \text { chipped stones, } 5000 \text { bones, } 150 \\
\text { bone tools, } 50 \text { human skeletal fragments }\end{array}$ \\
\hline & & & \multirow[t]{3}{*}{ Botswana } & $\begin{array}{l}\text { !Kangwa, /ai/ai Valleys } \\
\text { (LSA) }\end{array}$ & 600 objects: 100 chipped stones, 500 bones \\
\hline & & & & $\neq \mathrm{Gi}(\mathrm{MSA}, \mathrm{LSA})$ & 1,000 chipped stones and bones \\
\hline & & & & Toromoja, Gooi Pan (LSA) & 200 chipped stones \\
\hline & & & Ethiopia & Aduma $1,2,4,5,8,8 \mathrm{a}$ & none \\
\hline & & & \multirow[t]{2}{*}{ India } & Hunsgi-Baichbal Valley & 8 chipped stones, experimental pieces \\
\hline & & & & Malaprabha Valley & 7 chipped stones, experimental pieces \\
\hline & & & China & Bose Basin & 15 chipped stones, sediment samples \\
\hline
\end{tabular}

from Le Moustier (gnawed?) (Figure 43), and a worked bone fragment (Figure 44) and a stag antler with a polished end from Massat (Figure 45).

In the same letter, Lartet cautioned Henry to be careful about obtaining objects, as fraudulent artifacts were being produced for commercial purpose:

You tell me, Sir, that your museum is destitute of specimens from...the repositories of France which have become celebrated from the discoveries made therein. As many objects from these different localities have long been articles of commerce, I suppose it will be easy for your correspondents to procure them for you, only they should take care not to be imposed on by the counterfeiting which has been exercised on a grand scale, whether in France or elsewhere; to furnish you an example, I have placed in the box an authentic hatchet taken by myself from St. Acheul, and another repeated false, proceeding from the celebrated repository of Moulin Quignon near Abbeville, according to the note which accompanied it when sent to me.

Lartet suspected that one of the handaxes was fraudulent. His concern was justifiable considering "L'Affaire Moulin Quignon," when in 1863, Boucher de Perthes, the famous discoverer of handaxes at Abbeville, France, in the 1850s, announced the discovery of a human jaw in supposed association with Acheulian handaxes in a gravel pit at Moulin Quignon in the Somme Valley. The jaw eventually was proven to be modern, and some stone tools from Moulin Quignon were confirmed to be counterfeits produced by Boucher de Perthes workmen, who had been financially rewarded for "discovering" the artifacts (Grayson, 1983; Trinkaus and Shipman, 1992).

On 3 May 1869, Henry replied to Lartet, acknowledging the value of the collection to the National Museum:

You have placed us under obligation which we shall not readily forget, by the present of the beautiful series illustrating the prehistoric period of France, both of original specimens and of casts, which has recently come to us in good condition, and I beg you to receive, herewith, the hearty acknowledgments of the Smithsonian Institution for your liberality.

Will you, also, convey to Mr. Rebourg our acknowledgments for the specimens presented by him.

Although a substantial collection had already been sent, Lartet sent more material, as noted in his letter to Henry on 13 June 1869:

I caused to be packed up, for immediate transmission to you, quite a fine block which we have placed in reserve, and which contains, besides teeth, the bones of diverse animals and wrought horns of the reindeer, a considerable number of pieces of cut silex which are embedded therein. In the same box, I have placed other packages of cut silex, and also a stone for crushing or grinding very similar to a specimen of the same nature which came from the Upper Missouri and which 1 succeeded in procuring at the Universal Exposition of 
TABLE 5.-Preliminary faunal identifications (counts are tabulated from Table 4).

\begin{tabular}{|c|c|c|c|}
\hline Locality & Accession & Faunal count & Identifications*+ \\
\hline Abri des Merveilles & 84988,95150 & 379 (122 bones, 1 antler, 256 teeth) & Bison, Equid, Reindeer, Deer \\
\hline Aurignac & 1529 & 13 ( 2 bones, 6 jaws, 5 teeth) & Cervids, Rhinoceros, Bear \\
\hline Blaireaux & 10470 & 1 (jaw cast) (maxilla) & Cervus sp. \\
\hline Breonio Cave & 25949 & 8 (bones, teeth) & Ursus sp. \\
\hline Chaleux & 10470 & 11 (bone casts) & Ursus sp. \\
\hline Chelles & 42207 & 2 (teeth) & Equid \\
\hline Church Hole & 10115 & 94 ( 46 bones, 33 teeth, 15 antlers) ( 8 tooth casts) & $\begin{array}{l}\text { Rangifer tarandus, Ursus sp., Coelondonta antiquitatis, Mam- } \\
\text { muthus primagenius, Crocuta crocuta, Vulpes vulpes }\end{array}$ \\
\hline Derbyshire & 10115 & 1 (bone) & Rangifer tarandus metapodial \\
\hline Frontal & 10470 & 3 (bone casts) & Capra ibex \\
\hline Goyet & 10470 & 13 ( 11 bones, 2 worked bone casts) ( 2 cave bear skulls) & Ursus cf. spelaeus \\
\hline Grotte de Cabrières & 46030 & 1 (antler) & Reindeer \\
\hline Grotte de L'Herm & 46030 & 3 (bones) & Bear \\
\hline Grotte de Minerve & 46030 & 2 (teeth) & Bear \\
\hline Grotte de Passaron & 46030 & 2 (teeth) & Equids \\
\hline Grottes de Fin Alliez & 1529 & 2 (bones) & Equids \\
\hline Hastière & 10470 & 2 ( 1 jaw cast, 1 bone cast) & Ursus spelaeus skull cast; Ursus sp., bear femur \\
\hline Kent's Cavern & 13075,38778 & 1347 (661 bones, 686 teeth) & $\begin{array}{l}\text { Crocuta crocuta, Coelodonta antiquitatis, Equus sp., Rangifer } \\
\text { tarandus, Ursus cf. spelaeus, Mammuthus primigenius, Bi- } \\
\text { son } \mathrm{sp} ., \text { Megaloceros giganteus, Felis leo }\end{array}$ \\
\hline La Madeleine & $\begin{array}{c}1529,42207 \\
103151\end{array}$ & $\begin{array}{l}71 \text { ( } 23 \text { bones, } 2 \text { jaws, } 9 \text { antlers, } 1 \text { hoof, } 36 \text { worked } \\
\text { bones), ( } 14 \text { worked bones, } 5 \text { antlers) }\end{array}$ & Bison, Reindeer, Cervid \\
\hline La Quina & $\begin{array}{l}55671,71514 \\
71635\end{array}$ & 20 ( 1 antler, 17 bones, 2 teeth) & Cervid \\
\hline Laugerie & 1529,42207 & $\begin{array}{l}129 \text { (77 bones, } 1 \text { jaw, } 7 \text { worked antlers, } 6 \text { antlers, } 18 \\
\text { worked bones, } 15 \text { worked bone casts, } 5 \text { teeth) }\end{array}$ & Reindeer \\
\hline Le Moustier & 1529 & 5 (4 teeth, 1 worked antler) & Reindeer \\
\hline Les Eyzies & 1529,42207 & 4 ( 1 jaw, 1 tooth, 1 bone, 1 engraved bone cast) & Bison \\
\hline Menton & 42207 & 59 ( 31 bones, 20 teeth, 6 antlers, 2 tusks) & Reindeer, smaller Cervids, Equid, Caprids \\
\hline $\begin{array}{l}\text { Mother Grundy's } \\
\text { Parlour }\end{array}$ & 10115 & 14 ( 1 bone, 1 jaw cast, 12 tooth casts) & $\begin{array}{l}\text { Coelodonta antiquitatis teeth, Hippopotamus sp. mandibular } \\
\text { tooth row cast }\end{array}$ \\
\hline Petit Puy Rousseau & 42207 & 2 (teeth) & Reindeer \\
\hline Robin Hood & 10115 & 196 ( 163 bones, 2 jaws, 30 teeth, 1 antler) & $\begin{array}{l}\text { Coelodontia antiquitatis, Crocuta crocuta, Equus sp., Rangifer } \\
\text { tarandus, Vulpes vulpes }\end{array}$ \\
\hline Rossignol & 42207 & 20 ( 2 bones, 15 worked bones, 2 teeth, 1 worked antler) & Carnivore, Cattle, Pig \\
\hline Solutré & 3546,4044 & 403 (397 bones, 4 teeth, 2 antlers) & Equid, Reindeer, Bear \\
\hline Taubach & 55436 & 14 ( 3 bones, 11 teeth) & Reindeer, Bear, Equid, Bison \\
\hline Trou de Nuton & 10470 & 26 ( 25 bone, 1 skull casts) & Ursus sp., Capra ibex, Gulo luscus, Canis lupus, Rupricapra \\
\hline Trou Rosette & 10470 & 3 (bone casts) & Cervus sp. \\
\hline Windy Knoll & 10115 & 94 ( 88 bones, 5 teeth, 1 antler) & Rangifer tarandus, Rhinoceros antiquitatis, Ursus sp., Bison sp. \\
\hline
\end{tabular}

* Identified by Melinda Zeder. Note that species identifications are not comprehensive, and additional species may be present.

+ Bison (bison); Cervus (deer); Canis lupus (wolf); Capra (ibex); Coelondonta antiquitatis (wooly rhinoceros); Crocuta crocuta (hyena); Equus (horse); Felis leo (?); Gulo luscus (wolverine); Hippopotamus (hippopotamus); Hyena (hyena); Mammuthus primagenius (mammoth); Megaloceros giganteus (?); Rangifer tarandus (reindeer); Rhinoceros antiquitatis (rhinoceros); Rupricarpa (rupricarpa); Sus (pig); Ursus (bear); Vulpes vulpes (fox). 


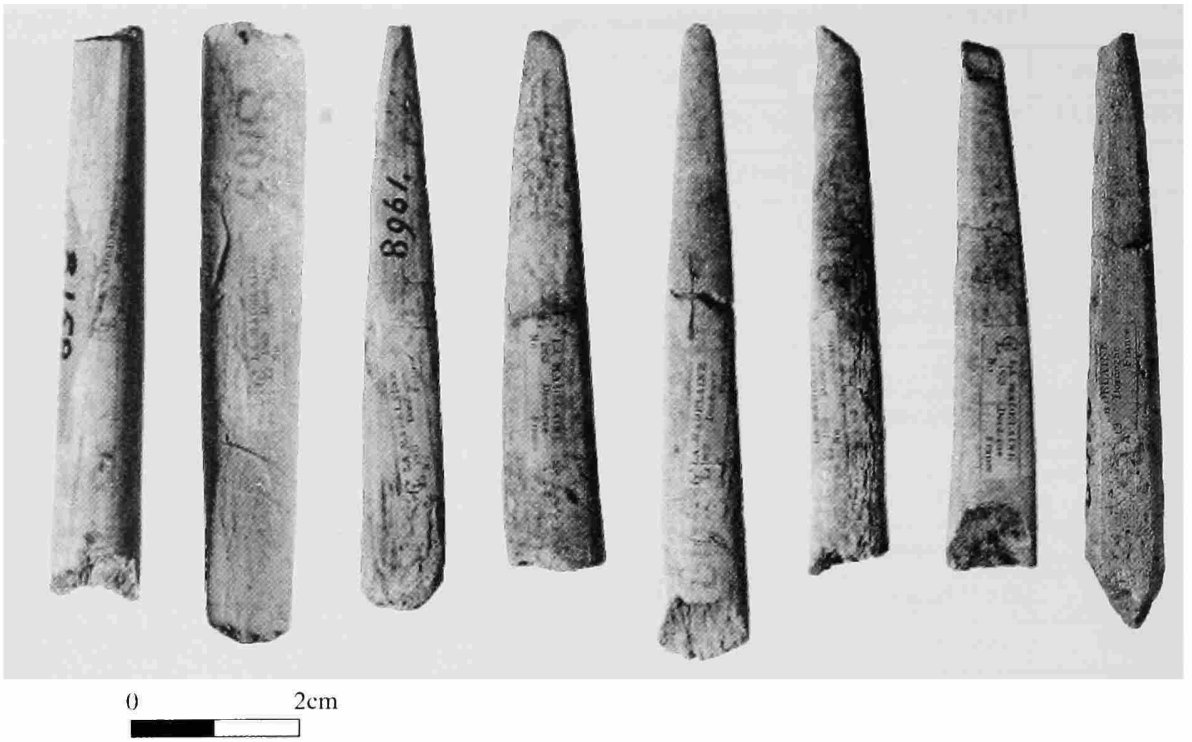

FiGURE 36.--Sagaies [catalog numbers from left to right, 8158, 8163, 8961, 8167, 8165, 8164, 8166, 8168] from La Madeleine, France. [Lartet accession (accession 1529).]

1867. In Europe, we have not yet found the stones of the Paleolithic era except in the reindeer stations of Dordogne.

If it would suit you to receive a block of breccia from Eyzies larger than that which I now send, please intimate to me your wishes; it will be profitable for me, when I go to the south, in the coming August, to give my personal attention to its transmission to you from Bordeaux.

Lartet's mention of the "stone for crushing or grinding" is likely the mortars from La Madeleine (Figure 46), which have been described and analyzed for organic residues (Petraglia and Potts, 1992; Vandiver et al., 1994).

Concerning materials for exchange, Henry asked how he could repay Lartet's generosity. On 3 May 1869, Henry offered publications or biological material:

You will do us a favor by informing us in what way we can repay the obligation under which you have laid us. Such of our publications as you may require in your studies are at your command, as far as copies may now be on hand, and a list of them you will find accompanying this letter in a separate package. Should you so desire specimens of the extinct mammalia... [they] can, alas, be furnished. Any suggestion you may make as to a return will be carefully noted.

Lartet also indicated in his letter (13 June 1869) that he would enjoy receiving these materials and noted that a longterm exchange would be fruitful:

It remains for me to thank you, Sir, for the kind offer which you make me of some of the publications of the Smithsonian Institution, of which I have not received the list which you announced to me by your last letter. You see, Sir, that it is not desiderata which will be found wanting on my part. On your own part, be pleased to make known wherein it will be profitable for me to be of service, and you will always find me disposed to be so. What I send you at this time comes solely from my personal collections. But as 1 have just been called, as successor to M. D'Archaic, to the chair of Paleontology at the Muscum of Nat- ural History, it is profitable that, in a longer or shorter time, my laboratory will acquire resources sufficient to place us on a footing of exchange with the different scientific societies which may be willing to enter into such relations with us.

On 15 July 1869, Henry responded to Lartet, acknowledging receipt of the valuable artifact collection:

We are in due receipt of your letter of June 13, and hasten, in reply, to say that we are very thankful for the continued kindness evidenced by you in the additional contributions of articles of prehistoric date. The osseous and archaeological breccia from Eyzies will be highly prized, as also the remains of the Mastodon auyustidens the Rhinoceros, etc, the oldest species of the European Miocene. The large, massive, slab which you offer of the Eyzies breccia will be very acceptable also. Among our specimens of large size are a number of much interest, such as an annular iron meteorite of 1500 pounds; a mass of native copper of 3000 pounds; one of cinnabar of 500, etc; - with these the Eyzies block would find an appropriate place. It will give us the greatest pleasure to send you specimens of the... fossil[s] of which you speak and of which we possess a considerable number of duplicates.

In addition to what we send you to be exchanged we shall take pleasure in sending for lending for any reasonable time specimens of the regular series of fossils such as may be desired by you. We have been favored several times in this way by the "Museum d'Histoire Naturelle," and shall be most happy to return the favor to one of its professors.

As we have already mentioned, our special attention is now directed towards the establishment of as complete an archaeological collection in the Smithsonian Institution as we can bring together and the proffer of your assistance is very welcome. We are indebted to you for all we have of prehistoric man in Europe, and you know, therefore, how far we are already supplied; anything additional lending to extend this series, whether originals or casts, will be very welcome.

In a final letter regarding the acquisition of Paleolithic material, Henry wrote to Lartet on 18 November 1869 . Henry sought to acquire a more systematic and representative collection of Old World Paleolithic material and Pleistocene fauna 

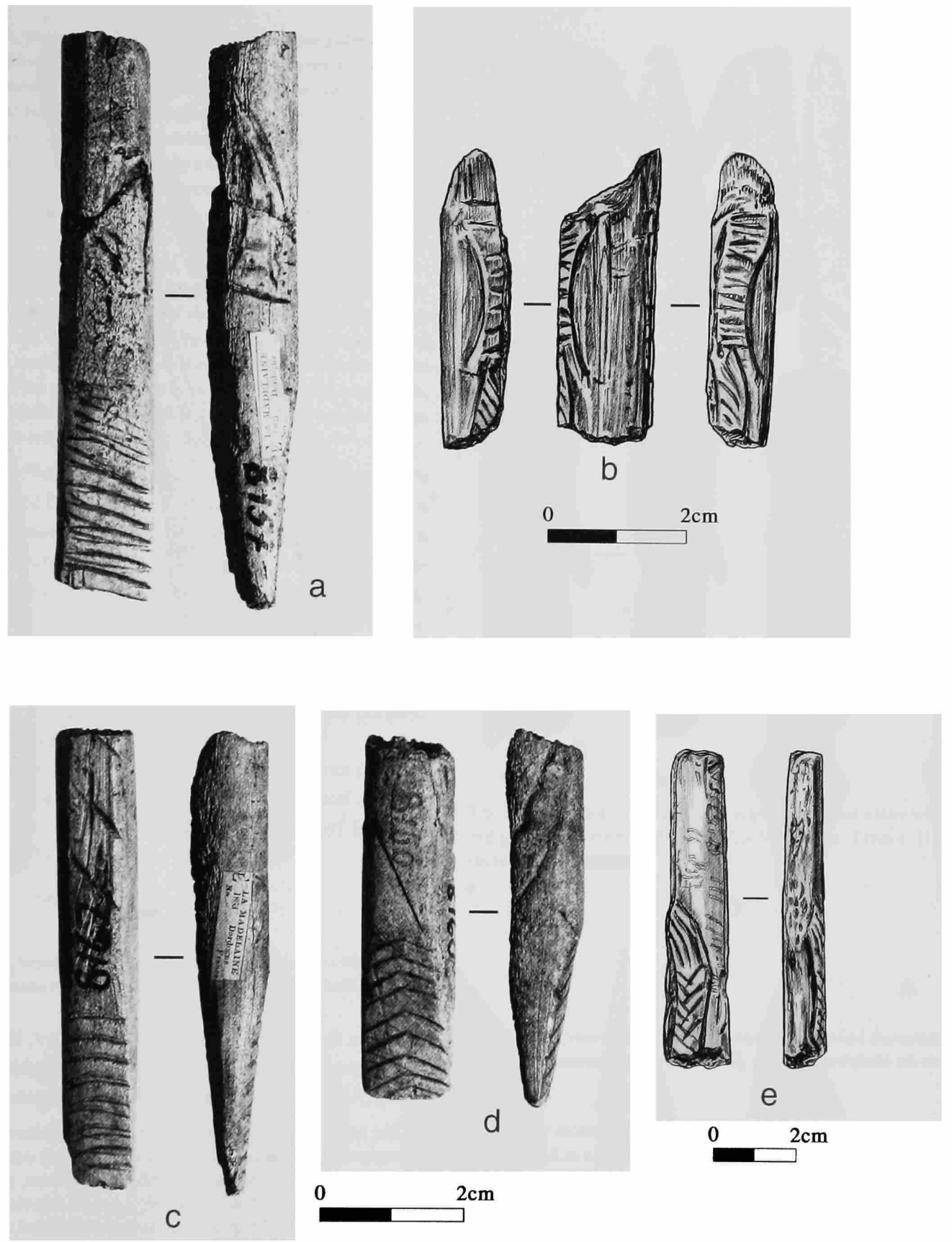

FIGURE 37.-Worked and incised bones, decorated sagaies [catalog numbers for $a-e$, respectively, 8157 ,

$8162,8160,8159,8959$ (cast)] from La Madeleine, France. [Lartet accession (accession 1529).]

and offerred New World collections appropriate for exchange. Henry made his plea to Lartet:

Emboldened by the liberality to which you have distributed the treasures of duplicates of Archaeology, at your disposal, we venture to enquire whether you have not still some specimens that you could present to the museum of the Smithsonian Institution. You are, doubtless, aware of the fact that the Institu- tion has given much attention to the antiquities of North America and has made several publications relative to it in its Contributions to Knowledge. We are still prosecuting the work with renewed effort. Stimulated by the example of yourself and other eminent archaeologists we have now collected what we think the best series of American specimens in this country. Recent researches into the caves, the ancient shell heaps, the mounds and the Indian graves have added largely to the series. We are now preparing for immediate publication a 


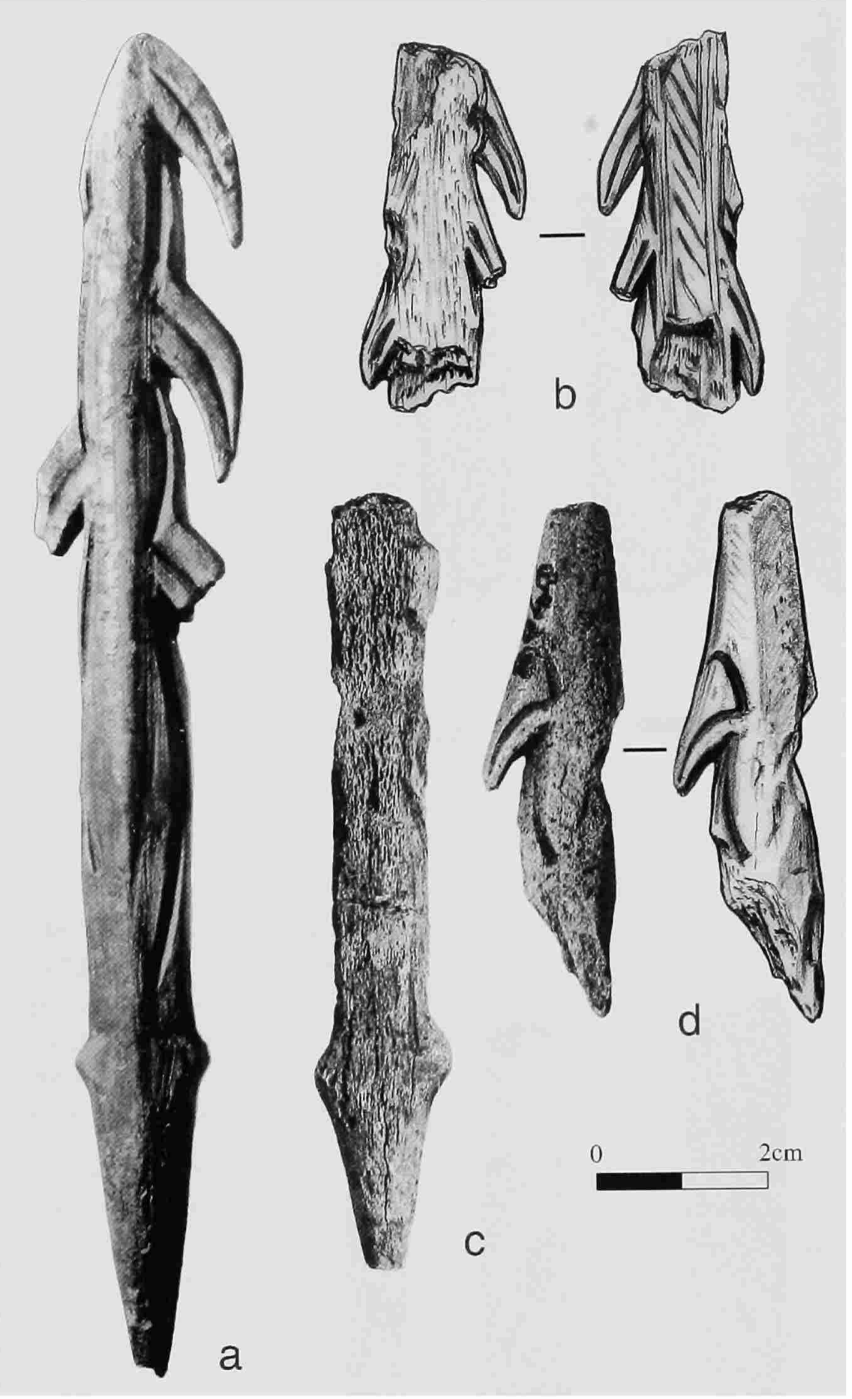

FIGURE 38.-Harpoons [catalog numbers for $a-d$, respectively, 8149,8962 , 8956,8960 ] from La Madeleine, France. [Lartet accession [(accession 1529).]

descriptive catalogue to be illustrated by wardens of the collections to make the articles more generally known and at a future time to be used in illustrating a systematic treatise on American Antiquities, comparing them with those of the Old-World. Unfortunately for the latter purpose we have at present very little material. Since we possess nothing except a few implements of stone from Denmark. We have nothing whatever of stone or of bone from France or Switzerland and if you can put us in the way of obtaining specimens of these you will place us under obligations and greatly aid in the work in question. Should you desire, we can send duplicates from our collections in such amount as can be spared and any other returns in our power will be made in addition to ample acknowledgments. Our agent, Gustav Bousange of Parıs will receive and forward any thing you may send us. It would give as much pleasure to have any specimens you can spare, illustrating the mammalia of the cave period of France. We are in due receipt of the great work of yourself and Mr. [Henry] Christy, Reliquae Aquitanicae ... and value it as one of the most important contributions to archaeology of modern times.

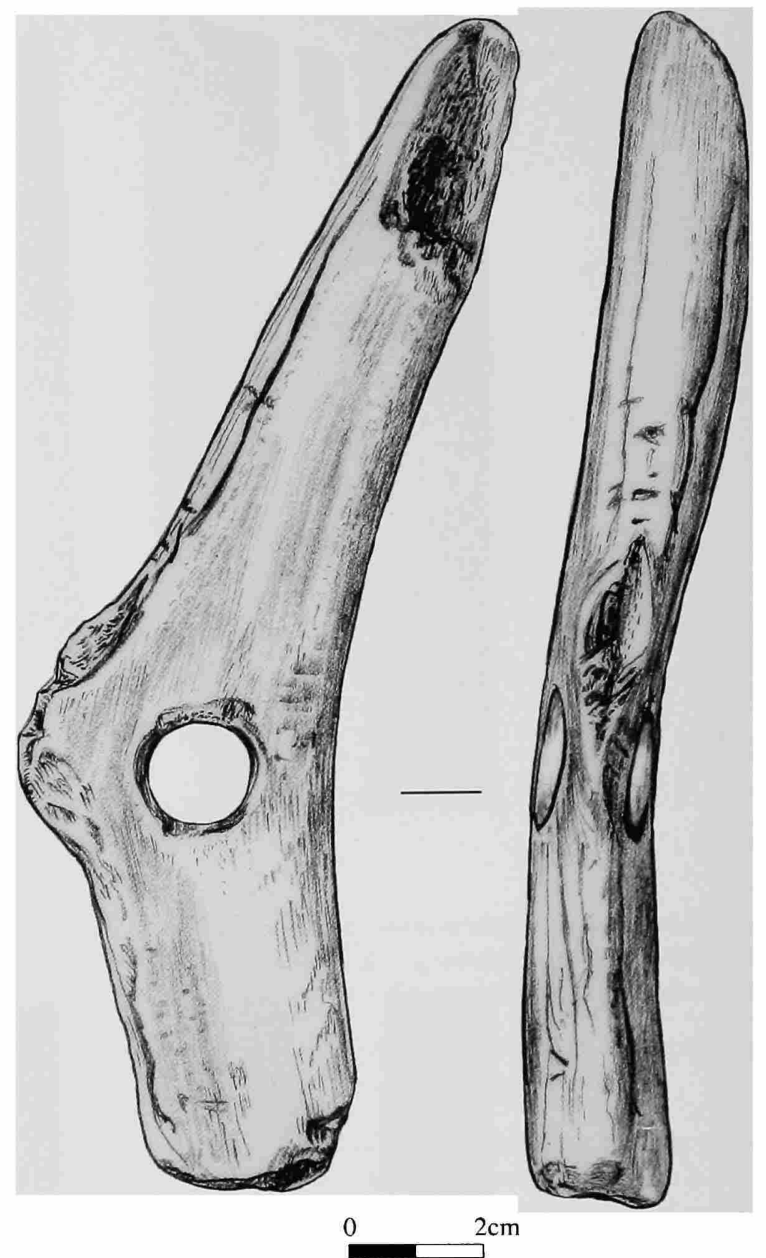

FIGURE 39.-Drawing of Baton de Commandement [catalog number 8095] from La Madeleine, France. [Lartet accession (accession 1529).]

In the Report of the Secretary for 1869 , Henry described the importance of the collection and highlighted certain acquisitions (Annual Report, Smithsonian Institution, 1871:46-47):

The prehistoric caverns and rock shelters of France, under the persevering investigation of Professor E. Lartet, have yielded such a harvest of precious relics, and of ingenious and interesting deductions, as to have conferred on him a world-wide renown. Out of his abundant materials he has with much liberality presented to the Institution several cases filled with objects, of which it will suffice to enumerate a few prominent specimens. Of the animals contemporaneous with man in those obscure times, there are bones of the horse, some of them gnawed by wolves; of the aurochs, rhinoceros, wild goat, chamois, hyena, reindeer, including a very perfect jaw and teeth of the cave-bear. Associated with these are two small bones of the human skeleton, apparently belonging to the phalanges of the hand. Among the implements of war, of domestic use, and articles of ornament, are casts of bone implements, chiefly for making perforations, stone knives, sculptured hom of reindeer, and bone aigrettes, probably for fastening skin or fur dresses; also a mortar for grinding grain or fruits, and casts of arrow-heads, in forms very similar to those of American specimens; and many flakes of flint struck from the core while making knives, arrow-points, or other articles. The European flint is better adapted to this manufacture than any 
stone found in America, except obsidian. These flint chips were gathered from fourteen different localities in France, indicating the prevalence of the art of forming cutting implements of stone and the density of the population. Professor Lartet has also contributed several large masses of the breccia which occupies the floor of the caves, consisting of bones and teeth of animals, flint flakes, pebbles, and other objects cemented together in a solid pavement. The composition of these masses apparently indicates the great antiquity of man, since they present the stone implements of his construction embedded in the same materials with the bones of the rhinoceros and other extinct animals. The most remarkable portion of this collection may, however, be said to consist of the illustrations of the art of sculpture as it existed among the prehistoric races. The material employed was the broad portion of the horns of the reindeer or the ivory tusks of the elephant. These carvings exhibit a remarkable appreciation of form and composition, undoubtedly derived from constant observation of the wild animals depicted. They chiefly represent the more remarkable quadrupeds, such as the elephant, reindeer, bear, aurochs, \&c. These are all exhibited or in striking attitudes, such as leaping, fighting, or flying from pursuit.

As mentioned by Henry, fauna and breccia from Solutré were represented, including horse teeth, a large piece of breccia with a horse maxilla, and another piece of breccia that represents a pavement floor. (Figure 47). In addition, a number of well-preserved horse medapodials were in the collections, and the phalanx shows systematic fracture, probably for marrow extraction. The European collections donated by Lartet were given prominent exhibition space in the Smithsonian (Figure 9). The Old World collections were arranged in display cases for the purpose of comparison with North American artifacts.

Notice of Lartet's death (on 28 January 1871), was marked by the publication of a translated article in the Annual Report, Smithsonian Institution, "The Scientific Labors of Edward Lartet" (Fischer, 1873).

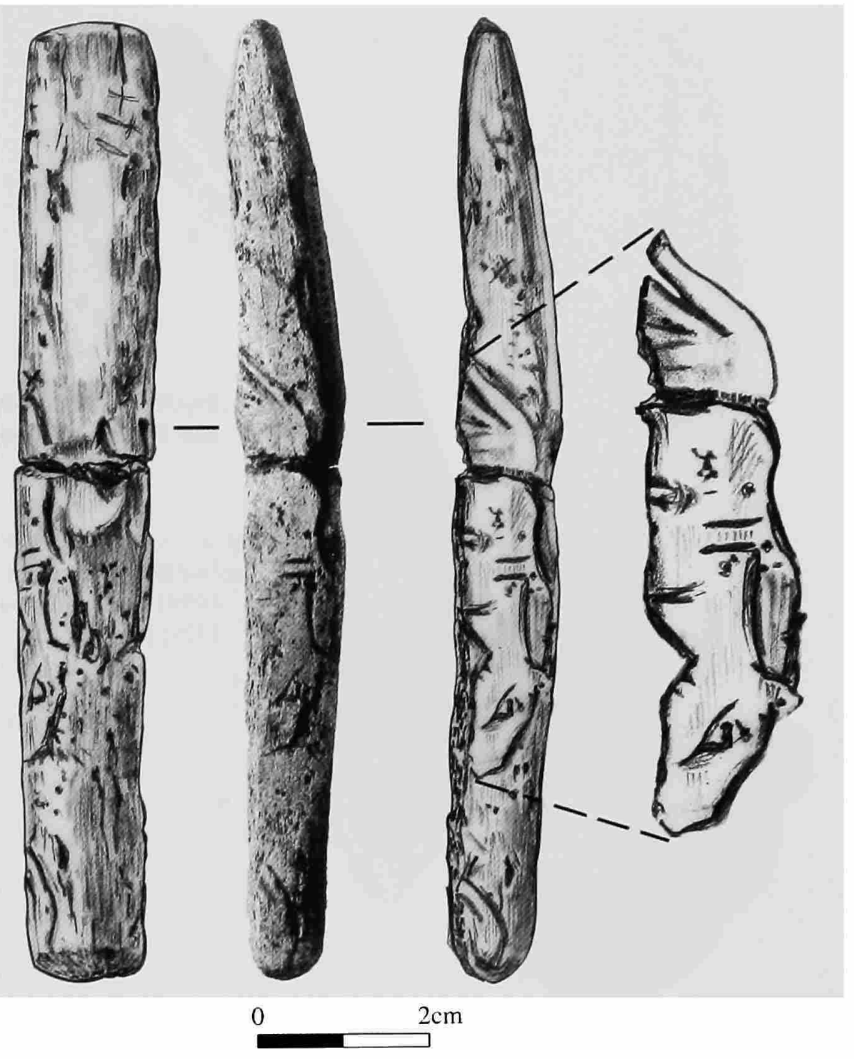

FIGURE 40.-Photograph and drawings of a worked antler with horse engraving [catalog number 8156] from La Madeleine, France. [Lartet accession (accession 1529).]

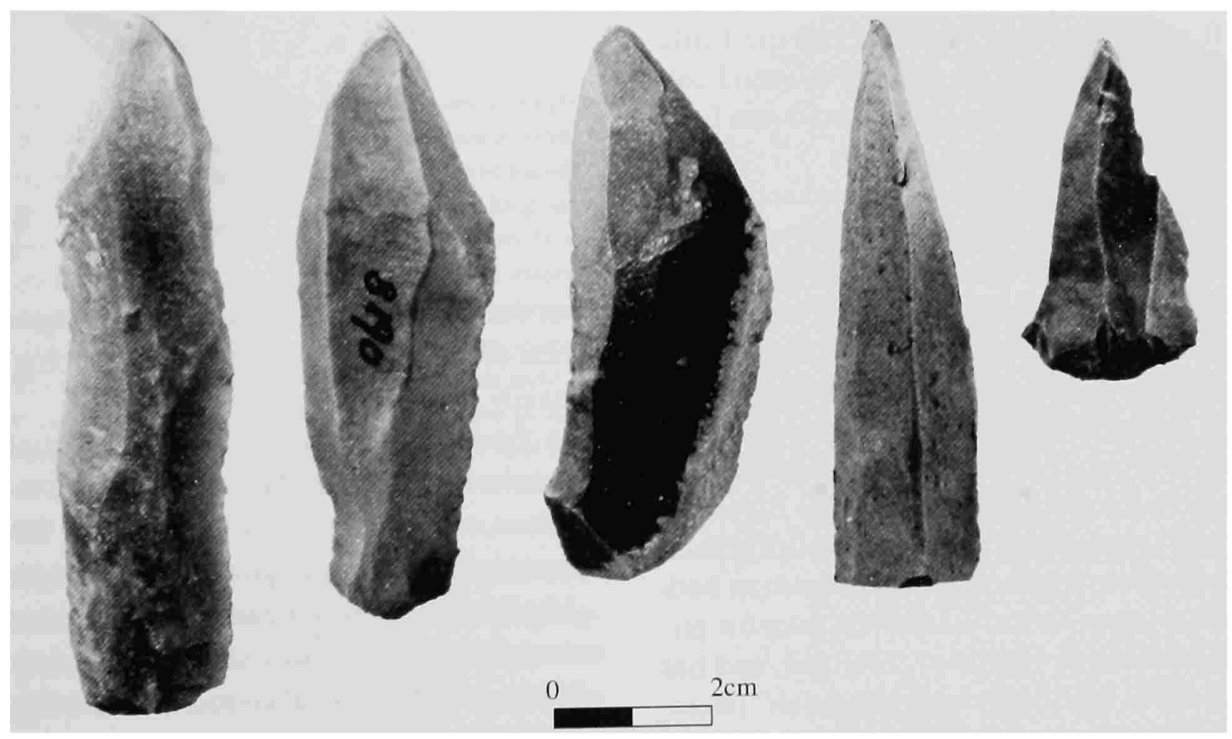

FIGURE 41.-Burins and composite burin-scrapers [catalog number 8190] from La Madeleine, France. [Lartet accession (accession 1529).] 


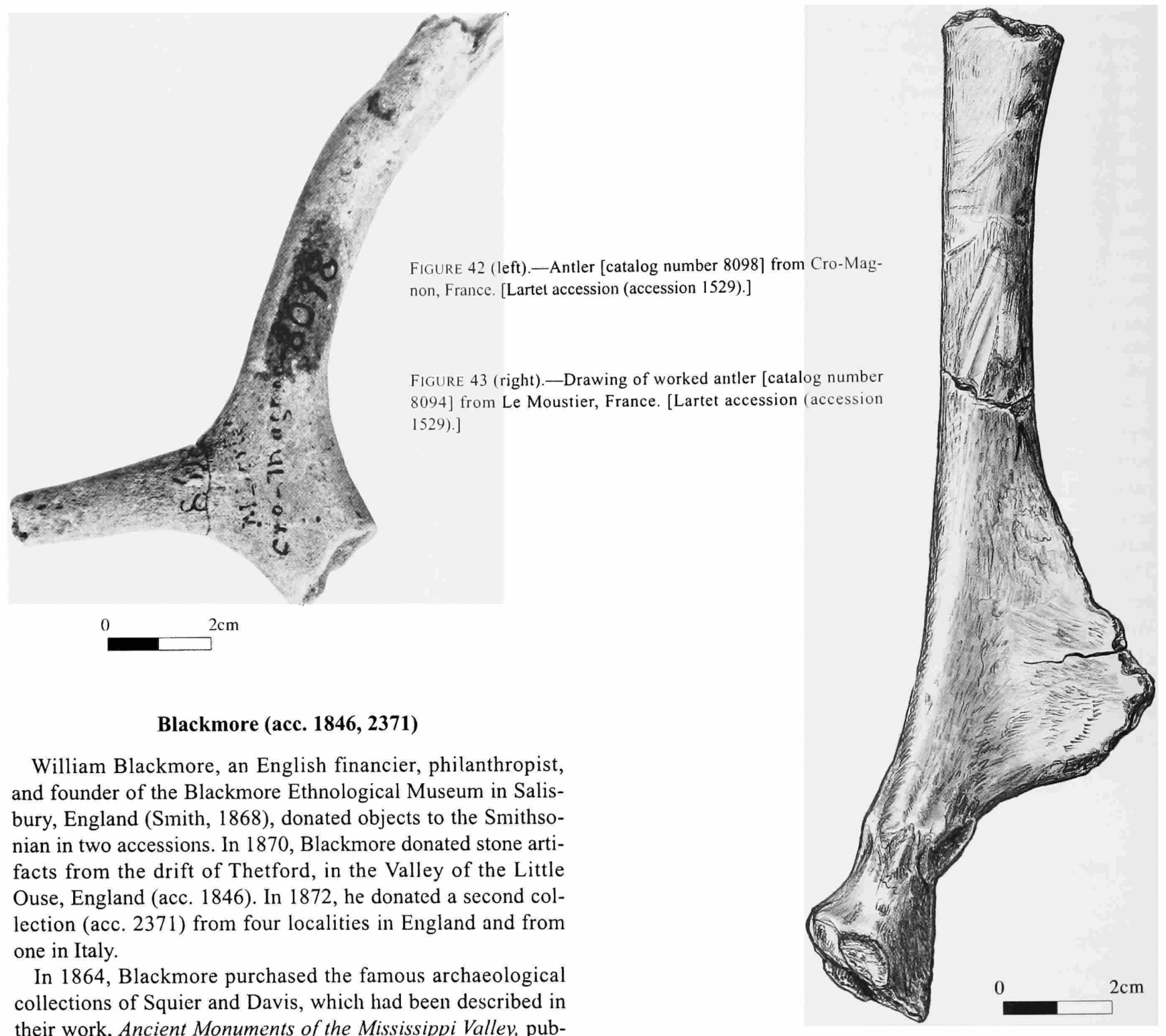
their work, Ancient Monuments of the Mississippi Valley, published by the Smithsonian in 1848 (Meltzer, 1998:68). Blackmore was described as "a gentleman of wealth and intelligence who has founded an ethnological museum at Salisbury" and who was visiting the United States "for the purpose of obtaining additions to his collections" (Annual Report, Smithsonian Institution, 1869:26-27). Secretary Henry noted the following concerning Blackmore's reputation: "He is an English gentleman of wealth and influence; a general patron of science, both in his own and in our country; he has established from his private funds a public museum in Salisbury, England, and has made valuable donations to the Smithsonian Institution" (memorandum, 17 April 1872). The new museum was of interest to the Smithsonian, as indicated by the publication, "Notice of the Blackmore Museum, Salisbury, England. Opened September the $5^{\text {th }}, 1867$ " (Annual Report, Smithsonian Institution, 1869). As the Smithsonian was just beginning to receive antiquities

from the Old World, the exhibition, arrangement, and classification of objects in the Blackmore Ethnological Museum was certainly of interest.

In the initial discussions about potential exchanges with Blackmore, Dr. Charles Rau, a contributor to Smithsonian publications, wrote to Secretary Henry, on 15 December 1868: "At a meeting of the Ethnological Society, held about ten days ago ...Mr. Blackmore was present. Through him, I think, we shall enter into pleasant relations with the prominent archaeologists of England." This initial contact resulted in personal visits and material exchanges, as described in Assistant Secretary Baird's letter to Blackmore on 11 June 1870:

Today we have a box from our agent, Mr. Wesley, which he invoices as forwarded by you and which contains a magnificent treasure of books on archaeology and other... sciences together with a package of flint implements. 


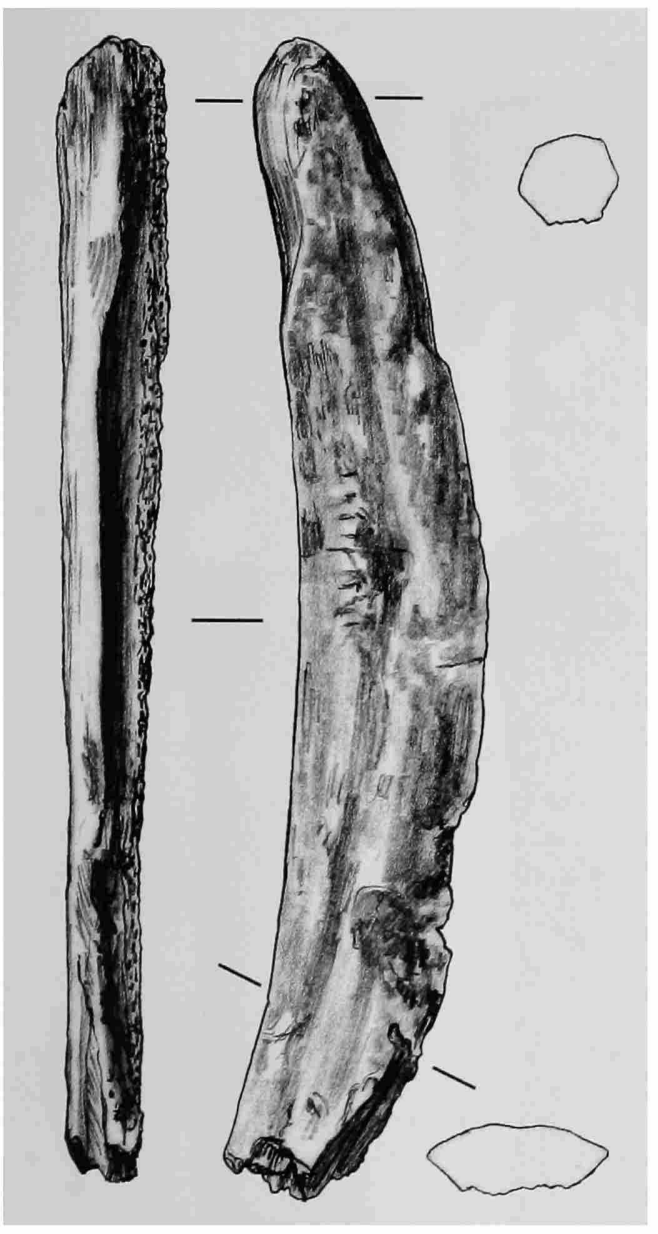

FIGURE 44 (left).-Worked bone [catalog number 8097] from Massat, France. [Lartet accession (accession 1529).]

FIGURE 45 (right).-Worked stag antler [catalog number 8099] from Massat, Ariège, France. [Lartet accession (accession 1529).]

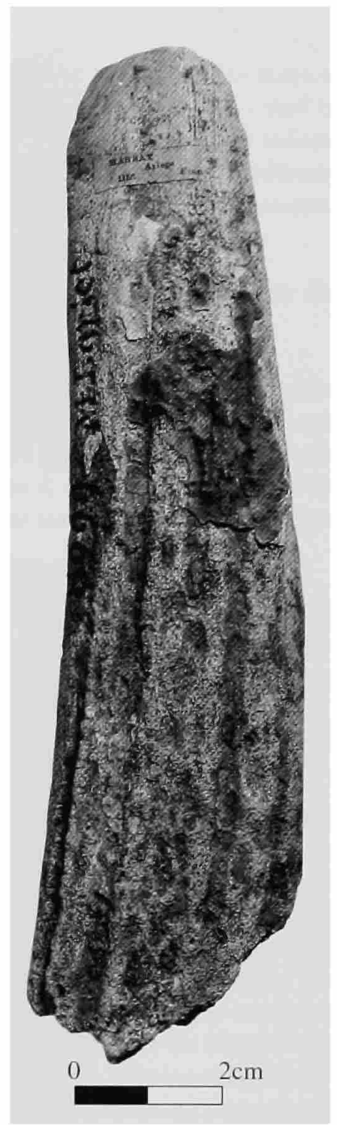

0

$2 \mathrm{~cm}$

Profr. [Professor] Henry has just left us for a visit to Europe and one of his principal anticipations of pleasure, during his three months absence, was in visiting your museum at Salisbury and in renewing that acquaintance which he found so delightful while you were in Washington. I trust he may not before long some method by which we may make a suitable return for your many favors. It will give Profr. Henry the greatest pleasure, if can supply your library or museum with what you consider of interest. Our duplicates are, now, somewhat numerous and no one has a better right to the first choice from among them than yourself. If we could only look forward to a speedy visit from you and have you make the selection for yourself it would be a source of the highest gratification to us. In accordance with what I believe would be Professor Henry's wish, we shall send, in a few days, to the Blackmore Museum, through Mr. Wesley, a full series of the Smithsonian Contributions and Miscellaneous Collections.

The exchanges between Blackmore and Smithsonian officials were beneficial to both parties as both received publications and archaeological materials. The Thetford artifacts acquired by the Smithsonian are of historical interest as these pieces were from the original collections of two prominent British antiquarians, Sir John Lubbock and John Evans, both of whom participated in the debates about early man in Europe (Figure 48). Information on the nature of the collections was described in Blackmore's letter to Henry on 17 June 1870:

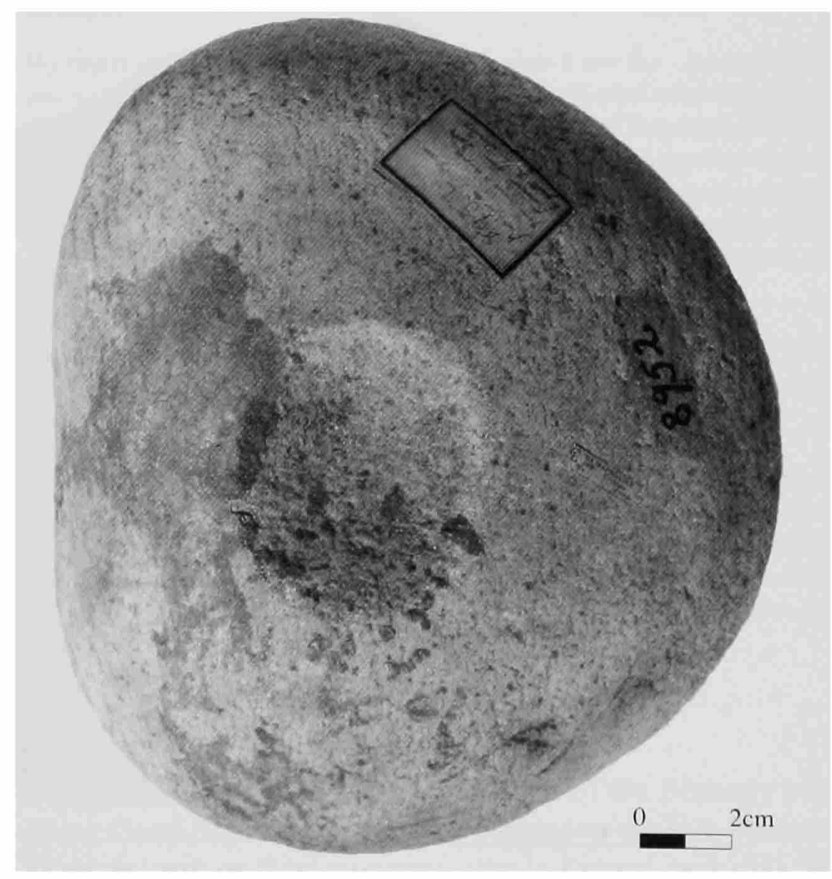

FIGURE 46.--"Mortar" [catalog number 8952] from La Madeleine, France. [Lartet accession (accession 1529).] 

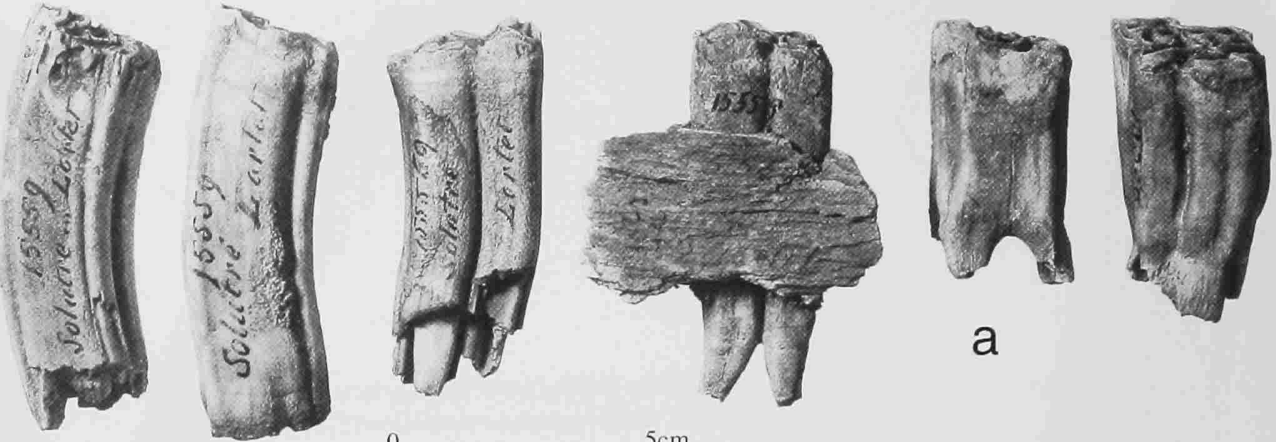

a
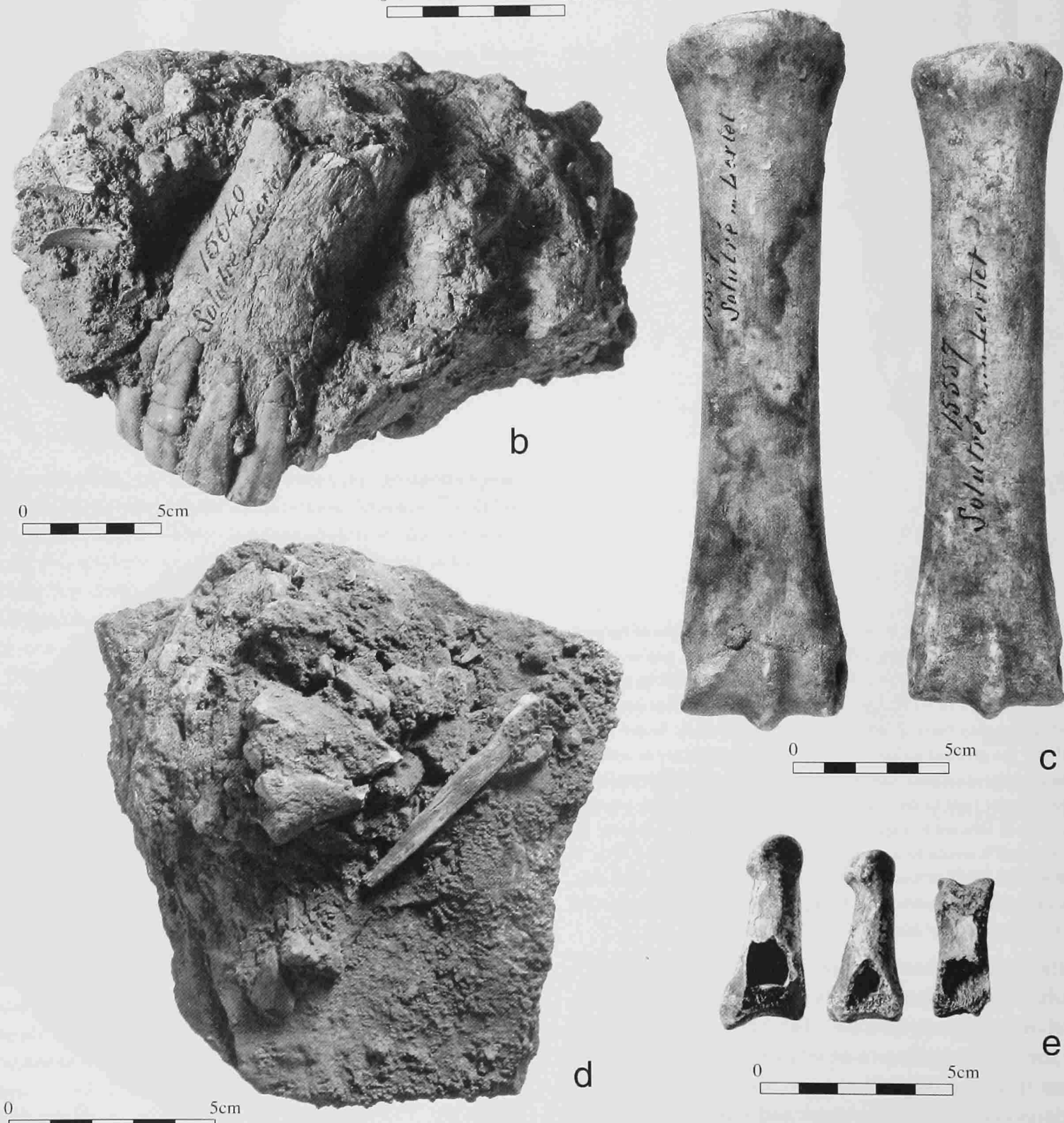

e

FIGURE 47.-Horse skeletal elements from Solutré, France. [(a) Teeth (catalog number 15559); (b) breccia with horse maxilla (catalog number 15640); (c) metapodials (catalog number 15557); (d) breccia referred to as "fused
Solutrean hearthstone" (catalog number 15554); and (e) split phalanges (catalog number 15577).] [Lartet accession (accession 3546).] 


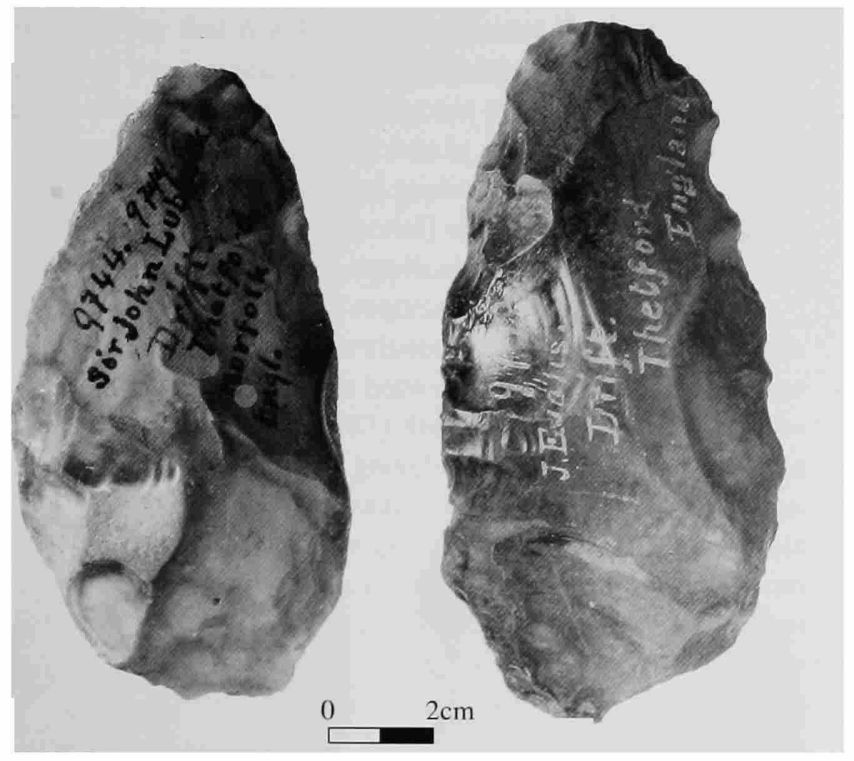

FIGURE 48.-Handaxes [catalog nos. 9744 (left), 9745 (right)] from Thetford, England. An inscription on the handaxe on the left reads, "Sir John Lubbock, Drift, Thetford, Norfolk, Engl.," and the inscription on the other reads, "J. Evans, Drift, Thetford, England.” [Blackmore accession (accession 1846).]

Since the dispatch of the first box I have sent you another containing volumes which I believe will be acceptable to your Institution.

I have also sent you for distribution 20 copies of "Flint Chips" [Stevens, 1870] a descriptive catalogue of some of the principal stone objects in the Blackmore Museum as well as a guide to Prehistoric Archaeology.

The stone implements are some specimens lately found in the Valley of the Little Ouse River and I enclose an account of them by my friend Mr. L.W. Flower who with Sir John Lubbock and Mr. John Evans have presented them to your Institution. You ask me to indicate what I should like you to send me for the Blackmore Museum. I shall be very glad if you will send me all your publications relating to Archaeology and Ethnology.

The Blackmore artifacts represented some of the first archaeological material acquired from Europe, in addition to Lartet's contributions. Baird's desire for publications and artifacts were expressed in his letter to Blackmore on 5 July 1870:

As we wrote you a few weeks ago, the several books and specimens you sent came duly to hand, the value of which is duly appreciated. The desired distribution of the "Flint Chips" has been made. Should you have additional copies of this work we should be glad to have as many as you can spare as several gentlemen have expressed a desire to possess it. We could use to good advantage as large a number as you have already sent, and there is no doubt of their distribution the cause of American Archaeology would be greatly advanced. The Drift-implements were extremely welcome, as we had but a single specimen in the collection and that from France. Prof. Lartet has kindly sent us a good series of Dordogne relics and we are gradually gathering a fair collection of some of the prominent European objects of this kind. As you are informed, we have sent to the Blackmore Museum a complete set of the Smithsonian publications, this being the least in our power for as valuable donations on your part.

In response to queries about what the Smithsonian could provide to the Blackmore Museum, Edward Stevens, Honorary Curator of the Blackmore Museum, wrote to Baird on 20 July 1870 , requesting artifact "duplicates":

It is pleasing to find that our work "Flint Chips" is in demand with those inter- ested in the subject of which it treats.

You mentioned in your first letter that you would be happy to place some of your duplicates at our disposal. Should the Council desire to do this, I shall be only too happy to forward a list of desiderata, or, possibly, you would indicate what the duplicates are, $\&$ in this way I could avoid robbing you needlessly, whilst you could no doubt render our collections far more generally representative of American Archaeology than it is at present.

To of clarify the location in the Little Ouse valley where the objects were discovered, Stevens wrote in a postscript:

I believe they all come from the valley of the Little Ouse, \& probably from Brandon, Thetford, Shrub Hill, and Santon Doroham. You may see some special letter upon certain of them, if so \& you could give me an outline of the typical form, I think that I could determine locality \& give you particulars of the deposits in which they are found, which, I need scarcely add, is all important with drift implements.

On 11 October 1870, Baird requested additional copies of publications and inquired again about what could be sent to the Blackmore Museum to fulfill obligations. The provenience of the objects sent by Blackmore apparently had been clarified, as the objects were given locality designations:

The copies of the "Flint Chips" sent by Mr. Blackmore have, all, been distributed and we shall, therefore, be much pleased to have the additional ones to which you refer in order to supply a number of establishments where they will be highly prized. If you will send us a memorandum of the particular forms you desire from the American flint implements we will take pleasure in overhauling our duplicates, in your interest, and in sending you such as we can spare. Our stock is increasing rapidly and we can, doubtless, supply you some interesting desiderata. The drift implements sent by Mr. Blackmore with the aid of certain memoranda subsequently furnished, were all susceptible of being assigned their proper positions and they now occupy a conspicuous place among our treasures.

After Henry's return from Europe, he wrote to Blackmore, on 7 November 1870, expressing his appreciation for the exchange:

My regret in not seeing you was discovered when I saw the ...[contribution] you had made to the library of the Institution. It has afforded much admiration, and I doubt not will be highly... [prized] by the Board of Regents to whom it will be exhibited at their visiting in Jan. 1871. I beg to assure you that we shall grandly embrace any opportunity which may offer to sending you any service. Although we cannot hope to equal your liberality yet we shall be able in the course of the year to send you a specimen which may not be considered as unworthy additions to your unrivaled collection.

The final correspondence regarding the exchanges was written by Henry on 11 June 1872, to Stevens, indicating that ethnological objects were being sent:

It gives us much pleasure to announce.... box containing a number of originals and casts of ethnographical objects selected from the duplicates in the Smithsonian Institution, and intended as a present to the Blackmore Museum. We are under so many obligations to Mr. Blackmore for services rendered the Institution, from time to time, that we are very happy in being able to make even this slight return.

\section{Wyman (acc. 2587)}

In 1872, Dr. Jeffries Wyman, director of the Peabody Museum, Cambridge, Massachusetts, donated to the U.S. National Museum artifacts from numerous sites in Europe, including objects from two Paleolithic sites in France. Wyman was the first curator of the Peabody Museum and had been a well-known 
and respected professor of comparative anatomy (Hinsley, 1985). Under Wyman's tenure, numerous excavations were made in the New World, most intended to demonstrate parallels with European models of antiquity (Hinsley, 1985). He also purchased European collections for comparative purposes.

In exchange for European artifacts from the Peabody's collections, the Smithsonian offered objects from North American sites. In regard to the desired exchange, Henry wrote to Wyman on 24 January 1872, requesting the European materials:

It gives me pleasure to announce that we shall shortly forward to the Peabody Museum a collection of interesting objects in American Archaeology of which we beg your acceptance. These specimens are presented in accordance with the spirit of the Institution to advance, as much as it can, the knowledge of the science of Anthropology, which may be done especially through cooperation with the establishment under your charge. We presume the Directors of the Peabody Collection are actuated by a spirit similar to that which prompts the Institution in the present instance, and that, in due time, they will make the Smithsonian the recipient, for study at the National Capital, of copies of such French, Swiss and other implements as can be spared from the duplicates in your care.

In exchange for the North American material, Wyman indicated to Henry, in a letter dated 19 December 1872, that archaeological objects from various sites in Europe would be donated to the Smithsonian by the trustees of the Peabody Museum. Wyman noted that some of the objects were acquired by the Peabody Museum from the original collections of French prehistorians Gabriel de Mortillet and Edouard Lartet.

The final letter on this exchange was sent to Wyman on 28 December 1872, Henry wrote: "We write to acknowledge the receipt of your letter of the 19th just, and to request that you will present our thanks to the Peabody Museum for the antiquities you announce as presented to the Institution. These will form a very interesting addition to the Ethnological specimens in our collection. It gives us pleasure to cooperate with the Peabody Museum in collecting and preserving the remains especially of the people who formerly inhabited this country as well as such foreign specimens as may be necessary to their comparative study."

\section{Garrow (acc. 4044)}

In 1875, Dr. H.C. Garrow of Washington, D.C., donated a collection from Solutré, France. Garrow may have delivered the material himself, as there is no correspondence on this collection.

\section{Feuardent (acc. 7825)}

In 1879, a gift of artifacts from France was donated by Gaston L. Feuardent (Figure 49). The collection may have been delivered in person, as no correspondence was found. In the Annual Report of the Board of Regents of the Smithsonian Institution for 1879, it was noted (pp. 41-42) that "an extremely interesting collection of prehistoric articles of France and other localities in Europe was presented by Mr. Gaston L. Feuardent, of New

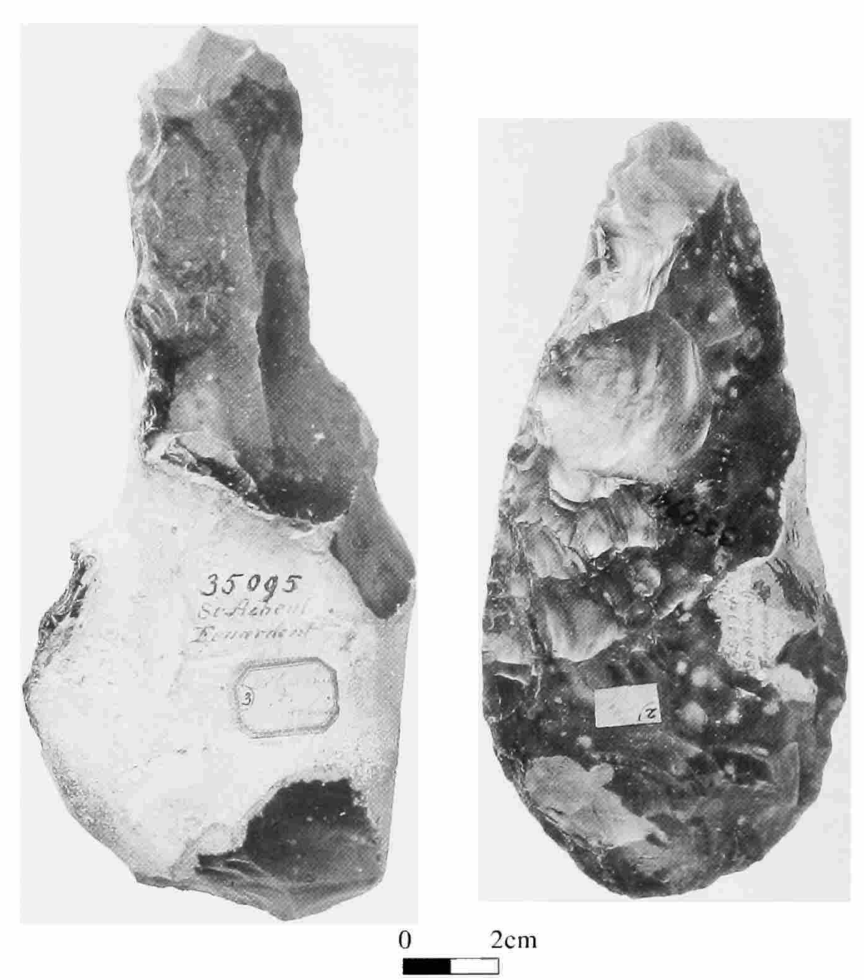

FIGURE 49.-Handaxes [catalog numbers 35095 (left), 35094 (right)] from St. Acheul, France. [Feuardent accession (accession 7825).]

York. The great archaeological knowledge of this gentleman renders the collection particularly valuable in the authentic indication of the character of the different pieces."

\section{Dawkins (acc. 10115)}

In 1881, W. Boyd Dawkins, chairman of Geology at Owens College, Manchester, England, donated a collection from Creswell Crags and Sink, in the limestone caves of Windy Knoll, Derbyshire, England. The accession mainly consisted of faunal remains from a variety of animals. Major publications by Dawkins $(1874,1880)$ contributed to an early theory regarding the antiquity of human ancestry (Grayson, 1986).

As indicated by existing correspondence, Secretary Henry, Assistant Secretary Baird, and Dawkins had met and had agreed to exchange material from their respective museums. On 20 October 1871, Henry wrote to Dawkins concerning his wish to obtain the Derbyshire faunal material they had spoken of, and he indicated the material would be highly prized by the National Museum. Henry sought casts as well as type specimens from the site of Kent's Hole. About a year later, Henry wrote to Dawkins on 9 November 1872, noting: "I have just received...y your last two contributions to the Palaeontological Society. Though not in my line I shall examine them with interest, since they are the result of your labors. And in this connec- 
tion I may say that it will give me pleasure if at any time I can aid you in your researches by promising such specimens as may be of importance in carrying out your investigations. You were so good as to say, when I was in your company, that if the Institution would make formal application there for specimens from the Kent-Cavern [, material] would be sent to us. Please inform me to whom such application should be made and whether any special form is requisite."

Eight years later, Dawkins visited the United States, in part to investigate possible parallels between the prehistories of America and Europe (Meltzer, 1983). Dawkins met with Charles Abbott and visited the Trenton gravels in New Jersey to determine if the American Paleolithic was comparable in age and evolutionary grade to that of Europe (Dawkins, 1883). During his visit, Dawkins met with Baird. Later, he wrote to Baird from New York, on 4 December 1880, summarizing the agreement reached during their conversation: "You told me last Saturday that I might beg some of your duplicates for the Manchester Museum, Owens College, Manchester, England, and mentioned some of the recent dredgings and travelings. We shall value greatly anything zoological, (or archaeological) that you can spare. On my return home I will send you a box of remains from our caverns." On 26 February 1881, Dawkins wrote to Baird that he was assembling the collection: "I have packed up, and will send off to you before the end of this month a case containing 1. the remains of Man \& Beast from the Hyeana dens of Creswell Crags. 2. The remains of Grissly Bear, Reindeer and Bison from a 'sink' in the limestone at Windy Knoll, Castleton Derbyshire. 3. The pamphlets and a proof relating to them. All the specimens are ready to go into a museum." In one of the final letters on the exchange, Baird wrote to Dawkins on 24 November 1881 , indicating that the collections had arrived. "On returning from a three month's absence I find a box endorsed as being sent by you, \& which I presume contains the much desired bones etc. from the British caves."

\section{Musée Royal d'Histoire Naturelle de Belgique (acc. 10470)}

Casts of fossil mammals and of stone and bone implements found by prehistorian Edouard Dupont in classic cave sites of southern Belgium were accessioned as a gift from the Musée Royal d'Histoire Naturelle de Belgique. Dupont $(1869,1872)$ had excavated the caves and had recovered important fossil collections. In a letter dated 1 September 1880, Baird requested material from Réclard, Secretary of the Belgian museum. Réclard replied on 24 June of 1881 , indicating shipment of archaeological material.

\section{Museum of Le Havre (acc. 10666)}

In 1881, a gift was received from the Museum of Le Havre, France. The collection consisted of a handaxe from Moulin Quignon, near Abbeville, France. The handaxe was cataloged and noted to be "fraudulent." There is no accompanying corre- spondence in this accession (see Lartet accession above, on "L'Affaire Moulin Quignon").

\section{Pengelly (acc. 13075)}

William Pengelly was a geologist and educator from Lamorna, Torquay, in southwestern England. Pengelly played a major role in the excavations of important caves, including Kent's Cavern in Devonshire, England. He also figured prominently in proving the antiquity of man in England (Grayson, 1983). Pengelly was associated with the Torquay Museum, which provided donations to the Smithsonian. The first contact between the Smithsonian administration and Pengelly was made on 21 December 1872, when Secretary Henry solicited material:

I have the honor to make application on the behalf of the Smithsonian Institution for a set of the remains from Kent's Cavern whenever these are ready for distribution. The National Museum of the United States is in charge of the Smithsonian Institution and already possesses very extensive collections in American Archaeology, Prehistory, Palaeontology and Zoology, embracing, among other series, the results of extensive explorations in the caves, shellheaps and ancient mounds of America, as well as numbers of American vertebrata both recent and fossil. For this reason we feel assured that a collection of the remains from Kent's Cavern will if presented to the Institution be well placed since here they can be directly compared with American objects of the same general character.

In response to Henry's request and suggestions, Pengelly wrote a letter of acknowledgment on 9 January 1873, indicating that he would put the Smithsonian's request for fossil materials before the Kent's Cavern Committee. For 10 years, there was no further correspondence on this issue. On 3 March 1883, however, Pengelly wrote to Baird, indicating that Kent's Cavern material was available: "There was some years ago a correspondence between the Secretary of your Institution and myself respecting a present of specimens of the bones found in Kent's Cavern... which it was hoped would be sent to your Museum. Will you kindly inform me as soon as convenient whether it will still be agreeable to your Committee to receive a small present of the kind. The chest with its contents will probably require two men to carry it, and I shall hope to be informed how it should be directed, and by what route it should be sent."

Assistant Secretary Baird wrote to Pengelly on 17 March 1883 , indicating his pleasure in receiving the fossil assemblage for exhibit and scientific purposes: "I have not forgotten the kind promise of the Committee on the Exploration of Kent's Cavern to place a series of the specimens in the National Museum of the U.S., and I hasten to renew the assurance that such a collection will be extremely welcome to us, and that there will be accorded to it ample space for public exhibition in the best manner. We are making a speciality of this class of remains for the U.S., and the means of comparison with objects of a similar character from foreign countries will be highly appreciated, and doubtless of much advantage to science."

The bones from the Kent's Cavern collection correspond with an innovative system of horizontal and vertical plotting 
used by Pengelly (Campbell and Sampson, 1971). Disclosing important information on the contents of the chest of fossils, Pengelly wrote to Baird on 7 April 1883:

I have had the pleasure of sending... a chest containing 30 complete 'finds' from Kent's Cavern, as a present to the Smithsonian Institution, from the late Lord Holden, (proprietor of the Cavern) and the British Association, which I trust it may be agreeable to the Directors of your Museum to accept. Of the 'finds' now sent; 23 were met with in the 'Cave Earth'=the 'Hyaenine deposit,' and the remaining 7 in the 'Breccia'=the 'Ursine deposit'=the oldest deposit found in the cavern. Within the box, containing the Earth 'find,' will be found a label similar to that now enclosed which may be thus interpreted-'Kent's Hole'; 51st 'Series of Workings'; 22nd 'Parallel,' 1st 'Level' (i.e., from 0 to 1 foot below the bottom of the Stalagmitic Floor); 3rd 'Yard' on the right of Datum line, found 31st March, 1874. No. 6397 (the 6397th 'find') in the 'Breccia' (see refr. Brit. Assoc. 1865, page 20). I request you to have the number of the find to which it belongs written on every bone and fragment of bone on which it is not already written, so that its exact place in the Cavern may, if necessary, be determined from my journal.

In a postscript, Pengelly noted that he was sending papers on the Devonshire Caverns, for the Smithsonian library. The box of fossil material arrived at the Smithsonian, as indicated by Baird to Pengelly on 1 May 1883. Apparently Baird was satisfied with the assemblage and also was impressed with the explorations conducted by the Kent's Cavern researchers. He suggested that an article be submitted for publication in the Smithsonian Reports:

We shall at once proceed to unpack it carefully and arrange it in a series of special cases, taking care to preserve all the marks that you have affixed to the several pieces. We already possess a somewhat similar collection from the bone caves of the U.S. The work of exploration has been done, however, with less care than that which characterizes your researches; and we hope that your collection will serve as a model for construction in all future work. There is a large field of research in this direction in the U.S., and it is very important that proper methods be devised for carrying it on. Would it be asking too much from you for a brief article in the general subject of cave exploration; and the method of research, to be published by the Smithsonian Institution as one of its special series of directions for the promotion of scientific investigation. It, of course, will be prepared under your name, and published with any amount of illustration you may select.

I need hardly say that additional specimens from time to time, to continue and complete the series, will always be acceptable, and receive the most distinguished consideration in the National Museum.

Pengelly was pleased that the material reached Washington, and with Baird's offer to publish an article on cave explorations. On 23 May 1883, he replied to Baird: "It is most pleasant to receive such cordial letters as yours of 1 st inst., and very satisfactory to learn that the box of specimens has duly reached you. I shall be most happy to prepare, in compliance with your gratifying proposal, an article on Cavern Exploration, to appear in one of the Reports of the Smithsonian Institute [sic]."

After unpacking the fossil material, Charles Rau, a curator in the Department of Antiquities, realized that identification of species would be difficult. In a letter dated 23 May 1883, Rau wrote to Baird: "The accompanying list gives the original numbers of Mr. Pengelly's collection from Kent's Cavern. Please, send him this list, to be returned after he has identified the bones, teeth, etc., by comparison with his journal. There have been found in Kent's Cavern some characteristic flint implements, casts of which would be very desirable for a better representation of our series from that important locality." In accordance with Rau's request, Baird wrote to Pengelly on 24 May 1883, stating: "I am happy to say that the collection of Kent's Cavern remains, which you kindly transmitted to the Smithsonian Institution some months ago, are already unpacked and suitably arranged for exhibition in [the] Archaeological Hall. Dr. Rau, the officer in charge, is much embarrassed by the difficulty of identifying the several bones, and have drawn the enclosed list of numbers corresponding to opposite blanks, which he asks that you will kindly fill up and return to the Smithsonian Institution." Apparently, Pengelly was not able to satisfy this request, and in a final letter on the Kent's Cavern accession, he replied on 11 June 1883 , stating: "I can only say that no attempt was made to identify any of the bones sent to the Smithsonian. The work of identifying the whole was so perfectly Herculanean, that unless the authorities at each Museum identified the specimens they received there was no prospect that it would ever be done at all" (see Table 4).

\section{White (acc. 26918)}

In 1883, a collection of Acheulian handaxes was donated to the U.S. National Museum by the Geological Survey of India, through C.A. White. White was a geologist with the U.S. Geological Survey who corresponded for many years with Secretaries Henry and Baird about geology and paleontology. The handaxes were found near Madras, India. No correspondence concerning this accession was found.

\section{Wilson (acc. 42207)}

In 1904, the National Museum purchased a large and extremely important collection of Paleolithic artifacts from the estate of Thomas Wilson (see earlier section on Wilson). The collection was previously deposited by Wilson in twelve separate installments during his tenure as a curator of prehistoric archaeology at the Smithsonian. Wilson began his collecting activities before his tenure at the Smithsonian. The Wilson deposits contained about 2633 objects, many from classic Paleolithic sites in France. Among the objects are Solutrean points, scrapers, and burins from Laugerie Haute (Figure 50); worked bone, worked antler, needles, gravers, and scrapers from Laugerie Basse (Figures 51-53); and both unworked bone and splintered, engraved, and worked bone from Rossignol (Figure 54). Wilson also collected natural history specimens thought to be associated with cave dwellers, such as bear coprolites from Italy (Figure 55).

In a letter to John Wesley Powell, director of the Smithsonian's Bureau of American Ethnology, on 22 June 1883, Wilson expressed interest in acting as a liaison for exchanging material from the Old and New Worlds: 


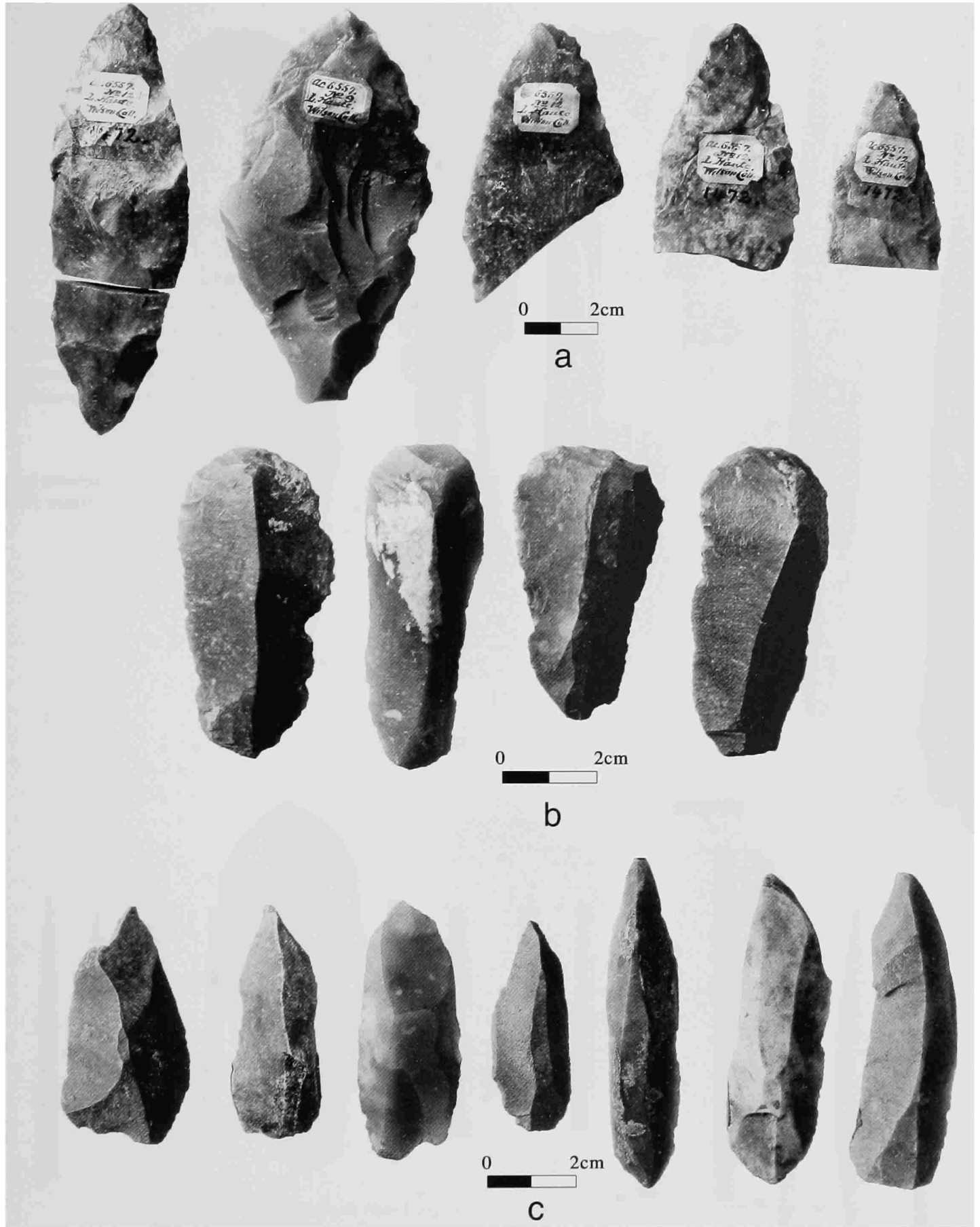

FIGURE 50.-Stone tools from Laugerie Haute, France. [(a) Solutrean points (catalog nos. from left to right: 1472, 1465, 1472, 1472, 1472); (b) scrapers (catalog number 1462); and (c) burins (catalog number 1465).] [Wilson accession (accession 42207).]

I have been making some few collections or some few articles. A collection is not made without difficulty - the prices are high \& there is much competition. Many articles are fraudulent $\&$ downright forgeries. Their principal value arises from the certainty as to their place of deposit $\&$ this the first owner (or finder) is unwilling \& the record unusable to give with certainty \& reliability. I was out the other day with the School of Anthropology of Paris to a station or dwelling place of prehistoric man... of the Oise \& got many specimens. Some gentlemen here are anxious to get specimens from America, either ethnological 


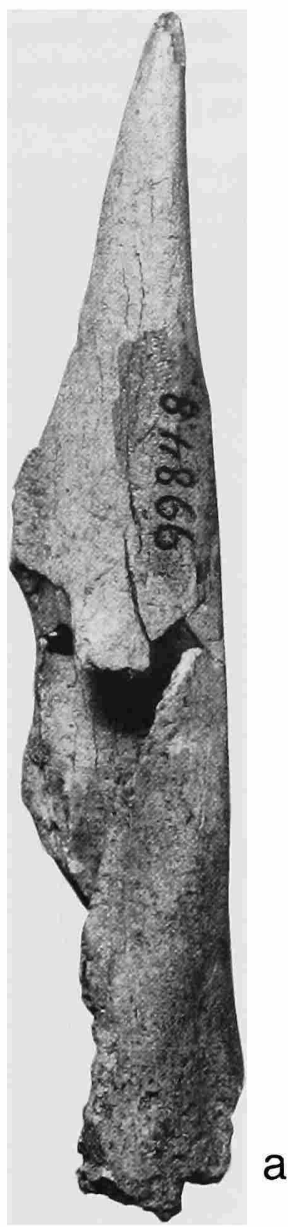

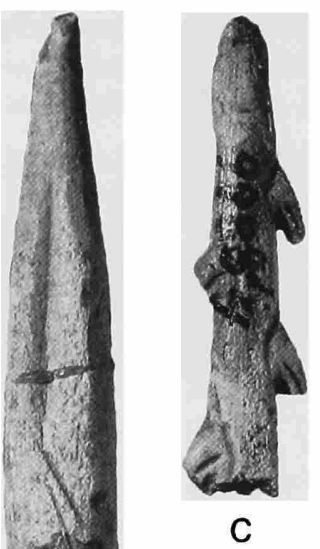

a

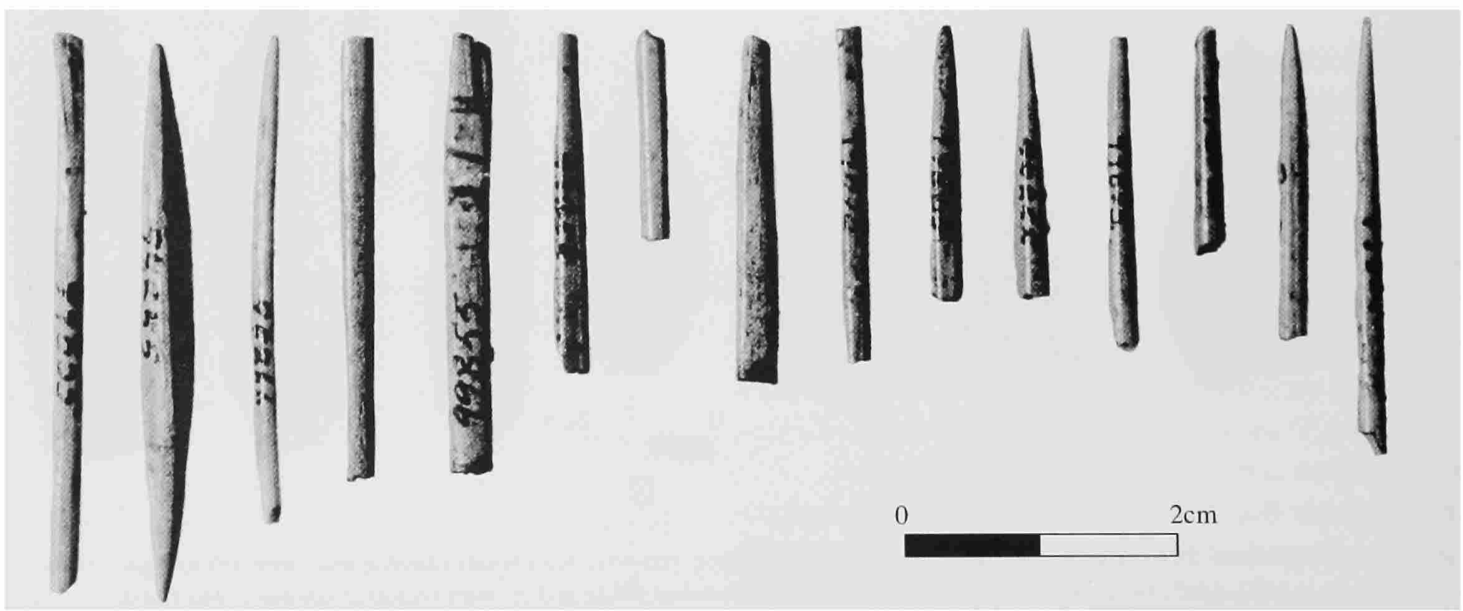

FIGURE 51 (left).-Artifacts from Laugerie Basse, France. [(a) Worked bone (catalog number 99848); (b), sagaie (catalog number 99848); (c) harpoon (catalog number 99854); and (d) drawings of worked bone (catalog number 99850).] [Wilson accession (accession 42207).]

FIGURE 52 (below).-Needle fragments [catalog number 99855] from Laugerie Basse, France. [Wilson accession (accession 42207).] or geological-\& if I had some I could make some exchange which would be valuable to me. I could do this by going to the collectors \& making my own selections. Will it be possible for you to aid me? Any suggestions you may be able to give will be thoughtful received $\&$ highly appreciated. When I return to my home on Connecticut Avenue I shall hope for some choice pleasure in comparing notes $\&$ talking of inan before the flood.
Secretary Baird was interested in making exchange agreements with Wilson and found his location in France to be ideal for such an arrangement. On 12 December 1883, Baird wrote: "At your new station you will have an opportunity of continuing your archaeological researches, as many discoveries have 


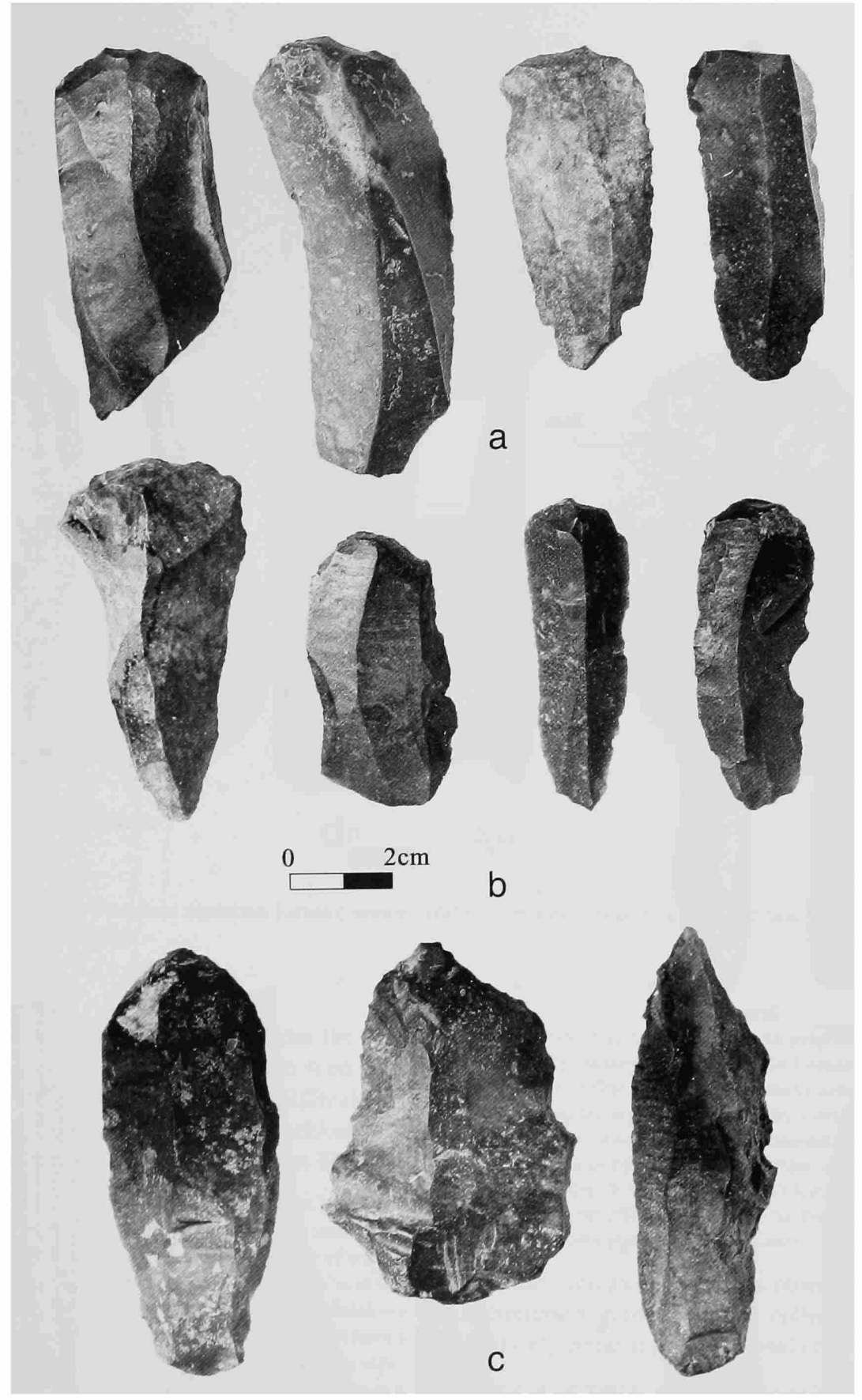

FIGURE 53.- Stone tools from Laugerie Basse, France. [(a) End-scrapers (catalog number 1491); (b) burinated scrapers (catalog number 1491); and (c) gravers (catalog number 1489).] [Wilson accession (accession 42207).]

been made there about. We will be most happy to enter into close relationships with Mons. [Monsieur] Gailliard, and will send him any of the archaeological publications of the Institution in return for contributions. You have made a magnificent gain in...specimens. I trust that you may enlarge the collections and that ultimately it will come to the National Museum."

In response to Wilson's suggestion to deposit his personal collection in the Smithsonian, Baird expressed some interest in his letter of 30 September 1884, "I am much gratified at your proposal to send us your collection. If you will do this, we will 


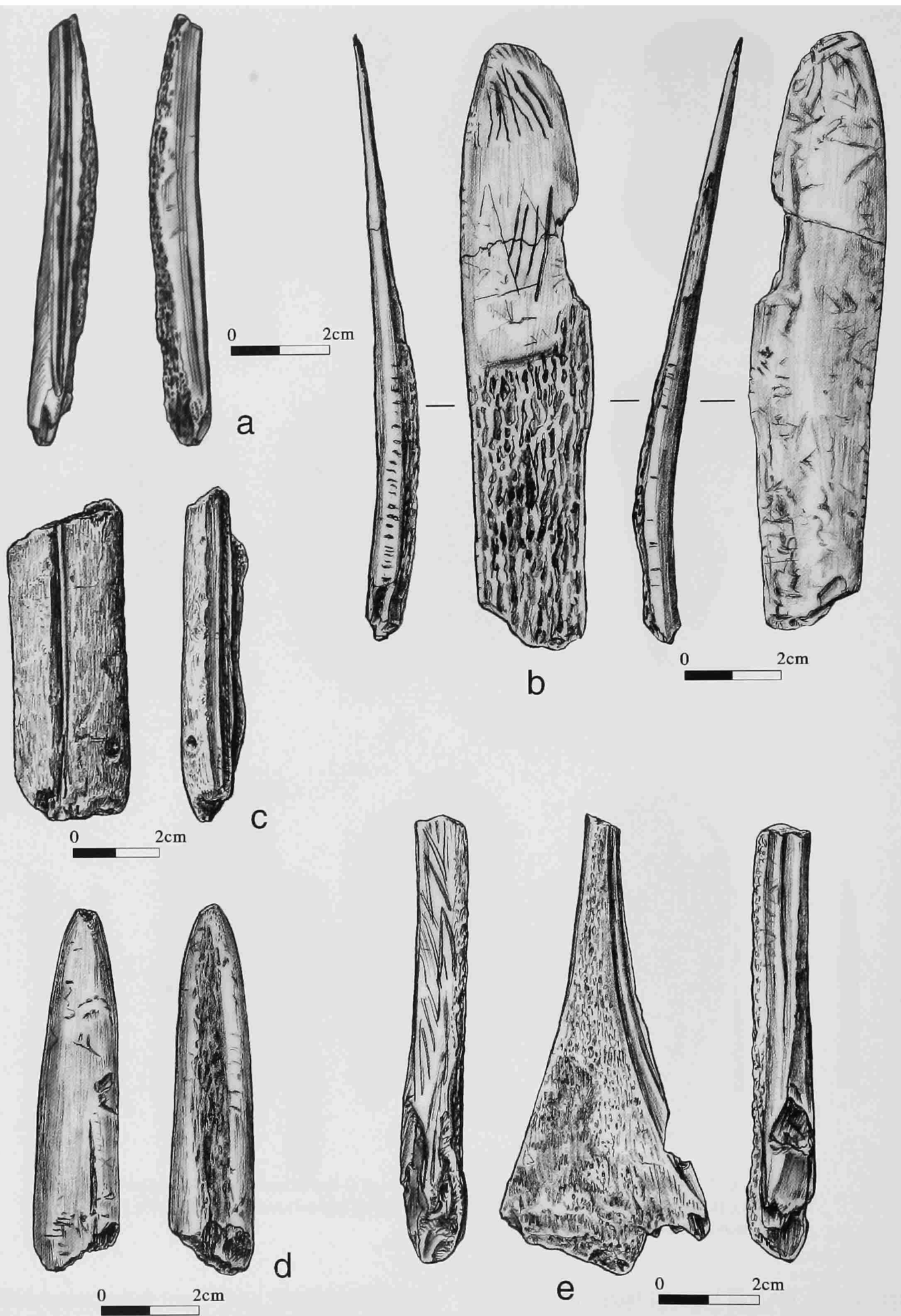

FIGURE 54.-Dratvings of worked bone [catalog number 100290] from Risssignol, France. [Wilson accession (accession 42207).] 


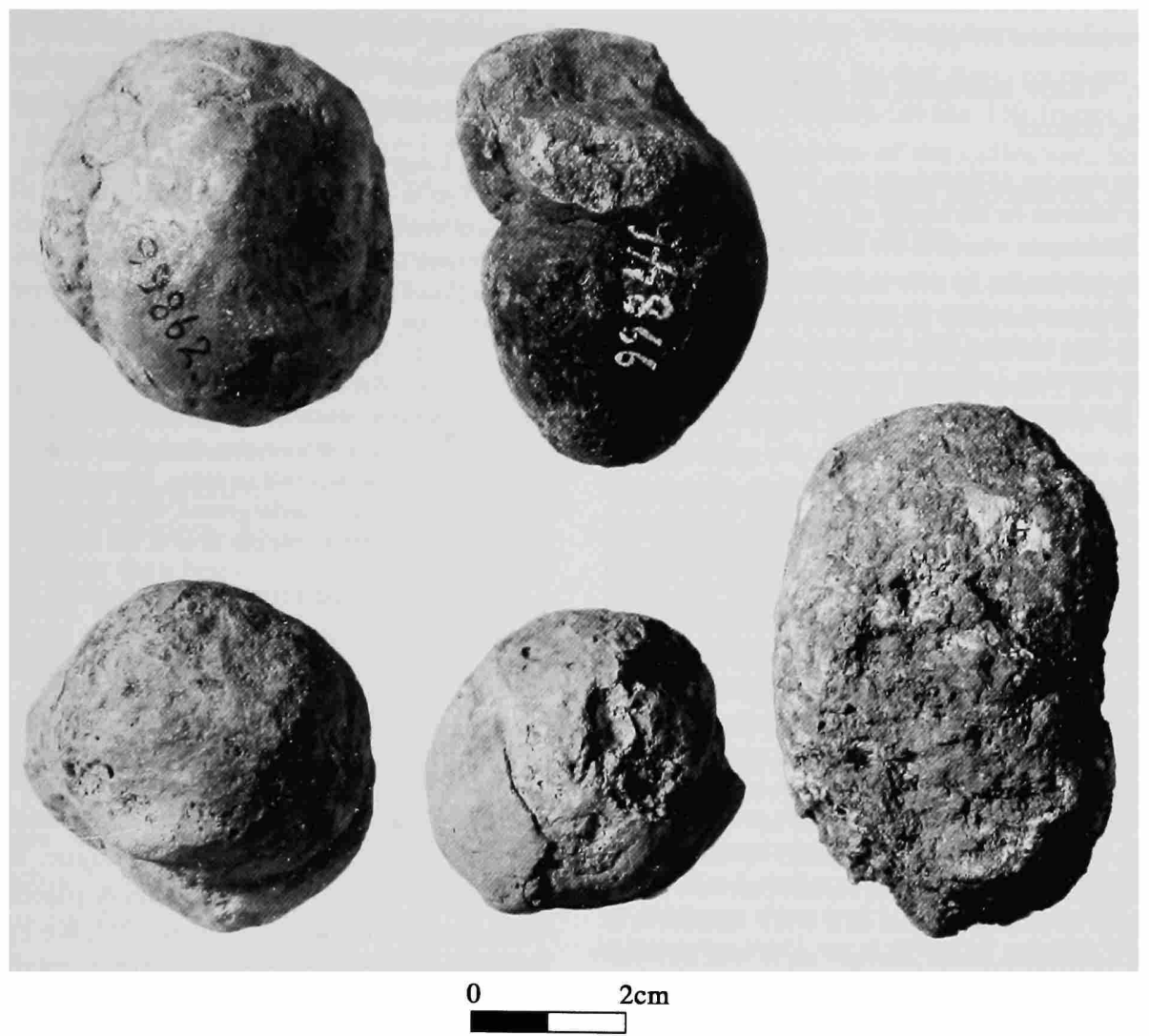

FIGURE 55.-Cave bear coprolites [catalog number 99862] from a cave near Pisa, Italy. [Wilson accession (accession 42207).]

have it carefully unpacked \& mounted, in readiness for such further action as you may wish to take in regard to it on your return." In the same letter, Baird indicated the difficulty in sending New World objects because of a heavy workload, but he maintained his desire to acquire objects from Europe:

I had intended to send you a collection of American implements, to be used by you in exchange for other specimens but, in truth, we have been under such drive of work for the last year that it was impossible for our curator of archacology to do anything in the matter. As a general thing material comes in as fast as we can catalogue it, leaving no time for the finer elaboration by which we might know what is duplicate \& can be spared. If not too late then, I will have a collection picked out \& sent to you. I cannot promise to send anything especially rare. What is common with us might, however, be very attractive to a French naturalist. Of course the objects from the caves of the south of France will be very interesting. We are very desirous of getting as complete a series as we can of European prehistory.

In a letter dated 18 October 1884 , Wilson reiterated his desire to obtain New World materials from the Smithsonian for exchange:

You may send me anything else pertaining to Prehistoric man in America and it will be of great use. They are now seeking to extend their collections to include representations from other countries, for purposes of comparison and in North American objects they are very poor. So I could utilize them with effect. I do not wish rare or fine or fancy or expensive articles-but only those of every day use among the savages of our country. I saw at Turin a collection sent from Washington consisting [of] stone axes, hammers spear and arrow heads \&c.\&c. from 'Bennings Bridge,' 'Little Falls,' 'Maryland' \&c.\&c. amounting to about a thousand pieces. Who sent them I don't know, but when I saw this riches and thought with what effect I might use it for the benefit of your Institution I confess to a feeling of jealousy and annoyance.

Wilson indicated that unless objects could be obtained from the Smithsonian for exchange, collection of European material could only come at great personal cost:

I am still of the mind to send my collection home next spring \& should like to include any exchange I might be able to make up to that time.

I suggest that you should send me a box of specimens. I could use them with great benefit for your Institution. In justification of my request for specimens I have to say that it when I visit a collection private or public where they may have many duplicates and be told 'no we do not sell, but we will exchange' and in the next place 'Yes we will sell or exchange, we will exchange these for others of equal value or we will sell these at such and such a price.' Then for want of articles to exchange I have to put my hand in my pocket and pay 20, 40 or 100 francs cash. My collection has cost me not far from 5000 francs \& as much more in traveling expenses \& yet I have no object which could not have been 
obtained in exchange for articles from the U.S.

In the same letter, Wilson indicated his motivation for obtaining the Paleolithic objects:

I wish to get a respectable showing of Prehistoric man in western Europe \& then present it all to your Museum for the benefit of our people \& especially my scientific friends of Washington who have not had the opportunity that I have. As to publishing any memoirs \&c. we will see further. I am only trying to give our friends pleasure and am not seeking for private glory. I have plenty of them written out, but have been retaining them for future reference and information as well as possible correction. I make my memoranda and take my photos as I go along so that I may preserve a vivid recollection as well as necessary data.

Baird sent North American specimens to Wilson, as indicated in his letter of 23 December 1884: "I have much pleasure in announcing that a box containing 355 specimens of North American implements, as per accompanying invoice, is now packed, and awaiting shipment to you. Hoping that you may be able to make some good use of these articles in the interest of the National Museum." Wilson responded to Baird three months later, on 30 March 1885, enumerating his comments:

1. I received in good order the box of Indian implements and was greatly pleased with the contents. 1 expect to make a trip through the interior of France and ...make some exchanges for 'cavern' objects—-thru to Paris \& to the Musee St. Germain. Will those objects please you? 2. I have nearly completed the packing \& catalogue of my collection for sending to you. I have endeavored to separate the objects in two ways (1) by periods \& (2) by places. In this I have not been altogether successful as I have only the odd times which I can spare to work at it, and I have it do all myself which makes it laborious \& tedious. I hope that you will appreciate my efforts. I hope to enjoy them on my return. 3. I wrote a paper... on Prehistoric art which I sent to my son J. Frank Wilson to be read 1 st from the art club \& 2 nd to be given on to Col. Lively for use before the Anthrop. Soc. I should like you to see it. There is nothing original or striking. I only tried to group the article displays of various prehistoric epochs so our artists could understand them.

Baird replied to Wilson on 13 April 1885: "Your letter of March 30th is just at hand. I am glad to know that the box of Indian implements pleased you. I am rather inclined to think that we have already supplied the Stockholm and Copenhagen Museums with specimens of the principal forms of stone implements. If, however, there be any special thing that they want, please let us know. We shall be very happy indeed to obtain any cave objects from the interior of France."

Wilson wrote to Baird on 14 May 1885 concerning the mailing of the archaeological collection to Washington: "I have finished my packing and have mailed up my boxes numbering 24 ....I certainly look forward with much eagerness to the anticipated pleasure of personal intercourse with the Anthropologists of Washington. I will send.... a copy of my catalogue. The objects as you will see by the catalogue are divided by numbers into the various epochs to which they belong, so that they can be easily \& satisfactorily classified by age, but not by places where found. That is the coarse procedure at St. Germain. I have endeavored to pack each epoch in its separate box."
During this time, Wilson continued his collecting with greater vigor. Wilson also indicated that he had begun to dig at certain localities. On 16 June 1885, Wilson wrote to Baird:

I am ... at Ussat in L'Ariège, making a tour among the grottes of Southern France. I go to Toulouse tomorrow. Mrs. Wilson is with me $\&$ we spend some portion of nearly every day up or down in to see grottes. We have visited Gourdan, Marmet, Gargas, Mas d'Azil, L'Aubrive [Lombrive], Bédeilhac, Niaux, l'Eglise [Les Eglises] \& yesterday Bouichéta where we fouillés until dark \& got many of the bones of the grand ours des cavernes which I have been boxing today to send to you when the occasion arrives. I sent you my catalogue \& invoices of my collection. To this was added a case from Genoa consisting of mostly an entire squelette of a grand ours except the head. I will try my best to get one while I am in this country. An entire squelette, mounted, still cost 1000 or 1200 francs, so they told us today. I hope, \& Mrs Wilson said yesterday while we were $1 / 4$ mile under ground, digging away at our grand ours, that she hoped you would appreciate our labor in this behalf.

Wilson acquired more archaeological material through diggings and exchanges, as indicated in his letter to Baird on 18 July 1885: "I have, we have, now passed two months in voyaging through the midi de France \& we have gathered a mass of things for your museum which I will have rendezvoused at Havre \& sent to you from there. They have been gathered in various places \& under all sorts of circumstances, so that it has been impossible to make any catalogue. But we have tried to keep up all indications of the kind \& places so that they can be catalogued." Wilson continued: "I have exhausted all the objects you sent me \& if you have any more they should be sent at once to me."

Baird acknowledged receipt of Wilson's collections on $4 \mathrm{Au}-$ gust 1885: "I... am glad to know that you still continue to make collections in archaeology and natural history. I assure you that we fully appreciate all that you are doing for us. I do not know how the 19+ boxes actually arrived, but I am advised that they are safely stored in the Smithsonian, where they are held for such action as you may wish in the future. Unless you authorize it, they will not be opened excepting in your presence. Of course, with the catalogue, which came duly to hand, we could unpack the collection, and have it ready for your inspection when you return; but this is in no sense a pressing matter, and it will be decided by your choice. We shall be very glad to obtain specimens of European archaeology from any country you may visit, and will make such return as we can."

Further indicating his zeal to amass collections, Wilson wrote to Baird from Rennes, France, on 12 August 1885, about his activities: "I have just left Mr Gaillard's house where we have been making some interesting fouilles. I am gathering up articles concerning prehistoric man, having them boxed on the spot (which may account for the want of tickets, catalogues, etc.) sent to Havre from whence I will forward thru to you when I have all complete." On 28 August, Baird replied: "I will be pleased to have you collect any additional specimens you can illustrating the archaeology of Europe. Our European collections are very small, and we can not have too much of this kind of material." Regarding the boxes Baird spoke of in the earlier correspondence, Wilson replied, on 15 September: "As 
to my boxes in Washington! I had intended you should open these \& classify the objects but on your suggestion I agree that it would be best I should do it. Some of the boxes are so packed that I could identify the objects better - thus the work would be considerable for you, while it would be a pleasure for me."

Wilson intended to return to Washington as described in his letter to Baird on 4 May 1886: "I am going to quit Nice. I have enjoyed myself, had a good time \& much pleasure. Am entirely satisfied \&c. But I have had enough. To stay longer only means to spend my time in idle, pleasure good enough for invalids, but not for me. I have packed up my collection and only trying to label a lot of fossils." Wilson moved to Washington, D.C., and in 1887 he became the administrator, and then later, curator of the Department of Prehistoric Anthropology at the U.S. National Museum. Wilson then began corresponding with D. Peyrony and M. Capitan, two famous French prehistorians, for the purpose of acquiring more Paleolithic collections.

On 19 February 1900, Peyrony wrote to Wilson from Les Eyzies, France, concerning the sale of Paleolithic materials: "The collection of which I have spoken with Mr Capitan consists of 160 pieces. I have sent a sketch of the most beautiful for you to have an idea of those we have. I have made for you a package of the collection for you to see what there is, if you desire. My final price is 300 francs. I have, if you desire, 15 to 20 large pieces, but it is not possible to diminish the price since all the pieces are very rare and of a very high value." Capitan also was in contact with Wilson concerning the sale of Peyrony's collections, as indicated in his letter of Monday 11 June 1900. Regarding a previous sale, Capitan indicated that he received one of Wilson's checks for 150 francs and forwarded it to Peyrony. Capitan indicated that Peyrony was a "poor and honest schoolmaster," and was in need of money and would happily sell part of his collection. Captian added: "You can have total confidence in him that when he says a piece is beautiful it is always true. It is often more beautiful when you can be absolutely sure of the provenience. Peyrony is not dishonest. I assure you that the affair is good and that the money will be well placed." Capitan indicated the type of material and the provenience of some of Peyrony's material:

For Moustier there is a pointed scraper and handaxes and you will find these are varied-For La Micoque (this pretty Acheulean station near Laugerie Haute described by [Gustave] Chauvet, Rivière and me) there is a very good series of small Acheulean handaxes. For Laugerie Haute you have several pieces of an excavation entirely run out. With these tools are the scrapers, piercers, and knives. For Laugerie Basse the series is also beautiful. There are 75 pieces of first choice but the remains are not composed of entire pieces but a little less fine. There you have it, the values of the exact numbers: Solutrean Laugerie Haute: 40 very fine pieces of the 1st order, 20 fine pieces; Magdalenian (Laugerie Basse) 20 very fine pieces, 40 fine pieces; La Micoque (Acheulean) 7 very fine pieces, 18 fine pieces; Moustier 5 very fine pieces, 8 fine pieces; 2 Acheulean handaxes of the plateaus. There are 160 pieces (good and very good) of which the pieces are ordinary. This fine fellow and honest man [Peyrony] would want 300 francs of this series and the price which appears very reasonable.
Peyrony wrote to Wilson from Les Eyzies on 12 November 1900. Wilson had, by that time, received the collection. Peyrony thanked Wilson for the 150 francs and wanted to know Wilson's evaluation of the collection, hoping that it pleased him. Providing additional information on the provenience of the artifacts, Peyrony wrote:

Here is the detail of the case: 1. At the bottom, in a small wooden box, you will find 45 pieces, the finest of the Solutrean found in our Station of Laugerie Haute. By its side, folded in paper, there are other less fragile objects coming from the same locality. In the locality where I have excavated, the breccia bed was about 2 meters or 2.5 in depth and comprised: the surface, a very poor stratum containing only chips, broken bone and some crude scrapers $(0 \mathrm{~m} 80$ approximately). Underneath this there was a stratum of large pebbles $0 . \mathrm{m} .40$ to $0 . \mathrm{m}$. 50 thick. Then a good stratum, or rather several superposed strata, about 1 meter in thickness, containing the finest pieces. Finally, the last stratum contained very little, and rare pieces that one here meets with, of the Mousterian type. I have ones that I omitted to put in this sketch that I sent to you, but which I can address to you with the plan of the station, if you desire. 2. Separated by a newspaper, the objects mentioned above, is found, two Acheulean hatchets wrapped together, coming from an open air station on the plateau of the vicinity of Les Eyzies. 3. Above the two hatchets, are Mousterian points and scrapers, a series from our beautiful, classic station of Moustier. These objects have become very rare now. 4 . Another series of objects of white color, coming from the station Cheleo-Mousterian, of Micoque, situated about a thousand meters from the Solutrean station of Laugerie Haute. It is composed of terraces as at Moustier. There is no abri; it is situated on the hillslope 40 or 50 meters above the level of the Vezére. 5. Finally, in the upper part of the case, are to be found objects from the Magdalenian station of Laugerie Basse. This station has been so disturbed that a study is impossible. These pieces were found within places which remained intact, mixed with pieces of reindeer horn.

In the same letter, Peyrony indicated that other materials might be available:

Now, if you desire that I should complete this series with objects that I can find in the future, will you tell me those that you desire, I shall reserve those that I may find. In a few days I will also have pieces from the Grotte des Eyzies, and from the great station of La Madelaine-do you desire them? I promise to you, that because of Dr. Capitan, I will continue to make to you advantageous conditions.

Although descriptions of the artifact contexts are rather general, often referring to site, and sometimes level, worse provenience information is often the case for important objects in the Wilson collection. This may be a consequence of artifact collection at the time, emphasis on objects and stratigraphy, or imprecise management of artifacts during inventory and curation. Although Peyrony separated artifacts from the nearby sites of Laugerie Haute and Laugerie Basse, they were collectively accessioned as "Laugerie Haute and Laugerie Basse" (Figure 56). The accession contains impressive objects of uncertain provenience, such as "Solutré or Madeleine" (Figure 57), and still worse, "unknown France" (Figure 58).

Wilson may have purchased additional materials from Peyrony. During Wilson's visit to the Paris Exhibition in 1889, he also purchased from Capitan a small collection of flint implements from France and Italy. 


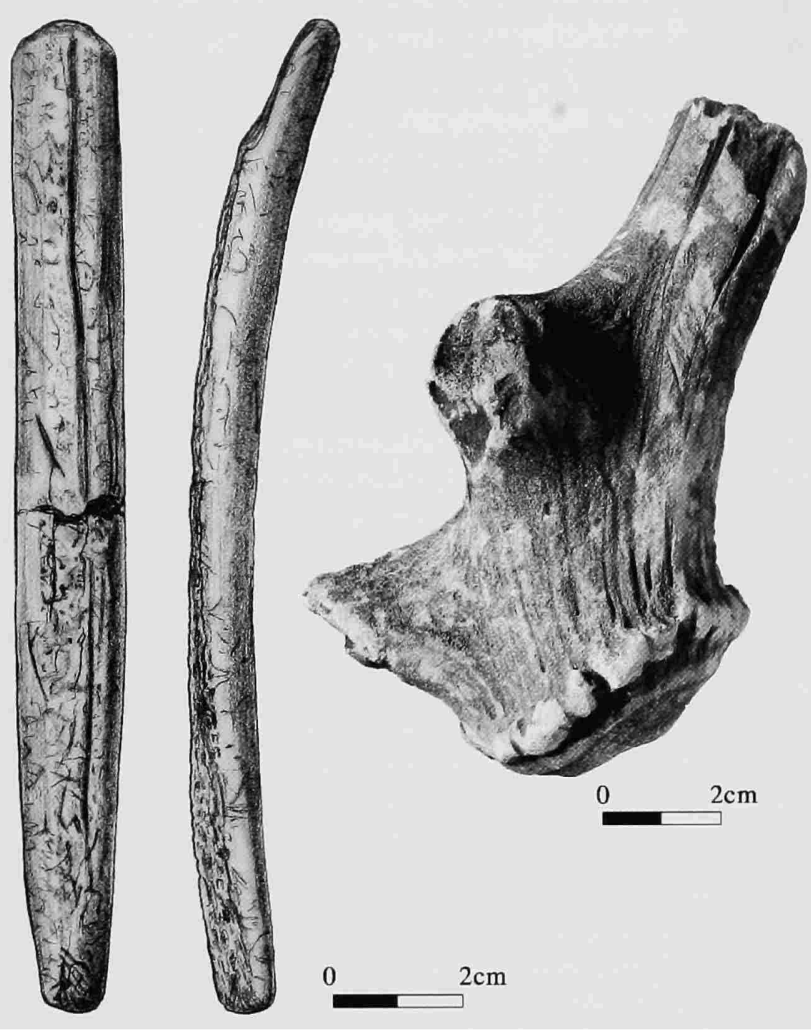

FIGURE 56.-Drawings of worked bone (left) [catalog number 99563] and photograph of splintered antler [catalog number 99569] from Laugerie Haute/ Basse, France. [Wilson accession (accession 42207).]

\section{Musée des Antiquités Nationales, St. Germain- en-Laye (acc. 18891)}

In 1887, a collection of casts of bone specimens from France and Switzerland was donated by the museum in St. Germainen-Laye, France. In a letter of 18 March 1887, Wilson indicated to Smithsonian anthropologist O.T. Mason that the plaster casts of engraved and worked bones and figurines were requested by him for the Smithsonian Institution. Many of these casts appear as figures in Wilson's publication (1896) "Prehistoric Art."

\section{Rau (acc. 19931)}

Dr. Charles Rau was born in Belgium in 1826 and emigrated to the United States in 1848. Rau began publishing anthropological studies in 1859 , and, in 1863 , he became a contributor to Smithsonian publications (Glenn, 1992). Rau and Secretary Henry corresponded from 1867 to 1872 . Rau indicated his great interest in conducting comparative work on new archaeological findings from North America and Europe. He wrote to Henry on 24 February 1867 :

For many years I have devoted all my leisure hours to the study of comparative archaeology, and nothing has afforded me greater satisfaction than to trace the similarity in the development of the human race in both hemispheres. These investigations naturally led me to a careful study of the relics left by the various branches for the human family, and my attention was devoted to everything that can serve to illustrate their former condition, from the simple implement upwards to the ruins of temples and cities. Some years ago, I went to Europe almost exclusively for the purpose of examining the archaeological and ethnological collections.

Rau's appointment at the Smithsonian began in 1875, when he became an assistant to prepare exhibits for the 1876 Centennial Exposition in Philadelphia. At that time, Rau published a series of popular articles on archaeological and skeletal evidence of early man in Harper's New Monthly Magazine, which were reprinted as a volume, Early Man in Europe (1876). In 1881, Rau was appointed curator of the Department of Antiquities, a position he held until his death in 1887 (Hinsley, 1981). During those years, Rau was instrumental in collecting some significant Paleolithic materials from Europe, in addition to ethnological and archaeological materials from North America and other parts of the world. More than any other individual in the United States, Rau was most knowledgable about developments in archaeology in the Old and New Worlds between 1860 and 1880 (Hinsley, 1981). Wilson (1890d:123) noted that "almost the entire life of Dr. Rau was spent in archaeologic studies. He was faithful, zealous, and devoted to his science." Despite his zeal, Rau did not make seminal contributions to theory or to fieldwork research, but he is best known as an early classifier of museum antiquities (Hinsley, 1981).

In 1887, after Rau's death, a bequest from the his estate was accessioned (Annual Report, U.S. National Museum, 1890) that included Rau's personal library and his archaeological and ethnological collection. Wilson (1890d:125) indicated that the Rau collections derived from work prior to his Smithsonian appointment, indicating that "he had been an enthusiastic archaeologist and this was the collection of his life-time. He added nothing to his private collection after his appointment as curator." Rau acquired his archaeological collection during his youth in Europe and during subsequent visits. Because the collections were personally developed by Rau, there is neither associated correspondence nor any identified object descriptions.

\section{Lovett (acc. 20116, 20225, 23040, 23170, 25615, 27077)}

Beginning in the early 1880 s, a number of exchanges were made between Edward Lovett, of Croydon, England, and the U.S. National Museum. The exchanges were diverse and included accessions other than anthropological material. Lovett was an avid collector of anthropological material, both ethnological and archaeological. Mason wrote to A.L. Kroeber, professor of anthropology at the University of California, regarding Lovett's background: "He is an officer of the Bank of Scotland and is deeply interested in primitive culture. He has filled his house with all sorts of nice things from different parts of the world" (letter dated 25 June 1908). 

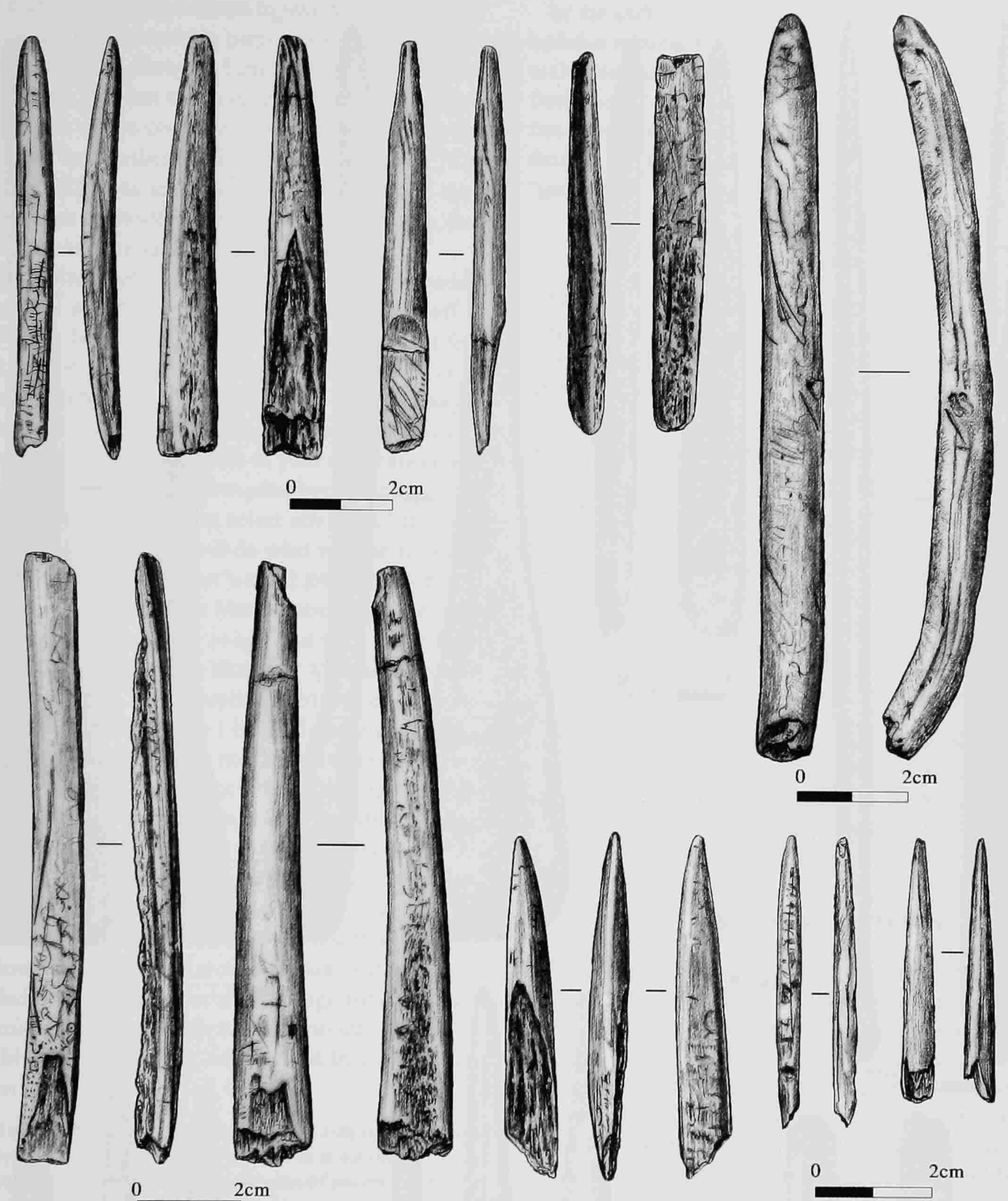

FIGURE 57.-Drawings of worked bones [catalog number 99809] from Solutré and La Madeleine, France. [Wilson accession (accession 42207).]

During 1884, Lovett corresponded and made exchanges with Goode (assistant director of the USNM) and Mason. In particular, Lovett sought North American ethnological material, as indicated in Goode's letter dated 29 November 1887: "Professor Mason has shown me your letter of Nov. 7th, expressing a desire to receive more of our duplicate ethnological material, and your willingness to send certain objects in exchange, a list of which you enclose. These objects, Professor Mason states, he would very much like to receive, and I shall, therefore, be very glad if you will send them to us at your convenience. Prof. Mason will get up a nice collection for you in exchange."

In 1886, Lovett proposed to Secretary Baird an exchange of Brandon flints for North American material. On 30 December 1886, Baird replied: "I am duly in receipt of your letter of December 11 th, in which you send a very interesting account of the gun flint manufactory in your Country, and offer to furnish a series of these flints, and illustrations of the work of manufacturing them, in exchange for archaeological specimens from the United States. In reply, I beg to say that I shall be much 


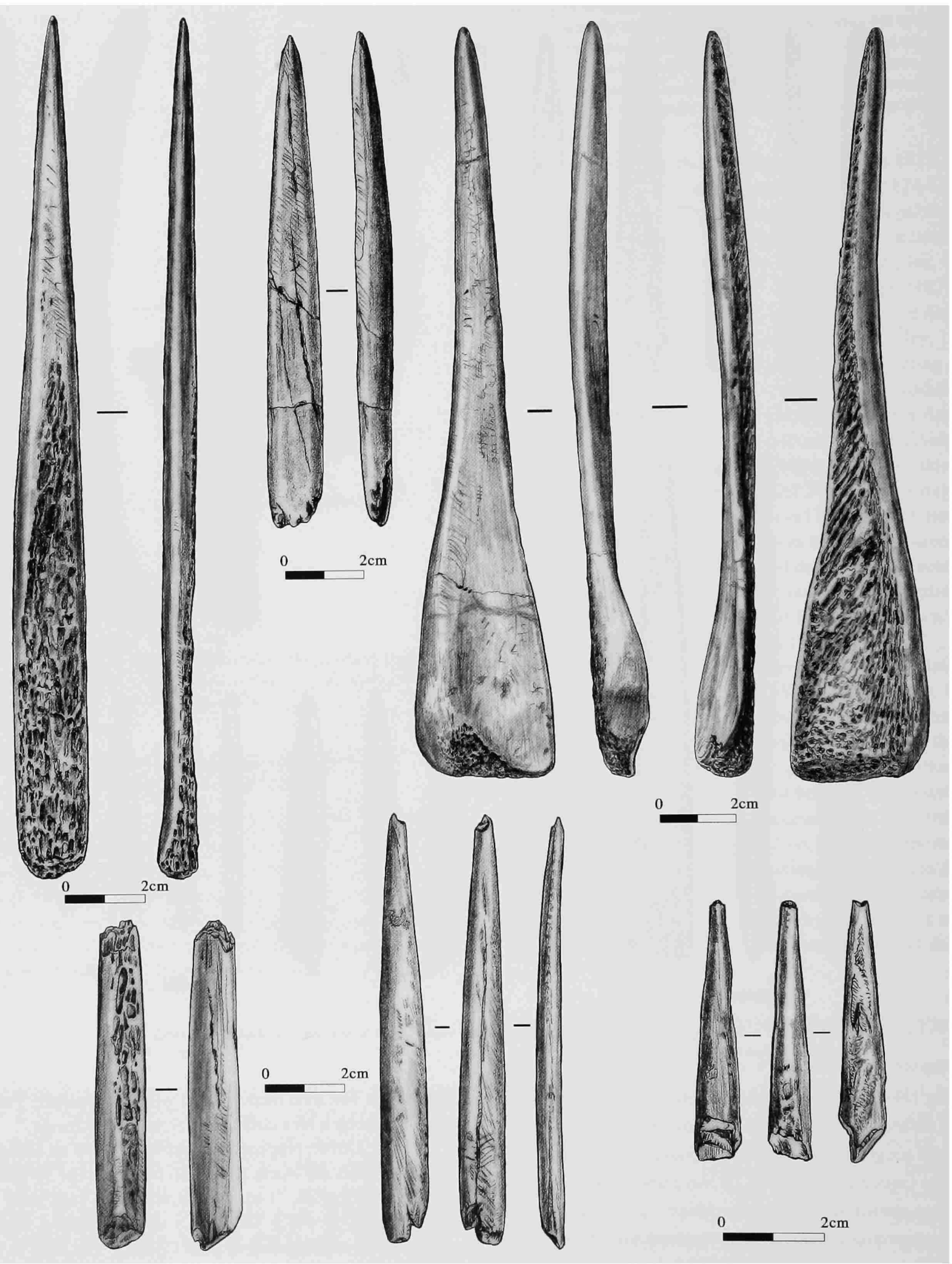

FIGURE 58.-Drawings of bone awls [catalog number 99733] from unknown provenience, France. [Wilson accession (accession 42207).] 
pleased to have the series of specimens to which you refer, particularly the cores with replaceable parts showing the original nodule and its derivatives. How far I can meet your wishes for specimens in return, I cannot now say; but I would be glad to have you inform me of the cost of such a collection, with the privilege of paying for it either in money or in exchanges." The exchange (acc. 20225) was later received (in 1888), and consisted of a collection of modern gun flints from Brandon, England, and Paleolithic material from Grime's Graves.

Lovett wrote to Mason on 7 November 1887, regarding additional exchanges: "I understand your museum is not well off in European \& British Ethnology. I beg to enclose a list of a few things I could send you. They may or may not be of service to you, but some of them may; and if you came to select any, I will send them carefully packed and fully labeled, and you could send me in exchange a few more of your duplicate ethnological specimens. I will not say now what sort of things I am in want of, but when I send (if you select any) I will then tell you what I want \& I am sure you will do what you can to oblige me in this way." Apparently, Mason wanted the collection, and on 7 January 1888, Lovett wrote to Mason concerning the shipment: "Some of the contents are rough and may be perhaps plainly called flakes, whilst others like the 2 Madras Paleolithics are rare and valuable." Lovett replied to Mason on 27 January 1888: "As regards exchange I have already sent you a greedy list of wants to which I have not the bad taste to add; but if you will allow me to say it, I might tell you that many things that are common to you would be valuable to my Museum, and also that in case of variety a broken or fragmentary specimen would be better than none at all; also, that when you are really able to spare more than one of a thing I can find room for two or three; as I like series where possible." As a result of this contact, a collection (acc. 20116) of archaeological material from England and India was received as an exchange for ethnological and archaeological objects from North America.

Lovett and Mason met in 1889, as indicated by Lovett's letter to Goode on 19 August 1889:

I was delighted of seeing Prof. Mason whose conversation I enjoyed very much indeed. I am happy also to say that I think his visit will be to our mutual advantage; for on my part I understand much better, the class of objects which your Museum desires and although many of them are hard to get \& will take months to obtain, still I feel almost able to say that in time I can send you nearly all the things Prof. Mason named. I am fortunate in having many friends (and ones who know a thing when they see it) at the Cape of Good Hope \& also in India and I have at once written out explaining what is required. I have also written to enough 'agents,' as I call them in these islands \& as I said before I hope to get you some of the things you want, if not all. I will try to send a box next month. Of course I also look forward to several objects of interest from your side, \& Prof. Mason was very kind as to his promises to try to help me in my own special branch of study. I have derived much pleasure from the correspondence \& exchange I have had with your museum \& I hope that I may yet be of more service to you than I have hitherto, and enjoy the advantage of further correspondence \& exchanges. On my part I will always do what I can for the Smithsonian, and although at times, objects are hard to get and expensive too, I always feel that I am more than repaid by the kindness \& courtesy that I have invariably received from your museum officials.
In the early 1890 s, four additional accessions, including $\mathrm{Pa}$ leolithic materials, were received. Goode and Lovett wrote several letters concerning the exchange of ethnological objects from the United States for Old World artifacts. In one of the last letters to Mason, on 15 May 1893, Lovett expressed his thanks for the specimens, indicating that the items were "greatly desired and pleasurable."

\section{Ransom (acc. 20668)}

In 1888, a miscellaneous collection of Paleolithic stone implements from England was received from William Ransom, Esq., of Hitchin, Hertfordshire, England. In exchange, a series of Native American stone implements and projectile points were sent to England. Ransom noted that eight of the Paleolithic implements were found about 13 feet below the surface, in yellow clay, near Hitchin, Hertfordshire. Just below the implements were bones of Ursus spelaeus, Elephas primigenius, and the antler of red deer. On 29 November 1888, Assistant Secretary Goode wrote to Ransom and acknowledged receipt of the specimens and the shipment of exchange specimens to England.

\section{American Museum of Natural History (acc. 21293)}

In 1888 , a cast of a flint implement from St. Acheul, France, was made from a specimen borrowed from the American Museum of Natural History (AMNH), New York. The cast was probably made for exhibition purposes. The original implement was returned in January of 1889.

\section{Reynolds (acc. 21386)}

Secretary Spencer Baird began corresponding with Dr. Elmer R. Reynolds of the Pension Office, in Washington, D.C. during 1878. On 9 April 1879, Baird acknowledged Reynolds interest in obtaining a position at the museum and stated: "I am well aware of your interest in American Archaeology and the ability with which you have prosecuted researches into aboriginal remains in this vicinity." In 1888 , a variety of stone implements from France were purchased from Reynolds. In a memorandum from Reynolds, dated 17 November 1888, the collection was noted to contain Paleolithic tools from a number of sites. Reynolds indicated that he purchased the material from three French aristocrats: "They are from the collection of the Count de Maricourt of Senlis, France, the Baron of Maricourt of Vendôme, and Dr. Auguste Baudon of Mouy." Although most of the artifacts were considered genuine, Reynolds considered the St. Acheul specimens to be "pseudo-antiquities."

\section{Cresson (acc. 23766)}

In 1890, materials from Le Moustier [Les Eyzies], France, were received as a loan from Dr. Hilborne T. Cresson of Philadelphia. Cresson studied art and archaeology in France from 
the mid 1870s until 1880 . In a letter dated 30 October 1890 , Cresson informed Wilson that he had collected pieces from Le Moustier in 1875. Cresson also was involved in the discovery of purported North American Paleolithic sites (Cresson, 1890, 1892). During this time, Cresson loaned artifacts to the Smithsonian. The artifacts were from eastern North America and were thought to represent "preglacial" Paleolithic objects ( $A n$ nual Report, U.S. National Museum, 1891).

In December of 1889 , Cresson publicly revealed the Holly Oak specimen as evidence for Paleolithic people in North America. Carving on the specimen depicted a woolly mammoth (Meltzer and Sturtevant, 1983) and closely resembled Lartet's famous woolly mammoth engraving from La Madeleine. In the early 1890 s, the Holly Oak specimen was displayed at various international expositions and museums, including the Smithsonian, where it was accessioned. The specimen was given little publicity because of its dubious authenticity, but Wilson (1898) apparently considered the artifact genuine. He subsequently illustrated it in "Prehistoric Art." Cresson was suspected of manufacturing this piece, likely to enhance his role in demonstrating the existence of a Paleolithic in America. Cresson eventually committed suicide in September of 1894 .

\section{Balfour (acc. 24708)}

In 1891, the U.S. National Museum exchanged specimens with Henry Balfour, curator of the Ethnographical Department, Pitt Rivers Collection, University Museum, Oxford, England. Prior to 1891, Balfour was subcurator and assistant curator with responsibility for organizing anthropological collections, including cataloging archaeological and ethnological specimens in the large collections of General Pitt-Rivers (Chapman, 1985).

Part of the small exchanged collection consisted of Paleolithic objects from Les Eyzies, France, and the rest were from an unknown location in France. Balfour and Holmes exchanged collections and corresponded on the similarities and differences between Old World Paleolithic artifacts and Native American specimens from Piney Branch Quarry in Washington, D.C. (see Holmes, 1897). A letter from Balfour to Holmes dated 9 September 1890 is of interest because it referred to Holmes' disbelief of a Paleolithic record in North America:

Please accept my best thanks for the series of quartzite implements, which have safely reached me, \& which I have acknowledged to Mr. Goode. I am delighted to have a series of the 'rejects' $\&$ to have had the opportunity of reading at leisure your valuable remarks upon the finds. Your evidence is certainly very convincing, \& from a few specimens which had previously been sent to our museum, I was very much set against the possibility of their having any claim to be considered as finished Paleolithic implements. The resemblance to the European Paleoliths is, it seems to me, comparatively slight, though it is very interesting to find that [in] the early stages the Columbian implements so nearly correspond with forms which we believe to have been the finished tools of Paleolithic Man. The, so to speak, 'Embryological' aspect is interesting \& suggestive. I do not see that the interest attached to these stones is in any way lessened by their being considered as of Indian manufacture rather than of $\mathrm{Pa}$ leolithic date.

This correspondence on tool form appears to be an obvious reaction against those who claimed that similar forms indicated the same antiquity.

\section{Museo Zoologico dei Vertebrati, Florence (acc. 24918, 25949)}

Murico H. Giglioli, director of the Museo Zoologico dei Vertebrati, Royal University, Florence, Italy, corresponded with Goode about a possible exchange agreement. Although exchanges of biological material had been made between the institutions as early as 1880 , it was not until 1889 that ethnologi$\mathrm{cal}$ and archaeological exchanges were discussed. In a letter of 15 July 1889, Assistant Secretary Goode attempted to establish contact between Giglioli and Otis Mason, who was about to visit Europe to attend an Exposition: "I have written a letter introducing to you Prof. Mason, our Curator of Ethnology, and I hope that if you are at the Exposition you will try to find him, for I am sure that there will be many subjects which it will be agreeable for both of you to discuss together." Nine months later, on 18 April 1890, Giglioli informed Goode that Wilson had visited him and had met his colleague at the museum. Giglioli also stated that he had recently read a letter from Wilson seeking material from Italy:

My friend and colleague Professor Mantegazza [anthropologist, in Florence] showed me the other day a letter which he had received from Mr. Thomas Wilson..., in that letter he tells Professor Mantegazza that he has sent him a box of archaeological specimens from North America for which he desires like specimens from Italy. Mantegazza and I will combine to do our best for him.

Giglioli further noted that ethnological and archaeological materials were being prepared to exchange for the North American materials:

I write briefly to offer you my very cordial thanks for what you have, with marked and special kindness, done to meet my wishes regarding some of the types of modern stone implements used by the Natives of North America. I am fully aware that such specimens are now rare and very difficult to get, in fact my only chance of getting them was through you and the U.S. National Museum, and I need scarcely say how greatly I appreciate your kindness in letting me have what you could spare, giving me thus considerable aid in completing the comparative researches on which I am engaged.

I am putting together a set of specimens, ethnological and others, to be forwarded to the National Museum as an exchange for those sent to me; and you may be sure that I shall do my very best to meet the wishes of the Curators of Ethnology and Archaeology.

In May and June of 1890, Giglioli and Goode corresponded several times, noting that materials were being gathered and sent. On 14 November 1890, Giglioli wrote to Goode that he was shipping ethnological and archaeological materials:

I send you with this letter the lists of the specimens sent under the two headings 'Ethnological and Archaeological'; and I hope that you and both Prof. Otis Mason and Mr. Th. [Thomas] Wilson will be satisfied with the specimens I have sent, and that these will fill up gaps and serve to complete the series of your grand collections. 


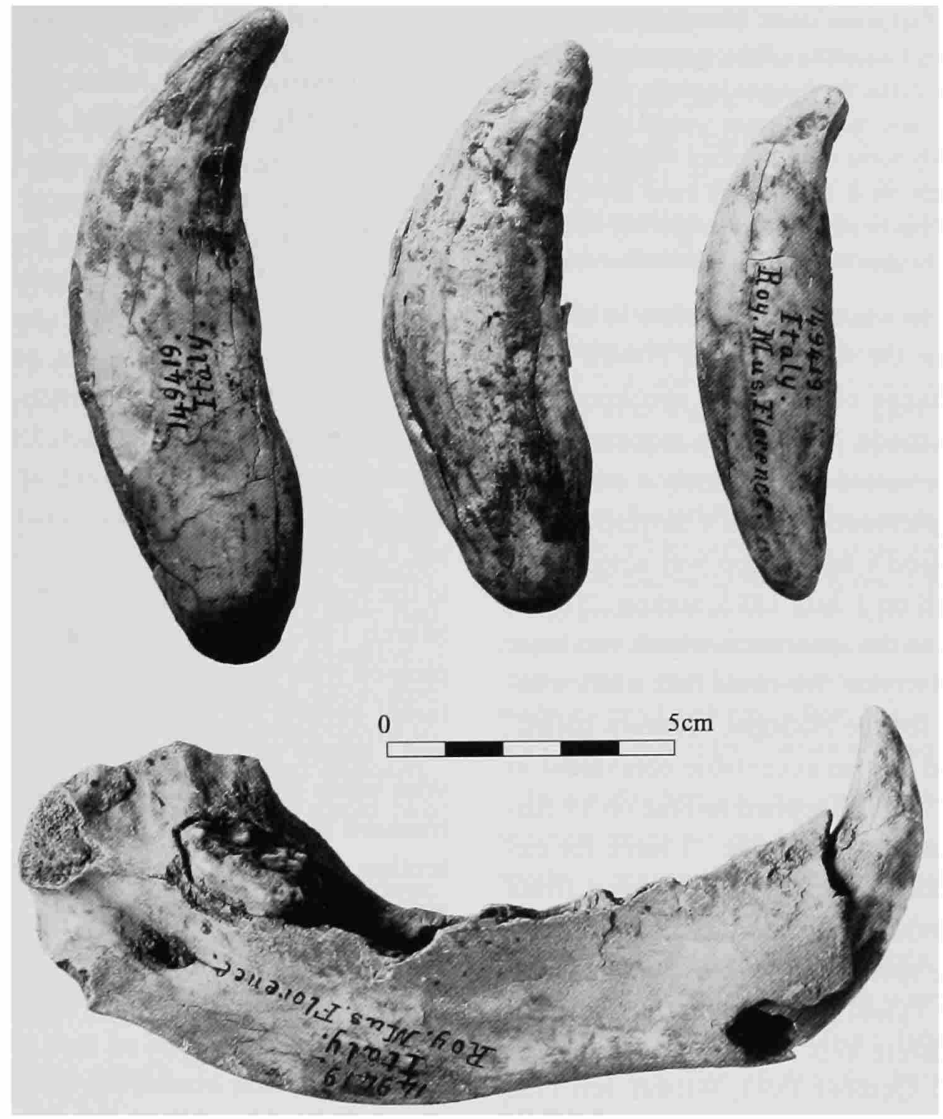

FIGURE 59.-Cave bear canines (top) and mandible (bottom) [catalog number 149419] from Breonio Cave, Italy. [Museo Zoologico dei Vertebrati accession (accession 25949).]

I have done my best and shall continue to bear in mind the desiderata of both gentlemen, for if, I trust my send[ing] will meet their approbation. I hope that they may be able to spare for me a few more types of ancient and modern stone implements and weapons from North America, yet missing in the small collection of types of such implements for which I am forming; and thus our exchanges may be continued. In the case with my specimens, in a wooden basket, you will find also a set of Archaeological specimens from Italy sent by Professor Mantegazza in exchange for the specimens of a similar nature sent to him last March by Mr. Th. Wilson. I helped Prof. Mantegazza to select his duplicates so we have avoided sending the same things.

Two exchanges of archaeological and ethnological material were made between the institutions. Correspondence on the second accession concerned ethnological objects and archaeological materials from the Andaman Islands. Material associated with the Paleolithic was sent to the Smithsonian, including a lower jaw, teeth, and bones of Ursus spelaeus from a cave near Breonio (Verona) (Figure 59). In exchange, ethnological and archaeological objects from North America were sent to Italy, including stone tools collected by Holmes from the Piney Branch quarry in Washington, D.C. Receipt of the material was acknowledged by Frederick True, curator of mammals at the Smithsonian, who wrote to Giglioli on 5 December 1891.
Giglioli's letter to Goode, on 30 November 1892, indicated his pleasure with the exchanges: "I have just received the box last sent to me through the Bureau of International Exchanges, containing the archaeological specimens which at your kind suggestion Mr. Wilson, was so good as to select for me. I am very much pleased with the specimens now received and very grateful for them, even the casts, which as you know are not favorites with me, and of which there is a fine assortment, are of great interest and represent well such types as I cannot get originals of, being rarities or unique specimens." In closing, Giglioli noted that artifacts sent by Goode gave him "intense joy."

\section{Powell (acc. 27665)}

In 1893, an exchange was made for a collection of stone implements from England and France. The collection was obtained from T.H. Powell of London. In a letter to Assistant Secretary J. Brown Goode on 10 June 1890, Powell indicated how the exchange was initiated:

My late friend Mr. W.R. Davies of Overshorpe House Wallingford, Berks[hire] wrote me shortly before he died that an American gentleman had called upon 
him \& purchased a large number of flint arrowheads, celts \& other neolithic implements found on the neighbouring Oxfordshire Hills. I am nearly sure he said this gentleman was connected with the Washington Institute. This would be about 18 months ago; $\&$ he further said this gentleman wished him to send more specimens from time to time. My home is not far from Wallingford \& I now $\&$ then have flint arrowheads sent me $\&$ have a good many more specimens than I require. If this gentleman can be placed $\&$ still wants any I shall be pleased either to sell him some or exchanges for American prehistoric relics.

The "American gentleman" to whom Powell refers in his letter may have been Otis Wilson. On the bottom of Powell's letter, Wilson noted that an exchange of American specimens for the European objects could be made. Wilson also requested that Powell should specify what he would send, namely a summary of the number and kind of implements, so that a corresponding exchange could be made. Wilson's suggestion was acted upon by True, who replied to Powell on 1 July 1893, stating: "If you feel inclined to forward a list of the specimens which you have to exchange, I shall be obliged to you. We could then make a selection of such as are desired for the National Museum collection, and could doubtless send you an acceptable equivalent in American prehistoric objects." Powell replied to True on $19 \mathrm{Au}-$ gust, indicating what material was available: "I have for exchange a number of flakes cores, scrapers \& other cut flints (neolithic) from various localities in England, but mostly from the South Downs, many of the specimens are bleached others in black flint; I have also a few Paleolithic celts, \& some arrowheads in flint from the Oxfordshire hills."

In a memorandum dated 21 October 1893, Wilson informed True what he could send: "I will take pleasure in making up a collection of 50 or 100 pieces to be exchanged with Mr. Powell. I will exchange our Paleolithic forms for his Paleolithic forms, also series of flints from Flint Ridge, Ohio. I should like to have in return, as I have said, his Paleolithic implements." True replied to Powell on 24 October 1893, stating: "Referring to your letter of August 19, reply of which has been delayed by the absence of Mr. Thomas Wilson, our Curator of Pre-historic Anthropology. I now take pleasure in saying that the National Museum will be pleased to exchange Paleolithic implements with you. We can send you a number of implements and also a series of flints from Flint Ridge, Ohio, representing in large part the method of quarrying flint, and showing many of the various kinds of implements manufactured. In exchange, we shall be pleased to receive some of your Paleolithic implements." In a letter dated 17 November, Powell responded by listing some of the objects to be forwarded, including Paleolithic implements from England and one from France. On 7 February 1895, Goode announced the shipment of the specimens to Powell, finalizing the exchange: "I am very glad to be now able to announce the shipment of two boxes containing two hundred and twelve archaeological specimens in exchange for the collection received from you in 1893. I very much hope that the collection now transmitted will be considered a satisfactory equivalent."

\section{Camp (acc. 28914)}

Two handaxes from Africa were purchased by the Smithsonian from J.H. Camp in 1895. Camp was a steamboat operator who had a long relationship with the Smithsonian and who collected a wide range of natural history specimens. Noting Camp's relationship with the Institution, True wrote to F.H. Newell of the National Geographic Society on 19 March 1892: "Mr. Camp has been a correspondent of the Museum since 1885 , and has, at various times, presented collections of natural history and ethnological objects to the Museum, including a somewhat extensive collection from the Congo region. He has never asked for compensation, appearing to prefer to place his collections where they may, in his opinion, be of greatest value. Mr. Camp is in charge of the steamer 'Henry Reed,' belonging to the American Baptist Missionary Union." In a letter dated 19 March 1892, True indicated to Camp that the museum was pleased with their relationship: "Your kind offer to collect additional objects for the National Museum is highly appreciated, and I assure you that we shall be glad to receive and exhibit in your name any specimens which you may find it convenient to transmit to Washington." Years later, Camp expressed his intention to provide more specimens to the National Museum, writing to Secretary Samuel P. Langley on 11 January 1895: "Please remember that I am always ready to do what I can for our Museum in any way and at any time."

\section{Quick (acc. 29853)}

In 1895, an exchange was made for ethnological and archaeological material from the collections of Richard Quick, who was a curator of the Horniman Museum in London. In a letter to Assistant Secretary Goode, dated 7 March, Quick expressed an interest in exchanging material for North American artifacts. On 18 April, Goode indicated that a set of casts of prehistoric implements was being transmitted in exchange for the ethnological and archaeological material. Among the collection sent by Quick were two Paleolithic handaxes from England.

\section{Harrison (acc. 30109)}

In 1895, the Smithsonian purchased a Paleolithic collection (for 5 pounds Sterling) from Benjamin Harrison of Ightham, Kent, England, which is located $40 \mathrm{~km}$ southeast of London. Harrison, who was a grocer, had made significant discoveries of ancient British artifacts at Gravesend, Thames Valley, and at unknown localities, for which he eventually received the Lyell Geological Fund Award from the Geological Society of London (Grayson, 1986). Sir Joseph Prestwich, a famous geologist, and chairman of Geology at Oxford University, had written several publications on Harrison's significant discoveries (e.g., Prestwich, 1889, 1892, 1895). Because the age of the artifacts was controversial, excavations were conducted and additional ancient artifacts were found (Harrison, 1895), although scientists could not agree upon the definitive cultural nature of the 
specimens (Grayson, 1986). The purchase included crudely chipped flint implements, or "eoliths," from the Chalk Plateau, Kent, and from the Thames gravel.

In a letter dated 5 April 1895, Harrison wrote to Wilson about the eolithic controversy and the value of the collection. With regard to the field work associated with establishing the authenticity of the eoliths, Harrison noted: "It has been a long arduous task \& necessitated close \& persistent work \& observation for the past 8 years (though noticed many years before)." Harrison indicated that Prestwich had proven the existence of "eolithic man" in England, and this was now assumed. Harrison also revealed that there was some controversy concerning the existence of the eolithic deposits, stating that "all the scientists who came to examine [the localities] went away convinced $-\&$ those who went to the Plateau [were] equally satisfied as to the geological position-whilst those I have had to fight against refrained from coming to carefully examine." Harrison also noted that the British Association had excavated on the Plateau and had uncovered rudely flaked implements in a seam of gravel underlying seven feet of stratified deposits, which was capped by later Paleolithic tools from the upper two feet of drift.

Regarding the potential availability of collections, Harrison offered to carefully select a series of the eolithic implements, some of the materials originating from the Thames on the 100foot gravel terrace. Harrison noted that the collection could be purchased and informed Wilson that he had "offers from dealers in London... but [was] desirous you should possess because you have been keen on the track of Paleolithic Man" (5 April 1895). The collection from the Thames Valley and the Chalk Plateau was eventually sold.

\section{Hough (acc. 31440)}

In 1896, 16 prehistoric objects from a cave in the "Red Rocks" at Menton, France, were donated to the Smithsonian by Walter Hough. Hough was an employee of the U.S. National Museum, and had personally collected the artifacts in 1893; therefore, there is no correspondence concerning this collection.

\section{Seton-Karr (acc. 32485, 40597, 47957)}

From 1896 to 1907, Sir Henry W. Seton-Karr, who resided in Wimbledon, Surrey, England, corresponded with Smithsonian officials concerning the institution's purchase of natural history specimens, including archaeological collections. The Seton-Karr collections were received with interest, and the account of one of his expeditions was published by the Smithsonian (Seton-Karr, 1906). According to Smithsonian accession documents, Seton-Karr was considered a "big-game hunter" and "discoverer of archaeological sites," who sold objects to various museums. Seton-Karr died tragically at the age of 61 when the ocean-liner he was on, the RMS Empress of Ireland, sank on 29 May 1914 in the gulf of the St. Lawrence River in Canada as a result of a collision (Zeni, 1998).

Seton-Karr had been admitted to the Bar in 1879, and he served for 20 years as a Conservative Member of Parliament (Zeni, 1998). His archaeological discoveries and collecting were recounted by Jacques de Morgan (1926:156-157) in his book, La Préhistoire Orientale:

It is to Mr. Heywood Seton-Karr... whom we owe the discovery of the flint mines in Egypt. It was this great hunter of the most redoubtable animals of Africa and Asia, and who was at the same time an amateur who was as knowledgeable as he was enthusiastic concerning matters of prehistory; it was he who had discovered the beautiful Paleolithic sites of Somaliland [now Somalia]. In India, he had collected some highly interesting Quaternary pieces on the Penaar [sic; Penner] River; finally, passing through Egypt, among other places in 1896, he left his carbine rifles at rest and began to explore the desert. It was thus that he discovered the flint mines of Wadi-el-Sheikh and of Wadi-Sodjour. A very generous man, Mr. Seton-Karr profited numerous museums of these magnificent discoveries, the series of Cairo are indebted to him for hundreds of objects from Upper Egypt and the Fayum, the Museum of Saint-Germain is amply endowed with pieces from Somaliland and I have seen gifts made by this explorer even in the Museum of Malta.

In La Préhistoire Orientale, Morgan (1926:156-157) described many of the localities in Somalia where Seton-Karr worked, noting that artifact assemblages were deposited in the Musée de Saint-Germain, France. Morgan described the Egyptian specimens as chipped stone tools from mines, whereas those from Somalia and India were described as Paleolithic objects. Seton-Karr's collections from these same archaeological localities are now in several museums in Europe and North America.

Seton-Karr (1896) described the circumstances of his Somalian investigations in an article, "Discovery of the Paleolithic Stone Age in Somaliland (Tropical Africa)." In the article he noted he had discovered some stone implements during his third and fourth journeys in Somaliland, and that this was the first evidence of the Stone Age found in tropical Africa. He also mentioned that Sir John Evans doubted the Paleolithic age of the specimens because of their surface position, but SetonKarr was confident of their great antiquity (Seton-Karr (1896:271-272). He also described the reasons for the success of his subsequent explorations: "Equipped with the experiences of four previous expeditions, during which I have traversed the flint producing district in various directions, and now more precisely knowing where they were not to be found, I was able to confine myself to searching the most promising places. I was also better acquainted with the forms of the larger and heavier palaeoliths which I had not previously seen, but which might be expected to occur, of a size equal to those found in the gravel drifts of the valley of the Somme. The result was the discovery of numbers of very heavy and perfect weapons, principally in one spot." The locations of the discoveries were noted as between the Red Sea and $9^{\circ} 30^{\prime} \mathrm{N}$ latitude and between $44^{\circ} \mathrm{E}$ and $45^{\circ} \mathrm{E}$ longitude, in soil that "was and is in process of being gently washed away by showers or blown away by wind, leaving the surface in a gradual state of denudation." 

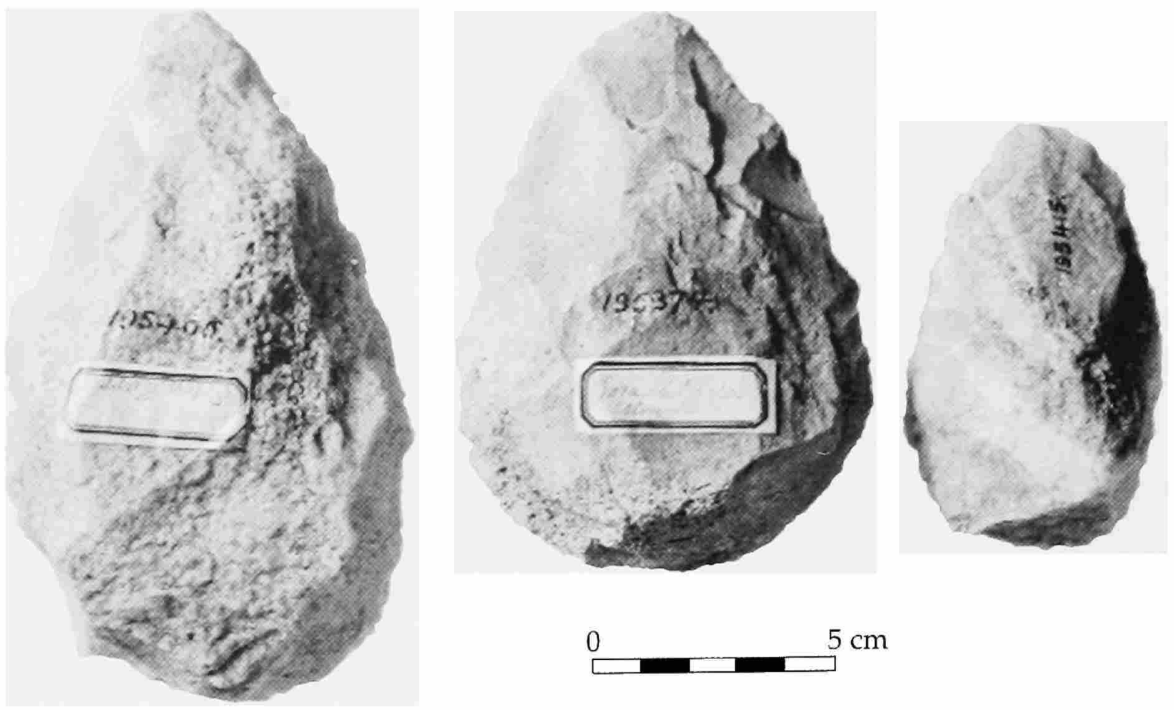

FIGURE 60.-Handaxes [catalog numbers from left to right, 195405, 195374, 195415] from Somaliland [Somalia]. [Seton-Karr accession (accession 32485).]

In a letter dated 29 April 1896, Seton-Karr described his discovery of African Paleolithic objects and expressed his interest in selling some of the objects:

On four out of five journeys in Somaliland [Somalia] I have found some probable Paleolithic stone implements. These are, as far as I know, the first which have come from tropical Africa, excepting a few from Upper Egypt. After reading a paper about previous finds, at the British Association Meeting last September at Ipswich, I determined to make about a month's journey into the interior to about lat. 8.N. from Berbera, and, solely to search for other and larger types than hitherto found. Of the largest types (of quartz and flint) $I$ brought to the coast sufficient [numbers] to be able to spare one or two to each of the principal museums which are able to pay. The only persons who have yet seen them are Sir John Evans, who this week makes a communication on the subject to the Royal Society and Mr. C.H. Read of the British Museum, who came here to see them yesterday and who already has some smaller ones I found on previous expeditions.

In 1897, the Smithsonian purchased this Paleolithic stonetool collection from Seton-Karr (Figure 60). After another field visit to the same area, Seton-Karr wrote a letter on 28 June 1897, offering additional materials: "I returned from the E.[ast] about 3 weeks ago, \& wish to ask if you desire to acquire some of my new Somaliland Palaeoliths, the most perfect known, and from the only palaeolithic locality ever discovered." SetonKarr then described the number of specimens available for purchase and their prices. In a response on 14 July 1897, True indicated the Smithsonian was interested in making a second purchase: "The various propositions contained in your letter of June 28, with reference to selling to the Institution some of your paleoliths from Somaliland, have been duly considered, and I now take pleasure in enclosing an order for a series of fifty at a cost of ten pounds. Please select as perfect specimens as can be supplied." Seton-Karr replied in July of 1897: "I have sent the implements from the Palaeolithic City in Somaliland. As it was for the Smithsonian Instit.[ution] I have sent a good deal more than the 50 you requested, \& as perfect a series as I could. I should be glad if you could keep the series together as much as possible. I have packed them in five boxes ( $\&$ two packets of flakes from Marodijeh $20 \mathrm{~m}$. S. of the 'City'), all enclosed in a steel case."

Several years later, Seton-Karr sent labels for the Somaliland artifacts that were then on display at the National Museum. Assistant Secretary Rathbun acknowledged their receipt in a letter to Seton-Karr dated 17 October 1902: "I am informed by Mr. W.H. Holmes, Head Curator of the Department of Anthropology, that the labels have now been placed as requested on the stone implements from Africa which you were so good as to present to the Museum." Exhibit cards that were placed with the artifacts in the 1930s described Seton-Karr's expeditions. The first card, entitled "Early Man in Africa" (an extract from the Journal of the Royal Geographical Society, 1931), stated: "Mr. Seton-Karr found prehistoric implements in East Africa in 1893-the first ever found there, although some had been discovered in South Africa in 1866, by Dale. The late Sir John Evans, Treasurer and Vice-President of the Royal Society, wrote concerning them (see proceedings of the R.S. [Proceedings of the Royal Society] 359:19, 1896). "Mr Seton-Karr was fortunate enough to meet with specimens in form absolutely identical with those from the valley of the Somme (in France) and we need not hesitate in claiming some as palaeolithic." The second card, entitled "Man's Early African Ancestors" (dated 1935), read:

Mr. H.W. Seton-Karr during nineteen expeditions to Somaliland, E. Africa, has concluded his examination of the district round Hargeisa. The prehistoric stone 
tools are found in certain spots where Palaeolithic Man seems to have lived, and where the surface could neither be washed away nor the site buried. Chellean, Acheulean, and other types are represented. It has been shown by the East African Archaeological Expedition to Kenya, from the deposits and lake-beds near Nakuru and other places that the artifacts date back to the Mindel-Riss interglacial (before the 2nd Major-pluvial or Gamblian) or even up to the 1st Major-pluvial or Kamasian, corresponding to the Guntz-Mindel glaciation in the Alps.

In addition to the Somalian material, Seton-Karr donated materials collected in India. The first accession consisted of 15 Paleolithic implements from the laterite deposits of Poondi, 29 miles (46 km) west of Madras, India. On 1 January 1903, Seton-Karr wrote that he shipped 96 implements found in the laterite deposits at Poondi and requested that the Smithsonian coordinate the distribution of these materials as follows: the National Museum would retain five good examples and 10 others; other institutions would get the 81 remaining pieces, including the University of California at Berkeley; the Field Columbian Museum, Stanford University; Amherst College; the University of Pennsylvania; and the Drexel Institute (now University) in Philadelphia. In a memorandum dated 19 February, Holmes wrote to Mason stating that he would assist in distributing the specimens according to Seton-Karr's wishes. On 9 March 1903, Rathbun wrote the following form letter to the six institutions: "At the request of Mr. H.W. Seton-Karr (31 Lingfield Road, Wimbledon, S.W., London, England), I am sending you by express a box containing some Paleolithic implements which he collected in the lateritic deposits at Poondi, near Madras. Mr. Seton-Karr begs that you will accept the specimens for the institution over which you preside; that they be suitably exhibited and labeled; and that you will send him an acknowledgment of their receipt."

Stimulated by a personal visit to Washington in 1907, SetonKarr wrote to Rathbun on 23 June, asking him about the exhibits: "I forgot whether during my last visit to Washington you said that there would be a gallery or place devoted to the Stone Age of Europe, Africa, and Asia; my impression was that at present the foreign things were not represented. I think I donated Somali, Egyptian, and Indian collections to you? I should be pleased to present my own private collection of selected implts [implements] if you would inform me whether it is intended to add a prehistoric foreign gallery to the Museum." Holmes drafted a memorandum for Rathbun, stating the following:

I was pleased to hear from you and glad that you made the inquiry in reference to our exhibit of archeology, from Europe Africa and Asia. I may say that the nucleus of a collection in which your contributions occupy a prominent place in value and importance is exhibited in the great Hall of Prehistoric Archeology where as much as is possible under our present limited space is put on view. The new building will allow healthy expansion and there will be a separate hall or space devoted to Europe Asia and Africa. Permit me to thank you in the name of culture history students for your interest in this research and in museum-building and to assure you that your contributions of prehistoric objects are much appreciated.

Rathbun responded to Seton-Karr on 10 August 1907, indicating the importance of the future exhibits:
Replying to your inquiry as to whether it is the intention of the Museum to provide for the exhibition of prehistoric foreign objects, I would say that the nucleus of such a collection, in which I need hardly mention that your contributions occupy a prominent place, is already on exhibition in the Hall of Prehistoric Archeology in the Smithsonian building, where as much space as is now possible has been assigned to it. In the new Museum building, now in the course of erection, it is planned to have a separate section entirely devoted to the archeology of Europe, Asia and Africa, and in this space, I shall be very glad to exhibit your own collection, which you have so generously offered to present, and which, I may add, the Museum will be glad to receive.

Apparently satisfied with responses from both Holmes and Rathbun, Seton-Karr then donated a second collection of material from India.

Seton-Karr wrote to Rathbun on 19 September 1907, describing the provenience of the Indian objects and the nature of their discovery: "In accordance with my promise I have much pleasure in donating the following from my private colln. [collection] to your Museum if you will honor by accepting them. ...The remainder consist of a splendid series of Paleolithic Implements from the pleistocene lateritized alluvium of the Pennaar [sic; Penner] river valley, now high up on the hillsides, and dug from a depth of many feet, generally by natives digging water-pits. I hope you will be able eventually to give them a good location with suitable inscriptions in the new foreign prehist. sec. of the National Museum." Regarding labels, Seton-Karr made a request: "Might I suggest that when Museum labels are attached it makes it more interesting if it is made plain that the donor is (as in this case) also the finder; otherwise the objects might be supposed merely to have been purchased" (Figure 61). Assistant Secretary Rathbun replied on 19 November 1907: "Mr. W.H. Holmes, Curator of Prehistoric Archaeology, considers the collection to be one of exceptional interest and value, and I can assure you that it will be exhibited to the best advantage in the foreign prehistoric section of the Museum. I entirely concur with you opinion that, in cases where

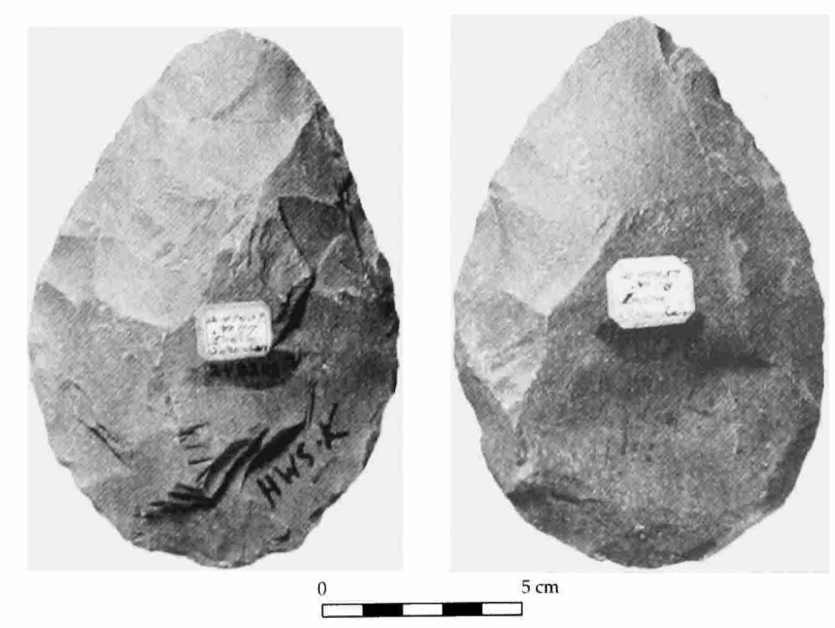

FIGURE 61.-Handaxes [catalog numbers 248202 (left), 248203 (right)] from Penaar [sic; Penner] River valley, India. [Seton-Karr accession (accession 47957).] 
the collector and donor of specimens are the same person, the label should signify this fact, and I have directed that this be done with reference to the present gift."

\section{Miguel (acc. 36097, 43727, 44831, 46030)}

Beginning in the late 1890s, the Smithsonian made exchange agreements with Jean Miguel, a geologist from Barrubio, Hérault, in southeastern France. In 1898, a collection of geological and paleontological material was sent to Miguel, and in letter dated 15 December 1899, Miguel indicated that material from Hérault and a neighboring region were being sent, in exchange for the fossils from the United States. Sometime during 1899, the first archaeological material from him (acc. 36097) was received.

In 1905, a gift of two lots of prehistoric specimens from France and Algeria were sent to the Smithsonian by Miguel (acc. 43727, 44831). In an undated letter to Mason, Miguel wrote: "I have the honor to send you by post a small collection of prehistoric objects from France and Algiers. If it suits your convenience, I would like to make...exchanges, and hope that I will be able to give you entire satisfaction. I have tried to offer you especial types. An analogous sending from your country would be entirely to my liking." Apparently the Smithsonian did send specimens as an exchange, as indicated by Miguel's letter to Langley, dated 15 June 1905:

Several days ago I received the fine lot of prehistoric objects which you were good enough to send me. I thank you for it. For many years I have been on the best relations with the U.S. National Museum for the exchange of geological and prehistoric objects. I shall be happy to continue them. I beg you to transmit to the authorities of the Smithsonian Institution my offers for important collections of chipped flint and of fossils from the best deposits of France. I shall add to my next exchange a complimentary box of prehistoric specimens to complete the compensation for your last sending.

Although Miguel was apparently satisfied with the previous exchanges, he wrote to the Smithsonian on 5 August stating that he had an additional 50 prehistoric items, but that this time a purchase by the Smithsonian would be most desirable, as he was in need of funds. He noted that the price for the material was very reasonable, one-half or even less than the normal price. Upon receipt of this proposal, Assistant Secretary Rathbun solicited the advice of anthropologists in the U.S. National Museum. In a memorandum to Head Curator W.H. Holmes, dated 19 October, Smithsonian anthropologist E.P. Upham forwarded the results of his review of the existing collections: "The specimens heretofore received from Mr. Miguel are mainly from the caverns in southern France, and although interesting in themselves do not add much except as duplicates to the collections we already have. With the exception of a few specimens from Algeria, the Wilson collection recently acquired covers about the same ground with a representative series of objects. Still the offer of ' 50 good, various and well preserved prehistoric objects' might be worth considering." After considering this offer, Rathbun replied to Miguel on 30 October: "The Museum will be pleased to continue to exchange specimens with you, but cannot purchase any new as it has no funds available for the purpose. The fifty prehistoric objects referred to in your letter of August 5th, may be forwarded at any time. Unless there are certain special classes of objects which you desire to obtain in return, I will endeavor to have a suitable equivalent selected for you from the duplicate series of specimens." In a letter to Rathbun, dated 10 May 1906, Miguel noted that he would send additional material as another exchange (acc. 46030), but he also made a stronger appeal that future sendings must be through purchase:

I had prepared a fine collection of large and small museum specimens; but, when I came to send them, the expense of carriage was too great for my slender purse. I had to replace the large flint prices by much lighter bones. I hope, however, that the collection thus modified will still be to your taste. It includes some very good specimens. In return, I shall receive with great pleasure anything you may be fit to give me in the way of chipped stone, preferably arrowpoints. It would be an easy matter for me to send to you flint and fossil specimens of every age, superb specimens... but, in addition to making exchanges, it would be necessary to purchase a case from me time to time, as other museums do, in order to recompense me a little for carriage and the expense of excavating. I should send good things, cheap, and I am sure you would be pleased. If you would order a trial collection for 100 francs in geology or even in prehistoric specimens, you would be at liberty to lower the price or to return the box if you were not satisfied.

After this final accession was received, correspondence with the Smithsonian ceased, and no additional purchases or exchanges were made with Miguel.

\section{McGuire (acc. 37330)}

In 1900, an archaeological collection was donated to the U.S. National Museum by Judge Joseph D. McGuire of Washington, D.C. The assemblage consisted mainly of a private collection of North American material, but within the collection was material from Paleolithic sites in France. A few years earlier McGuire had published "A Study of the Primitive Methods of Drilling" in the Report of the U.S. National Museum for 1894 (pages 623-756). McGuire wrote to Secretary Langley on 7 April 1900 to inform him that he had been in contact with Baird, Wilson, and Holmes for many years. The letter concerned the North American collection but did not mention the Paleolithic material.

\section{Steierli (acc. 38268)}

In 1901, a collection of Paleolithic material was donated to the U.S. National Museum by Professor J. Steierli of the University of Zurich. Most of the material was from a cave near Schaffhausen, Switzerland, although a few objects were from Dordogne, France. In a letter dated 10 May 1901 to the American Consul at Zurich, Steierli noted that the collection was a "gift to the U.S. National Museum in Washington (Prehistoric Division, Tho.[mas] Wilson, Curator)." He enclosed his book, Urgeschichte der Schweiz, and "a small collection from the famous cavern, Kesslerloch, Thayngen, (Schaffhausen)," which included breccia, cores, waste, scrapers, knives, perforators, 
gravers, and animal bones. A. Lieberknecht, United States Consul in Zurich, arranged the material transfer. Following this, the Third Assistant Secretary, United States Department of State, wrote to Secretary Langley, on 10 June 1901, that a book and two boxes of specimens were being sent to the museum.

\section{Else (acc. 38778)}

In 1901, a collection of archaeological specimens from Kent's Cavern was purchased from W.J. Else, curator of the Torquay Museum, England. In a letter dated 13 September, Else indicated that the material was from the original Pengelly excavations:
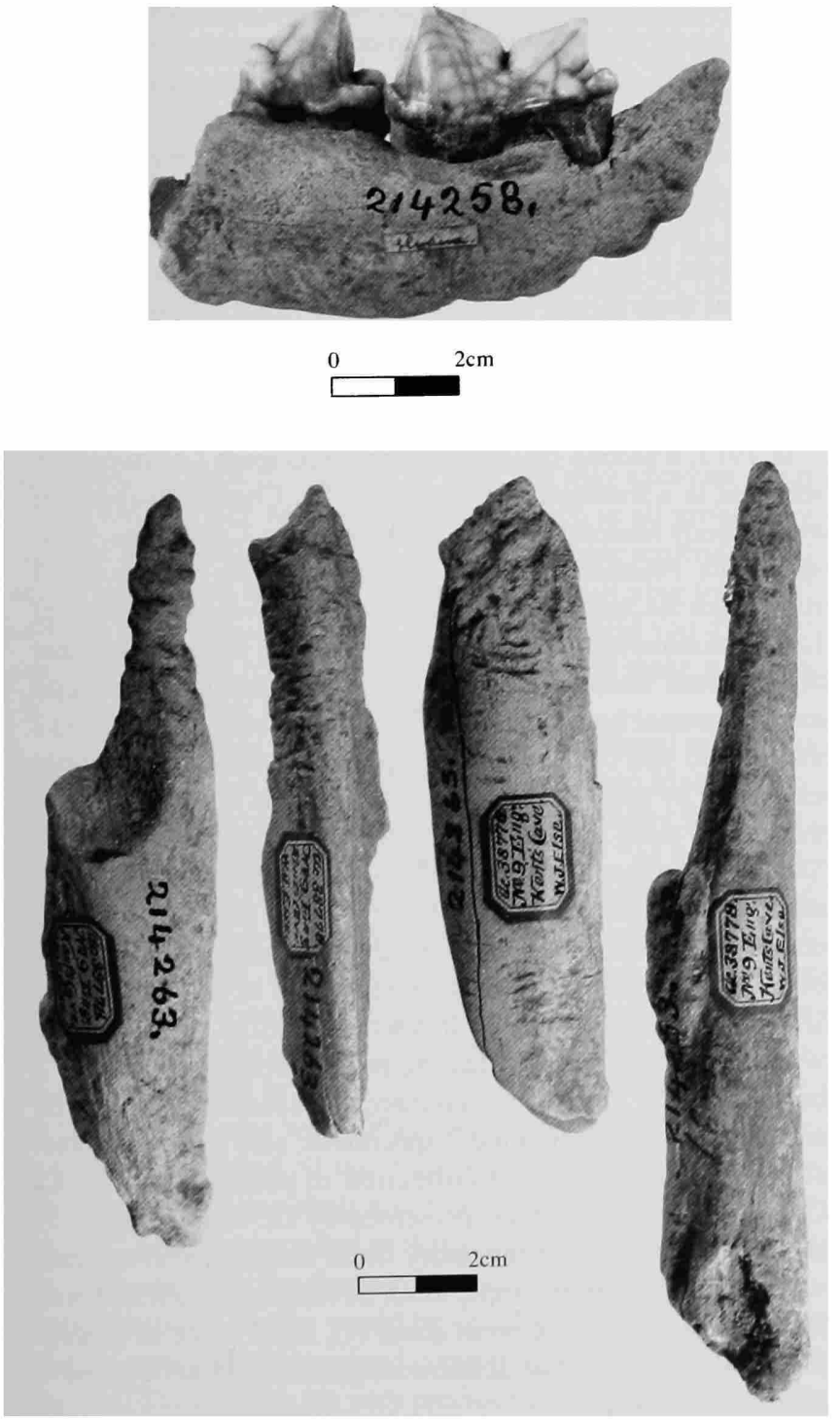

FIGURE 62.-Hyaena mandible (top) [catalog number 214258] and gnawed bones (bottom) [catalog number 214263] from Kent's Cavern, England. [Else accession (accession 38778).]
I am sending you a rough list of a collection of Kent's Cavern remains which I have for sale. I expect you to have heard all about the cavern... [and] the reports of the exploration. [Given the need for]...space for other things, I want [to] the sell most of them. I would take L6 for them. The Director of Museums at Liverpool H.C. Forbes Esq. L.L.D. advised me to write to you. The name of the deposits from which the specimens were taken I can give you, as they were packed are to be found in the British Association Reports 1865 to 1880 . My father was the curator of this museum for 25 years, until his death in 1896 and helped Mr. Pengelly, the explorer of the cavern, a good deal, and just before Mr. Pengelly was taken ill he gave 6 or 7 large boxes to my father, and most of them contained Kent's Cavern remains. I have had them in cabinets at my home.

On 17 December, Else provided a list of objects from Kent's Cavern that he described as flint scrapers, worked flakes, and bones of "mammoth, Irish elk, hyaena, cave bear, lion(?), and horse" from the "Cave Earth," and samples of the "Granular Stalagmite" and the "Black Band" deposits. Among the faunal pieces in this collection are a hyaena mandible and gnawed, long, bone fragments (Figure 62). In an internal Smithsonian memorandum of 15 October 1901, anthropologist Thomas Wilson wrote that he found the Kent's Cavern collection of interest: "We have quite a number of examples from Kent's Cavern, received during the excavation. But these (in this list) are interesting. The price is not exorbitant \& I suppose other museums would gladly pay that sum for them. This would furnish us with a good showing from that cavern $\&$ that country $\&$ that epoch." In a memorandum dated 26 October, the Acting Chief Clerk wrote to R.I. Geare, the chief of the Division of Correspondence and Documents: "By direction of the Assistant Secretary I send herewith for transmission to W.J. Else of the Museum of Torquay, England...covering a collection of Kent's Cavern Remains ... the price agreed upon being $\$ 30$ [about $\$ 731$ in 2003 dollars]."

\section{Albany Museum (acc. 43544)}

In 1904, an exchange was made for an assorted collection of stone implements from the Albany Museum, in Grahamstown, Cape Colony, South Africa. The accession was acquired through Dr. Selmar Schönland, who was the director of the museum. Correspondence between Schönland and Smithsonian officials dates from 1889 , the majority of which concerns the exchange of biological specimens. For example, in a letter dated 18 September 1889 , Schönland mentioned his interest in receiving an exchange for some of his archaeological materials: "I should be very happy if the exchanges instituted between the Smithsonian Institution and the Albany Museum would be continued. At present I can only offer you a number of ... rocks from the Transvaal, ... but if you would let me know what you would like to have from this colony I would write to some of our numerous correspondents who would not fail to assist me in collecting for you."

It was not until five years later, however, that the exchange of archaeological material commenced. Schönland wrote to Assistant Secretary Rathbun on 5 September 1904 that he intended to send shortly "a consignment of stone implements 
from South Africa for which I would like to have some more ethnological specimens from North America in exchange." In an undated letter, Rathbun replied: "Regarding the new exchange which you propose, we shall be pleased to receive the stone implements, etc., offered, and will endeavor to send you a suitable equivalent in North American ethnological objects, as you desire." The material was sent to the Smithsonian, as noted in Schönland's letter to Rathbun on 26 September 1904: "I have pleasure in informing you I have to-day forwarded... a box containing stone implements from South Africa. I trust that your specialists will find a few things amongst them that may be of interest to them." In a list provided by Schönland, he noted that the archaeological material was of variable ages, including relatively late material, consisting of "bushman" and "pigmy" artifacts from open-air sites and caves. Of the material that he considered of "extreme antiquity," there were artifacts from East London, Cape Colony, from a gravel bed below aeolian rock, and from a mud 70 to 80 feet above the Buffalo River. Artifacts from the Bezuidenhout Valley, Transvaal, had been collected by J.P. Johnson (1904), who attempted to place the items in a culture-stratigraphic sequence, from the Eolithic to the Neolithic.

\section{Nightingale (acc. 46550, 49416)}

The Reverend Robert C. Nightingale of Beachamwell Rectory, Swaffham, Norfolk, England, donated two collections of archaeological material to the Smithsonian. The first donation was proposed in a letter to the director of the Bureau of American Ethnology, dated 9 October 1905, in which Nightengale provided some information about the Swaffham material: "This Parish is on the chalk; and flint is found on and very near the surface. My idea is, the prehistoric men came here, to hunt and to work the flint, in the summer on the higher grounds. We are just on the edges of the fenland, and the adjoining provinces are Bar (Bear) ton, Ox (from the wild oxen) borough." On 16 November, Assistant Secretary Rathbun accepted the offer. On 17 August 1906, Nightingale wrote to Rathbun and stated: "I propose forwarding to your agency... a box containing fourteen packages of flint implements and one package of Romano-British Pottery, etc. The implements have been mainly selected to show processes of manufacture. Generally the contents of each package have been in one spot, and if not they have been found near together." Regarding the Paleolithic objects, "The flints are selected from over a thousand specimens. With respect to parcels 12 and 13 , I would refer to 1161 or (perhaps) 1242 bulletins from Reports of [the] Smithsonian Institution." In 1908, a second collection of worked flint was accessioned as a gift. Four pieces were chosen to illustrate the process of producing a scraper, four were finished scrapers and three were 'potboilers.' In a letter to the Secretary, dated 9 September 1908, Nightingale noted that the pieces were found in Swaffham.

\section{Martin (acc. 47416, 55671, 71635)}

For twenty years, from 1907 to 1926, Dr. Henri Martin, a Parisian medical doctor and the excavator of La Quina, in Charente, France, corresponded with Smithsonian officials. They wrote about exchanging North American material for Middle Paleolithic collections from La Quina and about scientific issues regarding the Neanderthals. The first of three accessions of La Quina material from Martin was made in 1907. In a letter dated 6 February 1907, probably to Walcott, Martin wrote: "I have just received your box containing the 2 humeri of bisons which I had asked for. They give me the greatest pleasure and will enable me to make comparisons with our Quaternary bison. I shall at once forward some Mousterian flints from La Quina for the U.S. National Museum, and am glad to know that they are esteemed in America. Our distant Stone Age is abundantly represented in France, and the few specimens that I shall send you will probably fill a gap in the museum." Months later, on 12 May, Martin sent the material to the Smithsonian and wrote: "Finally I have sent you a case of worked flint, demonstrating the Mousterian period. I have found them in the site of La Quina (Charente) France. I should have sent them to you long since, in exchange for the two fine humeri of the bison which you sent me, but I have always delayed the sending-being much occupied with my many patients."

In 1913, a second collection of artifacts from La Quina was received in a transaction arranged by Dr. Charles Peabody of the Peabody Museum of Harvard University, Cambridge, Massachusetts. Peabody queried Head Curator W.H. Holmes on 13 June about the Smithsonian's interest in receiving a donation of La Quina material: "May I trouble you as far as to ask whether the National Museum has any of the 'Moustérien' flints and marked animal bones from La Quina (Charente, France). As I think I told you Dr. Henri Martin presented three series (partly excavated by Mrs. Peabody \& myself) and is anxious (I think) that one of these should be presented in his name to the United States Government." On 18 June, Assistant Secretary Rathbun replied to Peabody: "We shall be very much pleased to receive one of the series of the specimens above mentioned, which you believe Dr. Henri Martin wishes presented in his name to the United States Government." In a letter dated 28 June, Peabody wrote to Holmes: "I take pleasure in forwarding you this day a box containing 12 packages containing 6 specimens each (with an extra package containing 2 specimens; also a piece of breccia) - 75 in all, being the collection of palaeoliths from La Quina, (Charente), France, presented by Dr. Henri Martin, 50 rue Singer, Paris." The inventory listed scrapers, gravers, rude worked flakes, flakes, chips, tooth of reindeer, tooth of horse, bones of ox, bones of Cervus dama (?), and 1 piece of breccia. Rathbun sent letters of acknowledgment to Peabody and to Martin on 16 July.

Martin and Hrdlička met in 1912, after Martin had made major discoveries of Neanderthals at La Quina. Hrdlička made some of his major anthropological conclusions based upon the 
La Quina specimens. Like Hrdlička, Martin thought that the Mousterian had shown an increase in technological sophistication from its earlier phases and was indicative of a gradual transition from earlier stone-tool industries (Spencer, 1979; Spencer and Smith, 1981). Hrdlička corresponded with Martin on matters relating to La Quina and the acquisition of casts of the recovered Neanderthals. On 27 August 1913, Hrdlička requested additional information on La Quina from Martin, noting that he was writing a brief summary of the most important discoveries in Europe relating to "early man," for inclusion in Smithsonian publications. Hrdlička thanked Martin for sending the La Quina cranial and postcranial casts in exchange for $\mathrm{Na}-$ tive American crania and requested additional cast reconstructions. From 1922 to 1926, Hrdlička and Martin corresponded regarding the acquisition of casts, and during a visit to France in 1923, Hrdlička met with Martin. After the visit, Hrdlička wrote to Martin on 12 November 1923, indicating his interest in the site: "I have brought back a very vivid recollection of your site at La Quina. You have a hard and long work before you and I trust you will be able to carry it out to the end for it seems to me that the deposits are bound to give you such valuable information; they are quite unique in some of their features. I shall be glad to hear of any discoveries that you may make." Further evidence of Hrdlička's intense interest is shown in his letter to Martin dated 8 May 1926: "I suppose that before long you will be leaving again for your cherished spot in southern France. I hope that sooner or later you may excavate again in the old and rich Mousterian layers which in all probability contain additional treasures. At all events please remember that every bit of news from you as to the progress of your work will always be of genuine interest to me; and should you discover any new skeletal remains I should endeavor to make it known at once in a proper form in our country."

A third exchange was made in 1924 for additional specimens from La Quina. On 14 December 1923, Dr. Henri Martin wrote to Secretary Walcott, inquiring about the possibility for acquiring faunal material for comparative purposes: "At the suggestion of my friend Dr. Hrdlička I write to ask whether you could let me have by way of exchange some skeletal pieces of the blue fox. A skull, even if defective, and some bones of the limbs would be sufficient for me. I could send you some bones - teeth principally - of the reindeer, bison and Mousterian horse, as well as Ursus spelaeus." On 7 January 1924, W. de C. Ravenel, who was the administrative assistant to Secretary Walcott, replied: "I take pleasure in announcing the transmittal to you of one skull and four feet and leg bones of the Alopex." Martin responded to Walcott on 26 January, indicating his pleasure with the faunal remains and describing the exchange material that he would be sending: "I thank you for the sending which I have received containing skeletal pieces of the blue fox. These bones are very precious to me to compare those of the Mousterian fox of the Charente which differs from our present fox: and the fossil fox has affinities with the one from Alaska. I am sending you some pieces; but in Charente I own numerous specimens, while in Paris I cannot send you any important series. Nevertheless here I have made a selection of pieces from the museum." The collection consisted of five Mousterian flint scrapers and three worked bones. In the letter of 26 January, Martin provided one photograph and three sketches of bones. The photograph is of a first phalanx of a horse, in Mousterian context, noted to have "utilisation profonde." One sketch is of a first phalanx of a bovid, from Upper Mousterian deposits. On the sketch Martin noted that there is on one face of the anterior section a zone of grinding, suggesting the piece was used for compression. In the sketch of the left astragalus of a reindeer, there are traces on the internal face corresponding to disarticulation of the tibio-tarsals. The third sketch is of a first phalanx of a horse found in the Upper Mousterian deposits. On the anterior face there are deep grooves. Ravenel, administrative assistant to the Secretary, sent a formal acknowledgment to Henri Martin on 22 April 1924 for the collection.

\section{Stonestreet (acc. 49689)}

In 1909 , a collection of roughly shaped stone implements found near Christiana, southwestern Transvaal, South Africa, was donated by George D. Stonestreet of New York City. There are no documents referring to this collection except for a visiting card, referring to Stonestreet's delivery in person.

\section{Musée d'Histoire Naturelle, Elbeuf (acc. 49696, 50268)}

In 1909, two exchanges were made with the Musée d'Histoire Naturelle, Elbeuf. During 1908, the director of the museum, Professor L. Coulon, and Smithsonian officials corresponded about possible exchanges. Coulon wrote on 9 June 1908: "You asked me for some archeological objects. I imagine you desire objects of prehistoric archeology, that is to say, tools of flint. In that case I shall be able to give you full satisfaction. Please let me know if these are what you desire, and I shall act immediately." On 29 June, Head Curator Holmes dictated to W. de C. Ravenel what should be said in reply: "We are glad to receive, in exchange, collections illustrating the prehistoric archeology of some particular district in France, especially if arranged to show the successive stages and purposes of culture." Ravenel expressed Holmes' wish on 3 July, in a letter to Coulon. Coulon replied on 29 October, stating that he had just received some very important local collections and would take up the exchange soon. In a letter dated 1 January 1909, Coulon wrote: "I send you 4 boxes containing a certain number of prehistoric flint objects from this vicinity. I have selected them as carefully as possible; but, as I am not very well informed on the subject, I beg you to tell me candidly whether you are satisfied with them. If not, I shall send another lot after consultation with a competent person who will select the specimens for the collection. I have done my best to please you. If I have not succeeded, it is owing to my ignorance." Coulon indicated that the 

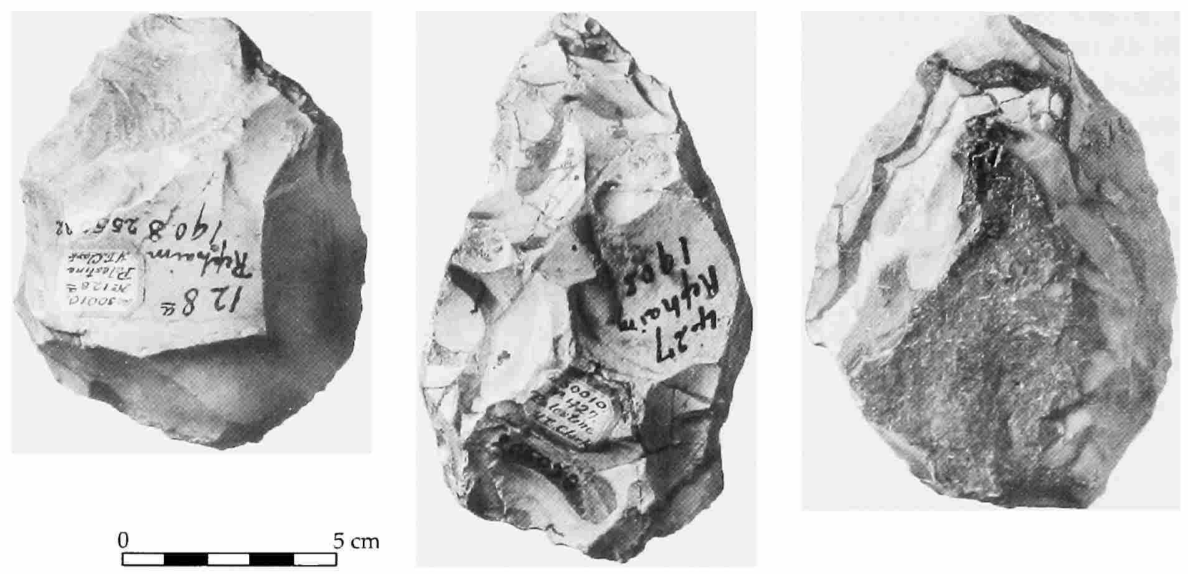

FIGURE 63.-Handaxes [catalog numbers from left to right, 255082, 255078, 255090] from Rephaim, Palestine. [Clark accession (accession 50010).]

collections were from the vicinity of Elbeuf, including Petit-Essarts, Commune of Grand Couronne, from Paleolithic clays of the plateau, at about 114 meters; Radepont, in Eure, from clays along the coast; and St. Julien de la Liégne, in Eure. In an internal memorandum to anthropologist Walter Hough, dated 11 February 1909, anthropologist Edwin P. Upham indicated that the collection was evaluated and found to be "adequate." The materials also were noted to be from "localities not heretofore represented in the Museum," and therefore were considered "a fair exchange." On 17 February, Ravenel thanked Coulon for the prehistoric flints, noting that they "constitute a satisfactory equivalent" to the exchange for biological specimens.

In the summer of 1909 , a second exchange was made for materials from the same localities, as well as material from Critot. Coulon was prepared to send additional material, as noted in his letter of 7 June 1909: "I have just got ready two little boxes of prehistoric flint specimens which I am going to forward to you at once. They are from the same deposits as the preceding ones, and will enable you to complete the series. I have selected them with the greatest care." The material from Critot (Seine-Inférieure), France, was Mousterian in age. In exchange, Coulon expressed interest in receiving additional biological specimens. In a memorandum to Hough dated 13 July, Upham noted that the material was complementary to the first accession: "The specimens belonging to this accession... forwarded by Prof. Coulon, are entirely satisfactory, and with the former sending (No. 49696), make an instructive exhibit from the prehistoric stations." In a letter to Coulon, dated 19 July 1909 , Ravenel noted that the boxes of archaeological material had arrived safely, the specimens were satisfactory, and the collection would be recorded as an exchange for duplicate biological materials.

\section{Clark (acc. 50010, 57311)}

In 1909, a collection of objects from Bethlehem, near Jerusalem, was received from Herbert E. Clark, United States ViceConsul for Palestine. In a letter of 19 April 1909, written by Herbert's brother, Frank C. Clark, it is stated that a collection of flint objects was being donated to the museum. In a reply to Herbert Clark, on 7 May, Assistant Secretary Rathbun stated: "These specimens are very interesting, and constitute a most acceptable addition to the collection of archeological objects from the Holy Land." On 15 May 1909, Herbert Clark wrote from Jerusalem, describing his finds. He indicated that he had collected so many flint implements that he felt some should be sent to the Smithsonian and some to the British Museum. Clark noted that he found the stone artifacts (Figure 63) in 1907 "along a water course and depression of the Plain of Rephaim, Gen. XIV, 5; Joel [sic; Joshua] XV, 8; XVIII, 16-an extensive Paleolithic camp half a mile long....The place on the Plain of Rephaim is one mile from the Jaffa Gate of this city in a S.W. direction." In 1914, a second collection of chipped-flint implements, from a valley west of Samaria in Palestine, was donated by Clark. The second accession contained no other documentation because Clark made his presentation in person, leaving only his calling card.

\section{Gorjanović-Kramberger (acc. 54826)}

In 1912, plaster casts of hominid skeletal remains and associated stone implements from the site of Krapina, Croatia, were donated to the U.S. National Museum by Dr. D. Karl Gorjanović-Kramberger, of the Narodni Museum, Zagreb. Gorjanović-Kramberger was a Croatian paleontologist and was the principal excavator of the Krapina cave. Hrdlička visited the Narodni Museum in 1912, and afterwards he wrote to Gorjanović-Kramberger on 10 October requesting skeletal casts of the Neanderthals from Krapina: 
I had the pleasure during the latter part of July to visit your museum, though regrettably you were just then absent. Professor Suklje showed me very kindly your precious collections of the human remains from Krapina, and I begged him to ask you for one or two casts of the complete lower jaw... for the U.S. National Museum. We now possess in plaster the representations of nearly all the skeletal materials of ancient man, but have nothing from your collection, which I regard as one of the greatest possible interest and value. With your permission, I beg to renew herewith my request and trust that you will favor us with my request and trust that you will favor us with the desired casts.

In a letter dated 25 November 1912, Hrdlička thanked Gorjanović-Kramberger for the casts. Gorjanović-Kramberger and Hrdlička maintained a collegial friendship for many years thereafter, and he later became a defender of Hrdlička's thesis that Neanderthals were direct ancestors of modern humans (Trinkaus and Shipman, 1992).

\section{Talken (acc. 54988)}

In 1913, a collection from South Africa was donated to the U.S. National Museum by Albert Talken of Windsorton, Cape Province. An introductory letter concerning the gift was written by William A. Haygood, United States Vice Consul-General to South Africa, on 19 November 1912: "I have the honor to report that Albert Talken, a Pensioner of the United States Government, who is engaged in digging diamonds near Windsorton, on the Vaal River, Cape Province, has sent to this Consulate-General a package containing 8 stone implements" (Figure 64). In the letter, Haygood quoted Talken's correspondence to him: "I have sent you a parcel of stone implements. We call them 'Battle Axes.' I got them in a shaft $24 \mathrm{ft}$. deep, about 200 yards from Vaal River. They are in the gravel [in] which we find diamonds. An eternity must have gone by since they were deposited there. I would like to send them to the Museum, but you may do what you like [with] them." In the letter, Haygood stated that he submitted the stone implements to Dr. L. Peringuey, the director of the South African Museum, to ascertain if they were of sufficient historical interest to jus- tify sending them to the United States. Haygood paraphrased Peringuey's response:

With regard to the Stone Implements you showed me, and which were sent to you from Windsorton, on the Vaal River, Cape Province, it is impossible for me to assign an age, beyond saying that they are of a type considered to be... very old; the designation for these artifacts being 'palaeolithic.' The specimens are of very great interest owing to their situation; and I have dealt with these and similar objects, at length, in a paper 'The Stone Ages of South Africa,' in the Annals of the South African Museum. They are found in a gravel and boulder-bed situated from 50 to 80 yards from the present bed of Vaal River, and it is in these gravels that search is made for diamonds (the dry diggings of the miners).

Assistant Secretary Rathbun wrote to Haygood and Talken on the 7th and 8th of February 1913, respectively, acknowledging the shipment and indicating that "the specimens are of particular interest and value on account of the bearing they have on the general question of the antiquity of man."

\section{Rehlen (acc. 55321)}

In 1913, an exchange was made with Dr. W. Rehlen, of Nurnberg, Germany, for Egyptian stone artifacts. The nature of the exchange was described in a letter dated 12 July 1912, from Holmes to Assistant Secretary Rathbun: "Recently Mr. Wilhelm Rehlen, Vicepräsident des Verbandes Bayerischer Geschichts-and Urgeschicht-svereine und der Anthropologischen Gesellschaft, Nurnberg, visited Washington, bringing a letter of introduction from Clarence B. Moore of Philadelphia. This letter is as follows: 'Prof. Wilhelm Rehlen is on his way around the world in quest of evidence relating to Paleolithic times. He has had the Abbott side of the Trenton gravels, and is visiting Washington expressly to see you. He is, as you know, about the foremost man in Bavaria in his specialty'." Head Curator Holmes described his meeting with Rehlen, noting that he sought an exchange for American specimens:
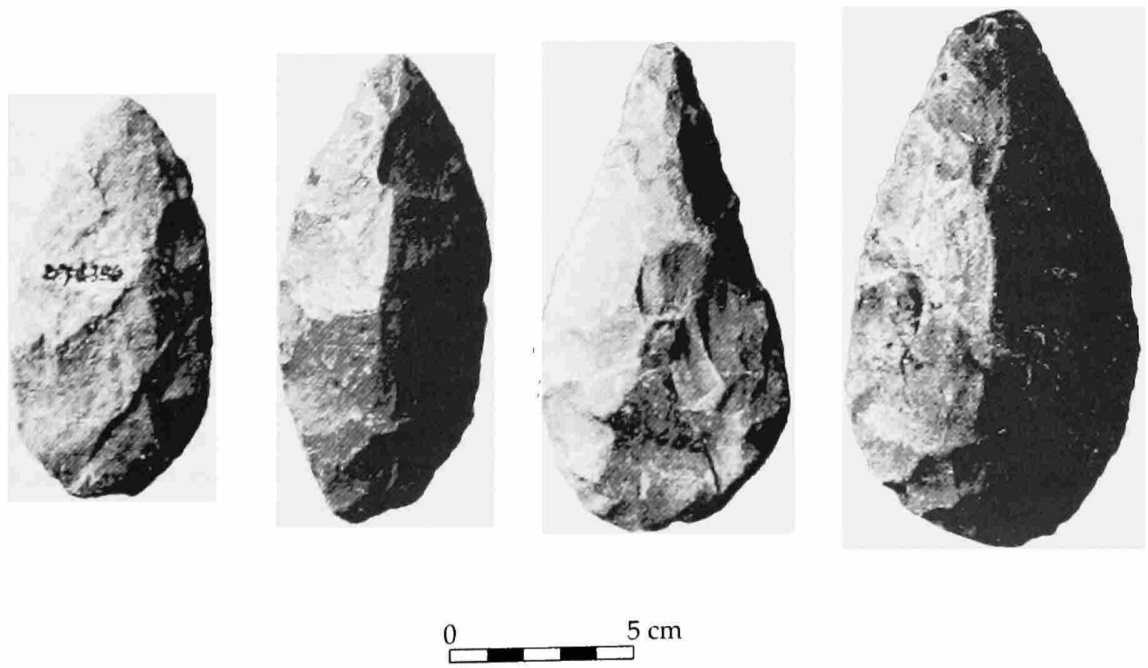

FIGURE 64.-Handaxes [catalog numbers from left to right, 276191, 276189, 276186, 276184] from Windsorton, South Africa. [Talken accession (accession 54988).] 
Mr. Rehlen spent a day with me and I had considerable difficulty in getting him to understand the true conditions in American Archeology relating to the Paleolithic man, and I shall be extremely glad to be able to forward to him a set of the Piney Branch relics. Mr. Rehlen was anxious to get, not only some of these specimens, but a few representative pieces of the various classes of American stone implements. He is willing to undertake to make some retum in exchange, but I did not have time to reach any decision regarding the material that he may have available. If you approve of the sending, as indicated, I shall be very glad to make up a limited series of such archeological specimens along these lines as we can spare.

In a written note at the bottom of the letter, Rathbun approved the exchange. "Prof. Rehlen should be given to understand by letter that a return is necessary."

In a letter to Rehlen on 28 August 1912, Holmes apologized for the delay in fulfilling his promise to send archaeological material:

It was necessary that I should again visit the Piney Branch quarries and make certain excavations for the purpose of securing the specimens required in completing the series. I may also say that I had difficulty in obtaining for you certain other specimens which you desired, since our law requires that specimens already recorded in the Museum shall not be given away; they can, however, be sent out in exchange, and what I wish now to say is that I trust you will be able to secure for me a limited number of specimens illustrating the Stone Age in Germany or other European countries. This will enable me to conform with the established rules of the Institution.

In a letter dated 24 December 1912, Rehlen replied:

I understand perfectly your insisting upon the exchange. Also our Museums and Universities are bound by the same rules. The evil in my case is, however, that the Museum of which I am the protector is chiefly a Museum of local prehistory and has only a few duplicates; the same is with my private collection. I am therefore not able to give you much in exchange and I must renounce if that would not be sufficient.

I can send you ... some palaeolithic tools... from Egypt (Luxor). More to give is quite impossible to my great regret and that is very few. If that is sufficient I would be pleased to receive the goods you had the kind intention to send me directly to Nurnberg. I know that the tools offered from me to you are not yet in your collection.

On 22 January 1913, Holmes expressed appreciation for the offer and wrote that he would select a small set of objects to exchange for the objects mentioned in the letter. On 27 March Rehlen answered that the desired objects were sent. In the final letter on the matter, dated 24 July, Rathbun acknowledged receipt of the collection, noting: "In return the United States National Museum is forwarding... a box containing 64 stone implements. A diagram explaining the process of manufacture is transmitted. Besides the Piney Branch material, which embraces 60 of the specimens in the present sending, there are also included two blades and two spear heads, in partial compliance with your request for examples of the various classes of American stone implements."

\section{Stadtisches Museum (acc. 55436)}

In 1913, an exchange was made with the Stadtisches Museum of Weimar, for a collection of German archaeological material from the Taubach caverns (Germany). Dr. L. Pfeiffer, the museum's curator, had written to Head Curator Holmes on
28 September 1912, offering material from Taubach in exchange for American artifacts, noting that German interest in North American prehistory was increasing. In a reply to an undocumented letter from Holmes, Pfeiffer on 10 December 1912 , wrote that he appreciated the information concerning the Piney Branch quarry technology and expressed the need for a better understanding of the work being done in America. He also made the following offer: "I shall send you tomorrow for your museum a piece of stone from the calcareous tuff of Taubach-Ehnugedorf, with ashes, bones, coal and flint. Flint is very rare and generally imported. Usually mere chips are found. The proceedings of the Congress of Anthropologists in Weimar 1912 have not made it clear whether Taubach is to be regarded as Mousterian or Aurignacian. It is certainly post-glacial. If you wish to exhibit Taubach in your museum, I offer my services to complete the series." In a letter dated 12 May 1913 to Assistant Secretary Rathbun, Holmes noted that he wanted to exchange material, and in a note on the bottom of the letter, Rathbun approved of the exchange. In correspondence dated 3 July 1913, Rathbun wrote the final letter on the subject, thanking Pfeiffer for the specimens and noting that "six cases containing 430 specimens of archeological relics" had been sent in return.

\section{Rutot (acc. 55867, 56614, 58532)}

In 1913, 1914, and 1915 three exchanges were made with Professor Aimé Louis Rutot, an engineer, geologist, and conservator of the Musée Royal d'Histoire Naturelle de Belgique, Brussels. Rutot was a major publisher on scientific subjects, many of which dealt with the prehistory of Belgium (see Grayson, 1986). This included publications on human ancestors and archaeological sites (e.g., Rutot, 1900, 1919). Originally an opponent of the notion of an Eolithic Period, Rutot later became a leading proponent of Eolithic artifact industries, engendering fierce controversy and debate with many other leading scientists from 1887 to 1910 .

During the summer of 1912, Hrdlička visited Europe, where he met Rutot. In a letter dated 13 July 1912, Head Curator Holmes informed Assistant Secretary Rathbun that Hrdlička sought exchange agreements with European scholars. Holmes quoted Hrdlička regarding his desire to obtain European material:

I think ... it would be well to offer a large set of the Piney Branch stones, with perhaps some other primitive implements, etc., such as the 'turtlebacks,' and a few 'argillites' from Trenton, to Rutot (Mus. d'Histoire Naturelle, Brussels), for a selection from his paleoliths, many among which are wonderful specimens. The whole thing, the skulls, bones, stones, is, indeed, wonderful and is growing more so the more is found. And it is everywhere perceptible that Anthropology is reviving in consequence, assuming the position of a science not merely with a growing and promising superstructure but also with a solid and precious foundation.

Holmes told Rathbun that he would be pleased to exchange some Piney Branch material: "I shall be extremely glad to have your approval of these proposed exchanges as I have an over- 
stock of the Piney Branch material. We have so little to represent Europe in our Archeological collections that these suggested contributions will be more than welcome." Rathbun approved the exchange.

Concerning the first exchange, Rutot wrote to Hrdlička on 19 May 1913:

The consignment of Paleolithic instruments was ready, but after your departure it occurred to me to make casts of my finest pieces from the Pre-Strepyian, of which I send you an original series. I desire to add the casts of the principal pieces to the original series. They will thus make a magnificent series.

On account of the difference in weight, my sending will comprise two boxes, one with the original pieces (Mesvinian and Pre-Strepyian) and one with the casts (Mesvinian, Pre-Strepyian, and Strepyian).

On 10 June, Rutot again wrote to Hrdlička: "I have the pleasure to announce the three boxes of flint and casts [from Belgium and France] are about to leave for Washington. One box contains the original pieces (flint) of the Mesvinian and of the Pre-Strepyian. A second box contains the casts of the principal Pre-Strepyian pieces to add to the originals of the PreStrepyian. The third contains the casts of the Strepyian and a cast to add to the Mesvinian." In a memorandum of 12 September to Rathbun, Hrdlička explained how the exchange should be handled: "The specimens received from Prof. Rutot are really a gift to our Museum, secured by me while abroad and due in a large measure to the friendly personal relations which I had with the Professor. However, he is very desirous of obtaining a few specimens showing the manufacture of Indian implements, from us, and they should be sent to him as a matter of courtesy. Officially, the whole transaction may be entered as an exchange but the word 'exchange' should not be used in correspondence with Prof. Rutot because it might not please him." On 18 December, Hrdlička wrote to Rutot about the shipment of American material: "We have shipped you, in return for the archeological material which you have kindly sent us, a collection of stone implements illustrating various American types and their manufacture." In a letter of acknowledgment, dated 20 January 1914, Rathbun thanked Rutot for the collection, and indicated that the American material was being sent: "Doctor Hrdlicka [sic] states that you expressed a desire to obtain in return specimens illustrating the manufacture of Indian implements. I am very glad now to comply with your wishes, and a box containing 71 stone implements, enumerated on the enclosed invoice, is forwarded to you through the Smithsonian Bureau of International Exchanges. There is also sent to you by mail a tube containing a diagram showing the steps employed in the manufacture of these implements."

A second exchange was made in 1914. The collection included material from the Chellean, Acheulean, and Mousterian. In a letter to Rutot on 28 March 1914, Rathbun indicated that the artifacts were being sent to Rutot, and that more satisfactory pieces were wanted from him:

It is found that among the Mousterien specimens in the last lot which you sent,
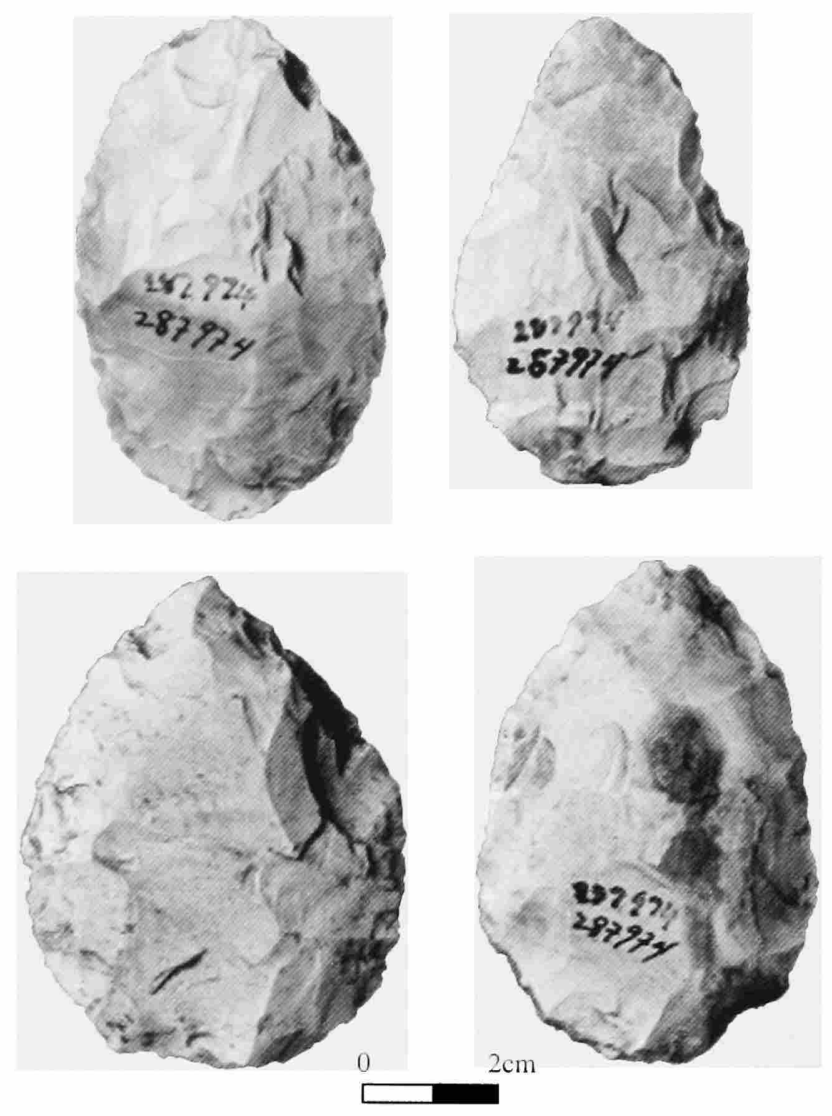

FIGURE 65.-Handaxes [catalog number 287974] from Templeux Le-Guerard, France. [Accession through Rutot for Panama-California Exposition (accession 58532).]

only a very few show specialization of shapes for any purpose or indications of any kind of use, and in this connection permit me to say that a somewhat complete series of types of actual implements is desirable, as unspecialized forms have but little significance or value. There is now being sent to you by freight, charges prepaid, a box containing one hundred and thirty-four specimens of United States chipped implements together with a small set of thirty-nine of the higher class of pecked-abraded forms, of which some of the rarer ones are represented by casts. This shipment, together with the series of seventy-one refuse objects from the Piney Branch quarries in the District of Columbia, which was forwarded to you in January, is intended to complete our indebtedness up to date and to provide something to our credit for a continuation of exchanges.

Rathbun also thanked Rutot for the archaeological specimens from the first two accessions.

The final exchange occurred in 1915, when Rutot forwarded archaeological material for display at the Panama-California Exposition, held in San Diego, California. In addition to the artifacts from Belgium and France, Rutot sent stone tools from another French site, Templeux Le-Guerard (Figure 65). Hrdlička and Holmes designed the exhibits at the exposition, and, at the completion of the show, the items received for this exhibition were sent to the U.S. National Museum and were classified as an exchange. 

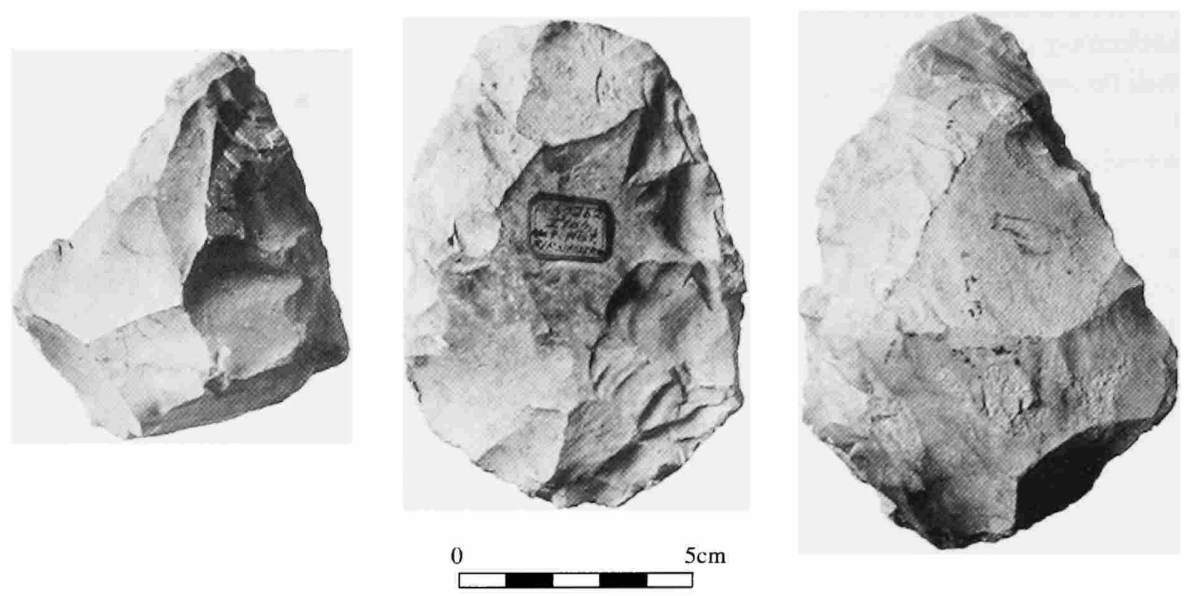

FIGURE 66.-Handaxes [catalog number 284883] from Caraminco, Italy. [Naturhistoriska Riksmuseum, Stockholm, accession (accession 57262).]

\section{Marett (acc. 56924)}

In 1914, a collection of objects from two caves in Jersey, England, were donated to the museum by R.R. Marett, of Exeter College, Oxford. Hrdlička and Marett corresponded between 1912 and 1916 regarding a number of prehistory topics. On the subject of the explorations in the Jersey caves and the nature of the forwarded material, Marett wrote to Hrdlička on 5 May 1914:

I send you herewith a box containing 100 flint implements, hammerstones, etc. from our two palaeolithic (Mousterian) caves in Jersey. They are nothing much as specimens, but for the present at any rate everything is being kept in Jersey, so that students may study the collection as a whole. I asked leave of the Societe Jersiaise before sending them (though they are all of my own personal finding), and, barring a handful of about the same quality which I have given the Pitt Rivers Museum, you will be the only museum to possess specimens from these sites at all; though later we may have more-and better ones-to distribute to the leading museums, including, of course, yours. The stuff from La Cotte de St. Owen (which I take to be the older site of the two-see Archaeologia, 1913) is extraordinarily rough throughout, and if unsupported by the evidence from the other cave, might well nigh prove indeterminable; through included there are just a few well defined Mousterian points, and also an implement worked on both sides and resembling one of the Acheulean (Carmont's (?) Mousterian avec coup-de-poing). The other cave has yielded some splendid points, a characteristic pleistocene fauna, and 13 teeth of Neanderthal type (as on Keith's showing). Our new excavation has been most fruitful, and I shall tell you about it when we meet in October. There is no flint in the island as you know; so every piece found in either of these caves has been carved and chipped by man. The happiness stones-small granite pebbles often broken so as to give a flat edge - are very characteristic of this site; also the thin diabase pebbles often split which served presumably as 'polissoires.' One I am sending has a very well-marked rubbing-edge. One stone is from the hearth and shows the marks of fire; another also has been subjected to heat and is possibly a 'boiling-stone.' The implements show plenty of utilization but very little secondary chipping. These people, however, were capable of occasional masterpieces in that line but they are as 1 in 1000. Don't thank me. I owe the Smithsonian Institution an unpayable debt already for the gift of literature. But the Little Museum (and library) of the Societe Jersiaise would welcome all sorts of unconsidered trifles, and the commonest things from America would be education over there.

\section{Naturhistoriska Riksmuseum, Stockholm (acc. 57262)}

In 1914, an exchange was made with the Naturhistoriska Riksmuseum in Stockholm, Sweden, through Professor C.V. Hartman, the head curator. The correspondence mainly concerned the North American material, only noting that Paleolithic objects from Caramanico, Italy, had been donated to the U.S. National Museum in return (Figure 66).

\section{Buckingham (acc. 59162)}

In 1915, stone objects from North America and Paleolithic artifacts from France were donated to the U.S. National Museum by Mrs. Edgar Buckingham of Chevy Chase, Maryland. The accession was probably delivered in person, as no correspondence was found.

\section{The Royal Ontario Museum of Archaeology (acc. 62402)}

In 1918, an exchange was made with The Royal Ontario Museum of Archaeology, Toronto, through its director, C.T. Currelly, for a collection of antiquities from Europe and Africa. In early 1912, Hrdlička suggested an exchange with the Toronto museum. Currelly responded on 3 February, notifying Hrdlička that materials were available and that the museum would be glad to make an exchange. A number of additional letters were exchanged between Head Curator Holmes and Currelly in 1912 and 1913, and an exchange of specimens was arranged. It was not until Currelly's visit to the U.S. National Museum in 1918, however, that he acquired Paleolithic collections. In a letter to the Secretary's administrative assistant, W. de C. Ravenel, on 23 January 1918, Holmes explained the nature of the exchange: "The Department of Anthropology has been discussing a prospective exchange between this Museum and the Royal Ontario Museum of Toronto. Dr. T.C. Currelly, the Curator of that Museum has recently been here and we have made certain selec- 
tions of stone and pottery antiquities (84 American Archeological and 62 Ethnological) which we wish to exchange for archeological collections from the Old World-a branch in which we are very weak." On 28 January 1918, Holmes acknowledged receipt of the Currelly collection.

The inventory included with the collection noted that material came from Furze Platt, Maidenhead, England (Figure 67), and from the Thebaid, Libyan Desert. Currelly made note of several artifacts in the inventory, and in describing "Palaeolithic spearhead" number 4P8, he noted that these were "intensely rare, probably only about fifty being in existence" for the area. Of Palaeolith number 53, Currelly described a scenario for its use and discard: "Picked up during the palaeolithic period after the ovate had ceased to be used, and a large flake knocked out of it; some hundreds have been found that were treated in this manner and I think two or three were included in the former lot. These are particularly interesting as they show the double patination." Describing palaeolith number 57, he wrote: "These were all found lying on the bare rocks in the Libyan Desert where they had been lying since palaeolithic man had dropped them. In many places it was possible to see the stone on which the man had sat and the flakes and discards lying around. An examination of many thousands of pieces has shown that the patination of the pieces that have been lying in the open varies according to the length of time since they were made."

Currelly wrote to Holmes on 20 February 1918, providing more information on the Egyptian and English collections: "They were all found lying on the top of the limestone plateau in the Libyan Desert due west from Thebes. The English palaeoliths were from the higher gravels, now a considerable distance above the present valley. As you will see the most characteristic form is what are called the old points; these, though known in Egypt, are comparatively rare, and run only a comparatively short existence." Currelly also noted that he had classified artifacts based upon patination, indicating that the classification corresponded with distinct artifact styles. Of the French material in the accession, Currelly simply noted that "the pieces of great rarity are the ivory needle and the mysterious 'Pointe á crain,' which are both exceedingly rare and valuable." Ravenel wrote to Currelly on 4 February 1918, stating that ethnological and archaeological specimens from North America were being shipped to him in exchange.

\section{Marriott (acc. 63670)}

In 1919, a collection of prehistoric flint implements and bone fragments from France was donated to the museum by Mr. Crittenden Marriott of Washington, D.C. The accession notes that the materials were collected by Marriott and M. Peyrony, a French prehistorian. Ravenel wrote to Marriott on 6 June 1919, acknowledging receipt of the collection and expressing his "appreciation of this very interesting addition to the national collections."

\section{American Presbyterian Congo Mission (acc. 70046)}

In 1923, Paleolithic implements from gravels near Luebo, Belgian Congo, Africa, were donated to the U.S. National Museum by the American Presbyterian Congo Mission in Luebo. The objects were delivered in person, and a Smithsonian staff member wrote a note about the collection, stating that "a missionary brought it in but declined to give his name asking that all credit be given to the Mission." Ravenel wrote a letter of acknowledgment to the Congo Mission on 25 May 1923.
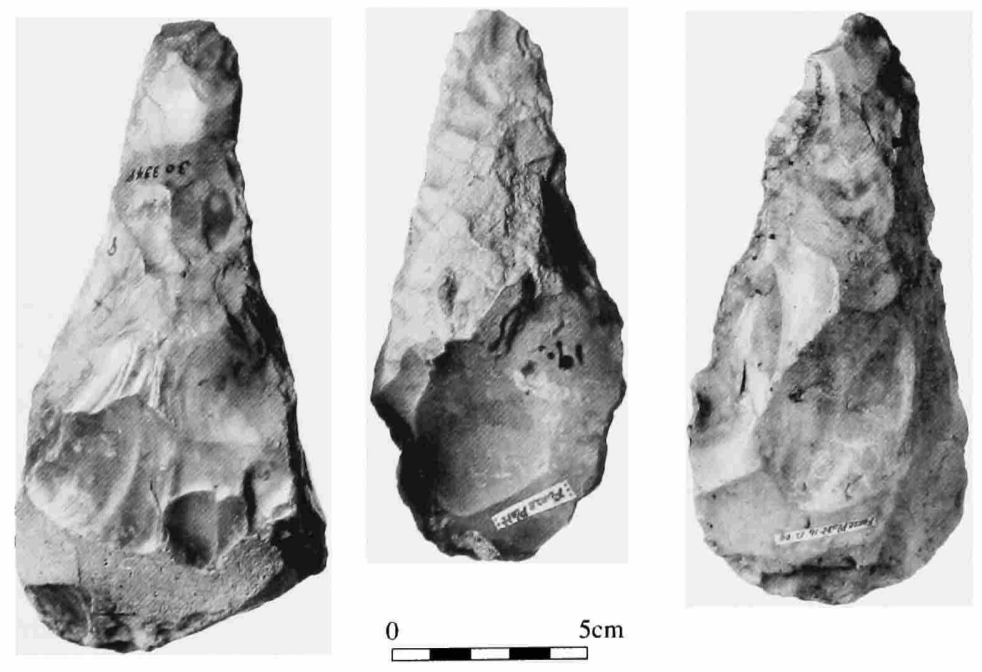

FIGURE 67.-Handaxes [catalog numbers 303348, 303349, 303348, left to right] from Maidenhead, England. [The Royal Ontario Museum of Archaeology accession (accession 62402).] [The applied notes on the handaxes provide the site name and the date the specimens were found, "Furze Platt, 14-2-09." Each of the specimens carries an inked artifact number, as noted by Currelly in his correspondence.] 


\section{Moir (acc. 71310)}

In 1924, an exchange was made with J. Reid Moir of England for a collection of supposed eoliths. Moir's work during 1910 to 1939 (Grayson, 1986) was focused in Ipswich, Suffolk, on the east coast of England, where he documented "pre-Paleolithic" tools (e.g., Moir, 1919). In the Red Crag deposits at Foxhall, near Ipswich, Moir discovered deeply buried Eolithic deposits (Figures 68,69), which were accepted as genuine by many in the 1920 s but which were subsequently discredited in the 1930 s.

The accession of these eoliths was engendered by Aleš Hrdlička through correspondence with Moir and by a visit by the American School of Prehistoric Research to England in the summer of 1923. Hrdlička wrote a letter to Moir on 9 June, indicating that he planned to visit England: "On July 2 I expect to reach London with three or four students ... of the 'American School in France for Prehistoric Studies.' One of our needs and hopes is to visit Ipswich, see your collections, and then visit the most important sites where the reported Tertiary human implements etc. come from. I have known of your work for many years both from your publications and through Miss Fletcher, and I trust that you will make possible to us a visit both to your collections and to the sites mentioned." Hrdlička wrote to Smithsonian anthropologist Walter Hough from Europe on 18 July, indicating that the group had visited various sites and had viewed several collections.

We went to Ipswich, where we were... awaited by Mr. Guy Maynard, the Curator of the Ipswich Museum. The 7th was spent in the Museum, which has archeological collections of much value, and in visiting the most important sites that show traces of Quaternary Man about Ipswich including Foxhall. On the 8 th we were at Cromer, where Mr. Savin showed us his invaluable paleontological collection, and where under the guidance of Professor Barnes from Oxford (arranged by J. Reid Moir) we examined the worked flint bearing cliffs, the beech accumulations containing many chipped stones, and the Cromer forest-bed location, as well as a large private collection of what are supposed to be Tertiary implements.

As a result of these visits, Hrdlička proposed an exchange to Moir on 13 October: "I was very sorry indeed to have missed you, for I wanted to make your personal acquaintance, to thank you for all the help we received at your Museum and about Ipswich and to ask you whether we could not possibly obtain by exchange a small representative series of the highly interesting worked stones from the vicinity of Ipswich and Cromer in your collection." Moir responded on 29 October: "I shall be pleased to exchange a small series of Mt. Crag and Cromer flints but I am badly off for the former at present, as I have parted with so many, and you must give me some time to get some together for you." On 10 November, Hrdlička indicated to Moir that material from Piney Branch would be exchanged for the eoliths: "I am glad to have your letter of October 29 in which you promise to form a small representative collection of flints for our Institution. We could send you American stone implements including a series from Piney Branch, some of which so closely resemble palaeoliths and even eoliths." Ravenel sent a letter of acknowledgment to J. Reid Moir on 11 February
1924, also indicating that the Piney Branch material was being sent to Moir.

\section{Hrdlička (acc. 71514, 89903)}

In 1924, Aleš Hrdlička, the head curator of the Department of Physical Anthropology, U.S. National Museum, donated a collection of material from several sites and countries. No correspondence accompanied the accession. It may have been Hrdlička's personal collection, amassed during his trips to Belgium, France, and Egypt from 1908 to 1923. The Secretary's administrative assistant, W. de C. Ravenel, acknowledged the donation on 26 March 1924.

In 1925, Hrdlička donated a second collection of material, which he had acquired during his visit to South Africa. The trip to Africa was part of his worldwide trip in 1925 to meet colleagues and to acquire collections. In an unpublished manuscript, Hrdlička (n.d.) described the results of his visit to Rhodesia and the stone objects from Victoria Falls and vicinity:

As to the 'paleoliths,' South Africa is very rich. They may be found in favorable spots along the sea shore; they occur in the gravels, banks and vicinity of rivers, and they are also common in caves. On the whole they present forms rather more like those of India than those of old western Europe; but here and there are also close resemblances to the earlier or later European types. The question of the antiquity of these implements is doubtless complex and has not yet been satisfactorily worked out. A great many are found on the surface and are plainly recent; others may be ancient. That not all the sites where such implements occur and have hitherto been regarded as ancient, are of that nature, was seen along the Zambesi on both sides of the River at Victoria Falls. Here stone implements were reported as occurring in the ancient gravels of the river, deposited along the sides of the stream before the formation of the falls. A three-days' examination of conditions, in company with two Americans, a South African engineer and some negroes were sufficient to show that the cultural remains here extend over a considerable distance along both sides of the river, are numerous, superficial, and in all probability not very ancient. A goodsized collection of the worked stones from this locality is on its way to the National Museum.

Assistant Secretary Wetmore formally acknowledged the gift on 7 January 1926.

\section{Archaeological Society of Washington and American School of Prehistoric Research (acc. 84988, 90005, 98484, 95150, 95604, 103151, 107359, 112197, 115831, 121286, 126298, 132332, 133080)}

From 1925 to 1935,13 accessions, consisting of 8413 Paleolithic artifacts, were received from the American School of Prehistoric Research. The artifacts were found at sites excavated by the American School under the auspices of the Archaeological Society of Washington; thus, the collections often were alternately transmitted as a "loan," "deposit," or "gift" to the Smithsonian. The acquisition of this Paleolithic material resulted from Hrdlička's direct involvement with the founding and development of activities of the school in Europe from 1925 to 1928 and the Near East from 1929 to 1935. 


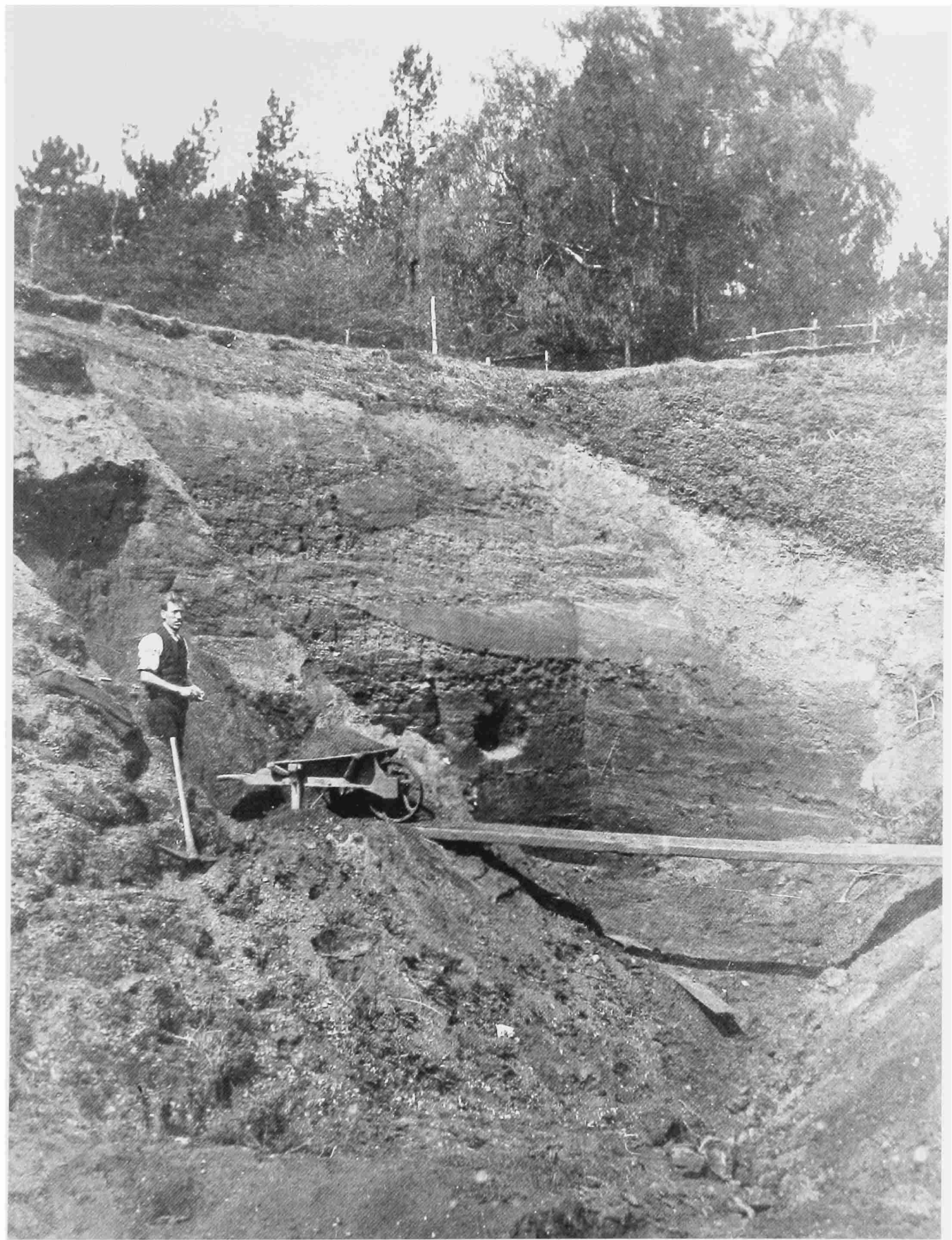

FIGURE 68.-The label on the photograph, written by J. Reid Moir in 1924, reads "View showing excavation at Foxhall pit near Ipswich. The 16-foot level from which the implements, flakes and burnt flints have been recovered rests at the level indicated by the plank." [Hrdlička collection, National Anthropological Archives, NMNH.]

From 1925 to 1930 , seven accessions (acc. 84988, 90005, $98484,95150,95604,103151,107359$ ) from the Castel Merle (Abri des Merveilles, France) excavations were received by the U.S. National Museum (Figure 70). During those five years, the transmission of the accessions followed a certain routine. Typically, at the conclusion of each summer's excavation, MacCurdy wrote to Hough, indicating that the Smithsonian's share of the collections was being shipped. After the materials 


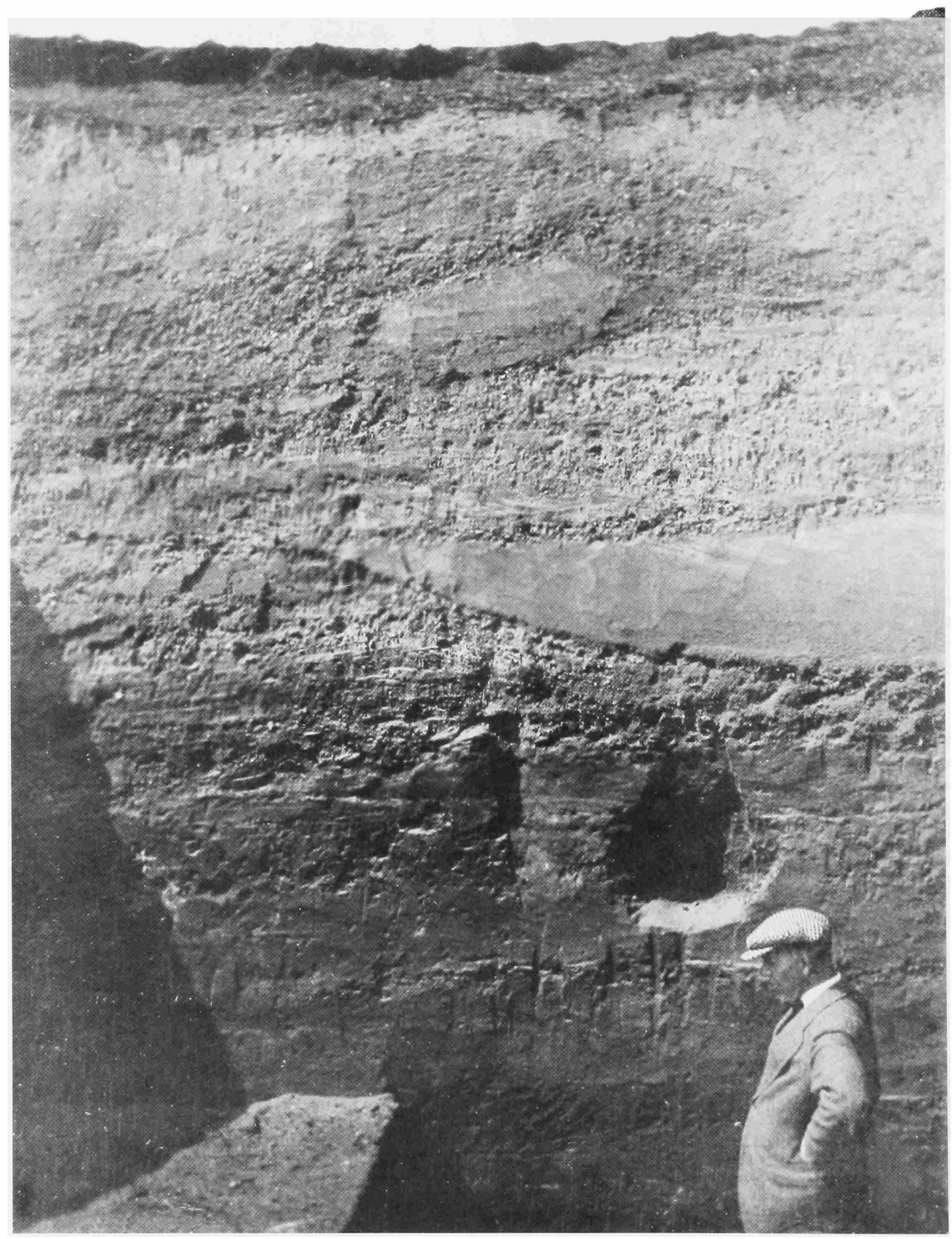

FIGURE 69.-The label on the photograph, written by J. Reid Moir in 1924, reads "View showing the Foxhall pit near Ipswich-also a view of myself? The implementiferous layer is indicated by the shelf on the left of the photograph. The crag is capped by stratified glacial gravel." [Hrdlička collection, National Anthropological Archives, NMNH.]

arrived in the museum, Russell inventoried them and Assistant Secretary Wetmore wrote to Riggs, director of the Archaeological Society of Washington, to acknowledge their receipt. The Castel Merle accessions consisted of Mousterian and Aurigna- cian collections, including faunal remains that were identified as Cervid, Irish deer, Reindeer, Bison, and horse. The collections also had a variety of stone artifacts, including a large number of Middle Paleolithic tools, such as scrapers of various 


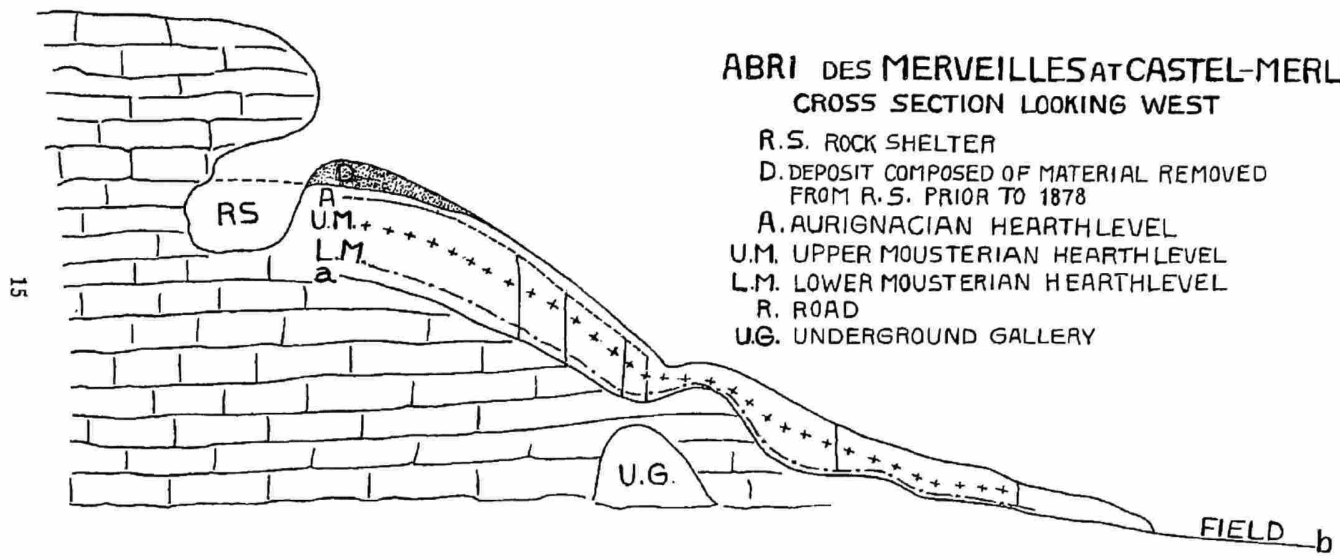

FIGURE 70.-Cross section of Abri des Merveilles excavations. [Note the schematic portrayal of the archaeological layers and time periods. Published in MacCurdy, 1931, Bulletin of the American School of Prehistoric Research, fig. 5.]

types and sizes (Figure 71). MacCurdy wrote to Hough on 29 August 1928, supplying information about labeling procedures: "Specimens not marked are from the lower Mousterian level (Middle Paleolithic Period). Specimens marked 'U.' are from the Upper Mousterian level (Middle Pal. Per.). Specimens marked 'A,' are from the Aurignacian level (Upper Pal. Period)."

During Russell's evaluation of the Castel Merle collections, he decided that some specimens were, in his opinion, unworthy for accessioning. This decision is documented in a letter from Wetmore to Riggs, dated 20 February 1929, in which Wetmore explained why specimens from the 1926 deposit (acc. 90005) were discarded: "Mr. J. Townsend Russell, Jr., Assistant in Archeology, has recently gone over this collection with the result that of the 976 specimens referred to only 765 found to be of value to the collection. The remaining 211 specimens include many fragments of mammal teeth and bones, unworked cobbles and stone hammers showing minimum of use, and Mr. Russell recommends that these fragments be destroyed." These fragmentary and minimally used items apparently were discarded. Some faunal specimens, however, were considered worthy of curation, and some splinters were saved, perhaps because of the markings on their surfaces (Figure 72a,b) or because they showed fracture patterns on certain diagnostic bones (Figure 72c). The specimens deemed worth saving included formal tools, such as those classified as "cleavers" (Figure 73a) and the heavily used "hammerstones" (Figure 73b).

The 1930 collection (acc. 95604) also was reduced somewhat, after Russell determined that some of the material was worthless. In a memorandum dated 25 October 1930, Russell noted: "With this accession was a small quantity of splintered mammal bone and a few teeth which are useless for either exhibit or study purposes. I have therefore disposed of them." In another culling, "duplicates" of the Castel Merle collections were sent to another institution, as indicated by Wetmore to Riggs on 26 June 1933: "I am advised of your conversation sev- eral weeks ago with Mr. J. Townsend Russell when you acquiesced in his suggestion that a few of the numerous duplicates in the collection from Castel Merle...be included in the series of 173 Paleolithic and neolithic artifacts we are presenting to Elmira College, Elmira, New York. None of the above Castel Merle specimens is of special interest and none is needed for the Mousterian exhibit we propose to install upon Mr. Russell's return to Washington next autumn." On 30 June 1933, Riggs replied that the Society adopted a resolution approving of Mr. Russell's suggestion, authorizing the U.S. National Museum to send to Elmira College the selected specimens: "It was felt by the Society that this action is a constructive one, and that it would benefit the Museum by relieving it of the custody of otherwise unimportant duplicates, while at the same time filling out gaps in the College's collection."

In addition to the Castel Merle collections, two other sites were represented in the 1925 and 1929 accessions. The 1925 accession (acc. 84988) included skeletal and archaeological specimens from the Solutré excavations. Mitchell Carroll, the secretary and director of the Archaeological Society of Washington, noted in his letter to Secretary Walcott on 14 November 1924, that the Solutré collections were being shipped to the museum: "On behalf of the Board of Trustees of the Archaeological Society of Washington, I write to say that there has been transmitted to the U.S. National Museum by Professor George Grant MacCurdy, director of the American School of Prehistoric Research in Europe, four (4) cases of skeletal material secured in the excavations of Solutré, France, under the auspices of the Archaeological Society of Washington. We request that these may be referred to Dr. Hrdlicka [sic], Head Curator of Physical Anthropology, for purposes of research and for such permanent disposal as he may deem wise, as part of the loan collections deposited with the National Museum by the Archaeological Society of Washington, Inc.” The 1929 accession (acc. 103151) contained specimens from La Madeleine, France, the type site of the Magdalenian. 


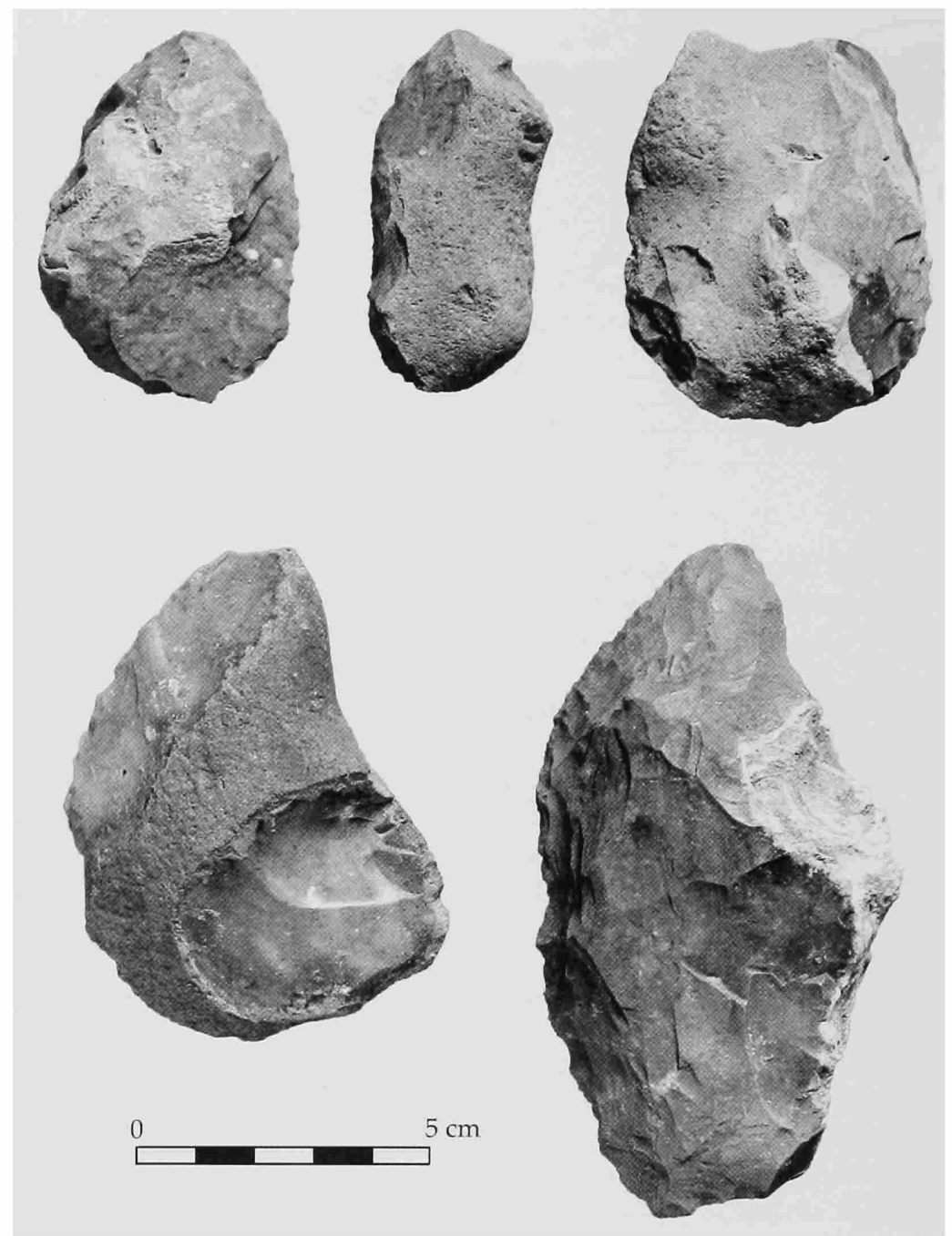

FIGURE 71.-Scrapers [catalog number 341844] from Abri des Merveilles, France. [Archaeological Society of Washington and American School for Prehistoric Research accession (accession 98484).]

During the winter of 1929 , the geographic focus of the American School began to change from Europe to the Near East. On 25 January 1929, MacCurdy contacted Hrdlička, indicating that an invitation had been received from the British School of Archaeology to excavate in Palestine: "In Palestine they have just discovered a site which has yielded what appear to be examples of Paleolithic art. The site is to be quarried out within the next half year so that the only chance to dig it will be this spring. Miss Garrod has invited our School to cooperate in the digging in March, April and May of this year. The opportunity is so unusual and attractive that Miss Allyn [probably Dean Harriet M. Allyn, see Garrod and Bate (1937)] has decided to go as our representative."

The new focus of the school led to a joint project sponsored by the American School and the Percy Sladen Memorial Fund to excavate sites in the Middle East. In 1930, MacCurdy do- nated material (acc. 112197) from two caves in southern Kurdistan. The collections consisted of 20 Aurignacian stone artifacts from the Cave of Zarzi, 50 kilometers west of Sulaimani (Sulaymaniyah), and eleven Mousterian scrapers, reworked flakes, and flakes from the Dark Cave (Ashkot-I-Tarik), 8 kilometers southwest of Sulaimani. On 1 November 1930, Wetmore wrote to MacCurdy to officially acknowledge the gift.

From 1931 to 1935, five accessions (acc. 115831, 121286, $126298,132332,133080$ ) were received as a result of extensive excavations conducted by the school at four major caves (Mugharet el-Wad, Kebara, Skūhl, Tabūn) at Mount Carmel, Palestine. The collections represented the U.S. National Museum's share of the artifacts found at the four sites. The accessions were either gifts from MacCurdy, or loans or deposits from the Archaeological Society of Washington. Importantly, provenience information had been assigned to all artifacts, 


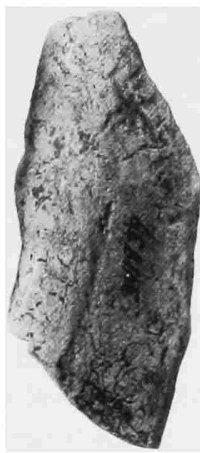

0

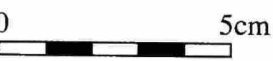
cm

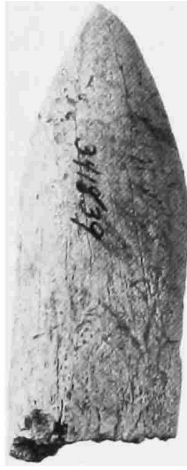

a

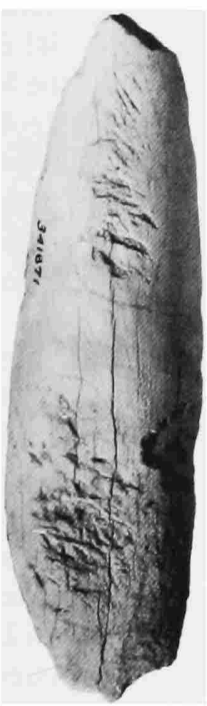

b
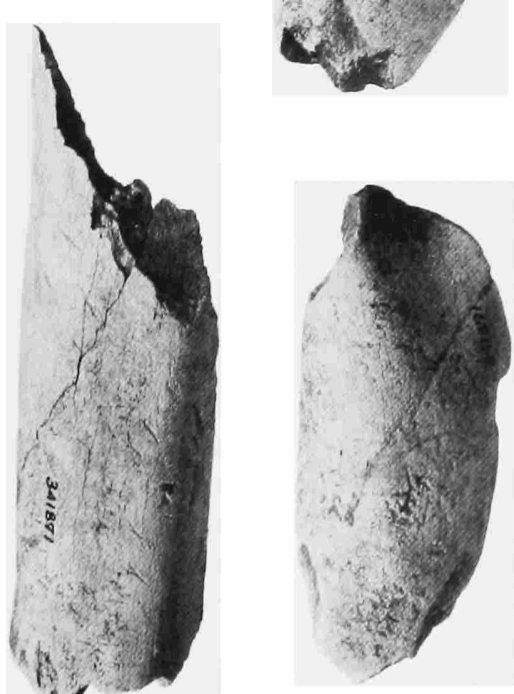

$5 \mathrm{~cm}$

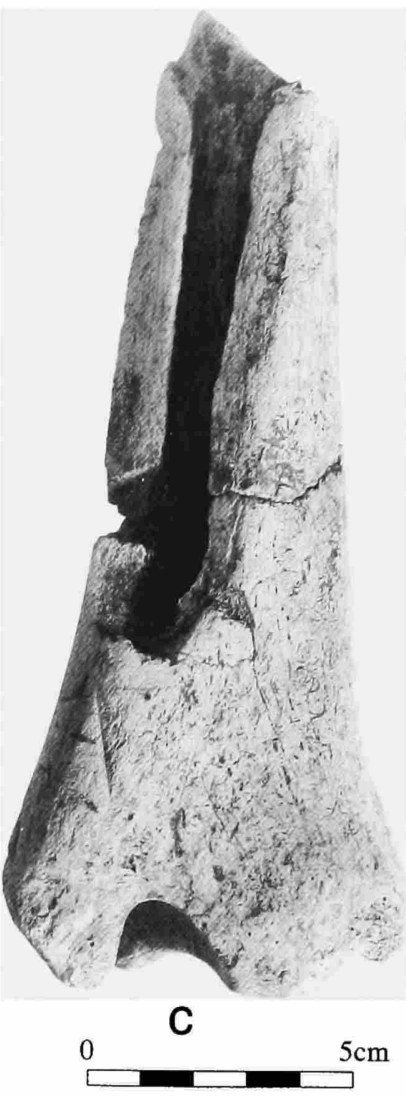

$5 \mathrm{~cm}$

FigURE 72.-Bone fragments from Abri des Merveilles, France. [(a) long-bone fragments [catalog number 341839] showing pitting, gouging, and rootlet marks; (b) long-bone fragments [catalog number 341871]; and (c) split long-bone shaft [catalog number 341838]. [Archaeological Society of Washington and American School for Prehistoric Research accessions [accessions 95150, 98484].]

which agreed with the stratigraphic descriptions provided in a published compendium of the excavations (Garrod and Bate, 1937).

The Mugharet-el-Wad collection was received in two separate installments (acc. 115831, 121286) in 1932. MacCurdy wrote to Hough, on 7 May 1931, providing information about the first collection from el-Wad:

The Director of the University [of Pennsylvania] Museum, Philadelphia, will soon send to your institution... a series of prehistoric specimens dug from the cave of Mugharet-el-Wad, near Athlit, Palestine, by the joint expeditions of the
American School of Prehistoric Research and the British School at Jerusalem. Each specimen is marked 'MW' which stands for Mugharet-el-Wad (Cave of the Valley). The additional letter on the specimen (A, B, C, D, E) refers to the culture level as follows: A. Bronze Age to recent. B. Mesolithic. C. Upper Paleolithic of Capsian affinities. D. Middle Aurignacian. E. Lower Middle Aurignacian.

The second accession was similar but included, in addition to Upper Paleolithic and Aurignacian assemblages, Mousterian artifacts that were found in stratum $\mathrm{F}$ of the excavations. The final installment of el-Wad material consisted exclusively of Mesolithic assemblages. In a letter dated 5 October 1933, Mac- 


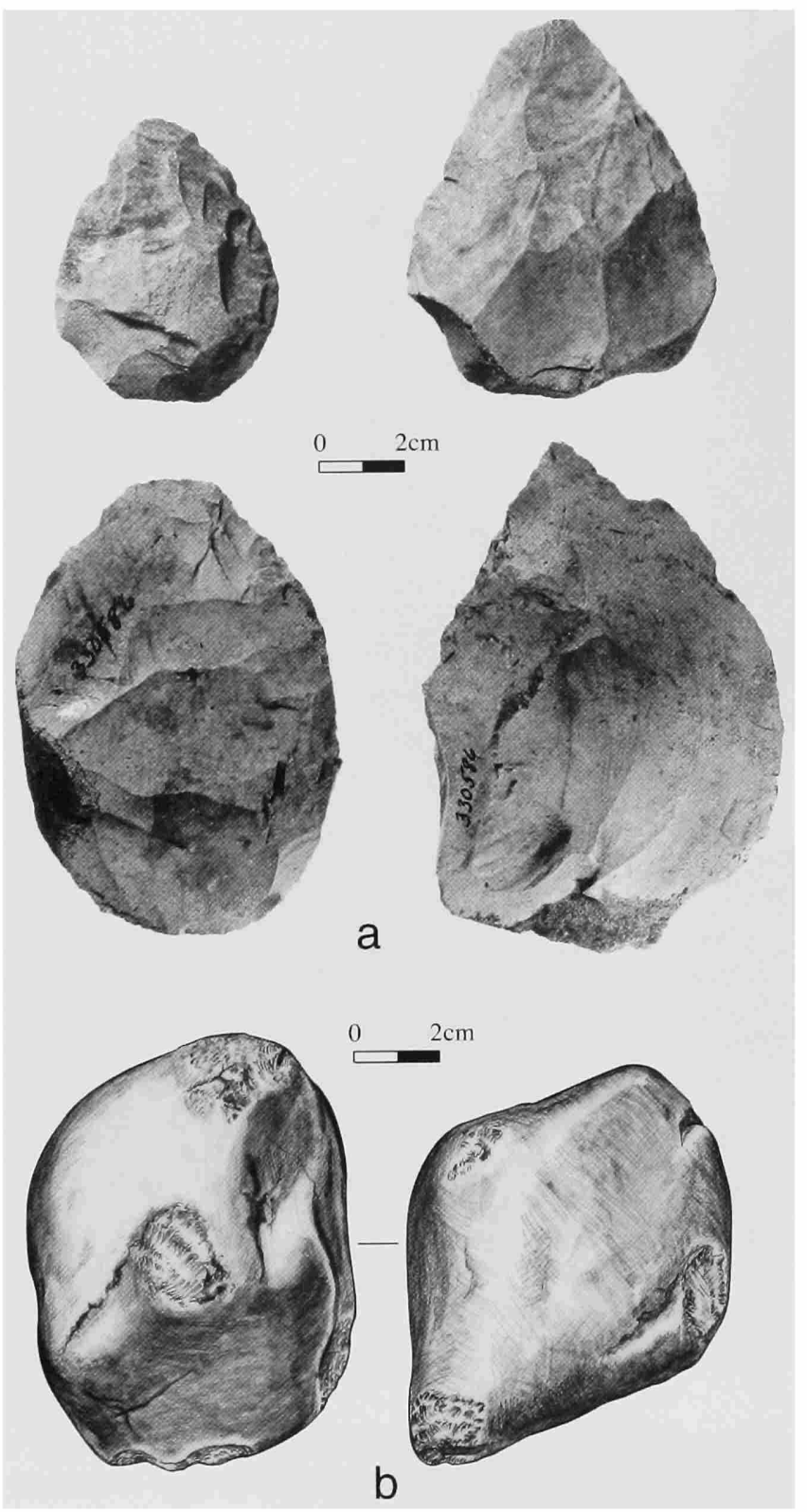

FIGURE 73.-Stone tools from Abri des Merveilles, France. [(a) cataloged as "cleavers" [catalog number 330586] and (b) hammerstone [drawing, catalog number 330619].] [Archaeological Society of Washington and American School for Prehistoric Research accession (accession 90005).]

Curdy noted that the B level was divided into a B1, Upper Natufian (Mesolithic) and a B2, Lower Natufian (Mesolithic). MacCurdy also noted that the site was briefly described in the Bulletin of the American School of Prehistoric Research, in numbers 7 and 8 . The Upper Paleolithic to Mousterian assemblages included stone blades, retouched blades, scrapers, gravers, nuclei (cores), points, rejects, and Levalloisian flakes.

The Mugharet-el-Kebara assemblages were accessioned in
1932 as a loan (acc. 121286) from the Archaeological Society of Washington. On 1 October 1932, MacCurdy provided Hough with information on the collections and their labeling: "Each specimen is marked $\mathrm{K}$ (for Kebara) followed by a letter (B to E) indicating the level (age) from which the specimen came. See Bulletin of the American School of Prehistoric Research No. 7." The collection from Kebara was classified as Mesolithic, Upper Paleolithic, Middle and Lower Aurignacian. The Upper Paleolithic materials included retouched blades, retouched flakes, scrapers, perforators, nuclei (cores), and flakes (Figure 74). Among the unusual artifacts were an oval stone with engraved bands and a red ochre fragment. On 4 November 1932, the associate director of the U.S. National Museum, John E. Graf, wrote to Riggs to acknowledge receipt of the collection.

The Mugharet-es-Skūhl materials were received in 1934 as a deposit (acc. 126298) from the Archaeological Society of Washington. In a letter to Hough, dated 5 October 1933, MacCurdy provided provenience and labeling information: "Those from Mugharet es-Skūhl are marked M.S.; B1 (upper level of the Mousterian Epoch); B2 (lower level of the Mousterian Epoch). In addition there are a few Upper Paleolithic flints, as well as potsherds of a still later date." An inventory noted that the Paleolithic collection consisted of Aurignacian and Lower and Upper Mousterian assemblages. Among the assemblages noted were scrapers (Figure 75), points, retouched flakes, spoke shaves, cores, and flakes.

The Mugharet et-Tabūn collections were received as three separate deposits, two in 1934 (acc. 126298, 132332) and one in 1935 (acc. 133080) (Figure 76). The collections included many bifacial and unifacial tool types (Figure 77). The Tabūn collections comprised a rich assortment of materials from specific proveniences, including Upper Mousterian industries from Chimney I and Chimney II, Lower Mousterian from Levels $\mathrm{C}$ and $\mathrm{D}$ were Acheuleo-Mousterian from Level E, Upper Acheulean from Level F, and Tayacian from Level G. After reviewing the first deposit, Judd wrote to MacCurdy on 14 May 1934: "The specimens form an unusually instructive series and we shall be pleased to place them on exhibit in the near future." MacCurdy replied on 21 May, noting that the results of the excavations would be published in bulletin 10 of the school, which described the Tabūn excavations. After reviewing the publication, Judd wrote to MacCurdy on 8 June: "This morning I have read Miss Garrod's article in the May Bulletin of the American School and am greatly impressed with the thoroughness of her excavations. I congratulate you not only upon the success of last year's expedition but express the hope that the one now in the field may prove equally profitable." On 9 June, MacCurdy wrote to Judd that a collection from Tabūn had been sent to the U.S. National Museum. "Each specimen is marked ' $T$ ' for Tabūn and with a letter for the level from which the specimen came (see Bulletin 10, plate II). The specimens belong in the following categories: handaxes, scrapers, steep scrapers, gravers, choppers, cores, flakes, Levallois flakes, blades, discs, various. A few are marked 'Chimney I' and 


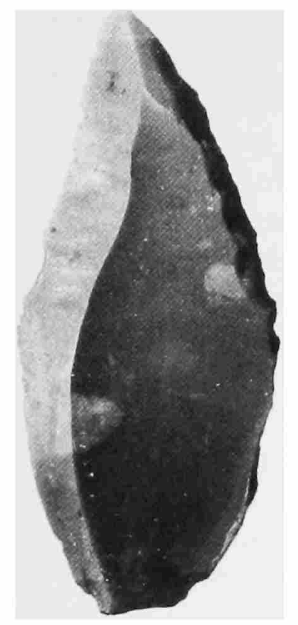

a

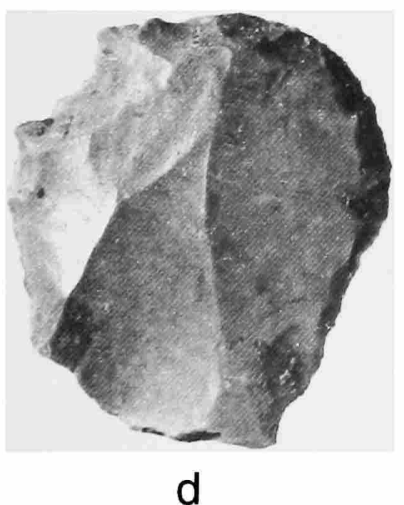

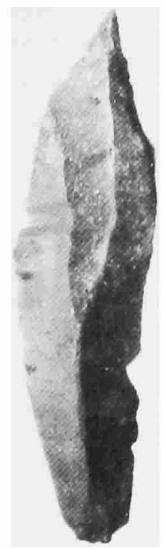

b

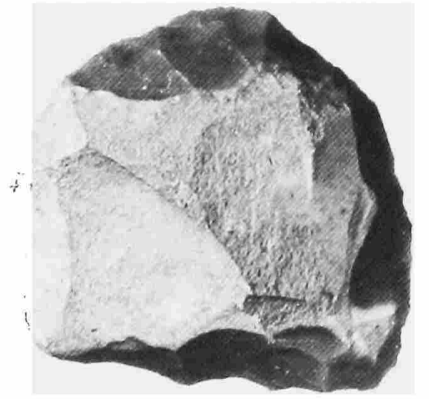

e

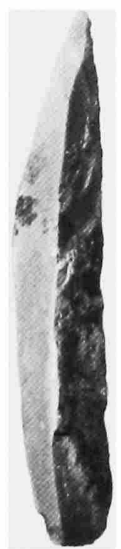

C

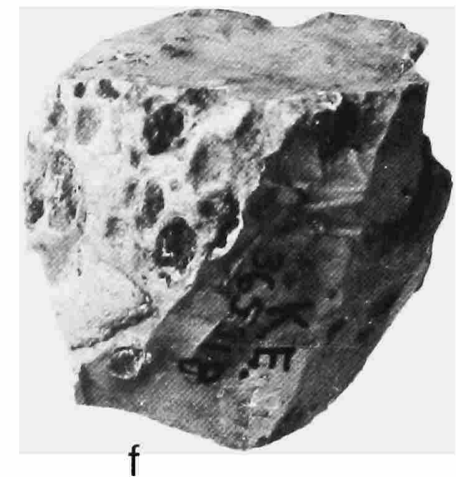

0 $2 \mathrm{~cm}$

FIGURE 74.-Point, perforators [catalog number 365308]; scrapers [catalog number 365315]; and core [catalog number 365318] from Kebara, Palestine. [Archaeological Society of Washington and American School for Prehistoric Research accession (accession 121286).]

'Chimney II'." The age of the artifacts from the Chimney proveniences was clarified in a later letter by MacCurdy to Judd, dated 29 October 1934: "Miss Garrod says that 'Chimney I, II, and III are on top of Layer B in the cave.' They are therefore Upper Mousterian." On 19 February 1935, MacCurdy indicated to Judd the meaning of additional letters on artifacts: "The capital letters (C, D, E, F, and G) are the layers and the lower-case letters (a, b, c, and d) are the hearth levels of the Layer in question." The value of the Tabūn collections was acknowledged in Wetmore's letter to MacCurdy on 28 August 1935: "It is a fine series, indeed, and I wish to congratulate you and your assistants upon the exceptional success of this important investigation." He continued: "I cannot, however, let pass the present opportunity to express our thanks to you for the obvious care taken to select a series which thoroughly illustrates the successive cultural levels in Mugharet et-Tabūn."
During the last years of the acquisitions, Smithsonian officials and archaeologists recognized the generosity of the American School for Prehistoric Research and the Archaeological Society of Washington, the importance of the collections they provided to the National Museum, and also the pivotal role played by George Grant MacCurdy. On behalf of the museum, Associate Director Graf wrote to Riggs on 15 June 1934 and expressed appreciation for the collections: "I would assure you that we greatly appreciate the interest of the Society in placing this material in the national collections where its public exhibition is not only of great educational interest but serves also as a very tangible evidence of the value and results of the Society's contributions to the work of the American School of Prehistoric Research." Judd expressed his thanks to MacCurdy in a letter dated 20 February 1935: "I wish you to know how greatly we all appreciate the personal attention you have given to se- 


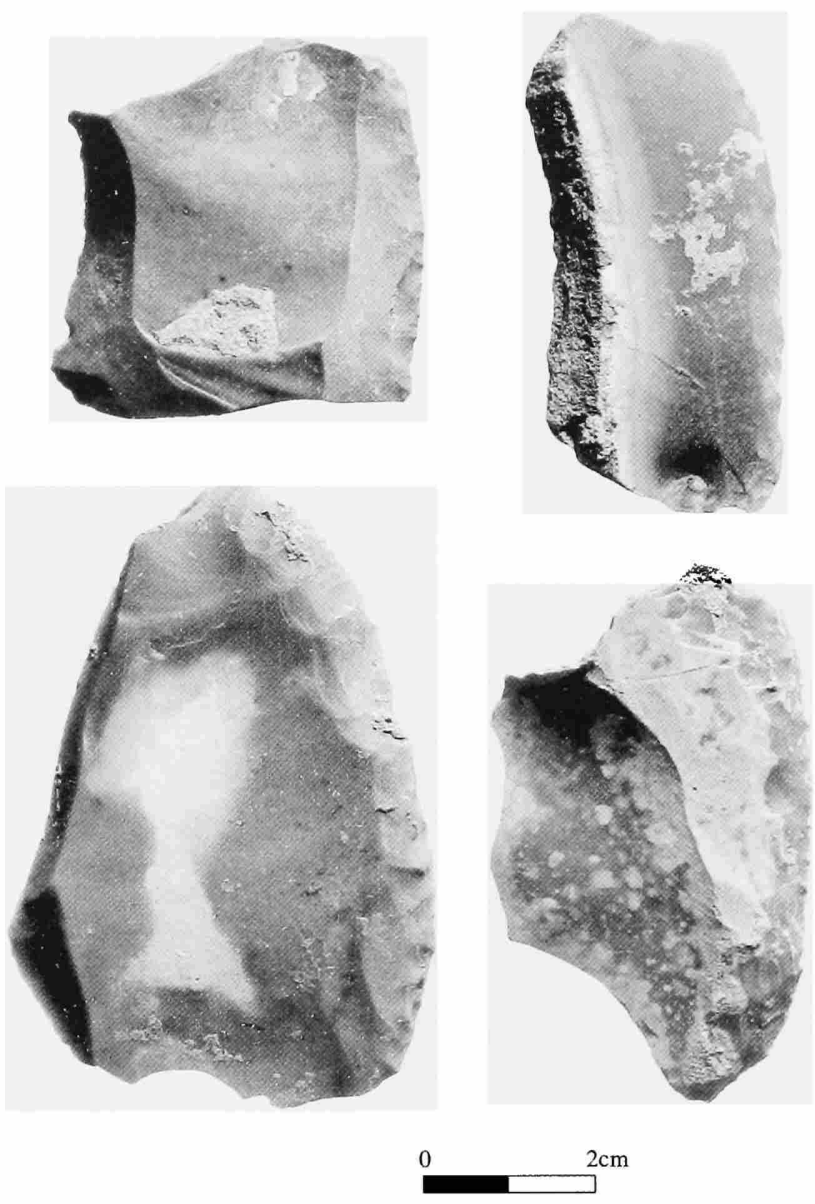

FIGURE 75.-Scrapers [catalog number 368608] from Mugharet es-Skūhl, Palestine. [Archaeological Society of Washington and American School for Prehistoric Research accession (accession 126298).]

lection of that portion of the annual collections intended for the National Museum through the Archaeological Society." The Archaeological Society of Washington obviously viewed the relationship as of benefit to the museum. This is clear in Riggs' final letter to Wetmore on 31 August 1935, in which he expressed his "gratification...to contribute in slight measure to the enrichment of your collections."

\section{Williams College (acc. 85687)}

In 1925, an exchange was made with the Department of Geology, Williams College, Massachusetts, through H.F. Cleland. Cleland was interested in acquiring Paleolithic materials to round out his teaching collection. On 18 January, Cleland wrote to the museum stating that he was teaching a course in European prehistory and that he did not have a representative collection of Paleolithic artifacts. Cleland requested from the museum any potential "duplicates to show the technique of chipping used in the different cultures." Cleland noted that he had Magdalenian collections from Dordogne, France, for exchange and was willing to give up his "choicest material in exchange for typical specimens." Ravenel, who was the administrative assistant to the secretary, responded on 25 January 1925: "I beg to say that your suggestion of an exchange of specimens is noted with interest and gladly agreed to. We have Chellean and Mousterian specimens which we will exchange for the Magdalenian material which you offer." Cleland provided more details on 1 February 1925 , stating that he was sending Magdalenian materials from Laugerie Basse, Dordogne: "The specimens come from the rock shelter in the peasant's house just above the rock shelter of Laugerie Basse. Peyrony says it is Magdalenian. I have tried to select as great a variety of forms and materials as possible. I have omitted broken specimens. Anything you will give in exchange will be useful in my course on Prehistory [and] will be very welcome." The next day Cleland noted that he also was sending material from Les Eyzies: "I am sending by mail to-day a small box of Magdalenian specimens from Les Eyzies, France. You will see upon examination that the specimens are first class. They are as good or better than those I have kept." In a letter on 13 February, Ravenel acknowledged the receipt of the exchange, noting that the National Museum was sending to him 21 Paleolithic specimens. In a final letter on 18 February, Cleland expressed his pleasure in receiving the material: "The Mousterian and Chellean specimens which you sent in exchange for our Magdalenian material came yesterday. As we had only one Chellean coup de poing we are glad of these specimens. The Mousterian is not as good as I hoped for but it will fill a gap."

\section{Reygasse (acc. 88916)}

In 1925, a collection of stone implements from North Africa was received as an exchange from Maurice Reygasse, Administrator of the Commune of Tébessa, Algeria. Reygasse suggested an exchange with the U.S. National Museum on 3 April 1924: "I shall be very much obliged to you to kindly inform me whether it would be agreeable to you to enter into exchange relations with me. I would send you [a] very good series of the African Paleolithic and would be glad to receive [a] good series, quite characteristic and in very good condition, of the different American prehistoric civilizations. I would be particularly enchanted to have fine specimens in obsidian which are missing in my collections." Ravenel replied on 25 April 1924: "I beg to say that the United States National Museum would be glad to receive additional specimens of African archeological material, and in order that the matter may be brought to a definite understanding I should be glad if you would indicate the particular specimens which you are prepared to furnish with a tentative money value for each. We will then be able to send you in exchange, American archeological specimens to the same amount. Unfortunately our collection of obsidian is lim- 


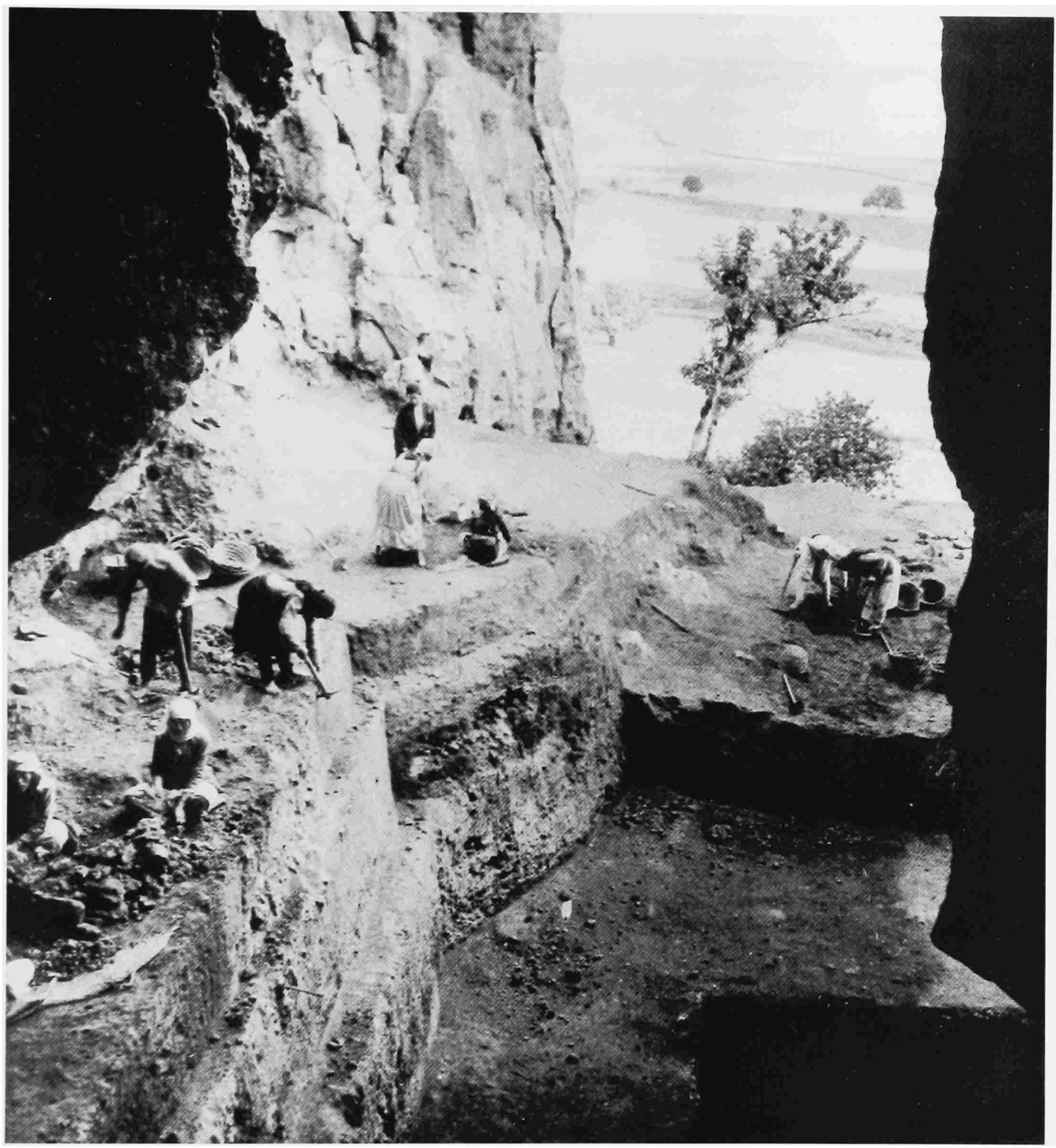

FIGURE 76.-Photograph of the Mugharet et-Tabūn excavations. [Labeled, "Looking out toward the Mediterranean from the mouth of the Mugharet et-Tabūn (cave of the oven). The American School of Prehistoric Research excavations at Mt. Carmel. Arab workmen digging for Neandertal remains." Science Services, National Anthropological Archives, NMNH (number 50790). The photograph was published in Garrod, 1935, Bulletin of the American School of Prehistoric Research, plate 8.]

ited, but we can supply you with specimens made from other materials."

On 27 September, Reygasse responded that he could send neolithic and African Paleolithic artifacts, noting: "I shall be happy to possess an American series of equal value.... Kindly let me know also exactly what you want me to send you." The collection was valued at $1100 \mathrm{fr}$. by Reygasse, but he added: "The prices that I am fixing as a basis of exchange are entirely relative. It is certain that it would be absolutely impossible to obtain at that price the series which I offer you. In fact I am the only one to possess rich series of the African prehistoric. I have never sold, and I will never sell, a single specimen. I only agree to enter into exchange-relations, which will enable each of us to have serious materials for study." On 29 July 1925, Assistant Secretary Wetmore provided Reygasse with the list of specimens available for exchange, noting: "If the matter meets with your approval, therefore, we would suggest that you now prepare and forward the materials you listed." Reygasse replied on 


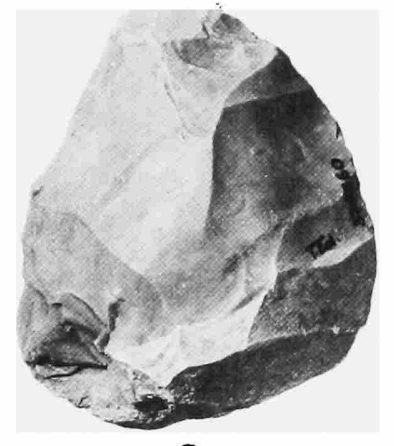

a

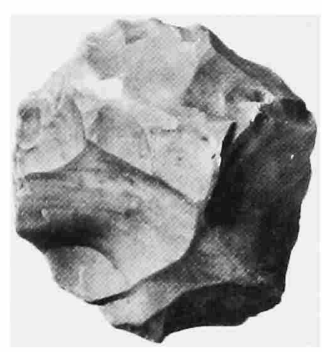

b

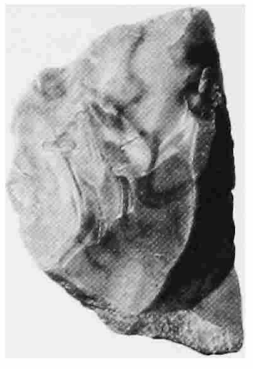

C

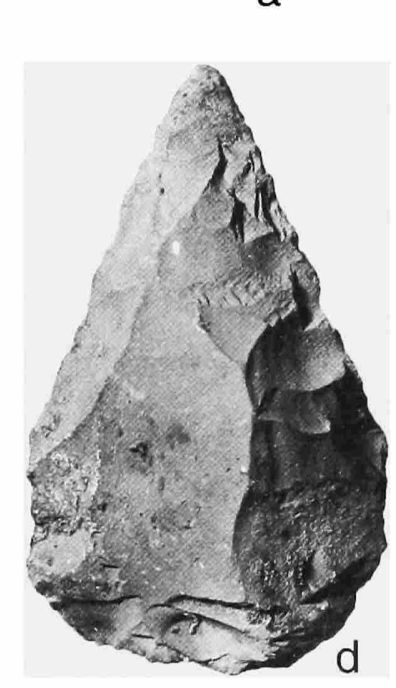

。 $5 \mathrm{~cm}$

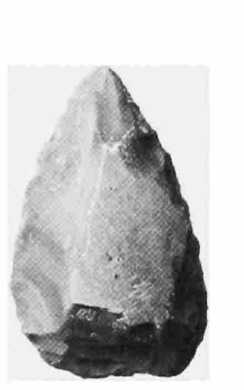

e

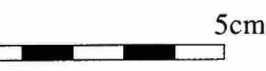

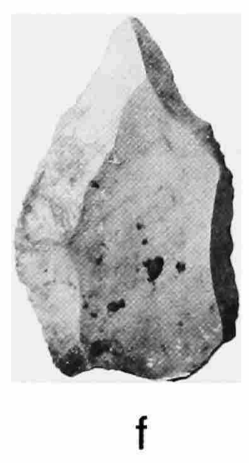

$5 \mathrm{~cm}$

FIGURE 77.- Stone tools from Mugharet et-Tabūn, Palestine. Top row (left to right): chopper, discoid, and side scraper [catalog numbers $374360,374361,374357$, respectively]; bottom row (left to right): handaxe, points, and graver [catalog numbers 372587, 374351, 368618, 374350, respectively]. [Archaeological Society of Washington and American School for Prehistoric Research accessions (accessions 133080, 132332, 133080, 126298, 133080).]

21 August: "I have the honor to inform you that I am sending you by mail this day a very fine series of my Proto-Solutrian Industry, as well as a typical collection of our Middle Paleolithic." On 19 October 1925, Wetmore wrote that the North African materials were received, and as an equivalent exchange, 22 obsidian implements from the United States and Mexico were sent.

\section{Government Museum, Madras (acc. 88426)}

In 1926, Paleolithic specimens were donated to the U.S. National Museum by the Madras Government Museum. In 1925, Hrdlička visited India in search of anthropological, archaeological, and paleontological collections. On 28 April 1925, Hrdlička wrote to Hough from India, and after some discussion about travel, modern peoples and race, and collections, he noted: "Am now on the way to Calcutta to examine their collections. From there will probably go direct to Madras, where they have the largest collection of the 'palaeoliths'." In 1925, Hrdlička wrote about his travel to Madras in an unpublished manuscript:

A great collection of Paleolithic implements is preserved in the Museum at Madras. These implements are similar to those of other parts of India. They are all of one general class, so much that there can hardly be a question as to their contemporary origin in the different parts of India and their connection with people in the same race and belonging to the same though perhaps a large cultural period. They do not show great variety. They resemble some of the Paleolithic implements of Europe, but on the whole cannot be associated with any one of the European cultural periods. They are something apart and, according to indications, hardly very ancient. In certain parts of India, such as the Santal country north of Calcutta, such implements have been collected in thousands. They are found by the farmers as they plough, and curiously, ...the natives call them "lightning stones." In other parts, especially near Madras, they are partly on the surface soil, partly from one to four or five feet and even deeper below the sur- 
face. In places they occur in the alluvium of the rivers and occasionally in the "laterite" a talus-like debris resulting from the disintegration of the older rocks. In short, evidence as to early man in India up to the present, may be reduced to the statement that there are plentiful Paleolithic implements over large portions of the country, but that as yet they do not in any case definitely indicate a man of geological antiquity.

Assistant Secretary Wetmore wrote to Dr. F.H. Gravely, director of the Madras Government Museum, on 30 June 1925, requesting material from Madras" "Dr. Aleš Hrdlicka [sic], $\mathrm{Cu}$ rator of Physical Anthropology in the U.S. National Museum, has written to me of his recent visit to your museum, and I would assure you of my appreciation of the many courtesies which you have extended to him." Wetmore continued: "We would ... like to secure a copy of each of the four catalogues of ancient implements published by your museum as well as a small representative collection of duplicates from your large collections of 'palaeoliths' of southern India. Please be assured that this museum will be glad to exchange any of its duplicate specimens which may be desired." The materials were sent to the Smithsonian, and Wetmore formally acknowledged their receipt on 8 January 1926.

\section{Jones (acc. 89904)}

In 1926, a collection of stone implements from Rhodesia was donated to the museum by Neville Jones of the London Mission School, located near Bulawayo, Southern Rhodesia. The gift was the result of a transaction made by Hrdlička, probably during his visit to that country. On 7 January 1926, Wetmore acknowledged the gift.

\section{Bodding (acc. 90169)}

In 1926, a collection of stone implements was donated to the U.S. National Museum by the Reverend P.O. Bodding of Mohulpahari, Santal Parangas, India. In a letter to Wetmore dated 21 October 1925, Bodding acknowledged his receipt of a collection of Smithsonian Annual Reports, indicating that it would be of assistance to him for his work on linguistics and ethnology. Bodding also alluded to how the subject of the potential gift was first raised: "When I had the pleasure of meeting Dr. Hrdlicka [sic] here in May I promised him that I should send a sample collection of ancient stone implements found here in this district. I am having these packed and shall forward them through your Consul General in Calcutta very soon. I am sending samples of the different kinds met with here." Bodding wrote to Hrdlička on 11 November, indicating that he had sent the specimens:

At last I have been able to send the stone implements I promised you when I had the pleasure and privilege of meeting you in Darjeeling. They are packed in a wooden box which I sent down from the American Consul General in Calcutta, and I have an acknowledgment from him that he has received the box and will send it as soon as possible to Washington. I waited so long, partly because I wanted to be sure that you were back in Washington, partly because I wanted to try to get hold of one special and very seldom form. I have sent in all 100 specimens, some fairly large ones, many quite small, so it is not easy to un- derstand what they may have been used for. They are all found here in this district (if you look at a map of India, you will see when the Ganges commences to turn to the southeast; the Santal Parganas district is south of the Ganges here).

On 9 December 1925, Hrdlička wrote to Bodding: "We have just had from our Consul in Calcutta the welcome news that you are ready to send us a lot of the stone implements from your region. They will be of great value." Wetmore wrote to Bodding, on 24 March 1926, acknowledging receipt of the collection. After examining the collection, Hrdlička again wrote to Bodding, on 19 April 1927, indicating that the assemblage was an assortment of stone-age material: "The stones from you came in good condition. They evidently date all from the later or polished stone period, though some of them are not polished. There are no new forms, but the collection is a very interesting one nevertheless, and is I believe the only one of its kind in America."

\section{MacCurdy (acc. 92141, 99368, 108178)}

Three small accessions were donated to the museum by Dr. George Grant MacCurdy of the Peabody Museum, Yale University, in 1926, 1927, and 1929. Apart from the "gifts" transmitted by MacCurdy during the operations of the American School for Prehistoric Research from 1925 to 1935, these collections apparently were selected during MacCurdy's visits to Palestine and France. There is no correspondence associated with the last two collections.

In 1926, seven Paleolithic stone implements from Palestine were donated by MacCurdy. The donation was preceded by a letter from MacCurdy to Hough, dated 2 May 1926, in which he stated: "On April 28 I sent you a parcel containing Paleolithic (Acheulian) flints found by Mrs. MacCurdy and myself at Sambariyeh near Mutallah, headwaters of the Jordan, Palestine. They are sent to your Museum with our compliments." On 14 June 1926, Wetmore acknowledged the gift.

In 1927, stone artifacts from three sites in France were donated by MacCurdy. A typed list indicated there were 4 Acheulian, 1 Mousterian, and 1 Chellean specimens. Wetmore acknowledged the gift on 9 December 1927. In 1929, MacCurdy donated six artifacts from La Magdalaine, Dordogne, France. The material was from the Magdalenian level of the rockshelter. In a memorandum from Judd to Hough (Smithsonian curators), dated 9 December 1929, the collection was noted to consist of three scrapers and three gravers. On 13 December 1929, Wetmore acknowledged MacCurdy's gift.

\section{Bushnell (acc. 93521)}

In 1926, a collection of stone implements, mostly from various localities in Europe, was donated to the U.S. National Museum by David I. Bushnell of Washington, D.C. Bushnell was a collector of Native American artifacts, and he had written on the subject (e.g., Bushnell, 1939). The objects were delivered personally by Bushnell; thus, there are no accompanying 
records, except for a letter of acknowledgment from Administrative Assistant Ravenel on 13 October 1926.

\section{Indian Museum, Calcutta (acc. 88427)}

An exchange was made with the Indian Museum in Calcutta, through Rai Bahadur Ramaprasad Chanda, superintendent of the Archaeological Section, for a collection of stone implements from India. Assistant Secretary Abbott wrote to Sir John Robert Marshall, director of the Archaeological Survey of India, on 25 June 1925, requesting an exchange: "Dr. Aleš Hrdlicka [sic], Curator of Physical Anthropology in the U.S. National Museum, has written to me of his recent pleasant visit to your department. He advised me of the very interesting work being done by the Archaeological Survey of India and has asked that I request you to favor this Museum with a small collection of representative duplicates of Indian 'paleoliths' from the large collection now under your care in the Museum of Calcutta. We would, of course, be glad to send in exchange whatever you might wish from the collections in this museum along the same line." Chanda replied on 15 June 1926: "I beg to state that I shall be very glad to spare a set of small representative collection of the Indian Palaeoliths for exchange with your Institution, and in exchange I should like to have a representative collection of American palaeoliths." In reply, on 8 December 1926, Wetmore confirmed that a box containing 94 American stone implements had been sent to the Indian Museum in Calcutta.

\section{South African Museum (acc. 101485)}

In 1928, seven Stone Age implements from Montagu Cave, South Africa were donated to the U.S. National Museum by the South African Museum in Capetown, through its director, Leonard Gill. The gift was likely the result of Hrdlička's visit to South Africa. On 26 March 1928, Gill wrote to Hrdlička, stating that a small collection of Early Stone Age implements from South Africa had been sent, which illustrated the series of chipped stone objects that could be found in the site (Figure 78). Assistant Secretary Wetmore sent Gill a letter of acknowledgment for the collection on 25 May.

\section{Provincial Museum, Czechoslovakia (acc. 107637)}

In 1929, casts of worked bone and a statuette found in Czechoslovakia were donated to the museum by the Provincial Museum, in Brno, Moravia, through Dr. Karl Absolon, who was a curator. Hrdlička corresponded with Absolon throughout the mid- to late 1920 s, and on 9 February 1926 he acknowledged Absolon's discoveries: "I wish to congratulate you heartily on the important discoveries which you have made in Southern Moravia and to wish you the greatest possible success in further research. There is a substantial hope that you may find another large burial place of Aurignacian man." In a subsequent letter, dated 7 May 1928, Hrdlička offered some ad-

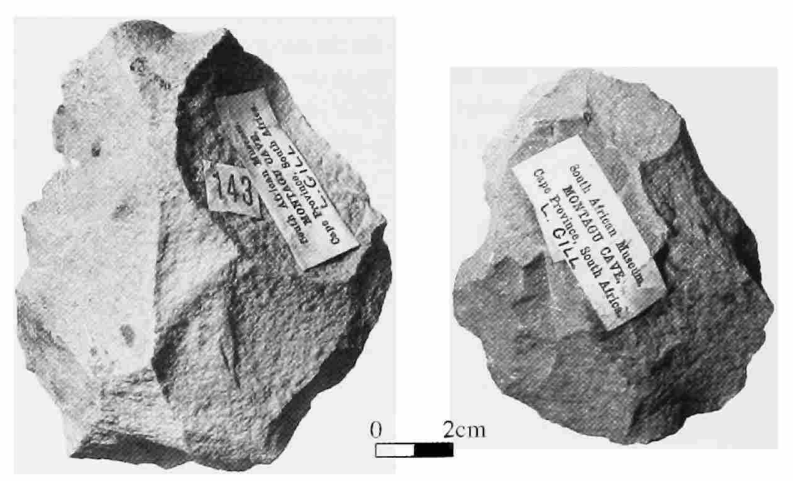

a
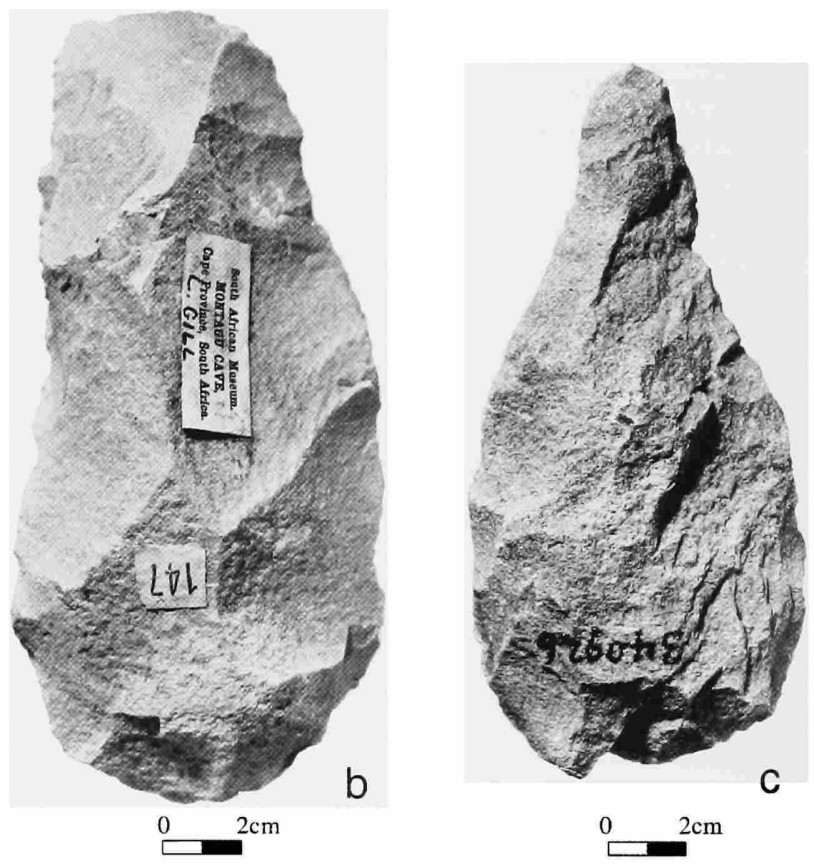

Figure 78.- Stone tools from Montagu Cave, South Africa: (a) cores [catalog numbers 340931, 340930]; (b) handaxe (cleaver) [catalog number 340928]; and (c) handaxe [catalog number 340926]. [South African Museum accession (accession 101485).]

vice: "I trust you will soon be starting with further work at Viestonice, and wish you all the possible success. I should like to urge again extensive soundings, for the determination of the total extent of the site, and location of its richest parts. I beg you to keep me posted on the results of the work, and particularly as to the finds of additional skeletal remains. You are bound sooner or later to discover numerous skeletons." A memorandum from Judd to Hough, dated 1 November 1929, identified the casts as a statuette of a woman, from Dolni Vestonice, identified as Aurignacian (now Pavlovian), a carving of a mammoth, and a cave bear skull with an embedded arrow point from a cave in the Moravian central hills. Wetmore sent Absolon an acknowledgment on 4 November 1929. 


\section{Russell and Old World Archaeology Fund (acc. 112339, 116916, 117631, 117750, 118935, 121411, 124072)}

The Smithsonian acquired seven gift accessions from 1930 to 1933 as a result of donations by J. Townsend Russell. The gifts consisted of Russell's personal collections, purchased collections from the Old World Archaeology Fund, and artifacts uncovered at excavations by the Franco-American Union for Prehistoric Research in France.

In 1930, a cast of the Willendorf Venus from the Lower Aurignacian (now Gravettian) was donated to the U.S. National Museum (acc. 112339) by the Landes Museum in Vienna, Austria. The piece may have been sought for exhibit purposes. Russell wrote to Judd on 20 September 1930, indicating that while in Vienna he secured the cast that the U.S. National Museum sought. The gift was acknowledged by Assistant Secretary Wetmore in a letter to Russell on 30 October.

In 1931, twenty-five water color reproductions of Upper Paleolithic Spanish cave art and fourteen casts of Upper Paleolithic bone art objects and implements were donated to the museum (acc. 117631) by the Old World Archaeology Fund. Russell arranged the transaction with Father [Don] Jesús Carballo, of the Museo Prehistórico of Santander, Spain, and author of a book on the prehistory of Spain, Prehistoria Universal y Especial de España (1924). Members of the American School of Prehistoric Research visited Carballo and the cave site of El Pendo, in Spain (Carballo, 1931). On 6 August 1930, Russell wrote to thank Carballo for his courtesy during Russell's stay in Santander, and expressed the hope that there was progress on the paintings that they discussed. On 23 September 1931, Carballo wrote to the treasurer of the U.S. National Museum to inform him that the materials were sent: "As per Instruction of my good friend Mr. J. Townsend Russell I had the pleasure of sending to you some paintings and reproductions of prehistoric objects." Carballo indicated that the total expense (including payment for the artist) was 1413 ptas. The same day, Carballo wrote to Russell that "in all of this I won't get any benefit, I will have the pleasure of having being of some use to you." In a letter, dated 9 January 1932, Wetmore acknowledged the payment for the Carballo collection.

In 1932, Russell donated his European collections (acc. 116916), mostly consisting of single specimens or a small number of pieces from various sites (Figure 79). The most thoroughly reported artifacts in the collection are those from Chambe, France (Figure 80). Russell (1928) briefly described these artifacts in an article titled "A Summer of Prehistoric Research in the 'Pays Civraisien'." Subsequently, some of the same objects were illustrated in an article titled Report on Field Work in France, Season of 1928 (Russell, 1929) (Figure 81). Russell described the circumstances of this transaction to Wetmore on 25 September 1931: "There is in the Museum part of my personal collection in two cases. I plan to present this to the Museum but have never done so as I wished to hold up the gift until I could get the confusion in the collections straightened out. I have just ordered a third case, that was still here in stor-

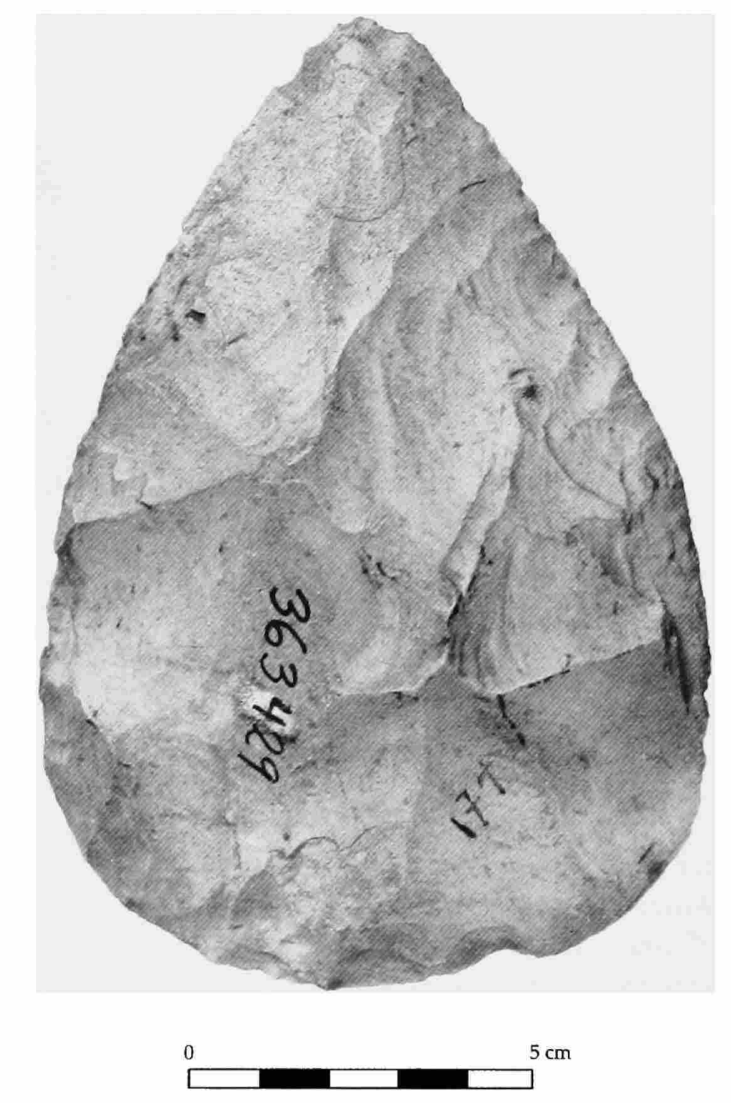

FIGURE 79.-Handaxe [catalog number 363429] from Meyral, France. [Russell and Old World Archaeology Fund accession (accession 116916).]

age, shipped to the Museum in my name." On 8 February 1932, Wetmore acknowledged Russell's gift.

In 1932, two accessions (acc. 117750, 118935), consisting of Upper Paleolithic collections excavated in southern France under the direction of Russell during the 1931 season, were donated to the U.S. National Museum by the Old World Archaeology Fund. The collection was excavated under the auspices of the Franco-American Union for Prehistoric Research in France by the University of Toulouse and the Smithsonian Institution. The results of this fieldwork were published by Russell in "Report on Archaeological Research in the Foothills of the Pyrenees," Smithsonian Miscellaneous Collections, 1932, and in La Campagne de Fouilles de 1931, by Bégouën and Russell, issued by publisher Edouard Privat, Toulouse, 1933 (Figure 82 ). Among the collections were a variety of chipped stone artifacts from Roquecourbére, Ariège; chipped stone artifacts, bone fragments, and breccia from Tarté, Commune of Cassagne, Haute Garonne; and chipped stone, bone fragments, ochre, shells, travertine, and a photo from Marsoulas, Commune of Marsoulas, Haute-Garonne. Among the spectacular art objects is a palette from Tarté (Figure 83) (Petraglia et al., 1992).

In 1932, the museum accessioned (acc. 121411) a collection of photographs of Paleolithic cave art of Ariège and Haute Ga- 

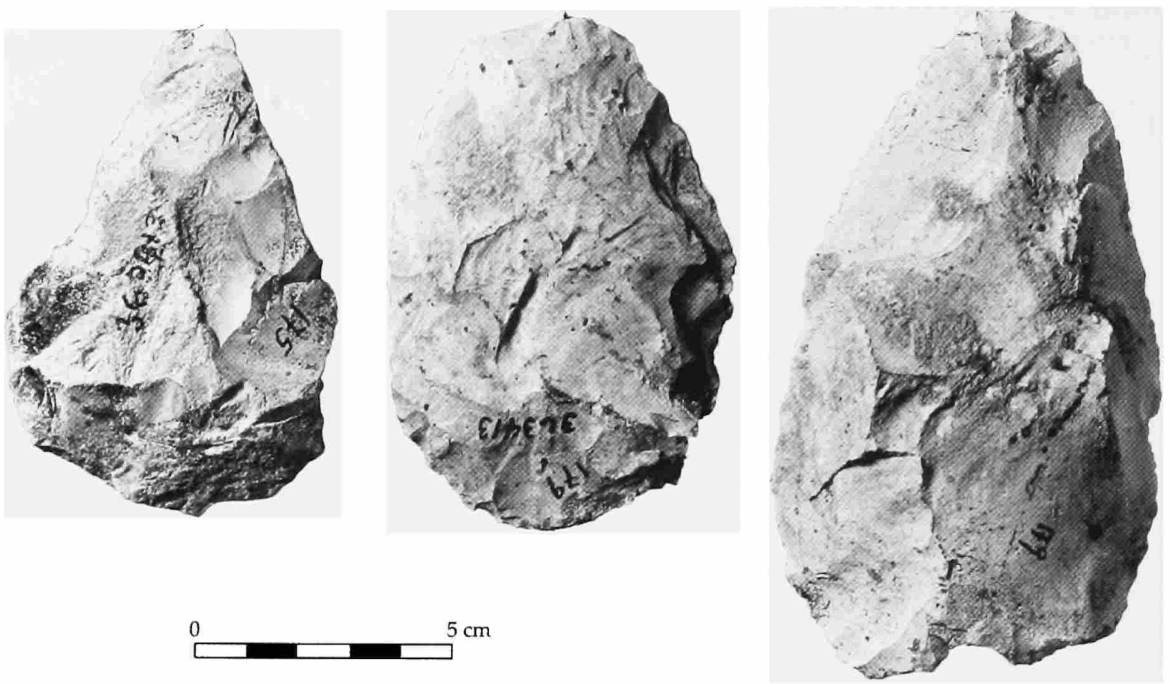

FIGURE 80.-Handaxes [catalog number 363413] from Chambe, France. [Russell and Old World Archaeology Fund accession (accession 116916).]

ronne, France. The collection was purchased for 775 francs by J. Townsend Russell from Count Henri Bégouën of the University of Toulouse. The photographs consisted of the most famous views, paintings, sculptures, and engravings from caves in the Ariège and Haute-Garonne regions of France. In 1933, the museum accessioned (acc. 124072) a collection of photographs of Paleolithic sites and of fossils obtained from originals furnished by Hrdlička, as well as films belonging to Russell. The photographs from these two accessions were used to develop future exhibits.
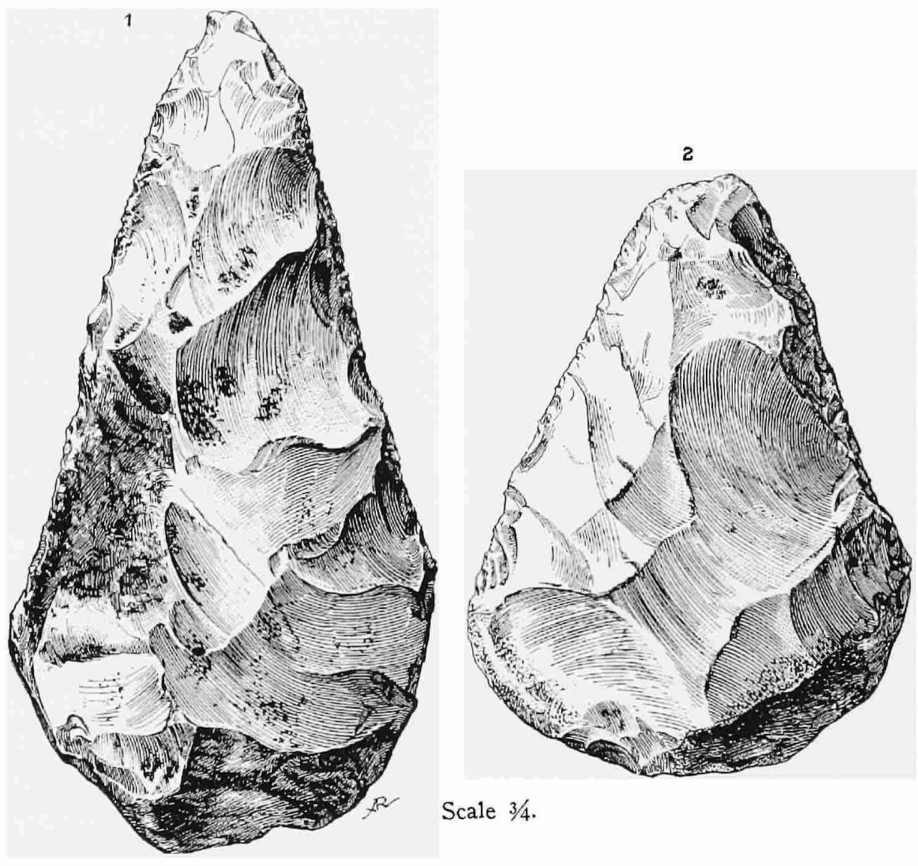

Scale $3 / 4$.

FIGURE 81.-Drawings of two flint artifacts from Chambe, France, representing an "Early type of cleaver or handaxe resembling those found at La Micoque (Dordogne)" and considered to be of the "Mousterian Epoch" (Russell, 1928:11). [These pieces are in the NMNH collection (accession 116916). Published in Russell, 1928, Bulletin of the American School of Prehistoric Research, fig. 1.] 


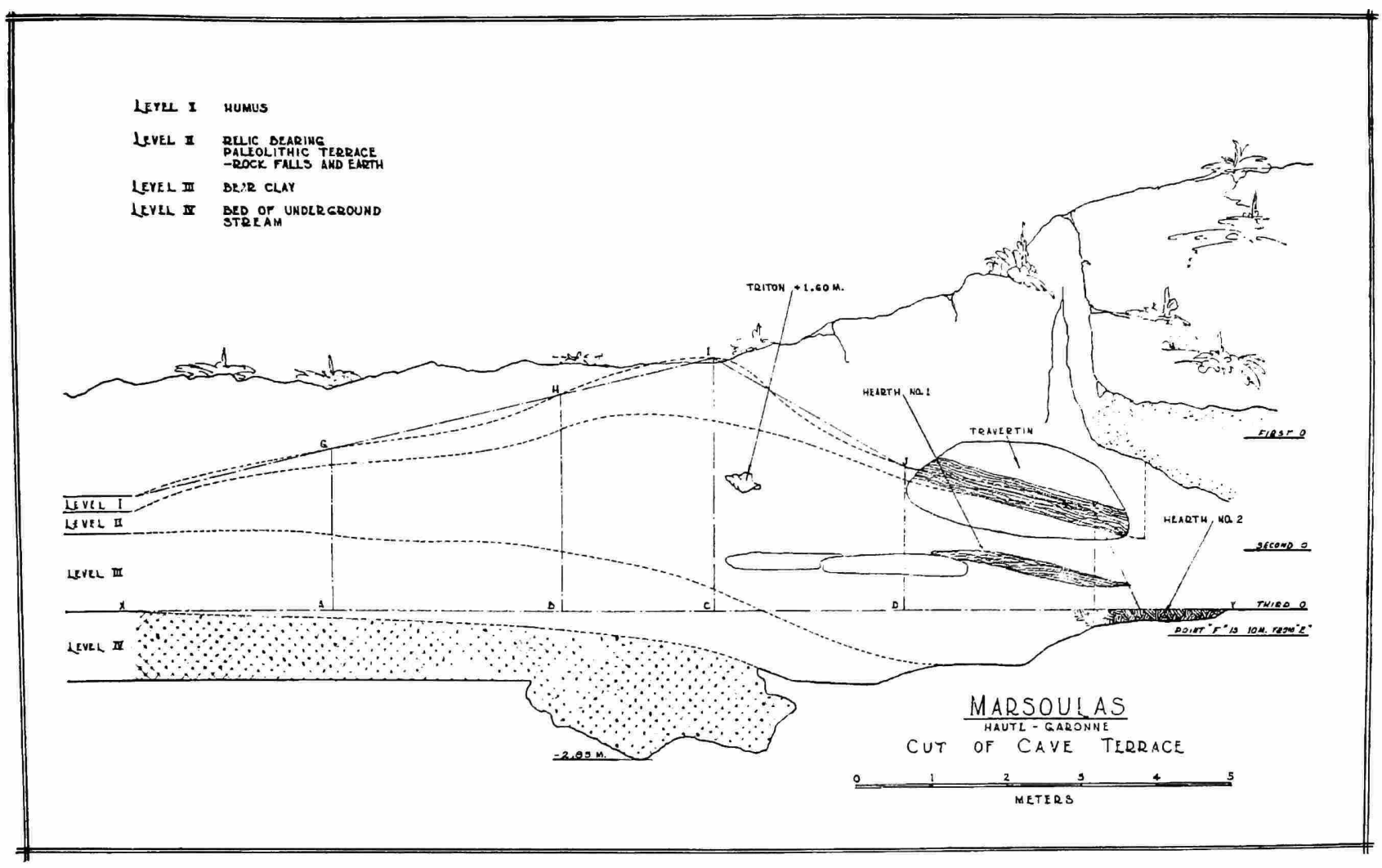

FIGURE 82.-Cross section of the Marsoulas excavations (Russell, 1932).

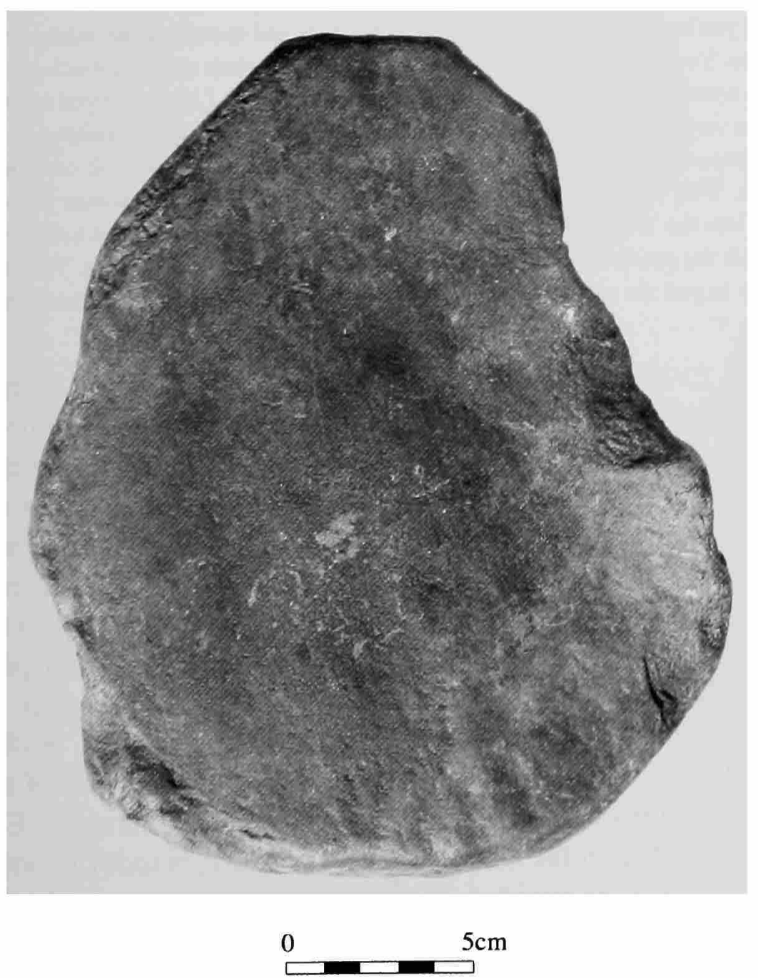

Serrano y Sanz (acc. 114125)

In 1931, a collection of artifacts from the Manzanares River Valley at Villaverde Bajo, Madrid, Spain, was donated to the U.S. National Museum by Manuel Serrano y Sanz, of Madrid, Spain. On 12 February, Sanz inquired whether the Staff would like to have Mousterian objects from Madrid for the National Museum. On 15 March, John E. Graf, associate director of the U.S. National Museum, responded: "I regret to advise you that we have no prehistoric objects whatever from Spain in our national collections and for this reason would be particularly grateful for a small but representative series illustrating the Musteriense of Madrid. We should also be glad to receive in this connection notes describing the relationship of the species, their horizon, and any publications which may be available concerning the site or sites whence they were secured." On 2 May, Sanz indicated that he was sending objects from Villa Verde Bajo, and that the deposit was confirmed by P. Wernert and J. Pérez de Barradas to be "Precapsian, synchronous with a final phase of the Acheulian." Serrano y Sanz wrote that the

FIGURE 83 (left).- - Artist's Palette" [catalog number 363247] from Tarté, France. [Russell and Old World Archaeology Fund accession (accession 117750).J 
prehistory of the Manzanares Valley was published in various monographs by the Committee of Excavations in Madrid. In a drawing of the site stratigraphy supplied by Serrano y Sanz, the sequence was shown to consist of three strata; the artifacts were found in the lower part of the white sand at a depth of two to six meters. Graf acknowledged the gift in a letter dated 2 June 1931.

\section{Bégouën (acc. 117494)}

In 1931, casts of engravings of animals and of footprint and fingerprint impressions taken from caves were donated to the U.S. National Museum by the Count Henri Bégouën, Professor of Prehistory, University of Toulouse, France. Although the material was purchased by Russell during his explorations with Bégouën in the Pyrenees, the accession was recorded as a gift from Bégouën. Bégouën and H. Vallois described the casts in "Les Empreintes Préhistoriques," which was published in Comptes Rendus, in 1927. Graf acknowledged the receipt of the collection on 24 December 1931.

\section{Abbott (acc. 124660, 128495, 134685, 140811, 150229)}

Wilfred C. Abbott, of the Standard Bank of South Africa, donated archaeological collections to the U.S. National Museum in five separate accessions from 1933 to 1938 . The first accession (acc. 124660) was received during Abbott's visit to the museum in 1933. It consisted of a small collection made at Tanbryn Farm, District of Bainsvlei, near Bloemfontein, South Africa. The artifacts were found on a hard bed of shallow pans in the veld during 1931 and 1932. On 10 June 1933, L.L. Wedlock, J. Townsend Russell's temporary assistant, wrote to Abbott after the visit, stating: "I enjoyed very much indeed your visit to Washington and feel the hours spent with you were among those which I have enjoyed most during my brief career as an archeologist. Mr. Judd joins me in thanking you for your kind disposition toward the Museum and we both appreciate very much your efforts in assisting us toward the acquisition of more complete collections from South Africa. We wish these to be as educationally useful as possible."

Nine months later Assistant Secretary Wetmore wrote to Abbott, on 5 March 1934, indicating that additional materials from South Africa were wanted: "The stone implements which you forwarded about a year ago were of much interest and a most desirable addition to our meager prehistoric exhibit from South Africa. We should be pleased indeed to add any additional specimens which you may care to forward." Soon after, Abbott sent materials from two localities as part of a second accession (acc. 128495). Abbott noted that, although the artifacts were probably Paleolithic, they were of uncertain age.

The third accession (acc. 134685) of South African material was received in 1935, during Abbott's second visit to the U.S. National Museum. On 27 May 1935, Judd wrote to Abbott to express his appreciation for the collection: "Before your depar- ture from New York, Doctor Wetmore will formally acknowledge the specimens you so generously brought with you for our modest African collection. If I could make you believe how thoroughly welcome these artifacts are, I am sure you would be amply rewarded for all the trouble you went to in collecting them and bringing them over in person." Wetmore acknowledged the gift on 28 May 1935. Abbott replied on 6 June: "You are more than welcome to the few artifacts I was able to bring over. I was only sorry I was not able, before leaving Cape Town, to get at my full collection, as I have many duplicates from other areas \& of different cultures \& could have left you a more varied selection." In 1936, Abbott sent another small collection of artifacts (acc. 140811) from three localities near Capetown. In a letter dated 1 July 1936, Wetmore thanked Abbott for his "continued and generous interest" in donating material.

The final accession (acc. 150229) of South African material was received in 1938. In a letter to Judd, dated 6 February 1938, Abbott described camping in the "Witsands," or the white sand dunes of Criqualand West, Cape Province, on the border of the Kalahari Desert, and at the foot of the Langeberg Hills. Abbott indicated that microliths were found in several areas in the dunes, and in one area in particular, "Mousterian" artifacts were found. "Towards the end of our stay we found a site somewhat further from our camp, and on lower ground where we picked up a number of Mousterian implements, some of them quite large and these will be included in the parcel going on later." Judd responded on 25 April, expressing appreciation for the parcel:

From your photographs and description I can readily imagine what a delightful time you had camping at the foot of Langeberg and searching the nearby sand dunes. Your description of the Witsand country reminds me very much of our own western Texas and southern New Mexico where I have enjoyed experiences very similar to yours. It adds much to the adventure when drinking water is distinctly at a premium; where casual pools must be shared with cattle and goats. With you as guide, it would be a pleasure to lead a Smithsonian expedition into the Witsand region and rugged ravines of Langeberg. But I am quite certain the possibility of such a jaunt is too remote for consideration. We must leave to you the satisfaction of searching out the rock shelters to be explored there.

On 23 August 1938, Abbott provided information on his finds and sent newspaper clippings about which he opined: "These archaeologists seem to be on the track of some startling discoveries, though I don't hold with the theory of a 'missing link.' If one accepts that life, human life, was created \& not evolved. I can't understand why scientists want to establish that man, in the marvelous perfection as we know him, evolved from an ape \& was not created by a beautiful being." Anticipating the disruptions that would soon occur in the exchange of objects, Judd wrote to Abbott on 24 September 1938: "Radio and daily press are bringing echoes of the unhappy state of affairs in Europe. It is most disheartening and discouraging. Every individual in the United States, I am sure, is today praying that war may be avoided. But how to stop a madman without war?" On 23 December 1938, John E. Graf, associate director of the U.S. National Museum, acknowledged the gift. 


\section{Leach (acc. 134860, 134861)}

In 1935, two accessions from the Thames River valley were donated to the U.S. National Museum by A.L. Leach, of Woolrich, England, through Miss Mary S. Johnston. The materials were donated after Johnston attended a Geological Congress in Washington, D.C. On 7 October 1934, Johnson wrote to Judd: "I noticed when I was wandering round your archaeological galleries, with your Dr. Collins, that you had not many British examples. I am not a good archaeologist, myself tho' I am very interested, I was talking to my great friend Mr. Leach and asked him to tell me how I could get a small series to send you and he said he was sure, he and his colleague, Mr. Chandler could get together some specimens, worth sending, and properly named. So in a short time, you will receive 3 small parcels, containing the results of this colloquy. I hope you will be pleased and find them interesting."

The first accession of material was soon received and consisted mostly of bifacial pieces from Swanscombe, England (Figure 84). Judd replied to Johnson on 31 October 1934: "As an archeologist, I was quite overjoyed upon receipt of the fine series of paleoliths contributed, through you by Messrs. Leach and Chandler. It is extremely thoughtful, and generous, of you to have come in this way to the aid of our modest collection from England. The specimens arrived duly and will prove a most welcome addition to our archeological hall. Naturally, we wish our European exhibits to be as representative as possible." In a memorandum to Hough, on 7 June 1935, Judd stated that two lots of fine Paleolithic implements were received, noting that materials from the famous site of Swanscombe were well documented in the literature. Assistant Secretary Wetmore wrote to Leach on 10 June to express appreciation for the collection: "Together with those received at the same time from Mr. R.H. Chandler, the implements provide a most acceptable exhibit-one that clearly illustrates the comparative youth of certain North American artifacts which were formerly assigned to the Paleolithic horizon." Judd wrote a second letter to Johnston on 12 July: "Your confidence in the high quality of archeological researches pursued by British amateurs is thoroughly justified. While European prehistory is not among my major interests I fully appreciate the merit of those contributions which have come to my attention. Among these, the papers by Mr. Chandler impress me most favorably." In a letter dated 15 July, Leach replied to Wetmore that both he and Mr. Chandler were pleased to send the Thames Valley specimens. Leach enclosed a copy of a report entitled, "The Clactonian Industry and Report of a Field Meeting at Swanscombe (III)" by R.H. Chandler, published in the Proceedings of the Geologists' Associa-

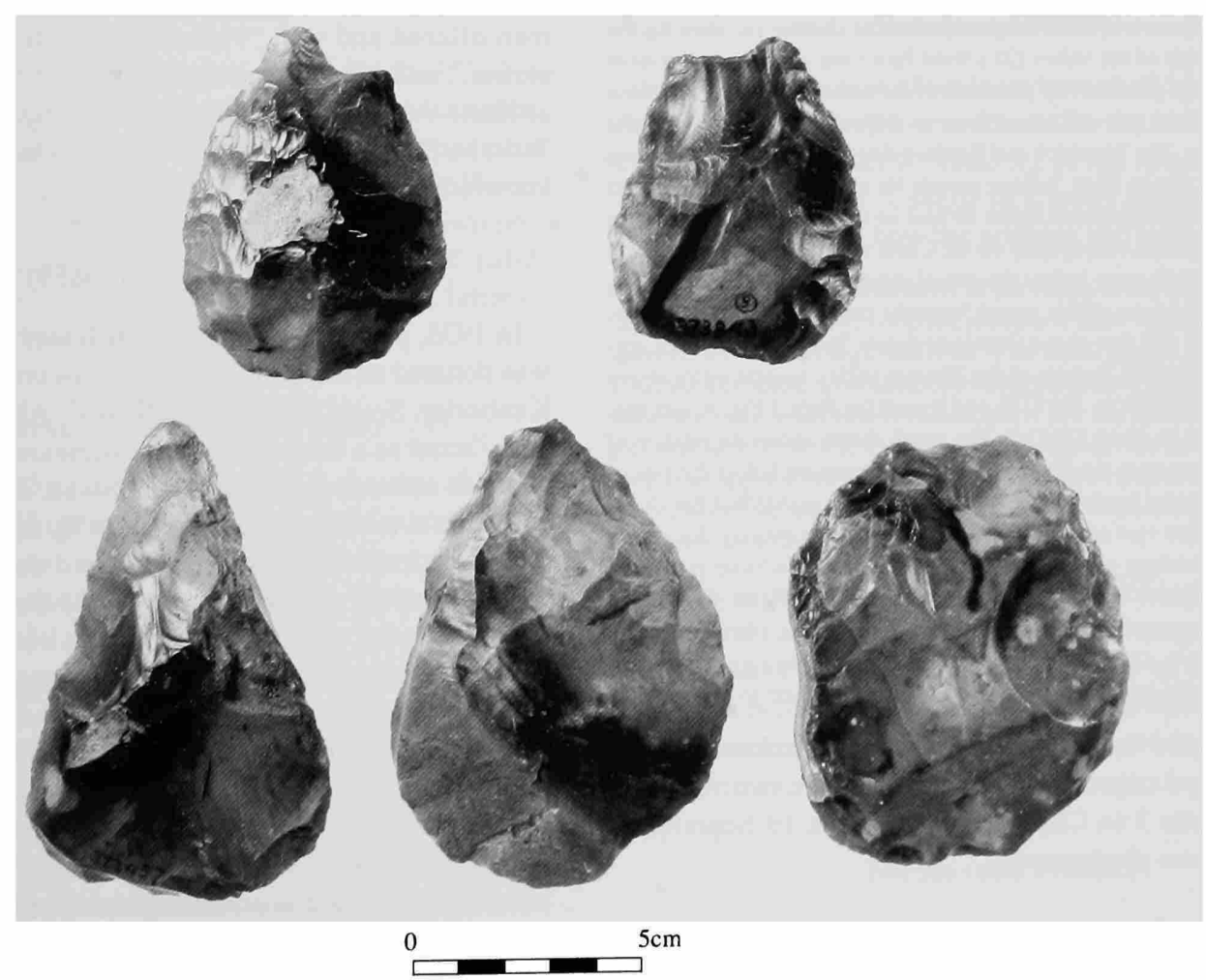

FIGURE 84.-Handaxes [catalog numbers 373462, 373843, 373457, 373840, 373841, left to right] from Swanscombe, England. [Leach accessions (accessions 134860, 134861).] 

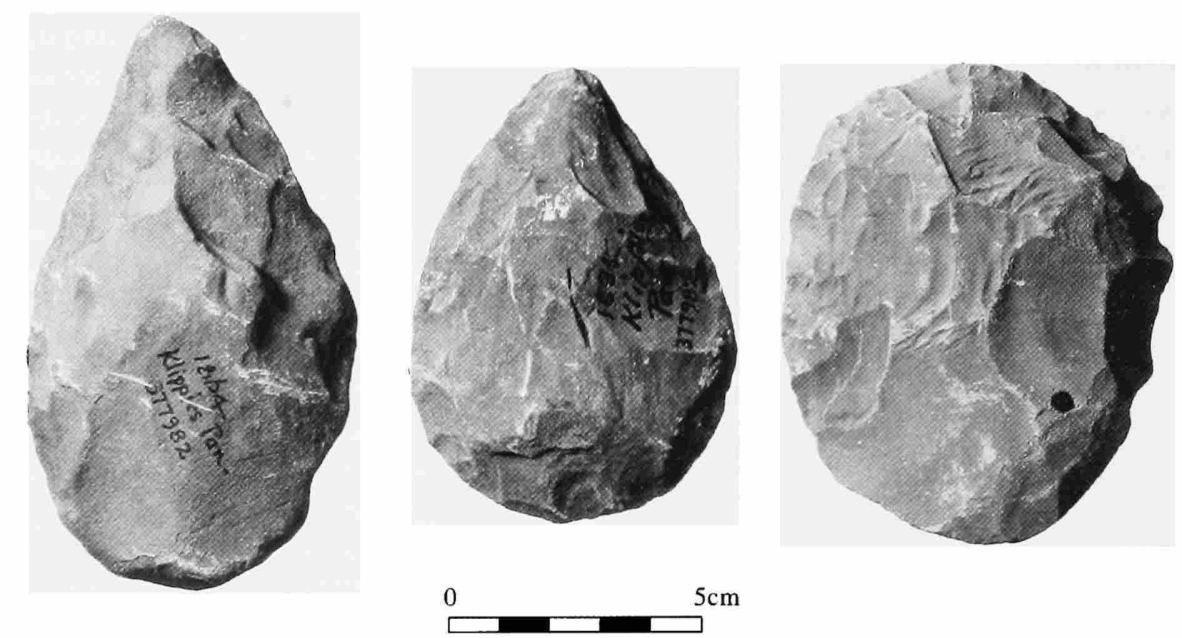

FIGURE 85.-Handaxes (left and iniddle) [catalog number 377982] and discoid (right) [catalog number 377981] from Klippies Pan, South Africa. [McGregor Museum accession (accession 141245).]

tion (46:43-45) with the letter. He also provided a summation of the context of the finds in relation to two published plates:

It has occurred to Mr. Chandler and myself that some illustrations of the gravels in which these implements are found may be of some interest in relation to the specimens from Swanscombe. To illustrate the brief report of one of our Field Meetings (Geologists' Association) I took two photographs which show (1) the gravel in a section transverse to the original bed of the channel i.e. showing the base rising on the side of the valley (2) a front-face view of the gravel. I have pencilled on the rough plan the two positions of the camera. By the aid of these views and the side notes you will I think have no difficulty in understanding the conditions of the site. The Woodrich and Reading Beds and the Thanet Sand are our lowest Eocene. These High Terrace gravels lie in a channel cut in Thanet Sand down to and sometimes even below its base so that the gravel in places, in other pits at Swanscombe, rest directly on the Chalk all the Thanet Sand having been eroded completely away before the gravel deposit began to be laid down. The lowest part of the base of this gravel formerly called High, or $100 \mathrm{ft}$, (because approximately 100 feet above Ordnance datum Terrace)-not often correlated with the Boyn Hill Terrace of the Thames valley several miles above London, lies about 95 O.D. to 100 O.D. and it rises (as Plate 3 Fig. A was specially taken to show) to about 120 O.D. The rough sketch shows the relation of the gravels (two terraces) to the Chalk and Eocene formations before the side of the valleys were altered by the enormous workings for gravel and for Chalk workings so great that vast areas of the gravels have been entirely destroyed. We hope these illustrations of the Barnfield Pit (called 'Milton Street pit' in old accounts of this district) will be of some service. Rixon's Farm pit is in the same High Terrace gravel, $1 / 2$ mile or so from Barnfield pit: therc the gravel rests on the Chalk. Mr. Chandler has been able to spare three copies of the report and on his behalf I have much pleasure in forwarding them to you.

In a letter dated 2 August 1935, Wetmore acknowledged Leach's letter and requested photographs of the two views reproduced as plate 3 in Chandler's paper. On 19 September, Leach sent the two photographs.

\section{McGregor Museum (acc. 141245)}

In 1936, an exchange was made with the McGregor Memorial Museum, in Kimberley, South Africa, for a collection of stone implements from various localities in Cape Province, South Africa. The accession was arranged by Miss M. Wilman, director of the museum, and was assisted by W.C. Abbott, who had previously provided other South African artifacts to the Smithsonian. In a letter of 14 February 1923, Wilman wrote to thank Hough for the Native American artifacts. In return, Wilman offered and sent "Paleolithic implements," "perforated stones," and "Bushman implements." Among the Paleolithic artifacts were those of Klippies Pan (Figure 85). In a letter to Wilman dated 24 October 1936, Associate Director Graf acknowledged the receipt of the collection.

\section{Swan (acc. 150659)}

In 1938, a collection of stone implements from South Africa was donated to the U.S. National Museum by James Swan, of Kimberley, South Africa, through W.C. Abbott, who had previously acted as a liaison for other accessions. The accession file contains no correspondence from Swan. The only information available is a letter of 23 August 1938, in which Abbott mentioned to Judd that Swan would send the material. Graf acknowledged the gift in a letter dated 23 December.

\section{Franssen (acc. 159728)}

In 1941, an exchange was made with Dr. C. Franssen for a collection of archaeological material from Java. In a letter of 30 September 1940, Franssen proposed the exchange: "I have done considerable original research work in West Java, and have been fortunate in collecting numbers of entirely new specimens, most of which have as yet not been published. I also have a number of the palaeolithic specimens as published by [G.H.R.] von Koenigswald in the Bulletin of Raffles Museum, Singapore (Serie B no 1 pp. 25-60, 1936)." Associate Director 


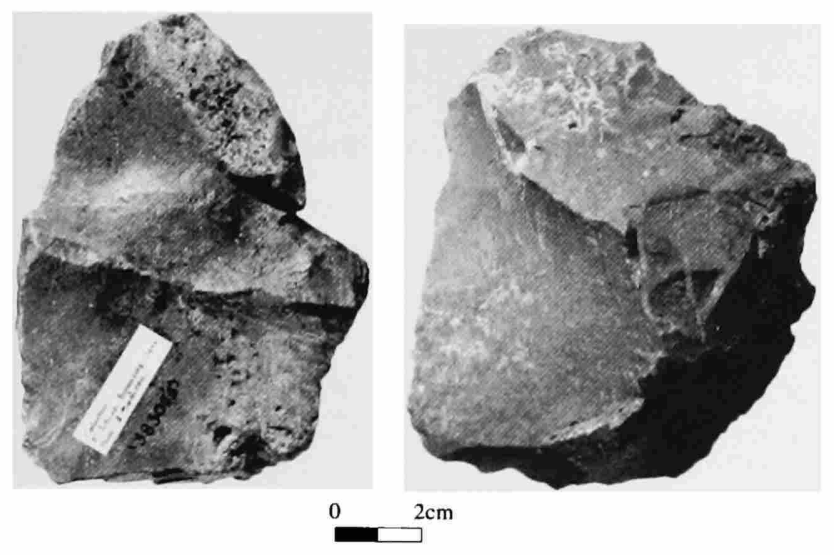

FIGURE 86.-Worked stone [catalog numbers 383075 (left), 383076 (right)] from Patjitan, Java. [Franssen accession (accession 159728).]

John E. Graf, replied to Franssen on 6 November 1940, expressing interest in receiving Paleolithic collections as those described by von Koeningswald. On 13 January 1941, Franssen sent a variety of material from Java, including material identified as Paleolithic from the site of Patjitan (Figure 86). In exchange, the Smithsonian sent Franssen collections from Middle and South America.

\section{Reeves (acc. 170049)}

In 1945, artifacts from England were donated to the U.S. National Museum by Colonel Dache M. Reeves, of Alexandria, Virginia. A memorandum indicates that the artifacts had been given to Reeves during "his 1944 sojourn in England." The artifacts consisted of a Chellean handaxe from an unknown provenience and a Chellean handaxe marked "Woodgreen" (Middlesex or Berkshire). Associate Director Graf sent a letter of acknowledgment on 19 April 1945.

\section{Bruce Hughes Fund (acc. 177782)}

In 1952, a collection from Jordan was donated to the museum by the Bruce Hughes Fund of the Smithsonian Institution. The accession was acquired from a well-known Biblical archaeologist, Dr. Nelson Glueck, at Hebrew Union College. The materials were collected by the American Schools of Oriental Research, during a surface survey led by Glueck. On 31 December 1946, Glueck informed Secretary Wetmore that a shipment had been sent. Smithsonian anthropologist Frank Setzler wrote to Glueck on 3 October 1947, indicating that the collection had been received. On 15 October, Glueck responded that provenience information would be provided during his personal visit to the National Museum and with the publication of his forthcoming book, Explorations in Eastern Palestine. Glueck visited the museum in April of 1949, as indicated in a letter from director Remington Kellogg, dated 15 April 1949. Glueck wrote to Wetmore on 3 April 1951 to inform Wetmore that he was sending the monograph: "These two volumes will demonstrate to you, I trust, that I have tried to follow your example and continue my scientific work despite administrative obligations." Wetmore replied on 12 April, acknowledging the publication, adding: "I compliment you definitely on your accomplishment in the production of this valuable work in the midst of your administrative responsibilities. It is an outstanding contribution and one that will have permanent value." Glueck (1951) described the Jordanian collections in his Explorations in Eastern Palestine.

\section{Wymer (acc. 197463)}

In 1953, a collection of implements from England was donated to the U.S. National Museum by Bertram O. Wymer of England. In a letter to W. Wedel, a curator in Anthropology, on 8 December 1952, Wymer indicated the provenience of the artifacts: "I am enclosing a diagramatic section of the Drift gravel from which the Boyn Hill, Maidenhead palaeolithic implements was excavated [100 foot terrace of the Thames]. The Clactonian flake implements from Grays Thurrock, are from the Thames Lower gravel of Boyn Hill age [75 foot terrace]. The Warren Hill, Icklingham Acheulian ovate is from the gravels of the River Lark." Director Kellogg sent a formal letter of acknowledgment to Wymer on 11 March 1953.

\section{Vass (acc. 197993)}

In 1953, a collection of artifacts from the Lulua River, Kasai District, Belgian Congo, was donated to the U.S. National Museum by Mrs. Lachlan C. Vass, Jr., of the American Presbyterian Congo Mission, Luebo. In a letter dated 29 November 1952, Vass described how the artifacts had been discovered:

My husband and I are missionaries of the Presbyterian Church in the Belgian Congo. As a hobby I have collected prehistoric stone implements which I have found on the banks of the Lulua river in the Kasai district. I have Chellean and Solutrean axe heads, spear heads, throwing stones and knives. It is a very small collection, only about twenty pieces, but if you are interested in them, I'll be glad to send them to you. The colonial government was installing a big cement ramp as an approach to the ferry for the cars. These pieces are the best of those I found where the river bank excavations were made, anywhere from two to ten feet under the surface.

Setzler replied on 14 December 1952: "Since our African archeological materials are very limited in scope and quantity, we are always interested in the possibility of expanding them with specimens that will be suitable for exhibit purposes and scientific interest." Director Kellogg acknowledged the gift on 28 April 1953.

\section{Bordes (acc. 213032)}

In 1956, a collection of archaeological and experimental flint artifacts was donated to the U.S. National Museum by Dr. François Bordes of the University of Bordeaux, France, through Dr. Ralph Solecki, who was a curator at the U.S. Na- 


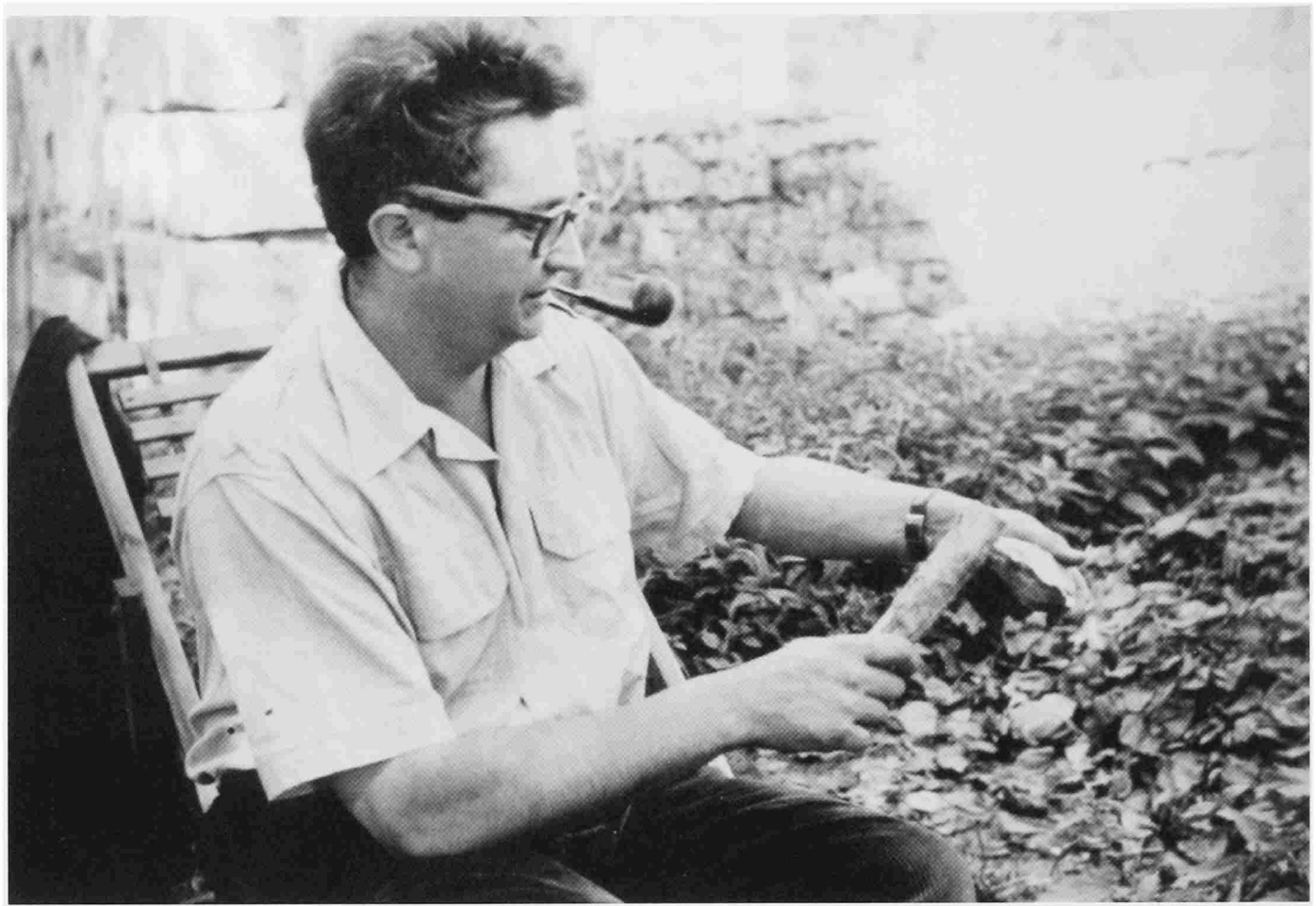

FIGURE 87.-François Bordes replicating stone-tool manufacture. [Photograph taken by Ralph Solecki. Solecki collection, National Anthropological Archives (MS 7091), NMNH (no. 94-11096).]

tional Museum. The Paleolithic specimens consisted of objects collected by Solecki from the Dordogne.

Bordes was a leader in lithic typological studies and was one of the few scientists of the time capable of replicating Paleolithic tools (Figure 87). The collection produced by Bordes consisted of 34 flint tools plus an 8-inch hammer stick of boxwood that was used to make the tools. On 8 September 1956, Solecki wrote to Setzler, indicating the circumstances of his accession of the material: "We have been in the Dordogne area for about two weeks, studying the classic palaeolithic sites and collections, as well as helping Bordes excavate his Mousterian site of Combe Grenelle. All this experience is a wonderful background for Shanidar because all the literature refers to the classic French sites in palaeolithic studies, and it is good to be on familiar terms with the stuff." Solecki indicated how the experimental materials were produced: "I watched Bordes make the flints. He used a simple stone pebble and a piece of boxwood as his tools, scaling the flakes off by percussion only. The method is very effective, and the flints are the exact duplicates of the authentic things. It will make a good study collection." Solecki also noted that Bordes was one of the few people who could make a Levallois flake. Solecki photographed Bordes during his experimental work, noting that the specimens were manufactured at Bordes summer home in Carsac (Dordogne). The experimental objects consisted of burins, hand- axes, a hammerstone, points, backed blades, scrapers, Levallois flakes, Levallois cores and associated flakes, and an exhausted core on a flake. Director Remington Kellogg acknowledged the gift on 13 December 1956.

\section{Paige (acc. 214613)}

In 1957, a collection of Paleolithic artifacts from an estate near Tongres, Province of Limburg, Belgium, was donated to the U.S. National Museum by Mr. Jason Paige, Jr., of Virginia. In a letter to Setzler, dated 17 February 1957, Paige described the circumstances of his acquisition of the collection and their provenience:

The tools were obtained from an antiquities dealer in Brussels, M. Jean Withofs, 10 rue Ernest Allard. He stated that he had received them from an estate near Tongres, in the province of Limbourg, Belgium. They were described as surface finds which had been picked up over a period of time on the estate. While I was at the University Museum in Philadelphia last spring I had an opportunity to show the whole collection of tools to John d'A. Waechter of the British Museum who was spending some time at the Peabody Museum in Boston on a project for Dr. Movius. Waechter, whom Carleton Coon considers one of the very best on flint tools, stated that the Belgium tools were of a type with which he was familiar, and that they were contemporary with the Thames Pick Industry in England. It is my understanding that they would be of the Mesolithic period for that particular area. According to Waechter, one large flake might be a Levallois Flake tool, but he could not tell by examining it out of context. 
Director Kellogg acknowledged the gift in a letter dated 26 May 1957.

\section{Solecki (acc. 217009)}

In 1957, a collection of Paleolithic artifacts from Ras Beirut, Lebanon, was collected for the Smithsonian Institution by Dr. Ralph Solecki, a curator at the U.S. National Museum. The collection consisted of Lower to Middle Paleolithic materials obtained from the surface of the ground at Ras Beirut. The collection was brought to the Smithsonian by Solecki; consequently, there is no correspondence associated with the acquisition.

\section{Iraq Museum (acc. 220078)}

In 1958, collections from Shanidar Cave and Zawi Chemi Shanidar were donated to the U.S. National Museum by the Directorate General of Antiquities, Iraq Museum, through Dr. Naji al Asil of the Iraq Museum and the Bruce Hughes Fund of the Smithsonian Institution (Figure 88). Shanidar was discov- ered in 1951 during survey work conducted by Dr. Ralph Solecki (Trinkaus, 1983, 1997; Trinkaus and Shipman, 1992). Excavations were conducted in 1951, 1953, 1956-1957, and 1960 but eventually were terminated because of political tensions in the region. Fourteen meters of stratified deposits were excavated. Solecki established that layers D through A represented Middle Paleolithic, early Upper Paleolithic (Baradostian), Mesolithic and proto-Neolithic and Neolithic to modern periods, respectively (Figure 89). The recovered artifacts were divided among several institutions.

On 1 January 1958, Naji al Asil wrote to Smithsonian curator T.D. Stewart concerning casts of Shanidar I, a Neanderthal skeleton:

\begin{abstract}
Now that your very useful stay in Iraq has approached its end, we would like to thank you for the delicate and exact work you have done in the restoration of the human skeletons, which formed the most important part of the latest discovery at Shanidar Cave. We are grateful to you also for your examination and study of these remarkable remains, and the reports which you have been preparing for publication in Sumer. It gives us pleasure to present you with a plaster cast of the skull and skeletal remains of the adult man from Shanidar Cave for the Smithsonian Institution.
\end{abstract}

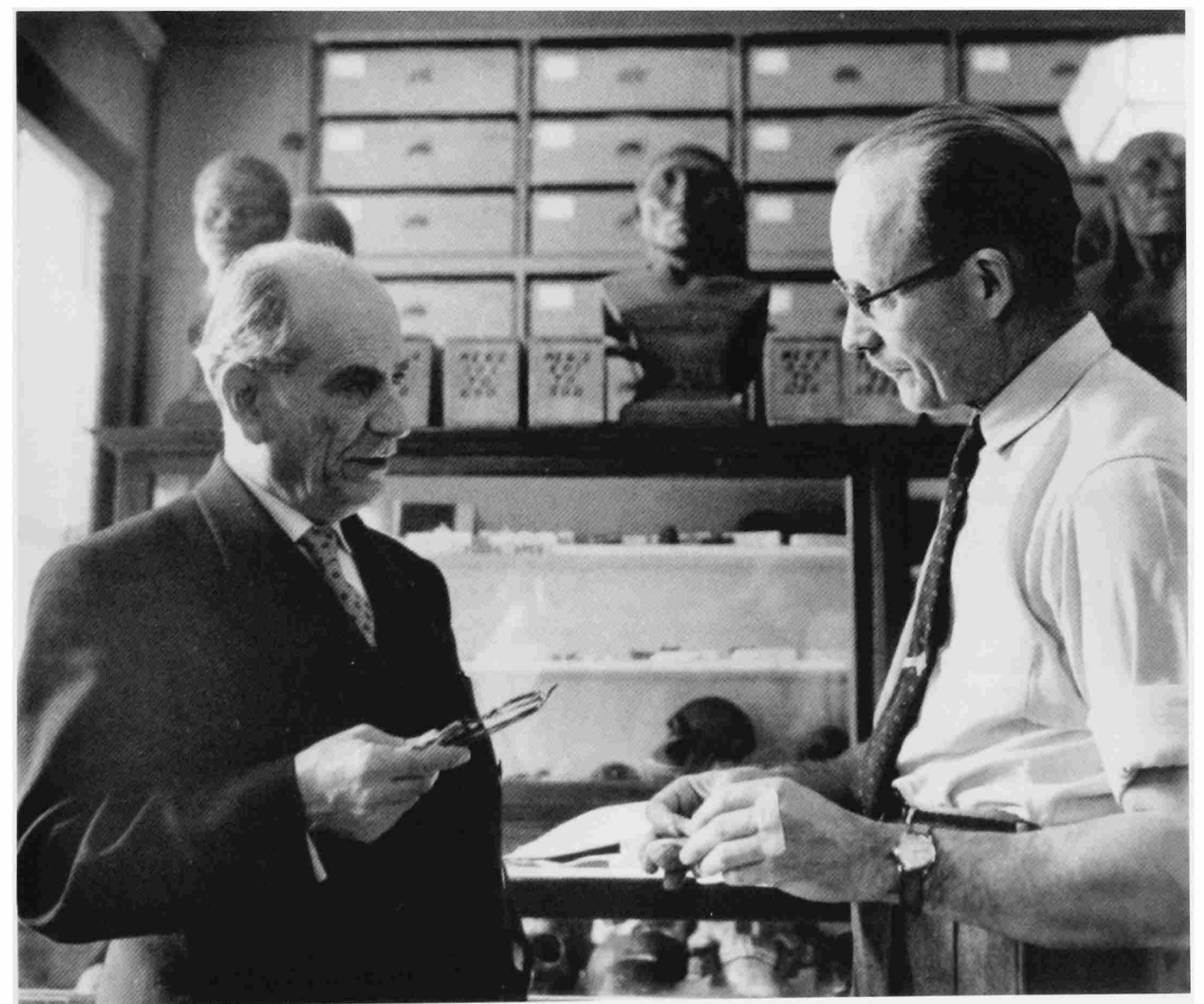

FIGURE 88.-Photograph of T. Dale Stewart meeting with Dr. Naji al Asid from Baghdad, in January 1959 [Solecki collection, National Anthropological Archives (MS 7091), NMNH (number 94-11100).] 


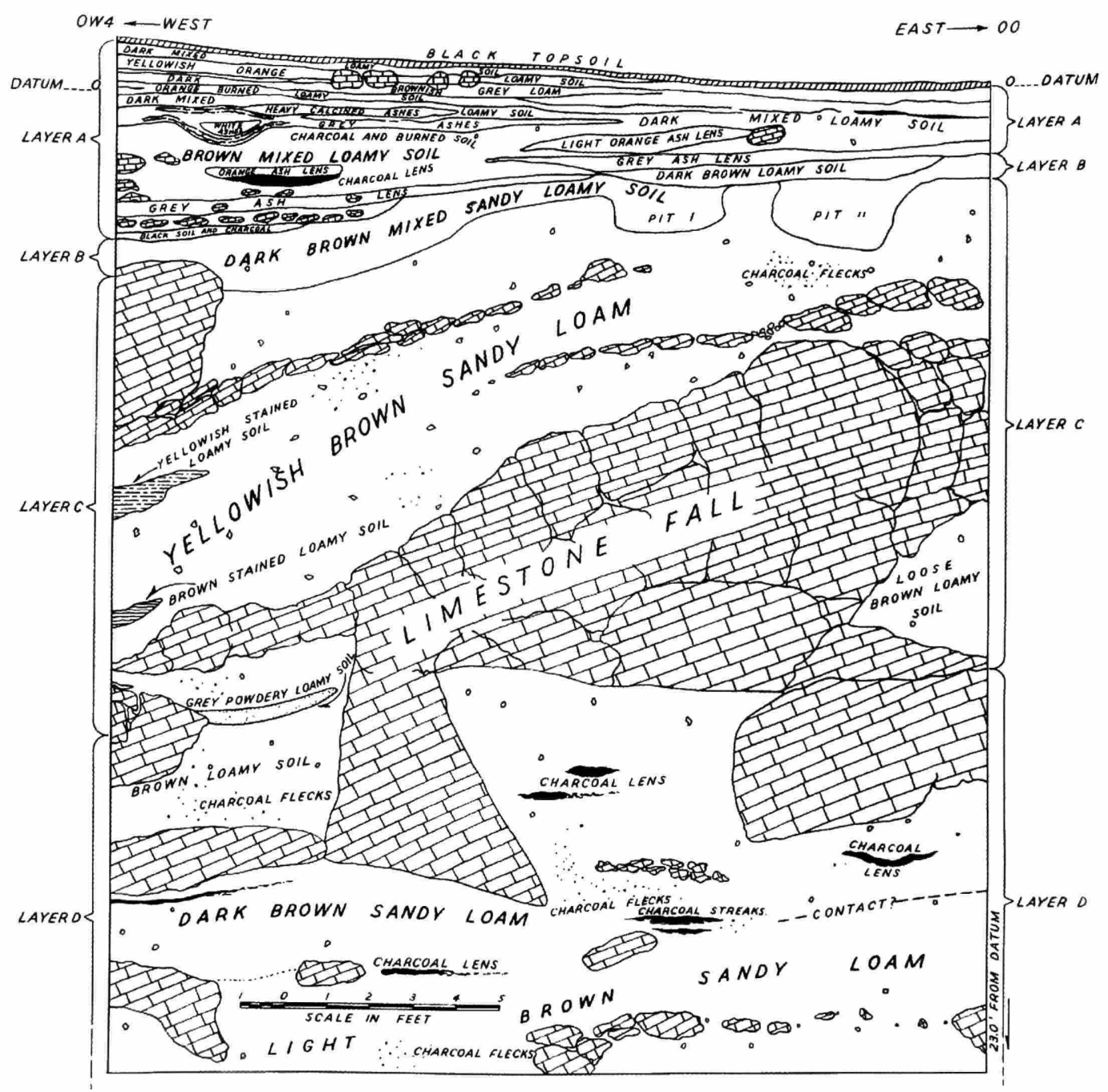

FIGURE 89.-Cross section of Shanidar excavations, on line 00-0W4 (north face, upper half section) showing complex stratigraphy and charcoal concentrations for radiocarbon dating. [Solecki collection, National Anthropological Archives (MS 7091), NMNH.]

On 21 January 1958, Secretary Carmichael replied to al Asil, citing the importance of the Neanderthal finds and the joint research with the Iraq Museum:

I am indeed happy to know that Dr. Stewart completed his assignment to your satisfaction. Although I have not seen him yet, Dr. Stewart returned to his office on the 13th, having hand carried all the way from Baghdad the precious cast of the Shanidar I skull. His return at this time enabled us to exhibit the cast at the annual meeting of the Smithsonian Regents which included Chief Justice Warren and members of the United States Congress. Not only was there general interest in this new example of Neanderthal man but in the fact that the Smithsonian has been collaborating with the Iraq Government in anthropological research.

Assistant Secretary Kellogg wrote to al Asil on 15 May 1958. He indicated that the Shanidar I casts had been accessioned as a gift, and he remarked upon the importance of the casts: "I am aware of the uniqueness of these casts and therefore am especially grateful to you for this splendid gift. Dr.
Stewart exhibited the cast of the skull on 11 April at a public lecture he gave at Harvard University in connection with the annual meeting of the American Association of Physical Anthropologists. He tells me that it was very favorably commented upon."

Additional remains of Neanderthals were found in the Middle Paleolithic levels (Figure 90). These were sent to T.D. Stewart in 1957 for analysis. Ralph Solecki of the U.S. National Museum took extensive soil samples from the site and carefully recorded the relationship between animal bones, Neanderthal skeletal material, and rocks (e.g., Figure 91). An analysis conducted by Arlette Leroi-Gourham on soil samples associated with one skeleton (Shanidar 4) yielded wildflower pollen, suggesting this had been an intentional burial on the part of Neanderthals. This theory was popularized in the book Shanidar, the First Flower People (Solecki, 1971). Stewart was responsible 


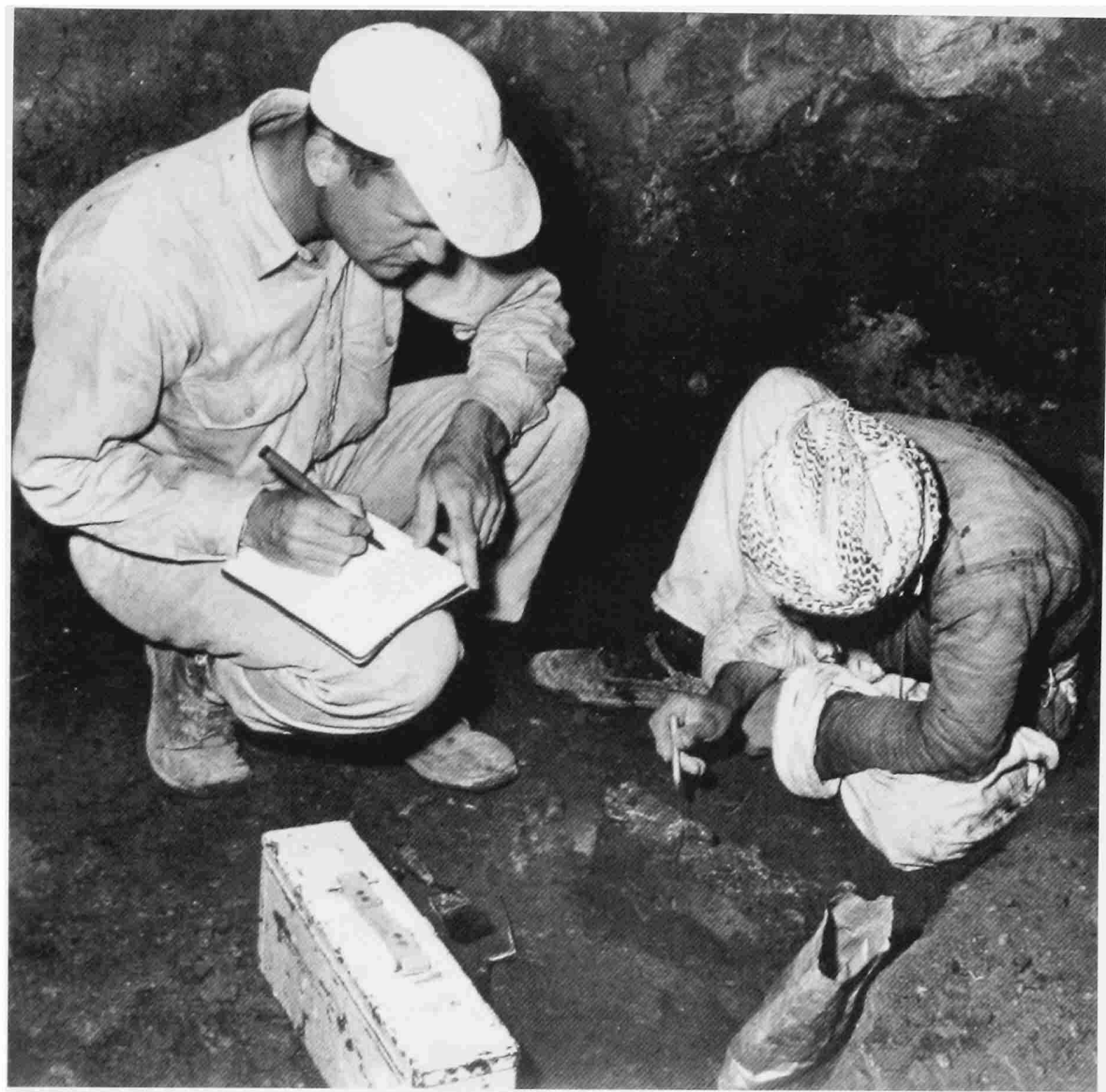

FIGURE 90.-The photograph is labeled, "Ralph Solecki (left) and Kurdish woman excavating skeleton of a child found in Mousterian deposits at depth of 26 feet in Shanidar Cave, Zagros Mountains, Valley of the Great Zab River, northern Iraq, June 22, 1953." [Solecki collection, National Anthropological Archives (MS 7091), NMNH.]

for skeletal restorations, and he conducted much of this work in Baghdad. A summary of the results of his work was published in his compendium of 1977 (Stewart, 1977). The remaining reconstructions were later accomplished and fully described by Erik Trinkaus (1983).

The Shanidar collection originally consisted of only a set of casts of the Shanidar I Neanderthal skeleton, but it was soon expanded to include multiple casts of the reconstructed specimens prepared by Stewart. In 1960, 8770 archaeological specimens from Shanidar Cave and Zawi Chemi Shanidar were added temporarily to the collection. The Smithsonian collections consisted of partial assemblages from the Mousterian through the Neolithic, with the main Paleolithic specimens consisting of early Upper Paleolithic Baradostian artifacts (Figure 92). A number of sediment samples in this collection may be useful for dating and palynological analysis.

The Shanidar accession records include archival data from the National Anthropological Archives (Manuscript 7091). The manuscript file contains standard field notes, drawings, and photographs dating from 1953 to 1959. Data cards concerning finds made by the Third Shanidar Expedition have been kept with the collection. The cards include detailed records of the discovery of three Neanderthal skeletons in Mousterian contexts, as well as descriptions, notes, and sketches of artifacts, mollusks, faunal remains, soil, pollen, and charcoal samples. The photographic prints, negatives, and slides depict the specimens, the excavations, and aspects of travel by team members.

Although the field notes describe the excavation proveniences, detailed information about the artifacts is lacking, and the material collections have never been published in detail. A portion of the faunal remains from the site was loaned to the University of Chicago as part of the multidisciplinary study. On 2 January 1958, Solecki wrote to Dr. Charles Reed of the Oriental Institute, University of Chicago, stating that three cases containing 7500 animal bones were being sent on loan for study through Dr. Robert J. Braidwood: "The cases contain 13 boxes of bones of archeological importance as noted on the itemized list enclosed with this letter. Also enclosed are the 


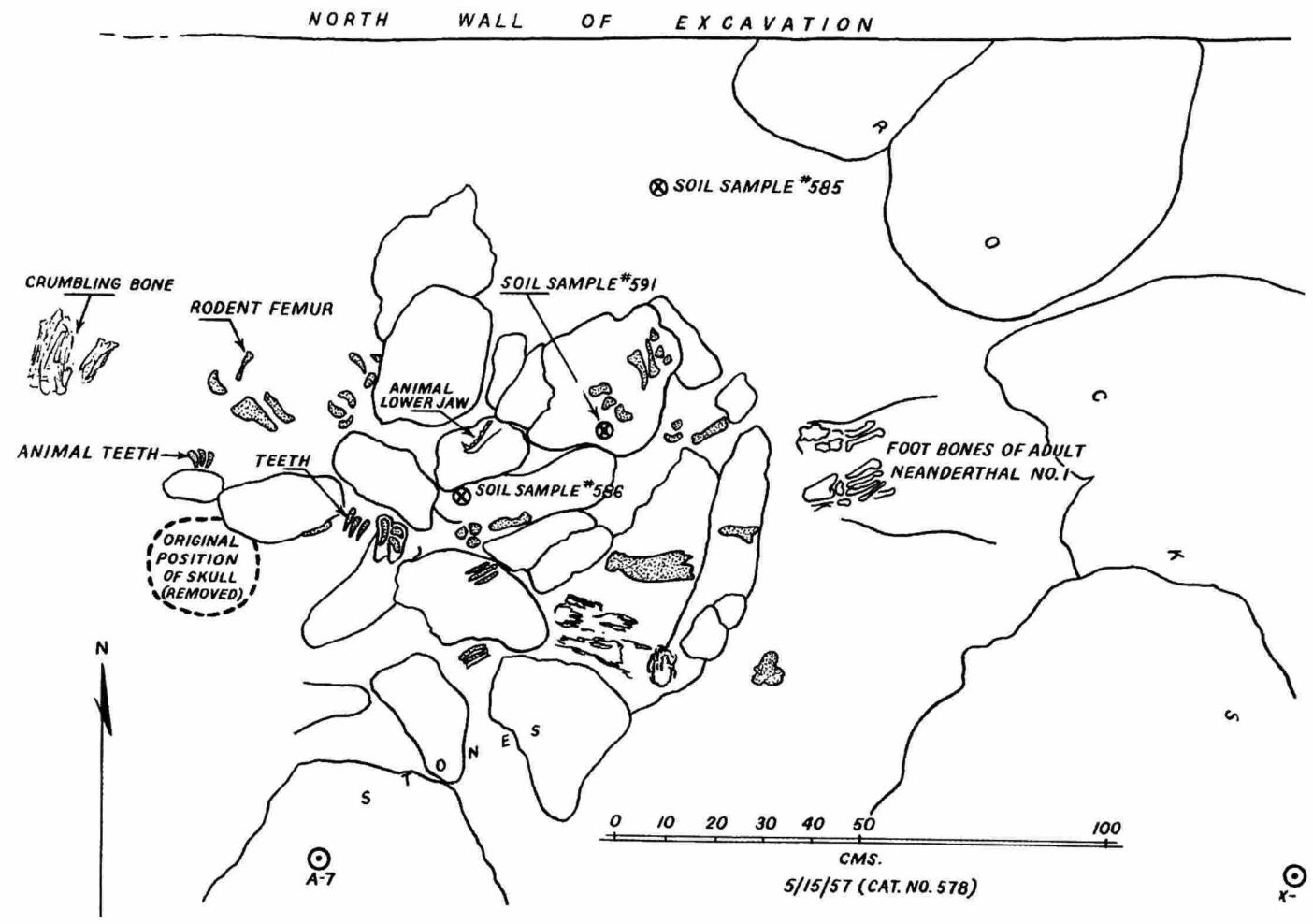

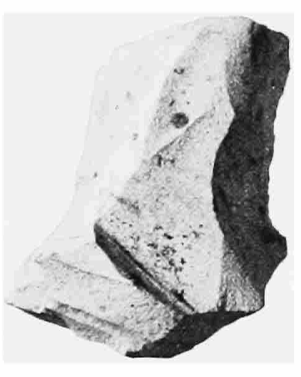

a

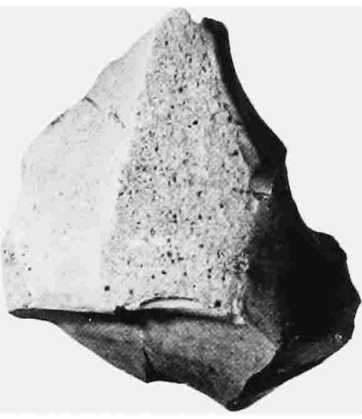

b

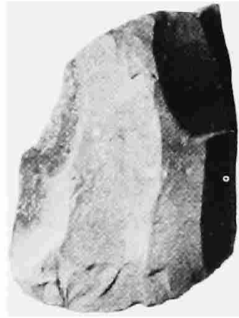

C

FIGURE 91 (above).-Drawing of animal bones found on stones lying over Neanderthal skeleton number 1 in Shanidar Cave, and showing areas of soil samples for botanical analysis. [Solecki collection, National Anthropological Archives (MS 7091), NMNH.]

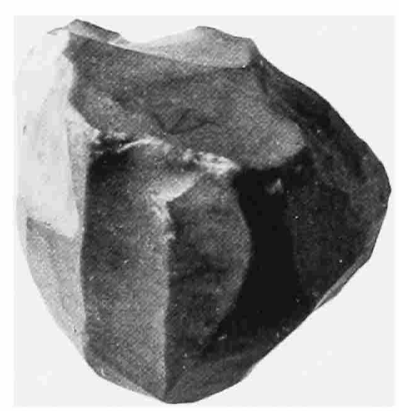

d

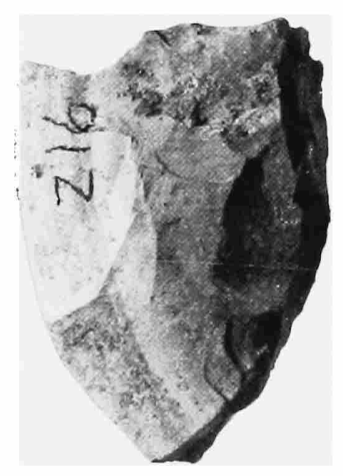

e
FIGURE 92 (left).-(a,b) Carinated burins [catalog numbers 425890,425885 , left to right], (c) Baradostian burin [catalog number 425891], and (d,e) cores [catalog numbers 425890,425805 , left to right] from Shanidar Cave, Iraq. [Iraq Museum accession (accession 220078).] 

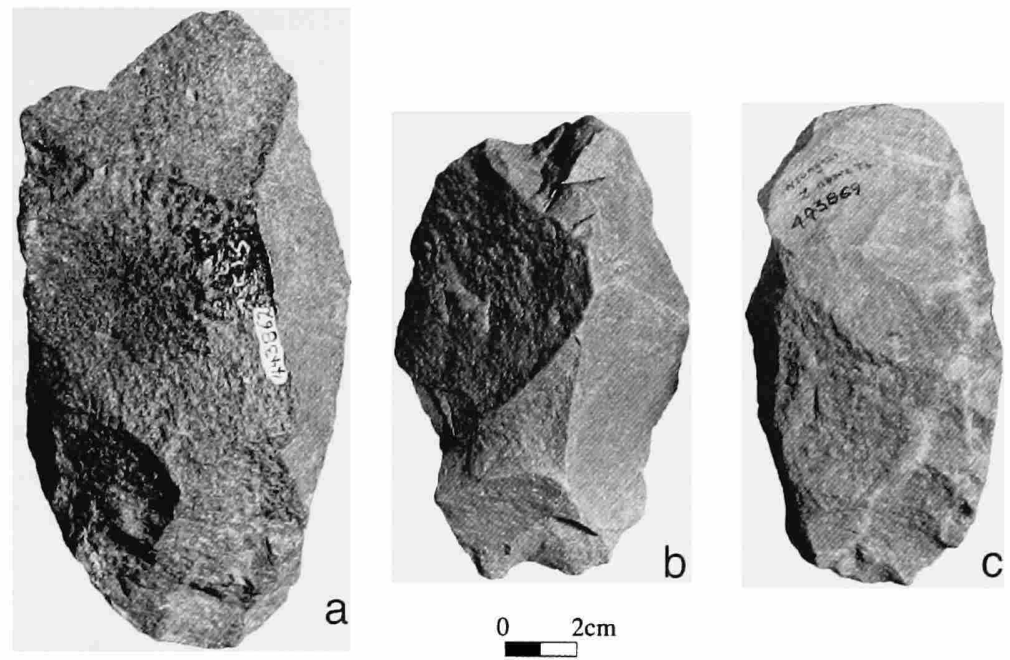

FIGURE 93.-Bifaces [catalog numbers $443862,443869,443869$, left to right] from Nsongezi, Uganda. [Uganda Museum accession (accession 259009).]

catalog number lists pertaining to the bones from both the Shanidar Cave and Zawi Chemi Shanidar sites, from which the bones were recovered. Included are seven pages of itemization from Layers A to D from Shanidar Cave, and three pages of itemization from Layers A and B from Zawi Chemi Shanidar." In 1975, bird bones from Zawi Chemi Shanidar were "indefinitely loaned" to Solecki, who was then affiliated with Columbia University.

\section{Government Museum, Madras (acc. 202973)}

In 1959, an exchange of ethnographic materials and two Paleolithic artifacts was arranged by Dr. S.T. Satyamurti, assistant superintendent of the Madras Government Museum, Madras State, India. In a letter dated 10 June 1954, superintendent C.J. Jayadev inquired about the possibility of an exchange, and on 17 August 1954, Setzler accepted the proposal. On 10 June 1955 , Dr. A. Aiyappan, the current superintendent, wrote to Setzler and offered Paleolithic stone implements from southern India of the Madras facies in exchange for North and South American ethnographic materials. In a letter to Aiyappan, dated 20 September 1955, Setzler suggested a preliminary exchange, noting that if the transaction was "mutually satisfactory" to both sides, "a more comprehensive exchange might later be arranged of materials from the duplicate reserve collections of our respective museums." Included in the Paleolithic material sent to the Smithsonian was one cleaver from Attirampakkam and one chopper from Manjanakaranai, both of the Chingleput District, Madras State. Apparently no other exchanges were made.

\section{Jones (acc. 249458)}

In 1963, a collection of four stone tools, including one Paleolithic handaxe, from Temenhent in Fezan Province, Libya, was received as a gift from James R. Jones, a groundwater geologist for the United States Aid Mission to Libya. The objects were brought personally to the Smithsonian by Jones, who stated that the site was on low ground, possibly in an old lake bed. He noted that the zone stretched in a westerly direction for several kilometers, and that artifacts were recovered in blown out areas. The artifacts had been sand-blasted and were found in an area eight feet in diameter, which contained 20 artifacts of the same type. On 14 January 1964, Stewart expressed appreciation for the gift, noting: "Our holdings of Libyan materials are few indeed, and your donation constitutes a significant contribution to the national collections."

\section{Uganda Museum (acc. 259009)}

In 1965, Paleolithic material from two sites (Nsongezi and Magosi) in Uganda was donated to the NMNH by the Board of Trustees of the Uganda Museum, through Dr. Glen H. Cole, one of the excavators of the sites. The Nsongezi collection consisted of hundreds of artifacts excavated by Cole (later of the Field Museum of Natural History in Chicago) in 1962 and 1964, following the work of van Riet Lowe (1952) (Figure 93). Magosi is a type site (Wayland and Burkitt, 1932) where artifact assemblages have been found in rock shelters formed in a granitic inselberg (Posansky and Cole, 1963). At the Magosi site, trench excavations uncovered large numbers of artifacts, indicating the presence of Late Stone Age assemblages. The excavations were useful in clarifying stratigraphy and material sequences. The donated Magosi assemblage consisted of hun- 
dreds of Late Stone Age artifacts excavated in 1963 from "Trench a/b."

On 4 January 1964, Cole wrote to Dr. Gus Van Beek, a curator of anthropology at the National Museum of Natural History (USNM), providing information on the collection:

The main bulk of the stuff is Acheulian from the Nsongezi--N Horizon. It is mostly from a single excavation (labeled C1-S). This is a good representative collection and, in fact, apart from waste material, is not very much selected. All implements, a goodly selection of cores and virtually all non-waste flakes are included. A little of the waste material, other than cores, is also included. I would mention that some of the flakes and even some of the tools are quite small so unpack with care.

Another small bag was put in the final crate to take up space when I ran out of $\mathrm{Cl}$-S material. This is some surface stuff from Nsongezi which I had not yet had a chance to examine. On packing it I noted that it is a fairly good assortment of some of the late MSA from the area. There are also some miscellaneous specimens from the $\mathrm{M}-\mathrm{N}$ Horizon in various places which will provide some good examples of certain tool types which may not be included in the $\mathrm{Cl}$ $\mathrm{S}$ collection.

Cole's references to the M-H Horizon were based upon the earlier work of Van Riet Lowe (1952), who had described the geology and the Acheulean assemblages. In the same letter, Cole indicated that material from Magosi also was included in the shipment: "There is also a bag of material from Magosi. I didn't have time to sort through this so this will be largely waste material but there should be a good assortment of flakes, blades, miscellaneous tools and a few microliths." Clifford Evans, a curator of anthropology at the National Museum of Natural History, acknowledged the gift on 26 February 1965.

\section{Hole (acc. 265162)}

In 1966, Paleolithic collections from Kunji Cave and Gar Arjeneh Rockshelter, Khorramabad Valley, Luristan Province, Iran, were donated to the National Museum of Natural History (NMNH) by Dr. Frank A. Hole of Rice University, through Kent V. Flannery of the NMNH, Smithsonian Institution. Hole and Flannery jointly excavated the cave and rockshelter sites during July and August of 1963. According to the them, the Kunji Cave tools are Mousterian and have two radiocarbon dates older than 40,000 years that were based upon associated charcoal. Gar Arjeneh Rockshelter had Mousterian material at the bottom of the deposits, overlain by Upper Paleolithic "Baradostian" material at the top of the deposit, surmised to date to ca. 25,000 B.C. (Hole and Flannery, 1967). Notes indicate that the stratigraphy had been badly disturbed by intrusive porcupine burrows; thus, tools were cataloged by type and not by stratigraphic level (Figure 94). India ink markings on objects, other than catalog numbers, indicate grid square and depth.

\section{Citron (acc. 268093)}

In 1966, surface archaeological material from Sabata and Melka Kontouré, near Addis Ababa, Ethiopia, was donated to the National Museum of Natural History by Mr. Robert Citron, of the Smithsonian Astrophysical Observation Station, Addis Ababa. Sabata is 24 kilometers southwest of Addis Ababa, and Melka Kontouré is 51 kilometers south-southwest of Addis Ababa, on the Awash River. On 9 February 1966, Gus Van Beek, a curator at the museum, wrote to Citron, apparently in response to a query from Citron about the need for archaeological collections from Ethiopia. Materials were sought by Van Beek: "As you can imagine, I am much interested in building up our study and research collections in Ethiopia. What we need are well documented, representative collections of surface material from prehistoric as well as historic sites. From a prehistoric site for example, we would like to have a representative sample of various tool types, cores, and waste flakes as well as precise location, description and size of site, and photographs and possibly drawings of the site." In a letter dated 15 February 1966, Citron informed Van Beek that he had sent a parcel containing 50 to 60 tools, mainly from Sabata, with a few from Melka Kontouré: "I've sent representative samples of points, blades, scrapers, flakes, and possible microliths. All of the material, except one possible handaxe, is obsidian. All, except four blades that I picked up near Melka Kontour' [sic], come from the Sabata site." Citron also enclosed a series of photographs of some of the tools and of the site, as well as drawings showing the location and layout of the site and fullscale drawings of about 30 tools. "Let me say that I am not a professional archaeologist, but I'm keenly interested in prehistoric archaeology, particularly as it relates to the emergence of man in Africa. Ethiopia is virgin territory for prehistoric archaeology and there is the exciting possibility of finding a connection between the Olduvai hominids and similar man-apes that may have lived in this area." In a letter to Citron, dated 13 April 1966, Van Beek stated that it was a pleasure to receive well-documented material from Sabata and Melka Kontouré, suggesting that descriptions of the site and the artifacts should be published. Richard Woodbury, chairman of the Department of Anthropology, NMNH, acknowledged the gift on 9 August 1966.

\section{Shiner (acc. 278180)}

In 1968 , a handaxe was donated to the NMNH by Dr. Joel Shiner, an archaeologists at Southern Methodist University. The handaxe was found at Khashm el Girba in the Sudan, on the Atbara River near Kasala. While visiting the museum, Shiner viewed the exhibit "Man's Earliest Weapons." He noticed that the exhibit lacked an example of his specimen, and citing the need for better continuity, he donated it to the Department of Armed Forces History. The gift was acknowledged, in a letter dated 26 April 1968, by M.L. Peterson, chairman of the Department of Armed Forces History, Smithsonian Institution. 


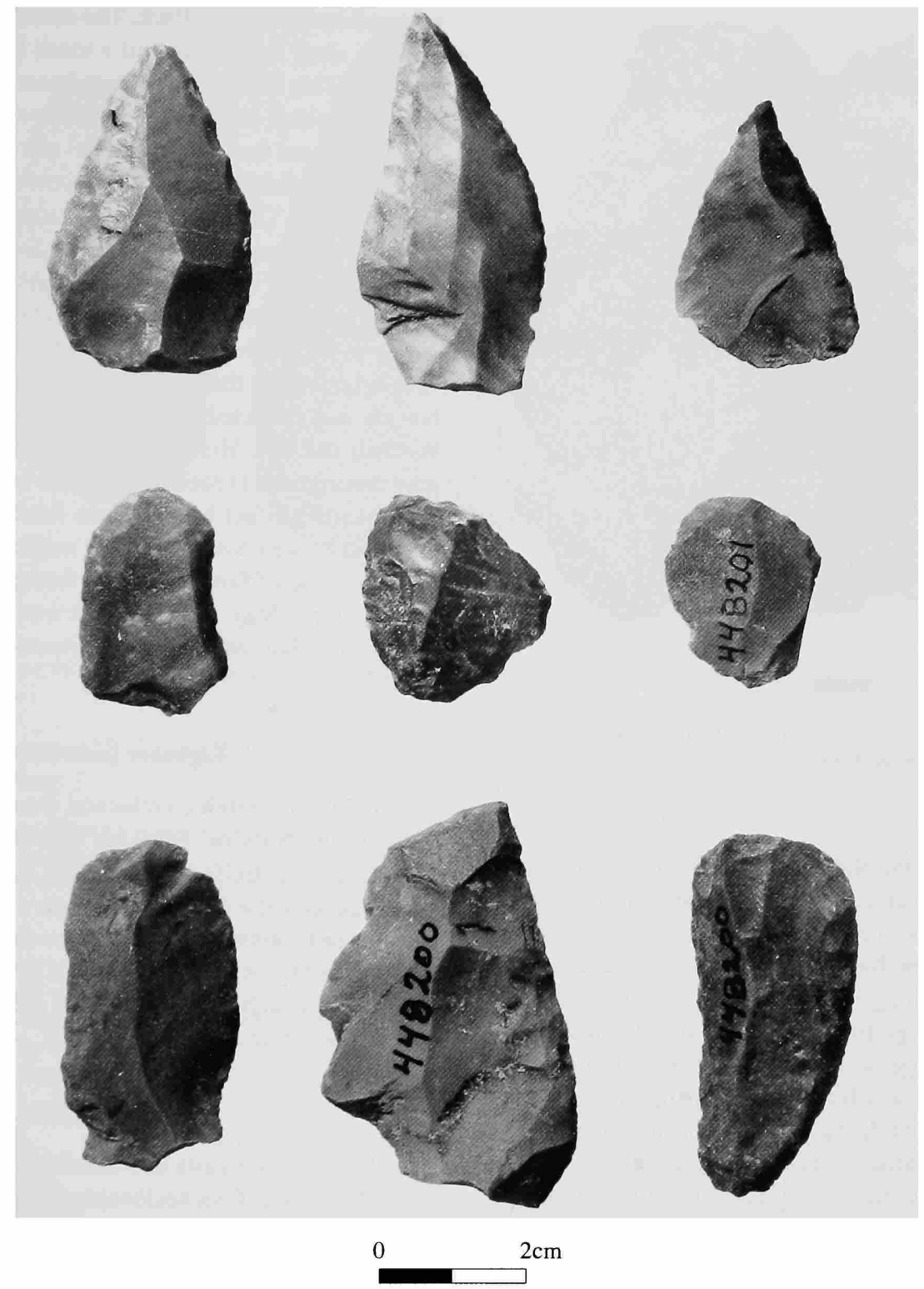

FIGURE 94.-Points (top row) [catalog number 448205], scrapers (middle row) [catalog number 448201], and side scrapers (bottom row) [catalog number 448200] from Gar Arjeneh, Iran. [Hole accession (accession 265162).]

\section{Muséum National d'Histoire Naturelle (acc. 295641)}

In 1971, a plaster cast of the "Woman of Lespugue" was donated to the NMNH by the Muséum National d'Histoire Naturelle, Paris, France to Secretary S. Dillon Ripley. The cast was made from the original Gravettian "Venus" figurine discovered at the site of Lespugue, Haute-Garonne, France.

Gibson (acc. 307731)

In 1973, a collection of Paleolithic material from Angola was donated to the NMNH by Dr. Gordon D. Gibson of the National Museum of Natural History, Smithsonian Institution. The site of Munhino is located in the Distrito de Huila, on land owned by the Missao Catolica do Munhino. The materials were collected from the surface of the ground, and from among rock piles, which had been made when the fields were cleared.

\section{Barbour (acc. 305126)}

In 1973, geological and cultural objects and field records from 


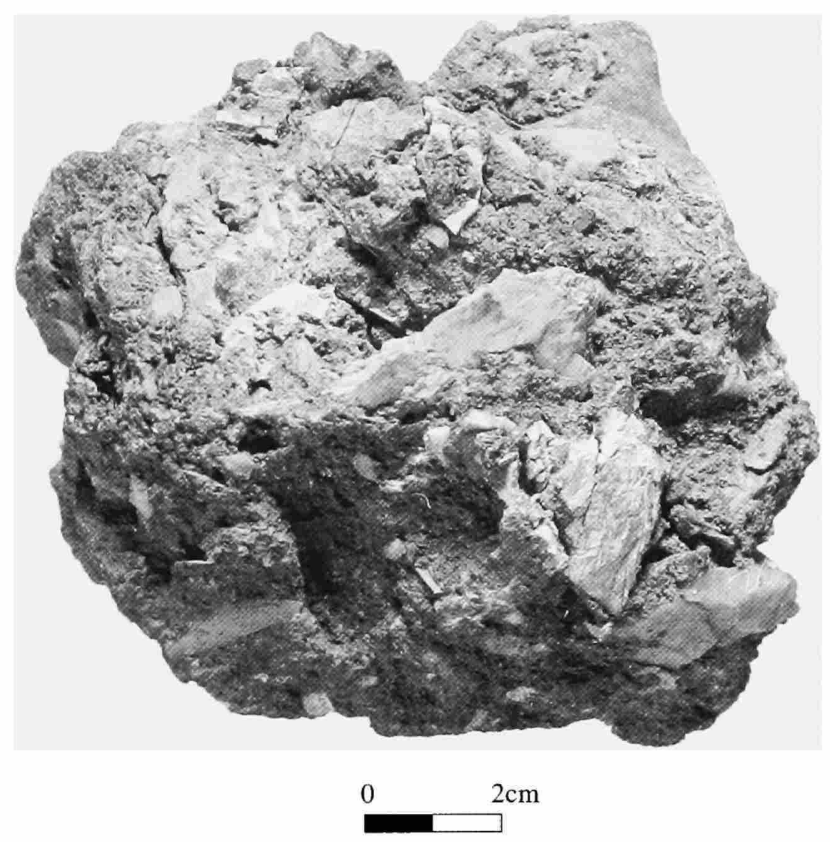

FIGURE 95.-Breccia [catalog number 383415] from Choukoutien, China. [Barbour accession (accession 305126).]

China were donated to the National Museum of Natural History by Mrs. Dorothy Barbour and Dr. George Barbour. In a letter to Eugene I. Knez, curator of Asian Anthropology at the Museum, dated 28 July 1972, Mrs. Barbour inquired whether the museum was interested in acquiring material from China. The collection was obtained by George Barbour during his 14 years at Yenching University, Peking, and during four months of field work conducted every year at Choukoutien during the 1920s and 1930s in connection with dating the site of Peking Man.

The collection consisted of geological specimens, human paleontological casts, a piece of breccia from Choukoutien, books, correspondence, and field notes. Mrs. Barbour described the contents of the collection to Knez in her letter of 14 September 1972, stating that it included a portfolio containing Dr. Barbour's best sketches, diagrams, and maps of Choukoutien, as well as documentation regarding the "thousands of miles on foot required in trying to make certain the age of the cave and of its fauna." Knez replied on 25 October, indicating that the Peking Man skeletal remains were shown to "T. Dale Stewart, our senior physical anthropologist, who found them of research value and worthy of acceptance. He did compare them with other casts of Peking Man that are here and thought that all were made under the supervision of Prof. Davidson Black by the same English firm, R.F. Damon and Company." The human skeletal remains included a bronze replica of a Sinanthropus tooth, which had been made in honor of a celebration banquet of the Peking Society of Natural History, where the discovery of the first Sinanthropus tooth was initially an- nounced by Davidson Black. The collection also included casts of three skull fragments and a tooth from Locus E of Choukoutien. (This first series of casts became valuable because the original skeletal remains were destroyed during World War II.) Knez indicated that the geological material was of little value, although the field journals were considered important, so they were retained. The materials the museum did not want, including book duplicates and geological specimens, were shipped to Dr. Hodgkins of the Geography Department of Kent State University, in accordance with the wishes of Mrs. Barbour.

The piece retained by the Smithsonian was a fragment of cave breccia from the Choukoutien excavation (Figure 95). The breccia was collected 80 feet below ground surface by George Barbour in 1931. His notes indicate that "careful inspection may distinguish (1) rockfall from the limestone roof, (2) crude vein-quartz artifact brought into the cave by human agency, [and] (3) broken bone with grey surface calcine discoloration indicating use of fire (red-brown ferruginous matrix fills interstices)." On 1 May 1973, the gift was acknowledged by Clifford Evans, chairman of the Department of Anthropology at the NMNH.

\section{Lightner (acc. 316299)}

In 1975, a Paleolithic collection from Sebha, Libya, was donated to the National Museum of Natural History by Mr. E. Lightner, Jr., of Belfast, Maine. The Acheulian handaxes were collected in 1964 from the surface of the ground in a small sandy area (Figure 96). No flakes or chips were recovered, and no stone source was identified. The gift was acknowledged by William Fitzhugh, chairman of the Department of Anthropology, in a letter dated 13 March 1975.

\section{Klima (acc. 322222)}

In 1976, plaster casts of Paleolithic objects from the site of Dolni Věstonice, Czechoslovakia, were donated to the museum by Professor Bohuslav Klima of Brno, Czechoslovakia. The original objects had been excavated by the donor. On 24 May 1976, William Fitzhugh, chairman of the Department of Anthropology, wrote a letter of acknowledgment to Klima.

\section{Institute of Vertebrate Paleontology and Paleo- anthropology (acc. 323176)}

In 1976, a small collection of artifacts from Dingcun, Shanxi, China, was donated to the National Museum of Natural History by the People's Republic of China. The gift was received through Mr. Chang Li-pin of the Revolutionary Committee of the Institute of Vertebrate Paleontology and Paleoanthropology (IVPP) of the Academia Sinica in Peking (Beijing) (Figure 97). This was one of many gifts (including two pandas for the National Zoo) received as symbols of improving SinoAmerican relations during President Nixon's administration. 

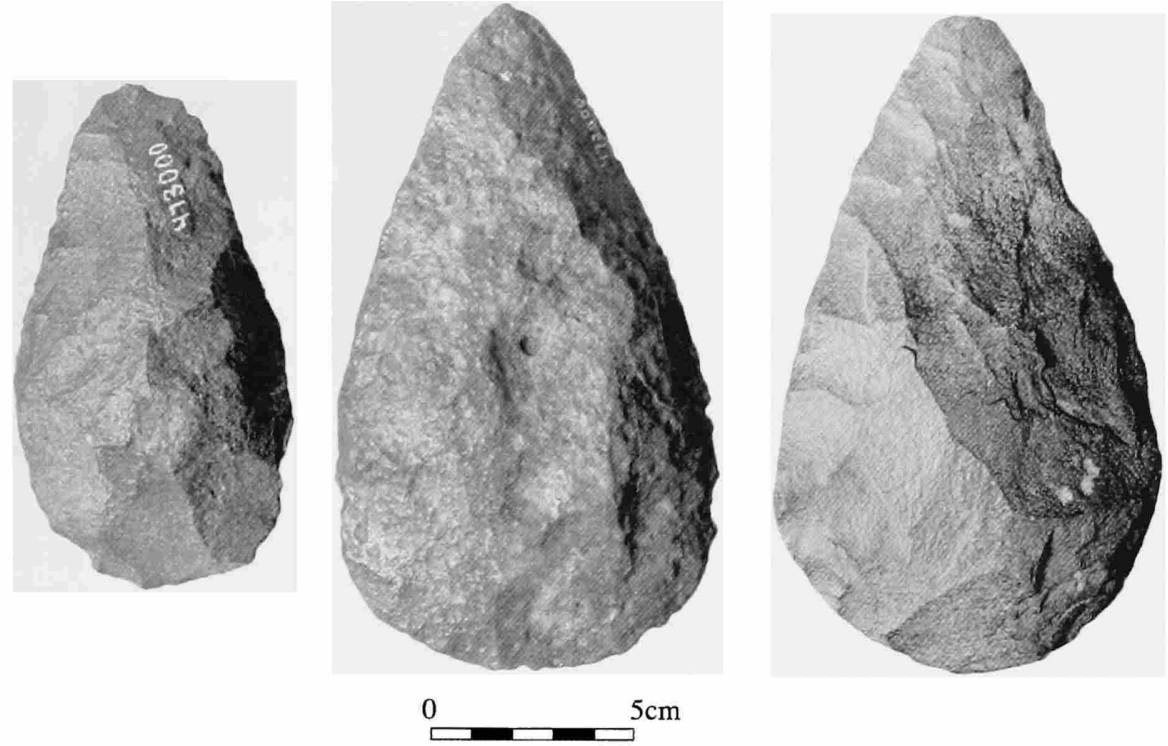

FIGURE 96.-Handaxes [catalog number 473000] from Sebha, Libya. [Lightner accession (accession 316299).]

On 1 August 1975, Secretary S. Dillon Ripley wrote a letter to Mr. Chang Li-pin, stating:

This morning we received from Peking a splendid present of five pieces of stone tools of the Middle Palaeolithic period collected on Dingcun, Shanzi [sic], through your good offices. I would like to say that the Smithsonian Institution is deeply grateful for this honor, and that we will welcome and treasure these beautiful stone flakes with the greatest respect. Not for many years has such a splendid tribute been paid to the Smithsonian Institution, and I can assure you that this gift is received with great enthusiasm. Please convey to my friends in the Academia Sinica our warm respects and gratitude, and be assured that the objects will be carefully cared for and greatly respected by our paleoanthropologists in the United States.

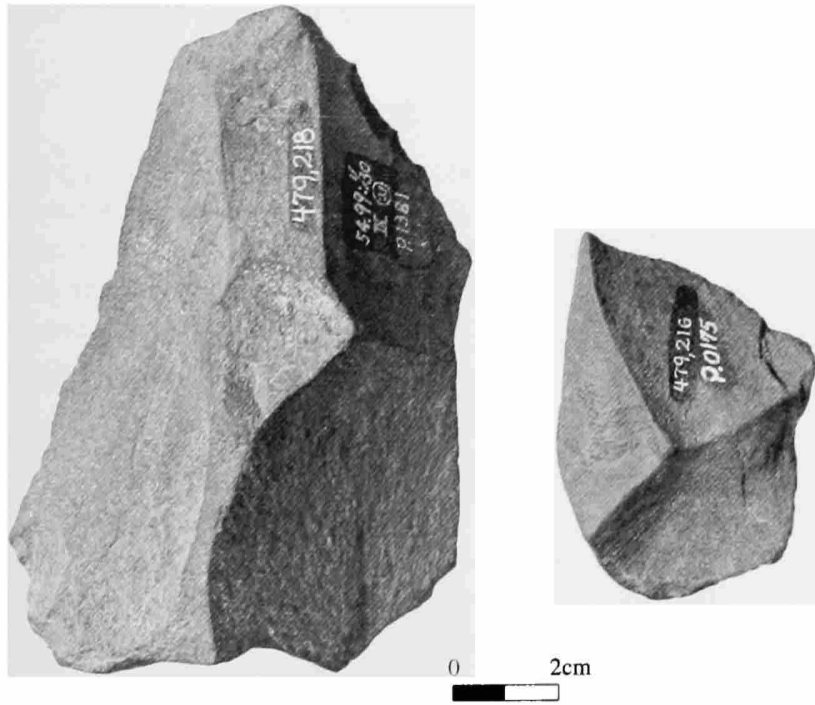

FIGURE 97.-Flakes [catalog numbers 479216 (left), and 479218 (right)] from Dingcun, China. [People's Republic of China accession (accession 323176).]
Copies of the letter were sent to K.C. Chang of Yale University and George H.W. Bush, United States Ambassador to China [and later U.S. President]. On 25 June 1976, Herman Viola, acting chairman of the Department of Anthropology, also sent a letter of acknowledgment to Chang Li-pin.

\section{Sims (acc. 351570)}

In 1986, two stone tools were donated to the National Museum of Natural History by Mr. George Sims of Bakersfield, California. The two artifacts were part of a larger ethnological and archaeological collection acquired by the donor during his travels around the world. A label with the stone tools states that they were originally acquired as gifts from Louis B. Leakey, curator of the Coryndon Museum, in Nairobi. The label also indicates that the items were obtained in 1958 from Leakey's excavations in the Great Rift Valley. Although the objects were thought to be from Olduvai, the artifacts were labeled "Olliasalic, Site 3," which refers to the site of Olorgesailie, in Kenya.

\section{Eichenberger (acc. 358176)}

In 1986, a collection of casts from archaeological sites throughout the world was donated to the National Museum of Natural History by J. Allen Eichenberger of Saverton, Missouri. Dennis Stanford, of the Department of Anthropology, Smithsonian Institution, arranged for the donation of the artifact casts, which had been made by Eichenberger during a period of twenty years. On 29 February 1984, Douglas Ubelaker, chairman of the Department of Anthropology, wrote an official letter of acknowledgment for the collection. 

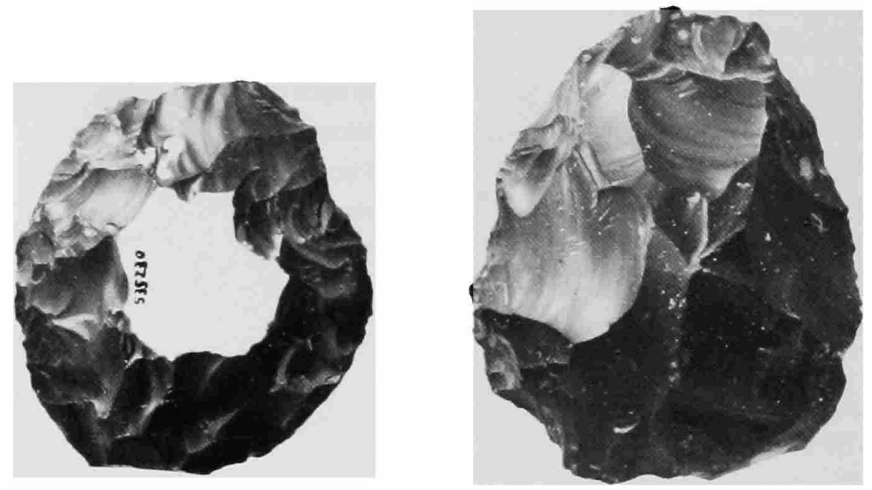

FIGURE 98 (right).-A discoid (top left) [catalog number 535230] and three handaxes [catalog number 535229] from Fjaje, Jordan. [Old accession (accession 387104).]

FIGURE 99 (below).-Scrapers [catalog number 535238] from Qasr Kharanah, Jordan. [Old accession (accession 387104).]
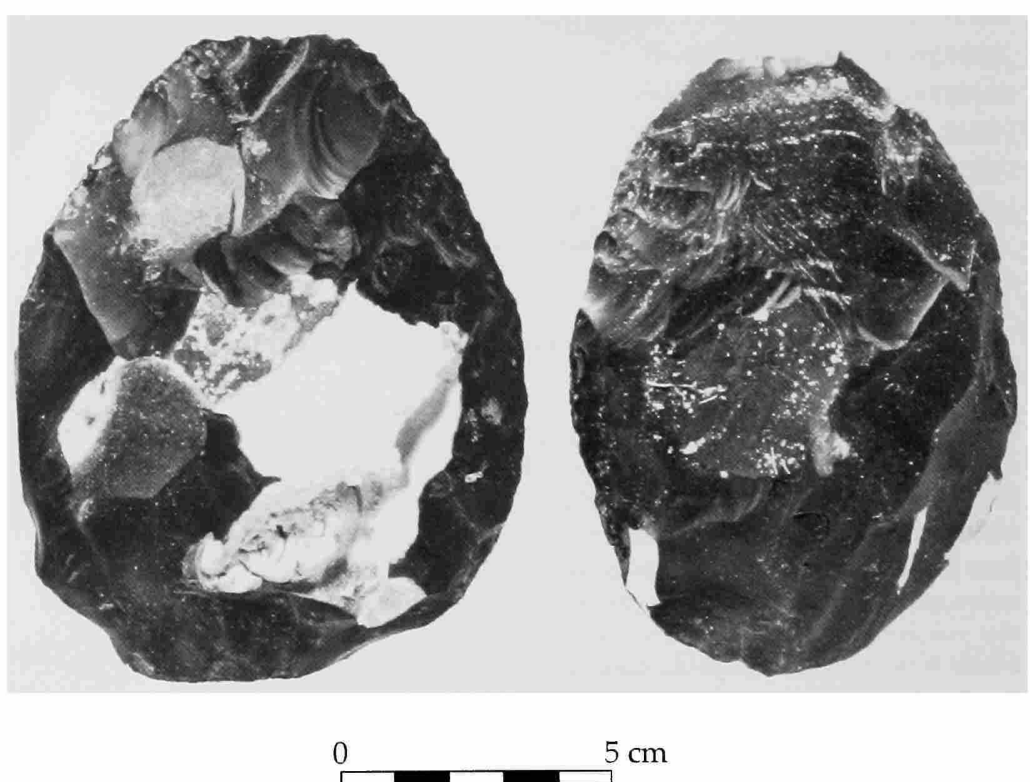

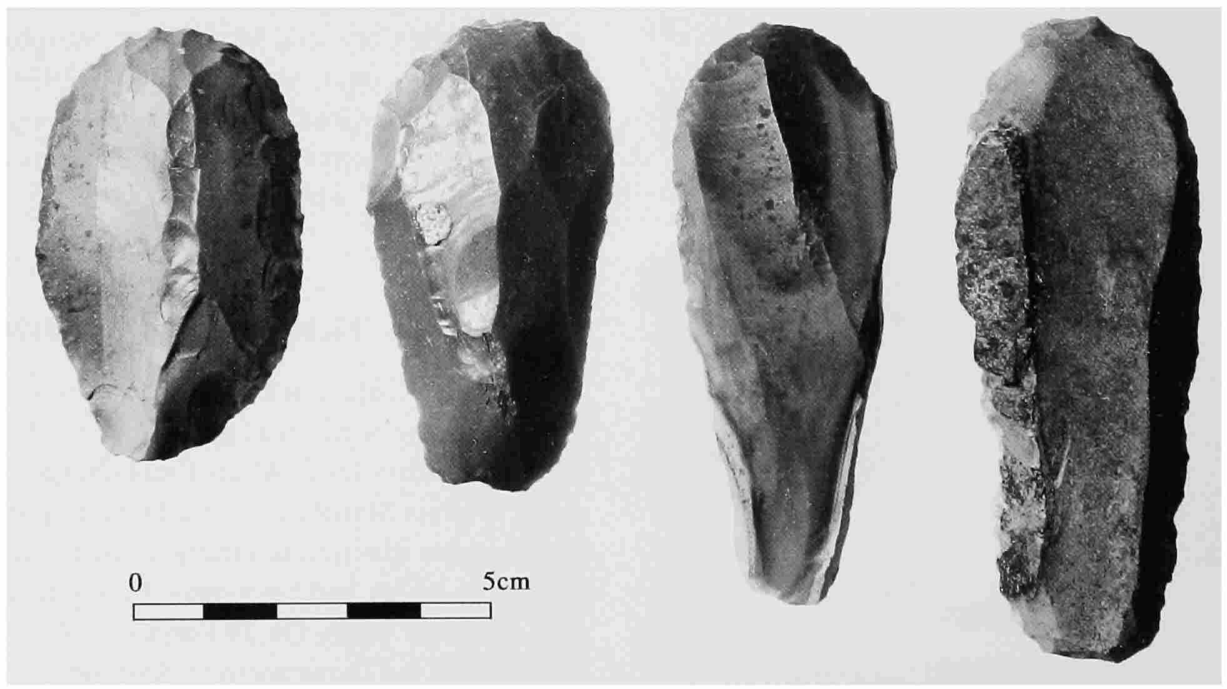




\section{Old (acc. 387104)}

In 1990, a collection of Paleolithic artifacts from Jordan was donated to the National Museum of Natural History by Randolph B. Old of Severna Park, Maryland. The collection, which had been surface collected by the donor between 1978 and 1982, consisted of stone tools from six sites in Jordan. In 1978, Old took an archaeology course with Dr. Gary O. Rollefson, who estimated the approximate age of the artifacts. On the basis of artifact typology, the site of Jebel Uweinid was considered Lower Paleolithic; Ain el-Assad, Fjaje and Jafr were Middle Paleolithic; and Wadi Qilat and Qasr Kharaneh were Middle to Upper Paleolithic. In a undated letter to Mr. Douglas Ewing of the American Association of Dealers in Ancient Oriental and Primitive Art, Mr. Old stated he was interested in having his collection of artifacts appraised because he planned to use his donation as a tax deduction. On 24 June 1986, Harmer Johnson, an appraiser and the president of the Appraisers Association of America, valued the collection at $\$ 8,595.00$.

Old provided information concerning the provenience of the artifacts and the nature of the various sites. Dr. Rollefson and Mr. Old's family found handaxes and choppers while camping at Jebel Uweinid in the spring of 1981. Ain el-Assad was the site of previous discoveries in 1920 and was located along a spring as a result of more recent excavations by Rollefson. Fjaje was located on a modern agricultural farm, overlooking Wadi Araba, which is part of the rift that extends into Africa (Figure 98). Jafr was a southern town at the center of what had been a large lake. A variety of tools had been found along the former lake shore. Wadi Qilat was in the desert and comprised an area of about one square mile. Bifaces and flake tools of different ages were found there; all had been made using the soft hammer technique. Qasr Kharanah was a large, Upper Paleolithic site that contained blades and flakes distributed within a
100 square yard area and in a deposit several feet thick (Figure 99).

In a letter dated 24 November 1986, Adnan Hadidi, director general of the Royal Jordanian Department of Antiquities gave Old permission to donate to the Smithsonian Institution the flint tools collected during his residence. "I am pleased to inform you of my approval of this request, and that I appreciate your interest in the prehistoric archaeology of this country and its promotion in the U.S. by letting more people enjoy and learn about the past of Jordan through studying these artifacts." In a memorandum dated 21 September 1989, Curator Gus Van Beek noted the significance of the collection:

This relatively small collection of stone tools from various sites in Jordan is notable for three reasons: (1) It contains all major stages in the technological development of tools from Lower Paleolithic to Neolithic, (2) It is a fully documented collection as to provenience of each tool, and (3) The artifacts have been identified by Prof. Gary Rollefson, Dept. of Anthropology, San Diego State University, San Diego, California. Rollefson is the ranking specialist on the prehistory of Jordan, having conducted research and fieldwork there for the past 11 years. The collection is, therefore, representative and well documented.

Van Beek related the 1990 collection to previous research at the Smithsonian:

In the context of this museum, it compliments our collections from the Mt. Carmel caves in Israel, and from Shanidar Cave in northern Iraq. The Mt. Carmel caves preserved the most complete stratified series of deposits of early man as yet known in the Near East and South Asia. This collection came to us from the British excavations by Dorothy Garrod in the 1930s through the American School of Prehistoric Research. It is supplemented by smaller collections from other caves in Israel. With the Old Collection, it will be possible for researchers to undertake comparative studies on materials and tool development in the southern Levant, i.e., between Israel and Jordan, here in our museum. In addition to research, the Collection augments our prehistoric materials available for future exhibits.

On 19 October 1990, Melinda Zeder, acting chairperson of the Department of Anthropology, wrote to Old to acknowledge the gift.

\section{Human Origins Program}

The Smithsonian Insttitution's Human Origins Program has conducted excavations in Kenya, Zaire, Botswana, Ethiopia, India, and China. The artifacts discovered during these excavations belong to the countries of origin; thus, they were not accessioned into the Smithsonian collections. The Paleolithic materials recovered by these projects are described below.

\section{Kenya Collections}

The Olorgesailie project, which continues at the time of this publication, is a formal collaboration between the National Museums of Kenya (NMK) and the Smithsonian Institution. Since 1986, almost 60,000 stone artifacts and an equivalent number of associated faunal remains of early and middle Pleistocene age ( 1.2 million to 500,000 years old) have been exca- vated by the Human Origins Program from the Olorgesailie Basin, southern Kenya rift valley (Figures 28, 29). Potts' investigations of Acheulean hominid activities and ecological settings in the Olorgesailie Basin have been augmented by geological investigations of the Olorgesailie Formation, particularly by National Museum of Natural History (NMNH) scientists A.K. Behrensmeyer (Department of Paleobiology) and W.G. Melson (Department of Mineral Sciences). More than one dozen scientists have participated in the study of geochronology, geochemistry, stone technology, and fossil animals and plants of the area (e.g., Potts, 1989, 1994; Deino and Potts, 1990; Tauxe et al., 1992; Sikes et al., 1999).

The Olorgesailie research project was the first to institute a strategy of in situ sampling of early hominid artifacts and local habitats on a landscape scale, by focusing excavations within 
narrow stratigraphic horizons that can be traced for long outcrop distances. The Paleolithic collections were found during detailed excavation of five main paleolandscape levels within the Olorgesailie Formation (Potts et al., 1999). Virtually all the faunal collections are housed in the NMK's Nairobi Museum, whereas the stone artifacts are kept in a building constructed by the project at the Olorgesailie Prehistoric Site Museum. A new museum building and exhibits also were developed by the Human Origins Program and the NMK in the early 1990s.

A set of representative Acheulean stone artifacts $(n=30)$ from Olorgesailie are on loan to the Human Origins Program for educational purposes and for specialized analysis. The collections in the NMNH include several hundred sediment and other rock samples that were collected for dating and for paleoenvironmental, isotopic, and other geochemical analyses.

A 1985 survey of the Kanjera locality, on the Homa Peninsula (western Kenya), led to Smithsonian excavations in 1987 and 1988, which were directed by Potts and conducted in collaboration with the NMK (Figure 30). Approximately $220 \mathrm{~Pa}$ leolithic stone artifacts of early and middle Pleistocene age were found in excavations and in surface surveys, along with bone fragments of a hippopotamus butchery and other loci of hominid activity (Plummer and Potts, 1989, 1995; Plummer, 1991; Behrensmeyer et al., 1995). The collections of stone tools and associated fauna are housed in the NMK, Nairobi.

Digging resumed at Kanjera in 1994 under the co-direction of Thomas Plummer (Human Origins Program Research Associate, and City University of New York) and Potts. The research, like that at Olorgesailie, was part of a formal research and training agreement between the NMK and the Smithsonian Institution. This research led to the discovery of a small series of archaeological sites approximately 2.2 million years old, which are among the oldest known stone-tool sites in East Africa (Ditchfield et al., 1999; Plummer et al., 1999).

\section{Zaire Collections}

Excavation of Early to Late Stone Age archaeological sites in Zaire (now Democratic Republic of the Congo) by Alison Brooks and John Yellen in the early 1990s led to the recovery of extensive stone tool and faunal collections (Figures 31, 32). The following samples are currently housed in the NMNH (counts of objects are approximations):

- 100 Early Stone Age (ESA) tools from excavated and nearby controlled surface contexts from Kasaka, Kivu Province.

- 1,000 Oldowan tools and 400 associated faunal remains from the excavated ESA site of Katanda 2 (in association with reversed polarity sediments).

- 100 excavated Sangoan and Late Acheulean stone tools from Katanda 2.

- Collections of Middle Stone Age (MSA) artifacts, associated fauna, and bone tools from the sites of Katanda 2,9 , and 16. Counts of lithics, fauna, and bone tools, re- spectively, are as follows: Katanda 2 upper: 3,700, 75, 0; Katanda 2 lower: 270, 110, 1; Katanda 9: $>8,000$, 7,369, 10; Katanda 16: 1,500, 10,350, 1.

- 10,000 early Late Stone Age (LSA) lithic artifacts, 5,000 faunal specimens, 150 barbed harpoon points (in three successive styles), and 50 human skeletal fragments from the sites of Ishango 11 and Ishango 14.

These remains are significant because they represent several important prehistoric landmarks in East Africa's western rift valley and because they provide insights into human behavioral evolution. The Katanda 2 Oldowan and Kasaka collections are two of the very few excavated Oldowan and Acheulean assemblages from Zaire. The MSA collections from Katanda include the oldest known barbed bone points in the world and provide evidence for MSA technologies and fishing in the western rift valley (Brooks et al., 1995; Yellen et al., 1995; Yellen, 1996, 1998). The LSA Ishango collections contain bone harpoons and evidence of complex fishing and microlithic technology from 20 to 25 thousand years ago in the western rift (Brooks and Smith, 1987). The Ishango sites also provide evidence for a contact zone with Ituri forest sites, even though the human remains from the Ishango sites appear to differ considerably from those of forest populations. Besides these Pleistocene assemblages, Brooks and Yellen made collections at two Holocene localities. These consist of approximately 1,000 "Mesolithic" stone tools and sparse faunal specimens from the Kabale 3 site, and 12 Iron Age skeletons and associated materials from Tongo, which provide evidence for a relationship of early Iron Age peoples of the region with its modern inhabitants. All of the collections summarized herein are on loan to the Smithsonian from the National Museums of Zaire.

\section{Botswana Collections}

From 1968 to 1983, Smithsonian research associates John Yellen and Alison Brooks conducted archaeological and ethnographic research in Botswana (e.g., Yellen, 1977; Brooks et al., 1980; Brooks and Yellen, 1987; Yellen et al., 1987). Collections that resulted from this research are kept in Botswana, although some small samples are on loan to the Department of Anthropology, NMNH, from the National Museum of Botswana. These loaned collections include the following (counts are approximations):

- 100 stone tools and 500 faunal remains stored in NMNH (out of a collection of 20,000 stone tools and faunal specimens) excavated during 1968-1970 from LSA sites in the !Kangwa and /ai/ai Valleys, Botswana (Northwest District).

- 1,000 MSA and LSA artifacts and faunal remains stored in NMNH (out of a collection of 8,000 LSA and 3,000 MSA artifacts, and 1,000 faunal fragments) excavated from 1968 to 1983 from $\neq \mathrm{Gi}$, Botswana (Northwest District). 
- 200 LSA artifacts stored in NMNH (out of a collection of 3,000 LSA artifacts and 10,000 faunal remains) collected during 1980 from Toromoja and Gooi Pan, Botswana (Central District).

These collections provide evidence of the prehistory of southern Africa, including the antiquity of the MSA and the complexity of MSA technology and hunting strategies; the earliest evidence of Iron Age intrusion; the ancestry of the San "bushmen"; and the existence of ethnic divisions in the Kalahari region during the Holocene.

\section{Ethiopia Collections}

Beginning in the mid-1990s, Yellen and Brooks began excavations in the Middle Awash region of Ethiopia, near the border between Shoa and Wollo Provinces. To date, six sites have been excavated (Aduma 1, 2, 4, 5, 8, and 8a), and controlled surface collections have been made at two other sites, spanning the MSA of the region. These collections provide some of the best evidence of MSA occupations for northeastern Africa. The collections consist of about 12,000 stone tools and 2,000 faunal specimens, all of which are stored in the Paleoanthropology repository of the National Museums of Ethiopia, Addis Ababa.

\section{India Collections}

In 1988, Petraglia visited the Department of Archaeology, Deccan College, Pune, India, for the purpose of lecturing and conducting a pilot study to examine Paleolithic collections in the college's museum. As a result of this trip, Dr. K. Paddayya invited Petraglia to examine the integrity and formation of Acheulian sites in the Hunsgi and Baichbal Valleys of Karnataka (Paddayya and Petraglia, 1993). As a follow-up to this research, intact Acheulian surfaces were identified, and excavations have been conducted at the Isampur Quarry (Petraglia et al., 1999) (Figure 33). Excavation of 159 square meters yielded 15,000 stone tools. The Isampur Quarry is an unprecedented source of evidence for stone-tool making in the original spots of reduction, as well as information regarding stone-tool design and hominid decision making.

In 1992, Dr. Ravi Korisettar of Karnatak University, Dharwad, India, invited Petraglia to conduct a survey in the Malaprabha Valley (Korisettar and Petraglia, 1993). This research resulted in the identification of an extensive landscape of
Acheulian and Middle Paleolithic quarries and reduction areas (Petraglia et al., 2003) (Figure 34). The collaborative work has led to syntheses concerning Paleolithic chronology, site formation, and behaviors (Petraglia, 1995, 1998). A representative set of Paleolithic artifacts $(n=15)$ from the Hunsgi-Baichbal Valley and the Malaprabha Valley, and replicated bifaces and debitage by Michael Noll (NMNH, postdoctoral fellow), are housed in the Paleoanthropology Laboratory of the Human Origins Program.

\section{China Collections}

In 1989, Alison Brooks visited and lectured at the Institute of Vertebrate Paleontology and Paleoanthropology (IVPP), Beijing, People's Republic of China (Brooks and Wood, 1990). The visit culminated in jointly sponsored excavations at Zhoukodian (formerly Choukoutien) and various other localities near Beijing. Since the discovery of Peking Man (Homo erectus pekinensis) in the 1920 s, the sites have been renowned for their value in understanding human origins between 780,000 and 18,000 years ago. In view of its special significance, Zhoukoudian was placed on the World Heritage List by UNESCO in 1987. All material recently excavated has remained at the Zhoukoudian research center.

In 1991, Potts visited the IVPP to lecture and to study the collections. Subsequently, Potts was invited to conduct field research in the Bose Basin of Guangxi Zhuang Autonomous Region, South China, in collaboration with Professor Huang Weiwen, head of the Archeology Department at the IVPP. Excavations at the sites of Gaolingpo and Xiaomei in 1995 and 1996, coupled with excavations at Bogu from 1988 to 1993 by Huang, have resulted in discovery of several hundred in situ Paleolithic artifacts that link the thousands of surface-collected stone tools to a single horizon throughout the $800 \mathrm{~km}^{2}$ basin (Figure 35). On the basis of argon dating of associated tektites, the horizon and the tools are ca. 803,000 years old. The presence of Acheulean-like handaxes and other large cutting tools demonstrates that such implements were used in East Asia more than 500,000 years ago (Hou et al., 2000; Yuan et al., 1999). A representative set of Paleolithic artifacts $(n=15)$, tektites, and sediment samples from Bose are housed in the Paleoanthropology Laboratory of the Human Origins Program.

\section{Concluding Remarks and Future Prospects}

The previous sections of this book have documented the historic and scientific context of the acquisition of collections from 1869 to 1990 . While preparing this book, the authors became aware that the current status and foreseeable future of Old World Paleolithic research were foreshadowed by the early correspondence and memoranda of Smithsonian researchers and administrators responsible for creating most of the collection.

In the Annual Report, Smithsonian Institution (1871), it was noted that "the antiquity of the remains [of early humans] is much greater than was formerly supposed." Although the estimate for the length of the human experience changed through- 
out the twentieth century, the chronology of humans and archaeological remains was continually being pushed back. The oldest artifacts (stone tools) are now known to be at least 2.5 million years old, and the oldest human ancestors possibly between 6 and 7 million years old, whereas five decades ago, human ancestry was thought to extend back only several hundred thousand years.

In the Annual Report, Smithsonian Institution (1872), Joseph Henry, the first Secretary of the Smithsonian, remarked that the goal of the Institution's acquisition of Paleolithic artifacts was "to furnish the means throughout the world of a more comprehensive comparison, and consequently to facilitate the study of the various states of the development of human invention." This comment presages the importance of comparative analysis in the study of Paleolithic technology and early human evolution. With a few exceptions (Tobias and von Koenigswald, 1964; Rightmire, 1990; Hou et al., 2000), the field of paleoanthropology has made only tentative steps toward synthesis and the type of comprehensive, cross-continental comparison of archaeological remains and fossils suggested by Henry's remark. This remains a significant goal of paleoanthropological research.

Nearly two decades after Henry's observation, NMNH Curator Thomas Wilson (1890b:513-514) stated that the purpose of prehistoric archaeology was not to study ancient objects in isolation but to learn about the people who made them, their behavior and way of life. Throughout the past century, Paleolithic archaeologists have concentrated their attention on the classification of artifacts rather than on the behavior of their users. The tool typologies of F. Bordes (1961) and M. Leakey (1971), for example, were considered enormous advances in the analysis of Paleolithic remains. Yet, during the past 30 years, archaeological studies of early humans have focused on how Paleolithic objects may lead to valid inferences about various aspects of early human life, including subsistence, mobility, and cognitive capacity.

Wilson's sense of the importance of context was illustrated in his notes, in which he observed, "everything is needed to study the history of prehistoric man,... every specimen of every kind, with all its associations from all localities and in as great number as possible" (Wilson, n.d.). This statement suggested what is now a common understanding in archaeological research-namely, the importance of sediments, preserved fauna, paleobotanical remains, and all manner of contextual data. Associations-such as datable substances, paleoenvironmental clues, and spatial relationships among objects—are now a vital part of Paleolithic studies. They lead to the larger subject "beyond the objects"-i.e., how early humans and other hominid groups interacted with their surroundings, including other social groups, organisms, and resources. The Paleolithic collections, therefore, are not just beautiful ancient icons. They are evidence about where early humans lived and how they conducted their lives.
In 1908, Hrdlička recognized the necessity of traveling to foreign countries to study collections and to see the latest discoveries of Paleolithic artifacts and fossil humans. Hrdlička's travels took him most frequently to Europe, but he also visited the Near East, East Asia, India, Southeast Asia, and Australia. It has long been understood that the roots of the human species are in the Old World; thus, paleoanthropological research continues to depend upon travel to foreign institutions and collaboration with researchers in Europe, Asia, and Africa. During the past sixty years, the most significant change in the study of the Paleolithic and human ancestry has been the increase of evidence found in Africa. Besides an earlier trip to Egypt, Hrdlička's only visit to Africa was in 1925 (South Africa and Rhodesia). Today, he surely would wish for more frequent travels to that continent, so rapid is the rate of well-dated discoveries there of very ancient human fossils and artifacts.

In short, an important part of the basis of current Paleolithic research can be discovered in the perspectives of the leading curators, administrators, and collectors who amassed the Smithsonian's holdings of early human artifacts. It is mostly for this reason that we have chosen to quote so extensively in this volume from the archival correspondence and notes - to let these researchers speak for themselves. In one way or another, these voices echo the themes of greater and greater antiquity and the necessity of comparison, context, object and sediment associations, and international travel that encompass what the study of Paleolithic humans entails.

The current state of Paleolithic research also has been affected significantly by new factors. These factors include, first, the development of new research questions that motivate the quest for archaeological evidence, and, second, the development of antiquities laws and museum collections in countries that preserve rich early Paleolithic records. These same factors have made it possible to assemble collections that will have greater scholarly value.

The new research questions reflect an even greater connection between Old World Paleolithic research and the overall study of human evolution. This linkage is reflected in the formal recognition of paleoanthropology as the synthetic field of human origins research, including the evolution of behavior, physical form, ecological dimensions, and the study of geological and environmental contexts. At the beginning of the twenty-first century, the underlying idea of paleoanthropology is that the edges, or areas of overlap, of the disciplines have become the centers of investigation. Thus, sedimentary geology informs the behavioral interpretation of archaeological sites; the environmental sciences are strongly coupled with the study of human biological evolution; and the functional morphology of early hominids and other large mammals helps to test theories about ecological settings and adaptive evolution. In 1992, the Paleoanthropology Society, with its broad international membership, was established at the initiative of John Yellen, a NMNH research associate. More locally, the Smithsonian's Paleoanthropology Seminar series, which has existed since 1985, 
has helped to encourage human origins research by scholars in the Washington, D.C., area.

Development of this synthetic approach is evident in the recent progression of early human archaeological studies. This progression is characterized by the following sequence, from earlier to later:

$\begin{array}{ll}\text { Stage I } & \text { Artifacts } \\ \text { Stage II } & \text { Assemblages } \\ \text { Stage III } & \text { Sites and their context }\end{array}$

The main period during which the NMNH's collections were built occurred during the first stage - a time when the principal goal was to collect artifacts, often obtained by exchange, purchase, or donation from collectors or owners. By the time of the Shanidar excavation in the 1950s, archaeologists were more interested in the characteristics of assemblages of artifacts. Even then, however, the collections were divided among museums with little perception of the value of keeping an assemblage intact as a unit of analysis and interpretation. By the late 1960 s, it had become apparent that not only do whole assemblages of artifacts need to be studied but so do the sediments, archaeobiological remains, and spatial positions of the artifacts and their associations. Consequently, the study of entire excavations as activity areas subject to the biases of site formation and taphonomic processes has emerged as a crucial arena of research and debate.

Contemplating current and future directions, we may continue the progression by adding two more developments:

\section{Stage IV Paleolandscapes \\ Stage V Comparison across regions and continents}

During the past two decades, paleoanthropologists have increasingly recognized that places of ancient hominid activity could be sampled by excavation across considerable distances. Since 1985, Smithsonian investigations have helped to pioneer this type of research in East Africa, in which specific artifactand fossil-rich layers are traced laterally across long distances (Potts, 1989; Potts et al., 1999). Similar research also has been started in China and India (Hou et al., 2000; Petraglia et al., 2003).

Making the paleolandscape a unit of analysis encourages new ways of examining how hominid artifacts and sites varied spatially with habitat, and how these activity-habitat relationships changed over time (Sikes et al., 1999; Potts et al., 1999). This type of research also encourages the finely detailed analysis of stone artifact distributions relative to lithic source rocks and the spatial relationships between hominids, carnivores, and potential prey animals. In addition to the recovery of Paleolithic collections, this research strategy also requires the recovery of new kinds of data, for example, detailed spatial data through the use of Global Positioning System (GPS) and Geographic Information System (GIS) technologies, and paleoenvironmental data that can be obtained through stable isotopic and other geochemical methods. The growing importance of multiple, interrelated archaeological assemblages and all the pertinent data from each excavated site requires the manipulation of large computerized databases. In this perspective, individual artifacts are treated as part of a much larger picturelandscapes, resource distributions, and ecological settings in which the toolmakers operated. The artifacts, in fact, represent the primary means of identifying how those toolmakers adapted to the larger context.

At many sites, such as caves and rock shelters, Paleolithic localities are not amenable to paleolandscape analysis, because of the spatial restriction of the artifact-bearing strata. Such analysis, therefore, can be employed in only certain kinds of settings, primarily large sedimentary basins. Whatever the spatial expanse of an individual locality, however, it has become apparent that future progress in the archaeological understanding of early humans requires comparison across localities, basins, regions, and eventually continents. Thus, a reasonable profile of hominid behavior and ecology for any period will need to draw extensively from the evidence from all relevant sites (e.g., McBrearty and Brooks, 2000). Paleolithic archaeology's contribution to human origins research now requires a breadth of comparison that contrasts with the tendency to view any one locality, particularly one's own field site, as the primary or sole source for reconstructing early human life.

What does this direction of Old World Paleolithic research, as outlined above, mean for the future of museum collections? The only way this method can succeed is if the collections from archaeological sites are kept intact. The best way to do this is to store and maintain entire assemblages in the countries where the artifacts and associated materials were found. Indeed, the factor that most strongly affects collections at the Smithsonian and at other Euro-American institutions, where professional archaeology has long been an interest, is the development of antiquities laws and the building of museums in developing countries of Africa and Asia, where the longest archaeological records exist. Although they vary, the purpose of antiquities laws is generally to protect archaeological (and historical) remains as cultural resources of national interest. They generally require Paleolithic artifacts to remain in the country unless permission is granted for specialized preparation and/or analysis. International cooperation among museums and other repositories of Paleolithic materials is extremely important. A formal agreement between the Smithsonian and the National Museums of Kenya (NMK) is an example of how long-term collaboration has led to the recovery of new Smithsonian collections that are expertly cared for in the country of origin.

The NMK is one of the best museum systems in sub-Saharan Africa, and it is well known for its collections of early human fossils (currently more than 3,500) and archaeological finds. In 1987, a formal agreement concerning research and training was signed by the Smithsonian and the NMK. The agreement has enabled Smithsonian research teams to work long-term at Paleolithic sites in Kenya (principally Olorgesailie, Kanjera, and Kanam) under a research permit granted by the NMK. The 
Smithsonian, in turn, has agreed to train the NMK's professional scientific and museum staff in collections management, registrar activities, exhibition design, library science, public relations, and other aspects of museum operation. It also has provided funds for NMK researchers to attend graduate programs in the United States.

The agreement between the two institutions is consistent with a new concept of international collections, in which those developed by Smithsonian researchers result from collaboration with growing or established museum systems and other institutions in other countries. The Smithsonian's Human Origins Program considers this approach to offer the best way to respect the antiquities of another country as an important cultural resource. This approach also makes sense scientifically in that entire assemblages of materials are kept together in the country where similar materials may be excavated in the future, and where comparison between assemblages or even individual specimens is crucial to scientific analysis.

As countries retain their antiquities, there is still the possibility for the exchange, loan, or donation of small samples of representative artifacts from well-documented contexts. In recent years, the Smithsonian has received small collections of artifacts (not yet accessioned) from Olorgesailie, Kenya; Bose, China; and Hunsgi and Baichbal, India - all of which were found by Smithsonian researchers and collaborating scientists of other institutions.

In addition to the recovery of artifacts, the current international research environment allows opportunity for contextual studies of Paleolithic sites and for developing extensive, exportable collections related to the geology, dating, and paleoenvironmental analysis of early human sites. Smithsonian laboratories, for example, now maintain research collections relevant to the sedimentary, geochronological, and environmental settings of Paleolithic sites. These collections are consistent with the research developments noted above, in which site context and paleoecological studies have become an integral part of the field of paleoanthropology. These areas of study are important in recent human origins research conducted by the Smithsonian.

As a result, paleoanthropological teams working in Africa, Asia, and Europe may include sedimentologists, soils experts, structural geologists, geomorphologists, geochronologists, geochemists, other environmental scientists, in addition to archaeologists and paleontologists. The specialists typically make their own research collections, some of which may need to be transported out of the country for technical analysis. Each type of collection has its own particular relevance to under- standing the archaeological collections left in the country of origin. Furthermore, considerable funding is required to get research teams into the field, or to encourage specialists to visit other study sites and collections.

In this most recent phase of Paleolithic research, archaeologists must strive to understand the contributions of other disciplines. This effort may require expanding one's research background, reading outside of one's own area of expertise, and conversing with scientists in diverse fields. This approach to Paleolithic studies-and to modern paleoanthropology in general-also requires effective management of research teams and the organization of collaborators. In this aspect of their work, scientists who may have no training in these activities, must play the role of personnel managers, accountants, and diplomats, and must be able to define a project's direction while allowing collaborators and students some flexibility in their own research.

An intriguing remark was made by Huang Weiwen of the Chinese Academy of Sciences, who is the principal Chinese collaborator on the Smithsonian's project in southern China (in litt. to Potts, 1994). Professor Huang wrote that China and other developing countries are seeking the "internationalization" of research. He urged the Smithsonian, in its current Paleolithic studies, to play a crucial role in this process, which encourages scientists to reach across political borders, create their own form of diplomacy, encourage the scholarly exchange of information, and eventually build a more integrated, cross-cultural intellectual enterprise. This effort remains an important future goal, one that is essential to the modern study of human origins.

In short, the development and use of collections to examine the details of human evolutionary history cannot be done without the combination of interdisciplinary study, effective planning, and international collaboration that affects every aspect of current Paleolithic investigations. As research on the Old World Paleolithic continues, it is certain that formal negotiation and personal connections, the availibility of research opportunities, the pursuit of the oldest (and crudest) artifacts and the most beautiful, will play as important a role as it did for the people who built the collections described herein. New approaches will lead to the development of entirely different types of collections and databases, and new scientific findings will inevitably follow from the study of future collections. Existing collections also will benefit, we may expect, as analytical techniques continue to blossom and offer novel ways of extracting clues to Paleolithic life from the objects left behind by human ancestors. 


\section{Appendix 1 \\ Location of Correspondence}

(Smithsonian Institution Archives=SIA; National Anthropological Archives=NAA; National Museum of Natural History Office of Registrar=OR)

\begin{tabular}{|c|c|c|c|}
\hline Date & Correspondent & Recipient & Sources \\
\hline n.d. & Wilson & Manuscript & NAA \\
\hline undated & Miguel & Mason & OR \\
\hline undated & Rathbun & Schönland & OR \\
\hline 24 Feb 1867 & Rau & Henry & SIA \\
\hline 17 Nov 1868 & Henry & Lartet & SIA \\
\hline 15 Dec 1868 & $\mathrm{Rau}$ & Henry & SIA \\
\hline 4 Mar 1869 & Lartet & Henry & SIA \\
\hline 3 May 1869 & Henry & Lartet & SIA \\
\hline 13 Jun 1869 & Lartet & Henry & SIA \\
\hline 15 Jul 1869 & Henry & Lartet & SIA \\
\hline 7 Oct 1869 & Rau & Henry & SIA \\
\hline 25 Oct 1869 & Henry & Rau & SIA \\
\hline 18 Nov 1869 & Henry & Lartet & SIA \\
\hline 11 Jun 1870 & Baird & Blackmore & SIA \\
\hline 17 Jun 1870 & Blackmore & Henry & SIA \\
\hline 5 Jul 1870 & Baird & Blackmore & SIA \\
\hline $20 \mathrm{Jul} 1870$ & Stevens & Baird & SIA \\
\hline 11 Oct 1870 & Baird & Stevens & SIA \\
\hline 7 Nov 1870 & Henry & Blackmore & SIA \\
\hline 20 Oct 1871 & Henry & Dawkins & SIA \\
\hline $24 \operatorname{Jan} 1872$ & Henry & Wyman & SIA \\
\hline 17 Apr 1872 & Henry & (unknown) & SIA \\
\hline 11 Jun 1872 & Henry & Stevens & SIA \\
\hline 9 Nov 1872 & Henry & Dawkins & SIA \\
\hline 19 Dec 1872 & Wyman & Henry & SIA \\
\hline 21 Dec 1872 & Henry & Pengelly & SIA \\
\hline 28 Dec 1872 & Henry & Wyman & SIA \\
\hline 9 Jan 1873 & Pengelly & Henry & SIA \\
\hline 9 Apr 1879 & Baird & Reynolds & SIA \\
\hline 1 Sep 1880 & Baird & Réclard & SIA \\
\hline 4 Dec 1880 & Dawkins & Baird & SIA \\
\hline $26 \mathrm{Feb} 1881$ & Dawkins & Baird & SIA \\
\hline 24 Jun 1881 & Réclard & Baird & OR \\
\hline 24 Nov 1881 & Baird & Dawkins & SIA \\
\hline 3 Mar 1883 & Pengelly & Baird & OR \\
\hline 17 Mar 1883 & Baird & Pengelly & SIA \\
\hline 7 Apr 1883 & Pengelly & Baird & OR \\
\hline 1 May 1883 & Baird & Pengelly & SIA \\
\hline 23 May 1883 & Pengelly & Baird & SIA \\
\hline 23 May 1883 & Rau & Baird & SIA \\
\hline 24 May 1883 & Baird & Pengelly & SIA \\
\hline 11 Jun 1883 & Pengelly & Baird & $\mathrm{OR}$ \\
\hline 22 Jun 1883 & Powell & Wilson & NAA \\
\hline 22 Jun 1883 & Wilson & Powell & NAA \\
\hline 12 Dec 1883 & Baird & Wilson & SIA \\
\hline
\end{tabular}




\begin{tabular}{|c|c|c|c|}
\hline Date & Correspondent & Recipient & Sources \\
\hline 30 Sep 1884 & Baird & Wilson & SIA \\
\hline 18 Oct 1884 & Wilson & Baird & OR \\
\hline 23 Dec 1884 & Baird & Wilson & SIA \\
\hline 30 Mar 1885 & Wilson & Baird & OR \\
\hline 13 Apr 1885 & Baird & Wilson & SIA \\
\hline 14 May 1885 & Wilson & Baird & OR \\
\hline 16 Jun 1885 & Wilson & Baird & OR \\
\hline 18 Jul 1885 & Wilson & Baird & OR \\
\hline 4 Aug 1885 & Baird & Wilson & OR \\
\hline 12 Aug 1885 & Wilson & Baird & OR \\
\hline 28 Aug 1885 & Baird & Wilson & OR \\
\hline 15 Sep 1885 & Wilson & Baird & $\mathrm{OR}$ \\
\hline 4 May 1886 & Wilson & Baird & OR \\
\hline 11 Dec 1886 & Lovett & Baird & SIA \\
\hline 30 Dec 1886 & Baird & Lovett & SIA \\
\hline 6 Jan 1887 & Baird & Cosmos Club & SIA \\
\hline 18 Mar 1887 & Wilson & Mason & OR \\
\hline 7 Nov 1887 & Lovett & Mason & OR \\
\hline 29 Nov 1887 & Goode & Lovett & SIA \\
\hline 7 Jan 1888 & Lovett & Mason & OR \\
\hline 27 Jan 1888 & Lovett & Mason & OR \\
\hline 17 Nov 1888 & Reynolds & (unknown) & OR \\
\hline 29 Nov 1888 & Goode & Ransom & OR \\
\hline 15 Jul 1889 & Goode & Giglioli & OR \\
\hline 19 Aug 1889 & Lovett & Goode & SIA \\
\hline 18 Sep 1889 & Schönland & Smithsonian Institution & SIA \\
\hline 18 Apr 1890 & Giglioli & Goode & SIA \\
\hline 10 Jun 1890 & Powell & Goode & OR \\
\hline 9 Sep 1890 & Balfour & Holmes & SIA \\
\hline 30 Oct 1890 & Cresson & Wilson & OR \\
\hline 14 Nov 1890 & Giglioli & Goode & OR \\
\hline 5 Dec 1891 & True & Giglioli & OR \\
\hline 19 Mar 1892 & True & Camp & SIA \\
\hline 19 Mar 1892 & True & Newell & SIA \\
\hline 30 Nov 1892 & Giglioli & Goode & SIA \\
\hline 15 May 1893 & Lovett & Mason & OR \\
\hline 1 Jul 1893 & True & Powell & SIA \\
\hline 19 Aug 1893 & Powell & True & OR \\
\hline 21 Oct 1893 & Wilson & True & OR \\
\hline 24 Oct 1893 & True & Powell & SIA \\
\hline 17 Nov 1893 & Powell & True & OR \\
\hline 11 Jan 1895 & Camp & Langley & OR \\
\hline 18 Jan 1895 & Wilson & Goode & OR \\
\hline 19 Jan 1895 & Goode & Wilson & OR \\
\hline 7 Feb 1895 & Goode & Powell & SIA \\
\hline 7 Mar 1895 & Quick & Goode & OR \\
\hline 5 Apr 1895 & Harrison & Wilson & OR \\
\hline 18 Apr 1895 & Goode & Quick & SIA \\
\hline Aug 1895 & Wilson & Cosmos Club address & SIA \\
\hline 29 Apr 1896 & Seton-Karr & Smithsonian Institution & SIA \\
\hline 28 Jun 1897 & Seton-Karr & Smithsonian Institution & OR \\
\hline (?) Jul 1897 & Seton-Karr & Smithsonian Institution & OR \\
\hline 14 Jul 1897 & True & Seton-Karr & SIA \\
\hline
\end{tabular}




\begin{tabular}{|c|c|c|c|}
\hline Date & Correspondent & Recipient & Sources \\
\hline 20 Jul 1897 & Wilson & Walcott & SIA \\
\hline 11 Aug 1897 & Wilson & True & SIA \\
\hline 15 Dec 1899 & Miguel & Smithsonian Institution & SIA \\
\hline 19 Feb 1900 & Peyrony & Wilson & OR \\
\hline 7 Apr 1900 & McGuire & Langley & SIA \\
\hline 11 Jun 1900 & Capitan & Wilson & OR \\
\hline 12 Nov 1900 & Peyrony & Wilson & OR \\
\hline 10 May 1901 & Steierli & American Consulate in Zurich & OR \\
\hline 10 Jun 1901 & $\begin{array}{l}\text { Third Assistant Secretary } \\
\text { US State Department }\end{array}$ & Langley & OR \\
\hline 13 Sep 1901 & Else & Smithsonian Institution & OR \\
\hline 15 Oct 1901 & Internal SI Memo: Wilson & (unknown) & OR \\
\hline 26 Oct 1901 & Acting Chief Clerk & Geare & OR \\
\hline 17 Dec 1901 & Else & Smithsonian Institution & OR \\
\hline 17 Oct 1902 & Rathbun & Seton-Karr & SIA \\
\hline 1 Jan 1903 & Seton-Karr & Smithsonian Institution & OR \\
\hline 26 Jan 1903 & Hemphill and Peter & Langley & OR \\
\hline 19 Feb 1903 & Homes & Mason & OR \\
\hline 9 Mar 1903 & Rathbun & Seton-Karr & SIA \\
\hline 9 Apr 1903 & Geare & Rathbun & OR \\
\hline 23 Jun 1903 & Seton-Karr & Rathbun & SIA \\
\hline 5 Dec 1903 & Rathbun & Langley & OR \\
\hline 7 Dec 1903 & Rathbun & Langley & OR \\
\hline 16 Jan 1904 & Hemphill and Peter & Langley & OR \\
\hline 17 Feb 1904 & Ravenel & Coulon & OR \\
\hline 5 Sep 1904 & Schönland & Rathbun & OR \\
\hline 26 Sep 1904 & Schönland & Rathbun & OR \\
\hline 15 Jun 1905 & Miguel & Langley & OR \\
\hline 5 Aug 1905 & Miguel & Rathbun & OR \\
\hline 9 Oct 1905 & Nightingale & Bureau of American Ethnology & OR \\
\hline 19 Oct 1905 & Upham & Holmes & OR \\
\hline 30 Oct 1905 & Rathbun & Miguel & OR \\
\hline 10 May 1906 & Miguel & Rathbun & OR \\
\hline 17 Aug 1906 & Nightingale & Rathbun & OR \\
\hline 6 Feb 1907 & Martin & Walcott & OR \\
\hline 12 May 1907 & Martin & Smithsonian Institution & OR \\
\hline 23 Jun 1907 & Seton-Karr & Rathbun & SIA \\
\hline 10 Aug 1907 & Rathbun & Seton-Karr & SIA \\
\hline 19 Sep 1907 & Seton-Karr & Rathbun & OR \\
\hline 19 Nov 1907 & Rathbun & Seton-Karr & OR \\
\hline 24 Jan 1908 & Hrdlička & Hough & NAA \\
\hline 1 May 1908 & Hrdlička & Mason & NAA \\
\hline 4 May 1908 & Mason & Rathbun & NAA \\
\hline 9 Jun 1908 & Coulon & Smithsonian Institution & OR \\
\hline 25 Jun 1908 & Mason & Kroeber & SIA \\
\hline 29 Jun 1908 & Holmes & Ravenel & OR \\
\hline 3 Jul 1908 & Ravenel & Coulon & SIA \\
\hline 9 Sep 1908 & Nightingale & Secretary & SIA \\
\hline 29 Oct 1908 & Coulon & Smithsonian Institution & OR \\
\hline 1 Jan 1909 & Coulon & Smithsonian Institution & OR \\
\hline 11 Feb 1909 & Upham & Hough & OR \\
\hline 17 Feb 1909 & Ravenel & Coulon & SIA \\
\hline 19 Apr 1909 & Frank Clark & Smithsonian Institution & OR \\
\hline
\end{tabular}




\begin{tabular}{|c|c|c|c|}
\hline Date & Correspondent & Recipient & Sources \\
\hline 7 May 1909 & Rathbun & Herbert Clark & OR \\
\hline 15 May 1909 & Herbert Clark & Smithsonian Institution & OR \\
\hline 7 Jun 1909 & Coulon & Smithsonian Institution & OR \\
\hline 13 Jul 1909 & Upham & Hough & OR \\
\hline 19 Jul 1909 & Ravenel & Coulon & OR \\
\hline 3 Feb 1912 & Currelly & Hrdlička & SIA \\
\hline 12 Jul 1912 & Holmes & Rathbun & OR \\
\hline 13 Jul 1912 & Holmes & Rathbun & OR \\
\hline 28 Aug 1912 & Holmes & Rehlen & OR \\
\hline 28 Sep 1912 & Pfeiffer & Holmes & OR \\
\hline 10 Oct 1912 & Hrdlička & Gorjanović-Kramberger & NAA \\
\hline 19 Nov 1912 & Haygood & $\begin{array}{l}\text { US Vice Consul General to South } \\
\text { Africa }\end{array}$ & OR \\
\hline 25 Nov 1912 & Hrdlička & Gorjanović-Kramberger & OR \\
\hline 10 Dec 1912 & Pfeiffer & Holmes & OR \\
\hline 24 Dec 1912 & Rehlen & Holmes & OR \\
\hline 22 Jan 1913 & Holmes & Rehlen & OR \\
\hline 7 Feb 1913 & Rathbun & Haygood & SIA \\
\hline 8 Feb 1913 & Rathbun & Talken & SIA \\
\hline 27 Mar 1913 & Rehlen & Holmes & OR \\
\hline 12 May 1913 & Holmes & Rathbun & OR \\
\hline 19 May 1913 & Rutot & Hrdlička & OR \\
\hline 10 Jun 1913 & Rutot & Hrdlička & OR \\
\hline 13 Jun 1913 & Peabody & Holmes & OR \\
\hline 18 Jun 1913 & Rathbun & Peabody & OR \\
\hline 28 Jun 1913 & Peabody & Holmes & OR \\
\hline 3 Jul 1913 & Rathbun & Pfeiffer & OR \\
\hline 24 Jul 1913 & Rathbun & Rehlen & OR \\
\hline 27 Aug 1913 & Hrdlička & Martin & NAA \\
\hline 12 Sep 1913 & Hrdlička & Rathbun & OR \\
\hline 18 Dec 1913 & Hrdlička & Rutot & NAA \\
\hline 20 Jan 1914 & Rathbun & Rutot & OR \\
\hline 28 Mar 1914 & Rathbun & Rutot & OR \\
\hline 5 May 1914 & Marett & Hrdlička & OR \\
\hline 23 Jan 1918 & Holmes & Ravenel & OR \\
\hline 28 Jan 1918 & Currelly & Holmes & OR \\
\hline 4 Feb 1918 & Ravenel & Currelly & OR \\
\hline 20 Feb 1918 & Currely & Holmes & OR \\
\hline 6 Jun 1919 & Ravenel & Marriott & OR \\
\hline 6 Dec 1920 & Hrdlička & Peabody & NAA \\
\hline 31 Jul 1921 & MacCurdy & Hrdlička & NAA \\
\hline 3 Dec 1921 & Hrdlička & MacCurdy & NAA \\
\hline 20 Jan 1922 & Peabody & Hrdlička & NAA \\
\hline 23 May 1922 & Peabody & Hrdlička & NAA \\
\hline 14 Feb 1923 & Wilman & Hough & OR \\
\hline 4 May 1923 & MacCurdy & Hrdlička & NAA \\
\hline 5 May 1923 & Hrdlička & Peabody & NAA \\
\hline 5 May 1923 & Hrdlička & MacCurdy & NAA \\
\hline 25 May 1923 & Ravenel & Congo Mission & OR \\
\hline 9 Jun 1923 & Hrdlička & Moir & NAA \\
\hline 18 Jul 1923 & Hrdlička & Hough & NAA \\
\hline 31 Jul 1923 & Peabody & Hrdlička & NAA \\
\hline 13 Oct 1923 & Hrdlička & Moir & NAA \\
\hline
\end{tabular}




\begin{tabular}{|c|c|c|c|}
\hline Date & Correspondent & Recipient & Sources \\
\hline 17 Oct 1923 & Peyrony & Hrdlička & NAA \\
\hline 29 Oct 1923 & Moir & Hrdlička & NAA \\
\hline 2 Nov 1923 & Hrdlička & Peyrony & NAA \\
\hline 10 Nov 1923 & Hrdlička & Moir & NAA \\
\hline 12 Nov 1923 & Hrdlička & Martin & NAA \\
\hline 14 Dec 1923 & Martin & Walcott & OR \\
\hline 7 Jan 1924 & Ravenel & Martin & OR \\
\hline 26 Jan 1924 & Peabody & MacCurdy & NAA \\
\hline 26 Jan 1924 & Martin & Walcott & OR \\
\hline 11 Feb 1924 & Ravenel & Moir & OR \\
\hline 16 Feb 1924 & Hrdlička & MacCurdy & NAA \\
\hline 26 Mar 1924 & Ravenel & Hrdlička & OR \\
\hline 3 Apr 1924 & Reygasse & Smithsonian Institution & OR \\
\hline 22 Apr 1924 & Ravenel & Martin & $\mathrm{OR}$ \\
\hline 25 Apr 1924 & Ravenel & Reygasse & OR \\
\hline 25 Jun 1924 & Hrdlička & Peyrony & NAA \\
\hline 9 Jul 1924 & Peyrony & Hrdlička & NAA \\
\hline 10 Aug 1924 & MacCurdy & Hrdlička & NAA \\
\hline 26 Aug 1924 & Hrdlička & Ami & NAA \\
\hline 30 Aug 1924 & Ami & Hrdlička & NAA \\
\hline 27 Sep 1924 & Reygasse & Ravenel & OR \\
\hline 14 Nov 1924 & Carroll & Walcott & NAA \\
\hline 18 Jan 1925 & Cleland & Smithsonian Institution & OR \\
\hline 25 Jan 1925 & Ravenel & Cleland & OR \\
\hline $1 \mathrm{Feb} 1925$ & Cleland & Smithsonian Institution & OR \\
\hline 13 Feb 1925 & Ravenel & Cleland & OR \\
\hline $18 \mathrm{Feb} 1925$ & Cleland & Ravenel & OR \\
\hline 28 Apr 1925 & Hrdlička & Hough & NAA \\
\hline 25 Jun 1925 & Abbott & Marshall & OR \\
\hline 30 Jun 1925 & Wetmore & Gravely & OR \\
\hline 29 Jul 1925 & Wetmore & Reygasse & OR \\
\hline 21 Aug 1925 & Reygasse & Wetmore & OR \\
\hline 19 Oct 1925 & Wetmore & Reygasse & OR \\
\hline 21 Oct 1925 & Bodding & Wetmore & OR \\
\hline 11 Nov 1925 & Bodding & Hrdlička & NAA \\
\hline 9 Dec 1925 & Hrdlička & Bodding & NAA \\
\hline 7 Jan 1926 & Wetmore & Hrdlička & OR \\
\hline 7 Jan 1926 & Wetmore & Jones & OR \\
\hline 8 Jan 1926 & Wetmore & Gravely & OR \\
\hline 9 Feb 1926 & Hrdlička & Absolon & NAA \\
\hline 19 Feb 1926 & Hrdlička & Wetmore & NAA \\
\hline 24 Mar 1926 & Wetmore & Bodding & OR \\
\hline 2 May 1926 & MacCurdy & Hough & OR \\
\hline 8 May 1926 & Hrdlička & Martin & NAA \\
\hline 10 Jun 1926 & MacCurdy & Hrdlička & NAA \\
\hline 14 Jun 1926 & Wetmore & MacCurdy & OR \\
\hline 15 Jun 1926 & Chanda & Smithsonian Institution & OR \\
\hline 13 Oct 1926 & Ravenel & Bushnell & OR \\
\hline 8 Dec 1926 & Wetmore & Chanda & OR \\
\hline 19 Apr 1927 & Hrdlička & Bodding & OR \\
\hline 9 Dec 1927 & Wetmore & MacCurdy & OR \\
\hline $26 \operatorname{Mar} 1928$ & Gill & Hrdlička & OR \\
\hline 7 May 1928 & Hrdlička & Absolon & NAA \\
\hline
\end{tabular}




\begin{tabular}{|c|c|c|c|}
\hline Date & Correspondent & Recipient & Sources \\
\hline 25 May 1928 & Wetmore & Gill & OR \\
\hline 29 Aug 1928 & MacCurdy & Hough & NAA \\
\hline 18 Oct 1928 & Wetmore & Russell & SIA \\
\hline 25 Jan 1929 & MacCurdy & Hrdlička & NAA \\
\hline 20 Feb 1929 & Wetmore & Riggs & OR \\
\hline 1 Mar 1929 & MacCurdy advert. & (unknown) & NAA \\
\hline 3 Apr 1929 & Russell & Wetmore & SIA \\
\hline 17 May 1929 & Wetmore & Russell & SIA \\
\hline 1 Nov 1929 & Judd & Hough & OR \\
\hline 4 Nov 1929 & Wetmore & Absolon & OR \\
\hline 9 Dec 1929 & Judd & Hough & OR \\
\hline 13 Dec 1929 & Wetmore & MacCurdy & OR \\
\hline 9 Feb 1930 & Russell & Judd & SIA \\
\hline 27 Jun 1930 & Russell & Wetmore & SIA \\
\hline 6 Aug 1930 & Russell & Wetmore & SIA \\
\hline 6 Aug 1930 & Russell & Carballo & SIA \\
\hline 20 Aug 1930 & Wetmore & Russell & SIA \\
\hline 20 Sep 1930 & Russell & Judd & SIA \\
\hline 25 Oct 1930 & Russell & (unknown) & OR \\
\hline 30 Oct 1930 & Wetmore & Russell & SIA \\
\hline 1 Nov 1930 & Wetmore & MacCurdy & OR \\
\hline 12 Feb 1931 & Sanz & Smithsonian Institution & OR \\
\hline 15 Mar 1931 & Graf & Sanz & OR \\
\hline 2 May 1931 & Sanz & Graf & OR \\
\hline 7 May 1931 & MacCurdy & Hough & OR \\
\hline 2 Jun 1931 & Graf & Sanz & OR \\
\hline 23 Sep 1931 & Carballo & Russell & SIA \\
\hline 23 Sep 1931 & Carballo & USNM & SIA \\
\hline 25 Sep 1931 & Russell & Wetmore & SIA \\
\hline $24 \operatorname{Dec} 1931$ & Graf & Bégouën & OR \\
\hline 9 Jan 1932 & Wetmore & Carballo & SIA \\
\hline 8 Feb 1932 & Wetmore & Russell & SIA \\
\hline 5 May 1932 & Hrdlička & MacCurdy & NAA \\
\hline 9 May 1932 & MacCurdy & Hrdlička & NAA \\
\hline 12 May 1932 & Hrdlička & MacCurdy & NAA \\
\hline 7 Jun 1932 & MacCurdy & Hrdlička & NAA \\
\hline 1 Aug 1932 & Binghamton Press article & (unknown) & SIA \\
\hline 23 Sep 1932 & MacCurdy & Hrdlička & NAA \\
\hline 26 Sep 1932 & Hrdlička & MacCurdy & NAA \\
\hline 1 Oct 1932 & MacCurdy & Hough & OR \\
\hline 10 Oct 1932 & MacCurdy & Hrdlička & NAA \\
\hline 4 Nov 1932 & Graf & Riggs & OR \\
\hline 2 Dec 1932 & Russell & Wetmore & SIA \\
\hline 10 Feb 1933 & Abbott & US Secretary of State & SIA \\
\hline 10 Jun 1933 & Townsend & Abbott & OR \\
\hline 26 Jun 1933 & Wetmore & Riggs & OR \\
\hline 30 Jun 1933 & Riggs & Wetmore & OR \\
\hline 5 Oct 1933 & MacCurdy & Hough & OR \\
\hline 5 Mar 1934 & Wetmore & Abbott & SIA \\
\hline 5 Apr 1934 & Moritz & Wetmore & SIA \\
\hline 19 Apr 1934 & Wetmore & Russell & SIA \\
\hline 14 May 1934 & Judd & MacCurdy & OR \\
\hline
\end{tabular}




\begin{tabular}{|c|c|c|c|}
\hline Date & Correspondent & Recipient & Sources \\
\hline 21 May 1934 & MacCurdy & Judd & OR \\
\hline 8 Jun 1934 & Judd & MacCurdy & OR \\
\hline 9 Jun 1934 & MacCurdy & Judd & OR \\
\hline 15 Jun 1934 & Graf & Riggs & SIA \\
\hline 7 Oct 1934 & Johnson & Judd & OR \\
\hline 29 Oct 1934 & MacCurdy & Judd & $\mathrm{OR}$ \\
\hline 31 Oct 1934 & Judd & Johnson & OR \\
\hline 19 Feb 1935 & MacCurdy & Judd & OR \\
\hline 20 Feb 1935 & Judd & MacCurdy & OR \\
\hline 27 May 1935 & Judd & Abbott & OR \\
\hline 28 May 1935 & Wetmore & Abbott & OR \\
\hline 6 Jun 1935 & Abbott & Wetmore & OR \\
\hline 7 Jun 1935 & Judd & Hough & SIA \\
\hline 10 Jun 1935 & Wetmore & Leach & OR \\
\hline 15 Jun 1935 & Graf & Riggs & OR \\
\hline 12 Jul 1935 & Judd & Johnson & OR \\
\hline 15 Jul 1935 & Leach & Wetmore & OR \\
\hline 2 Aug 1935 & Wetmore & Leach & OR \\
\hline 28 Aug 1935 & Wetmore & MacCurdy & OR \\
\hline 31 Aug 1935 & Riggs & Wetmore & OR \\
\hline 1 Jul 1936 & Wetmore & Abbott & OR \\
\hline 24 Oct 1936 & Graf & Wilman & OR \\
\hline 6 Feb 1938 & Abbott & Judd & OR \\
\hline 25 Apr 1938 & Judd & Abbott & OR \\
\hline 23 Aug 1938 & Abbott & Judd & SIA \\
\hline $24 \operatorname{Sep} 1938$ & Judd & Abbott & OR \\
\hline $23 \operatorname{Dec} 1938$ & Graf & Abbott & OR \\
\hline 23 Dec 1938 & Graf & Swan & OR \\
\hline 30 Sep 1940 & Franssen & Smithsonian Institution & OR \\
\hline 6 Nov 1940 & Graf & Franssen & OR \\
\hline 19 Apr 1945 & Graf & Reeves & OR \\
\hline 31 Dec 1946 & Glueck & Wetmore & OR \\
\hline 3 Oct 1947 & Setzler & Glueck & OR \\
\hline 15 Oct 1947 & Glueck & Setzler & OR \\
\hline 15 Apr 1949 & Kellogg & Glueck & SIA \\
\hline 3 Apr 1951 & Glueck & Wetmore & OR \\
\hline 12 Apr 1951 & Wetmore & Glueck & OR \\
\hline 2 Jan 1958 & Solecki & Reed & OR \\
\hline 29 Nov 1952 & Vass & Smithsonian Instituion & OR \\
\hline 8 Dec 1952 & Wymer & Wedel & OR \\
\hline 14 Dec 1952 & Setzler & Vass & OR \\
\hline 11 Mar 1953 & Kellogg & Wymer & OR \\
\hline 28 Apr 1953 & Kellogg & Vass & OR \\
\hline 10 Jun 1954 & Jayadev & Smithsonian Institution & OR \\
\hline 17 Aug 1954 & Setzler & Jayadev & OR \\
\hline 10 Jun 1955 & Aiyappan & Setzler & OR \\
\hline 20 Sep 1955 & Setzler & Aiyappan & OR \\
\hline 8 Sep 1956 & Solecki & Setzler & OR \\
\hline 13 Dec 1956 & Kellogg & Bordes & OR \\
\hline 17 Feb 1957 & Paige & Setzler & OR \\
\hline
\end{tabular}




\begin{tabular}{clll}
\hline Date & \multicolumn{1}{c}{ Correspondent } & & Recipient \\
\hline 26 May 1957 & Kellogg & Paige & OR \\
1 Jan 1958 & al Asil & Stewart & OR \\
2 Jan 1958 & Solecki & Reed & OR \\
21 Jan 1958 & Carmichael & al Asil & OR \\
15 May 1958 & Kellogg & al Asil & OR \\
4 Jan 1964 & Cole & Van Beek & OR \\
14 Jan 1964 & Stewart & Jones & OR \\
26 Feb 1965 & Evans & Cole & SIA \\
9 Feb 1966 & Van Beek & Citron & OR \\
15 Feb 1966 & Citron & Van Beek & OR \\
13 Apr 1966 & Van Beek & Citron & OR \\
9 Aug 1966 & Woodbury & Citron & OR \\
26 Apr 1968 & Peterson & Shiner & OR \\
28 Jul 1972 & Barbour & Knez & OR \\
14 Sep 1972 & Barbour & Knez & OR \\
25 Oct 1972 & Knez & Barbour & OR \\
1 May 1973 & Evans & Barbour & OR \\
13 Mar 1975 & Fitzhugh & Lightner & OR \\
1 Aug 1975 & Ripley & Li-pin & OR \\
24 May 1976 & Fitzhugh & Klima & OR \\
25 Jun 1976 & Viola & Li-pin & OR \\
29 Feb 1984 & Ubelaker & Eichenberger & OR \\
24 Nov 1986 & Hadidi & Old & OR \\
21 Sep 1989 & Van Beek & (unknown) & OR \\
19 Oct 1990 & Zeder & Old & OR \\
\hline
\end{tabular}




\section{Literature Cited}

Alexander, C.A.

1872. Man as the Contemporary of the Mammoth and the Reindeer in Middle Europe. In Annual Report, Smithsonian Institution, pages 406-407. Washington, D.C.: Government Printing Office [translation].

Angel, J.L.

1976. T. Dale Stewart. American Journal of Physical Anthropology, 45: 521-530.

Annual Report, Smithsonian Institution

1869. Annual Report of the Board of Regents of the Smithsonian Institution. 474 pages. Washington, D.C.: Government Printing Office.

1871. Annual Report of the Board of Regents of the Smithsonian Institution. 494 pages. Washington, D.C.: Government Printing Office.

1872. Annual Report of the Board of Regents of the Smithsonian Institution. 456 pages. Washington, D.C.: Government Printing Office.

1879. Annual Report of the Board of Regents of the Smithsonian Institution. 575pages. Washington, D.C.: Government Printing Office.

1885. Annual Report of the Board of Regents of the Smithsonian Institution. 1203 pages. Washington, D.C.: Government Printing Office.

1886. Annual Report of the Board of Regents of the Smithsonian Institution. 813 pages. Washington, D.C.: Government Printing Office.

1932. Annual Report of the Board of Regents of the Smithsonian Institution. 497 pages. Washington, D.C.: Government Printing Office.

Annual Report, U.S. National Museum

1890. Annual Report of the Board of Regents of the Sinithsonian Institution, U.S. National Museum. 788 pages. Washington, D.C.: Government Printing Office.

1891. Annual Report of the Board of Regents of the Smithsonian Institution, U.S. National Museum. 837 pages. Washington, D.C.: Government Printing Office.

1904. Annual Report of the Board of Regents of the Smithsonian Institution, U.S. National Museum. 751 pages. Washington, D.C.: Government Printing Office.

Bahn, P.G.

1984. Pyrenean Prehistory: A Paleoeconomic Survey of the French Sites. 511 pages. Warminster: Aris \& Philips.

Bahn, P.G., and G.H. Cole

1986. La préhistoire pyrénénne aux Etats-Unis. Bulletin de la Société Préhistorique Ariège-Pyrénées, 41:95-149.

Beggs, V

1938. Removal of a Side in the Transformation of Keeled Endscrapers at Mount Carmel, Palestine. Bulletin of the American School of Prehistoric Research, 14:55-61.

Bégouën, H., and J.T. Russell

1933. La campagne de Fouilles de 1931 à Marsoulas, tarté et roquecourbère. 20 pages. Toulouse: Privat.

Behrensmeyer, A.K., R. Potts, T.W. Plummer, L. Tauxe, N. Opdyke, and T. Jorstad

1995. The Pleistocene Locality of Kanjera, Western Kenya: Stratigraphy, Chronology, and Paleoenvironments. Journal of Human Evolution, $29: 247-274$

Bordes, F.

1961. Typologie du Paléolithique ancien et moyen. Publications de l'Institut de Préhistoire de l'Université de Bordeaux, mémoire 1, 2: 85 pages.

Broca, M.P.

1873. The Troglodytes, or Cave-Dwellers, of the Valley of the Vézèrc. In Annual Report, Smithsonian Institution, pages 310-347. Washington, D.C.: Government Printing Office. [Translation from French.]
Brooks, A.S., A.L. Crowell, and J.E. Yellen

1980. $\neq \mathrm{Gi}$, A Stone Age Archaeological Site in Northern Kalahari Desert, Botswana. In R.E.F. Leakey and B.A. Ogot, editors, Proceedings of the VIII Panafrican Congress of Prehistory and Quaternary Studies (Nairobi, 1977), pages 304-309. Nairobi: The International Louis Leakey Memorial Institute for African Prehistory.

Brooks, A.S., D.M. Helgren, J. Cramer, A. Franklin, W. Hornyak, J.M. Keating, R.G. Klein, W.J. Rink, H. Schwartz, J.N.L. Smith, K. Stewart, N.E. Todd, J. Verniers, and J. Yellen

1995. Dating and Context of Three Middle Stone Age Sites with Bone Points in the Upper Semliki Valley, Zaire. Science, 268:548-553.

Brooks, A.S., and C.C. Smith

1987. Ishango Revisited: New Age Determination and Cultural Interpretations. African Archaeological Review, 5:65-78.

Brooks, A.S., and B. Wood

1990. The Chinese Side of the Story. Nature, 344:288-289.

Brooks, A.S., and J.E. Yellen

1987. The Preservation of Activity Areas in the Archaeological Record: Ethnoarchaeological and Archaeological Work in Northwest Ngamiland, Botswana. In S. Kent, editor, Method and Theory for Activity Area Research, pages 63-106. New York: Columbia University Press.

Bushnell, D.I.

1939. The Use of Soapstone by the Indians of the Eastern United States. In Annual Report, Smithsonian Institution, pages 471-489. Washington, D.C.: Government Printing Office.

Campbell, J.B., and C.G. Sampson

1971. A New Analysis of Kent's Cavern, Devonshire, England. University of Oregon Anthropological Papers, 3: vii +40 .

Carballo, J.

1924. Prehistoria universal y especial de España. 426 pages. Madrid: Imprenta de la Vivda del Horno.

1931. The American School of Prehistoric Research Visits the Cavern of El Pendo. Bulletin of the American School of Prehistoric Research, 7:24-27.

Carroll, M.

1925. Les Eyzies, Capital of the Prehistoric World. Art and Archaeology, 19:115-120.

Chapman, W.R.

1985. Arranging Ethnology: A.H. Pitt Rivers and the Typological Tradition. In G.W. Stocking, editor, Objects and Others: Essays on Museums and Material Culture, pages 15-48. Madison: The University of Wisconsin Press.

Clottes, J.

1997. New Laboratory Techniques and Their Impact on Paleolithic Cave Art. In M. Conkey, O. Soffer, D. Stratmann, and N. Jablonski, editors, Beyond Art. Memoirs of the California Academy of Sciences, 23:37-52.

Cook, J., and H. Martingell

1994. The Carlyle Collection of Stone Age Artifacts from Central India. 162 pages. London: British Museum.

Cresson, H.T.

1890. Early Man in the Delaware Valley. Proceedings of the Boston Society of Natural History, 24:141-150.

1892. Paleolithic Man in the Southern Portion of the Delaware Valley. Science, 20:304-305.

Daniel, G.

1975. A Hundred and Fifty Years of Archaeology. Second edition, 410 pages. London: Duckworth. 
Dawkins, W.B.

1874. Cave Hunting: Researches on the Evidence of Caves Respecting the Early Inhabitants of Europe. xxiv +455 pages. London: MacMillan.

1880. Early Man in Britain and His Place in the Tertiary Period. xxiii+ 537 pages. London: MacMillan.

1883. Early Man in America. North American Review, 137:338-349.

Deino, A., and R. Potts

1990. Single Crystal ${ }^{40} \mathrm{Ar} /{ }^{39} \mathrm{Ar}$ Dating of the Olorgesailie Formation, Southern Kenya Rift. Journal of Geophysical Research, 95(B6): $8453-8470$

DeSimone, A.A.

1997. MacCurdy, George Grant (1863-1947). In F. Spencer, editor, History of Physical Anthropology, volume 2, pages 629-631. New York: Garland Publishing, Inc.

Ditchfield, P., J. Hicks, T. Plummer, L. Bishop, and R. Potts

1999. Current Research on the Late Pliocene and Pleistocene Deposits North of Homa Mountain, Southwestern Kenya. Journal of Human Evolution, 36:123-150.

Dunnell, R.C.

1986. Methodological Issues in Americanist Artifact Classification. Advances in Archaeological Method and Theory, 9:149-207.

Dupont, E.

1869. Decouverte d'une cavern à Goyet. Bulletin of the Royal Academy of Belgium, 27:193.

1872. Les temps prehistoriques en Belgique. 250 pages, 4 plates. Bruxelles: L'Homme pendant les ages dans les environs de Dinant-Sur-Meuse.

Ferembach, D.

1997. Lartet, Edouard (Armand Isidore Hippolyte) (1801-1871). In F. Spencer, editor, History of Physical Anthropology, volume 1, pages 605-607. New York: Garland Publishing, Inc.

Fischer, $\mathrm{P}$.

1873. The Scientific Labors of Edward Lartet. In Annual Report, Smithsonian Institution, pages 172-184. Washington, D.C.: Government Printing Office. [Translation from French.]

Foucher, P., and C. San Juan

2000a. La Grotte de Roquecourbère (Betchat, Ariège): Ses Industries Lithiques Solutréennes et la Révision Critique de son Art Pariétal. Bulletin de la Société Préhistorique Francaise, 97:199-210.

2000b. Redécouverte d'un Atelier de Plein Air Solutréen a Roquecourbère (Betchat, Ariège). Bulletin de la Société Préhistorique AriègePyrénées, 55:19-25.

Garrod, D.A.E.

1930. The Palaeolithic of Southern Kurdistan: Excavations in the Caves of Zarzi and Hazar Merd. Bulletin of the American School of Prehistoric Research, 6:8-43.

1931. Excavations in the Caves of the Wady-el-Mughara, 1929 and 1930. Bulletin of the American School of Prehistoric Research, 7:5-11.

1932. Excavations in the Wady al-Mughara (Palestine), 1931. Bulletin of the American School of Prehistoric Research, 8:6-11.

1934. Excavations at the Wady al-Mughara (Palestine), 1932-33. Bulletin of the American School of Prehistoric Research, 10:7-12.

1935. Excavations in the Mugharet et-Tabūn (Palestine), 1934. Bulletin of the American School of Prehistoric Research, 11:54-58.

1936. A Summary of Seven Seasons' Work at the Wady el-Mughara. Bulletin of the American School of Prehistoric Research, 12:125-130.

1937. The Near East as a Gateway of Prehistoric Migration. Bulletin of the American School of Prehistoric Research, 13:17-21.

Garrod, D.A.E., and D.M.A. Bate

1937. The Stone Age of Mount Carmel: Excavations at the Wady ElMughara. Volume 1, 240 pages. Oxford: Clarendon Press.

Glenn, J.R.

1992. Guide to the National Anthropological Archives, Smithsonian Institution. xvi+314 pages. Washington, D.C.: National Anthropological Archives.
Glueck, N.

1951. Explorations in Eastern Palestine. Annual of the American Schools of Oriental Research, volumes 25-28. New Haven, Connecticut.

Grayson. D.K.

1983. The Establishment of Human Antiquity. xii +262 pages. New York: Academic Press.

1986. Eoliths, Archaeological Ambiguity, and the Generation of "Middle Range" Research. In D.J. Meltzer, D.D. Fowler, and J.A. Sabloff, editors, American Archaeology Past and Future, pages 77-133. Washington, D.C.: Smithsonian Institution Press.

1990. The Provision of Time Depth for Paleoanthropology. In L. Laporte, editor, The Establishment of a Geologic Framework for Paleoanthropology. Geological Society of America Special Paper, 242:1-13.

Griffin, J.B.

1985. The Formation of the Society for American Archaeology. American Antiquity, 50:261-271.

Harper, A.B., and W.S. Laughlin

1982. Inquiries into the Peopling of the New World: Development of Ideas and Recent Advances. In F. Spencer, editor, A History of American Physical Anthropology 1930-1980, pages 281-304. New York: Academic Press.

Harrison, B.

1895. High-Level Flint-Drift of the Chalk: Report of the Committee, Consisting of Sir John Evans (Chairman), Mr. B. Harrison (Secretary), Professor J. Prestwich, and Professor H.G. Seeley. British Association for the Advancement of Science Report, 65:349-351.

Hinsley, C.M., Jr.

1976. Amateurs and Professionals in Washington Anthropology, 18791903. In J. Murra, editor, American Anthropology: The Early Years, pages 36-68. St. Paul, Minnesota: West Publishing.

1981. Savages and Scientists: The Smithsonian Institution and the Development of American Anthropology 1846-1910. 319 pages. Washington, D.C.: Smithsonian Institution Press.

1985. From Shell-Heaps to Stelae: Early Anthropology at the Peabody Museum. In G.W. Stocking, editor, Objects and Others: Essays on Museums and Material Culture, pages 49-74. Madison: The University of Wisconsin Press.

Hole, F., and K. Flannery

1967. The Prehistory of Southwestern Iran: A Preliminary Report. Proceedings of the Prehistoric Society, 33(9):147-206.

Holmes, W.H.

1890. A Quarry Workshop of the Flaked-Stone Implement Makers in the District of Columbia. American Anthropologist, 3:1-26.

1897. Stone Implements of the Potomac-Chesapeake Tidewater Province. Annual Report of the Bureau of American Ethnology, 152 pages. Washington, D.C.: Government Printing Office.

Hou, Y., R. Potts, B. Yuan, Z. Guo, A. Deino, W. Wang, J. Clark, G. Xie, and W. Huang

2000. Mid-Pleistocene Acheulean-like Stone Technology of the Bose Basin, South China. Science, 287:1622-1626.

Hrdlička, A.

n.d. Unpublished Manuscript. National Anthropological Archives, Smithsonian Institution, Hrdlička Papers.

1913. The Most Ancient Skeletal Remains of Man. In Annual Report, Smithsonian Institution, pages 491-552. Washington, D.C.: Government Printing Office.

1920. Shovel-Shaped Teeth. American Journal of Physical Anthropology, 3:187-193.

1921. The Peopling of Asia. Proceedings of the American Philosophical Society, 45:535-545.

1923. Studies on Early Man in Europe. Smithsonian Miscellaneous Collections, 76:56-66.

1927. The Neanderthal Phase of Man. Journal of the Royal Anthropological Institute, 47:249-274. 
1930a. The Skeletal Remains of Early Man. Smithsonian Miscellaneous Collections, 83: $x+379$ pages. Washington, D.C.: Government Printing Office.

1930b. Anthropological Survey in Alaska. Annual Report of the Bureau of American Ethnology, pages 19-374. Washington, D.C.: Government Printing Office.

1944. The Anthropology of Kodiak Island. xix +486 pages. Philadelphia: Wistar Press.

1945. The Aleutian and Commander Islands and Their Inhabitants. $\mathrm{xx}+$ 630 pages. Washington, D.C.: Carnegie Institute.

Jacknis, $\mathrm{I}$.

1985. Franz Boas and Exhibits: On the Limitations of the Museum Method of Anthropology. In G.W. Stocking, editor, Objects and Others: Essays on Museums and Material Culture, pages 75-111. Johnson, J.P. Madison: The University of Wisconsin Press.

1904. On the Discovery of Implement-Bearing Deposits in the Neighbourhood of Johannesburg: Their Relative Age, and Bearing on the Question of the Antiquity of Man in South Africa. Transactions of the Geological Society of South Africa, 6:60-67.

Keith, A.

1925. The Antiquity of Man. xx+519 pages. London: Williams and Norgate. [First publication 1915.]

1931. New Discoveries Relating to the Antiquity of Man. 512 pages. New York: W.W. Norton and Co.

Keith, A., and T.D. McCown

1937. Mount Carmel Man: His Bearing on the Ancestry of Modern Races. Bulletin of the American School of Prehistoric Research, 13:5-16.

Kennedy, K.A.R.

1997. McCown, Theodore $\mathrm{D}$ (oney) (1908-1969). In F. Spencer, editor, History of Physical Anthropology, volume 2, pages 627-629. New

Kohlstedt, S.G. York: Garland Publishing, Inc.

1991. The Origins of Natural Science in America: Essays of George Brown Goode. $\mathrm{xi}+411$ pages. Washington, D.C.: Smithsonian Institution Press.

Korisettar, R., and M. Petraglia

1993. Explorations in the Malaprabha Valley, Karnataka. Man and Environment, 18:43-48.

Landau, M.

1991. Narratives of Human Evolution. xiii+202 pages. New Haven: Yale University Press.

Lartet, E., and H. Christy

1865-1875. Reliquae Aquitanicae, being Contributions to the Archaeology and Palaeontology of Perigord and the Adjoining Provinces of Southern France. xxii +302 pages. London.

Leakey, M.D.

1971. Olduvai Gorge. Volume 3, 306 pages. Cambridge: Cambridge University Press.

Loring, S., and M. Prokopec

1994. A Most Peculiar Man, the Life and Times of Aleš Hrdlička. In T.L. Bray and T.W. Killion, editors, Reckoning with the Dead, pages 2640. Washington, D.C.: Smithsonian Institution Press.

Luquet, G.-H.

1926. L'Art et la religion des hommes fossiles. 229 pages. Paris: Masson \& Cie.

1930. The Art and Religion of Fossil Man. xiv +213 pages. Translated by J.T. Russell. New Haven: Yale University Press.

MacCurdy, G.G.

1922. The First Season's Work of the American School in France for Prehistoric Studies. American Anthropologist, 24:61-71.

1924. Human Origins. Volumes 1-3. London: D. Appleton and Company.

1925. American School of Prehistoric Research in Europe, Excavations and Researches, 1924. Art and Archaeology, 19:121-130.
1927. Report by the Director on the Work of the Sixth Season. Bulletin of the American School of Prehistoric Research, 3:1-22.

1928. Report by the Director on the Work of the Seventh Season. Bulletin of the American School of Prehistoric Research, 4:3-8.

1930. Preface. In G.-H. Luquet, The Art and Religion of Fossil Man. Translated by J.T. Russell, pages vii-viii. New Haven: Yale University Press.

1931. The Abri des Merveilles at Castel-Merle near Sergeac (Dordogne). Bulletin of the American School of Prehistoric Research, 7:12-23.

1934. Excavations in Palestine by Great Britain and the United States. Science, 79(2047):265.

1938. Report of the Director, To the Board of Trustees of the American School of Prehistoric Research. Bulletin of the American School of Prehistoric Research, 14:3-5.

Martin, $\mathrm{H}$.

1911. Sur un squelette humain l'époque Moustérienne trouvé en Charente. Comptes Rendus Hebdomadaires des Séances de l'Académie des Sciences, 153:728-730.

1912a. Position stratigraphique des ossements humains recueillis dans le moustérien de La Quina de 1908 et 1912. Bulletin de la Société Préhistorique Française, 9:700-709.

1912b. Le crane de l'homme fossile Moustérien dans le gisement de La Quina (Charente) III: L'homme fossile. Association Française de l'Advancement de Science, 41:538-539.

Mason, O.T.

1902. In Memorium, Thomas Wilson. American Anthropologist, 4:1-6.

McBrearty, S., and A.S. Brooks

2000. The Revolution that Wasn't: A New Interpretation of the Origin of Modern Human Behavior. Journal of Human Evolution, 39:453563.

McCown, T.D

1932. A Note on the Excavation and the Human Remains from the Mugharet es-Sukhūl (Cave of the Kids), Season of 1931. Bulletin of the American School of Prehistoric Research, 8:12-15.

1933. Fossil Men of the Mugharet es-Sukhūl near Athlit, Palestine, Season of 1932. Bulletin of the American School of Prehistoric Research, 9:9-16.

1934. The Oldest Complete Skeleton of Man. Bulletin of the American School of Prehistoric Research, 10:13-17.

1936. Mount Carmel Man. Bulletin of the American School of Prehistoric Research, 12:131-140.

1948. George Grant MacCurdy, 1863-1947. American Anthropologist, 50: 516-524.

McCown, T.D., and A. Keith

1939. The Stone Age of Mount Carmel: The Fossil Human Remains from the Levalloiso-Mousterian. Volume 2. Oxford: Clarendon Press.

Meltzer, D.J.

1983. The Antiquity of Man and the Development of American Archaeology. Advances in Archaeological Method and Theory, 6:1-51.

1985. North American Archaeology and Archaeologists, 1879-1934. American Antiquity, 50:249-260.

1998. Introduction: Ephraim Squier, Edwin Davis, and the Making of an American Archaeological Classic. In D.J. Meltzer, editor, Ancient Monuments of the Mississippi Valley, by E.G. Squier and E.H. Davis, pages 1-98. Washington and London: Smithsonian Institution Press.

Meltzer, D.J., and R.C. Dunnell

1992. Introduction. In D.J. Meltzer and R.C. Dunnell, editors, The Archaeology of William Henry Holmes, pages vii-1. Washington, D.C.: Smithsonian Institution Press.

Meltzer, D.J., and W.C. Sturtevant

1983. The Holly Oak Shell Game: An Historic Archaeological Fraud. In R.C. Dunnell and D.K. Grayson, editors, Lulu Linear Punctated: Essays in Honor of George Irving Quimby. Anthropological Papers, 


\section{Mitchell, $\mathrm{P}$}

Museum of Anthropology, University of Michigan, 72:325-352.

2002. Catalogue of Stone Age Artifacts from Southern Africa in the British Museum. 240 pages. London: British Museum Press.

Moir, J.R.

1919. Pre-Palaeolithic Man. Pages 7-67. Ipswich: W.E. Harison.

Montagu, A.

1944. Aleš Hrdlička, 1869-1943. American Anthropologist, 46:113-117.

Morgan, J. de

1926. La préhistoire Orientale, II: L'Egypte et L'Afrique du Nord. 433 pages. Paris: Librairie Orientaliste Paul Geuthner.

Mortillet, G. de

1872. Ethnological Department of the French Exposition, 1867. In Annual Report, Smithsonian Institution, pages 407-411. Washington, D.C.: Government Printing Office [translation].

Paddayya, K., and M. Petraglia

1993. Formation Processes of Acheulean Localities in the Hunsgi and Baichbal Valleys, Peninsular India. In P. Goldberg, D.T. Nash, M.D. Petraglia, editors, Formation Processes in Archaeological Context, pages 61-82. Madison: Prehistory Press.

Patterson, T.C.

1995. Toward a Social History of Archaeology in the United States. $\mathrm{x}+$ 181 pages. Fort Worth, Texas: Harcourt Brace Publishers.

Peabody, C.

1923. Annual Report of the Director of the American School in France of Prehistoric Studies, 1922-23. Bulletin of the Archaeological Institute of America, 14:115-118.

Penniman, T.K.

1974. A Hundred Years of Anthropology. 397 pages. New York: William Morrow and Company, Inc.

Petraglia, M.D.

1995. Pursuing Site Formation Research in India. In S. Wadia, R. Korisettar, and V.S. Kale, editors, Quaternary Environments and Geoarchaeology of India, pages 446-465. Bangalore: Geological Society of India.

1998. The Lower Palaeolithic of India and Its Bearing on the Asian Record. In M.D. Petraglia and R. Korisettar, editors, Early Human Behaviour in Global Context, pages 343-390. London: Routledge Press.

Petraglia, M.D., R. Korisettar, and J. Schuldenrein

2001. Paleolithic Assemblages and Landscapes of the Lakhmapur Locality, Peninsular India. [Unpublished manuscript in possession of authors.]

Petraglia, M.D., P. LaPorta, and K. Paddayya

1999. The First Acheulian Quarry in India: Stone Tool Manufacture, Biface Morphology, and Behaviors. Journal of Anthropological Research, 55:39-70.

Petraglia, M.D., and M. Noll

2001. Indian Palaeolithic Collections in the Smithsonian Institution: International Exchanges and Their Archaeological Potential. Man and Environment, 26:57-68.

Petraglia, M.D., and R.B. Potts

1992. Deux "mortiers" du Paléolithique supérieur de La Madeleine, Dordogne, France. L'Anthropologie, 96(1):209-212.

Petraglia, M., R. Potts, L.G. Straus, and P. Vandiver

2001. Upper Paleolithic Collections from the Salat Valley of Pyrnean France. [Unpublished manuscript in possession of authors.]

Petraglia, M.D., R. Potts, and P.B. Vandiver

1992. Une "Palette d'Artiste" du Paléolithique supérieur provenant de la Grotte de Tarté, Haute Garonne, France. Bulletin de la Société Préhistorique de L'Ariège, 47:161-175.

Petraglia, M.D., J. Schuldenrein, and R. Korisettar

2003. Landscapes, Activity, and the Acheulean to Middle Paleolithic Transition in the Kaladgi Basin, India. Eurasian Prehistory, 1(2):3-24.
Petraglia, M.D., L.G. Straus, and R. Potts

2002. French Pyrenean Collections in the Smithsonian Institution: Upper Paleolithic Assemblages from the Salat Valley. Bulletin de la Société Préhistorique de L'Ariège-Pyrénées, LVII:171-194.

Plummer, T.W.

1991. Site Formation and Paleoecology at the Early to Middle Pleistocene Locality of Kanjera. 537 pages. Unpublished doctoral dissertation, Yale University.

Plummer, T., L.C. Bishop, P. Ditchfield, and J. Hicks

1999. Research on Late Pliocene Oldowan Sites at Kanjera South, Kenya. Journal of Human Evolution, 36:151-170.

Plummer, T., and R. Potts

1989. Excavations and New Findings at Kanjera, Kenya. Journal of Human Evolution, 18:269-276.

1995. The Hominid Fossil Sample from Kanjera, Kenya: Description, Provenance and Implications of New and Earlier Discoveries. American Journal of Physical Anthropology, 96:7-23.

Posansky, M., and G.H. Cole

1963. Recent Excavations at Magosi, Uganda: A Preliminary Report. Man, 133:104-106.

Potts, R.

1982. Lower Pleistocene Site Formation and Hominid Activities at Olduvai Gorge, Tanzania. xii+494 pages. Unpublished doctoral dissertation, Harvard University.

1983. Foraging for Faunal Resources by Early Hominids at Olduvai Gorge, Tanzania. In J. Clutton-Brock and C. Grigson, editors, Animals and Archaeology, 1: Hunters and Their Prey. British Archaeological Reports, International Series, 163:51-62.

1988. Early Hominid Activities at Olduvai. xi +396 pages. New York: Aldine de Gruyter.

1989. Olorgesailie: New Excavations and Findings in Early and Middle Pleistocene Contexts, Southern Kenya Rift Valley. Journal of $\mathrm{Hu}$ man Evolution, 18:477-484.

1994. Variables vs. Models of Early Pleistocene Hominid Landuse. Journal of Human Evolution, 27:7-24.

Potts, R., A.K. Behrensmeyer, and P. Ditchfield

1999. Paleolandscape Variation in Early Pleistocene Hominid Activities: Members 1 and 7, Olorgesailie Formation, Kenya. Journal of Human Evolution, 37:747-788.

Prestwich, J.

1889. On the Occurrence of Palaeolithic Flint Implements in the Neighbourhood of Ightham, Kent, Their Distribution and Probable Age. Quarterly Journal of the Geological Society of London, 45:270-297.

1892. On the Primitive Characters of the Flint Implements of the Chalk Plateau of Kent, with Reference to the Question of Their Glacial or Pre-Glacial Age. Journal of the Anthropological Institute, 21:246276.

1895. The Greater Antiquity of Man. Nineteenth Century, 37:617-628.

Rau, C.

1876. Early Man in Europe. 162 pages. New York: Harper and Brothers.

1889. Report on the Department of Archaeology in the U.S. National Museum, 1887. Annual Report, Smithsonian Institution, part 2, pages 83-85. Washington, D.C.: Government Printing Office.

Riedman, S.R.

1961. Trailblazer of American Science: The Life of Joseph Henry, 224 pages. New York: Rand-McNally and Co.

Rightmire, P.G.

1990. The Evolution of Homo erectus: Comparative Anatomical Studies of an Extinct Human Species. xii +260 pages. Cambridge and New York: Cambridge University Press.

Rivinus, E.F., and E.M. Youssef

1992. Spencer Baird of the Smithsonian. $\mathrm{x}+228$ pages. Washington, D.C.: Smithsonian Institution Press. 
Russell, J.T., Jr.

1928. A Summer of Prehistoric Research in the "Pays Civraisien." Bulletin of the American School of Prehistoric Research, 4:9-17.

1929. Report on Field Work in France, Season of 1928. Bulletin of the American School of Prehistoric Research, 5:9-10.

1932. Report on Archeological Research in the Foothills of the Pyrenees. Smithsonian Miscellaneous Collections, 87(11):1-5.

Rutot, A.L.

1900. Note sur la découverte d'importants gisements de Silex Taillés. 103 pages. Bruxelles: Imprimeur de L'Académie Royale de Belgique.

1919. Un essai de reconstitution plastique des races humaines primitives. 172 pages. Bruxelles: Imprimeur de L'Académie Royale de Belgique.

Sackett, J.R.

1981. From de Mortillet to Bordes: A Century of French Paleolithic Research. In G. Daniel, editor, Towards a History of Archaeology, pages 85-99. London: Thames and Hudson.

1991. Straight Archaeology French Style: The Phylogenetic Paradigm in Historic Perspective. In G.A. Clark, editor, Perspectives on the Past, pages 109-139. Philadelphia: University of Pennsylvania Press.

Schultz, A.H.

1945. Aleš Hrdlička, 1869-1943. National Academy of Sciences Biographical Memoirs, 23:305-338.

Seton-Karr, H.W.

1896. Discovery of Evidences of the Palaeolithic Stone Age in Somaliland (Tropical Africa). Journal of the Anthropological Institute, 25:271275.

1906. Flint Implements of the Fayum, Egypt. Annual Report, U.S. National Museum, pages 747-751. Washington, D.C.: Government Printing Office.

Sieveking, A.

1987. A Catalogue of Palaeolithic Art in the British Museum. 228 pages. London: British Museum Publications.

Sikes, N.E., R. Potts, and A.K. Behrensmeyer

1999. Early Pleistocene Habitat in Member 1 Olorgesailie Based on Paleosol Stable Isotopes. Journal of Human Evolution, 37:721-746.

Simek, J.

1986. A Paleolithic Sculpture from the Abri Labattut in the American Museum of Natural History Collection. Current Anthropology, 27(4):402-407.

Smith, A.C.

1868. Preface. In Some Account of the Blackmore Museum, pages iii-v. London: Bell and Daldy.

Smith, P.E.L.

1966. Le Solutréen en France. 238 pages. Bordeaux: Delmas.

Smithsonian Institution

1996. Guide to the Smithsonian Archives. 796 pages. Washington, D.C.: Smithsonian Institution Press.

Solecki, R.S

1971. Shanidar: The First Flower People. $x v+290$ pages. New York: Knopf.

Spencer, F.

1979. Aleš Hrdlička, M.D., 1869-1943: A Chronicle of the Life and Work of an American Physical Anthropologist. Unpublished doctoral dissertation, Department of Anthropology, University of Michigan, Ann Arbor.

1981. The Rise of Academic Physical Anthropology in the United States (1880-1980): A Historical Overview. American Journal of Physical Anthropology, 56:353-364.

1982. Introduction. In F. Spencer, editor, A History of American Physical Anthropology 1930-1980, pages 1-10. New York: Academic Press.

1990. Piltdown: A Scientific Forgery. xxvi +272 pages. Oxford: Oxford University Press.

1997. Hrdlička, Aleš (1869-1943). In F. Spencer, editor, History of Physi- cal Anthropology, volume 1, pages 503-505. New York: Garland Publishing, Inc.

Spencer, F., and F.H. Smith

1981. The Significance of Aleš Hrdlička's "Neanderthal Phase of Man:” A Historical and Current Assessment. American Journal of Physical Anthropology, 56:435-459.

Stevens, E.T.

1870. Flint Chips: A Guide to Pre-historic Archaeology, as Illustrated by the Collection in the Blackmore Museum, Salisbury. xxxviii+593

Stewart, T.D. pages. London: Bell and Daldy.

1940. The Life and Writings of Dr. Aleš Hrdlička. American Journal of Physical Anthropology, 26:3-40.

1958. First View of the Restored Shanidar I Skull. Sumer, 14:90-96.

1962. The Skull of Shanidar II. Sumer, 17:97-106.

1965. Shanidar Skeletons IV and VI. Sumer, 19:8-26.

1977. The Neanderthal Skeletal Remains from Shanidar Cave, Iraq: A Summary of Findings to Date. Proceedings of the American Philosophical Society, 121:121-165.

1981. Aleš Hrdlička, 1869-1943. American Journal of Physical Anthropology, 56:347-351.

Stewart, T.D., and Spencer, F.

1978. Paris on the Potomac: Aleš Hrdlička's Vision of American Physical Anthropology. American Journal of Physical Anthropology, 48:440.

Straus, L.G.

1985. La collection magnant: un témoin de la préhistoire Charentaise. Bulletins et Mémoires de la Société Archéologique et Historique de la Charente, 1985, 1:21-34.

1991. Southwestern Europe at the Last Glacial Maximum. Current Anthropology, 32:189-199.

1994. The Abbé Henri Breuil: Pope of Paleolithic Prehistory. In J.A. Lasheras, editor, Homenaje al Dr. Joaquin González Echegaray. Museo y Centro de Investigación de Altamira, Monografias, 17: 189-198.

1996. Hugo Obermaier and the Cantabrian Solutrean. In A. Moure, editor, El Hombre Fósil: 80 Años Después, pages 195-209. Santander: Universidad de Cantabria.

Tauxe, L., A. Deino, A.K. Behrensmeyer, and R. Potts

1992. Pinning Down the Brunhes/Matuyama and Upper Jaramillo Boundaries: A Reconcillation of Orbital and Isoptopic Time Scales. Earth and Planetary Science Letters, 109:561-572.

Tobias, P.V., and G.H.R. von Koenigswald

1964. A Comparison between the Olduvai Hominids and Those of Java and Some Implications for Hominid Phylogeny. Nature, 204:515- 518.

Trigger, B.G.

1989. A History of Archaeological Thought. xv+500 pages. Cambridge: Cambridge University Press.

Trinkaus, E.

1982. A History of Homo erectus and Homo sapiens Paleontology in America. In F. Spencer, editor, A History of American Physical Anthropology 1930-1980, pages 261-280. New York: Academic Press.

1983. The Shanidar Neandertals. xxiv +502 pages. New York: Academic Press.

1997. Shanidar (Iraq). In F. Spencer, editor, History of Physical Anthropology, volume 2, pages 925-927. New York: Garland Publishing, Inc.

Trinkaus, E., and P. Shipman

1992. The Neandertals: Changing the Image of Mankind. xxiii+454 pages. New York: Alfred A. Knopf.

Ubelaker, D.

1997. Stewart, T(homas). Dale (1901- ). In F. Spencer, editor, History of Physical Anthropology, volume 2, pages 999-1001. New York: Garland Publishing, Inc.

Van Riet Lowe, C.

1952. The Pleistocene Geology and Prehistory of Uganda, Part II: Prehistory. Geological Survey of Uganda, Memoir, 6: ix +113 pages. 
Colchester, England: Benham and Company Limited.

Van Riper, A.B.

1993. Men among the Mammoths. xv+267 pages. Chicago: University of Chicago Press.

Vandiver, P.B., M.D. Petraglia, and R.B. Potts

1994. Analyses techniques de deux "Mortiers" du paléolithique supérieur de La Madeleine, Dordogne, France. L'Anthropologie, 98(4):674682.

Washburn, W.E.

1978. The Cosmos Club of Washington: A Centennial History 1878-1978. 406 pages. Washington, D.C.: The Cosmos Club.

Wayland, E.J., and C. Burkitt

1932. The Magosian Culture of Uganda. Journal of the Royal Anthropological Institute, 62:369-390.

White, $\mathrm{R}$

1986a. Rediscovering French Ice Age Art. Nature, 320:683-684.

1986b. Dark Caves, Bright Visions: Life in Ice Age Europe. 176 pages. New York: American Museum of Natural History.

1988. Objects Magdaléniens provenant de L'Abri du Soucy (Dordogne): La collection de H.M. Ami au Royal Ontario Museum, Toronto, Canada. L'Anthropologie, 92:29-40.

White, R., and L.B. Breitborde, editors

1992. French Paleolithic Collections in the Logan Museum of Anthropology. Logan Museum Bulletin (New Series), 1(2): 367 pages.

Willey, G.R., and J.A. Sabloff

1993. A History of American Archaeology. Third edition, xiii +384 pages. San Francisco: W.H. Freeman and Company.

Wilson, $\mathrm{T}$.

n.d. Unpublished Manuscript, National Anthropological Archives, Smithsonian Institution.

1888. Man in North America during the Palaeolithic Period. Annual Report, U.S. National Museum, pages 677-702. Washington, D.C.: Government Printing Office.

1889. The Paleolithic Period in the District of Columbia. American Anthropologist, 2:235-240.

1890a. A Study of Prehistoric Anthropology: Handbook for Beginners. Annual Report, U.S. National Museum, pages 597-676. Washington, D.C.: Government Printing Office.

1890b. The Smithsonian Institution and Its Anthropologic Work. Journal of the Royal Anthropological Institute of Great Britain and Ireland, 19:509-515.

1890c. Results of an Inquiry as to the Existence of Man in North America during the Paleolithic Period of the Stone Age. Annual Report, U.S. National Museum, pages 677-702. Washington, D.C.: Government Printing Office.

1890d. Report on the Department of Prehistoric Anthropology in the U.S. National Museum, 1888. Annual Report, U.S. National Museum, pages 123-138. Washington, D.C.: Government Printing Office.

1891a. Anthropology at the Paris Exposition in 1889. In Annual Report, U.S. National Museum, pages 641-680. Washington, D.C.: Govern- ment Printing Office.

1891b. Report of the Department of Prehistoric Anthropology in the U.S. National Museum, 1889. In Annual Report, U.S. National Museum, pages 317-339. Washington, D.C.: Government Printing Office.

1892a. Proposed Classification of the Section of Anthropology and Prehistoric Archaeology at the Chicago Exposition. Special Publication of the U.S. National Museum. 40 pages. Washington, D.C.: Government Printing Office.

1892b. Report of the Department of Prehistoric Anthropology in the U.S. National Museum, 1891. In Annual Report, U.S. National Museum, pages 183-198. Washington, D.C.: Government Printing Office.

1893. Primitive Industry. Annual Report, Smithsonian Institution, pages 521-534. Washington, D.C.: Government Printing Office.

1894. The Swastika, the Earliest Known Symbol, and Its Migrations. Annual Report, U.S. National Museum, pages 757-1011. Washington, D.C.: Government Printing Office.

1896. Prehistoric Art; or, the Origin of Art as Manifested in the Works of Prehistoric Man. Annual Report, U.S. National Museum, pages 325-664. Washington, D.C.: Government Printing Office.

1899a. Bluebeard: A Contribution to History and Folklore. xv+212 pages. Washington, D.C.: Government Printing Office.

1899b. Arrowpoints, Spearheads, and Knives of Prehistoric Times. Annual Report, U.S. National Museum, pages 811-988, 65 plates. Washington, D.C.: Government Printing Office.

Yellen, J.E.

1977. Archaeological Approaches to the Present: Models for Reconstructing the Past. xvi+259 pages. New York: Academic Press.

1996. Behavioural and Taphonomic Patterning at Katanda 9: A Middle Stone Age Site, Kivu Province, Zaire. Journal of Archaeological Science, 6:915-932.

1998. Barbed Bone Points: Tradition and Continuity in Saharan and SubSaharan Africa. African Archaeological Review, 15:173-198.

Yellen, J.E., A.S. Brooks, E. Cornelissen, M. Mehlman, and K. Stewart

1995. A Middle Stone Age Worked Bone Industry from Katanda, Upper Semliki Valley, Zaire. Science, 268:553-556.

Yellen, J.E., A.S. Brooks, R. Stuckenrath, and R. Welbourne

1987. A Terminal Pleistocene Assemblage from Drotsky's Cave, Western Ngamiland, Botswana. Botswana Notes and Records, 19:1-6.

Yochelson, E.L.

1990. The National Museum of Natural History: 75 Years in the Natural History Building. 216 pages. Washington, D.C.: Smithsonian Institution Press.

Yuan, B., Y. Hou, W. Wang, R. Potts, Z. Guo, and H. Huang

1999. On the Geomorphological Evolution of the Bose Basin, a Lower Paleolithic Locality in South China. Acta Anthropologica Sinica, 18:215-223.

Zeni, D.

1998. Forgotten Empress: The Empress of Ireland Story. 224 pages. New Brunswick, Canada: Goose Land Editions. 